Prepared in cooperation with the

U.S. Army Corps of Engineers, New England District

\title{
Borehole Geophysical Investigation of a Formerly Used Defense Site, Machiasport, Maine, 2003-2006
}

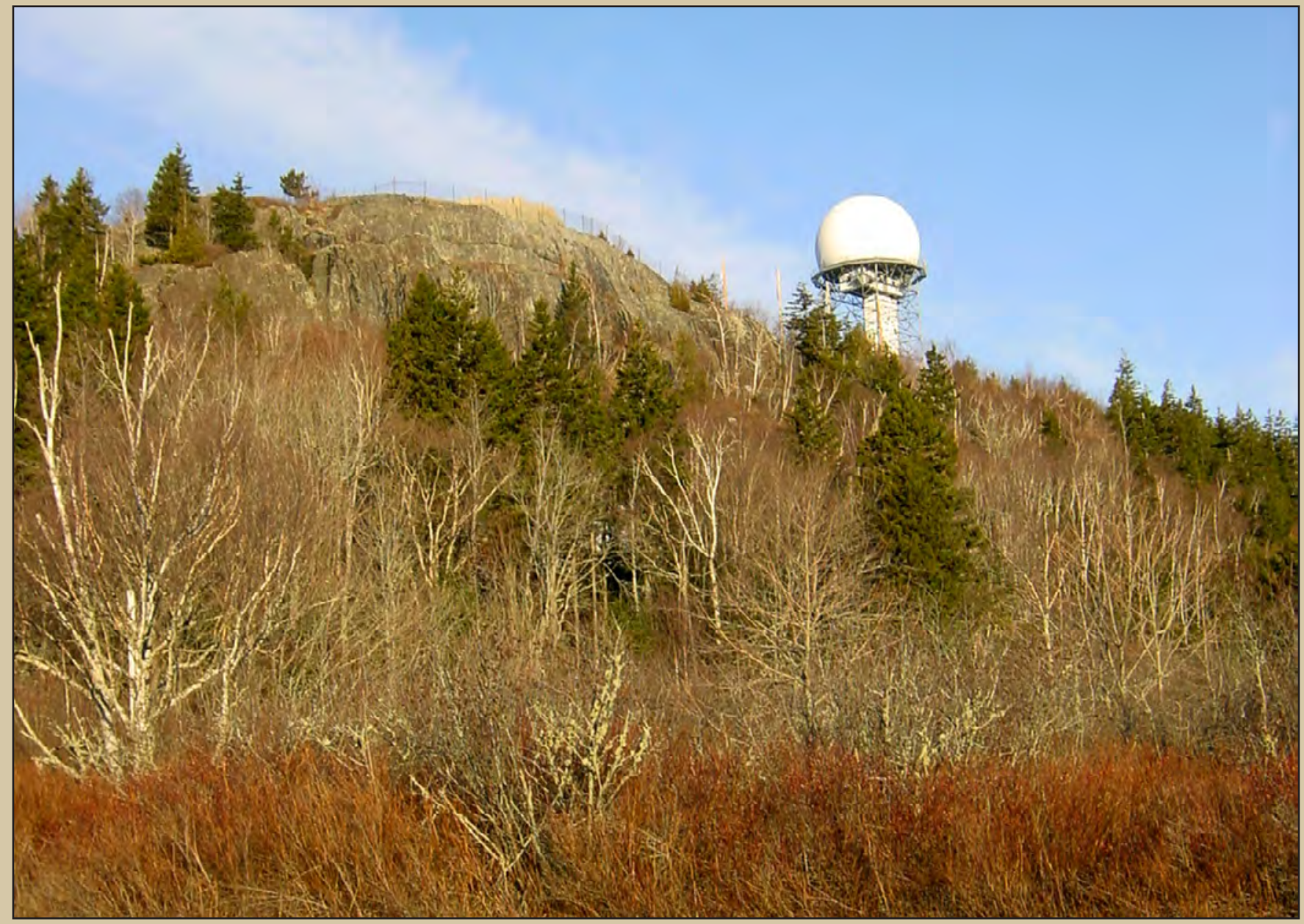

Scientific Investigations Report 2009-5120 
Cover. Photograph shows Air Force Radar Tracking Station at Howard Mountain, at a Formerly Used Defense Site, Machiasport, Maine. 


\section{Borehole Geophysical Investigation of a Formerly Used Defense Site, Machiasport, Maine, 2003-2006}

By Carole D. Johnson, Remo A. Mondazzi, and Peter K. Joesten

Prepared in cooperation with the

U.S. Army Corps of Engineers, New England District

Scientific Investigations Report 2009-5120 


\section{U.S. Department of the Interior \\ KEN SALAZAR, Secretary \\ U.S. Geological Survey \\ Marcia K. McNutt, Director}

U.S. Geological Survey, Reston, Virginia: 2011

For more information on the USGS - the Federal source for science about the Earth, its natural and living resources, natural hazards, and the environment, visit http://www.usgs.gov or call 1-888-ASK-USGS

For an overview of USGS information products, including maps, imagery, and publications, visit http://www.usgs.gov/pubprod

To order this and other USGS information products, visit http://store.usgs.gov

Any use of trade, product, or firm names is for descriptive purposes only and does not imply endorsement by the U.S. Government.

Although this report is in the public domain, permission must be secured from the individual copyright owners to reproduce any copyrighted materials contained within this report.

Suggested citation:

Johnson, C.D., Mondazzi, R.A., and Joesten, P.K., 2011, Borehole geophysical investigation of a Formerly Used Defense Site, Machiasport, Maine, 2003-2006: U.S. Geological Survey Scientific Investigations Report 2009-5120, 333 p., at http://pubs.usgs.gov/sir/2009/5120/. 


\section{Contents}

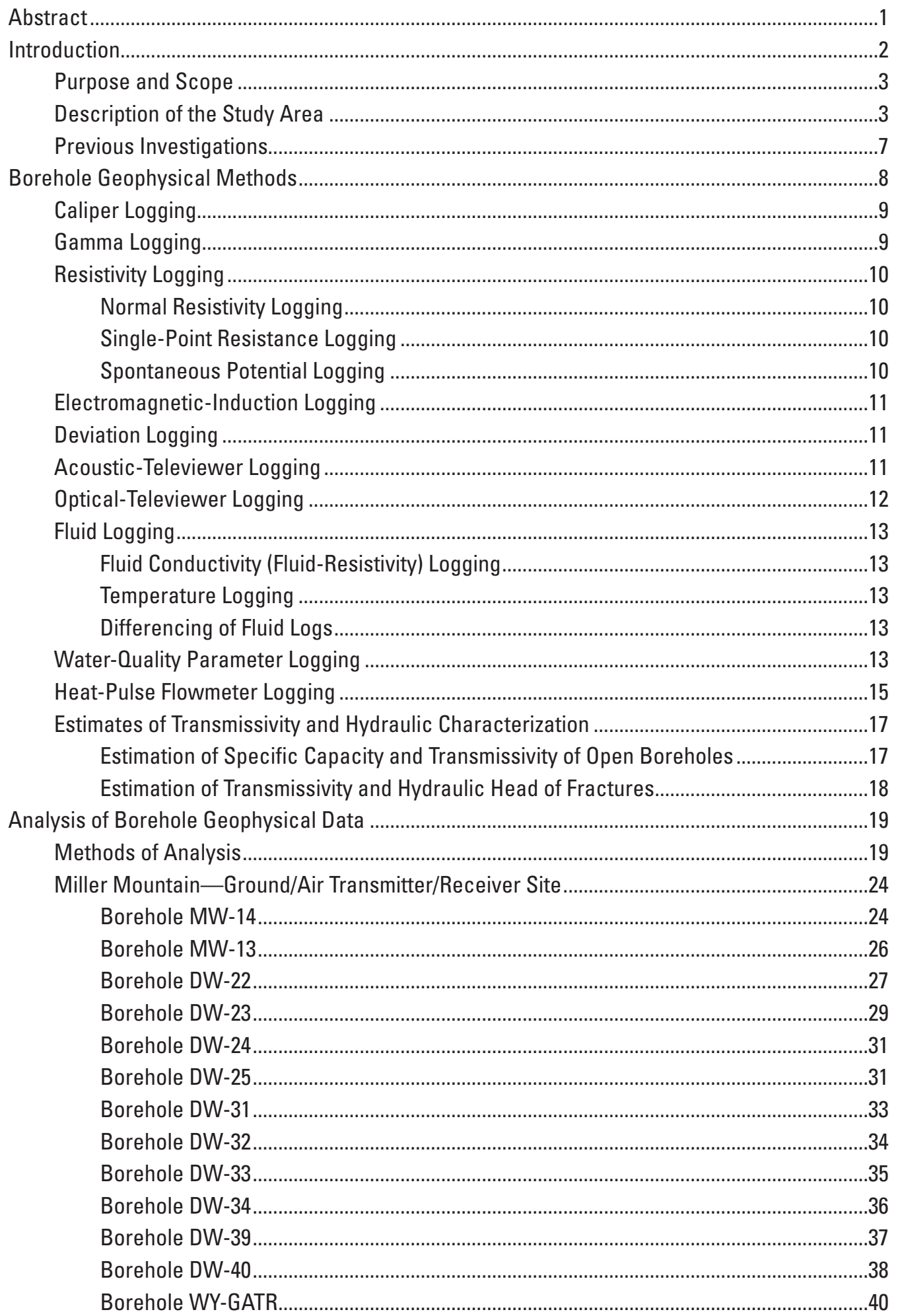


Howard Mountain—Air Force Radar Tracking Station Area .................................................41

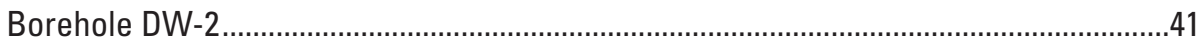

Borehole WY-3B

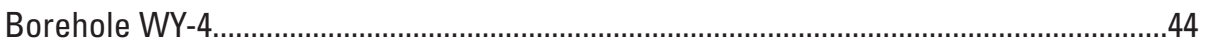

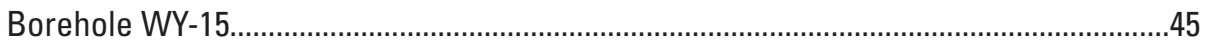

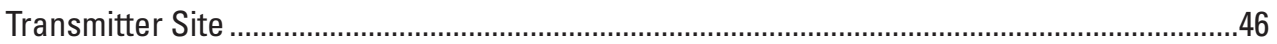

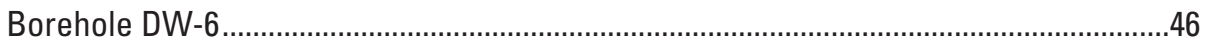

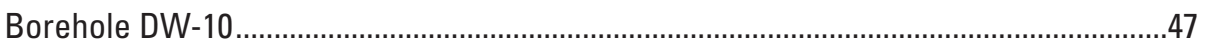

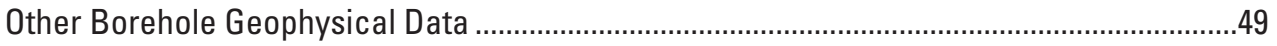

Results of the Borehole Geophysical Investigation ......................................................................

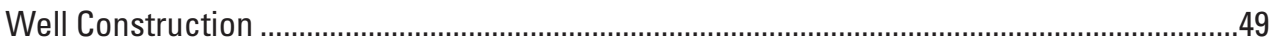

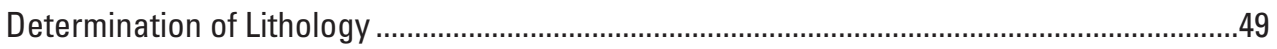

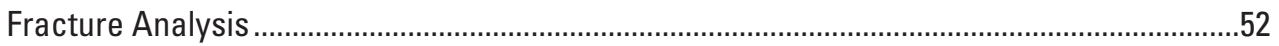

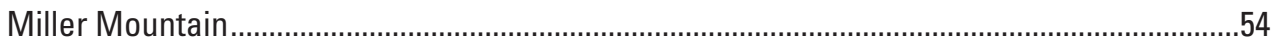

Howard Mountain—Air Force Radar Tracking Station ........................................................58

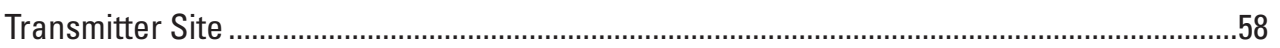

Hydraulic Characterization .............................................................................................63

Summary and Conclusions....................................................................................................

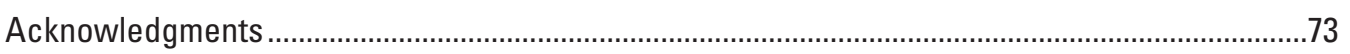

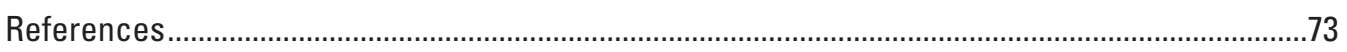

Appendix 1. Borehole geophysical logs from boreholes on or near Miller Mountain, near Machiasport, Maine

Appendix 2. Borehole geophysical logs from boreholes near the Air Force Radar Tracking Station on Howard Mountain, near Machiasport, Maine

Appendix 3. Borehole geophysical logs from boreholes near the Transmitter Site on Howard Mountain, near Machiasport, Maine

Appendix 4. Plots and interpretations of borehole geophysical logs collected by Geophysical Applications, Inc., for boreholes near Machiasport, Maine

Appendix 5. Plots and interpretations of borehole geophysical logs collected by Hager-Richter Geoscience, Inc., for boreholes near Machiasport, Maine

Appendix 6. Summary of structure interpreted from geophysical logs for boreholes near Machiasport, Maine 


\section{Figures}

1. Maps showing locations of boreholes near a Formerly Used Defense Site, Machiasport, Maine

2. Plot of example showing differences in fluid logs before and after imposing a hydraulic stress.......

3. Plot of example of interpretation of water-quality data to identify hydraulically active fractures

4. Cross-plots of selected borehole geophysical logs from borehole DW-10, near Machiasport, Maine

5. Plots of selected borehole geophysical logs and lithology in borehole DW-10, near

Machiasport, Maine, showing correlation of logs to the lithology

6. Cross-plot of data from gamma and acoustic televiewer reflectivity logs from borehole MW-14, near Machiasport, Maine

7. Cross-plot of data from gamma and acoustic televiewer reflectivity logs from borehole DW-23, near Machiasport, Maine

8. Plot of selected borehole geophysical logs and rock types in borehole MW-14, near Machiasport, Maine

9. Plot of flowmeter model for borehole DW-22, near Machiasport, Maine, showing solid model lines overlying interpretation of measured flow

10. Cross-plot of gamma emissions and acoustic reflectivity for selected segments of boreholes near Machiasport, Maine.

11. Plot of gamma and reflectivity logs and interpretations for boreholes in the Miller Mountain site, near Machiasport, Maine

12. Plot of gamma and reflectivity logs and interpretations for boreholes in the Howard Mountain area, near Machiasport, Maine.

13. Cross-plot of gamma emissions and acoustic reflectivity for selected segments of the boreholes in the Howard Mountain area, near Machiasport, Maine

14. Tadpole plot and stereoplot showing all fractures and lithologic features in the 37 boreholes near Machiasport, Maine.

15. Tadpole plots, stereoplots, and rose diagram showing all fractures and lithologic features in 14 boreholes on or near Miller Mountain, near Machiasport, Maine ...........56

16. Plots of poles to planes of transmissive fractures in 14 boreholes on or near Miller Mountain, near Machiasport, Maine.

17. Tadpole plots, stereoplots, and rose diagram showing all fractures and lithologic features in 17 boreholes near the Air Force Radar Tracking Station on Howard Mountain, near Machiasport, Maine

18. Plots of poles to planes of transmissive fractures in 17 boreholes near the Air Force Radar Tracking Station on Howard Mountain, near Machiasport, Maine...

19. Tadpole plots, stereoplots, and rose diagram showing all fractures and lithologic features in six boreholes near the Transmitter Site on Howard Mountain, near Machiasport, Maine

20. Plots of poles to planes of transmissive fractures in six boreholes near the Transmitter Site on Howard Mountain, near Machiasport, Maine

21. Stereoplots and rose diagrams for selected boreholes on or near Howard Mountain, Machiasport, Maine

22. Stereoplots and rose diagrams for selected boreholes on or near Miller Mountain, Machiasport, Maine

23. Graph showing comparison of open-hole transmissivity determined from Bradbury and Rothschild (1985) method and summed transmissivity determined from modeled heat-pulse flowmeter profiles and water levels. 


\section{Tables}

1. Boreholes at the Formerly Used Defense Site, Machiasport, Maine.

2. Borehole logs collected by the U.S. Geological Survey in 2004 and 2005, near Machiasport, Maine.

3. Borehole logs collected by others in 2003 and 2006, near Machiasport, Maine ...............9

4. Correction factors for gamma tools used in this study ..............................................10

5. Flow model for borehole DW-22, near Machiasport, Maine .........................................29

6. Flow model for borehole DW-23, near Machiasport, Maine .........................................30

7. Flow model for borehole DW-24, near Machiasport, Maine .........................................31

8. Flow model for borehole DW-25, near Machiasport, Maine ..........................................32

9. Flow model for borehole DW-31, near Machiasport, Maine .........................................34

10. Flow model for borehole DW-32, near Machiasport, Maine ............................................35

11. Flow model for borehole DW-33, near Machiasport, Maine ............................................36

12. Flow model for borehole DW-34, near Machiasport, Maine ..............................................37

13. Flow model for borehole DW-39, near Machiasport, Maine .............................................38

14. Flow model for borehole DW-40, near Machiasport, Maine ...........................................39

15. Flow model for borehole WY-GATR, near Machiasport, Maine.........................................41

16. Flow model for borehole DW-2, near Machiasport, Maine ...............................................42

17. Flow model for borehole WY-4, near Machiasport, Maine .................................................45

18. Flow model for borehole WY-15, near Machiasport, Maine ...........................................46

19. Flow model for borehole DW-6, near Machiasport, Maine..............................................4

20. Transmissivity results for borehole DW-10, near Machiasport, Maine............................48

21. Topographic setting and direction of ambient flow for boreholes near Machiasport, Maine, sorted by land-surface elevation.

22. Summary of transmissivity values derived from heat-pulse flowmeter data and hydraulic tests for boreholes near Machiasport, Maine 


\section{Conversion Factors, Datum, and Abbreviations}

\begin{tabular}{lcl}
\hline & Multiply & \multicolumn{1}{c}{ Bo obtain } \\
\hline & Length & \\
\hline inch (in.) & 2.54 & centimeter $(\mathrm{cm})$ \\
inch (in.) & 25.4 & millimeter $(\mathrm{mm})$ \\
foot (ft) & 0.3048 & meter $(\mathrm{m})$ \\
\hline & Volume & \\
\hline gallon (gal) & 3.785 & liter $(\mathrm{L})$ \\
gallon (gal) & 0.003785 & cubic meter $\left(\mathrm{m}^{3}\right)$ \\
gallon (gal) & 3.785 & cubic decimeter $\left(\mathrm{dm}^{3}\right)$ \\
\hline & Flow rate & \\
\hline foot per minute (ft/min) & 0.3048 & meter per minute $(\mathrm{m} / \mathrm{min})$ \\
gallon per minute (gal/min) & 0.06309 & liter per second $(\mathrm{L} / \mathrm{s})$ \\
\hline & Specific capacity & \\
\hline gallon per minute per foot $[(\mathrm{gal} / \mathrm{min}) / \mathrm{ft})]$ & 0.2070 \\
\hline & Transmissivity* & liter per second per meter $[(\mathrm{L} / \mathrm{s}) / \mathrm{m}]$ \\
\hline foot squared per day $\left(\mathrm{ft}^{2} / \mathrm{d}\right)$ & 0.09290 & meter squared per day $\left(\mathrm{m}^{2} / \mathrm{d}\right)$ \\
\hline
\end{tabular}

Temperature in degrees Celsius $\left({ }^{\circ} \mathrm{C}\right)$ may be converted to degrees Fahrenheit $\left({ }^{\circ} \mathrm{F}\right)$ as follows: ${ }^{\circ} \mathrm{F}=\left(1.8 x^{\circ} \mathrm{C}\right)+32$

Temperature in degrees Fahrenheit $\left({ }^{\circ} \mathrm{F}\right)$ may be converted to degrees Celsius $\left({ }^{\circ} \mathrm{C}\right)$ as follows: ${ }^{\circ} \mathrm{C}=\left({ }^{\circ} \mathrm{F}-32\right) / 1.8$

Vertical coordinate information is referenced to the North American Vertical Datum of 1988 (NAVD 88).

Horizontal coordinate information is referenced to the North American Datum of 1983 (NAD 83).

Elevation, as used in this report, refers to distance above the vertical datum.

*Transmissivity: The standard unit for transmissivity is cubic foot per day per square foot times foot of aquifer thickness $\left[\left(\mathrm{ft}^{3} / \mathrm{d}\right) / \mathrm{ft}^{2}\right] \mathrm{ft}$. In this report, the mathematically reduced form, foot squared per day $\left(\mathrm{ft}^{2} / \mathrm{d}\right)$, is used for convenience.

Specific conductance is given in microsiemens per centimeter at 25 degrees Celsius $(\mu \mathrm{S} / \mathrm{cm}$ at $\left.25^{\circ} \mathrm{C}\right)$.

Concentrations of chemical constituents in water are given either in milligrams per liter (mg/L) or micrograms per liter $(\mu \mathrm{g} / \mathrm{L})$. 


$\begin{array}{ll}\text { ABBREVIATIONS USED IN REPORT } \\ \text { APlu } & \text { American Petroleum Institute units } \\ \text { ATV } & \text { acoustic televiewer } \\ \text { cps } & \text { counts per second } \\ \text { EMI } & \text { electromagnetic induction } \\ \text { gal/min/ft } & \text { gallons per minute per foot } \\ \text { h } & \text { hour } \\ \text { HPFM } & \text { heat-pulse flowmeter } \\ \text { in } & \text { inch } \\ \text { min } & \text { minute } \\ \text { mg/L } & \text { milligrams per liter } \\ \mathrm{mmhos} / \mathrm{m} & \text { millimhos per meter } \\ \mathrm{mS} / \mathrm{m} & \text { millisiemens per meter } \\ \mathrm{mV} & \text { millivolts } \\ \text { ohm-m } & \text { ohm-meter } \\ \text { OTV } & \text { optical televiewer } \\ \mathrm{ppm} & \text { parts per million } \\ \mathrm{RMS} & \text { root-mean square } \\ \mathrm{SP} & \text { spontaneous potential } \\ \mathrm{SPR} & \text { single-point resistance } \\ \mathrm{SSE} & \text { sum of squares error } \\ \mu \mathrm{S} / \mathrm{cm} & \text { microseimens per centimeter } \\ & \end{array}$




\title{
Borehole Geophysical Investigation of a Formerly Used Defense Site, Machiasport, Maine, 2003-2006
}

\author{
By Carole D. Johnson, Remo A. Mondazzi, and Peter K. Joesten
}

\section{Abstract}

The U.S. Geological Survey, in cooperation with the U.S. Army Corps of Engineers, collected borehole geophysical logs in 18 boreholes and interpreted the data along with logs from 19 additional boreholes as part of an ongoing, collaborative investigation at three environmental restoration sites in Machiasport, Maine. These sites, located on hilltops overlooking the seacoast, formerly were used for military defense. At each of the sites, chlorinated solvents, used as part of defensesite operations, have contaminated the fractured-rock aquifer. Borehole geophysical techniques and hydraulic methods were used to characterize bedrock lithology, fractures, and hydraulic properties. In addition, each geophysical method was evaluated for effectiveness for site characterization and for potential application for further aquifer characterization and (or) evaluation of remediation efforts.

Results of borehole geophysical logging indicate the subsurface is highly fractured, metavolcanic, intrusive, metasedimentary bedrock. Selected geophysical logs were cross-plotted to assess correlations between rock properties. These plots included combinations of gamma, acoustic reflectivity, electromagnetic induction conductivity, normal resistivity, and single-point resistance. The combined use of acoustic televiewer (ATV) imaging and natural gamma logs proved to be effective for delineating rock types. Each of the rock units in the study area could be mapped in the boreholes, on the basis of the gamma and ATV reflectivity signatures. The gamma and mean ATV reflectivity data were used along with the other geophysical logs for an integrated interpretation, yielding a determination of quartz monzonite, rhyolite, metasedimentary units, or diabase/gabbro rock types. The interpretation of rock types on the basis of the geophysical logs compared well to drilling logs and geologic mapping. These results may be helpful for refining the geologic framework at depth.

A stereoplot of all fractures intersecting the boreholes indicates numerous fractures, a high proportion of steeply dipping fractures, and considerable variation in fracture orientation. Low-dip-angle fractures associated with unloading and exfoliation are also present, especially at a depth of less than 100 feet below the top of casing. These sub-horizontal fractures help to connect the steeply dipping fractures, making this a highly connected fracture network. The high variability in the fracture orientations also increases the connectivity of the fracture network.

A preliminary comparison of all fracture data from all the boreholes suggests fracturing decreases with depth. Because all the boreholes were not drilled to the same depth, however, there is a clear sampling bias. Hence, the deepest boreholes are analyzed separately for fracture density. For the deepest boreholes in the study, the intensity of fracturing does not decline significantly with depth. It is possible the fractures observed in these boreholes become progressively tighter or closed with depth, but this is difficult to verify with the borehole methods used in this investigation. The fact that there are more sealed fractures at depth (observed in optical televiewer logs in some of the boreholes) may indicate less opening of the sealed fractures, less water moving through the rock, and less weathering of the fracture infilling minerals.

Although the fracture orientation remained fairly constant with depth, differences in the fracture patterns for the three restoration sites indicate the orientation of fractures varies across the study area. The fractures in boreholes on Miller Mountain predominantly strike northwest-southeast, and to a lesser degree they strike northeast. The fractures on or near the summit of Howard Mountain strike predominantly east-west and dip north and south, and the fractures near the Transmitter Site strike northeast-southwest and dip northwest and southeast. The fracture populations for the boreholes on or near the summit of Howard Mountain show more variation than at the other two sites. This variation may be related to the proximity of the fault, which is northeast of the summit of Howard Mountain. In a side-by-side comparison of stereoplots from selected boreholes, there was no clear correspondence between fracture orientation and proximity to the fault. There is, however, a difference in the total populations of fractures for the boreholes on or near the summit of Howard Mountain and the boreholes near the Transmitter Site. Further to the southwest and further away from the fault, the fractures at the Transmitter Site predominantly strike northeast-southwest and northwest-southeast.

Heat-pulse flowmeter (HPFM) logging was used to identify transmissive fractures and to estimate the hydraulic properties along the boreholes. Ambient downflow was measured in 13 boreholes and ambient upflow was measured in 9 boreholes. In nine other bedrock boreholes, the HPFM did not detect measurable vertical flow. The observed direction of vertical flow in the boreholes generally was consistent with the 
conceptual flow model of downward movement in recharge locations and upward flow in discharge locations or at breaks in the slope of land surface.

Under low-rate pumping or injection rates $[0.25$ to 1 gallon per minute (gal $/ \mathrm{min})$ ], one to three inflow zones were identified in each borehole. Two limitations of HPFM methods are (1) the HPFM can only identify zones within 1.5 to 2 orders of magnitude of the most transmissive zone in each borehole, and (2) the HPFM cannot detect flow rates less than $0.010 \pm 0.005 \mathrm{gal} / \mathrm{min}$, which corresponds to a transmissivity of about 1 foot squared per day $\left(\mathrm{ft}^{2} / \mathrm{d}\right)$. Consequently, the HPFM is considered an effective tool for identifying the most transmissive fractures in a borehole, down to its detection level. Transmissivities below that cut-off must be measured with another method, such as packer testing or fluidreplacement logging.

Where sufficient water-level and flowmeter data were available, HPFM results were numerically modeled. For each borehole model, the fracture location and measured flow rates were specified, and the head and transmissivity of each fracture zone were adjusted until a model fit was achieved with the interpreted ambient and stressed flow profiles. The transmissivities calculated by this method are similar to the results of an open-hole slug test; with the added information from the flowmeter, however, the head and transmissivity of discrete zones also can be determined. The discrete-interval transmissivities ranged from 0.16 to $330 \mathrm{ft}^{2} / \mathrm{d}$. The flowmeter-derived open-hole transmissivity, which is the combined total of each of the transmissive zones, ranged from 1 to $511 \mathrm{ft}^{2} / \mathrm{d}$. The whole-well open-hole transmissivity values determined with HPFM methods were compared to the results of open-hole hydraulic tests. Despite the fact that the flowmeter-derived transmissivities consistently were lower than the estimates derived from open-hole hydraulic tests alone, the correlation was very strong (with a coefficient of determination, $\mathrm{R}^{2}$, of 0.9866), indicating the HPFM method provides a reasonable estimate of transmissivities for the most transmissive fractures in the borehole.

Geologic framework, fracture characterization, and estimates of hydraulic properties were interpreted together to characterize the fracture network. The data and interpretation presented in this report should provide information useful for site investigators as the conceptual site groundwater flow model is refined. Collectively, the results and the conceptual site model are important for evaluating remediation options and planning or implementing the design of a well field and borehole completions that will be adequate for monitoring flow, remediation efforts, groundwater levels, and (or) water quality. Similar kinds of borehole geophysical logging (specifically the borehole imaging, gamma, fluid logs, and HPFM) should be conducted in any newly installed boreholes and integrated with interpretations of any nearby boreholes. If boreholes are installed close to existing or other new boreholes, cross-hole flowmeter surveys may be appropriate and may help characterize the aquifer properties and connections between the boreholes.

\section{Introduction}

The U.S. Geological Survey (USGS) collected borehole geophysical logs in 18 boreholes and interpreted them along with logs from 19 additional boreholes as part of an ongoing, collaborative investigation at three environmental restoration sites in Machiasport, Maine (fig. 1). The former ground-air transmitter-receiver (GATR) site is on Miller Mountain (fig. 1). The former Air Force Radar Tracking Station (AFRTS) and a former Transmitter Site are on Howard Mountain. Collectively, the three sites have been classified by the U.S. Department of Defense as a Formerly Used Defense Site (FUDS), and the environmental restoration is managed by the U.S. Army Corps of Engineers (USACE). As part of the ongoing investigations, the USGS, in cooperation with the USACE, conducted borehole geophysical surveys to identify the location and orientation of fractures, to identify which fractures are hydraulically active, to test the potential applications of each borehole geophysical method for further aquifer characterization and (or) evaluation of remediation efforts, and to use the results to verify and refine the site conceptual groundwater flow models.

During the operation of the military base from the 1950s to the 1980s, the U.S. Air Force used solvents, including trichloroethylene (TCE), trichloroethane (TCA), and tetrachloroethene (PCE), for automotive maintenance, paint thinning, degreasing, and cleaning electronic equipment (Weston Solutions, 2005). TCE was reportedly disposed of directly on the ground surface at the three facilities and in the leach field at the GATR site. In addition, TCE was used as a defoliant and herbicide at the three facilities (Leitch and Clemens, 2006). Over the last 20 years, these chemicals have leached into the shallow groundwater and into the bedrock. During the 1990s, the Federal Aviation Administration (FAA) discovered numerous occurrences of groundwater contamination at the former AFRTS (fig. 1) in Machiasport, Maine.

Contaminant-distribution data indicated potential TCE source areas were present in the southern part of Howard Mountain summit area (Weston Solutions, 2005). Because residential wells were contaminated with fuel and TCE, in 1997, the Maine Department of Environmental Protection (MEDEP) ordered the USACE to clean up the site and to provide an alternative water supply for local residents (ABB Environmental Services, Inc., 1997).

The USGS conducted the logging investigation in two phases. The initial logging was conducted in November 2004 and continued in March and April 2005. Borehole geophysical surveys were conducted in 5 monitoring wells and 13 domestic wells that are collectively called "boreholes" in this investigation (table 1). Six of the boreholes are on or near Howard Mountain, including four near the AFRTS site and two near the Transmitter Site (fig. 1). Geophysical surveys also were collected in 12 boreholes on or near Miller Mountain. 


\section{Purpose and Scope}

This report summarizes the purpose, methods of investigation, and results of a borehole geophysical-logging investigation conducted in November 2004 and March-April 2005 at the former AFRTS in Machiasport, Maine. These investigations were conducted in cooperation with the USACE to expand the USACE existing hydrogeologic interpretation of the site. As a part of the evaluation, this report summarizes the borehole geophysical and hydraulic data collected from 18 boreholes and domestic wells completed in bedrock and summarizes the interpretation of geophysical logs from a total of 37 boreholes. Mechanical caliper logs, borehole imaging, and electromagnetic induction (EMI) logs were used to confirm borehole construction and borehole integrity. Borehole logging methods, including gamma and electric (EMI, normal resistivity, and single-point resistance), were used to determine electrical properties of the geologic formations. Borehole imaging, including acoustic televiewer (ATV) and optical televiewer (OTV), was used to identify the location and orientation of bedrock fractures. Fluid and hydraulic properties of the aquifer were determined using the fluid logging tool, which measures the specific conductance, temperature, $\mathrm{pH}$, oxidation-reduction potential, and percent oxygen of the water in the borehole column. The heat-pulse flowmeter (HPFM) was used to measure vertical flow in the borehole and to determine the depth of inflow and outflow under pumping and ambient conditions.

Borehole geophysical logs were collected in 12 boreholes by Geophysical Applications, Inc., in 2003 (Weston Solutions, 2005). Two of those boreholes, WY-3B and MW-13, were logged again in 2003 and in 2004 by the USGS. In 2006, seven additional boreholes were logged by Hager-Richter Geoscience, Inc. (The Johnson Company, 2006). The original data for these 19 additional boreholes have been published and are not reproduced in this report. However, the image data for these boreholes were interpreted as a part of this investigation and are summarized together with the boreholes logged by the USGS. The results of the three logging efforts were combined into a single borehole geophysical dataset. The structural interpretations for all 37 boreholes in the study area are summarized for each of the contaminated sites in the study area. There were a total of 14 boreholes at the Miller Mountain site, 17 boreholes at the Howard Mountain site, and 6 boreholes at the Transmitter Site (fig. 1).

\section{Description of the Study Area}

The study area includes the area around and between Howard, Miller, and Bucks Mountains (fig. 1). The study area is characterized by small hills that have been shaped by glacial and recent erosion, creating a northwest-southeast oriented drainage pattern parallel to the direction of glacial movement. The eastern side of Howard Mountain is characterized by a steep cliff face with highly fractured bedrock exposure that trends northwest-southeast and parallels a mapped fault zone. The study area ranges in elevation from $252 \mathrm{ft}$ on Miller Mountain and $243 \mathrm{ft}$ on Howard Mountain to boreholes at $43 \mathrm{ft}$ above NAVD 88 .

Four major rock types are mapped in the study area (Gates and Moench, 1981). The oldest rock unit is the early Devonian Eastport Formation, which is characterized by two distinct lithologic groups and original depositional settings. The unit is exposed at the land surface southeast of Miller Mountain near Bucks Neck in the northern part of the study area. The rock unit consists of shale, siltstone, and fine-grained bedded tuffs and is gray and maroon in color. The second rock type is a younger unit of the Eastport Formation, a bimodal volcanic unit consisting of silicic members including a rhyolitic eruptive unit with flow-banded stony rhyolite, vitrophyre, autobreccia, and pyroclastic zones. Dacite and tuff breccias also are locally present, but no basalt flows have been found in the study area (Drew Clemens, U.S. Army Corps of Engineers, written commun., 2006). This early Devonian volcanic unit is the most abundant rock in the study area and has been mapped on Howard Mountain southward and eastward to the coast. The volcanic units erupted along a fault bordering the Machias syncline.

The third rock type is a Devonian plutonic unit consisting of hornblende-bearing biotite, granodiorite, and quartz monzonite (a suite of quartz diorite to diorite rocks) that were intruded into the Eastport Formation. The granodiorite has been mapped on the northwest side of Howard Mountain and on the south-southeast flank of Miller Mountain. The unit has also been observed to a depth of about $52 \mathrm{ft}$ below land surface in rock core from borehole MW-14 on the south-southeastern flank of Miller Mountain (Weston Solutions, 2005).

The fourth unit consists of Silurian-Devonian-age diabase dikes and sills that were emplaced during and after volcanism. Many of these mafic dikes strike northwest-southeast. These mafic intrusives are present throughout the study area. Massive diabase and gabbro were mapped on the summit and eastern side of Miller Mountain (Gates and Moench, 1981).

Large-scale regional structures include a syncline, normal faults, and block faults. The site lies within the Machias syncline, which is a post-early Devonian, northeasttrending fold that includes the Pembroke Group and Eastport Formation. The Lubec fault zone, a northeast-trending fault, was mapped offshore from the Bucks Harbor site and is characterized by sheared and tightly folded rocks of the Eastport and Quoddy Formations (Gates and Moench, 1981). Subsequent block faulting associated with Silurian volcanism created numerous northwest-trending faults. A large normal fault transects the study area and is coincident with the northwest-southeast trending drainage between Howard and Miller Mountains (ENSR, 2006). The fault is mapped from the coast at Howard Cove and extends inland several miles to the northwest. Numerous northwest-southeast trending faults dissect the region with scattered northeast-southwest faulting and folding (Gates, 1981). These faults and associated fractures appear to have had an effect on the development of 


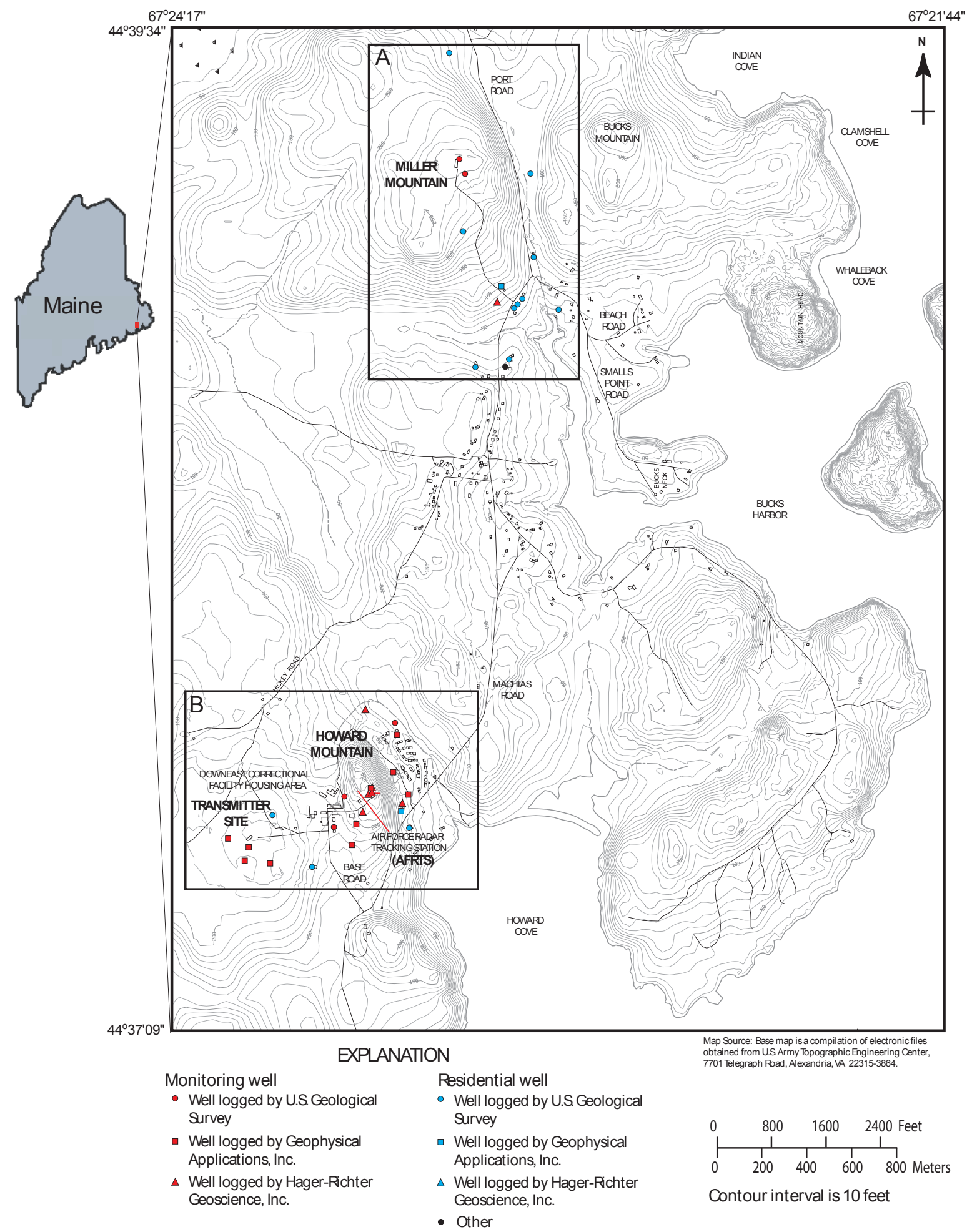

Figure 1. Locations of boreholes near a Formerly Used Defense Site, Machiasport, Maine. 

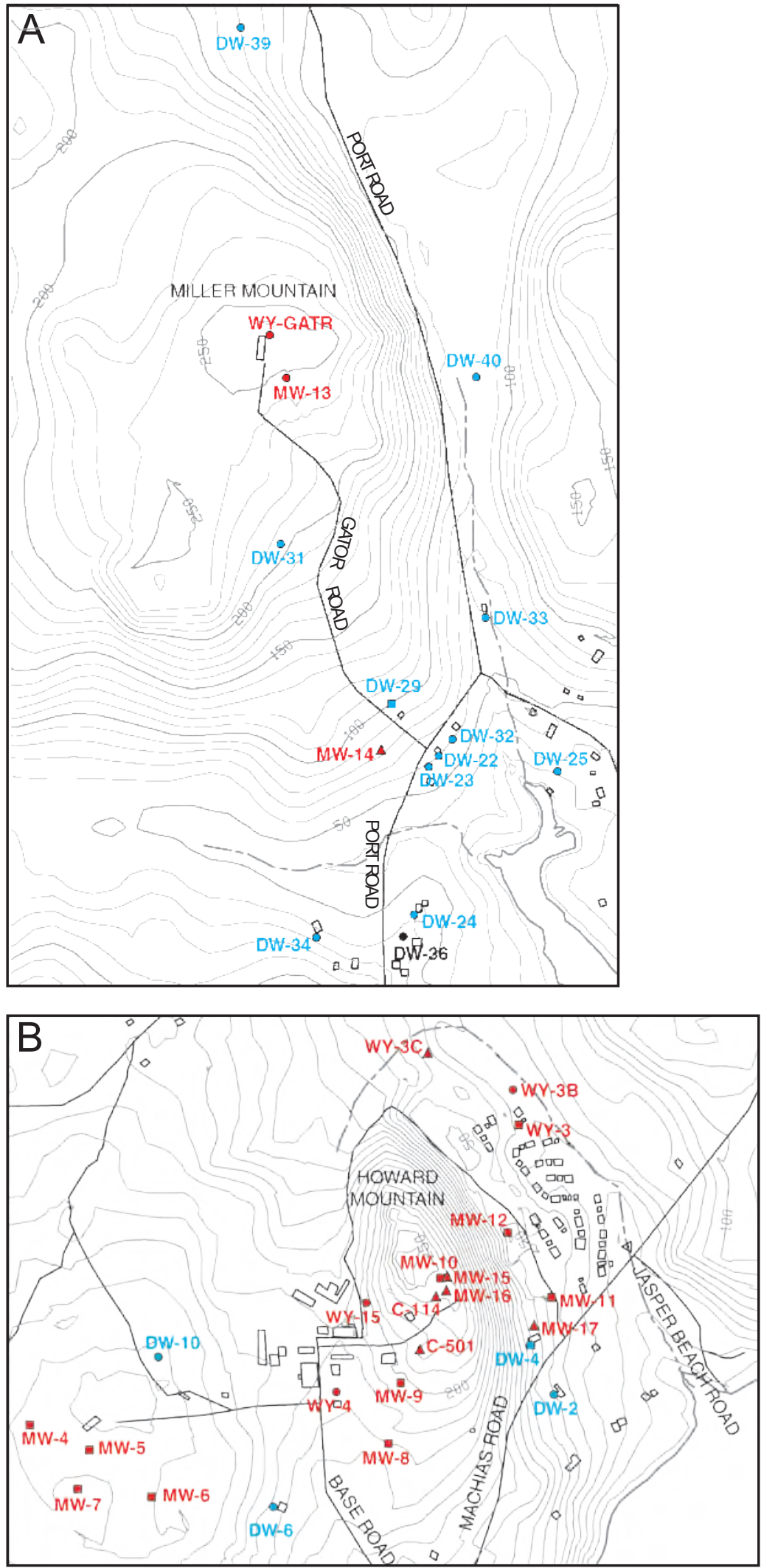

\section{EXPLANATION}

- MW-9 Monitoring well and identification number

- Well logged by U.S. Geological Survey

- Well logged by Geophysical Applications, Inc.

$\Delta \quad$ Well logged by Hager-Richter Geoscience, Inc.

- DW-6 Residential well and identification number

- Well logged by U.S. Geological Survey

․ Well logged by Geophysical Applications, Inc.

- DW-36 Residential well and identification number

Map Source: Base map is a compilation of electronic files obtained from U.S Army Topographic Engineering Center, 7701 Telegraph Road, Alexandria, VA 22315-3864.

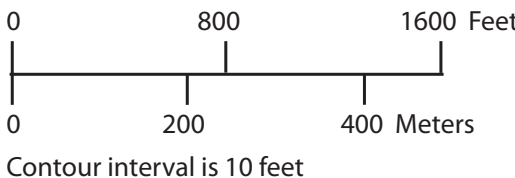

Figure 1. Locations of boreholes near a Formerly Used Defense Site, Machiasport, Maine.-Continued 
Table 1. Boreholes at the Formerly Used Defense Site, Machiasport, Maine.

[TOC is top of casing. Negative land-surface correction values indicate the top of casing is below land surface. Latitude and longitude shown in degrees, minutes, digital seconds for North American Datum of 1983; --, no data]

\begin{tabular}{|c|c|c|c|c|c|c|c|c|}
\hline Borehole & $\begin{array}{l}\text { U.S. Geological } \\
\text { Survey local } \\
\text { identifier }\end{array}$ & $\begin{array}{c}\text { Elevation } \\
\text { of borehole } \\
\text { TOC } \\
\text { (feet) }\end{array}$ & $\begin{array}{l}\text { Land } \\
\text { surface } \\
\text { correction } \\
\text { (feet) }\end{array}$ & $\begin{array}{l}\text { Depth of } \\
\text { borehole } \\
\text { from TOC } \\
\text { (feet) }\end{array}$ & $\begin{array}{c}\text { Casing } \\
\text { length } \\
\text { (feet) }\end{array}$ & Latitude & Longitude & Dates logged \\
\hline DW-22 & ME-WW 974 & 57.44 & 0.34 & 110 & 22.5 & 443854.39 & 672309.56 & $11 / 10-11 / 2004$ \\
\hline DW-23 & ME-WW 975 & 54.54 & 1.95 & 181.2 & 21.7 & 443853.84 & 672310.28 & $11 / 09-12 / 2004$ \\
\hline DW-29 & -- & 99.80 & 2.54 & 117 & 8 & 443856.94 & 672313.30 & 2006 \\
\hline DW-31 & ME-WW 978 & 208.80 & 2.20 & 245 & 17 & 443905.12 & 672320.50 & $11 / 11-12 / 2004$ \\
\hline DW-32 & ME-WW 979 & 64.55 & 1.40 & 105 & 23.5 & 443855.22 & 672308.57 & $11 / 13-14 / 2004$ \\
\hline DW-33 & ME-WW 980 & 52.80 & 1.98 & 82 & 34 & 443901.26 & 672306.20 & $11 / 13 / 2004$ \\
\hline MW-13 & ME-WW 982 & 253.90 & 3.48 & 220 & 20.5 & 443913.39 & 672319.96 & 6/2003, 11/09-10/2004 \\
\hline MW-14 & ME-WW 983 & 78.57 & 4.10 & 99.1 & 22 & 443854.63 & 672313.74 & $6 / 2003$ \\
\hline WY-GATR & ME-WW 970 & 255.26 & 3.45 & 417 & 27 & 443915.32 & 672321.04 & $\begin{array}{l}11 / 12 / 2004 \text { and } \\
3 / 30 / 2005-4 / 04 / 2005\end{array}$ \\
\hline \multicolumn{9}{|c|}{ Howard Mountain-Air Force Radar Tracking Station } \\
\hline DW-2 & ME-WW 964 & 66.31 & 2.60 & 222.3 & 17.7 & 443738.66 & 672333.11 & $3 / 30-31 / 2005$ \\
\hline DW-4 & -- & 83.96 & 1.06 & 243.1 & ${ }^{2} 16$ & 443741.05 & 672334.80 & 2003 \\
\hline MW-8 & -- & 165.16 & 3.42 & 58.4 & 29 & 443736.30 & 672344.93 & 2003 \\
\hline MW-9 & ME-WW 971 & 197.51 & 2.89 & 122.9 & ${ }^{2} 9$ & 443739.35 & 672343.83 & 2003 \\
\hline MW-10 & ME-WW 972 & 245.96 & 2.66 & 203.7 & ${ }^{2} 19$ & 443744.52 & 672340.88 & 2003 \\
\hline WY-3C & -- & 69.78 & 1.44 & 353.0 & 104.2 & 443755.67 & 672341.64 & 2006 \\
\hline MW-15 & -- & 243.69 & 2.77 & 52.2 & 20 & 443756 & 672342 & 2006 \\
\hline MW-16 & -- & 240.37 & 2.52 & 172.0 & 23 & 443756 & 672342 & 2006 \\
\hline MW-17 & -- & 74.93 & 2.29 & 251.0 & 67 & 443756 & 672342 & 2006 \\
\hline C-114 & -- & 237.30 & 2.30 & 82.0 & -- & 443743.38 & 672341.24 & 2006 \\
\hline C-501 & -- & 221.60 & 2.70 & 50.5 & -- & 443740.87 & 672342.42 & 2006 \\
\hline \multicolumn{9}{|c|}{ Transmitter Site } \\
\hline DW-6 & ME-WW 965 & ${ }^{3} 175$ & 1.80 & 123.5 & 20.0 & 443733.20 & 672352.92 & $4 / 06 / 2005$ \\
\hline DW-10 & ME-WW 984 & 215.45 & 0.97 & 380 & 20 & 443740.73 & 672400.70 & $11 / 14-15 / 2004$ \\
\hline MW-4 & -- & 217.53 & 3.31 & 101.3 & ${ }^{2} 15$ & 443737.47 & 672409.99 & 2003 \\
\hline MW-5 & -- & 224.16 & 3.50 & 101.5 & ${ }^{2} 11$ & 443736.17 & 672405.91 & 2003 \\
\hline MW-6 & -- & 223.66 & 3.21 & 123.2 & 29 & 443733.80 & 672401.51 & 2003 \\
\hline MW-7 & -- & 208.00 & 2.41 & 132.4 & ${ }^{2} 9$ & 443734.21 & 672406.72 & 2003 \\
\hline
\end{tabular}

\footnotetext{
${ }^{1}$ Elevation estimated from map.

${ }^{2}$ Casing elevation, land-surface correction, depth of borehole from TOC, and casing length have been changed after the logging was done. Three feet of additional casing were added to the borehole after the logging was complete.

${ }^{3}$ Casing length from ground surface (Weston Solutions, written commun., 2005).
} 
the surface drainage and may be strong controls on the flow of groundwater within the bedrock aquifer.

Maps of the surficial deposits indicate most of the area is covered by a thin veneer of till and brown silty sand and gravel of Pleistocene age (Borns, 1974). ABB Environmental Services, Inc. (1995), however, indicated the Downeast Correctional Facility (DCF) housing area, located on the western slope of Howard Mountain, is underlain by mixed fill, silt, sand, and gravel glaciomarine deposits overlying gray glacial marine clay. The thickness of the clay in this area ranges from about 20 to more than $25 \mathrm{ft}$. No substantial amounts of overburden material have been mapped outside of the DCF housing area.

This investigation focused on boreholes in locations near to, or downgradient from, three suspected contaminationsource areas (Weston Solutions, 2005):

1. The GATR site is north of Bucks Harbor on Miller Mountain, which has a thin ( 0 to more than $5 \mathrm{ft}$ ) veneer of till and is underlain by a granodiorite that has been intruded by quartz monzonite, diabase and gabbro dikes, and gabbro sills (Gates, 1981). In outcrop and borehole exposures, the contacts between mafic dikes and gabbro/ diabase commonly are sharp. Diabase, also known as dolerite, is the hypabyssal representative of gabbro and basalt and is texturally intermediary to the coarse-grained gabbro and the aphanitic (microcrystalline) basalt. The mafic dikes cannot be further classified without thin-section and (or) chemical analyses but are likely to be basalt. On Miller Mountain, coarse-grained rocks are found near the summit, and fine-grained units are found on the periphery (James Vernon, ENSR International, written commun., 2006). Boreholes near the GATR site and logged as a part of this investigation include MW-13, WY-GATR, DW-22, DW-23, DW-24, DW-25, DW-31, DW-32, DW-33, DW-34, DW-39, and DW-40 (table 1). Data from additional boreholes that were used in the analysis and summary include MW-14 and DW-29. Previous investigations have identified groundwater contamination at the GATR site and to the southeast of the former GATR site on Miller Mountain.

2. The AFRTS site is on top of Howard Mountain, which is underlain by highly fractured banded sequences of rhyolite and stony rhyolite intruded by mafic dikes (Gates and Moench, 1981). Rhyolite is a fine-grained volcanic rock comprised predominantly of quartz and feldspar, having a fine-grained or glassy texture called vitrophyric texture. A stony rhyolite has a very-fine-grained crystalline texture. Boreholes near the AFRTS site and logged as part of this investigation include WY-3B, WY-4, WY-15, and DW-2 (table 1). Data from additional boreholes that were used in the analysis and summary include DW-4, MW-8, MW-9, MW-10, MW-11, MW-12, WY-3, WY-3C, MW-15, MW-16, MW-17, C-114, and C-501. Previous investigations have identified groundwater contamination northeast of the Howard Mountain site as well as near the summit of Howard Mountain.
3. The Transmitter Site is on a hill west of the Howard Mountain summit. The hill consists of glacial and end moraine till that ranges in thickness from 0 to over $11 \mathrm{ft}$ (Borns, 1974). The Transmitter Site is underlain by fractured stony to vitrophyric rhyolite locally intruded by northwest striking mafic dikes (Gates, 1981). Boreholes logged for this investigation near the Transmitter Site include DW-6 and DW-10 (table 1). Data from additional boreholes that were used in the analysis and summary include MW-4, MW-5, MW-6, and MW-7. Previous investigations have identified groundwater contamination to the southwest and northeast of the Transmitter Site and at the site itself.

\section{Previous Investigations}

Surface geophysical investigations were conducted in 2003 to identify the depth to bedrock and to characterize fracture patterns in the bedrock (White and others, 2005; Thompson and others, 2005). These investigations confirmed the presence of a thin veneer of glacial deposits 0.5 to $10 \mathrm{ft}$ thick. In addition, the surface geophysical investigations identified locations with highly fractured bedrock surface and fracture zones extending into the bedrock subsurface. The surface geophysical data were used to identify possible fracture zones that could potentially serve as contaminant pathways in the crystalline rock (White and others, 2005). The results were used by the USACE to optimize the siting of boreholes for additional subsurface investigation (U.S. Army Corps of Engineers, 2004).

Results of the Remedial Investigation (RI) phase of drilling, coring, and borehole geophysical logging performed in 2003 were summarized by Weston Solutions (2005). Additional surface geophysical surveys were conducted to identify the former location of buildings used for the operation of the defense site (Thompson and others, 2005). Results of these investigations have been used by the USACE to help identify possible contamination-source locations and to plan additional remediation work at the site.

The USGS conducted a pilot investigation to determine the effectiveness of borehole-radar methods in the mafic dike-intruded rhyolite underlying Howard Mountain and to determine the optimal separation distance for hole-to-hole radar surveys (Johnson and Joesten, 2005). Because of the highly resistive rock, radar reflections were detected up to $130 \mathrm{ft}$ into the rock from the borehole. The radar surveys also showed that the subsurface bedrock on Howard Mountain is highly fractured with steeply dipping fractures consistent with fractures observed in outcrops.

In 2006, borehole geophysical logs were collected in five boreholes and two inclined coreholes (The Johnson Company, 2006). The coreholes, on Howard Mountain, were drilled at inclined angles in the area of the borehole radar investigations to intersect the maximum number of fracture planes. Four of the boreholes were on Howard Mountain and one was near Miller Mountain. 


\section{Borehole Geophysical Methods}

The USGS conducted borehole geophysical logging in the study area on November 9-16, 2004, and March 30April 5, 2005. The purpose of the geophysical logging was to characterize the fractured-rock aquifer and to evaluate the potential application of these geophysical tools to future remediation monitoring and evaluation efforts in this hydrogeologic setting. The geophysical logs collected in each borehole are summarized in tables 2 and 3.

Geophysical logs measuring a range of earth properties at different scales of resolution were collected in each of the bedrock boreholes. For each borehole, the different logs were synergistically analyzed together to provide an integrated interpretation, thereby reducing the ambiguity that can occur by interpreting each geophysical log individually.

Conventional and advanced borehole geophysical methods were used in this study to provide information about the physical, electrical, and chemical properties of the bedrock and fluids in the subsurface and to provide important information on subsurface structures including lithology, bedrock fabric, and location, orientation, and hydraulic properties of fractures. Conventional borehole geophysical methods include caliper, gamma, normal resistivity, single-point resistance, spontaneous potential, EMI, fluid resistivity/conductivity, fluid temperature, and deviation. Advanced borehole geophysical methods include optical-televiewer imaging, acoustic-televiewer imaging, HPFM logging (under ambient and pumping conditions), and water-quality logging, which measures typical field parameters of $\mathrm{pH}$, temperature, specific conductance, dissolved oxygen, oxidation-reduction potential, and pressure.

The gamma, resistivity, and acoustic and optical image data were used to determine changes in the subsurface lithology. Fracture location and orientations were identified using a combination of acoustic and optical imaging, mechanical caliper, and normal resistivity logs. Hydraulic characterization made use of the fluid temperature and resistivity, water-quality, and HPFM logs. The hydrogeologic interpretation included determination of the magnitude and direction of vertical flow within boreholes and calculation of the specific capacity and transmissivity of the open holes and of selected fractures or fracture zones in the boreholes. Collectively, these data are critical for understanding the sources of water obtained from pumping a borehole, whether it is for purposes of obtaining a water sample or for domestic water supply. These data can be used to assess large-scale recharge-discharge patterns, to design source-area remediation alternatives, to design a groundwater monitoring program, and (or) to identify the potential for cross-contamination within an open borehole.

Table 2. Borehole logs collected by the U.S. Geological Survey in 2004 and 2005, near Machiasport, Maine.

[EMI, electromagnetic induction logging; Res., resistivity; SP, spontaneous potential; SPR, single-point resistance logging; OTV, optical televiewer logging; ATV, acoustic televiewer logging; Temp., temperature; HPFM, heat-pulse flowmeter logging; X indicates the log was collected; -- indicates the log was not collected]

\begin{tabular}{|c|c|c|c|c|c|c|c|c|c|c|c|c|c|c|c|c|c|c|}
\hline \multirow[b]{2}{*}{$\log$} & \multicolumn{18}{|c|}{ Borehole } \\
\hline & พั & $\sum_{0}^{0}$ & $\frac{\frac{1}{1}}{3}$ & $\begin{array}{l}\text { ฟิ } \\
\text { ב̀ }\end{array}$ & $\begin{array}{l}\text { ָ̃ } \\
\text { خे }\end{array}$ & $\begin{array}{l}\text { స̃ } \\
\text { 宫 }\end{array}$ & $\begin{array}{l}\text { 㞻 } \\
\text { ב⿱ }\end{array}$ & 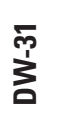 & 管 & 昰 & 琧 & 䒜 & 导 & 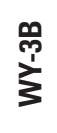 & $\frac{8}{3}$ & $\frac{12}{\frac{1}{3}}$ & 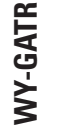 & $\sum_{\Sigma}^{\frac{m}{1}}$ \\
\hline Caliper & $\mathrm{X}$ & $X$ & $\mathrm{X}$ & $X$ & $\mathrm{X}$ & $\mathrm{X}$ & $\mathrm{X}$ & $\mathrm{X}$ & $\mathrm{X}$ & $\mathrm{X}$ & $X$ & $\mathrm{X}$ & $X$ & $\mathrm{X}$ & $\mathrm{X}$ & $X$ & $X$ & $\mathrm{X}$ \\
\hline Gamma & $\mathrm{X}$ & $\mathrm{X}$ & $\mathrm{X}$ & $\mathrm{X}$ & $\mathrm{X}$ & $\mathrm{X}$ & $X$ & $\mathrm{X}$ & $X$ & $\mathrm{X}$ & $X$ & $X$ & $\mathrm{X}$ & $X$ & $\mathrm{X}$ & $X$ & $\mathrm{X}$ & $\mathrm{X}$ \\
\hline EMI & $\mathrm{X}$ & $\mathrm{X}$ & $\mathrm{X}$ & $\mathrm{X}$ & $\mathrm{X}$ & $\mathrm{X}$ & $\mathrm{X}$ & $\mathrm{X}$ & $X$ & $X$ & $X$ & -- & -- & $\mathrm{X}$ & $\mathrm{X}$ & $X$ & $\mathrm{X}$ & $\mathrm{X}$ \\
\hline Normal Res. & $\mathrm{X}$ & $\mathrm{X}$ & $\mathrm{X}$ & $\mathrm{X}$ & $\mathrm{X}$ & $\mathrm{X}$ & $\mathrm{X}$ & $\mathrm{X}$ & $\mathrm{X}$ & $\mathrm{X}$ & $\mathrm{X}$ & $X$ & $\mathrm{X}$ & $X$ & $\mathrm{X}$ & $X$ & $\mathrm{X}$ & $\mathrm{X}$ \\
\hline SP & $\mathrm{X}$ & $\mathrm{X}$ & $\mathrm{X}$ & $\mathrm{X}$ & $\mathrm{X}$ & $\mathrm{X}$ & $\mathrm{X}$ & $\mathrm{X}$ & $\mathrm{X}$ & $\mathrm{X}$ & $\mathrm{X}$ & $\mathrm{X}$ & $\mathrm{X}$ & $\mathrm{X}$ & $\mathrm{X}$ & $\mathrm{X}$ & $\mathrm{X}$ & $\mathrm{X}$ \\
\hline SPR & $\mathrm{X}$ & $\mathrm{X}$ & $\mathrm{X}$ & $\mathrm{X}$ & $\mathrm{X}$ & $\mathrm{X}$ & $\mathrm{X}$ & $X$ & $\mathrm{X}$ & $\mathrm{X}$ & $\mathrm{X}$ & $X$ & $\mathrm{X}$ & $\mathrm{X}$ & $\mathrm{X}$ & $\mathrm{X}$ & $\mathrm{X}$ & $\mathrm{X}$ \\
\hline OTV & -- & -- & $\mathrm{X}$ & $\mathrm{X}$ & $\mathrm{X}$ & -- & -- & $\mathrm{X}$ & -- & -- & -- & -- & -- & -- & -- & -- & $\mathrm{X}$ & -- \\
\hline ATV & $\mathrm{X}$ & $\mathrm{X}$ & $\mathrm{X}$ & $\mathrm{X}$ & $\mathrm{X}$ & $\mathrm{X}$ & $\mathrm{X}$ & $\mathrm{X}$ & $\mathrm{X}$ & $\mathrm{X}$ & $\mathrm{X}$ & $\mathrm{X}$ & $\mathrm{X}$ & $\mathrm{X}$ & $\mathrm{X}$ & $\mathrm{X}$ & $\mathrm{X}$ & ${ }^{1} \mathrm{X}$ \\
\hline Fluid Res. and Temp. & $\mathrm{X}$ & $\mathrm{X}$ & $\mathrm{X}$ & $\mathrm{X}$ & $\mathrm{x}$ & $\mathrm{X}$ & $\mathrm{X}$ & $\mathrm{X}$ & $\mathrm{X}$ & $\mathrm{X}$ & $\mathrm{X}$ & $\mathrm{X}$ & $\mathrm{X}$ & $\mathrm{X}$ & $\mathrm{X}$ & $\mathrm{X}$ & $\mathrm{X}$ & $\mathrm{X}$ \\
\hline Water quality & $\mathrm{X}$ & $\mathrm{X}$ & $\mathrm{X}$ & $\mathrm{X}$ & $\mathrm{X}$ & $\mathrm{X}$ & $\mathrm{X}$ & -- & $\mathrm{X}$ & $\mathrm{X}$ & -- & -- & -- & $\mathrm{X}$ & $\mathrm{X}$ & $\mathrm{X}$ & $\mathrm{X}$ & ${ }^{1} \mathrm{X}$ \\
\hline HPFM-ambient & $\mathrm{X}$ & $\mathrm{X}$ & $\mathrm{X}$ & $\mathrm{X}$ & $\mathrm{X}$ & $\mathrm{X}$ & $\mathrm{X}$ & $\mathrm{X}$ & $\mathrm{X}$ & $\mathrm{X}$ & $\mathrm{X}$ & $\mathrm{X}$ & $\mathrm{X}$ & -- & $\mathrm{X}$ & $\mathrm{X}$ & $\mathrm{X}$ & ${ }^{1} \mathrm{X}$ \\
\hline HPFM-post stress & $\mathrm{X}$ & $\mathrm{X}$ & $\mathrm{X}$ & $\mathrm{X}$ & $\mathrm{X}$ & $\mathrm{X}$ & $\mathrm{X}$ & $\mathrm{X}$ & $\mathrm{X}$ & $\mathrm{X}$ & $\mathrm{X}$ & $\mathrm{X}$ & $\mathrm{X}$ & -- & $\mathrm{X}$ & $\mathrm{X}$ & $\mathrm{X}$ & ${ }^{1} \mathrm{X}$ \\
\hline
\end{tabular}

${ }^{1}$ Data collected by Geophysical Applications, Inc. (Weston Solutions, 2005). 


\section{Caliper Logging}

The "mechanical" caliper instrument generates a continuous record of the borehole diameter using a threearm, spring-loaded tool (Keys, 1990). Changes in borehole diameter are caused by drilling and borehole-construction procedures, collapse of less-competent rocks, and the presence of fractures. The borehole diameter was recorded in inches. Two mechanical caliper tools, manufactured by different companies, were used for this investigation. Their model numbers are Century Geophysical Corp. (CGC) 9065A and the Mount Sopris Instruments, Inc. (MSI) 2PCA/F. Both caliper tools were calibrated to 4- and 7-in. calibration rings prior to each measurement. Acoustic caliper methods are discussed with the acoustic televiewer.

\section{Gamma Logging}

Gamma logging records the total amount of gamma radiation emitted by the formation surrounding the borehole (Keys, 1990). The most common naturally occurring sources of gamma radiation are potassium- 40 and daughter products of the uranium- and thorium-decay series. The gamma logs were used to help delineate changes in rock type in the formation surrounding the borehole. Mafic igneous rocks typically have very low counts of total gamma relative to less mafic rocks such as rhyolites and dacites. Consequently, intrusions of mafic rock show fewer gamma counts than the country rock adjacent to them.

The vertical resolution of the gamma probe is 1 to $2 \mathrm{ft}$. Although a change in rock type or alteration associated with a fracture can be detected, the tool requires a thickness of $1 \mathrm{ft}$ to obtain a full response. The gamma logs were collected at a constant logging speed of 10 to $15 \mathrm{ft} / \mathrm{min}$.

The gamma tools are calibrated by the manufacturers to American Petroleum Institute units (APIu); however, over time, the tool can drift away from this calibration. Hence, without verification that the tool is referenced to APIu, the gamma emissions can be measured in units of counts per second. With measurements in counts per second, the gamma data are no longer referenced to a common standard, but the measurements collected by a single tool can be compared directly with each other. However, gamma data collected in counts per second with different tools may not be directly comparable to one another. If the counts per second logs are normalized to a single tool response, the measurements can be consistent across the site.

Table 3. Borehole logs collected by others in 2003 and 2006, near Machiasport, Maine.

[EMI, electromagnetic induction logging; Res., resistivity; SP, spontaneous potential; SPR, single-point resistance logging; OTV, optical televiewer logging; ATV, acoustic televiewer logging; Temp., temperature; HPFM, heat-pulse flowmeter logging; X indicates the log was collected; -- indicates the log was not collected]

\begin{tabular}{|c|c|c|c|c|c|c|c|c|c|c|c|c|c|c|c|c|c|c|c|}
\hline \multirow{3}{*}{$\log$} & \multicolumn{19}{|c|}{ Borehole } \\
\hline & \multicolumn{12}{|c|}{12003} & \multicolumn{7}{|c|}{22006} \\
\hline & $\frac{⿱ 亠 䒑}{\vdots}$ & $\sum_{\Sigma}^{\infty}$ & $\sum_{\Sigma}^{\infty}$ & $\frac{0}{\frac{1}{3}}$ & $\sum_{\Sigma}^{\bar{T}}$ & 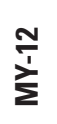 & $\grave{m}_{3}^{m}$ & 范 & $\sum_{\Sigma}^{+}$ & $\sum_{\Sigma}^{\text {L }}$ & $\sum_{\Sigma}^{0}$ & $\sum_{\Sigma}^{\top}$ & $\begin{array}{l}\text { న్ } \\
\text { خุ }\end{array}$ & $\frac{12}{3}$ & $\frac{0}{\sum}$ & $\underset{\sum}{\sum}$ & 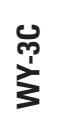 & $\frac{\mathbb{\Xi}}{\sigma}$ & لَ. \\
\hline Caliper & $X$ & $X$ & $X$ & $X$ & $X$ & $X$ & $X$ & $\mathrm{X}$ & $\mathrm{X}$ & $X$ & $\mathrm{X}$ & $X$ & $X$ & $X$ & $X$ & $X$ & $X$ & -- & -- \\
\hline EMI & $\mathrm{X}$ & $\mathrm{X}$ & $\mathrm{X}$ & $\mathrm{X}$ & $\mathrm{X}$ & $\mathrm{X}$ & $\mathrm{X}$ & $\mathrm{X}$ & $\mathrm{X}$ & $\mathrm{X}$ & $\mathrm{X}$ & $\mathrm{X}$ & -- & $\mathrm{X}$ & $\mathrm{X}$ & -- & -- & -- & $\mathrm{X}$ \\
\hline Normal Res. & $X$ & $X$ & $\mathrm{X}$ & $\mathrm{X}$ & $\mathrm{X}$ & $\mathrm{X}$ & $\mathrm{X}$ & $\mathrm{X}$ & $\mathrm{X}$ & $\mathrm{X}$ & $\mathrm{X}$ & $\mathrm{X}$ & $\mathrm{X}$ & -- & $\mathrm{X}$ & $X$ & $X$ & $\mathrm{X}$ & $X$ \\
\hline SP & $\mathrm{X}$ & $\mathrm{X}$ & $\mathrm{X}$ & $\mathrm{X}$ & $\mathrm{X}$ & $\mathrm{X}$ & $\mathrm{X}$ & $\mathrm{X}$ & $\mathrm{X}$ & $\mathrm{X}$ & $\mathrm{X}$ & $\mathrm{X}$ & $\mathrm{X}$ & -- & $\mathrm{X}$ & $\mathrm{X}$ & $\mathrm{X}$ & $\mathrm{X}$ & $\mathrm{X}$ \\
\hline SPR & $\mathrm{X}$ & $\mathrm{X}$ & $\mathrm{X}$ & $\mathrm{X}$ & $\mathrm{X}$ & $\mathrm{X}$ & $\mathrm{X}$ & $\mathrm{X}$ & $\mathrm{X}$ & $\mathrm{X}$ & $\mathrm{X}$ & $\mathrm{X}$ & $\mathrm{X}$ & -- & $\mathrm{X}$ & $\mathrm{X}$ & $\mathrm{X}$ & $\mathrm{X}$ & $\mathrm{X}$ \\
\hline Water quality & $\mathrm{X}$ & $\mathrm{X}$ & $\mathrm{X}$ & $\mathrm{X}$ & $\mathrm{X}$ & $\mathrm{X}$ & $X$ & $\mathrm{X}$ & $\mathrm{X}$ & $\mathrm{X}$ & $\mathrm{X}$ & $\mathrm{X}$ & -- & -- & -- & -- & -- & -- & -- \\
\hline HPFM-ambient & $\mathrm{X}$ & $\mathrm{X}$ & $\mathrm{X}$ & $\mathrm{X}$ & $\mathrm{X}$ & $\mathrm{X}$ & -- & -- & $\mathrm{X}$ & $\mathrm{X}$ & $\mathrm{X}$ & $\mathrm{X}$ & $\mathrm{X}$ & $\mathrm{X}$ & $\mathrm{X}$ & $\mathrm{X}$ & $\mathrm{X}$ & -- & -- \\
\hline HPFM-post stress & $\mathrm{X}$ & $\mathrm{X}$ & $\mathrm{X}$ & $\mathrm{X}$ & $\mathrm{X}$ & $\mathrm{X}$ & -- & -- & $\mathrm{X}$ & $\mathrm{X}$ & $\mathrm{X}$ & $\mathrm{X}$ & $\mathrm{X}$ & $\mathrm{X}$ & $\mathrm{X}$ & $\mathrm{X}$ & $\mathrm{X}$ & -- & -- \\
\hline
\end{tabular}


Four gamma tools were used in this investigation (table 4). In order to compare gamma data collected in counts per second using the different gamma tools, the logs were adjusted to a common datum. The gamma counts of the CGC 9042 tool were used as a common datum because most of the boreholes were logged with the CGS 9042 tool and because the counts were strong. To normalize the other logs to the 9042 tool response, gamma logs were adjusted with a multiplication factor that adjusts the counts to match the log collected with the 9042 tool. The normalization factors were determined by comparing logs in boreholes that were logged with multiple tools over the portions of the boreholes that were logged with more than one tool. The adjustments of the gamma counts per second values permit direct comparison of all the gamma logs. The gamma logs collected with the multi-parameter resistivity tool (MSI model number 2PEA 0-2500 ohm-m, Gam, Res) were multiplied by 1.4 (table 4 ). The gamma data collected with the CGC EMI tool (model number 9511) were multiplied by 0.77 . Because of a calibration error in the MSI fluid tool (model number 2PCA/F +PPGA), data collected with this tool were used sparingly. However, when the gamma data were adjusted to the 9042 -tool data by multiplying by 20 , they were consistent with data from the other tools.

\section{Resistivity Logging}

For this investigation, normal resistivity, single-point resistance (SPR), spontaneous potential (SP), and gamma were all measured with the same tool.

\section{Normal Resistivity Logging}

Normal resistivity logging measures the apparent resistivity of the formation in ohm-meters over a range of electrode spacings. The tool applies a constant current across two electrodes while measuring the potential between two other electrodes. Traditionally, normal resistivity was measured over two distances, called long and short normal. For this investigation, four measurement spacings were used. The volume of investigation is roughly a sphere whose diameter is equal to twice the potential-electrode spacing, which was fixed at $8,16,32$, and $64 \mathrm{in}$. However, the exact shape and volume of investigation change depending on the resistivity of the formation. To obtain the true resistivity, the apparent resistivity must be corrected for borehole diameter, drilling mud invasion, and formation bed thickness (Keys, 1990). In many cases, the apparent resistivity can be used to identify fractures and changes in the lithology. The normal resistivity tool is more accurate than the EMI tool for measuring the electrical properties of the rock when the resistivities are high, as is typical with crystalline and silicic volcanic rock.

The normal resistivity tool is only used in the uncased and saturated portion of the borehole. A MSI tool (model 2PEA 0-2500 ohm-m, Gam, Res) was used to collect the data.
Table 4. Correction factors for gamma tools used in this study.

[CGC, Century Geophysical Corporation; MSI, Mount Sopris Instruments, Inc.; EMI, electromagnetic induction]

\begin{tabular}{lc}
\hline \multicolumn{1}{c}{ Tool with gamma detector } & Correction factor \\
\hline CGC (9042) fluid tool & 1.0 \\
MSI (2PEA) normal resistivity tool & 1.4 \\
CGC (9511) EMI conductivity & 0.77 \\
MSI (2PCA/F + PPGA) fluid tool & 20 \\
\hline
\end{tabular}

For this investigation, a resistivity calibration box, with known resistivities ranging from 25 to $2,000 \mathrm{ohm}-\mathrm{m}$, was used prior to data collection to verify the tool was working correctly. All calibration measurements were verified to have less than 1 percent error. Because the resistivity of the rock formations at this site is higher than the functional range of the tool, the measured values should only be viewed qualitatively; relative changes in normal resistivity measurements were used to identify changes in lithology and the presence of fractures where the resistivity decreases adjacent to the fractures.

\section{Single-Point Resistance Logging}

Single-point resistance logging measures the electrical resistance between an electrode (or mudfish) buried at the land surface and a down-hole electrode. The resistance data are recorded in ohms. The measurement, which is highly influenced by borehole diameter, is a bulk measurement of the resistance of the formation, fluids saturating the formation, and fluids in the borehole. Increases in borehole diameter typically are associated with a decrease in resistance. Singlepoint resistance data can be used to delineate changes in lithology, clay content, porosity, and total dissolved solids in the formation water. The single-point resistance is measured below the casing in a water-filled borehole. For this investigation, the single-point resistance tool was checked against a calibration box and calibrated against a low of $20 \mathrm{ohms}$ and a high of $130 \mathrm{ohms}$. The tool was verified to have less than 3 percent error for the low-range measurement and less than 1 percent error for the high-range measurement.

\section{Spontaneous Potential Logging}

SP measures the electric potentials that develop between borehole fluid and the formation. Electric potentials occur at the contact between different materials with differing resistivities. In addition, potentials can be generated at locations of electrochemical or kinetic activity, such as at a flowing fracture. SP is measured in millivolts and represents the potential between the uppermost electrode in the tool and the armor of the cable, which is above the isolation bridle that extends to $24.7 \mathrm{ft}$ above the top of the tool. These logs are run only in the uncased and saturated sections of a borehole. 


\section{Electromagnetic-Induction Logging}

EMI logging measures the bulk electrical conductivity of the formation and the fluids in the formation surrounding the borehole (Williams and others, 1993). The tool uses an electromagnetic induction field to induce an electrical current in the surrounding formation. The induced current generates a secondary electromagnetic field. At low induction numbers (less than $100 \mathrm{mmhos} / \mathrm{m}$ ), the strength of the electromagnetic field is proportional to the formation conductivity. Changes in electrical conductivity are caused by variations in porosity, borehole diameter, concentration of dissolved solids of the water in the formation, and metallic minerals. The EMI probe is designed to maximize vertical resolution and radial penetration and to minimize the effects of the borehole fluid. The tool response is most sensitive to the bedrock and pore water approximately $1 \mathrm{ft}$ away from the probe, and the tool has a vertical resolution of approximately $2 \mathrm{ft}$. In boreholes with diameters of 6 in. or less, the specific conductance of the borehole fluids has a negligible effect on the induction-log response (Keys, 1990). Both CGC 9511 and MSI 2PIA tools were used for this study.

Calibration rings with conductivity values of either 15 or $98 \mathrm{mS} / \mathrm{m}$ and a free-air value of zero were used to calibrate the tools. During calibration, the tool is inserted into the calibration ring and held vertically in the air. It is best to calibrate the tool and to collect data at the same temperature because EMI tools do not compensate for thermal changes. During this investigation, the following procedure was used to maintain thermal equilibrium between tool calibration and data collection:

1. Turn the tool power on,

2. Lower the tool into the borehole until fully submerged in the water,

3. Wait approximately $15 \mathrm{~min}$ for the electronics and the tool to equilibrate to the borehole fluid temperature,

4. Remove the tool from the borehole for calibration, and

5. Conduct calibration procedures quickly in order to prevent the tool temperature from equilibrating with the open air temperature.

The boreholes were then logged with tools calibrated to the ambient temperature of the borehole. EMI logs typically were collected in both directions. The data from logging down the borehole were compared to the data from logging upward to assess and verify there was no thermal drift in the tool response. For analysis, the log collected going up the borehole with the cable under tension was used.

The EMI log is used to delineate changes in rock type or in electrical properties of water in the rock formation. Because the bedrock at this site is highly resistive, the measured conductivity values are very small. Although the tool was calibrated at each borehole, it is difficult in these electrically resistive rock units to calibrate the tool accurately enough to prevent the measured values from going negative. In this setting, the EMI tool is most effective for identifying the bottom of steel casing. This information is valuable especially when the water level is below the bottom of casing, in which case the high-resolution acoustic televiewer data are not available to determine the bottom of casing.

\section{Deviation Logging}

Deviation logging provides a continuous record of the three-dimensional geometry of a borehole (Keys, 1990). Data collected by a 3 -axis magnetometer and 3 -axis inclinometer are used to compute deviation in the azimuthal direction $\left(0-360^{\circ}\right)$ and inclination $\left(0-90^{\circ}\right)$ over the depth of the borehole. Borehole-deviation tools generally indicate an azimuthal bearing to within $\pm 2^{\circ}$ and inclination to within $\pm 0.5^{\circ}$. Deviation logs are collected simultaneously with ATV and OTV logs. The deviation tool is calibrated at the factory under controlled laboratory conditions, but the tool response was checked simultaneously with the field check of the ATV (see the next section).

The deviation logs were processed using WellCAD software version 4.0. In post-processing, the azimuthal bearing and the inclination angles were used to calculate the deviation in the northing and easting directions and the true vertical depth for each depth increment of the log. The magnetic declination for the Bucks Harbor site (17.5 $5^{\circ}$ west of true north) was incorporated into the deviation post-processing. Deviation results were plotted in radial plots and in cross sections, and the results were used for correcting the orientation of planar features intersecting the borehole and identified in the ATV and OTV data. In addition, the deviation logs can be used to identify badly deviated boreholes so that potential logging problems can be avoided. These data also are essential for processing any future hole-to-hole geophysical data.

\section{Acoustic-Televiewer Logging}

ATV logging produces a high-resolution, magnetically oriented, digital image that is used to map the location and orientation of fractures that intersect the borehole (Williams and Johnson, 2004). The ATV tool emits a narrow acoustic beam that rotates $360^{\circ}$ and is focused at the borehole wall. The acoustic wave moves through the fluid in the borehole, is reflected off the borehole wall, and is recorded by the tool. The log records the amplitude and traveltime of the reflected wave, which can be displayed as a flattened $360^{\circ}$ image of the borehole wall.

Two ATV tools were used at the Bucks Harbor siteCGC model 9801 and MSI model ABI40. The CGC model 9801 can collect logs at speeds of $12 \mathrm{ft} / \mathrm{min}$ and can log boreholes with diameters of up to $9 \mathrm{in}$. The MSI multi-echo ABI-40 can collect logs at speeds up to $3 \mathrm{ft} / \mathrm{min}$ but can $\log$ 
boreholes with diameters of up to 20 in. The ABI-40 tool uses a fixed head (source) and rotating mirror to direct the acoustic beam to the borehole wall and back to the transducer, producing higher-resolution images than the tools that have a rotating source and receiver (Williams and Johnson, 2004). Although the tool designs are slightly different, both produce oriented images of the acoustic traveltime and reflectivity of the borehole wall. The reflectivity values from the two tools vary. The tools were calibrated by the manufacturers under controlled laboratory settings. Only a field check was performed on the ATV tool prior to data collection in order to verify direction and deviation. Using a 6-in.-diameter casing with a vertical slot in a bucket of water, the image orientation and the bearing and magnitude of deviation were checked and the results recorded. The image and deviation data were collected relative to magnetic north, and the interpretation, images, and deviation were corrected for magnetic declination during post-processing.

The ATV logs are used to determine well construction, changes in lithology, and the location and orientation of fractures. The televiewer data also can be used to identify the bottom of the casing in both the traveltime and amplitude plots. The reflectivity or contrast in acoustic impedance between the fluid and the borehole wall can be correlated to the rock type. The traveltime and amplitude data were interpreted side-by-side.

A fracture that intersects the borehole causes scattering of the acoustic wave and appears as a high contrast, low amplitude line (dark feature) on the acoustic amplitude image. On the acoustic traveltime log, a fracture is indicated by an increase in the one-way traveltime of the wave because of an increase in borehole diameter. The "acoustic caliper," which is derived from the traveltime log, provides a much higher resolution continuous record of borehole diameter than that collected with a three-arm caliper. Interpretation of the magnetically oriented images in conjunction with other logs allows for the determination of transmissive fracture structures that may provide information about the hydraulics of the aquifer.

Using post-processing software, the ATV images were rotated $17.5^{\circ}$ east to correct for magnetic declination; the images were corrected for missing data at incremental depths by interpolation with data above and below the missing data; and statistical values were calculated, including maximum, minimum, mean, and median for amplitude and traveltime for each depth increment. In addition, these statistical values can be used to help optimize the display settings to maximize the image resolution. Images near the base of casing were corrected to remove the "spin" in the images, caused by the presence of steel on the tool's magnetometer, so the fractures near the base of the casing can be identified.

Once the images were rotated and displayed, they were analyzed to determine the depth and orientation of fractures and other planar structural features on the images. The deviations of the boreholes were applied to the interpreted features to correct the structural interpretations. Structural interpretations were plotted in projection mode, which overlays directly on the image data, and in tadpole and stereo plots that help in the analysis of the image data.

All fracture orientations were interpreted directly off of the image logs and were exported from the interpretation software in the format of dip azimuth, the direction of dip in azimuthal degrees east of north, and dip magnitude in degrees from horizontal. The dip azimuth was converted to strike in right-hand-rule (RHR), in which the dip is always $90^{\circ}$ to the right of the strike direction. Both formats, dip azimuth and strike in RHR, describe the orientation of a planar feature with respect to north and can be used interchangeably. However, the strike format is conventional and has been used in most geologic mapping. Strike and dip are reported in both formats.

The mean and median acoustic amplitude values were computed for each depth increment in the ATV log, resulting in logs that can be used for a more rigorous comparison between logs. Cross-plots were generated to visualize the correlation between pairs of logs, such as gamma and acoustic reflectivity or EMI conductivity and acoustic reflectivity. Because of design differences, the acoustic reflectivity values are different for the two ATV tools used in this investigation. The reflectivity values for the CGC tool are about 10 times greater than those of the MSI tool. Hence, logs collected by the same tool can be compared directly, but only relative comparisons can be made between logs collected with different tools.

\section{Optical-Televiewer Logging}

OTV logging records a magnetically oriented, $360^{\circ}$ optical image of the borehole wall (Williams and Johnson, 2004). The OTV can be used in air or below the borehole water level, provided the water has low turbidity. Fractures, foliation, flow banding, and lithologic changes nearly as small as the sampling interval can be interpreted from OTV images. Minor tonal changes visible in the images are because of changes in texture and mineralogy. Because the OTV is an optical system, features with low optical contrast, such as small fractures in dark rocks, can be difficult to delineate. Also, sediment, oxidation products, and biological activity that mask the borehole wall or cause turbidity in the water can degrade the quality of the OTV image. The OTV logs were analyzed to identify lithology and to determine the physical characteristics and orientation of fractures.

A major advantage of optical imaging over acoustic imaging is that surveys can be conducted above the water level. In this investigation, selected boreholes, where there was an extensive length of open borehole exposed above the water level, were logged with an OTV tool [Advanced Logic Technology (ALT) model 2OIA-1000 (ALT OBI40)]. Because of the time required to collect optical images, not all boreholes were logged with the OTV tool. The OTV image data were processed for rotation, analyzed, and corrected for deviation using methods similar to those described for the ATV data. 


\section{Fluid Logging}

Fluid electrical resistivity and temperature are measured simultaneously. Frequently, these logs are collected first in the borehole; the logs are collected while logging from the top of the borehole downward in order to minimize disturbance of the ambient water conditions in the borehole. For this investigation, CGC 9042 and MSI 2PFA-1000 fluid tools were used to measure the ambient water column in the borehole.

\section{Fluid Conductivity (Fluid-Resistivity) Logging}

The electrical resistivity of the borehole fluid is measured, and its inverse, fluid conductivity in microsiemens per centimeter, is calculated. The specific conductance, which is the fluid conductivity at a reference temperature (usually 25 or $20^{\circ} \mathrm{C}$ ), can be calculated using:

$$
\text { Specific conductance }=\frac{10,000}{\left[1+0.022\left(T-T_{\text {ref }}\right)\right][\Omega]},
$$

where

$$
\begin{array}{cl}
T & \text { is the temperature, in degrees Celsius; } \\
T_{\text {ref }} & \text { is the reference temperature, typically } 25 \text { for } \\
& \text { specific conductance at } 25^{\circ} \mathrm{C} \text {; and } \\
\Omega & \text { is the fluid resistivity at } T, \text { in ohm-meters. }
\end{array}
$$

Changes in specific conductance indicate differences in the concentration of total dissolved solids in the fluid in the borehole (Williams and Conger, 1990). These differences typically indicate sources of water that have contrasting chemistry and have come from different transmissive fracture zones where the water has a different residence time in the aquifer or, most dramatically, saltwater intrusion into freshwater aquifers.

A fluid log can be collected under ambient, undisturbed conditions and after pumping has stopped. A comparison of logs collected under ambient and hydraulically stressed conditions can help identify the locations of contributing inflow zones. In most boreholes in the study area, pumping was conducted and fluid logs were collected under undisturbed ambient conditions and after stressed conditions. However, in one borehole, WY-GATR, where the depth to water was deep, water was injected into the borehole, rather than pumped from the borehole, because of the difficulty in pumping water from below a depth of $150 \mathrm{ft}$ and the high contamination levels in the groundwater. In this case, the post-injection fluid resistivity and temperature logs were used to identify the injected water in the water column.

\section{Temperature Logging}

Temperature logging measures the temperature of the water in the borehole and is used to help identify where water enters or exits the borehole (Williams and Conger, 1990).
In the absence of fluid flow in the borehole, the temperature gradually increases with the geothermal gradient, about $1^{\circ} \mathrm{F}$ per $100 \mathrm{ft}$ of depth (Keys, 1990). Deviations from the local geothermal gradient indicate transmissive zones in the borehole. Intervals of vertical flow within the borehole are characterized by little or no temperature gradient. The differential or "del" temperature (the first derivative of the temperature plot) was calculated and inspected to help identify changes in the slope of the temperature profile and deviations from the geothermal gradient.

Temperature logs were interpreted in conjunction with specific conductance and flowmeter logs to identify fluid flow in the borehole under ambient and stressed conditions. For each borehole, the fluid resistivity, fluid conductivity, fluid temperature, and specific conductance were analyzed to identify hydraulically active fractures under pumping conditions and vertical flow through the borehole under ambient conditions.

\section{Differencing of Fluid Logs}

A comparison of fluid logs collected before and after hydraulically stressing a borehole can be used to determine where water entered the borehole under pumping conditions or exited the borehole under injection conditions. Using differencing methods, where the fluid log from background conditions is subtracted from a fluid log collected during or after an induced hydraulic stress, an image of the changes between the two data sets is produced, therefore delineating the hydraulically active fractures.

The example in figure 2 shows fluid logs (conductivity, temperature, and specific conductance) before and after pumping in borehole DW-2. A comparison of these logs suggests water entered the borehole at depths of about 80 , 52 , and $24 \mathrm{ft}$ below the top of casing. Interpretation with the imaging logs was used to attribute the inflow to a specific fracture or fractures. In addition, these results were used with HPFM data for an integrated interpretation of borehole hydaulics. This example demonstrates the importance of analyzing each of the fluid logs and the utility of differencing the fluid logs collected before and after pumping or injection.

\section{Water-Quality Parameter Logging}

Although water-quality samples are the best method for evaluating the water chemistry, a multi-parameter water-quality probe can help provide valuable information about water conditions in the borehole and can help identify transmissive fractures. Water-quality parameters of the borehole column can be used to help assess contaminant attenuation processes and to identify potential inflow or outflow zones, zones of vertical flow, and potentially zones with horizontal flow. An Ocean Seven 303 probe, manufactured by Idronaut, Srl, was used to measure pressure, temperature, dissolved oxygen, specific conductance, $\mathrm{pH}$, and oxidation-reduction potential. 


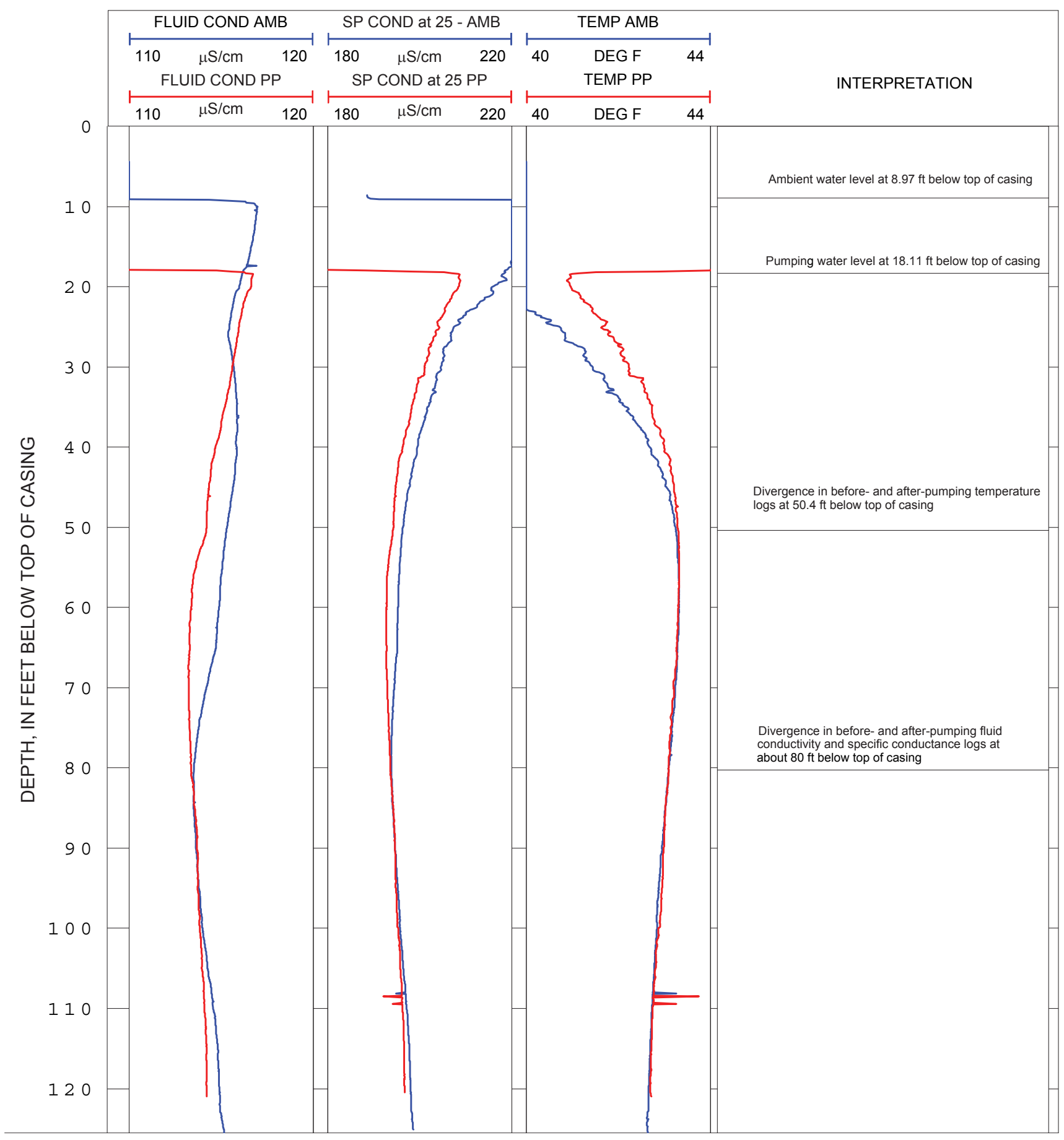

Figure 2. Example showing differences in fluid logs before and after imposing a hydraulic stress. (COND, conductivity; AMB, ambient; SP Cond at 25, specific conductance at 25 degrees Celsius; TEMP, temperature; PP, post pumping; Deg F, degrees Fahrenheit; $\mu \mathrm{S} / \mathrm{cm}$, microsiemens per centimeter) 
Similar to fluid logging, water-quality data can be collected under ambient and pumped conditions, and the differences can help identify hydraulically active zones in the borehole. For this investigation, the water-quality parameter tool was used in the ambient water column, unless otherwise noted. The waterquality parameter tool was checked with $\mathrm{pH}$ standards $(4,7$, and 10) and conductivity standards (usually 98,494 , and $1,000 \mu \mathrm{S} / \mathrm{cm}$ ) prior to measurements.

Because electrical properties are temperature dependent, the specific conductance is computed for a fixed temperature, $20^{\circ} \mathrm{C}$, so that data can be directly compared (Keys, 1990). The utility of the fluid $\log$ is not necessarily in the absolute value of the electrical resistivity, fluid conductivity, or temperature but rather in the relative changes along the water column that indicate potential inflow or outflow zones. The range of acidity and alkalinity of the water is measured with $\mathrm{pH}$ on a logarithmic scale of hydrogen and hydroxide concentration. When both ions have equal concentrations, the $\mathrm{pH}$ is neutral at 7.0. When more hydroxide ions are present, the $\mathrm{pH}$ is greater than 7 , and the water is alkaline. When more hydrogen ions are present, the $\mathrm{pH}$ is less than 7 , and the water is acidic, which can help mobilize elements in the water. Changes in $\mathrm{pH}$ in the water column can help identify inflow or outflow zones at fractures. Additionally, low $\mathrm{pH}$ values potentially indicate recharge zones. The typical $\mathrm{pH}$ in similar crystallinerock aquifers in nearby New Hampshire is 7.7; $\mathrm{pH}$ in sand and gravel is more acidic and closer to the $\mathrm{pH}$ of precipitation (Moore, 2004; Robinson and others, 2004).

Oxidation-reduction (redox) potential is a numerical index used to characterize whether water is under reducing conditions (negative values) or under oxidation conditions (positive values). In an oxidation-reduction process, electrons are transferred from the substance that is oxidized to the substance that is reduced. The redox potential is measured in millivolts. In the Idronaut tool, an electrochemical cell consisting of a reference electrode and a platinum electrode is used to measure the potential of the water in the borehole column. A correction factor must be added to the redox measurement to give a number relative to the potential of hydrogen, Eh (Idronaut, 2006). The correction factor for this tool is computed as follows:

$$
Y=-1.0239(T)+221.85,
$$

where

$Y \quad$ is the correction factor to be added to the redox measurement, in millivolts; and

$T$ is the temperature, in degrees Celsius.

Redox values along with $\mathrm{pH}$ values typically are used with the Nernst equation to predict the equilibrium behavior of multivalent elements such as iron and manganese (Hem, 1985). At sites contaminated with chlorinated solvents, redox conditions can be used as an indicator of whether conditions are favorable for reductive dechlorination or microbial oxidation (Bradley, 2003).
Dissolved oxygen (DO) logs are recorded in percent oxygen and in parts per million, which is equivalent to milligrams per liter. The presence of dissolved oxygen can be indicative of recharge zones where infiltrating water is rich in oxygen. In addition, dissolved oxygen can be used to determine the likelihood of aerobic or anaerobic conditions, which greatly impact the type and growth of microorganisms (Chapelle, 1993). Typically, DO greater than $1 \mathrm{ppm}$ indicates aerobic conditions; DO less than $1 \mathrm{ppm}$ indicates anaerobic conditions. Hence, at contamination sites, the characterization of DO may be important to identify the potential for natural attenuation or enhanced biodegradation.

Because the water-quality parameter tool measures the water in the water column in the borehole, it may not reflect the water chemistry in adjacent fractures. However, changes in the water chemistry may help identify ambient flow in the borehole or fractures that contribute to the borehole under stressed conditions. The results of the water-quality probe logging were used to optimize locations of the flowmeter measurements. The results also were compared to fluid logs collected under ambient and pumping conditions; temperature, fluid resistivity, and specific conductance data should be similar to those from the fluid tool; differences can be explained by changes in the water column imposed by pumping.

Where HPFM data were not collected, or where the interpretation of the HPFM profiles was ambiguous, the fluid and (or) water-quality logs were used to help identify hydraulically active zones in the borehole. Like the fluid conductivity and temperature tool, the water-quality tool can also be used in a differencing mode, by collecting logs before and after hydraulically stressing the borehole; in practice, it was not used in differencing mode because the log is time-consuming to collect (at a rate of $<5 \mathrm{ft} / \mathrm{min}$ ). Water-quality logs collected under ambient conditions, however, can identify zones where the flow rate is less than the resolution of the HPFM. Consequently, for all boreholes, the fluid conductivity, temperature, specific conductance, $\mathrm{pH}$, oxidation-reduction potential, and dissolved oxygen were plotted and compared with borehole imaging logs and flowmeter data for an integrated interpretation. In some cases where no flowmeter data were collected or where no flow was identified with the HPFM tool, the waterquality results were used to infer hydraulically active zones. The water-quality log in figure 3 shows an example of how these data were used to infer hydraulically active fractures.

\section{Heat-Pulse Flowmeter Logging}

HPFM logging measures the direction and rate of vertical flow in a borehole. Used in conjunction with other geophysical logs, fractures or fracture zones where water enters or exits the borehole can be identified with the flowmeter. Under ambient conditions, differences in hydraulic head between two transmissive fractures produce vertical flow in the borehole. Water enters the borehole at the fracture zone with the higher head and flows towards and out of the fracture with the lower 


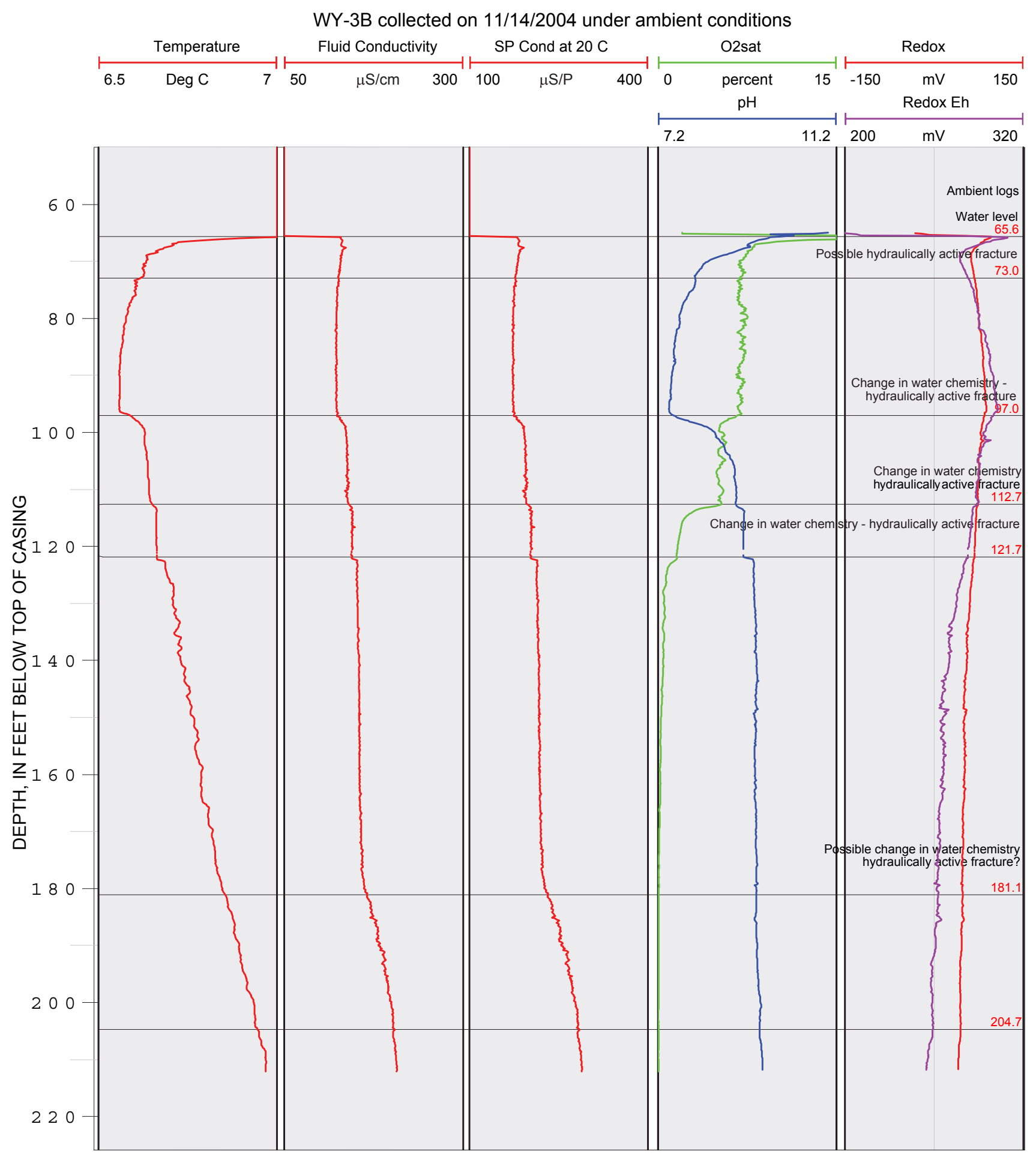

Figure 3. Example of interpretation of water-quality data to identify hydraulically active fractures. (Deg C, temperature in degrees Celsius; $\mu \mathrm{S} / \mathrm{cm}$, microsiemens per centimeter; SP Cond at 20C, specific conductance at 20 degrees Celsius; 02sat, dissolved oxygen in percent; Redox, oxidation-reduction potential, uncorrected; Redox Eh, redox oxidation-reduction potential relative to the potential of hydrogen, Eh; $\mathrm{mV}$, millivolt) 
head. If the hydraulic heads in transmissive zones are the same, there will be no vertical flow in the borehole. Therefore, flowmeter logging also is conducted under low-rate ( 0.25 to $1 \mathrm{gal} / \mathrm{min}$ ) pumping or injection to identify transmissive zones with similar ambient heads that would not be identified without stressing the aquifer. The flow under stressed (pumping or injection) conditions can be proportioned and attributed to specific fracture zones in the borehole.

The HPFM uses a heat-pulse tracer that moves upward or downward in the presence of vertical flow, and the tool measures the time it takes for the heat pulse to arrive at the sensor above or below the source. Typically, the flowmeter is outfitted with a diverter that channels all the flow through a measurement chamber. HPFM measurements were collected at discrete locations, usually above and below fractures at locations where the diverters seat well in the borehole and "capture" the vertical flow. Hence, the measurement locations were chosen in conjunction with the interpretations of the fluid temperature and resistivity, caliper, imaging, and water-quality parameter logs.

A MSI HPFM, model HPF-2293, was used for this investigation. The HPFM was calibrated at the factory under controlled conditions. When conditions permitted, flow measurements were made in the casing, which typically provides the best fit of the diverter, under known pumping conditions with a steady water level. These measurements were used to verify the performance of the tool. When necessary, the flowmeter measurements were normalized to these known flow rates.

The HPFM can measure flows as small as $0.01 \mathrm{gal} / \mathrm{min}$ (Hess and Paillet, 1990). In some cases, the temperature, specific conductance, and (or) other water-quality parameters may indicate potential inflow or outflow zones in a borehole, but the flow cannot be verified by flowmeter methods. Other methods such as discrete-interval packer testing (Shapiro, 2001) or hydrophysical logging (Tsang and others, 1990; Pedler and others, 1992) are needed to measure flow rates below the detection level of the HPFM. The upper detection limit of the HPFM is about $1 \mathrm{gal} / \mathrm{min}$ and can be extended by using an underfit diverter. An underfit diverter allows some of the water to by-pass the measurement channel, thereby reducing the amount of flow measured by the tool. In this investigation, four boreholes were pumped or were flowing under ambient conditions at rates greater than the range of the HPFM tool and required the use of an underfit (4-in.) diverter. By-pass factors, which are used to adjust measurements made with underfit diverters, were computed to determine how much water flows through the channel and how much bypasses the measurement channel with the specific underfit diverter. The measured flow rates are multiplied by the bypass factor, which is always greater than 1 (Paillet, 2004).

Water-level and HPFM measurements recorded during pumping ideally are made after the borehole reaches quasisteady state, in which the amount of water coming out of storage is less than the measurement resolution of the tool. The initial water level and the water level at quasi-steady state under stressed conditions were used in the numerical modeling of the flowmeter data. In addition, the specific capacity of the open boreholes was computed from the water level and pumping rates. The specific capacity is a relative measure of how much water can be pumped from the borehole per unit foot of drawdown. For selected wells that took a long time to reach steady state, the water-level data were used to compute how much water was derived from borehole storage, and this information was used in the interpretation of the flowmeter data.

For this investigation, selected low-yielding boreholes were pumped at a relatively high pumping rate to quickly lower the water level in the borehole. The flowmeter was then used to identify the inflowing zones as the water level recovered from pumping. However, the rate of recovery in this method is not steady because inflow rates are highest when the pump is turned off and dissipate as the water level recovers. Because the water levels in these low-yielding boreholes (for example, WY-15) did not reach steady state, transmissivity was estimated with transient solutions.

For selected boreholes, a pressure-sensitive transducer was used to record the water-level data before, during, and after stressing the boreholes. The results were analyzed to help identify oscillations or changes in the water level under ambient conditions as well as under stressed conditions. The water-level analysis helped identify tidal fluctuations and well interference.

\section{Estimates of Transmissivity and Hydraulic Characterization}

Transmissivity is a measure of the ability of the aquifer to transmit water. For each borehole, transmissivities were estimated for the open hole and for individual transmissive fractures and fracture zones within the borehole. Transmissivity values in this report should be considered estimates that are within an order of magnitude of the true borehole transmissivity.

\section{Estimation of Specific Capacity and Transmissivity of Open Boreholes}

The transmissivity was estimated in open boreholes from specific-capacity data collected concurrently with the HPFM logging under pumped conditions. The water-level drawdown and elapsed time of pumping were recorded in response to low-rate pumping. The duration of the single-hole pumping test was typically $1 \mathrm{~h}$ but ranged from 0.6 to $1.2 \mathrm{~h}$. The pumping rates for these tests were 0.25 to $1 \mathrm{gal} / \mathrm{min}$. Specific capacity, which is the yield of the borehole per unit length of drawdown, was calculated and recorded in gallon per minute per foot.

The open-hole transmissivity was calculated in one of three ways, depending on whether the borehole (1) reached a steady state under pumping, (2) did not reach steady state under pumping, or (3) was too hydraulically tight to pump. For boreholes that reached a steady water level under pumping 
conditions, an open-hole transmissivity was calculated using a program described by Bradbury and Rothschild (1985) with an assumed storage coefficient of 0.0005 for fractured rock (Freeze and Cherry, 1979). Well-loss coefficient is a parameter that quantifies the effects of turbulent flow, which causes drawdown in the borehole relative to the formation. The well-loss coefficient was not determined explicitly for these boreholes; thus, the value was set equal to 1.0 (Bradbury and Rothschild, 1985).

For selected boreholes that did not reach steady state, the Cooper-Jacob straight-line solution was used to estimate the transmissivity of the open borehole (Lohman, 1979). By this method, the drawdown was plotted against logarithmic time, and a straight line was fitted through late-time data. The change in water level over one log cycle was used to estimate transmissivity:

$$
T_{k}=(2.3 Q) /\left(4 \pi \Delta S_{1}\right)
$$

where

$$
\begin{array}{cc}
T_{k} \quad \begin{array}{c}
\text { is the transmissivity of zone } k, \text { in length } \\
\text { squared per time; }
\end{array} \\
Q \quad \begin{array}{c}
\text { is the constant pumping rate, in length cubed } \\
\text { per time; and }
\end{array} \\
\Delta S_{1} \quad \text { is the drawdown over } 1 \text { log cycle, in length. }
\end{array}
$$

For this method to be valid, the dimensionless parameter, $u$, should be less than or equal to about 0.01 , where $u=$ $\left(r^{2} S\right) /(4 T t) ; r$ is the borehole radius, $S$ is the storativity, $T$ is the transmissivity, and $t$ is the elapsed time of pumping. This method works best under confined conditions and when the distance between pumping and observation wells is small. When this method is used for a single-hole test, distance is set to 1. For comparative purposes, pumping tests analyzed with the Cooper-Jacob straight-line approximation also were analyzed with a Theis curve-matching solution (Lohman, 1979).

For boreholes that were thought to be hydraulically tight, a slug-test approach was used. A slug of water was removed quickly from the borehole, drawing the water level down several feet. Typically, the boreholes were pumped for about $10 \mathrm{~min}$ at the highest discharge rates, usually 3 to $5 \mathrm{gal} / \mathrm{min}$. After the pumping was terminated, the water-level recovery was monitored while concurrent HPFM measurements were made to identify inflow zones along the borehole. A CooperBredehoeft-Popadopulos (CBP) solution was used to approximate the open-hole transmissivity and storativity (Cooper and others, 1967). In the CBP method, the recovering head is normalized by the total initial displaced head and plotted against dimensionless time for type curves for dimensionless storage parameters. A curve-matching method is used to determine transmissivity and storativity for the borehole. The storage coefficient determined by this method does not yield highly reliable results (Cooper and others, 1967).

\section{Estimation of Transmissivity and Hydraulic Head of Fractures}

In all boreholes with HPFM data, transmissivity for the open-hole measurements was proportioned between transmissive zones using the method of subtraction (Paillet, 1995 and 2000). In boreholes with no measurable ambient flow, the open-hole transmissivity was apportioned according to HPFM results under pumping conditions. The total transmissivity determined for the open borehole was distributed among the hydraulically active zones in proportion to the relative contribution of each zone as measured by the HPFM. Proportioning the transmissivity to the individual fracture zones was used to estimate fracture-zone transmissivity; however, the transmissivity values determined by this method should be viewed qualitatively.

In boreholes with measurable ambient flow, numerical flow modeling was used to estimate transmissivity and the hydraulic head of each transmissive zone (Paillet, 1998). The difference between steady flows for each transmissive zone in a borehole under ambient and pumping conditions is a function of the transmissivity and water levels:

$$
Q_{k}^{s}-Q^{p}{ }_{k}=2 \pi T_{k}\left(w_{p}-w_{s}\right) \log _{e}\left(r_{d} / r\right),
$$

where

$$
\begin{aligned}
& Q_{k}^{s} \quad \text { is the flow into borehole from zone } k \text { under } \\
& \text { ambient conditions, in length cubed } \\
& \text { per time; } \\
& Q^{p} \quad \text { is the flow into borehole from zone } k \text { under } \\
& \text { pumping conditions, in length cubed } \\
& \text { per time; } \\
& T_{k} \quad \text { is the transmissivity of zone } k \text {, in length } \\
& \text { squared per time; } \\
& w_{p} \quad \text { is the water level in the borehole under } \\
& \text { pumping conditions, in length; } \\
& w_{s} \quad \text { is the water level in the borehole under } \\
& \text { ambient conditions, in length; } \\
& r_{0} \quad \text { is the zone radius, distance to the recharge } \\
& \text { boundary of the producing zone, in length; } \\
& \text { and } \\
& r \quad \text { is the borehole radius, in length. }
\end{aligned}
$$

The difference in flow between two fractures is directly proportional to zone transmissivity because the ratio between the zone and borehole radius can be treated as a constant. Because the open-hole head is a transmissivity-weighted average of all the heads in the borehole, the solution is further constrained by the open-hole heads under pumping and ambient conditions.

Using the FWRAP program by Paillet (1998 and 2000), the transmissivity and hydraulic head were determined for each hydraulically active zone. The method uses two flow regimes - either flow data for ambient and one pumping condition or flow data for two different pumping conditions - and 
the difference in water level between the two regimes. Model input requires information on the location of the transmissive fractures, ambient open-hole water level, quasi-steady-state water level under pumping conditions, HPFM data under two flow regimes, and estimates of transmissivity and head for each zone. The program produces models of the two flow regimes. The simulated regimes were graphically compared to the measured flow profiles, and the head and transmissivity parameters were iteratively varied until a unique solution was obtained for the transmissivity and head of each fracture. The model also provides a sum of squares error (SSE) analysis and root-mean square (RMS) values to assess the fit of the predicted flow profile to the measured profile and the validity of the solution. The final transmissivity and head estimates are presented in summary tables for each borehole.

\section{Analysis of Borehole Geophysical Data}

A brief summary of the methods of analysis is provided in this section. This is followed by a detailed explanation of data and interpretation for each of the boreholes, including a summary of the location and construction and a lithologic, fracture, and hydraulic characterization. The data for all boreholes are provided in appendixes 1-3. Interpretations of data collected by Geophysical Applications, Inc., in 2003 (Weston Solutions, 2005) and by Richter Geoscience, Inc., in 2006 (The Johnson Company, 2006) are in appendixes 4 and 5 , respectively.

\section{Methods of Analysis}

Borehole geophysical logs were used to determine construction of the borehole, to interpret the rock types, to identify fracture locations and orientations, and to estimate hydraulic parameters of the boreholes.

Lithology was determined using a combination of the borehole geophysical logs. Initially, cross-plots of data from multiple borehole logs were constructed to identify correlation of specific borehole logs with rock types and to determine a combination of individual logs that could be used to identify the rock types. Cross-plots of gamma and EMI conductivity, gamma and single-point resistance, and gamma and normal resistivity (figs. 4A-C) show bimodal clustering of gamma counts but scattered ranges of the second parameter. The cross-plot of gamma and mean amplitude of acoustic reflectivity, however, shows clustering of the gamma values and clustering of the reflectivity values (fig. 4D), making it a good indicator of lithology. Sections of borehole with low gamma counts had higher reflectivity and sections with higher gamma counts tended to have lower reflectivity. Although this analysis was done for several boreholes, figure 4 displays data collected for borehole DW-10, on Howard Mountain, to demon- strate the method and to describe how these data were used to interpret data from the other boreholes in the study area.

In figure 5, it is clear that the gamma and reflectivity logs ("GAM-fluid" and "ATV amp," respectively) for borehole DW-10 are visibility correlated with one another and with the OTV log and ATV traveltime log, which is also displayed in the form of an acoustic caliper plot. Together, these logs show a distinct correlation between gamma and acoustic reflectivity for the rock units. The mafic dikes centered at depths of 42 , $102,161,208$, and $298 \mathrm{ft}$ below the top of casing have very low gamma and high reflectivity, consistent with hard, mafic rock types. Acoustic and mechanical caliper logs support the conclusion that these low gamma zones are harder rock types than the country rock they intrude because the mafic dikes correspond to the smaller and smoother diameter sections of the borehole. The country rock, interpreted as rhyolite, has a higher gamma count and lower reflectivity and hardness than the mafic dikes. One additional consideration is that the reflectivity and gamma counts are affected by borehole diameter. Within the same rock unit, the reflectivity and gamma counts decline where the borehole is enlarged. Thus, these logs are interpreted closely with caliper, ATV, and OTV data, and minor variations at fractures were ignored while determining the rock types.

These logs describe two of the rock units in the study area, and hence borehole DW-10 was used as a borehole geophysical "type locality" for responses of the gamma and acoustic reflectivity tools to mafic dikes and rhyolite.

For borehole MW-14, the gamma and reflectivity logs were helpful in delineating major changes in the rock units. Geophysical logs collected in borehole MW-14 in June 2003 were plotted and compared to descriptions of the lithologic core (Weston Solutions, 2005) and to geologic maps (Gates and Moench, 1981). The core obtained from this borehole was described for texture, color, and mineralogy and is interpreted as quartz monzonite in the upper part of the borehole and diabase or gabbro in the lower part of the borehole. Relatively high gamma activity and low acoustic reflectivity amplitudes characterize the upper unit from the bottom of casing to about halfway down the borehole. The rock in the bottom half of the borehole is characterized by low gamma activity and high reflectivity. The cross-plot for gamma and acoustic reflectivity in borehole MW-14 shows a bimodal population in the gamma counts with one mode clustering just below $100 \mathrm{cps}$ and the other clustering over 200 cps (fig. 6). For the acoustic reflectivity, there is a large range of values, but the reflectivity values associated with low gamma values are higher than the reflectivity values associated with the higher gamma emissions. These logs are shown in further detail in the description of borehole MW-14. Because of the unique response of the gamma and reflectivity logs to the rock types in borehole MW-14, this borehole was used as another "type locality" for the gamma and acoustic reflectivity tools for two additional rock types in the study area - quartz-monzonite and diabase and (or) gabbro. 

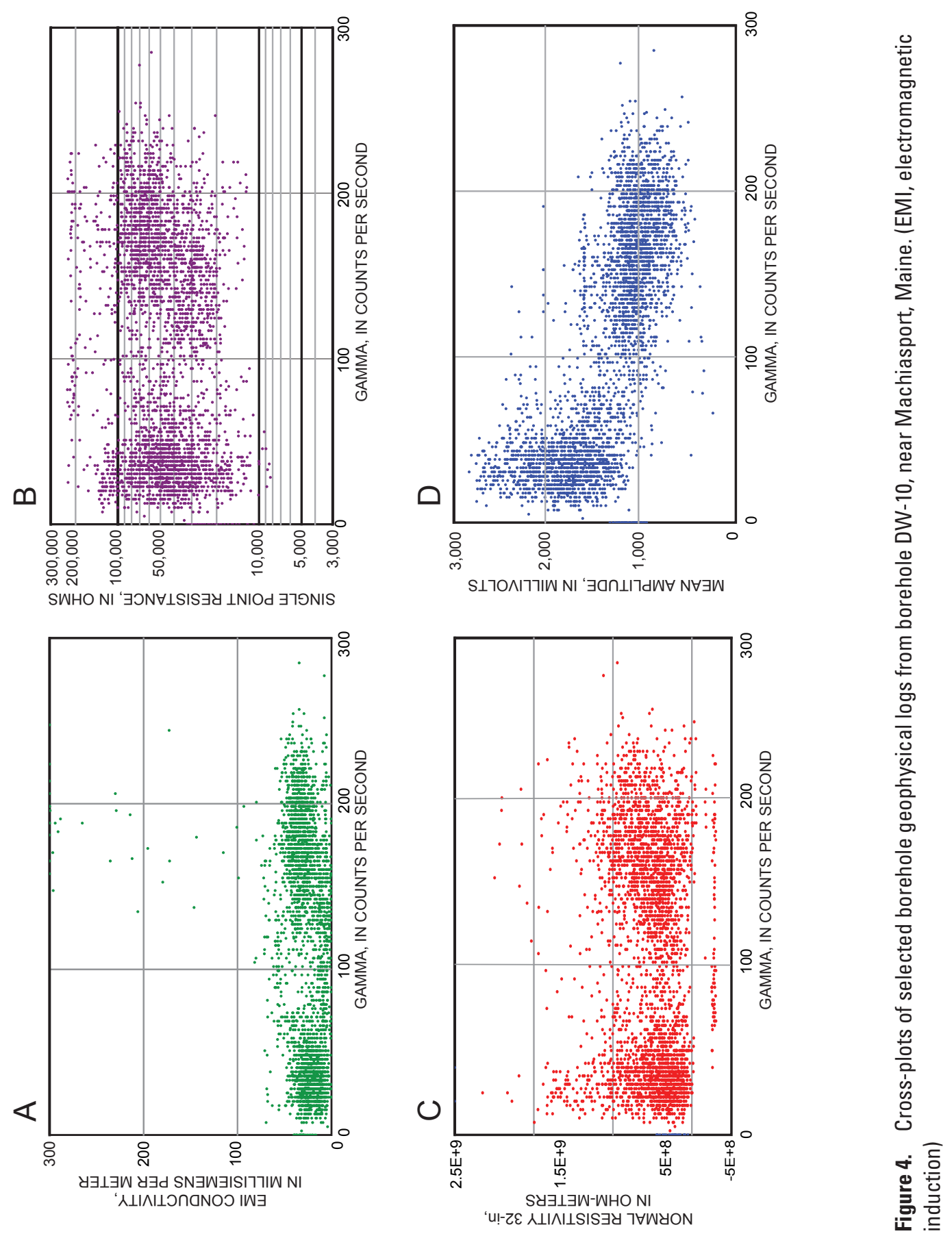


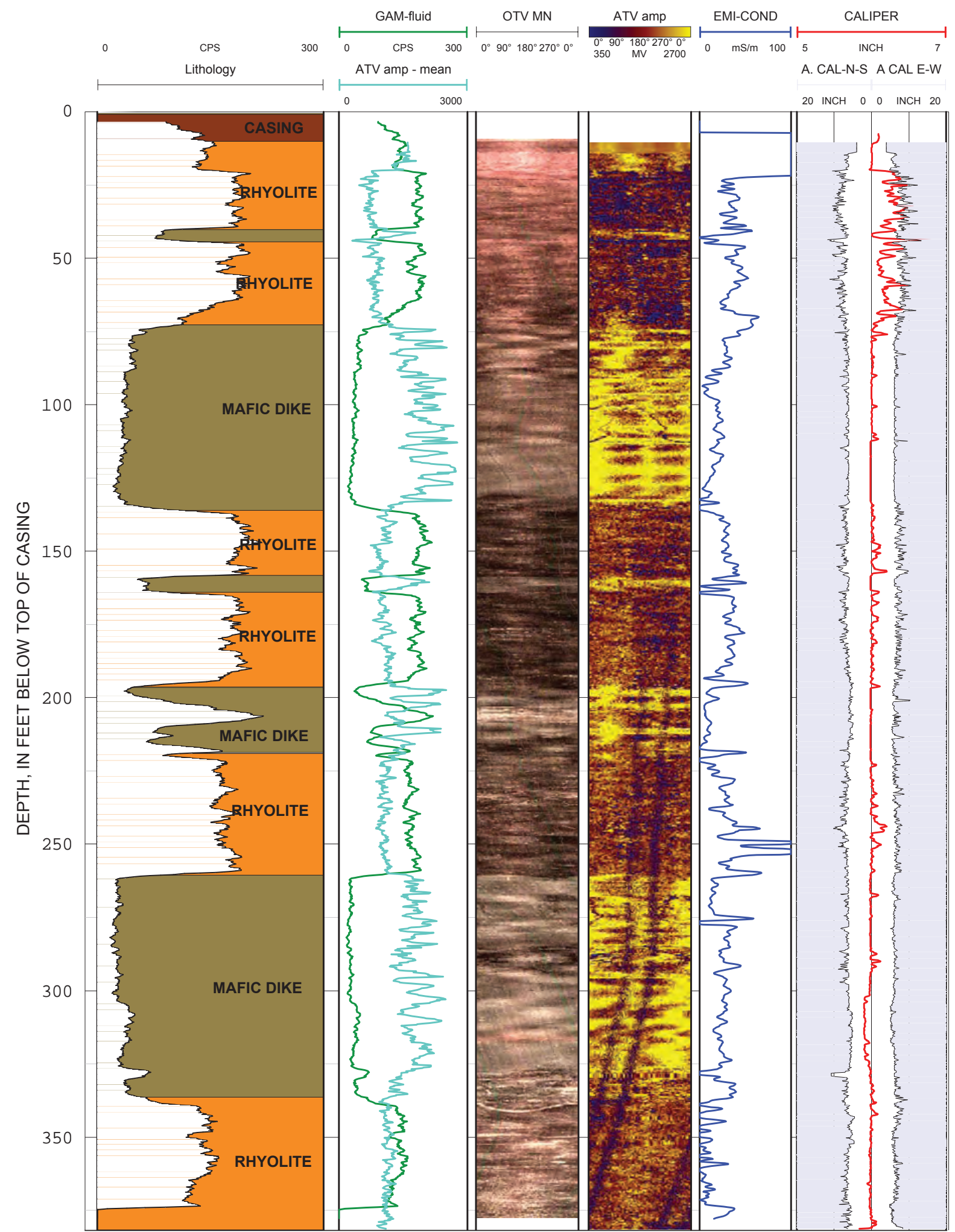

Figure 5. Selected borehole geophysical logs and lithology in borehole DW-10, near Machiasport, Maine, showing correlation of logs to the lithology. (cps, counts per second; GAM, gamma log; ATV, acoustic televiewer; OTV, optical televiewer; MN, magnetic north; amp, amplitude; $\mathrm{mV}$, millivolts; EMI-COND, electromagnetic conductivity; $\mu \mathrm{S} / \mathrm{m}$, microsiemens per meter; CALIPER, mechanical caliper; CAL-N-S, north-south measurement (shown in reverse); CAL E-W, east-west measurement) 


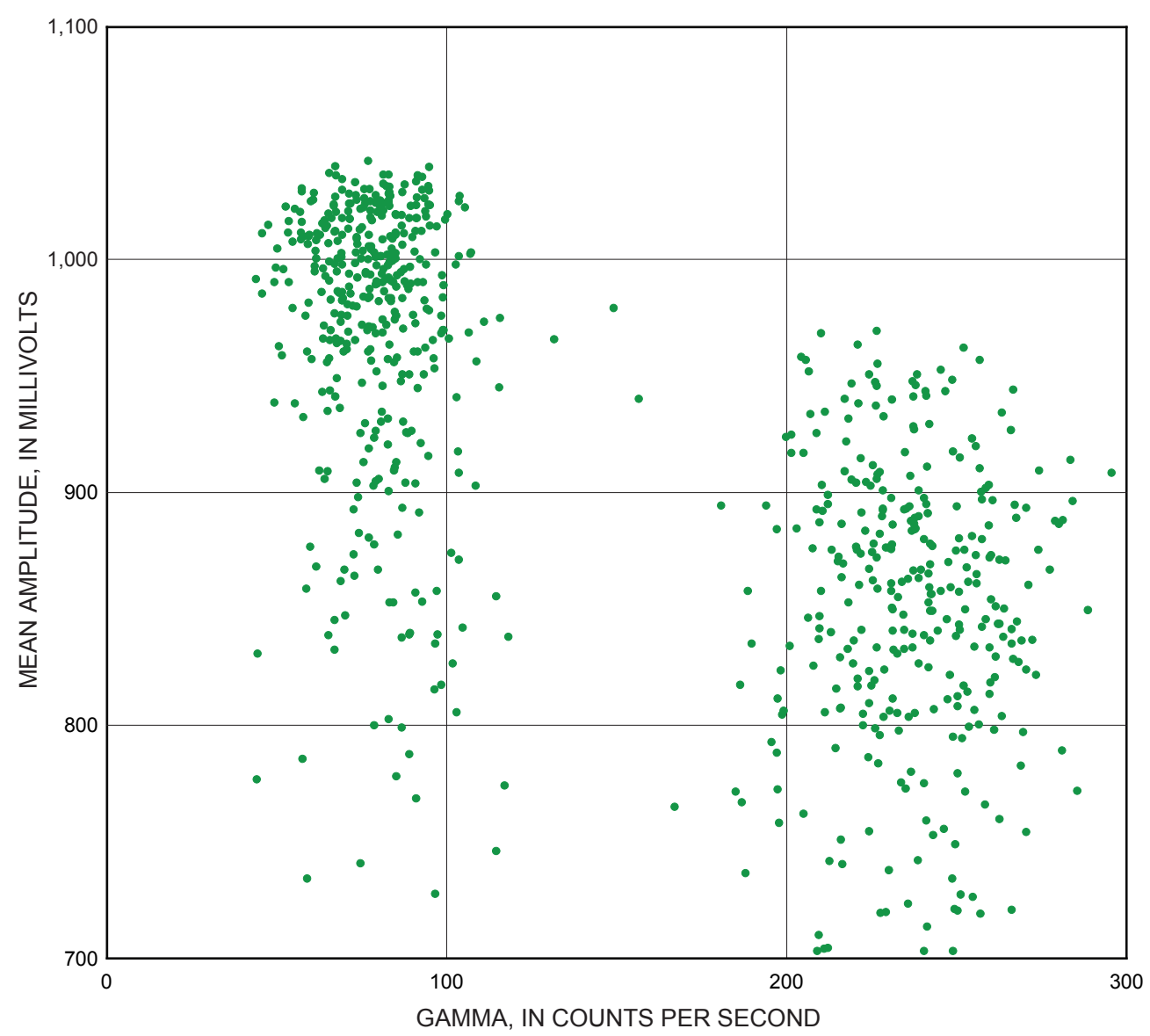

Figure 6. Cross-plot of data from gamma and acoustic televiewer reflectivity logs from borehole MW-14, near Machiasport, Maine.

The other major rock unit in the study area is the sedimentary sequence of the Eastport Formation (Gates and Moench, 1981). Borehole DW-23 was used as the "type locality" for the metasedimentary unit. Gamma counts in the metasedimentary unit are higher than in the quartz monzonite, gabbro/diabase, and mafic dikes. In borehole DW-23, the acoustic reflectivity and hardness of the metasedimentary units are generally lower and softer than the reflectivity and hardness of the gabbro/diabase (fig. 7). The more reflective, low-gamma-count unit that is represented on the left side of figure 7 was observed in the bottom half of borehole DW-23 and was interpreted as gabbro or diabase. The rocks in the upper part of borehole DW-23, interpreted to be metasedimentary units of the Eastport Formation, are represented on the right side of figure 7 , with the higher gamma counts. The gamma and reflectivity signatures were used along with the OTV images and ATV traveltime to identify the sedimentary layering of the rock units in borehole DW-23.

The geophysical logs collected in boreholes DW-10, MW-14, and DW-23 are discussed in further detail in the descriptions for the individual boreholes. The general correspondence between gamma and reflectivity measurements and their correlation with the rock types was used in the interpretation of all other boreholes in the study.

Fractures were identified in the ATV, OTV, caliper, and normal resistivity logs. In this report, the term "fracture" refers to planar discontinuities in the rock. No attempt was made to determine the genesis or mode of fracturing. The term "transmissive fracture" indicates a single fracture identified with the HPFM as transmitting water to or from the borehole 


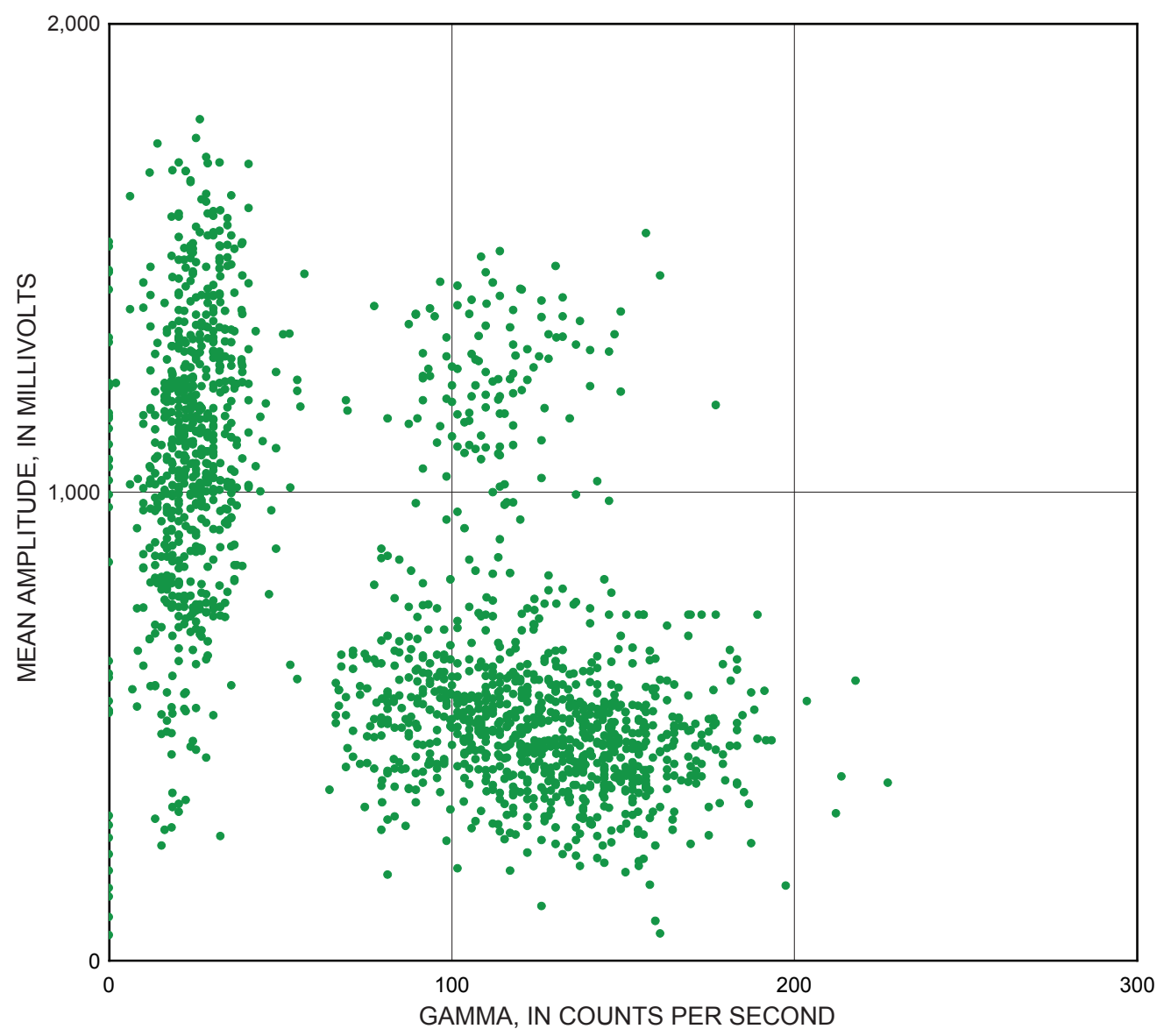

Figure 7. Cross-plot of data from gamma and acoustic televiewer reflectivity logs from borehole DW-23, near Machiasport, Maine.

under ambient or low-rate pumping conditions. The term "transmissive zone" refers to a region of the borehole where two or more closely spaced fractures were identified with the ATV and (or) OTV and where water flowed in or out of the borehole under ambient or pumping conditions. Because the HPFM cannot be placed between closely spaced fractures, the measured inflow was attributed to the fracture zone.

Hydraulic characterization was determined with a combination of results from fluid, water-quality, and flowmeter logs, along with pumping (or injection) and water-level monitoring.

The following is a brief outline of the procedures used in this investigation for analyzing and interpreting the data for each borehole.
- All logs were combined into a common collection and plotted side by side. WellCAD v4 was used to display the data and aid in the analysis.

- The fluid and caliper logs were used to verify the reported depth and diameter of the borehole, and EMI and imaging logs were used to verify the depth to the bottom of casing.

- Deviation data were corrected for magnetic declination, which is $17.5^{\circ}$ west of true north (TN).

- Average reflectivity logs were extracted from the ATV data, and the results were compared to gamma and resistivity logs to help identify changes in rock type. 
- ATV and OTV logs were oriented to TN by rotating the images $17.5^{\circ}$ such that TN was aligned with the left and right edges of the image. Strike and dip of planar features were determined and plotted as projection overlays directly on the images. The features in these structure logs were color-coded:

o red, prominent fractures;

o light blue, minor cracks;

o green, lithologic features including contacts, bedding planes, and layering;

o gray, sealed fractures;

o yellow, possible fractures; and

o dark blue, transmissive fractures.

- Structure logs were corrected from apparent to true strike and dip using the borehole deviation log that had been rotated to TN. The planar features were tabulated.

- Interpretations of planar features were plotted in stereoplots for assessing clustering of data. The interpretations were also plotted in tadpole plots to assess the change in orientation with depth and with interpreted rock types.

- Cross-plots of gamma and reflectivity, and gamma and resistivity, were constructed to assess lithology and to identify changes in rock types.

- Fluid and flowmeter logs were analyzed to determine transmissive fractures. These fractures or fracture zones were coded blue in the structure plots and stereoplots.

- HPFM data were processed for ambient and pumping conditions, and proportions of inflow were determined by the method of subtraction.

- Water-level data were analyzed, and open-hole specific capacity and transmissivity were computed using steady-state or transient solutions.

- Results of flowmeter tests were modeled to determine hydraulically active fractures in the borehole and to estimate the transmissivity and head of the individual modeled zones within the borehole.

- Interpretations of hydraulic properties were compared to water-quality parameter logs.

After the individual interpretations were completed, borehole to borehole comparisons were made to assess rock types and fracture patterns over larger portions of the aquifer. The results, which are summarized by borehole, are presented for each of the contaminated sites.

\section{Miller Mountain—Ground/Air Transmitter/ Receiver Site}

Previous investigations have identified chlorinated solvents in groundwater samples collected to the southeast of the Miller Mountain summit, strongly suggesting that Miller Mountain was the residual source area (Weston Solutions, 2005). Boreholes WY-GATR and MW-13 are on the top of Miller Mountain in or near two areas of contamination (table 1 and fig. 1A). Domestic wells DW-22, DW-23, DW-29, DW-31, and DW-32 are along the southeastern slope of Miller Mountain. Wells DW-34, MW-14, and DW-24 are south of Miller Mountain and upgradient from an east-west trending surface-water drainage. Domestic wells DW-33 and DW-40 are due east of Miller Mountain summit and in the surface drainage that runs between Miller and Bucks Mountains. Borehole DW-25 is east-southeast of the summit and further downgradient of boreholes DW-33 and DW-40 in the surface drainage. Borehole DW-39 is north of the summit along the flank of Miller Mountain.

In this section, borehole MW-14 is presented first because it provides a good review of the rock types and the tool responses in a cored borehole local to the Miller Mountain area. Boreholes logged by USGS for this investigation are presented after borehole MW-14. Finally, a brief summary is presented for borehole DW-29, logged in 2006 (The Johnson Company, 2006). All results are summarized together in the "Results of the Borehole Geophysical Investigation" section of this report.

\section{Borehole MW-14}

Geophysical logs and core descriptions were collected in borehole MW-14 in June 2003 (Mark Blackey, Geophysical Applications, Inc., written commun., 2003; Weston Solutions, 2005).

Lithology. The ATV, OTV, gamma, and selected logs were plotted along with lithologic descriptions of core obtained from the borehole (fig. 8). The OTV log indicates the bedrock from the bottom of casing to a depth of about $57 \mathrm{ft}$ below the top of casing is gray with some reddish and pink color. The rock unit appears to be massive, uniform, and fine grained, which is consistent with the quartz monzonite observed in core samples and the maps of Gates and Moench (1981). The contact at a depth of $57.8 \mathrm{ft}$, which is coincident with several fractures, is clearly evident in the OTV log. Above the contact, the fractures appear to be open and have no felsic infilling. Below the contact, the fractures appear to have felsic infilling. The generalized description of the drilling $\log$ is on the left, and the rock types are color-coded. The upper zone has been interpreted as quartz monzonite (Weston Solutions, 2005), and the lower unit, color-coded in green, has been interpreted as gabbro or diabase. The gamma log, shown in the shaded stratigraphic plot and in the standard line plot, shows a strong correlation to the rock types; the more mafic 


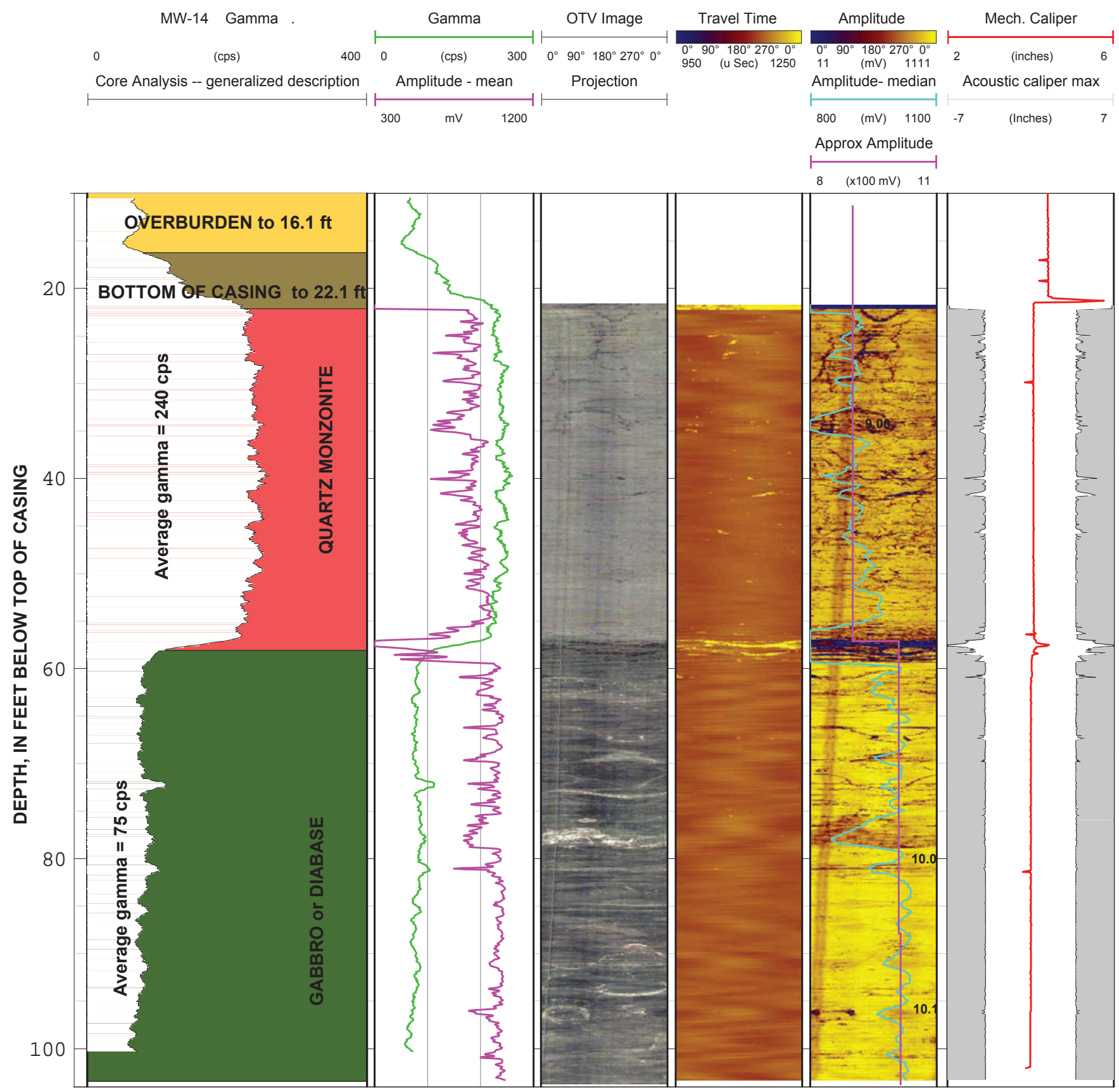

Figure 8. Selected borehole geophysical logs and rock types in borehole MW-14, near Machiasport, Maine. (cps, counts per second; mV, millivolts; OTV, optical televiewer; $\mu$ Sec, microseconds; Mech., mechanical; max, maximum; ft, feet) 
gabbro/diabase unit has low gamma emissions. The adjacent ATV logs show a slight variation in acoustic reflectivity above and below the contact at a depth of $57.8 \mathrm{ft}$. By converting the acoustic reflectivity image data to an average or median value for each depth increment, the results can be compared to the gamma log in a cross-plot (fig. 6). These plots indicate the uppermost zone, which has an average gamma of $240 \mathrm{cps}$ and a median reflectivity of $900 \mathrm{mV}$, is associated with the more felsic quartz monzonite. The unit below the contact at a depth of $57.8 \mathrm{ft}$ below the top of casing, which has an average gamma count of $75 \mathrm{cps}$ and a median reflectivity of $1,010 \mathrm{mV}$, is associated with the more mafic and very hard, reflective gabbroic or diabase unit.

Fractures. A series of fractures are at the contact between the two rock units, as seen in the OTV, ATV, caliper, acoustic caliper, and acoustic reflectivity plots. The contact has a moderate dip towards the southwest (with a strike and dip $\mathrm{N} 150^{\circ} \mathrm{E}, 57^{\circ}$ towards the southwest).

\section{Borehole MW-13}

Location and construction. Monitoring well MW-13 is on top of Miller Mountain and was installed in April 2003 for the environmental assessment of the GATR site (Weston Solutions, 2005). MW-13 is cased to a depth of $17 \mathrm{ft}$ below land surface, and the casing extends to $3.48 \mathrm{ft}$ above the land surface. The total depth of the well is about $220 \mathrm{ft}$ below the top of casing. Two rounds of borehole logs were collected in this borehole. MW-13 was logged in June 2003 (Weston Solutions, 2005 ) and again in November 2004. On November 9, 2004, the water level was $15.48 \mathrm{ft}$ below the top of casing, whereas in the spring of 2003, the water level was $32.1 \mathrm{ft}$ below the top of casing. The variability of the water level is likely because the borehole is in a recharge area on a hilltop; water levels highly correlate to precipitation and frequently are variable (Johnson and others, 2005).

Unlike any of the other boreholes in the study area, the water in borehole MW-13 had high amounts of suspended particles and grit, which looked more like rock flour from drilling than fault gouge. A tool that was lowered about $50 \mathrm{ft}$ into the borehole emerged from the borehole covered in a gritty, clay-rich mud, indicating the grit is not isolated to the bottom of the borehole. Because of the grit and suspended particles, water-quality probe, HPFM, and ATV logs were not collected in November 2004; they could be collected if the borehole was flushed out. Hence, the ATV and water-quality logs from 2003 were used in the composite log. Borehole MW-13 deviates about $17 \mathrm{ft}$ toward the northeast (appendix 1, fig. 1A-2). Logs and interpretations for borehole MW-13 are in appendix 1A.

Lithology. The gamma and acoustic reflectivity logs indicate fairly uniform lithology over the length of the borehole. The most substantial changes in gamma emissions and reflectivity occur at a depth of 40 to $51 \mathrm{ft}$ below the top of casing. Over this zone, the gamma counts increase to about $200 \mathrm{cps}$, and the reflectivity decreases to $300 \mathrm{mV}$; in the rest of the borehole, the average gamma activity and reflectivity are about $25 \mathrm{cps}$ and about $500 \mathrm{mV}$, respectively. The zone from a depth of 40-51 ft is consistent with a less mafic and softer rock type like the granodiorite and quartz monzonite in the upper unit in borehole MW-14 and may represent a countryrock roof pendent or xenolith. The rest of the borehole is characterized by very low gamma and high reflectivity and appears to be more similar to the rock unit in borehole WY-GATR than the rock unit in the bottom of borehole MW-14.

The borehole diameter changes at a depth of about 87 to $90 \mathrm{ft}$ below the top of casing. The change appears to be an artifact of drilling; the drilling logs, however, indicate this zone coincides with limonite- and hematite-healed fractures. This zone is characterized with a slightly higher reflectivity and larger diameter than the rocks above and below it. If the response of the ATV tool was simply caused by an increased borehole diameter, the reflectivity would decrease, but here it increases over the zone from 87 to $90 \mathrm{ft}$. The smaller diameter below this zone is because of a change to a smaller drill bit and is unrelated to the rock type. The normal resistivity logs and EMI logs indicate the bedrock is very resistive, but no major changes in rock type were identified. The SP log indicates minor changes at depths of about 50,69, and $105 \mathrm{ft}$ below the top of casing. The uppermost SP anomaly coincides with the bottom of the large gamma anomaly that is interpreted as a granodiorite or quartz monzonite.

Fractures. Stereoplots for features observed in the ATV $\log$ (appendix 1, fig. 1A-3) show pole to fracture planes that dip steeply towards the southwest and cluster fairly tightly. Another group of poles to fracture planes dips over a range of angles towards the east-southeast. Tadpole plots indicate the zone at the top of the log from a depth of 32 to $51 \mathrm{ft}$ is highly fractured relative to the rest of the borehole. The fractures over that zone show the same range in orientation as the rest of the borehole.

Hydraulic characterization. The ambient fluid conductivity and temperature logs collected in borehole MW-13 on November 2004 indicated the possibility of hydraulically active fractures at depths of 20 (at the base of casing), 42, and 132 or $145 \mathrm{ft}$. The water-quality log collected in spring 2003 showed possible hydraulically active fractures at depths of $38,50.6$, and 187 to $193 \mathrm{ft}$ below the top of casing. No ambient flow was measured with the HPFM in either 2003 or 2004; HPFM logs collected under pumping conditions in 2003 tentatively identified possible inflow at a depth of about 70 to $80 \mathrm{ft}$ below land surface. However, the rock flour in the borehole may have clogged the fractures in the borehole and (or) adversely affected the performance of the tool. Collectively, the inflections in the fluid and water-quality probe show possible transmissive fractures at depths of $38,41,51,132$ or 145 , and 187 to $193 \mathrm{ft}$ below the top of casing.

The water-quality probe may have been adversely affected by the remnant effects of the high rock-flour and grit content from the drilling. The $\mathrm{pH}$ was fairly constant over the depth of the borehole and was fairly high at about 8.5. The redox log indicated positive or oxidizing conditions throughout the length of the borehole. The fluid conductivity logs 
from the 2003 and 2004 logging events show similar profiles at the top of the borehole with a drop in temperature over the upper zone in the borehole, down to about a depth of $42 \mathrm{ft}$ below the top of casing. In the fluid log, collected in the spring of 2003, the fluid conductivity remained fairly constant, and the temperature decreased to the bottom of the borehole. In the November 2004 fluid log, the temperature remained constant and the fluid conductivity increased gradually to the bottom of the borehole. These differences may be because of seasonal changes or because the first round of logging was conducted shortly after drilling. Collectively, the fluid and water-quality logs from both rounds of logging were used to infer the transmissive zones in the borehole. The fluid and flowmeter logs may produce different results after the borehole is developed and cleared of rock-flour and drilling debris.

\section{Borehole DW-22}

Location and construction. Domestic well DW-22 is southeast of Miller Mountain along Port Road. The borehole has $22.5 \mathrm{ft}$ of casing; the casing extends $0.34 \mathrm{ft}$ above the land surface. Borehole DW-22 was completed to a total depth of $110 \mathrm{ft}$ below the top of casing, and is nearly plumb, deviating less than $1 \mathrm{ft}$ towards the west (appendix 1, fig. 1B-2). DW-22 is close to another domestic well, DW-23, which is about $100 \mathrm{ft}$ to the south. The ambient water level on November 10 , 2004, was $6.69 \mathrm{ft}$ below the top of casing at 7:30 a.m. Logs and interpretations for borehole DW-22 are in appendix 1B.

Lithology. Gamma, ATV, OTV, and normal resistivity logs indicate a change in rock type at a depth of about $100 \mathrm{ft}$ below the top of casing. Over most of the borehole, the rock type appears to be fairly uniform in gamma counts and acoustic reflectivity and is consistent with metamorphic sediments. Behind the casing, the gamma averages about $70 \mathrm{cps}$. From a depth of 23.5 to $100 \mathrm{ft}$ below the top of casing, the rock emits gamma radiation of about 100 to $170 \mathrm{cps}$ and has an acoustic reflectivity of 400 to $1,200 \mathrm{mV}$. Near the bottom of the borehole, at a depth $100 \mathrm{ft}$ below the top of casing, the rock is harder, is more reflective $(1,800$ to $2,250 \mathrm{mV}$, averaging about $1,900 \mathrm{mV}$ ), and has a lower gamma count (about $30 \mathrm{cps}$ ), which is consistent with gabbro or diabase. The gamma and reflectivity signatures are similar to that from the rock types in the lower portions of boreholes DW-23, DW-22, DW-32, DW-25, and DW-31 and in the top of borehole DW-39. The gamma and reflectivity signatures in the top of borehole DW-22 are similar to the signatures in the upper portions of boreholes DW-32 and DW-23.

The multi-spaced normal resistivity logs show an increase in the resistivity in the rock unit below a depth of $100 \mathrm{ft}$. In the OTV log, the rock in the top of borehole DW-22 appears to have numerous (non-planar) features that are either very minor cracks or expressions of textural relief along layers in the rock. There is also a near-vertical feature only on one side of the borehole from a depth of 51 to $54 \mathrm{ft}$ below the top of casing. It may be a vesicular feature or some other localized pod of crystallized minerals in the matrix of the rock.
Fractures. The ATV and OTV logs show a prominent fracture at a depth of about $82.5 \mathrm{ft}$, which was shown to be transmissive with the HPFM. This fracture strikes southeast and dips $27^{\circ}$ to the west-southwest [OTV and ATV logs indicate an average orientation of $\left.\mathrm{N} 213^{\circ} \mathrm{E}, 27^{\circ}(\mathrm{SW})\right]$. The fractures near the base of casing only had a signature in the OTV $\log$. These features may or may not be transmissive because there also appears to be borehole enlargement in one section of the well at the base of casing that may serve as an avenue for leakage. The HPFM did identify leakage near the base of casing. Several steeply dipping features that strike to the north, southeast, and southwest were observed in the OTV images (appendix 1, fig. 1B-3). Another set of shallow dipping features striking east and dipping south was observed in the ATV and OTV logs. Planar features in the borehole that are associated with tonal variations in the OTV image were coded green in the stereoplots and tadpole and projection plots. These features probably result from changes in texture or mineralogy because they do not appear to be open.

Hydraulic characterization. Ambient downflow was measured with the HPFM on November 10, 2004, at about 11:30 a.m. to 12:25 p.m. Water entered the borehole at the base of casing (at a depth of about $22.5 \mathrm{ft}$ or from the possible fractures at 23.3 and $23.5 \mathrm{ft}$ ) and exited the borehole at the fracture at a depth of $82.5 \mathrm{ft}$ below the top of casing. Under pumping conditions of $0.7 \mathrm{gal} / \mathrm{min}$, ambient flow was reversed, and water entered the borehole at the fracture at a depth of $82.5 \mathrm{ft}$ in addition to the inflow from the feature(s) just below the base of casing.

The open-hole transmissivity in borehole DW-22 was estimated using two methods. The water levels under pumping at $0.6 \mathrm{gal} / \mathrm{min}$ reached quasi-steady state prior to the flowmeter logging. The water level declined $5.6 \mathrm{ft}$ from the ambient water level. Using the water-level and pumping data, the open-hole transmissivity was determined using the methods of Bradbury and Rothschild (1985). The specific capacity was calculated to be $0.125(\mathrm{gal} / \mathrm{min}) / \mathrm{ft}$ of drawdown, and the openhole transmissivity was calculated to be $22.7 \mathrm{ft}^{2} / \mathrm{d}$.

The HPFM data were modeled using FWRAP to determine the transmissivity and head for the two transmissive zones in the borehole (fig. 9). Similar figures were constructed for the final model results for each borehole and are shown in the appendixes. Figure 9 is used to describe this presentation of HPFM data and the modeling results. In this figure, the points indicate HPFM measurements along the borehole. Dashed lines show the interpreted flow regime in the borehole, with downflow from a depth of about 25 to $82 \mathrm{ft}$ below the top of casing. After interpretation of the image and fluid logs, the inflow and outflow were attributed to specific fractures. By adjusting the transmissivity and initial heads in FWRAP, the model generates ambient and pumped profiles (shown with solid lines) that are compared to the interpreted profiles. The transmissivity and head parameters were adjusted as needed to generate a good match between the observed and modeled profiles. In borehole DW-22, the modeled profile directly overlays the observed profiles over most of the borehole. The 


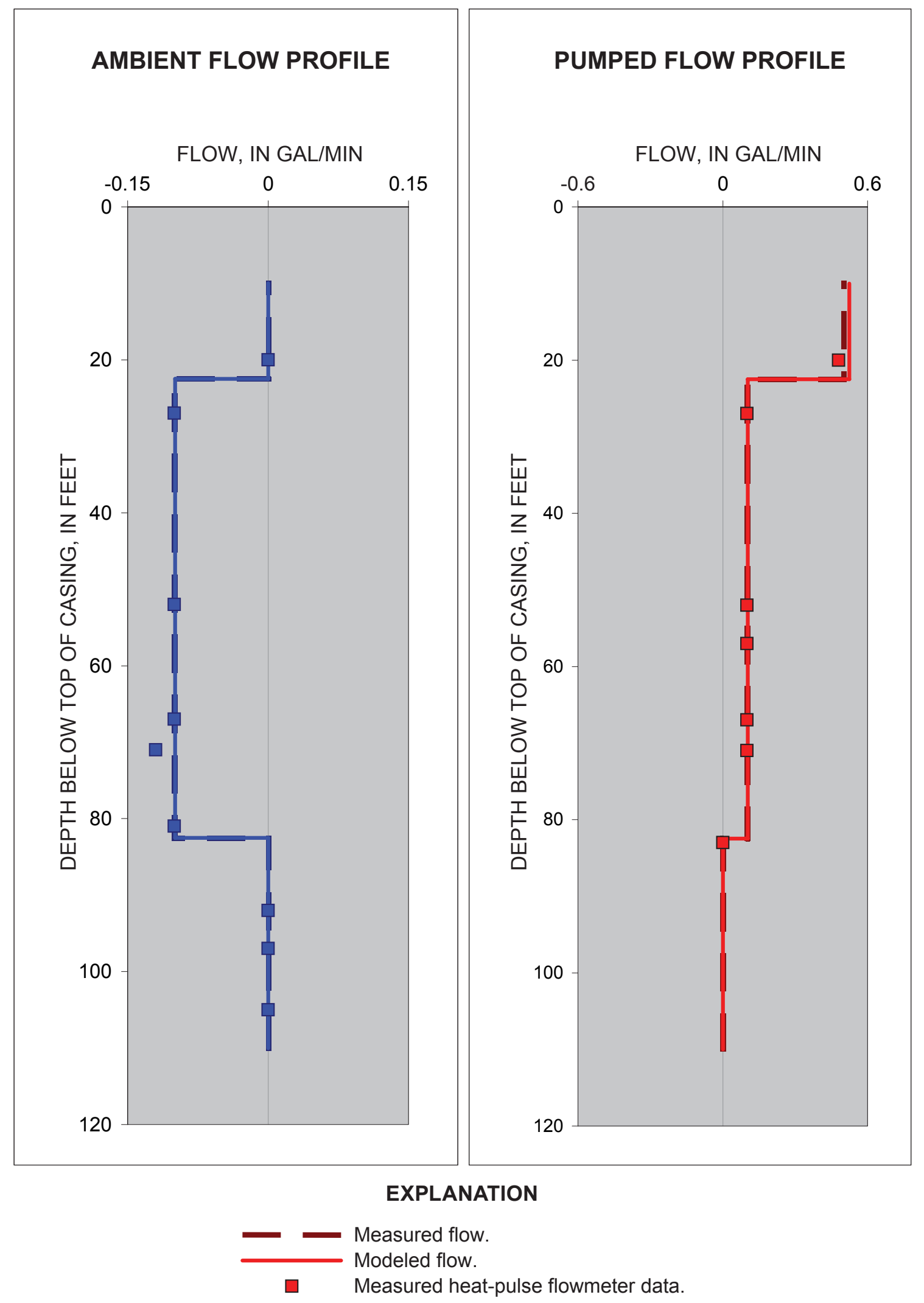

Figure 9. Flowmeter model for borehole DW-22, near Machiasport, Maine, showing solid model lines overlying interpretation of measured flow (dashed lines). (gal/min, gallon per minute; positive values of flow are upward flow, negative values of flow are downward flow) 
Table 5. Flow model for borehole DW-22, near Machiasport, Maine.

[ft, feet; gal/min, gallon per minute; $\mathrm{ft}^{2} / \mathrm{d}$, feet squared per day; TOC, top of casing]

\begin{tabular}{ccccccc}
\hline $\begin{array}{c}\text { Depth of } \\
\text { transmissive zone } \\
\text { (ft) }\end{array}$ & $\begin{array}{c}\text { Ambient flow above } \\
\text { transmissive zone } \\
\text { (gal/min) }\end{array}$ & $\begin{array}{c}\text { Pumped flow above } \\
\text { transmissive zone } \\
\text { (gal/min) }\end{array}$ & $\begin{array}{c}\text { Zone } \\
\text { transmissivity } \\
\text { (ft } \mathbf{2} / \mathbf{d})\end{array}$ & $\begin{array}{c}\text { Water level } \\
\text { (ft below TOC) }\end{array}$ & $\begin{array}{c}\text { Elevation of } \\
\text { water level } \\
\text { (ft) }\end{array}$ & $\begin{array}{c}\text { Percent of total } \\
\text { transmissivity }\end{array}$ \\
\hline 22.5 & 0.00 & 0.52 & 11.7 & 5.08 & 54.92 \\
82.5 & -0.10 & 0.10 & 6.8 & 9.48 & 50.52 \\
\hline
\end{tabular}

upper fracture or feature at the base of casing, at a depth of about $22.5 \mathrm{ft}$ below the top of casing, was modeled to have a transmissivity of $11.7 \mathrm{ft}^{2} / \mathrm{d}$ and the deeper zone, $82.5 \mathrm{ft}$ below the top of casing, a transmissivity of $6.8 \mathrm{ft}^{2} / \mathrm{d}$. The head of the upper fracture was $4.4 \mathrm{ft}$ more than the head in the lower zone, consistent with the ambient downflow in the borehole. Under pumped conditions, the ambient outflow through the fracture at a depth of $82.5 \mathrm{ft}$ was reversed, and additional water entered the borehole at the base of casing. These results are summarized in table 5, figure 9, and appendix 1, figure 1B-4. The SSE was 0.0006 (gal $/ \mathrm{min})^{2}$ or a RMS error of $0.017 \mathrm{gal} / \mathrm{min}$. By this method, the open-hole transmissivity is $18.5 \mathrm{ft}^{2} / \mathrm{d}$.

The fluid temperature, conductivity, dissolved oxygen, $\mathrm{pH}$, and oxidation-reduction potential indicate changes in the inflow to the borehole at a depth of $23.5 \mathrm{ft}$, just below base of casing, and at the fracture at a depth of $82.5 \mathrm{ft}$ below the top of casing. In addition, the fluid conductivity log shows a small deflection at a depth of about $100 \mathrm{ft}$ below the top of casing, suggesting the possibility of minor ambient downflow that is outside the resolution of the HPFM or the possibility that stagnant water next to the different rock type at the bottom of the borehole has a very small effect on the water column.

\section{Borehole DW-23}

Location and construction. Domestic well DW-23 is southeast of Miller Mountain along Port Road and about $100 \mathrm{ft}$ south of domestic well DW-22. The borehole casing has a total length of $21.7 \mathrm{ft}$ and extends $1.95 \mathrm{ft}$ above the land surface. Borehole DW-23 was completed to a total depth of $181.2 \mathrm{ft}$ below the top of casing. The borehole deviates less than a foot to the southwest. Because borehole DW-23 is a flowing borehole, a buried overflow pipe discharges downgradient toward the east. The rate of overflow ( $4.0 \mathrm{gal} / \mathrm{min})$ was measured with a bucket and stopwatch at the discharge pipe. The head in the borehole could not be measured without retrofitting the well with a system that would prevent overflow and allow the head to equilibrate. The discharge pipe is open to the borehole at a depth of $7.7 \mathrm{ft}$ below the top of casing. Logs and interpretations for borehole DW-23 are in appendix 1C.

Lithology. Image logs indicate the pitless adapter and the outflow pipe are above a depth of $10 \mathrm{ft}$ below the top of casing, suggesting the depth to bedrock is at least that deep.
The reduction in gamma counts at about $10 \mathrm{ft}$ may be related to the overburden/bedrock contact. The OTV, ATV amplitude, caliper, normal resistivity, and gamma logs indicate changes in lithology at a depth of $112 \mathrm{ft}$ below the top of casing. From the bottom of casing (at about a depth of $22 \mathrm{ft}$ ) to a depth of $112 \mathrm{ft}$, the bedrock is characterized by high gamma counts averaging $140 \mathrm{cps}$, relatively low resistivity, low SPR resistance averaging 2,500 ohms, highly variable EMI conductivity, low acoustic reflectivity averaging $340 \mathrm{mV}$, and dark gray and maroon units. Below a depth of $112 \mathrm{ft}$, the bedrock is characterized by low gamma counts averaging $20 \mathrm{cps}$, relatively high resistivity, high SPR resistance averaging 10,100 ohms, uniform EMI conductivity, high acoustic reflectivity averaging $1,130 \mathrm{mV}$, and light gray and greenish gray units.

Higher acoustic reflectivity amplitudes and lower traveltimes are consistent with the change in rock type to a harder and more competent rock below a depth of $112 \mathrm{ft}$. The rock type above $112 \mathrm{ft}$ appears to be a thinly bedded to laminated unit. Below a depth of $112 \mathrm{ft}$, the rock is a fine-grained (aphanitic), gray, massive unit with little to no structure. Sealed felsic veins are present within both units. The gamma log suggests the zone below a depth of $112 \mathrm{ft}$ is a mafic unit because it has very low gamma counts. Below a depth of $112 \mathrm{ft}$, the caliper log shows a smoother and slightly smaller diameter borehole, also indicating the rock below that depth is harder and more competent than the rock in the top of the borehole. These results suggest the deeper part of borehole DW-23 is similar to the massive gabbro/diabase, whereas the upper part of the borehole is characteristic of the sedimentary units of the Eastport Formation. The OTV log indicates the sedimentary layers strike about $\mathrm{N} 105^{\circ} \mathrm{E}$ and dip 13 to $21^{\circ}$ to the south. The contact between the two rock types is parallel to the sedimentary layers.

Fractures. This borehole intersects several steeply dipping fractures. Some fractures may be drilling induced and others are sealed with another felsic mineral. The sealed fractures are shown as gray features in the stereoplots. The sealed fractures generally cannot be seen in the ATV log but were visible in the OTV log. The ATV log, however, shows good agreement with the OTV log and identified the larger fractures, which are interpreted to be hydraulically active. The hydraulically active fractures in this borehole are nearly horizontal. Two fractures (at depths of 94.5 and $177.6 \mathrm{ft}$ ) 
were determined to be transmissive with the HPFM. They are shown in dark blue in the stereoplots and tadpole and projection plots. The transmissive fractures are oriented in the same direction with a strike and dip of $\mathrm{N} 99^{\circ} \mathrm{E}, 30^{\circ} \mathrm{S}$.

The tadpole plots and stereoplots indicate that above a depth of $112 \mathrm{ft}$, the fractures and bedding planes predominantly strike south-southeast and dip to the west-southwest. Below a depth of $112 \mathrm{ft}$, the fractures strike west and dip northward. The sealed fractures generally strike south and dip to the west. A fracture at a depth of $111.7 \mathrm{ft}$, just above the contact with the mafic unit at a depth of $112 \mathrm{ft}$, strikes southsouthwest and dips at a very shallow angle towards the west.

Hydraulic characterization. Under ambient conditions, upflow occurs over the entire length of the borehole (appendix 1, fig. 1C-4). Inflow enters the borehole at a depth of $177.6 \mathrm{ft}$ below the top of casing and flows upwards to the overflow pipe at a constant rate of $4 \mathrm{gal} / \mathrm{min}$. Although the HPFM data do not confirm it, it is possible there is inflow under pumping conditions from the fracture at a depth of about $95 \mathrm{ft}$ below the top of casing. Under pumping at $5.4 \mathrm{gal} / \mathrm{min}$, or $1.4 \mathrm{gal} / \mathrm{min}$ above the ambient inflow rate, the water level was drawn down below the overflow outlet, and all the water that was going to the pump was channeled through the borehole and through the casing. Under ambient conditions, HPFM measurements in the casing measured the total amount of flow at the overflow pipe $(4.0 \mathrm{gal} / \mathrm{min})$; under pumping conditions, the HPFM measurements in the casing measured the total amount of water going to the pump $(5.4 \mathrm{gal} / \mathrm{min})$. The flowmeter and discharge measurements were used to proportion the flow measured in the borehole with the underfit diverter. The results indicate the majority of inflow came from the fracture zone at $177.6 \mathrm{ft}$. Possible inflow was suggested in the fluid and HPFM logs at the fracture at 94 to $95 \mathrm{ft}$ below the top of casing.

Because of the design of the overflow pipe at the top of the borehole, the ambient water level could not be determined. If a packer were installed below the overflow pipe, the ambient water level could be measured. It is best, however, to measure the head concurrently with the flowmeter logging because the ambient head is likely to change. The ambient water level was estimated by plotting the time and depth to water level in a logarithmic plot and then extrapolating the straight line back to the time pumping was initiated, thereby providing an estimate of the starting head for the flowmeter modeling. The initial starting head estimate was a depth of $6.65 \mathrm{ft}$ below the top of casing. Once the other model parameters were stabilized, the starting head and drawdown were modified to produce the best fit, which indicated a starting head of $7.3 \mathrm{ft}$ below the top of casing.

Using a depth of $7.3 \mathrm{ft}$ below the top of casing for the starting head, the open-hole specific capacity was estimated at $1.07(\mathrm{gal} / \mathrm{min}) / \mathrm{ft}$ of drawdown, and the transmissivity was estimated at $237 \mathrm{ft}^{2} / \mathrm{d}$. Three fractures were modeled using the flowmeter data. Because the model requires a no-flow zone at the top of the borehole under ambient conditions, an additional fracture had to be modeled at the top of the borehole to accommodate the overflow. The transmissivity of that zone was set to 100 percent, such that it was able to accommodate all flow driven to the top of the borehole. Under this scenario, the lowermost fracture had a head that was $18 \mathrm{ft}$ higher than the top of the borehole, maintaining the ambient flow rate of $4.0 \mathrm{gal} / \mathrm{min}$. The modeling results using FWRAP gave a numerically poor-to-fair fit to the data with an RMS error of $0.83 \mathrm{gal} / \mathrm{min}$ and a transmissivity of only $153 \mathrm{ft}^{2} / \mathrm{d}$. This poor fit to the data indicates that one or more of the parameters are not adequately characterized. Because of the uncertainty in the ambient open-hole water-level measurement, sensitivity analyses were conducted by varying the starting water level and the percent transmissivity of the top of the borehole. But this solution produced the best results for the flowmeter modeling (table 6 and appendix 1, fig. 1C-4).

Fluid temperature and conductivity are consistent with a strong vertical flow rate in the borehole because they are fairly constant over the entire length of the borehole. There does appear to be a slight shift in the oxygen and $\mathrm{pH}$ above and below the fracture at a depth of $94.5 \mathrm{ft}$ below the top of casing, which may indicate some recharge to the borehole.

A water-quality log was collected after the pumping. Comparison of the ambient and post-pumping data indicates the water entering the borehole under ambient conditions comes from the fracture near the bottom of the borehole at a depth of $177.6 \mathrm{ft}$ below the top of casing, which is consistent with the flowmeter results. The log collected after pumping suggests water also entered the borehole from a fracture at a depth of $94.5 \mathrm{ft}$ below the top of casing.

Table 6. Flow model for borehole DW-23, near Machiasport, Maine.

[ft, feet; gal/min, gallon per minute; $\mathrm{ft}^{2} / \mathrm{d}$, feet squared per day; TOC, top of casing]

\begin{tabular}{|c|c|c|c|c|c|c|}
\hline $\begin{array}{c}\text { Depth of } \\
\text { transmissive zone } \\
\text { (ft) }\end{array}$ & $\begin{array}{c}\text { Ambient flow above } \\
\text { transmissive zone } \\
\text { (gal/min) }\end{array}$ & $\begin{array}{l}\text { Pumped flow above } \\
\text { transmissive zone } \\
\text { (gal/min) }\end{array}$ & $\begin{array}{c}\text { Zone } \\
\text { transmissivity } \\
\left(\mathrm{ft}^{2} / \mathrm{d}\right)\end{array}$ & $\begin{array}{c}\text { Water level } \\
\text { (ft below TOC) }\end{array}$ & $\begin{array}{l}\text { Elevation of } \\
\text { water level } \\
\text { (ft) }\end{array}$ & $\begin{array}{l}\text { Percent of total } \\
\text { transmissivity }\end{array}$ \\
\hline 94.5 & 3.94 & 5.39 & 69.0 & 6.88 & 53.12 & 45 \\
\hline 150.0 & 3.92 & 4.73 & 24.0 & 6.98 & 53.02 & 16 \\
\hline 175.0 & 3.92 & 4.48 & 60.0 & -4.52 & 64.52 & 39 \\
\hline
\end{tabular}




\section{Borehole DW-24}

Location and construction. Borehole DW-24 is southeast of Miller Mountain along Port Road and about $150 \mathrm{ft}$ north of domestic well DW-36. The borehole casing in DW-24 has a total length of $72 \mathrm{ft}$ and extends $1.52 \mathrm{ft}$ above the land surface. The borehole was completed to a total depth of $191 \mathrm{ft}$ below the top of casing. The borehole deviates about $4.5 \mathrm{ft}$ towards the northeast (appendix 1, fig. 1D-2). Logs and interpretations for borehole DW-24 are in appendix 1D.

Lithology. Gamma emissions were fairly uniform over the open length of the borehole and ranged from about 90 to $130 \mathrm{cps}$ (appendix 1, fig. 1D-1). One narrow gamma increase at a depth of 87 to $91 \mathrm{ft}$ below the top of casing had emissions of up to $200 \mathrm{cps}$. The increase coincides with an increase in SP, but there is no change in the reflectivity at that depth. This 4-ft wide zone is probably a change in rock type; it does not, however, exhibit the gamma and reflectivity signatures of a diabase intrusion. Reflectivity is high relative to the rest of the borehole in a few prominent zones including 109 to 122,160 to 171 , and $178 \mathrm{ft}$ to the bottom of the borehole. These zones exhibit a reflectivity of about 450 to $500 \mathrm{mV}$, whereas reflectivity in the rest of the borehole is about 120 to $160 \mathrm{mV}$. The high reflectivity zones do not exhibit a change in the gamma. These narrow bands may represent textural variations consistent with layering in metamorphic sediments.

Fractures. Much of this borehole appears to be highly fractured. Low resistivity zones are centered at a depth of about 95 to 100,126 , and $182.5 \mathrm{ft}$ below the top of casing (appendix 1, fig. 1D-1). These resistivity lows are associated with large fractures observed in the ATV log. However, the high reflectivity zone from a depth of 109 to $122 \mathrm{ft}$ below the top of casing appears to be unfractured relative to the zones above and below it. The stereoplot and tadpole and projection plots indicate the fractures (shown in light blue) dip to the northeast and southwest at steep to shallow angles (appendix 1, fig. 1D-3). Major fractures (shown in red) dip to the northeast and southwest at moderate to steep angles. The only transmissive fracture zone was at a depth of $182.5 \mathrm{ft}$ and strikes $\mathrm{N} 11^{\circ} \mathrm{E}$ and dips $26^{\circ}$ to the east. This fracture zone, consisting of several closely spaced fractures, intersects the borehole from a depth of 181.5 to $183.5 \mathrm{ft}$ and is listed with a depth set at the midpoint depth of $182.5 \mathrm{ft}$ below the top of casing.
Hydraulic characterization. During the borehole logging, the water levels and ambient flow in the borehole oscillated over a period of minutes, which suggested the borehole is affected by nearby pumping. HPFM logging under ambient conditions showed variable downflow in the upper part of the borehole and variable upflow in the lower part of the borehole (appendix 1, fig. 1D-4). A comparison of HPFM measurements and concurrent water levels confirmed that all the measured flow under ambient conditions was accompanied by concurrent changing water levels (drawdown and recharge) and the effects of nearby pumping. These flow measurements indicate borehole DW-24 is connected to another well through the fracture at a depth of $182.5 \mathrm{ft}$.

Under pumping at $1 \mathrm{gal} / \mathrm{min}$, flowmeter measurements were collected while the water level was still declining. Upflow of $0.8 \mathrm{gal} / \mathrm{min}$ was measured with the flowmeter and attributed to an inflowing fracture at a depth of $182.5 \mathrm{ft}$ below the top of casing. The concurrent water-level decline, when converted to volumetric flow rate, was $0.18 \mathrm{gal} / \mathrm{min}$, which accounted for the remainder of the pumped water that was coming from borehole storage. No other transmissive fractures were identified in borehole DW-24.

The open-hole transmissivity determined with the methods of Bradbury and Rothschild (1985) was $405 \mathrm{ft}^{2} / \mathrm{d}$ with a specific capacity of 1.7 (gal/min)/ft of drawdown. A simple model with one fracture at a depth of $182.5 \mathrm{ft}$ was used in FWRAP (table 7, appendix 1, fig. 1D-4). The transmissivity was estimated at $306 \mathrm{ft}^{2} / \mathrm{d}$ with an RMS error of $0.006 \mathrm{gal} / \mathrm{min}$.

\section{Borehole DW-25}

Location and construction. Domestic well DW-25 is off of Smalls Point Road, southeast of Miller Mountain and Port Road. The borehole has PVC and steel casing that begins at $0.78 \mathrm{ft}$ below land surface and extends to a depth of $81 \mathrm{ft}$ below the top of casing. The casing is in a vault with a manhole access. The borehole was designed with an overflow pipe that discharges sporadically to the gravel in the vault. Because of the design of the well, the outflow could not be measured to verify the flowmeter measurements. In addition, water levels could not be determined when the water level exceeded the level of the outflow pipe. Borehole DW-25 was completed to a total depth of $142.8 \mathrm{ft}$ below the top of casing. Under ambient conditions at 7:22 a.m. on November 13, 2005, the open-hole

Table 7. Flow model for borehole DW-24, near Machiasport, Maine.

[ft, feet; gal/min, gallon per minute; $\mathrm{ft}^{2} / \mathrm{d}$, feet squared per day; TOC, top of casing]

\begin{tabular}{ccccccc}
\hline $\begin{array}{c}\text { Depth of } \\
\text { transmissive zone } \\
\text { (ft) }\end{array}$ & $\begin{array}{c}\text { Ambient flow above } \\
\text { transmissive zone } \\
\text { (gal/min) }\end{array}$ & $\begin{array}{c}\text { Pumped flow above } \\
\text { transmissive zone } \\
\text { (gal/min) }\end{array}$ & $\begin{array}{c}\text { Zone } \\
\text { transmissivity } \\
\text { (ft } \mathbf{2} / \mathbf{d})\end{array}$ & $\begin{array}{c}\text { Water level } \\
\text { (ft below TOC) }\end{array}$ & $\begin{array}{c}\text { Elevation of } \\
\text { water level } \\
\text { (ft) }\end{array}$ & $\begin{array}{c}\text { Percent of total } \\
\text { transmissivity }\end{array}$ \\
\hline 182.5 & 0.00 & 0.82 & 306.0 & 9.80 & 50.20 \\
\hline
\end{tabular}


water level was $3.19 \mathrm{ft}$ below the top of casing, which is the level of the overflow.

The ATV data indicate the borehole deviates less than $1 \mathrm{ft}$ towards the north (appendix 1, fig. 1E-2). The EMI conductivity log, which was used to identify the bottom of casing, indicates the bottom of casing is at a depth of $81.3 \mathrm{ft}$ (appendix 1, fig. 1E-1). The gamma, ATV magnetometer, and ATV reflectivity data confirm this depth to the bottom of casing. However, the ATV images and the mechanical caliper log suggest there may be grout on the inside of the casing, giving it a rough appearance. The grout is possibly the remnant of a drilling process whereby the driller grouts the casing and then drills through it and into the bedrock after the grout sets. Thus, the ATV images and caliper data inside the casing and at the top of the borehole appear different from the logs collected in other boreholes in the study area. Logs and interpretations for borehole DW-25 are in appendix 1E.

Lithology. The lithology is uniform over the length of the borehole. The gamma emissions were uniform and low (about $60 \mathrm{cps}$ behind the casing and about $30 \mathrm{cps}$ in the open borehole). The high gamma from behind the casing may indicate the presence of grout. The ATV reflectivity log showed more variation than the gamma tool and ranged from 950 to $2,475 \mathrm{mV}$. The gamma and reflectivity signatures in borehole DW-25 are similar to the signatures in the bottom half of borehole DW-23 and the very bottom of borehole DW-32. The normal resistivity logs show an increase in resistivity from a depth of 105 to $120 \mathrm{ft}$ below the top of casing. This increase is probably related to lithology. Decreases in the resistivity logs are centered at depths of about 105, 120, and $135 \mathrm{ft}$ below the top of casing and coincide with fracture locations. Collectively, these results indicate borehole DW-25 intersects a mafic intrusive unit like gabbro or diabase.

Fractures. Interpretations of fracture locations and orientations (appendix 1, table 1E-1) are shown in stereoplots and structure and tadpole plots (appendix 1, fig. 1E-3). Fractures dip steeply towards the southeast, northwest, and east. The HPFM data indicate the fractures at depths of 128 and $137 \mathrm{ft}$ below the top of casing are transmissive. The ATV $\log$ indicates the transmissive fractures dip steeply towards the northeast (appendix 1, fig. 1E-3).
Hydraulic characterization. Using the HPFM, ambient flow was measured coming into the borehole at the fractures at depths of about 128,135 , and $138.5 \mathrm{ft}$ below the top of casing. The inflowing water flowed upward to the overflow pipe near the top of the borehole. The total ambient upflow rate was greater than the flow rate that could be measured with the HPFM with a fully fitted diverter. Hence, an underfit, 4-in. diverter was used, and flow rates as high as $5 \mathrm{gal} / \mathrm{min}$ were measured. Under pumping conditions, most of the flow comes from the fracture at a depth of $138.5 \mathrm{ft}$ below the top of casing, and a small amount comes from the fractures at depths of 128 and $135 \mathrm{ft}$.

The ambient water level was estimated in a method similar to that used in DW-23, in which the pumped water levels were used to estimate the initial water level at the initiation of pumping. The starting water level was estimated at $1.5 \mathrm{ft}$ below the top of casing. Using the very-early-time water-level data produced an ambient head of about $1 \mathrm{ft}$, and using the remainder of the early-time water-level response to pumping, the ambient water level was estimated at $2.25 \mathrm{ft}$ below the top of casing. Hence, the ambient water level was estimated as $1.5 \mathrm{ft}$ below the top of casing. Using the methods of Bradbury and Rothschild (1985), the open-hole specific capacity was estimated at $0.82(\mathrm{gal} / \mathrm{min}) / \mathrm{ft}$, and the transmissivity was $177 \mathrm{ft}^{2} / \mathrm{d}$. The transmissivity was estimated at $130 \mathrm{ft}^{2} / \mathrm{d}$ using FWRAP; however, the RMS error was fairly high at $2.9 \mathrm{gal} / \mathrm{min}$. Under this model, the lowermost fracture had a head that was $5 \mathrm{ft}$ higher than the top of the borehole. The high RMS error could be caused by poor estimates of the model parameters but could also be caused by the overflow at the top of the borehole, which was modeled as an artificial fracture. This fracture was assigned a transmissivity of 100 percent, which is sufficiently large to accommodate any upward flow in the borehole. The model results are shown in table 8 and appendix 1, figure 1E-4.

Under ambient conditions, the water-quality probe showed changes in dissolved oxygen, $\mathrm{pH}$, and oxidationreduction potential at depths of 121,128 , and $132 \mathrm{ft}$ below the top of casing and $2.19 \mathrm{ft}$ above the overflow outlet (appendix 1, fig. 1E-1). The ambient fluid log showed changes in fluid conductivity at depths of 132 and $138 \mathrm{ft}$, which are consistent with the transmissive fractures identified with the HPFM.

Table 8. Flow model for borehole DW-25, near Machiasport, Maine.

[ft, feet; gal/min, gallon per minute; $\mathrm{ft}^{2} / \mathrm{d}$, feet squared per day; TOC, top of casing]

\begin{tabular}{ccccccc}
\hline $\begin{array}{c}\text { Depth of } \\
\text { transmissive zone } \\
(\mathbf{f t})\end{array}$ & $\begin{array}{c}\text { Ambient flow above } \\
\text { transmissive zone } \\
(\mathbf{g a l} / \mathbf{m i n})\end{array}$ & $\begin{array}{c}\text { Pumped flow above } \\
\text { transmissive zone } \\
(\mathbf{g a l} / \mathbf{m i n})\end{array}$ & $\begin{array}{c}\text { Zone } \\
\text { transmissivity } \\
(\mathbf{f t} \mathbf{2} / \mathbf{d})\end{array}$ & $\begin{array}{c}\text { Water level } \\
\text { (ft below TOC) }\end{array}$ & $\begin{array}{c}\text { Elevation of } \\
\text { water level } \\
\text { (ft) }\end{array}$ & $\begin{array}{c}\text { Percent of total } \\
\text { transmissivity }\end{array}$ \\
\hline 128.0 & 1.816 & 3.671 & 40.5 & 0.818 & 39.18 & 31 \\
138.0 & 1.686 & 2.922 & 89.1 & -2.182 & 42.18 & 69 \\
\hline
\end{tabular}




\section{Borehole DW-31}

Location and construction. Domestic well DW-31 is off GATR Road on Miller Mountain, south of the summit. The borehole has steel casing that was completed to $2.2 \mathrm{ft}$ above land surface and extends to a depth of $17 \mathrm{ft}$ below the top of casing. Borehole DW-31 was completed to a total depth of $245 \mathrm{ft}$ below the top of casing. On November 12, 2005, at 1:00 p.m., under ambient conditions the open-hole water level was at a depth of $133.82 \mathrm{ft}$ below the top of casing, which is fairly deep relative to the other boreholes in the study area. However, boreholes WY-GATR and MW-10, which are on mountaintops, also have deep open-hole water levels. Borehole DW-31 deviated a total of $3.5 \mathrm{ft}$ towards the northeast (appendix 1, fig. 1F-2). The OTV log, which was only used to survey the top of the borehole above the water surface, confirms the direction and magnitude of the deviation for the upper portion of the borehole. Logs and interpretations for borehole DW-31 are in appendix 1F.

Lithology. The EMI and the OTV logs indicate the bottom of casing is at a depth of $17 \mathrm{ft}$ below the top of casing (appendix 1, fig. 1F-1). Gamma emissions are fairly uniform over the entire open length of the borehole. At a depth of 30 to $41 \mathrm{ft}$, there is a zone of increased gamma emissions, which averages about $200 \mathrm{cps}$ and is similar to borehole MW-13 and the upper part of borehole MW-14. From a depth of 41 to about $134 \mathrm{ft}$, the gamma log is fairly uniform with emissions of about $70 \mathrm{cps}$. At the water level, there is a small spike in the gamma emissions, which increases to about $160 \mathrm{cps}$ at depths of 134 to about $139 \mathrm{ft}$ below the top of casing. From a depth of $139 \mathrm{ft}$ to the bottom of the borehole, the total gamma emissions average 30 to $40 \mathrm{cps}$, suggesting a mafic unit such as gabbro or diabase. ATV logs could be collected only in the bottom part of the borehole, below the water level. The ATV reflectivity amplitude was variable (1,200 to $2,200 \mathrm{mV})$ but relatively high. In general, the low gamma and high reflectivity signatures in borehole DW-31 are similar to what was observed in the bottom portions of boreholes DW-23, DW-25, and DW-32 and in the upper half of DW-39.

The OTV $\log$ was collected in the top of the borehole above the water level. Below the water level, the water was turbid with high total suspended solids that prevented viewing the borehole wall beneath the water table. The rock type appears to be fairly uniform, massive, and gray. The zone with the increased gamma counts from a depth of about 30 to $41 \mathrm{ft}$ shows a change in texture in the OTV log and is darker than the rock above and below. This darker rock may be similar to the rock in the top of borehole MW-14 (granodiorite or quartz monzonite). The normal resistivity tool and EMI indicate uniform rock types. The normal resistivity tool exceeded the measurement range in the 8- and 16-in. logs. The 32- and 64-in. logs indicate a highly resistive rock with decreases in resistivity at fracture locations, including the major fracture at a depth of $235 \mathrm{ft}$ observed in the caliper log and the minorlooking fracture at a depth of $162 \mathrm{ft}$ in the ATV log.
Fractures. Only three "major fractures" (shown in blue in the stereoplots) were identified in the borehole (appendix 1, fig. 1-F3). The deepest fracture, at a depth of $235 \mathrm{ft}$ below the top of casing, is also the only fracture that was identified as hydraulically active with flowmeter methods. The other two major fractures were at depths of 84.5 and $146 \mathrm{ft}$ below the top of casing. The fracture at $84.5 \mathrm{ft}$ is oriented at $\mathrm{N} 189^{\circ} \mathrm{E}, 70^{\circ} \mathrm{W}$ (appendix 1, table $1 \mathrm{~F}-2$ ), and the fracture at $146 \mathrm{ft}$ is oriented at $\mathrm{N} 7^{\circ} \mathrm{E}, 76^{\circ} \mathrm{E}$ (appendix 1 , table $1 \mathrm{~F}-1$ ). The strike and dip of the hydraulically active fracture at $235 \mathrm{ft}$ could not be determined, because the ATV $\log$ did not extend through the fracture zone. Hence, the fracture was shown as a horizontal feature in the stereoplots and projection and tadpole plots. Also, several minor-looking fractures were observed in the borehole (light blue in appendix 1, figs. $1 \mathrm{~F}-1$ and 3 ). These minor fractures strike northeast and southwest and dip moderate to steeply toward the southeast and northwest. A few shallow-dipping fractures also were detected in the image logs.

Hydraulic characterization. The water level in borehole DW-31 was low relative to the other boreholes in the study area, except for the boreholes WY-GATR and MW-10, both of which are on the mountaintops where there is a strong downward gradient. On November 11, 2004, the water level in borehole DW-31 was $133.5 \mathrm{ft}$ below the top of casing. On the next day, the water level was $134.45 \mathrm{ft}$ below the top of casing and was declining at 2:31 p.m. The rate of decline of $0.63 \mathrm{ft}$ in $90 \mathrm{~min}$ translates to $0.01 \mathrm{gal} / \mathrm{min}$ in a 6-in. diameter borehole.

The HPFM identified the lowest fracture in the borehole, at a depth of $235 \mathrm{ft}$, as the fracture that was receiving water under ambient conditions, indicating water from the borehole was exiting the borehole into the formation at this fracture. The borehole was pumped at a rate of about $0.4 \mathrm{gal} / \mathrm{min}$. Under pumping conditions, the water level declined $6.18 \mathrm{ft}$ in $39 \mathrm{~min}$, which translates to a decline of $0.15 \mathrm{ft} / \mathrm{min}$ or $0.2 \mathrm{gal} / \mathrm{min}$ coming from borehole storage. Thus, all downflow measured with the HPFM under ambient conditions was attributed to changes in well-bore storage and ocean tidal influence. Hence, no ambient flow was included in the models. Under a pumping rate of $0.4 \mathrm{gal} / \mathrm{min}$, the ambient outflow was overcome and an inflow of $0.3 \mathrm{gal} / \mathrm{min}$ was measured from the fracture at a depth of $235 \mathrm{ft}$ below the top of casing. This was the most substantial transmissive fracture identified with the HPFM in the borehole. The fracture at a depth of $235 \mathrm{ft}$ accounts for 92 percent of the inflow to the borehole under pumping conditions. The remainder of the inflow comes from the fracture at a depth of $146 \mathrm{ft}$ below the top of casing. The RMS error for this model was $0.006 \mathrm{gal} / \mathrm{min}$. The open-hole transmissivity determined with FWRAP was $10.2 \mathrm{ft}^{2} / \mathrm{d}$. The model results are shown in table 9 and appendix 1 , figure $1 \mathrm{~F}-4$.

The OTV log suggests there might be other low-yielding fractures above the water table. The OTV log was collected above the water level in an upward direction. The vertical black lines on the images (from $85 \mathrm{ft}$ and above) may indicate water that had dripped onto the tool and obscured the view. 
Table 9. Flow model for borehole DW-31, near Machiasport, Maine.

[ft, feet; gal/min, gallon per minute; $\mathrm{ft}^{2} / \mathrm{d}$, feet squared per day; TOC, top of casing]

\begin{tabular}{ccccccc}
\hline $\begin{array}{c}\text { Depth of } \\
\text { transmissive zone } \\
\text { (ft) }\end{array}$ & $\begin{array}{c}\text { Ambient flow above } \\
\text { transmissive zone } \\
\text { (gal/min) }\end{array}$ & $\begin{array}{c}\text { Pumped flow above } \\
\text { transmissive zone } \\
\text { (gal/min) }\end{array}$ & $\begin{array}{c}\text { Zone } \\
\text { transmissivity } \\
\text { (ft } / \mathbf{d})\end{array}$ & $\begin{array}{c}\text { Water level } \\
\text { (ft below TOC) }\end{array}$ & $\begin{array}{c}\text { Elevation of } \\
\text { water level } \\
\text { (ft) }\end{array}$ & $\begin{array}{c}\text { Percent of total } \\
\text { transmissivity }\end{array}$ \\
\hline 146.0 & 0.00 & 0.33 & 0.8 & 134.45 & 73.55 & 8 \\
235.0 & 0.00 & 0.30 & 9.4 & 134.45 & 73.55 & 92 \\
\hline
\end{tabular}

These black lines are encountered at the fractures at depths of 84.5 and $33 \mathrm{ft}$, indicating dripping from these fractures. Because these fractures are above the water level, they could not be measured with the HPFM. Efforts to include the fracture at a depth of $85 \mathrm{ft}$ in the FWRAP model produced poor results.

Because the well did not reach steady state under pumping conditions, a transient solution was used for the open-hole test. A Cooper-Jacob straight line test for a pumping rate of $0.4 \mathrm{gal} / \mathrm{min}$ and a water-level decline of $7.85 \mathrm{ft}$ over one logcycle were used to estimate a transmissivity of $1.8 \mathrm{ft}^{2} / \mathrm{d}$. All the inflow was attributed to the fracture at $235 \mathrm{ft}$. This value is lower than the results determined with FWRAP.

\section{Borehole DW-32}

Location and construction. Domestic well DW-32 is south-southeast of Miller Mountain along Port Road, just north of neighboring well DW-22. The borehole casing extends $1.4 \mathrm{ft}$ above land surface and to a depth of $23.5 \mathrm{ft}$ below the top of casing. The borehole was completed to a total depth of $105 \mathrm{ft}$ below the top of casing. The borehole is almost plumb; it deviates less than $1 \mathrm{ft}$ towards the northwest (appendix 1, fig. 1G-2). Borehole DW-32 has a reported yield of $1.5 \mathrm{gal} / \mathrm{min}$. The ambient water level was $17.02 \mathrm{ft}$ below the top of casing at 7:23 a.m. on November 14, 2004. Logs and interpretations for borehole DW-32 are in appendix $1 \mathrm{G}$.

Lithology. Minor changes in lithology were observed in the ATV and gamma logs. In the first $65.5 \mathrm{ft}$ of open borehole, the bedrock is fairly uniform in acoustic reflectivity and gamma. In general, the bedrock emits gamma radiation of about 110 to $130 \mathrm{cps}$ and has a reflectivity of 700 to $1,000 \mathrm{mV}$, averaging about $780 \mathrm{mV}$, which is consistent with metamorphic sediments. At a depth $89 \mathrm{ft}$ below the top of casing, the borehole intersected a lithologic contact, below which the rock type is harder and more reflective $(955-1,900 \mathrm{mV}$, and averages about $1,300 \mathrm{mV}$ ) than above the contact. This zone from a depth of 89 to $105 \mathrm{ft}$ below the top of casing exhibits lower gamma counts (about $30 \mathrm{cps}$ ) relative to the top of the borehole. These results suggest a hard mafic rock below a depth of $89 \mathrm{ft}$.
Fractures. This borehole appears to be less fractured than other boreholes at the site. A few minor fractures are shown in light blue (appendix 1, fig. 1G-3) dipping steeply to the west (appendix 1, table 1G-1). Three transmissive zones were identified in the borehole with the HPFM at depths of about 26, 71, and $89.7 \mathrm{ft}$ below the top of casing. Five possible fractures were identified as transmissive (shown in stereo and tadpole plots in dark blue); three of the fractures comprise the uppermost transmissive zone. All the transmissive fractures in the upper part of the borehole were weakly clustered and dip to the south-southwest. The transmissive fracture at a depth of about $89.7 \mathrm{ft}$ strikes $166^{\circ} \mathrm{E}$ and dips $23^{\circ}$ to the west. The fracture is near the contact with a diabase dike.

Hydraulic characterization. Ambient downflow was measured in borehole DW-32 on November 13, 2004, with the HPFM. Under ambient conditions, water entered the borehole from a fracture (or fractures) just below the casing near a depth of $26 \mathrm{ft}$, flowed down the borehole, and exited the borehole at a depth of $89.7 \mathrm{ft}$ below the top of casing. The rate of downflow was $0.045 \mathrm{gal} / \mathrm{min}$ or about $65 \mathrm{gal}$ per day. Under a pumping rate of $0.6 \mathrm{gal} / \mathrm{min}$, water entered the borehole from fractures at depths of $26,71.5$, and $89.7 \mathrm{ft}$ below the top of casing. Using the water-level data from the open hole under pumping conditions, drawdown was only about $0.21 \mathrm{ft}$. The transmissivity was estimated using steady-state solutions; however, the water level may not have been at steady state because the pumping rate changed during the pumping test. Assuming steady-state conditions, under pumping conditions of $0.6 \mathrm{gal} / \mathrm{min}$, the open-hole transmissivity was estimated at $632 \mathrm{ft}^{2} / \mathrm{d}$, and the specific capacity was 2.86 (gal/min)/ft.

Using FWRAP and the flowmeter profiles, pumping information, and water levels, the open-hole transmissivity was determined to be $511 \mathrm{ft}^{2} / \mathrm{d}$. The model results are shown in table 10 and appendix 1 , figure $1 \mathrm{G}-4$.

The deepest of the three fractures at a depth of $89.7 \mathrm{ft}$ accounted for 65 percent of the flow. The fracture at a depth of $71.5 \mathrm{ft}$ below the top of casing accounted for 19 percent of the flow, and the rest of the flow came from the uppermost fracture at a depth of $26.3 \mathrm{ft}$.

Changes in specific conductance identified with the fluid resistivity and temperature probe and the water-quality probe occurred at the same depths as the transmissive fractures and helped identify these hydraulically active fractures. The 
Table 10. Flow model for borehole DW-32, near Machiasport, Maine.

[ft, feet; gal/min, gallon per minute; $\mathrm{ft}^{2} / \mathrm{d}$, feet squared per day; TOC, top of casing]

\begin{tabular}{ccccccc}
\hline $\begin{array}{c}\text { Depth of } \\
\text { transmissive zone } \\
\text { (ft) }\end{array}$ & $\begin{array}{c}\text { Ambient flow above } \\
\text { transmissive zone } \\
\text { (gal/min) }\end{array}$ & $\begin{array}{c}\text { Pumped flow above } \\
\text { transmissive zone } \\
\text { (gal/min) }\end{array}$ & $\begin{array}{c}\text { Zone } \\
\text { transmissivity } \\
\text { (ft/ } / \mathbf{d})\end{array}$ & $\begin{array}{c}\text { Water level } \\
\text { (ft below TOC) }\end{array}$ & $\begin{array}{c}\text { Elevation of } \\
\text { water level } \\
\text { (ft) }\end{array}$ & $\begin{array}{c}\text { Percent of total } \\
\text { transmissivity }\end{array}$ \\
\hline 26.0 & 0.00 & 0.57 & 82.5 & 16.95 & 45.05 & 16 \\
71.5 & -0.04 & 0.42 & 99.0 & 17.04 & 44.96 & 19 \\
89.7 & -0.05 & 0.30 & 330.0 & 17.07 & 44.93 & 65 \\
\hline
\end{tabular}

ambient fluid log showed very little variation from the top of the borehole down to the fracture at a depth of $89.7 \mathrm{ft}$, which is consistent with the interpretation of ambient inflow from the uppermost transmissive zone at a depth of about $26 \mathrm{ft}$, downflow and uniform specific conductance over most of the borehole, and outflow at the fracture at a depth of about $90 \mathrm{ft}$. After pumping, the water-quality log showed changes in the specific-conductance profile that showed probable inflow at depths of 72.7 and $26 \mathrm{ft}$ below the top of casing.

\section{Borehole DW-33}

Location and construction. Domestic well DW-33 is southeast of Miller Mountain on Port Road at the Bucks Harbor Shopping Mall. Borehole DW-33 is north of boreholes DW-32, DW-22, and DW-23 and south of DW-40 (fig. 1). The borehole has steel casing that extends $1.98 \mathrm{ft}$ above land surface and extends to a depth of $34 \mathrm{ft}$ below the top of casing. The well was completed to a total depth of $82 \mathrm{ft}$ below the top of casing. Under ambient conditions, the open-hole water level was $4.06 \mathrm{ft}$ below the top of casing, which is $2.08 \mathrm{ft}$ below land surface, on November 13, 2005, at 7:33 a.m. Borehole DW-33 is essentially plumb because the ATV tool indicates the borehole deviates only about $0.5 \mathrm{ft}$ towards the southwest (appendix 1, fig. 1H-1). Logs and interpretations for borehole DW-33 are in appendix $1 \mathrm{H}$.

Lithology. The lithology is uniform over the length of borehole DW-33 (appendix 1, fig. 1H-1). The gamma, EMI, and acoustic reflectivity logs are fairly uniform, indicating no change in the rock type over the length of the open borehole.

The gamma log indicates natural gamma emissions behind casing of about $65 \mathrm{cps}$ and about $20 \mathrm{cps}$ in the open borehole. The higher gamma values behind the casing may indicate clay or grout. The ATV reflectivity is approximately 70 to $120 \mathrm{mV}$ using the ABI-40. The gamma and reflectivity signatures in borehole DW-33 are similar to the signatures in the upper $145 \mathrm{ft}$ of borehole DW-40. Throughout borehole DW-33 and in the upper part of borehole DW-40, the gamma and reflectivity values are very low, indicating a mafic rock type. Although the reflectivity values in borehole DW-33 are similar to those in borehole DW-22, the gamma counts in DW-22 are higher than in DW-33. The increase in EMI conductivity and slight decrease in normal resistivity below a depth of $75 \mathrm{ft}$ may be related to iron-rich zones in the diabase. Because the fluid conductivity does not increase for that zone, the increase is not likely caused by conductive fluids in these fractures.

The normal resistivity logs show a zone of increased resistivity from a depth of 42 to $50 \mathrm{ft}$ below the top of casing. The zone appears to coincide with a zone that is unfractured relative to the rest of the borehole. Other local decreases in the normal resistivity correspond to fractures centered at depths of about 41 and $36 \mathrm{ft}$ below the top of casing. The resistivity below a depth of $50 \mathrm{ft}$ is similar to the resistivity above $40 \mathrm{ft}$ and is probably related to the presence of fractures.

Fractures. The ATV data show a high-resolution, high-quality image. No ambient flow was measured in borehole DW-33 using the HPFM (appendix 1, fig. 1H-4). Under pumping conditions (discharge rate of $0.5 \mathrm{gal} / \mathrm{min}$ ), all the inflow takes place between flowmeter measurements collected at depths of 44 and $38 \mathrm{ft}$ below the top of casing. Thus, the fractures at depths of $39.2,40.9$, and $41.1 \mathrm{ft}$ (appendix 1, table 1H-1) below the top of casing are shown in dark blue, indicating one or more of them are transmissive (appendix 1, figs. $1 \mathrm{H}-1$ and $1 \mathrm{H}-3$ ). These fractures were modeled as a single fracture zone at a depth of $41.0 \mathrm{ft}$ below the top of casing. The two lower fractures, which are closer to the changes in the fluid column under ambient conditions, dip steeply to the south. The fracture at a depth of $39.2 \mathrm{ft}$ dips steeply toward the northeast (appendix 1, fig. 1H-3). A fracture at a depth of $55 \mathrm{ft}$ below the top of casing was imaged prominently in the ATV and caliper logs. The fluid conductivity log showed a minor deflection at a depth of $54 \mathrm{ft}$, but this fracture was not identified as hydraulically active with the HPFM under ambient or pumping conditions.

Hydraulic characterization. The upflow rate measured at a depth of $30 \mathrm{ft}$ was slightly larger $(0.08 \mathrm{gal} / \mathrm{min})$ than the upflow rate at a depth of $35 \mathrm{ft}$ below the top of casing. However, the small increase in measured upflow may be because the $30-\mathrm{ft}$ measurement was in casing and may capture slightly more flow than in the measurement at the $35-\mathrm{ft}$ depth in the open borehole. Alternatively, there was a small amount of inflow from the vertical fracture that intersects the borehole at the base of casing. 
The HPFM did not measure any flow under ambient conditions. Under pumping conditions of $0.5 \mathrm{gal} / \mathrm{min}$, the open-hole transmissivity was estimated at $112 \mathrm{ft}^{2} / \mathrm{d}$ using the methods of Bradbury and Rothschild (1985). Two scenarios were modeled - one with a single fracture at a depth of $41.0 \mathrm{ft}$ and the other with inflow at the base of casing (at a depth of $34 \mathrm{ft}$ below the top of casing). The flowmeter profiles and water-level data were interpreted using FWRAP (the twofracture model results are shown in table 11 and appendix 1, fig. 1H-4). Total transmissivity for the single-fracture model in DW-33 is estimated as $100 \mathrm{ft}^{2} / \mathrm{d}$, with an RMS error of $0.012 \mathrm{gal} / \mathrm{min}$. Total transmissivity for the two-fracture model was essentially the same, at $98 \mathrm{ft}^{2} / \mathrm{d}$ with an RMS error of $0.004 \mathrm{gal} / \mathrm{min}$.

The ambient water-quality and fluid conductivity logs show changes in the water chemistry at the base of casing, at $41.4 \mathrm{ft}$, and a minor change at $54 \mathrm{ft}$ below the top of casing (appendix 1, fig. 1H-1). The difference in the fluidconductivity measurements between the two tools likely is caused by the difference in the temperature measurement of the same water for the two tools. The water-quality parameter tool consistently measures a lower temperature than the fluid tool. Temperature was not changed in the calibration. At a depth of $41.4 \mathrm{ft}$ below the top of casing, the fluid conductivity and $\mathrm{pH}$ increased and the oxygen decreased. These changes in the fluid column further support the interpretation that the fractures at just beneath the base of casing are transmissive.

\section{Borehole DW-34}

Location and construction. Domestic well DW-34 is south of Miller Mountain along Port Road and across the road and upgradient from neighboring well DW-24. The borehole has 6 -in. steel casing set to a depth of $40.5 \mathrm{ft}$ below the top of casing. The well was completed to a total depth of $312.7 \mathrm{ft}$ below the top of casing. The casing extends $2.25 \mathrm{ft}$ above the land surface. DW-34 deviates about $4 \mathrm{ft}$ to the south (appendix 1, fig. 1I-2). The ambient water level on April 3, 2005 , was $8.56 \mathrm{ft}$ below the top of casing at 8:15 a.m. Logs and interpretations for borehole DW-34 are in appendix 1I.
Lithology. Gamma logs collected in borehole DW-34 have an average activity of $375 \mathrm{cps}$ for the upper part of the borehole from the bottom of casing down to a depth of about $151 \mathrm{ft}$ below the top of casing. From a depth of 151 to about $157 \mathrm{ft}$ below the top of casing, the gamma counts are lower (about $155 \mathrm{cps}$ ) than the unit above, and from a depth of 157 to $270 \mathrm{ft}$, the activity is fairly uniform at $250 \mathrm{cps}$. Two narrow ( $<5$-ft wide) low-count gamma peaks (about $150 \mathrm{cps}$ ), which probably are associated with mafic dikes, are at depths of 275 and $297 \mathrm{ft}$ below the top of casing. The major change in gamma emissions is at a depth of $151 \mathrm{ft}$ below the top of casing. Also at this depth, the electromagnetic conductivity log increases slightly. The highest gamma values in this borehole at the top of the well and the lowest EMI conductivity values appear to be correlated. As observed in the mechanical caliper $\log$, the uppermost part of the borehole (above a depth of $151 \mathrm{ft}$ ) appears to have a more variable and slightly larger borehole diameter than the bottom of the borehole. The ATV reflectivity plot shows slightly higher amplitude $(200 \mathrm{mV})$ over the top portions of the borehole and less variable, lower average amplitudes (about $100 \mathrm{mV}$ ) in the bottom of the borehole. These results are consistent with a change in rock type at a depth of $151 \mathrm{ft}$ below the top of casing. No consistent pattern that would help identify a change in rock type was observed in the resistivity logs. The gamma and acoustic reflectivity signatures in borehole DW-34 are similar to nearby wells. Specifically, signatures in the bottom of borehole DW-34 and in the top of borehole MW-14 are similar and are interpreted to be quartz monzonite. The top of borehole DW-34 has higher gamma emissions than any other borehole in the study area. This unit, which is highly reflective and hard, is thought to be igneous and is interpreted to be a more alkali-rich unit than quartz monzonite, quartz diorite, and gabbro, such as quartz syenite.

Fractures. Because of a deviation-tool malfunction, the deviation data for the middle portion of the borehole were corrupted. Hence, the deviation data for the vertical tilt of the tool were interpolated between the good data at the top of the borehole and the good values at the bottom of the borehole (between depths of 95 and $295 \mathrm{ft}$ ) (appendix 1, fig. 1I-2).

Table 11. Flow model for borehole DW-33, near Machiasport, Maine.

[ft, feet; gal/min, gallon per minute; $\mathrm{ft}^{2} / \mathrm{d}$, feet squared per day; TOC, top of casing]

\begin{tabular}{ccccccc}
\hline $\begin{array}{c}\text { Depth of } \\
\text { transmissive zone } \\
\text { (ft) }\end{array}$ & $\begin{array}{c}\text { Ambient flow above } \\
\text { transmissive zone } \\
\text { (gal/min) }\end{array}$ & $\begin{array}{c}\text { Pumped flow above } \\
\text { transmissive zone } \\
\text { (gal/min) }\end{array}$ & $\begin{array}{c}\text { Zone } \\
\text { transmissivity } \\
\text { (ftr/d) }\end{array}$ & $\begin{array}{c}\text { Water level } \\
\text { (ft below TOC) }\end{array}$ & $\begin{array}{c}\text { Elevation of } \\
\text { water level } \\
\text { (ft) }\end{array}$ & $\begin{array}{c}\text { Percent of total } \\
\text { transmissivity }\end{array}$ \\
\hline 41.0 & \multicolumn{7}{c}{ Single-fracture model } \\
\hline & 0.00 & 0.50 & 100.0 & 3.97 & 48.83 & 100 \\
\hline 34.0 & 0.0 & 0.51 & Two-fracture model & & & \\
\hline 41.0 & 0.0 & 0.42 & 84 & 3.97 & 48.83 & 14 \\
\hline
\end{tabular}


The orientation of the image data was not affected by the tool malfunction.

The projection, stereo, and tadpole plots indicate most of the fractures in the borehole are steeply dipping to nearly vertical (appendix 1, fig. 1I-3). There are only a few shallow dipping fractures. The steeply dipping fractures strike a variety of orientations and dip to the west-northwest and to the east-to southeast.

Hydraulic characterization. The HPFM log collected under ambient conditions shows slight ambient flow that enters the borehole at a depth of $145 \mathrm{ft}$ and flows upward in the borehole, exiting at the fracture just below the base of casing at a depth of $40.5 \mathrm{ft}$ (appendix 1, fig. 1I-4). Under pumping conditions, water enters the borehole from the fracture at a depth of $145 \mathrm{ft}$ and at the fracture just below the base of casing. Additionally, a small proportion of water enters at a depth of $212 \mathrm{ft}$ below the top of casing.

Open-hole transmissivity was estimated using the open-hole water-level data collected during pumping and by modeling the HPFM and water-level data. The pumping rate was initially $0.5 \mathrm{gal} / \mathrm{min}$, but it had to be reduced to a final rate of $0.26 \mathrm{gal} / \mathrm{min}$. The specific capacity was estimated at $0.042(\mathrm{gal} / \mathrm{min}) / \mathrm{ft}$ and the transmissivity was estimated at $7.4 \mathrm{ft}^{2} / \mathrm{d}$ using open-hole methods of Bradbury and Rothschild (1985) (table 12). These preliminary transmissivity results were used as initial estimates for modeling the transmissivity and head of individual fractures using FWRAP.

HPFM profiles and water levels under ambient and pumped conditions were modeled to determine the head and transmissivity of the three fractures identified as transmissive. The heads and transmissivity are summarized in table 12 and appendix 1 , figure $1 \mathrm{I}-4$. The total transmissivity using this method was $8 \mathrm{ft}^{2} / \mathrm{d}$, which is more than the open-hole estimate.

A transducer was left in borehole DW-34 to monitor the recovery of the water level and its response to pumping and to verify if the water level in the borehole was influenced by tidal forces or by nearby pumping. The water level in borehole DW-34 recovered approximately $4 \mathrm{~h}$ after the pump was turned off. Once recovered, there were only small, random variations in the water level, which do not suggest tidal or pumping influences.

Under ambient conditions, the fluid conductivity log shows three changes that might indicate ambient flow. Prominent changes take place at depths of 142 and $165 \mathrm{ft}$ below the top of casing. A minor change takes place at a depth of $205 \mathrm{ft}$ below the top of casing. A fluid log collected after pumping indicates the temperature logs are nearly identical, so the fluid conductivity logs can be directly compared without converting to specific conductance at a fixed temperature.

The post-pumping fluid conductivity logs suggest water enters the borehole at the fractures at a depth of 145, possibly 212 , and around $265 \mathrm{ft}$ below the top of casing; however, no fracture was independently located at $265 \mathrm{ft}$.

\section{Borehole DW-39}

Location and construction. Domestic well DW-39 is north of Miller Mountain along the west side of Port Road. The borehole has 6-in. steel casing that extends $2.18 \mathrm{ft}$ above land surface and was completed to a depth of $20 \mathrm{ft}$ below the top of casing. The well was drilled to a total depth of $221 \mathrm{ft}$ below the top of casing. On November 16, 2005, at 4:04 p.m., under ambient conditions, the open-hole water level was $16.04 \mathrm{ft}$ below the top of casing. Borehole DW-39 deviates about $4.5 \mathrm{ft}$ to the southeast (appendix 1, fig. 1J-2). Logs and interpretations for borehole DW-39 are in appendix $1 \mathrm{~J}$.

Lithology. The lithology is fairly uniform over the length of the borehole with some minor changes. The gamma, acoustic reflectivity, and normal resistivity logs show minor variations, which are indicative of changes in the rock type (appendix 1, fig. 1J-1). From a depth of about 20 to $31 \mathrm{ft}$ below the top of casing, the borehole is slightly enlarged, rough, and not highly reflective in the ATV log, probably because of the highly fractured nature of the rock below the base of casing. From a depth of 31 to $135 \mathrm{ft}$ below the top of casing, the bedrock is less fractured and is characterized by low gamma (15 to $30 \mathrm{cps}$ ) and uniform reflectivity at approximately $1,600 \mathrm{mV}$. These signatures are typical of the gabbro/diabase unit.

Table 12. Flow model for borehole DW-34, near Machiasport, Maine.

[ft, feet; gal/min, gallon per minute; $\mathrm{ft}^{2} / \mathrm{d}$, feet squared per day; TOC, top of casing]

\begin{tabular}{|c|c|c|c|c|c|c|}
\hline $\begin{array}{c}\text { Depth of } \\
\text { transmissive zone } \\
\text { (ft) }\end{array}$ & $\begin{array}{c}\text { Ambient flow above } \\
\text { transmissive zone } \\
\text { (gal/min) }\end{array}$ & $\begin{array}{c}\text { Pumped flow above } \\
\text { transmissive zone } \\
\text { (gal/min) }\end{array}$ & $\begin{array}{c}\text { Zone } \\
\text { transmissivity } \\
\left(\mathrm{ft}^{2} / \mathrm{d}\right)\end{array}$ & $\begin{array}{c}\text { Water level } \\
\text { (ft below TOC) }\end{array}$ & $\begin{array}{c}\text { Elevation of } \\
\text { water level } \\
\text { (ft) }\end{array}$ & $\begin{array}{l}\text { Percent of total } \\
\text { transmissivity }\end{array}$ \\
\hline 40.5 & 0.000 & 0.262 & 6.0 & 8.65 & 58.25 & 75 \\
\hline 145.0 & 0.009 & 0.084 & 1.5 & 7.65 & 59.25 & 19 \\
\hline 210.0 & 0.002 & 0.022 & 0.5 & 7.65 & 59.25 & 6 \\
\hline
\end{tabular}


From depths of 135 to $176 \mathrm{ft}$ below the top of casing, the bedrock has a gamma signature of about $50 \mathrm{cps}$ and a reflectivity of 980 to $1,030 \mathrm{mV}$, which appears darker in the ATV amplitude image than the bedrock above and below it. Also, this zone has rough mechanical and acoustic caliper logs. At a depth of $176 \mathrm{ft}$ below the top of casing, there is a sharp contact that strikes $\mathrm{N} 205^{\circ} \mathrm{E}$ and dips $55^{\circ}$ to the west-northwest. The gamma and reflectivity signatures of this section of the borehole are similar to the gamma and reflectivity signatures observed for the diabase or gabbro unit in the lower part of borehole MW-14.

From a depth of 176 to $205 \mathrm{ft}$ below the top of casing, the bedrock is highly reflective (1,200 to $2,400 \mathrm{mV})$ and has a gradual increase in gamma emissions from 50 to about $200 \mathrm{cps}$. Below a depth of $205 \mathrm{ft}$ to the bottom of the borehole, the gamma emissions are generally 180 to $200 \mathrm{cps}$, and the reflectivity is lower (about $1,060 \mathrm{mV}$ ) than in the zone above it. The rocks at the bottom section of this borehole are not typical of the diabase but may be typical of granodiorite or quartz monzonite.

The 32- and 64-in. normal resistivity logs show a slight increase in resistivity from a depth of $145 \mathrm{ft}$ to the bottom of the borehole relative to the resistivity at the top of the borehole. Reductions in resistivity are consistent with prominent fractures observed in the borehole.

Fractures. The ATV log shows a rough and enlarged borehole from the bottom of casing at a depth of $20 \mathrm{ft}$ to about $30 \mathrm{ft}$ below the top of casing. In general, the fractures that intersect borehole DW-39 dip to the west and east and southeast and northwest. Hydraulically active fractures were identified at depths of 24.6, 75, and $90 \mathrm{ft}$ below the top of casing and dip to the northeast, west-southwest, and southeast, respectively. They are shown in dark blue in the stereoplots and tadpole and projection plots.

Hydraulic characterization. HPFM data indicate inflow at a depth of $24.6 \mathrm{ft}$ and outflow at depths of 75 and $90 \mathrm{ft}$ below the top of casing. Under ambient conditions, downflow originated at the upper fracture zone (with the most prominent fracture at a depth of $24.6 \mathrm{ft}$ ), flowed downward through the borehole at a rate of $0.16 \mathrm{gal} / \mathrm{min}$, and exited at depths of 75 and $90 \mathrm{ft}$ below the top of casing. Under pumping conditions, ambient outflow was reversed at the fractures at depths of 75 and $90 \mathrm{ft}$, and water continued to enter the borehole at the fracture zone just below base of casing. These hydraulically active fractures dipped to the northeast, west, and southeast and are shown in dark blue in the stereoplots and tadpole and projection plots (appendix 1, fig. 1J-3).

Under a pumping rate of $0.5 \mathrm{gal} / \mathrm{min}$, the specific capacity was $0.09(\mathrm{gal} / \mathrm{min}) / \mathrm{ft}$, and the open-hole transmissivity was estimated at $15 \mathrm{ft}^{2} / \mathrm{d}$ by the method of Bradbury and Rothschild (1985). Individual fractures and fracture zones were modeled using the HPFM profiles, pumping rates, and water levels. Because of the scatter in HPFM measurements, several models were attempted. Results of the best-fit model are summarized in table 13 and appendix 1 , figure $1 \mathrm{~J}-4$. The fracture at a depth of $75 \mathrm{ft}$ accounted for about 70 percent of the transmissivity; the lowermost fracture accounted for 21 percent; and the uppermost fracture accounted for 9 percent of the total transmissivity. Although the uppermost fracture has the lowest transmissivity, it has a very high head, about $20 \mathrm{ft}$ higher than the head of the lowermost fracture. The high head of this zone drives the ambient downflow in the borehole. The total transmissivity of borehole DW-39 was modeled as $18.6 \mathrm{ft}^{2} / \mathrm{d}$, with an RMS error of $0.012 \mathrm{gal} / \mathrm{min}$.

The fluid log showed changes in the temperature at depths of about 30 and $90 \mathrm{ft}$ below the top of casing. In addition, there were step-like changes in the specific conductance at depths of 22, 24, 26, 31, 34, 102, and $114 \mathrm{ft}$ below the base of casing (appendix 1, fig. 1J-1). No post-pumping fluid logs were collected.

\section{Borehole DW-40}

Location and construction. Borehole DW-40 is a domestic well east of Miller Mountain, on Port Road, north of borehole DW-33, and in a drainage valley. The well is adjacent to a wetland, and there was standing water about $4 \mathrm{ft}$ below the land surface near the well head, or about $6.5 \mathrm{ft}$ below the top of casing. The terrain has rugged hills with bedrock exposures both east and west of the house and well. The

Table 13. Flow model for borehole DW-39, near Machiasport, Maine.

[ft, feet; gal/min, gallon per minute; $\mathrm{ft}^{2} / \mathrm{d}$, feet squared per day; TOC, top of casing]

\begin{tabular}{|c|c|c|c|c|c|c|}
\hline $\begin{array}{c}\text { Depth of } \\
\text { transmissive zone } \\
\text { (ft) }\end{array}$ & $\begin{array}{c}\text { Ambient flow } \\
\text { above transmissive } \\
\text { zone } \\
\text { (gal/min) }\end{array}$ & $\begin{array}{c}\text { Pumped flow above } \\
\text { transmissive zone } \\
\text { (gal/min) }\end{array}$ & $\begin{array}{c}\text { Zone } \\
\text { transmissivity } \\
\left(\mathrm{ft}^{2} / \mathrm{d}\right)\end{array}$ & $\begin{array}{c}\text { Water level } \\
\text { (ft below TOC) }\end{array}$ & $\begin{array}{c}\text { Elevation of } \\
\text { water level } \\
\text { (ft) }\end{array}$ & $\begin{array}{l}\text { Percent of total } \\
\text { transmissivity }\end{array}$ \\
\hline 31.0 & 0.00 & 0.486 & 1.6 & -3.81 & 133.81 & 9 \\
\hline 75.0 & -0.127 & 0.309 & 13.0 & 12.19 & 117.81 & 70 \\
\hline 90.0 & -0.087 & 0.024 & 4.0 & 16.19 & 113.81 & 21 \\
\hline
\end{tabular}


steel casing extends $2.45 \mathrm{ft}$ above land surface and extends to a depth of $31.5 \mathrm{ft}$ below the top of casing. The well was completed to a total depth of $242 \mathrm{ft}$ below the top of casing. Borehole DW-40 deviates a total of $4.5 \mathrm{ft}$ toward the west (appendix 1, fig. 1K-2). On April 2, 2005, the ambient water level was consistently above the land surface and 0.5 to $0.7 \mathrm{ft}$ below the top of casing, indicating a strong upward gradient. Logs and interpretations for borehole DW-40 are in appendix $1 \mathrm{~K}$.

Lithology. The gamma and ATV logs are fairly uniform over the length of the borehole; however, there are subtle variations. The 32- and 64-in. resistivity data showed spikes at depths of $76,105,124,137.5,169,184,193,208.5$, and $228 \mathrm{ft}$ below the top of casing. The resistivity increase at a depth of $124 \mathrm{ft}$ below the top of casing is the largest spike. A second, smaller, resistivity spike extends down to a depth of $146 \mathrm{ft}$, ending at the fracture oriented with a strike of about $\mathrm{N} 221^{\circ} \mathrm{E}$, $83^{\circ}(\mathrm{NW}$ ) (appendix 1, table $1 \mathrm{~K}-1$ ). These spikes do not coincide with narrow spikes in the gamma data or with changes in acoustic reflectivity. The background resistivity level showed a gradual increase from a depth of $165 \mathrm{ft}$ to the bottom of the borehole, which coincides with a gradual increase in gamma over the same depths in the borehole. In the top of the borehole, from the bottom of casing to a depth of about $150 \mathrm{ft}$, the gamma was about $30 \mathrm{cps}$, and the mean amplitude of the reflectivity was about $1,000 \mathrm{mV}$. There is a narrow spike in the gamma data $(200 \mathrm{cps})$ centered at a depth of $185 \mathrm{ft}$ below the top of casing. Below a depth of $156 \mathrm{ft}$ to the bottom of the borehole, the gamma emissions increased from 50 to about $100 \mathrm{cps}$, and the mean amplitude was about $600 \mathrm{mV}$. Collectively, these logs indicate a change in rock type at a depth of about $156 \mathrm{ft}$ below the top of casing. These signatures are similar to borehole DW-39 and are consistent with gabbro in the upper part of the borehole and metamorphic sediments in the lower part of the borehole.

Fractures. The ATV images showed multiple fractures. Numerous minor fractures in the stereoplot (shown in light blue) strike southeast to west and dip moderately to steeply towards the southwest to north. The orientation of the contact at a depth of $145 \mathrm{ft}$ has a dip azimuth of $311^{\circ}$ with a dip of $83^{\circ}$
$\left(\mathrm{N} 221^{\circ} \mathrm{E}, 83^{\circ} \mathrm{NW}\right)$. The hydraulically active fractures strike west and dip steeply to the north or strike southeast and dip steeply to the southwest.

Hydraulic characterization. HPFM measurements do not indicate flow within the borehole under ambient conditions (appendix 1, fig. $1 \mathrm{~K}-4$ ). Under pumping conditions of about $0.45 \mathrm{gal} / \mathrm{min}$, the water level declined a total of $3.6 \mathrm{ft}$ to a depth of $4.16 \mathrm{ft}$ below the top of casing. The HPFM measurements collected under pumping conditions showed water entered the borehole at depths of about 34, 112, and $215 \mathrm{ft}$ below the top of casing. The specific conductance logs collected under ambient conditions and after pumping indicate the fracture zone at a depth of about $112 \mathrm{ft}$ accounts for flow into the borehole (appendix 1, fig. 1K-4). The specific conductance logs suggest ambient upflow in the borehole from a depth of 215 to about $118 \mathrm{ft}$.

Under pumping conditions of $0.45 \mathrm{gal} / \mathrm{min}$, the openhole specific capacity was $0.14(\mathrm{gal} / \mathrm{min}) / \mathrm{ft}$, and open-hole transmissivity was estimated at $8.6 \mathrm{ft}^{2} / \mathrm{d}$ using the methods of Bradbury and Rothschild (1985). The HPFM profiles and water-level data were interpreted using FWRAP (table 14 and appendix 1, fig. 1K-4). Because the borehole achieved a quasi-steady state under pumping, the decline in water level did not have to be accounted for in the model. A three-fracture model was used, and head and transmissivity values were fitted to the HPFM profiles, water levels, and measured pumping rate. The total modeled transmissivity for borehole DW-40 was $21.0 \mathrm{ft}^{2} / \mathrm{d}$, with a RMS error of $0.008 \mathrm{gal} / \mathrm{min}$. This model indicated the fracture at a depth of $215 \mathrm{ft}$ accounted for 29 percent of the transmissivity. The fracture at a depth of $112 \mathrm{ft}$ accounted for 14 percent of the transmissivity, and the fracture at a depth of $34 \mathrm{ft}$ accounted for 57 percent.

A comparison of before and after fluid conductivity, temperature, and specific conductance logs suggests there might be ambient flow that is less than the resolution of the HPFM. Post-pumping conditions indicate most of the inflow came from below the fracture at a depth of $112 \mathrm{ft}$, pulling more conductive water from the fracture at a depth of $215 \mathrm{ft}$ up the borehole and mixing with the water at $112 \mathrm{ft}$. These results are consistent with the HPFM results.

Table 14. Flow model for borehole DW-40, near Machiasport, Maine.

[ft, feet; gal/min, gallon per minute; $\mathrm{ft}^{2} / \mathrm{d}$, feet squared per day; TOC, top of casing]

\begin{tabular}{ccccccc}
\hline $\begin{array}{c}\text { Depth of } \\
\text { transmissive zone } \\
\text { (ft) }\end{array}$ & $\begin{array}{c}\text { Ambient flow above } \\
\text { transmissive zone } \\
\text { (gal/min) }\end{array}$ & $\begin{array}{c}\text { Pumped flow above } \\
\text { transmissive zone } \\
\text { (gal/min) }\end{array}$ & $\begin{array}{c}\text { Zone } \\
\text { transmissivity } \\
\text { (ft/ } / \mathbf{d})\end{array}$ & $\begin{array}{c}\text { Water level } \\
\text { (ft below T0C) }\end{array}$ & $\begin{array}{c}\text { Elevation of } \\
\text { water level } \\
\text { (ft) }\end{array}$ & $\begin{array}{c}\text { Percent of total } \\
\text { transmissivity }\end{array}$ \\
\hline 34.0 & 0.00 & 0.44 & 12.0 & 0.56 & 92.00 \\
112.0 & 0.00 & 0.20 & 3.0 & 0.56 & 92.00 \\
215.0 & 0.00 & 0.13 & 6.0 & 0.56 & 92.00 \\
\hline
\end{tabular}




\section{Borehole WY-GATR}

Location and construction. The WY-GATR well is at the top of Miller Mountain. This borehole had been previously used as a water-supply well for the GATR by the U.S. Air Force. The borehole has been unused since sometime prior to 1983. It has subsequently been used to monitor the subsurface water chemistry as part of the Bucks Harbor, R.I. The steel casing extends $3.45 \mathrm{ft}$ above the land surface and extends to a depth of $27 \mathrm{ft}$ below the top of casing (table 1). The total depth of the borehole is $417 \mathrm{ft}$ below the top of casing. The borehole deviates about $2.5 \mathrm{ft}$ towards the north (appendix 1 , fig. 1L-2). The water level was $155.73 \mathrm{ft}$ below the top of casing on March 30, 2005, at 8:00 a.m. Logs and interpretations for borehole WY-GATR are in appendix 1L.

Lithology. The gamma log shows fairly uniform gamma emissions over the length of the borehole with an average count of about $30 \mathrm{cps}$. The acoustic reflectivity also was uniform and was highly reflective, averaging about 2,000 $\mathrm{mV}$. Collectively, these logs suggest borehole WY-GATR penetrates a homogeneous diabase or gabbro, which is consistent with nearby outcrops and geologic maps (Gates and Moench, 1981).

From a depth of 280 to $366 \mathrm{ft}$ below the top of casing, the EMI conductivity increased. Conductivity also increased from depths of 366 to $390 \mathrm{ft}$ below the top of casing. However, no clear change in rock type was observed in the image log. The OTV log indicated the bottom of casing is at a depth of $26.9 \mathrm{ft}$, consistent with the results of the EMI log. Below casing to the water level, OTV images show a light gray mafic rock unit. Below the water level, images show a dark gray rock with some light gray layers and fractures sealed with felsic minerals.

Fractures. The OTV and ATV logs showed apparent rifling, which may have been caused by the drill rig used to ream the borehole in November 2004. The ATV and OTV images are of fairly high quality. Several fractures were observed in the ATV log below the water table and in the OTV log above and below the water table. In general, the OTV and ATV logs show agreement, although more features were identified in the OTV log than in the ATV log.

Two prominent enlargements were observed in the mechanical caliper log-one at a depth of 378 to $385 \mathrm{ft}$ below the top of casing and another larger one from a depth of $410 \mathrm{ft}$ to the bottom of the borehole. These prominent features also were observed in the televiewer logs. The average orientation of the fractures in the OTV log strikes to the north and dips steeply east $\left(\mathrm{N} 6^{\circ} \mathrm{E}, 86^{\circ} \mathrm{E}\right)$ (appendix 1, fig. 1L-4). There is a fairly tight clustering of poles to fracture planes that indicates a northwest strike and an easterly dip, and another cluster of poles that indicates a strike to the southwest with a very shallow to nearly horizontal dip.

Hydraulic characterization. The ambient fluid logs showed no change in temperature and fluid conductivity over the depth of the borehole indicating probable vertical flow within the borehole. The direction of flow cannot be determined with the fluid log alone. The HPFM confirmed vertical flow in the downward direction (appendix 1, fig. 1L-4). The HPFM log indicates that under ambient conditions water entered the borehole at a depth of $186 \mathrm{ft}$, flowed downward at a rate of $0.135 \mathrm{gal} / \mathrm{min}$, and exited the borehole at the bottom, below a depth of $411 \mathrm{ft}$. Below the large-aperture fracture at a depth of about $186 \mathrm{ft}$, the HPFM measured a downward vertical flow of $0.135 \mathrm{gal} / \mathrm{min}$, and these measurements were fairly constant to the bottom of the borehole. The deepest measurement in the borehole, at a depth of $410.5 \mathrm{ft}$, was $0.135 \mathrm{gal} / \mathrm{min}$ downward. Hence, outflow from the borehole was attributed to the fractures identified at depths of 411.5 to $415 \mathrm{ft}$ below the top of casing. This ambient flow rate of $0.135 \mathrm{gal} / \mathrm{min}$ is equivalent to about $194 \mathrm{gal} / \mathrm{d}$.

Because of the depth to the water and the high levels of contaminants in this borehole (3 ppm total volatile organic chlorides), water was injected into the borehole to stress the well while HPFM logging was conducted. Water from a USACE-approved source was injected through a hose extending from the top of casing down to below the water surface. The first attempt used a gravity-feed method; the flow rate, however, could not be held at a constant rate that was sufficiently low enough to be measured by the HPFM. In order to control the injection rate, water was pumped from a tank at the land surface into the borehole at a rate slightly less than $1 \mathrm{gal} / \mathrm{min}$. Under injection conditions, the HPFM data confirmed the fracture at the bottom of the borehole received all the flow.

During the injection test, the open-hole water levels and pumping rate were monitored. An open-hole transmissivity of $90 \mathrm{ft}^{2} / \mathrm{d}$ was estimated using the method of Bradbury and Rothschild (1985). The HPFM profiles, collected under ambient and injection conditions, and the water levels were modeled with FWRAP to estimate transmissivity and head for both of the hydraulically active zones in borehole WY-GATR. The upper fracture at a depth of $186 \mathrm{ft}$ had a transmissivity of $12 \mathrm{ft}^{2} / \mathrm{d}$; the deeper fracture zone had a transmissivity of $96 \mathrm{ft}^{2} / \mathrm{d}$. The head of the upper fracture was estimated to be about $3 \mathrm{ft}$ higher than the water level in the lower zone, which is consistent with the downward flow. These results are summarized in table 15 . The SSE was $0.0001(\mathrm{gal} / \mathrm{min})^{2}$, or an RMS error of $0.0066 \mathrm{gal} / \mathrm{min}$ (appendix 1, fig. 1L-4).

The USACE conducted a single-hole aquifer test in November 2004 (Robert Leitch, U.S. Army Corps of Engineers, written commun., 2005). Borehole WY-GATR was pumped at $6.25 \mathrm{gal} / \mathrm{min}$ for $4 \mathrm{~h}$ but did not reach steadystate conditions. This aquifer test did not affect levels in nearby boreholes, including MW-13. The open-hole water levels were used to estimate transmissivity using the CooperJacob straight-line, Theis curve-matching, and Bradbury and Rothschild (1985) methods. These tests produced similar estimates of transmissivity ranging from 70 to $190 \mathrm{ft}^{2} / \mathrm{d}$. The Cooper-Jacob straight-line method estimated an open-hole transmissivity of 70 to $190 \mathrm{ft}^{2} / \mathrm{d}$ using early- and later-time water-level data, respectively. Theis curve matching produced a transmissivity of $150 \mathrm{ft}^{2} / \mathrm{d}$ with a storativity of 0.01 . 
Table 15. Flow model for borehole WY-GATR, near Machiasport, Maine.

[ft, feet; gal/min, gallon per minute; $\mathrm{ft}^{2} / \mathrm{d}$, feet squared per day; TOC, top of casing]

\begin{tabular}{ccccccc}
\hline $\begin{array}{c}\text { Depth of } \\
\text { transmissive zone } \\
\text { (ft) }\end{array}$ & $\begin{array}{c}\text { Ambient flow above } \\
\text { transmissive zone } \\
\text { (gal/min) }\end{array}$ & $\begin{array}{c}\text { Pumped flow above } \\
\text { transmissive zone } \\
\text { (gal/min) }\end{array}$ & $\begin{array}{c}\text { Zone } \\
\text { transmissivity } \\
\text { (ft/d) }\end{array}$ & $\begin{array}{c}\text { Water level } \\
\text { (ft below TOC) }\end{array}$ & $\begin{array}{c}\text { Elevation of } \\
\text { water level } \\
\text { (ft) }\end{array}$ & $\begin{array}{c}\text { Percent of total } \\
\text { transmissivity }\end{array}$ \\
\hline 186 & 0.000 & -1.000 & 12 & 150.51 & 121.49 & 11 \\
412 & -0.142 & -1.006 & 96 & 153.31 & 118.69 & 89 \\
\hline
\end{tabular}

Although the aquifer test did not reach steady-state conditions, the rate of drawdown was declining. Using the methods of Bradbury and Rothschild (1985) on the USACE aquifer-test data, the transmissivity was estimated to be $147 \mathrm{ft}^{2} / \mathrm{d}$.

Specific-conductance logs collected under ambient conditions showed a uniform fluid column. After injection, however, the log showed the injected water advanced from the water level at a depth of $154 \mathrm{ft}$ down to $280 \mathrm{ft}$ below the top of casing. The peak increase in specific conductance was adjacent to the fracture at a depth of $186 \mathrm{ft}$ and probably indicates more conductive water flowing from the fracture into the less conductive injected water. The peak in specific conductance reached a maximum after the injection was terminated and prior to the collection of the post-injection fluid log. The fact that the fresh water "tracer" went down to a depth of about $280 \mathrm{ft}$ below the top of casing indicates that about $190 \mathrm{gal}$ of water were injected into the borehole. This is consistent with the estimated water use.

\section{Howard Mountain-Air Force Radar Tracking Station Area}

The AFRTS site is on top of Howard Mountain where former building locations are also possible contaminant-source locations. Boreholes on or near Howard Mountain (fig. 1B) were logged in 2003, including boreholes DW-4, MW-9, MW-10, MW-11, MW-12, and WY-3 (Weston Solutions, 2005). Additional domestic and former water-supply wells, including boreholes DW-2, WY-3B, WY-4, and WY-15, were logged as a part of this investigation. In 2006, boreholes MW-15, MW-16, MW-17, WY-3C, C-501, and C-114 were logged by Hager-Richter Geosciences (The Johnson Company, 2006) using all the same tools as the 2003-2005 field efforts, except for the water-quality parameter tool. Data from a total of 17 boreholes were used to characterize the fractures at this location.

\section{Borehole DW-2}

Location and construction. Domestic well DW-2 is southeast and downgradient from Howard Mountain and the former AFRTS site. The borehole was drilled to a depth of
$222.3 \mathrm{ft}$ below the top of casing. Steel casing was set to a depth of $17.7 \mathrm{ft}$ below the top of casing, and the top of casing was about $2.6 \mathrm{ft}$ above land surface. The borehole deviates $5.2 \mathrm{ft}$ to the northeast over the length of the borehole (appendix 2, fig. 2A-2). On March 30, 2005, the depth to water under ambient conditions was at a depth of $30.36 \mathrm{ft}$ below the top of casing. Logs and interpretations for borehole DW-2 are in appendix 2A.

During well logging, the water level was observed to decline without pumping the borehole. A transducer was placed in the borehole on March 31, 2005, to monitor the water level in the borehole. The transducer data showed it took $6 \mathrm{~h}$ for the water level to recover. Once the water level recovered at midnight, it declined again until the next day, when the transducer was removed. The water-level decline appears to be gradual and not oscillatory as if due to tidal influences. Over a 24-h period, the water level declined a total of $2.2 \mathrm{ft}$.

Lithology. The natural-gamma log showed only minor changes in gamma activity (appendix 2, fig. 2-A1). The gamma counts were about $90 \mathrm{cps}$ behind the casing. Below the casing to a depth of $210 \mathrm{ft}$, the gamma emissions increased to about $200 \mathrm{cps}$. Below a depth of $210 \mathrm{ft}$ to the bottom of the borehole, the gamma counts were about $160 \mathrm{cps}$. The only gamma anomaly in the borehole is a zone of decreased gamma activity (about $75 \mathrm{cps}$ ) from a depth of 81 to $86 \mathrm{ft}$ below the top of casing, which coincides with a borehole enlargement observed in the mechanical caliper and ATV images and is not related to a mafic dike. The rock type is interpreted to be rhyolite.

A comparison between the normal resistivity, ATV reflectivity, and gamma logs indicates no clear electrical signature. A few distinct zones in the SPR and 64-in. normal resistivity logs show decreases in resistivity at fracture locations; major decreases are centered at depths of 52, 83, and $130 \mathrm{ft}$. From a depth of $160 \mathrm{ft}$ to the bottom of the borehole, the SPR log increases slightly, indicating a possible change in rock type.

Fractures. The caliper log indicated increases in diameter at depths of 53.0, 58.6, 81.1 to 86.9, 103.0, 133.0, 141.2, 145.8 , and $157.6 \mathrm{ft}$ below the top of casing. Fractures were identified in the ATV logs at the same depths as the enlargements identified in the mechanical log. The ATV and caliper logs show variable borehole diameter and a high rugosity. 
A total of 28 fractures was identified in the ATV images (appendix 2, fig. 2A-3). The stereoplot shows highly variable orientations. Most of the features strike northeast-southwest and dip moderately to steeply to the southeast and northwest, respectively (appendix 2, table 2A-1). The most transmissive facture at a depth of $52.2 \mathrm{ft}$ strikes N240 $\mathrm{E}, 67^{\circ} \mathrm{NW}$. Another transmissive fracture at a depth of $106.5 \mathrm{ft}$ strikes and dips $\mathrm{N} 36^{\circ} \mathrm{E}, 49^{\circ} \mathrm{SE}$.

Hydraulic characterization. The HPFM logs under ambient conditions indicated upflow at a rate of about $0.018 \mathrm{gal} / \mathrm{min}$ was measured between depths of 52.2 and $106.5 \mathrm{ft}$. Borehole DW-2 was pumped at a rate of $0.45 \mathrm{gal} / \mathrm{min}$. During pumping, the water-level decline continued and did not reach a steady state. Because the amount of water coming from borehole storage (converted to a volumetric flow rate) was greater than the upper resolution of the HPFM tool, it had to be subtracted from the pumping rate. Approximately $0.1 \mathrm{gal} / \mathrm{min}$ of water going to the pump was derived from storage; thus, the actual stress to the aquifer was $0.35 \mathrm{gal} / \mathrm{min}$. Under pumping conditions of $0.02 \mathrm{gal} / \mathrm{min}$, a minor amount of inflow came from the fracture at a depth of $106.5 \mathrm{ft}$. The remainder of the water going to the pump was attributed to the fracture at a depth of $52.2 \mathrm{ft}$, where the upward flowing water was exiting the borehole under ambient conditions. A HPFM measurement could not be obtained between this fracture and the pump, which was set at a depth of $50.5 \mathrm{ft}$ below the top of casing. Because of the length of the tool and the placement of the pump, the highest measurement in the borehole was at a depth of $55.4 \mathrm{ft}$, which was below the most transmissive zone in the borehole.

A transducer left in the borehole monitored the recovery of the borehole from pumping conducted as part of the HPFM test. The water-level recovery continued for approximately $6 \mathrm{~h}$ after the pump was turned off. After recovering about 60 percent of the measured drawdown, the water level in the borehole began to decline at a constant rate of about $2.2 \mathrm{ft}$ in $24 \mathrm{~h}$. This water-level decline coupled with the ambient HPFM log indicates the water coming from borehole storage under ambient conditions is likely exiting the borehole at the fracture at a depth of $52.5 \mathrm{ft}$ below the top of casing. Although downflow was not measured between the water level and the fracture at a depth of $55.2 \mathrm{ft}$, upflow was measured immediately below the fracture. These data suggest a convergent flow regime in the borehole with water exiting at the fracture at a depth of $52.5 \mathrm{ft}$.

Using FWRAP, this interpretation of the flow regime in borehole DW-2 was quantified. Initially, flow was modeled with three fractures at depths of 52.2, 82.5, and $106.5 \mathrm{ft}$ below the top of casing. Ambient upflow between the depths of 106.5 and $52.5 \mathrm{ft}$ was included, and a pumping rate of $0.35 \mathrm{gal} / \mathrm{min}$ was simulated. In the iterative process of entering transmissivity and heads for each of the fractures, the transmissivity of the zone at a depth of $82.5 \mathrm{ft}$ was reduced to $0.02 \mathrm{ft}^{2} / \mathrm{d}$, indicating this is not a hydraulically active fracture despite the enlarged borehole and deflections in the water-quality logs. The borehole was modeled with a 2-fracture simulation; the uppermost fracture accounted for 97 percent of the transmissivity (table 16), and the rest of the transmissivity was from the fracture at a depth of $106.5 \mathrm{ft}$ below the top of casing. The total transmissivity for the borehole was $18.6 \mathrm{ft}^{2} / \mathrm{d}$ (appendix 2, fig. 2A-4). The lowermost, less-transmissive fracture was modeled with a head that was $4.1 \mathrm{ft}$ greater than the head of the upper fracture.

This HPFM interpretation is consistent with the deflections observed in the temperature, fluid conductivity, oxidation, oxidation-reduction potential, and $\mathrm{pH} \operatorname{logs}$, although it indicates that only two of the fractures were hydraulically active enough to be measured with the HPFM. The transmissivity values determined with the HPFM data are similar to the results of the open-hole specific-capacity models, which produced a transmissivity of $25.7 \mathrm{ft}^{2} / \mathrm{d}$ and a specific capacity of $0.129(\mathrm{gal} / \mathrm{min}) / \mathrm{ft}$ (Bradbury and Rothschild, 1985).

A fluid $\log$ was collected on March 31, 2005, and the water level was $40.36 \mathrm{ft}$ below the top of casing. The ambientfluid conductivity $\log$ indicates the potential for vertical flow between the fractures at depths of about 54 to $107 \mathrm{ft}$ below the top of casing. Changes in temperature, fluid conductivity, and specific conductance helped identify potentially active fractures where there were changes at depths of about 106.5 and $163 \mathrm{ft}$ below the top of casing. The specific conductance was computed at a uniform temperature of $20^{\circ} \mathrm{C}$ and is shown in units of microsiemens per centimeter. The specific-

Table 16. Flow model for borehole DW-2, near Machiasport, Maine.

[ft, feet; gal/min, gallon per minute; $\mathrm{ft}^{2} / \mathrm{d}$, feet squared per day; TOC, top of casing]

\begin{tabular}{|c|c|c|c|c|c|c|}
\hline $\begin{array}{c}\text { Depth of } \\
\text { transmissive zone } \\
\text { (ft) }\end{array}$ & $\begin{array}{c}\text { Ambient flow above } \\
\text { transmissive zone } \\
\text { (gal/min) }\end{array}$ & $\begin{array}{l}\text { Pumped flow above } \\
\text { transmissive zone } \\
\text { (gal/min) }\end{array}$ & $\begin{array}{c}\text { Zone } \\
\text { transmissivity } \\
\left(\mathrm{ft}^{2} / \mathrm{d}\right)\end{array}$ & $\begin{array}{c}\text { Water level } \\
\text { (ft below TOC) }\end{array}$ & $\begin{array}{c}\text { Elevation of } \\
\text { water level } \\
\text { (ft) }\end{array}$ & $\begin{array}{l}\text { Percent of total } \\
\text { transmissivity }\end{array}$ \\
\hline 106.5 & 0.016 & 0.031 & 0.6 & 40.24 & 25.76 & 3 \\
\hline
\end{tabular}


conductance $\log$ s before and after the pumping were consistent over most of the borehole; the only difference occurred above a depth of $57.7 \mathrm{ft}$, which indicates the fracture at $57.7 \mathrm{ft}$ is transmissive.

The water-quality parameter tool showed minor changes in the percent of oxygen saturation and oxidation-reduction potential. Changes occur at the fractures at depths of about 52, $77,83,96,106.5,137.5$, and $163 \mathrm{ft}$ below the top of casing. There was a small, gradual increase in the dissolved oxygen from the water level to the top of the borehole enlargement at a depth of about $79 \mathrm{ft}$ below the top of casing. From the bottom of the borehole enlargement, at $85 \mathrm{ft}$, to a depth of $106.5 \mathrm{ft}$, the concentration of dissolved oxygen remained fairly constant, and it increased from a depth of 106.5 to $137.5 \mathrm{ft}$ below the top of casing. The oxidation-reduction potential shows a similar signature to the dissolved-oxygen profile. The oxidation-reduction potential was positive from the water surface down to a depth of $180 \mathrm{ft}$ below the top of casing. Over the portion of the borehole where vertical flow is interpreted (from 52 to $106.5 \mathrm{ft}$ ), the oxidationreduction potential was fairly constant $(3,300$ to $340 \mathrm{mV})$. The oxidation-reduction potential declined steadily from a depth of $160 \mathrm{ft}$ to the bottom of the borehole. The $\mathrm{pH}$ showed a gradual increase from 7.2 at the fracture at a depth of $52.2 \mathrm{ft}$ to a $\mathrm{pH}$ of 8.2 at a depth of $106.5 \mathrm{ft}$. Collectively, these logs indicate the borehole enlargement near a depth of $83 \mathrm{ft}$ impacts the water-quality parameters, which may or may not correspond to borehole inflow or outflow at that depth. Other possible inflow or outflow zones include fractures at depths of 52.5, 106.5, 136.6 , and $163.5 \mathrm{ft}$ below the top of casing.

\section{Borehole WY-3B}

Location and construction. Monitoring well WY-3B is at the base of Howard Mountain, northeast of the summit, downgradient from the cliff, and west of Port Road. This well was drilled as part of the U.S. Air Force test-well program to locate a water-supply well near the DCF Housing Facility. It was completed with 8 -in. steel casing extending $1.87 \mathrm{ft}$ above the land surface and $58 \mathrm{ft}$ below the top of casing (table 1). Borehole WY-3B was completed to a depth of $221 \mathrm{ft}$ below the top of casing. The exact mode of construction is not known, but the completed borehole diameter is 8 in. or greater, which is not typical of rotary drilled wells. Borehole WY-3B deviates a total of $3.8 \mathrm{ft}$ to the north (appendix 2, fig. 2B-2). The water level on November 14, 2004, at 8:41 a.m. was $65.95 \mathrm{ft}$ below the top of casing. Logs and interpretations for borehole WY-3B are in appendix 2B.

The closest vehicle access to the borehole was a few hundred feet away, over irregular and snow-covered terrain. Because so much wireline was extended between the well head and the winch, it was difficult to log smoothly with the light-weight probes while logging in the downward direction. Care was taken to guide the fluid and water-quality tools down the borehole. The pressure log, collected as part of the water-quality tool, verified a gradual increase in pressure with only one small deflection at a depth of $122 \mathrm{ft}$ below the top of casing. All other logs were collected in the upward direction with the cable under tension.

Lithology. The gamma emissions behind the steel casing were about 70 cps (appendix 2, fig. 2B-1). Below the casing, over the entire length of the open borehole, the gamma emissions were fairly uniform, averaging about $150 \mathrm{cps}$. The acoustic reflectivity was also fairly uniform at about $300 \mathrm{mV}$. The normal resistivity, SP, SPR, and EMI conductivity logs are fairly uniform with only minor deflections at fracture locations.

Fractures. The acoustic caliper and mechanical caliper logs verify this is an 8-in. diameter borehole with an 8-in. inner diameter casing. The caliper logs show a very rough borehole wall, with enlargements centered at depths of 69.1, 95.3, 108.1, 113.0, 176.6, 203.0, and $205.9 \mathrm{ft}$ below the top of casing. Because of the roughness of the borehole wall, the quality of the ATV $\log$ is fairly poor. However, several small fractures were identified in the images. The minor fractures generally strike east-west and dip moderately to steeply to the north and south (appendix 2, table 1 and fig. 2B-3). The larger fractures strike north and dip east. Because of the lack of the flowmeter logs, the fluid and water-quality logs were used to estimate the locations of hydraulically active fractures. These features were coded with blue squares in the tadpole and stereo plots to identify that they were inferred from the water-quality log.

Hydraulic characterization. Because of difficulty in accessing the borehole during the November field effort, HPFM logging and pumping were not conducted in WY-3B.

Borehole WY-3B exhibits dramatic changes in the ambient-fluid log (appendix 2, fig. 2B-1). The pH decreased substantially from the water surface down to a depth of $73 \mathrm{ft}$, then decreased gradually to $97 \mathrm{ft}$ below the top of casing. The $\mathrm{pH}$ increased from 7.4 to 8.9 between 97 and $112 \mathrm{ft}$ in depth; then $\mathrm{pH}$ increased slightly more to 9.4 at a depth of $122 \mathrm{ft}$ below the top of casing. The actual values are not as important as the indication of a change. The temperature on the waterquality tool (not shown), and to a lesser extent on the fluid tool, followed a similar pattern of increases and decreases at the same depths as the $\mathrm{pH} \log$. The fluid-conductivity $\log$ showed only small increases at depths of 97, 112, 122, and $181 \mathrm{ft}$ below the top of casing. The percent oxygen exhibited decreases at depths of 97, 112, and $122 \mathrm{ft}$. Collectively, these logs indicate the fractures at depths of 69.0, 94.5, 95.5, 112.4, 176.1, and 202.9 are possibly hydraulically active fractures.

A comparison of the fluid and water-quality logs collected in November 2004 indicates some minor differences. The temperature of the fluid log was adjusted to match the fluid $\log$ of the water-quality probe, and the resultant specificconductance logs before and after pumping were compared. The results indicate water likely entered the borehole at depths of 73 and $122 \mathrm{ft}$ below the top of casing. 


\section{Borehole WY-4}

Location and construction. Former water-supply well WY-4 is on Howard Mountain, southwest of the summit and across from the DCF facility in an abandoned pump house. Borehole WY-4 was previously used to supply cooling water for the electronics in former Building 501 but was abandoned in the early 1990s after Building 501 was demolished by the FAA, and the pump house was converted to a storage shed. Borehole WY-4 was completed with 6-in. steel casing $0.7 \mathrm{ft}$ above land surface and to a depth of $53.8 \mathrm{ft}$ below the top of casing (table 1). The total depth of well WY-4 is $180 \mathrm{ft}$ below the top of casing. Borehole WY-4 deviates a total of $1.4 \mathrm{ft}$ to the southeast (appendix 2, fig. 2C-2). The water level on April 5, 2005, was $6.73 \mathrm{ft}$ below the top of casing at 7:15 a.m. Logs and interpretations for borehole WY-4 are in appendix $2 \mathrm{C}$.

Lithology. The natural gamma, acoustic televiewer, normal resistivity, and EMI conductivity logs show little variation over the length of the borehole. The gamma logs average about $200 \mathrm{cps}$ and show only small variations in the gamma counts. The variation appears to be correlated with borehole diameter. Where the borehole is larger, the gamma log showed less counts per second.

The long- and short-normal resistivity tool in borehole WY-4 showed extremely high resistivity values that exceeded the range of the tool. The 8- and 16-in. logs show negative values, but the relative tool response suggests a relation to borehole diameter. The 32- and 64-in. measurements were positive values that showed only a weak correlation to borehole diameter. The normal resistivity log shows little variation over the length of the borehole. Formation conductivity measurements with the EMI tool, coupled with logs from the ATV tool, verified the bottom of casing is at a depth of $53.8 \mathrm{ft}$ below the top of casing. In addition, there is a small increase in the formation conductivity from a depth of 130 to $150 \mathrm{ft}$ below the top of casing, but this zone does not appear to be correlated to anomalies in any of the other borehole logs. The acoustic reflectivity log shows only small variations that occur over short depths of the borehole, such as those that may be produced by narrow changes in rock type caused by flow banding in the rhyolites or the mafic dikes.

Fractures. The mechanical caliper and ATV logs in borehole WY-4 indicate the borehole wall was rough and diameter varied over short distances. Because of the rugosity of the borehole wall, the identification of fractures and determination of orientation were difficult. The bottom of the borehole showed an enlarged zone where no specific fractures could be determined. At the top of that zone, at a depth of about $172 \mathrm{ft}$ below the top of casing, the fracture strikes southwest and dips northwest $\left(\mathrm{N} 226^{\circ} \mathrm{E}, 28^{\circ} \mathrm{NW}\right)$. Most of the fractures that intersect borehole WY-4 plotted in the northwest or southeast quadrants of the stereoplot, indicating they strike northeast and dip southeast or strike southwest and dip northwest (appendix 2, fig. 2C-3). Most of the identified fractures were steeply dipping. The lack of identified horizontal fractures may be caused by the poor resolution caused by the rugosity of the borehole wall. Features that extend over an interval depth are easier to identify in the borehole images. The two deepest transmissive zones (at depths of 112 and $172 \mathrm{ft}$ ) had shallow dips. However, the actual orientation of fractures in the fracture zone at the bottom of the borehole is unknown (only the top of the zone was determined.)

Hydraulic characterization. Borehole WY-4 was logged with the HPFM under ambient and pumped conditions (appendix 2, fig. 2C-4). Under pumping conditions, borehole WY-4 achieved steady-state conditions, and HPFM measurements were made.

The HPFM logs show ambient upflow that extended over almost the entire length of the borehole. An inflowing fracture zone was identified at a depth of about $172 \mathrm{ft}$ from which water flowed upward (at $0.02 \mathrm{gal} / \mathrm{min}$ ) and exited the borehole just below the base of casing. Upflow was measured under ambient conditions at a depth of $58 \mathrm{ft}$, indicating water exits the borehole between this point and the bottom of casing. The most likely out-flowing fractures were at depths of 53.9 or $56.9 \mathrm{ft}$ (appendix 2, table 2C-1), or outflow was from a bad seal at the base of casing. Under pumping conditions, the HPFM measured upflow from the bottom of the borehole at a depth of $168 \mathrm{ft}$. Flow was attributed to the fracture zone at a depth of $172 \mathrm{ft}$ below the top of casing. Examination of the HPFM measurements from a depth of $168 \mathrm{ft}$ suggests the measurements were good, whereas for measurements between depths of 168 and $130 \mathrm{ft}$, the diverter seal in the borehole was not good, and the measurement did not capture the upflow in the borehole.

The open-hole transmissivity was determined with water-level monitoring in response to pumping using methods described by Bradbury and Rothschild (1985). Under pumping conditions of $0.5 \mathrm{gal} / \mathrm{min}$, the water level declined a total of $4.27 \mathrm{ft}$ below the ambient water level. Open-hole specific capacity was $0.117(\mathrm{gal} / \mathrm{min}) / \mathrm{ft}$ and transmissivity was estimated at $22.9 \mathrm{ft}^{2} / \mathrm{d}$.

The HPFM results were numerically modeled using FWRAP (Paillet, 2000). Two fractures were modeled using the HPFM profiles and water-level measurements that are shown in table 17 and appendix 2, figure $2 \mathrm{C}-4$. The transmissivity and relative head values were adjusted until the observed and simulated results matched. The final model has fractures at depths of 172 and $55 \mathrm{ft}$ with transmissivities of 20 and $1 \mathrm{ft}^{2} / \mathrm{d}$ and relative heads of 6.6 and $9.3 \mathrm{ft}$, respectively, indicating upward flow. The RMS error is $0.04 \mathrm{gal} / \mathrm{min}$. These results are consistent with the open-hole transmissivity results.

An alternative interpretation was explored in which the HPFM measurements at a depth of $168 \mathrm{ft}$ were attributed to transient effects and no inflow was identified at the bottom of the borehole. Because comparison of fluid conductivity and specific-conductance logs from before and after pumping shows a deviation in the fluid suggesting inflow from the fracture at a depth of $112 \mathrm{ft}$, the alternative interpretation assumes that all inflow is from the fracture at $112 \mathrm{ft}$. The alternative interpretation was modeled using FWRAP, and the results were not as good as the model discussed above. 
Table 17. Flow model for borehole WY-4, near Machiasport, Maine.

[ft, feet; gal/min, gallon per minute; $\mathrm{ft}^{2} / \mathrm{d}$, feet squared per day; TOC, top of casing]

\begin{tabular}{|c|c|c|c|c|c|c|}
\hline $\begin{array}{c}\text { Depth of } \\
\text { transmissive zone } \\
\text { (ft) }\end{array}$ & $\begin{array}{c}\text { Ambient flow above } \\
\text { transmissive zone } \\
\text { (gal/min) }\end{array}$ & $\begin{array}{c}\text { Pumped flow above } \\
\text { transmissive zone } \\
\text { (gal/min) }\end{array}$ & $\begin{array}{c}\text { Zone } \\
\text { transmissivity } \\
\left(\mathrm{ft}^{2} / \mathrm{d}\right)\end{array}$ & $\begin{array}{c}\text { Water level } \\
\text { (ft below TOC) }\end{array}$ & $\begin{array}{c}\text { Elevation of } \\
\text { water level } \\
\text { (ft) }\end{array}$ & $\begin{array}{l}\text { Percent of total } \\
\text { transmissivity }\end{array}$ \\
\hline 55.00 & 0.00 & 0.550 & 1.0 & 9.30 & 161.40 & 5 \\
\hline 172.00 & 0.020 & 0.537 & 20.0 & 6.60 & 164.10 & 95 \\
\hline
\end{tabular}

The fluid logs include fluid conductivity, temperature, oxygen, $\mathrm{pH}$, and oxidation-reduction potential. All but the temperature log show change at the fracture zone at the bottom of the borehole (appendix 2, fig. 2C-1). There were also minor deflections at the base of casing at a depth of $53.8 \mathrm{ft}$ and at depths of 110 to $120 \mathrm{ft}$ below the top of casing. Under ambient conditions, there was a step-wise increase in fluid conductivity at a depth of $172 \mathrm{ft}$ below the base of casing.

\section{Borehole WY-15}

Location and construction. Water-supply test well WY-15 is just southwest of the summit of Howard Mountain between the AFRTS and the DCF facility. Boreholes MW-9 and MW-10 are within $400 \mathrm{ft}$ of borehole WY-15 and are topographically higher than WY-15. Borehole WY-15 was completed with 6-in. steel casing to $4.4 \mathrm{ft}$ above the land surface and $28 \mathrm{ft}$ below the top of casing. The total depth of WY-15 is $297 \mathrm{ft}$ below the top of casing. Borehole WY-15 deviates about $7 \mathrm{ft}$ to the north (appendix 2, fig. 2D-2). On April 1, 2005, the ambient water level was $33.95 \mathrm{ft}$ below the top of casing at 9:06 a.m. Logs and interpretations for well WY-15 are in appendix 2D.

Lithology. The gamma log shows a fairly uniform response that averaged about 200 cps over most of the borehole (appendix 2, fig. 2D-1). The only anomaly in the gamma log was a narrow (3-ft) zone at a depth of about $200 \mathrm{ft}$ below the top of casing. The anomaly, which shows a lower gamma count than the rock above and below, is typical of a mafic dike relative to the rhyolite it intrudes. The ATV amplitude log shows higher median and average amplitudes associated with larger diameter parts of the borehole. However, there were no changes in amplitude that suggest a major change in rock type. The EMI log confirms the depth to base of casing is at $28 \mathrm{ft}$ below the top of casing; however, it did not identify any changes in rock type.

Fractures. The ATV log was of fair quality, and the borehole wall appears to be rough and enlarged over many sections of the borehole. The two most pronounced enlargements were at depths of about 130 to $170 \mathrm{ft}$ and at the bottom of the borehole at a depth of $291 \mathrm{ft}$. The fractures identified in the ATV log generally were steeply dipping and strike northnortheast with dips to east-southeast and strike southwest with dips to the west-northwest. The mechanical caliper and ATV data indicate the borehole was enlarged from a depth of 153 to $172 \mathrm{ft}$ below the top of casing. The ATV tool was unable to image the borehole wall over that part of the borehole (appendix 2, fig. 2D-3). Another smaller enlargement was identified from a depth of 289 to $295 \mathrm{ft}$. In the bottom half of the borehole below the fracture zone at a depth of 153 to $172 \mathrm{ft}$, the borehole walls appear to be rougher than the upper part of the borehole.

Hydraulic characterization. Under pumping conditions, the water level continued to decline and did not stabilize. The estimated total pumpage from borehole WY-15 was 22 gal. Initially, the borehole was pumped at a rate of $0.5 \mathrm{gal} / \mathrm{min}$, but the water level declined rapidly and the pumping rate could not be sustained. As the water level declined, the pump had to be lowered deeper so that flow measurements could be collected in the upper part of the borehole. After $40 \mathrm{~min}$ of pumping, the pumping rate declined to about $0.1 \mathrm{gal} / \mathrm{min}$, and the water level stabilized so that the HPFM measurements could be made. The water level reached a quasi-steady state of $40 \mathrm{ft}$ below the top of casing, which was equivalent to $6.85 \mathrm{ft}$ of drawdown. Under pumping conditions, HPFM measurements made at a depth of $282 \mathrm{ft}$ below the top of casing suggest water entered the borehole at the bottom of the borehole from the fracture at a depth of $291 \mathrm{ft}$ below the top of casing. The additional inflow entered the borehole between depths of 207 and $100 \mathrm{ft}$ below the top of casing. The measurements at depths of 176 and $145 \mathrm{ft}$ below the top of casing did not have a good seal, and less flow than was measured in the bottom of the borehole. Inflow was interpreted to come from the fracture zone at a depth of 153 to $172 \mathrm{ft}$ below the top of casing. Minor deflections in the fluid and water-quality logs occurred near a depth of 165 and $169 \mathrm{ft}$, supporting this interpretation.

This borehole did not support much of a pumping rate, and the lowest sustainable pumping rate of about $0.1 \mathrm{gal} / \mathrm{min}$ was used. The HPFM measurements collected under pumping conditions had to be normalized to the total discharge rate measured at the pump outlet. This assumes the total inflow going to the pump was coming from the fractures measured with the HPFM, and there were no additional fractures at the top of the borehole that could not be logged with the HPFM because of the declining water levels and the placement of the 
pump. Because the water levels had stabilized during these HPFM measurements, accounting for the contributions from borehole storage was not needed. HPFM measurements at depths of 56 and $100 \mathrm{ft}$ were normalized to $0.1 \mathrm{gal} / \mathrm{min}$. These results suggest the low-flow values may be beyond the lower resolution of the HPFM tool.

A comparison of fluid conductivity and specific conductance at $20^{\circ} \mathrm{C}$ collected before and after pumping indicates water entered at the bottom of the borehole from the fracture at a depth of $290 \mathrm{ft}$ (appendix 2, fig. 2D-1). Open-hole specific capacity was $0.017(\mathrm{gal} / \mathrm{min}) / \mathrm{ft}$, and transmissivity was estimated as $2.9 \mathrm{ft}^{2} / \mathrm{d}$ (Bradbury and Rothschild, 1985).

The ambient and pumped flow profiles, water levels, and pumping rate were used to model the head and transmissivity of three fractures in the borehole at depths of 44, 153, and $291 \mathrm{ft}$ below the top of casing. Results from the FWRAP model indicate the fracture zone from a depth of 153 to $172 \mathrm{ft}$ is the most transmissive of the three fractures (table 18 and appendix 2, fig. 2D-4). The model estimated a total open-hole transmissivity of $3.4 \mathrm{gal} / \mathrm{min}$ with an RMS error of $0.01 \mathrm{gal} / \mathrm{min}$.

The pumping associated with the HPFM testing, which pumped about 22 gal out of the borehole, produced a total water-level decline of about $7 \mathrm{ft}$. A transducer monitored the water levels in borehole WY-15 for a few days after the test. The transducer data indicate borehole WY-15 did not recover until about $15 \mathrm{~h}$ after pumping stopped, confirming that WY-15 is hydraulically tight.

Because of the low transmissivity in borehole WY-15 and the poor quality of the HPFM data, the water-quality data were important in the interpretation of the flowmeter data (appendix 2, fig. 2D-4). The fluid conductivity log under ambient conditions shows a large step change in fluid conductivity at a depth of $44.5 \mathrm{ft}$ indicating a zone of inflow or outflow (appendix 2, fig. 2D-1). The fluid logs had minor deflections at depths of 144, 168, and $203 \mathrm{ft}$ below the top of casing. The water-quality log was collected under ambient conditions but after the fluid column had been disturbed by other logs collected in the borehole (appendix 2, fig. 2D-1). The HPFM measured upflow under ambient conditions (appendix 2, fig. 2D-4). Flow entered the bottom of the borehole at a depth of about $291 \mathrm{ft}$ at a rate of $0.03 \mathrm{gal} / \mathrm{min}$.
The amount of upflow in the borehole declined between depths of 176 and $145 \mathrm{ft}$ below the top of casing. Because of the change in oxidation-reduction potential at the same depth, this upflow is thought to be real and indicative of some outflow in the large fracture zone (between a depth of 153 and $172 \mathrm{ft}$ below the top of casing). Above $140 \mathrm{ft}$, an upflow of about $0.1 \mathrm{gal} / \mathrm{min}$ was measured up to a depth of $44.4 \mathrm{ft}$. On the basis of the fluid conductivity log, the outflow was interpreted to be at the fracture at a depth of about $44.0 \mathrm{ft}$ below the top of casing.

\section{Transmitter Site}

The former Transmitter Site is southwest of Howard Mountain. Boreholes DW-6 and DW-10 were logged as part of this investigation. In addition, boreholes MW-4, MW-5, MW-6, MW-7, and MW-8 were logged previously by Weston Solutions (2005).

\section{Borehole DW-6}

Location and construction. Domestic well DW-6 is on Howard Mountain off Base Road, on a hill slope southeast of the Transmitter Site and south of the AFRTS site. Borehole DW-6 was drilled to a total depth of $123.5 \mathrm{ft}$ below land surface. Steel casing was set to a depth of $20 \mathrm{ft}$ below the top of casing and was completed with $1.8 \mathrm{ft}$ above the land surface. Borehole DW-6 deviates $2 \mathrm{ft}$ to the east (appendix 3, fig. 3A-2). The water level on April 6, 2005, was $8.97 \mathrm{ft}$ below the top of casing at 7:20 a.m. The reported well drillers' yield was $2 \mathrm{gal} / \mathrm{min}$. Logs and interpretations for borehole DW-6 are in appendix $3 \mathrm{~A}$.

Lithology. The natural gamma log was fairly uniform over the entire section of open borehole and did not indicate any changes in rock types (appendix 3, fig. 3A-1). The gamma counts were 150 to $200 \mathrm{cps}$. The SPR $\log$ was uniform (at about 25,500 ohms) over most of the borehole and showed a sharp increase (to 53,400 ohms) from a depth of 91 to $109 \mathrm{ft}$ below the top of casing. The normal resistivity logs show a similar pattern as the SPR log. The acoustic reflectivity logs show uniform values over the upper part of the borehole,

Table 18. Flow model for borehole WY-15, near Machiasport, Maine.

[ft, feet; gal/min, gallon per minute; $\mathrm{ft}^{2} / \mathrm{d}$, feet squared per day; TOC, top of casing]

\begin{tabular}{|c|c|c|c|c|c|c|}
\hline $\begin{array}{c}\text { Depth of } \\
\text { transmissive zone } \\
\text { (ft) }\end{array}$ & $\begin{array}{c}\text { Ambient flow above } \\
\text { transmissive zone } \\
\text { (gal/min) }\end{array}$ & $\begin{array}{c}\text { Pumped flow above } \\
\text { transmissive zone } \\
\text { (gal/min) }\end{array}$ & $\begin{array}{c}\text { Zone } \\
\text { transmissivity } \\
\left(\mathrm{ft}^{2} / \mathrm{d}\right)\end{array}$ & $\begin{array}{c}\text { Water level } \\
\text { (ft below TOC) }\end{array}$ & $\begin{array}{l}\text { Elevation of } \\
\text { water level } \\
\text { (ft) }\end{array}$ & $\begin{array}{l}\text { Percent of total } \\
\text { transmissivity }\end{array}$ \\
\hline 44.0 & 0.000 & 0.121 & 0.4 & 36.25 & 157.63 & 12 \\
\hline 153.0 & 0.006 & 0.111 & 2.0 & 35.25 & 158.63 & 59 \\
\hline 291.0 & 0.022 & 0.058 & 1.0 & 30.25 & 163.63 & 29 \\
\hline
\end{tabular}


averaging $230 \mathrm{mV}$. From a depth of 91 to $111 \mathrm{ft}$, the reflectivity was higher (about $650 \mathrm{mV}$ ) than above $91 \mathrm{ft}$ and below $111 \mathrm{ft}$, indicating a harder rock type. These signatures are consistent with a rhyolite.

Fractures. The ATV and caliper logs indicate the walls of the borehole are rough (appendix 3, fig. 3A-1). No clear fabric or layering of the bedrock could be seen in the ATV images; however, multiple fractures were identified over the depth of the borehole. The electrically resistive zone from a depth of 91 to $111 \mathrm{ft}$ exhibited apparently narrow aperture fractures, whereas elsewhere in the borehole the fractures were wider and more open. The lack of large fractures in the zone may be the cause of the increased electrical resistivity. In general, the minor fractures (shown in light blue in the stereo and tadpole plots) strike both east and west and dip at steep angles to the north and south (appendix 3, fig. 3A-3). The stereoplot indicates the transmissive fractures (dark blue) strike north, east, and southeast and dip moderately towards the east, south, and southwest.

Hydraulic characterization. No vertical flow was measured in borehole DW-6 with the HPFM under ambient conditions (appendix 3, fig. 3A-4). Under pumping conditions, water entered the borehole at the fractures identified at depths of 23.5, 52, and $82 \mathrm{ft}$ below the top of casing. These results are consistent with the fluid conductivity logs collected before and after pumping. The HPFM logs indicate about 74 percent of the transmissivity to the borehole came from the fractures near the top of the borehole, about 12 percent of the transmissivity was attributed to the fracture at a depth of $52 \mathrm{ft}$, and about 5 percent of the transmissivity came from the fractures near a depth of $82 \mathrm{ft}$ below the top of casing (table 19 and appendix 3, fig. 3A-4).

The total transmissivity determined with FWRAP was $2.4 \mathrm{ft}^{2} / \mathrm{d}$, which is similar to the specific-capacity models for open-hole transmissivity. The specific capacity was estimated at $0.016(\mathrm{gal} / \mathrm{min}) / \mathrm{ft}$, and the transmissivity was $2.6 \mathrm{ft}^{2} / \mathrm{d}$ (Bradbury and Rothschild, 1985).

A fluid log was collected on April 4, 2005, while the water level was $8.86 \mathrm{ft}$ below the top of casing. The ambient and pumped fluid resistivity (conductivity) and temperature profiles did not help identify transmissive fractures. However, a comparison of the specific conductance at $25^{\circ} \mathrm{C}$ before and after pumping indicates water entered the borehole under pumping conditions at a depth of $82 \mathrm{ft}$ below the top of casing. The before and after pumping temperature logs indicate inflow at the fracture at a depth of $52 \mathrm{ft}$ below the top of casing. Very slight deflections occur at depths of 52 and $23.5 \mathrm{ft}$ in the specific-conductance log collected under pumping conditions. The water-quality parameter tool collected under ambient conditions showed only minor changes and did not suggest ambient flow in the borehole. The $\mathrm{pH} \log$ showed deflections at the base of casing, and at depths of 21.3, 40, and $82 \mathrm{ft}$. The temperature log showed a change at a depth of $52 \mathrm{ft}$. No substantial changes were identified in the oxygen concentration, except for a change at the base of casing.

\section{Borehole DW-10}

Location and construction. Domestic well DW-10 is on the west side of Howard Mountain and west of the DCF, and is northeast and topographically downgradient from the Transmitter Site. The nearest boreholes are DW-6 and WY-4, logged in April 2005, and boreholes MW-4, MW-5, MW-6, and MW-7, which were logged in 2003 (Weston Solutions, 2005). Borehole DW-10 was completed with 6-in.-diameter steel casing that rises $0.97 \mathrm{ft}$ above the land surface and extends into the bedrock to a depth of $20 \mathrm{ft}$ below the top of casing. The total depth of the well is $380 \mathrm{ft}$ below the top of casing, and the well was reported to have a yield of $1 \mathrm{gal} / \mathrm{min}$ at the time of drilling. The OTV and ATV deviation tools indicate the borehole deviates a total of $13.6 \mathrm{ft}$ towards the northwest (appendix 3, fig. 3B-2). Logs and interpretations for borehole DW-10 are in appendix 3B.

Lithology. Changes in lithology were observed in the OTV, ATV, and gamma logs (appendix 3, fig. 3B-1). The more massive, light gray, fine-grained unit observed in the OTV log exhibits a lower gamma count, higher amplitude reflections, yellow zones in the ATV amplitude log, smooth sections on the mechanical and acoustic caliper logs, and possibly slightly lower conductivity than the country rock in which it intrudes. The country rock, which is the darker unit in the OTV log, exhibits a rougher and slightly larger borehole wall and a lower reflectivity, which collectively indicate the country rock

Table 19. Flow model for borehole DW-6, near Machiasport, Maine.

[ft, feet; gal/min, gallon per minute; $\mathrm{ft}^{2} / \mathrm{d}$, feet squared per day; TOC, top of casing]

\begin{tabular}{ccccccc}
\hline $\begin{array}{c}\text { Depth of } \\
\text { transmissive zone } \\
\text { (ft) }\end{array}$ & $\begin{array}{c}\text { Ambient flow above } \\
\text { transmissive zone } \\
\text { (gal/min) }\end{array}$ & $\begin{array}{c}\text { Pumped flow above } \\
\text { transmissive zone } \\
\text { (gal/min) }\end{array}$ & $\begin{array}{c}\text { Zone } \\
\text { transmissivity } \\
\text { (ft/ } / \mathbf{d})\end{array}$ & $\begin{array}{c}\text { Water level } \\
\text { (ft below TOC) }\end{array}$ & $\begin{array}{c}\text { Elevation of } \\
\text { water level } \\
\text { (ft) }\end{array}$ & $\begin{array}{c}\text { Percent of total } \\
\text { transmissivity }\end{array}$ \\
\hline 23.50 & 0.00 & 0.16 & 1.75 & 8.86 & 191.14 & 74 \\
52.00 & 0.00 & 0.04 & 0.28 & 8.86 & 191.14 & 12 \\
82.00 & 0.00 & 0.02 & 0.35 & 8.86 & 191.14 & 5 \\
\hline
\end{tabular}


is softer than the intrusive mafic dikes. The country rock is thought to be bimodal metavolcanic rock, and the intrusives are diabase. The mafic dikes in borehole DW-10 consistently have a strike and dip of about $\mathrm{N} 159^{\circ} \mathrm{E}, 54^{\circ} \mathrm{W}$ and a dip azimuth of about $\mathrm{N} 249^{\circ} \mathrm{E}$.

The mean acoustic reflectivity and gamma logs were effective in delineating changes in rock type in borehole DW-10 (fig. 4D). Gamma counts of 30 to 45 cps and amplitudes of about 1,600 to $2,600 \mathrm{mV}$ characterize zones of what is thought to be mafic dikes. The flow-banded stony rhyolite and rhyolitic vitrophyre units have gamma counts of 180 to $200 \mathrm{cps}$ and reflectivity values of about 800 to $1,200 \mathrm{mV}$.

Mafic dikes were identified at depths of 39 to 44.5 , 74 to $129.1,197.6$ to $204.7,208.7$ to 214.2 , and 260.6 to $322.5 \mathrm{ft}$ below the top of casing. The ATV and OTV logs indicate these dikes dip steeply towards the southwest (in right hand rule, strike is $\mathrm{N} 130$ to $170^{\circ} \mathrm{E}$, and dip is 38 to $75^{\circ}$, averaging $\mathrm{N} 159^{\circ} \mathrm{E}, 59^{\circ} \mathrm{W}$ ). The trend of the dikes is consistent with the orientation of mafic dikes on the local geologic maps.

Fractures. Interpretations of fracture locations and orientations are shown in structure, tadpole, and stereoplots (appendix 3, fig. 3B-3). Several small-aperture, less-open looking fractures (light blue) and a few larger aperture fractures (red) were identified in the ATV and OTV logs. HPFM logging and fluid temperature, conductivity, $\mathrm{pH}$, and dissolved oxygen logs indicate the fractures at depths of 43.7, 156.5, and $327.3 \mathrm{ft}$ below the top of casing are transmissive. Several sealed fractures, possibly filled with calcite, were identified in the borehole. They were observed in both the mafic dikes and the rhyolite volcanic units. The sealed fractures are steeply dipping southeast, steeply dipping southwest, and gently dipping toward the south.

Hydraulic characterization. HPFM logs collected under ambient conditions indicate a small amount of water inflowing to the well from a fracture at a depth of about $43 \mathrm{ft}$, flowing downward, and exiting the borehole at a depth of about $156 \mathrm{ft}$ below the top of casing. This borehole was pumped at a rate of about $5.0 \mathrm{gal} / \mathrm{min}$ for $10 \mathrm{~min}$. The water level declined $31.4 \mathrm{ft}$ in response to this pumping rate, which was high relative to the pumping rates used in other boreholes. After $10 \mathrm{~min}$, the pump was turned off and the inflow to the borehole was measured as the water level recovered. Under recovery conditions, the fractures at depths of about 327,156 , and $43.7 \mathrm{ft}$ showed inflow.

Because the inflow rate to this borehole was changing during the recovery, a steady-state solution is not appropriate. Instead, a Cooper-Bredehoeft-Papadopulos slug-test solution was used to approximate the open-hole transmissivity and storativity (Cooper and others, 1967). In this method, an instantaneous slug of water is removed from the well and the water-level recovery is monitored. In borehole DW-10, the water was removed quickly from the borehole, drawing the water level down $31.4 \mathrm{ft}$ below ambient conditions, the water-level recovery was monitored, and concurrent HPFM measurements were made to identify inflow zones. The method of subtractions, which subtracts ambient inflow from pumped inflow, was used to determine the relative proportions of transmissivity. By these methods, the openhole transmissivity was estimated at $1.9 \mathrm{ft}^{2} / \mathrm{d}$, and inflow was identified in fractures at depths of 43.7, 156, and $327 \mathrm{ft}$ (table 20 and appendix 3, fig. 3B-3). The zone at a depth of $156 \mathrm{ft}$ below the top of casing was the most transmissive at 65 percent of the total. Because this zone was receiving flow under ambient conditions, the ambient head is lower than the uppermost zone, which was inflowing under ambient conditions. The fracture at a depth of $286.6 \mathrm{ft}$, which appeared to have a change in water chemistry, was not found to be transmissive with the HPFM.

The fluid conductivity logs indicate a change in water chemistry at about $320 \mathrm{ft}$. Under ambient and stressed conditions, the fluid conductivity and temperature logs are almost identical and indicate a change in total dissolved solids at about 320 -ft depth. The temperature, fluid conductivity, oxidation-reduction potential, $\mathrm{pH}$, and dissolved oxygen logs were fairly uniform over most of the borehole. However, they all showed a large change below $320 \mathrm{ft}$, which is thought to be the lowermost hydraulically active fracture in the borehole. The dissolved oxygen, fluid conductivity, oxidation-reduction potential, and $\mathrm{pH}$ logs also indicate the open fracture at a depth of $286.6 \mathrm{ft}$ below the top of casing may be hydraulically active.

Table 20. Transmissivity results for borehole DW-10, near Machiasport, Maine.

[ft, feet; gal/min, gallon per minute; $\mathrm{ft}^{2} / \mathrm{d}$, feet squared per day]

\begin{tabular}{ccccc}
\hline $\begin{array}{c}\text { Depth of } \\
\text { transmissive zone } \\
\text { (ft) }\end{array}$ & $\begin{array}{c}\text { Ambient flow above } \\
\text { transmissive zone } \\
\text { (gal/min) }\end{array}$ & $\begin{array}{c}\text { Pumped flow above } \\
\text { transmissive zone } \\
\text { (gal/min) }\end{array}$ & $\begin{array}{c}\text { Zone } \\
\text { transmissivity } \\
\text { (ft'/d) }\end{array}$ & $\begin{array}{c}\text { Percent of total } \\
\text { transmissivity }\end{array}$ \\
\hline 43.7 & 0.00 & 0.254 & 0.4 & 21 \\
156.0 & -0.167 & 0.156 & 1.2 & 65 \\
327.0 & 0.00 & 0.072 & 0.3 & 14 \\
\hline
\end{tabular}




\section{Other Borehole Geophysical Data}

The USACE provided borehole geophysical data collected by Geophysical Applications, Inc., and Hager-Richter Geoscience, Inc., to the USGS for inclusion in this study. To improve spatial coverage and the total statistical population of fractures, these additional data were included in the integrated analysis of the three environmental restoration sites. The interpretations of the data from Geophysical Applications, Inc. (Weston Solutions, 2005) and Hager-Richter Geoscience, Inc. (The Johnson Company, 2006) are in appendixes 4 and 5, respectively.

\section{Results of the Borehole Geophysical Investigation}

Borehole geophysical logs and hydraulic tests were conducted to (1) verify borehole construction, (2) identify and characterize rock types in the boreholes, (3) locate and characterize locations and orientations of fractures that intersect the boreholes, and (4) characterize the hydraulics of the individual boreholes. The results of fracture logs were summarized for each borehole in the previous section of this report. The following discussion summarizes the logging results for multiple boreholes and provides an integrated interpretation of rock type, fracturing, and borehole hydraulics for the three environmental restoration sites in the study area.

\section{Well Construction}

The caliper, OTV, ATV, and EMI logs were most effective for identifying the bottom of casing, total depth, diameter, and integrity of the borehole wall. Where necessary, these physical parameters were updated in table 1 , and measured differences were reported to the USACE.

\section{Determination of Lithology}

Selected geophysical logs were cross-plotted to assess correlations between rock properties (fig. 4). These plots included combinations of gamma, acoustic reflectivity, EMI conductivity, normal resistivity, and SPR. Using the results from boreholes MW-14, DW-10, and DW-23, where there were OTV images, the rock types were correlated with the gamma and reflectivity signatures (figs. 4, 6, and 7). These cross-plots show general patterns that correlated to physical properties of the rock. For all the boreholes, gamma and ATV reflectivity were compared to the results of the ATV traveltime and amplitude images, OTV images, and caliper logs for an integrated interpretation, yielding a determination of either quartz monzonite, rhyolite, metasedimentary units, or gabbro/ diabase rock types.

Cross-plots were constructed using borehole logs from the boreholes in the study area (fig. 10). Average gamma and reflectivity values are shown for selected segments of the boreholes that appear to represent the major rock type in each borehole. Care was taken to avoid sections that were heavily fractured or enlarged and would give lower gamma and reflectivity values. Most of the boreholes had more than one value per well. The resultant plot was used to help identify similar rock units and determine gamma and reflectivity signatures that could be used to identify the rock types in other boreholes in the study area. Through this analysis, one of the rock types, that had previously not been "mapped" in the boreholes was identified in some of the boreholes. The interpretation of metasedimentary rocks of the Eastport Formation was corroborated by other geophysical logs and field mapping and is consistent with published geologic maps.

In this study area, the majority of the gamma emissions are thought to come from potassium. Because igneous rocks have varying amounts of potassium, the gamma tool can be effective in identifying changes in the rock related to compositionally different magmas or melts. In addition, the metasedimentary units have varying amounts of gamma emissions that are related because of clay content and emissions from other natural sources. The reflectivity of the rocks is related to the hardness (density and velocity), which is a function of the rock type (including mineralogy, texture, grain size, and the rugosity of the borehole wall). By combining the tool responses for natural-gamma emissions and acoustic reflectivity, signatures were determined for the major rock types in the study area. The signatures observed in figure 10 are described for each of the major rock types in the study area.

- The mafic dikes (example borehole DW-10) exhibit a very low gamma signature and high reflectivity.

- The gabbro/diabase units (example boreholes WYGATR and MW-14) exhibit very low gamma emissions and variable but generally high reflectivity.

- The metasedimentary units show the most variation in signature but tend to have moderate gamma and reflectivity counts. Some short-depth intervals of the boreholes (such as in borehole DW-40) have very high gamma counts and may be an original depositional layer that was rich in clay and fine sediments. Other short-depth increments show very high reflectivity relative to the rocks above and below them without a change in gamma. These zones may be the metasedimentary layers of quartzite, such as the very high reflectivity unit in the metasedimentary rocks in borehole DW-39. Because of the variation in the original depositional sediments, the reflectivity and gamma $\operatorname{logs}$ for the metasedimentary layers tend to be highly variable. 


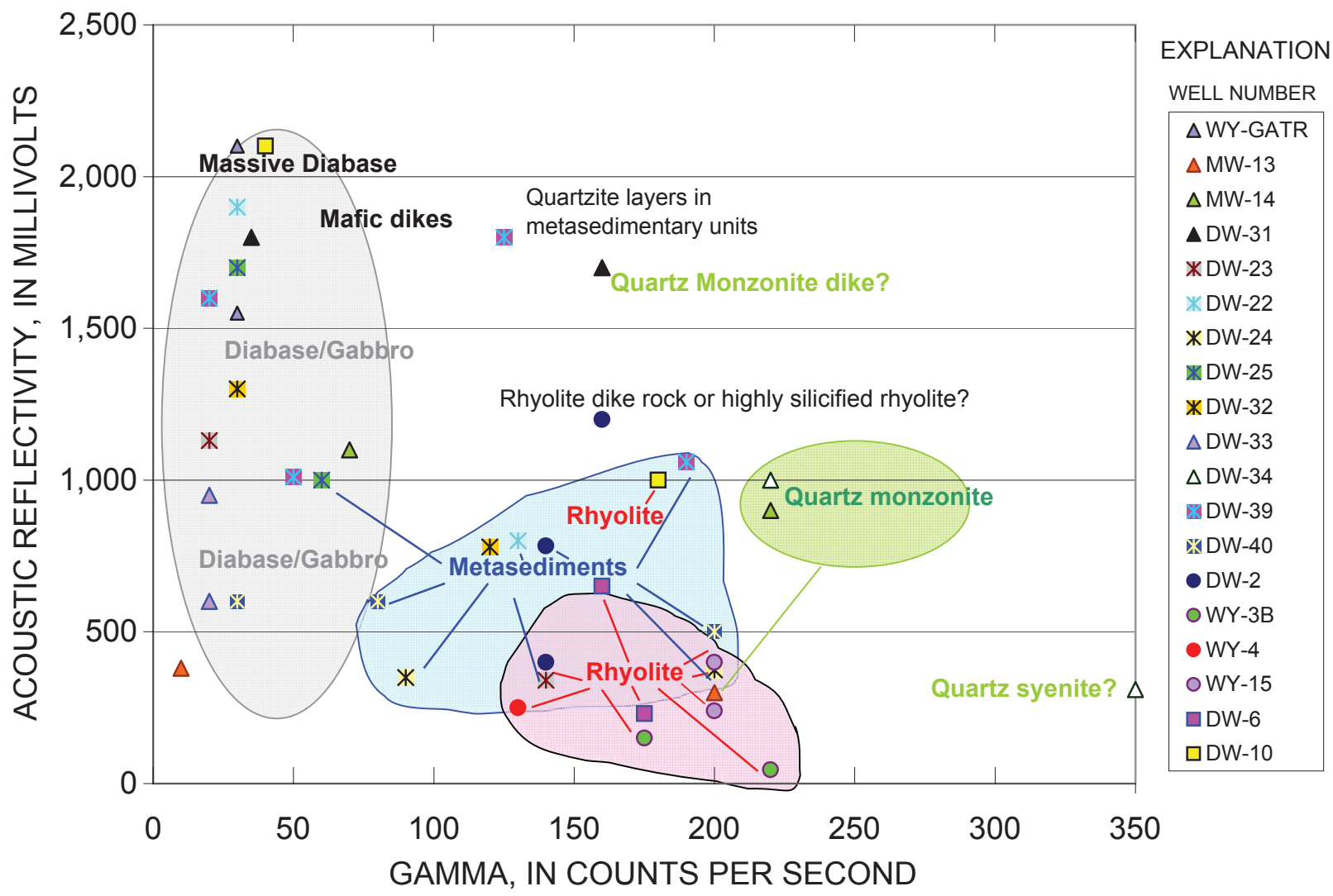

Figure 10. Cross-plot of gamma emissions and acoustic reflectivity for selected segments of boreholes near Machiasport, Maine.

- Quartz monzonite (example borehole MW-14) has high gamma counts and moderate reflectivity. The gamma and reflectivity signatures of quartz monzonite were similar to those of the metasedimentary units. But where OTV logs were available, the massive quartz monzonite could be distinguished from the laminated to banded metasedimentary units. In addition, the reflectivity logs in the metasedimentary units appear to be more variable over short distances than the more uniform and massive quartz monzonite.

- Rhyolite has moderately high gamma counts and fairly low to moderate reflectivity values. The higher reflectivity zones in some of the rhyolite zones may be associated with rhyolite dikes, whereas the lower reflectivity may be associated with the silicified rhyolite country rock (Drew Clemens, U.S. Army Corps of Engineers, written commun., 2006). Examples of these signatures are observed in borehole DW-2. These proposed interpretations can account for the minor variations in reflectivity; however, OTV logs would be helpful to confirm this interpretation.

- The reflectivity amplitudes for boreholes MW-13, MW-14, and MW-33, which were logged with the MSI tool, showed lower reflectivity values than the boreholes logged with the CGC tools. Despite the lower magnitude of the reflectivity response, the patterns in the gamma and reflectivity logs were sufficient to determine the rock type.

Collectively, these signatures were used to characterize the rock types in the boreholes. The borehole logs for the Miller Mountain site are shown in figure 11. The reflectivity and the gamma logs are superimposed on the general interpretation of the rock types. The logs have been plotted to a common elevation datum in feet above NAVD 88. 


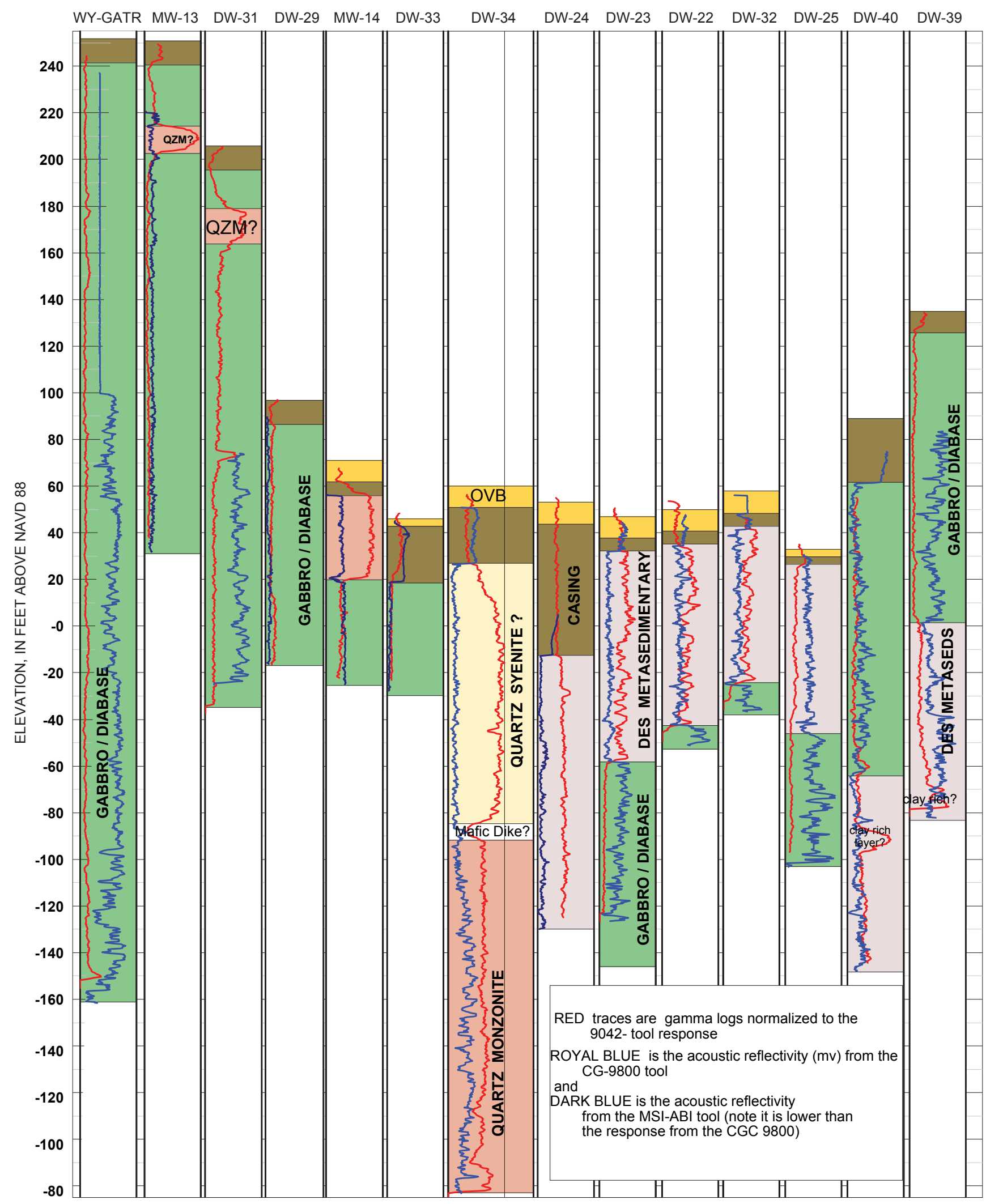

Figure 11. Gamma and reflectivity logs and interpretations for boreholes in the Miller Mountain site, near Machiasport, Maine. All gamma logs are shown from 0-300 cps, except for DW-34, which is 0-600 cps. Reflectivity is shown from 0-3,000 millivolts. (cps, counts per second; mV, millivolts; OZM, quartz monzonite; DES Metaseds, Devonian-Silurian metamorphosed sedimentary unit; OVB, overburden) 
The borehole logs indicate the rock types at the summit of Miller Mountain are mainly mafic gabbro or diabase (boreholes WY-GATR, MW-13, DW-31, and MW-29). Along the southeast flank of Miller Mountain, the rock types are quartz monzonite and possibly quartz syenite, an igneous rock that has more potassium feldspar than the quartz monzonite and could account for the increase in gamma emissions relative to those of the quartz monzonite (borehole DW-34). Further east of the Miller Mountain summit, there is at least a 60 -ftthick zone of metasedimentary rock overlying the gabbro and diabase (boreholes DW-22, DW-23, DW-32, and DW-25). In borehole DW-24, only metasedimentary units were identified. North and east of the summit of Miller Mountain, gabbro and (or) diabase overlays the metasedimentary units (boreholes DW-40 and DW-39).

The rock types on Howard Mountain are predominantly rhyolite with some mafic-dike intrusions (fig. 12). The rhyolitic rock units show some variation in texture and hardness, possibly depending on whether they are rhyolite country rock or rhyolite dikes; the rhyolite dikes have a higher reflectivity. The rock types at the Transmitter Site, southwest of the summit of Howard Mountain, also are rhyolite intruded with mafic dikes that dip steeply toward the west, which is consistent with the geologic maps (Gates, 1981). Most of the boreholes at the Howard Mountain and Transmitter Sites (boreholes DW-10 and MW-4) were logged with MSI tools; hence, the overall magnitude of the reflectivity is lower than the reflectivity obtained with the CGC tool. A cross-plot of gamma emissions and acoustic reflectivity for selected segments of the boreholes on or near Howard Mountain is shown in figure 13.

Core samples collected from boreholes MW-9 and MW-4 provided hand samples for description of mineralogy and texture and determination of the rock type. The borehole logs were compared to these interpretations. Borehole MW-9, which has rhyolite at the top of the borehole down to a depth of about $75 \mathrm{ft}$ below the top of casing, was characterized by moderate and variable gamma counts and low reflectivity. The mafic or gabbro dike below a depth of $75 \mathrm{ft}$ in borehole MW-9 is characterized by high gamma emissions and higher reflectivity than the rhyolite (fig. 12). The core in borehole MW-4 is interpreted as a mafic dike overlying a rhyolite with the contact at a depth of about $34 \mathrm{ft}$ below the top of casing. The entire core sample from borehole MW-4, from a depth of about $34 \mathrm{ft}$ to the bottom of the borehole, is interpreted as rhyolite. However, the acoustic reflectivity (and to a lesser extent the gamma log) shows variation from a depth of about 34 to $62 \mathrm{ft}$ and then much lower and uniform reflectivity from a depth of $62 \mathrm{ft}$ to the bottom of the borehole (fig. 12). These clearly defined changes in the borehole logs are probably because of textural changes in the rhyolite lava flows. A sideby-side comparison of multiple logs from Howard Mountain indicates variations in the gamma and reflectivity logs for the units interpreted as rhyolite and very clear delineations between rhyolite and the mafic dikes.

\section{Fracture Analysis}

Stereoplots and tadpole plots were generated individually for each borehole so that the orientation of fractures could be observed with location, depth, and rock type (appendixes 1-5). In addition, stereoplots and tadpole plots were generated for groups of boreholes including (1) all the boreholes in the study area, (2) boreholes on or near Miller Mountain, (3) boreholes near the AFRTS site on Howard Mountain, and (4) boreholes near the Transmitter Site on Howard Mountain. These summary plots were constructed to determine if fracture patterns vary at the three sites within the study area. The interpretations for all boreholes in the study area and interpretations for each of the three restoration sites are summarized in appendix 6 . For each site, the total population of fractures is shown as a function of depth in projection, tadpole and stereographic projection plots, rose diagrams, and fracture density plots. The density plots, which were constructed for all the fractures and for the transmissive fractures only, show the number of fractures in 10-ft intervals to quantify the intensity of fracturing with depth. The projection, tadpole, stereo, and rose diagram, and density plots also were constructed for $100-\mathrm{ft}$ depth intervals to assess changes in frequency and fracture orientation with depth. In addition, the same plots were constructed as a function of elevation in feet above NAVD 88 to assess any potential fracturing associated with changes in elevation. Because no clear pattern was observed in these plots, they were not included in this document.

For fracture analyses, all possible borehole data were used, including the 18 boreholes logged by the USGS for this investigation; the 12 boreholes logged by Geophysical Applications, Inc., in 2003; and the 7 boreholes logged by Hager-Richter, Inc., in 2006. The borehole data were corrected for deviation and magnetic declination. Composite tadpole and projection plots were generated for multiple boreholes and shown in depth in feet below land surface. For the two inclined boreholes, C-501 and C-114 (fig. 1), the depths were converted to true vertical depth for the tadpole and projection plots.

A total of 2,279 fractures and lithologic features from 37 boreholes were included in the tadpole and stereoplots. The fractures show a wide range of orientations, and poles to fractures cover most of the stereoplot (fig. 14). There is some clustering of the poles to fracture planes in the stereoplot. The clusters represent shallow dipping fractures to the southeast, fractures that strike north-northwest to the south-southeast and dip south-southwest and east-northeast, and another cluster that strikes southwest and dips northwest. The transmissive fractures (dark blue) in these boreholes do not appear to follow a distinct pattern either but have a wide distribution of orientations (fig. 14). The tadpole plot shows the depth-bias of the boreholes, which are mostly less than $200-\mathrm{ft}$ deep. It also shows a substantial population of steeply dipping fractures. Because vertical boreholes statistically under-sample vertical features, a sampling bias is commonly applied (Terzaghi, 1965). For these boreholes, however, because the tadpole plot 


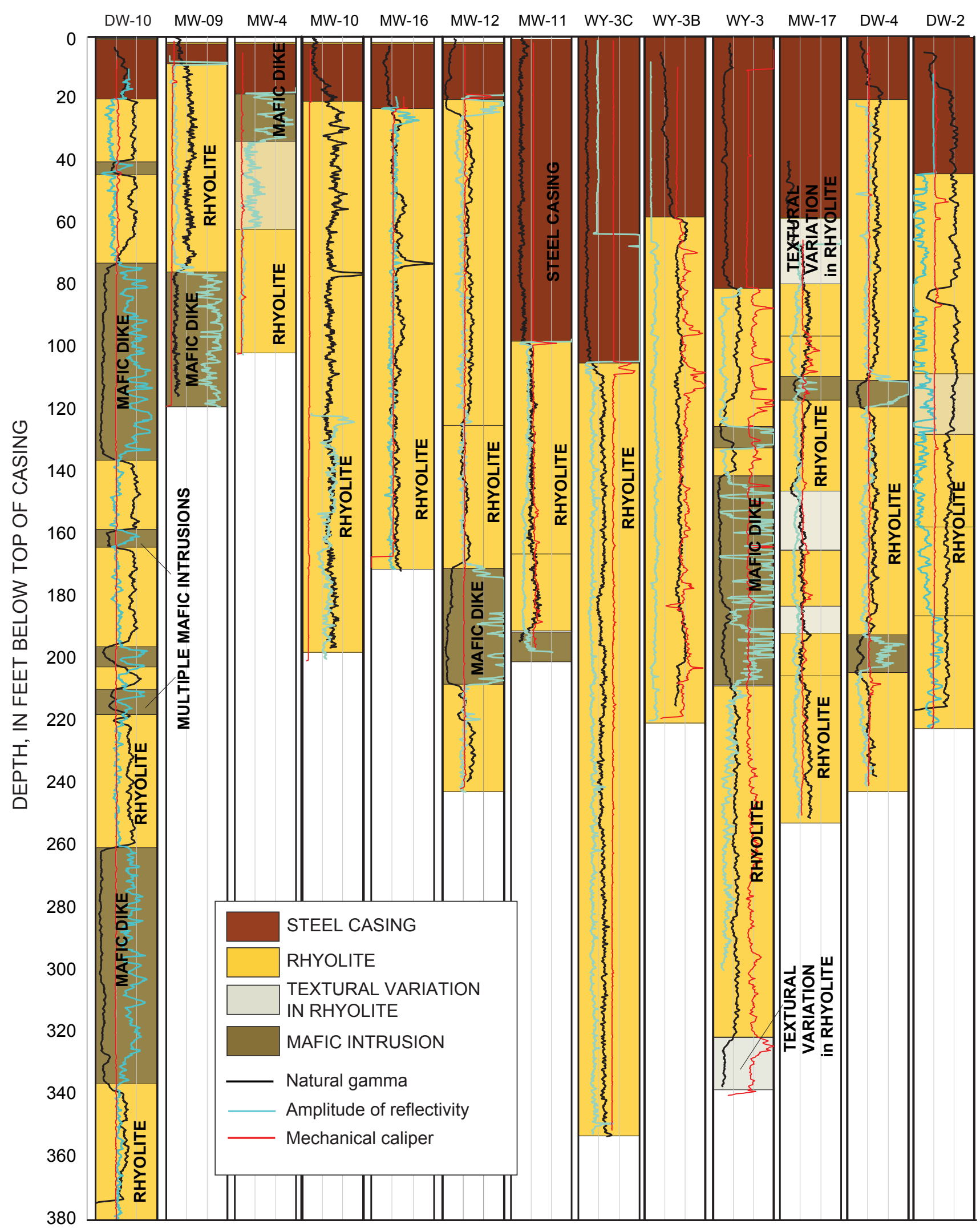

Figure 12. Gamma and reflectivity logs and interpretations for boreholes in the Howard Mountain area, near Machiasport, Maine. Shading indicates lithology. 


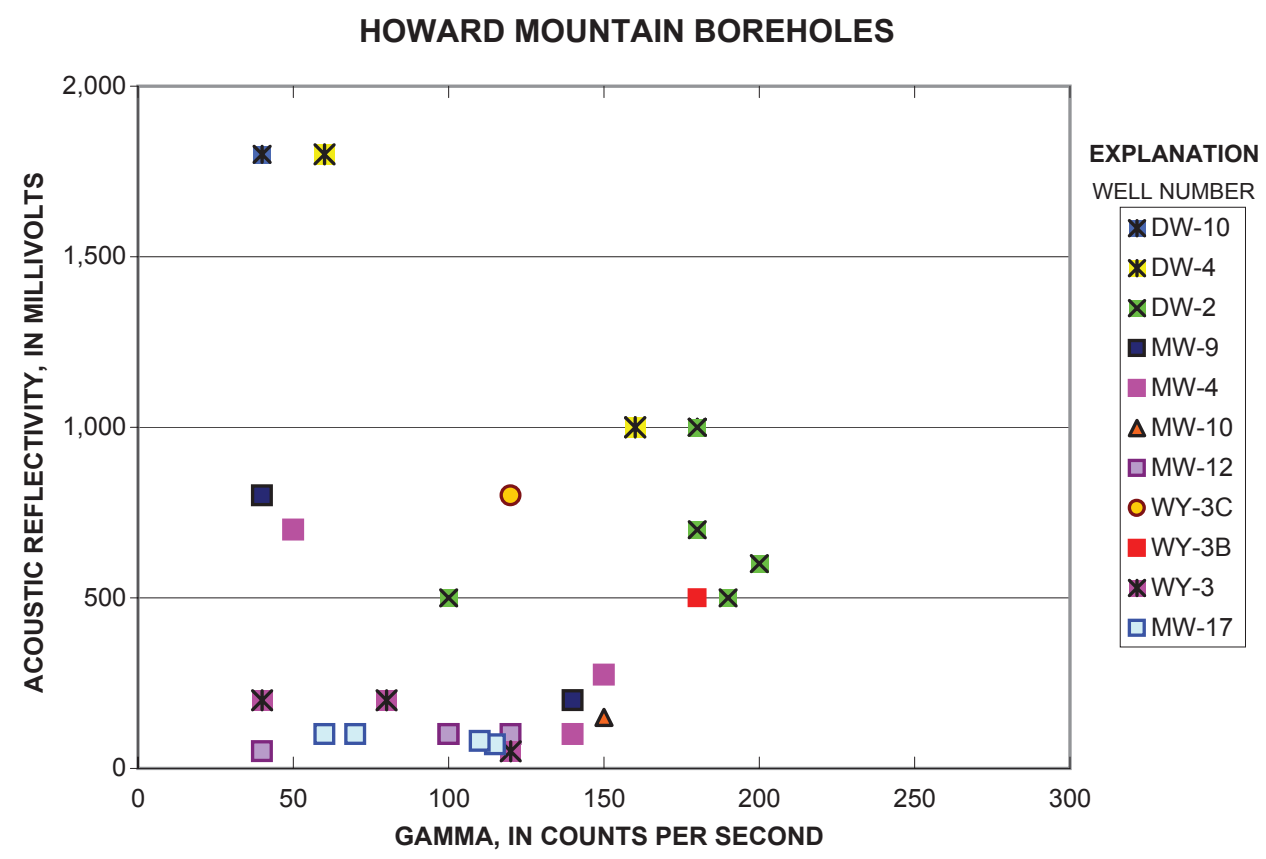

Figure 13. Cross-plot of gamma emissions and acoustic reflectivity for selected segments of the boreholes in the Howard Mountain area, near Machiasport, Maine. Boreholes MW-9 and MW-4 were interpreted in core samples. Boreholes DW-10, DW-4, and DW-2 were logged with a Century Geophysics acoustic televiewer; all other boreholes were logged with the Mount Sopris Instruments televiewer.

readily shows a very high proportion of vertical fractures, no vertical-bias corrections were applied. It is noteworthy that there are so many steeply dipping fractures because they may serve to connect low-dip-angle unloading or sheeting fractures that mimic the topography and are ubiquitous in the near surface. These sub-horizontal fractures appear to decrease in frequency with depth, as indicated by the lack of shallow-dipping tadpoles at depth, relative to the number of steeply dipping fractures at depth (fig. 14). A total of 144 lithologic features were identified and coded with green squares in the stereo and tadpole plots (fig. 14). These lithologic features show a wide range of orientations.

\section{Miller Mountain}

A total of 836 fractures and lithologic features were identified in the 14 boreholes on and near Miller Mountain. A stereoplot of the fractures shows a wide distribution of orientations (fig. 15). The maximum cluster of poles to fracture planes plots towards the center of the stereoplot and represents shallow-dipping fractures that strike northeast with an average bearing of about $\mathrm{N} 55^{\circ} \mathrm{E}$ (fig. 16). These shallowdipping fractures are most likely caused by unloading. The total population of fractures and the population of transmissive fractures in the Miller Mountain wells strike northwest and southeast and dip moderately to steeply towards the northeast and southwest, respectively. These fractures are parallel to local faulting and parallel to the incised valley between Miller and Bucks Mountains. Another cluster of poles to fracture planes strikes southwest and dips very steeply to the northwest at a dip azimuth of $\mathrm{N} 335^{\circ} \mathrm{E}$, which is parallel to the regional trend of fractures.

A total of 38 lithologic features were identified and coded with green squares in the stereo and tadpole plots (fig. 15). The lithologic features identified in the Miller Mountain boreholes were either very shallow dipping or steeply dipping towards the northwest. Fractures with infilling (gray circles) appeared to have the same orientations as the transmissive fractures and the total population of fractures for the Miller Mountain boreholes. 


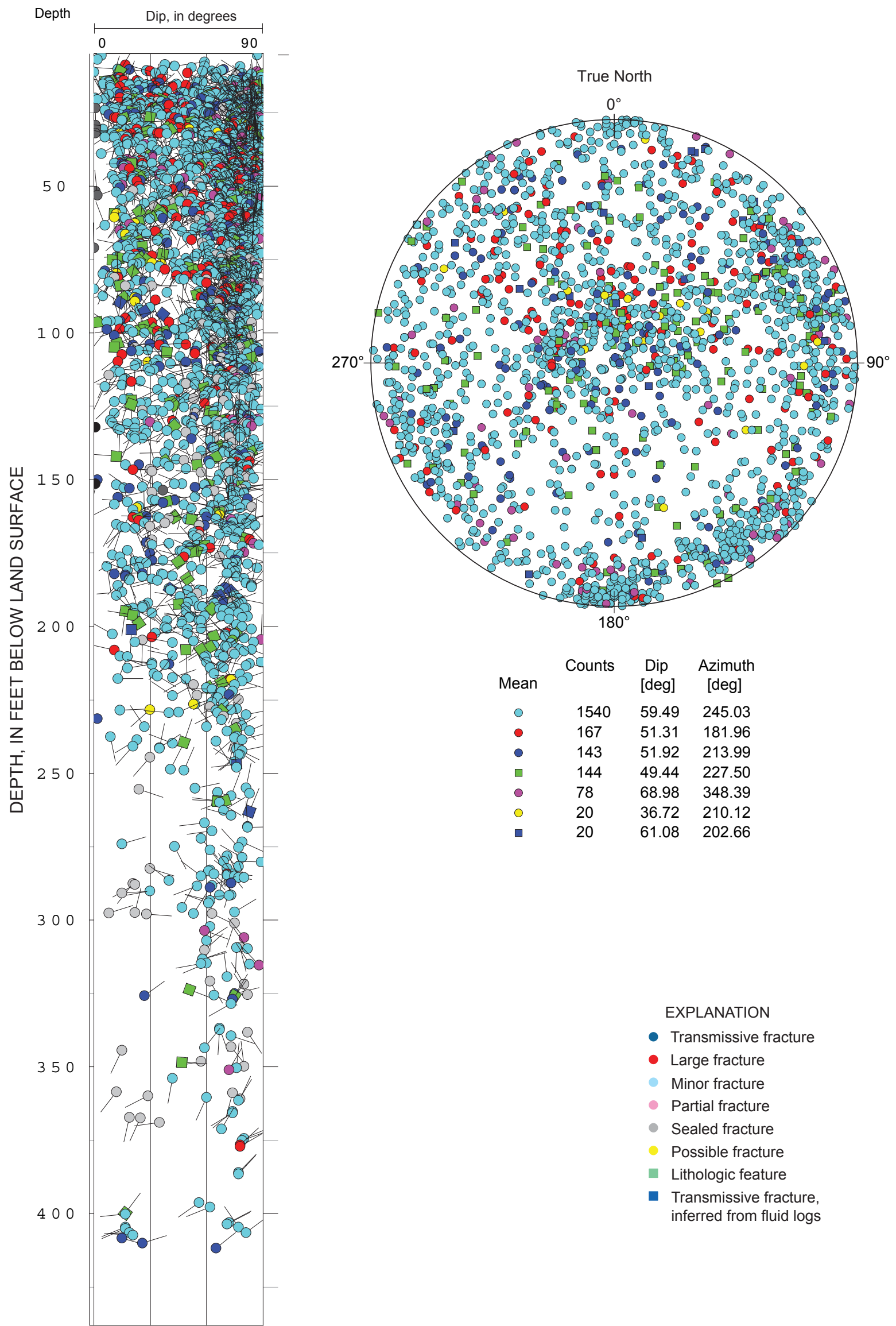

Figure 14. Tadpole plot and stereoplot showing all fractures and lithologic features in the 37 boreholes near Machiasport, Maine. Stereoplot is lower hemisphere Schmidt, equal area plot. (deg, degrees) 


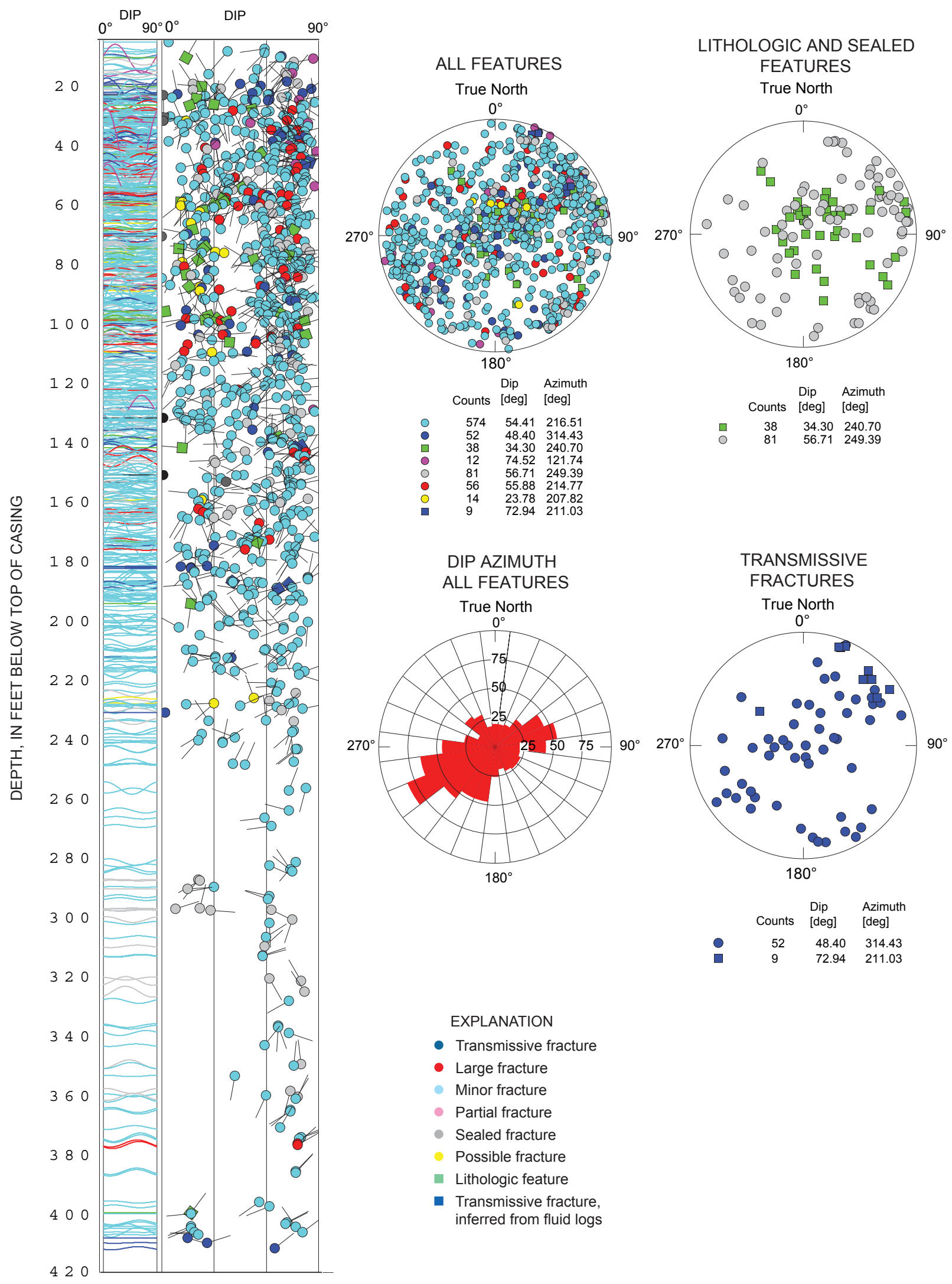

Figure 15. Tadpole plots, stereoplots, and rose diagram showing all fractures and lithologic features in 14 boreholes on or near Miller Mountain, near Machiasport, Maine. Stereoplots are lower hemisphere Schmidt, equal area plots. Rose diagram shows direction of dip azimuth, which is 90 degrees to the right of the strike. (deg, degrees) 


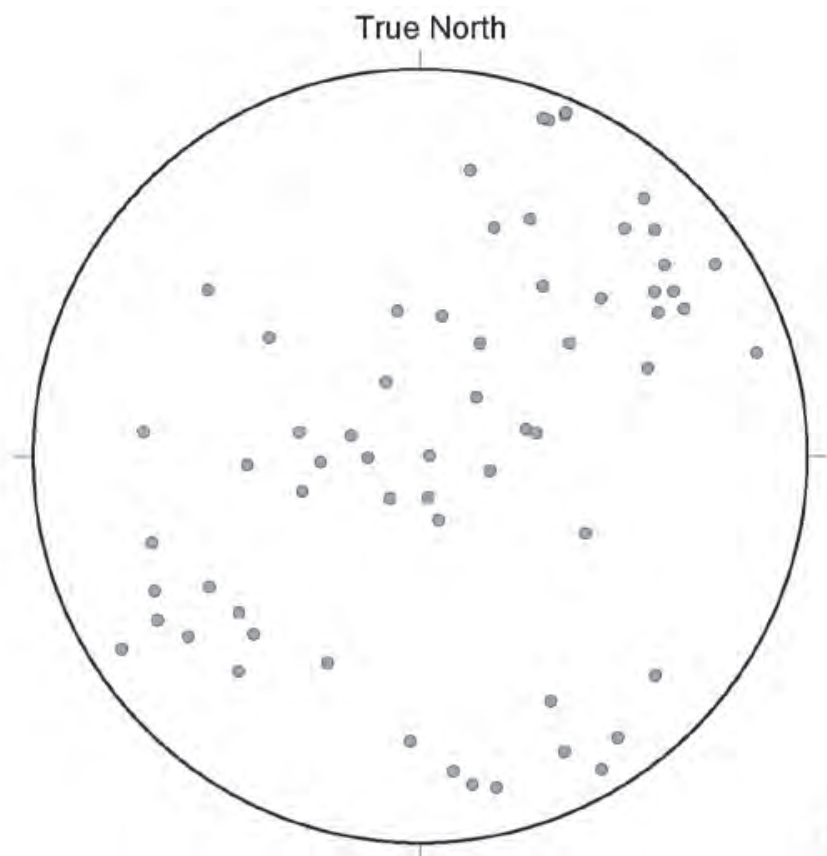

- Poles to planes

Number of poles $=61$

Maximum density 7.9 at $N 55^{\circ} \mathrm{E}, 24^{\mathrm{a}}$

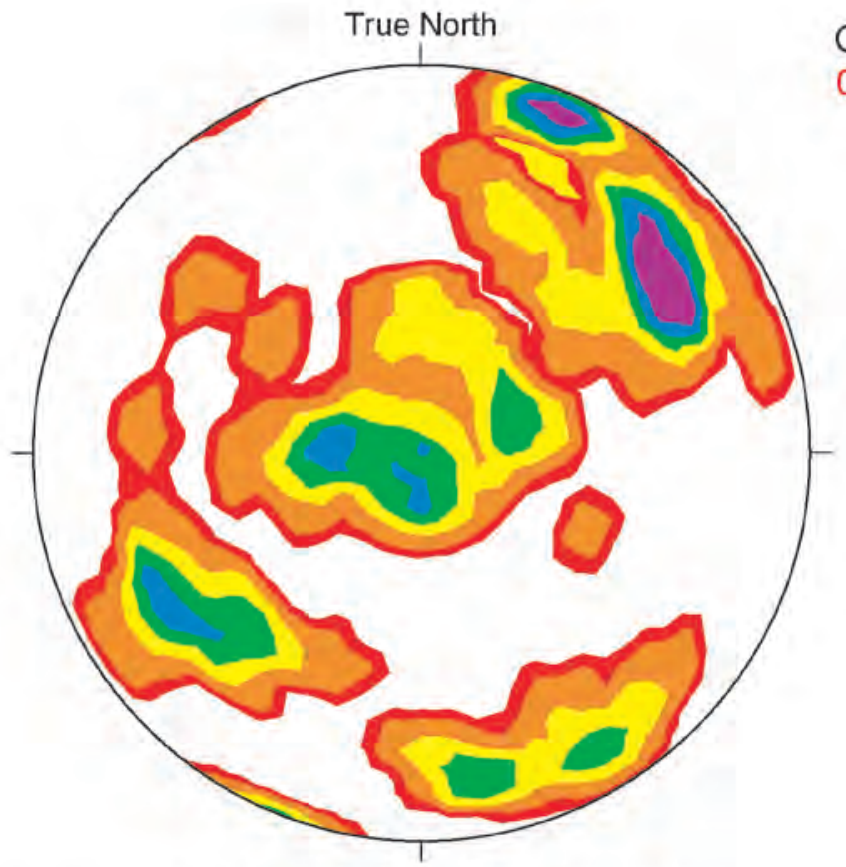

Contours at

$0.5,1.0,2.0,3.0,4.0,5.0$

Equal area projection, lower hemisphere

Figure 16. Poles to planes of transmissive fractures in 14 boreholes on or near Miller Mountain, near Machiasport, Maine. 
A total of 61 fractures were identified as transmissive in the 14 boreholes on and near Miller Mountain. The transmissive fractures are shown with dark blue circles for fractures identified with the HPFM and dark-blue squares for fractures inferred by water-quality or temperature logs. A stereoplot showing contours of transmissive fractures indicates the majority of these fractures strike southeast and dip southwest (fig. 16).

The tadpole and projection plots (fig. 15) and 100-ft incremental stereoplots and rose diagrams (appendix 6) show that as depth increases, the fracture orientation remains fairly constant. The transmissive fractures show a small amount of rotation with depth in the fracture strike (and dip azimuth) towards the west. Density plots, which show the number of fractures for a fixed-depth interval, were constructed for 10 - and 100-ft intervals to quantify the intensity of fracturing with depth. Density plots constructed with 10-ft intervals for all the wells in the Miller Mountain area show an apparent decrease in fracture density with depth (appendix 6 , fig. $6 \mathrm{~A}-1$ ). Because of the sampling bias of the well depths, more near-surface fractures were encountered in the shallow boreholes relative to the total population. When density is plotted as a function of elevation, the highest fracture density still shows a sampling bias. Hence, an assessment of fracture density with depth is probably best estimated by looking at the deepest boreholes individually. The OTV log for borehole WY-GATR (appendix 6, fig. 6A-4) shows only a small decrease in number of fractures with depth and an increase in sealed fractures with depth. The tadpole plot indicates most of the fractures at depth are steeply dipping, although the transmissive fractures in the bottom of borehole WY-GATR have shallow dips (fig. 6A-4).

\section{Howard Mountain—Air Force Radar Tracking Station}

A total of 898 fractures and lithologic features in 17 boreholes on or near Howard Mountain shows a wide range of orientations in the poles to fracture planes, with some minor clustering in the stereoplot. The stereo and tadpole plots for Howard Mountain indicate most of the fractures are steeply dipping; a smaller subset of fractures is sub-horizontal and dips towards the southeast (fig. 17). Similar to the fractures on Miller Mountain, there are many southeast-northwest striking fractures that dip very steeply toward the southwest and northeast, respectively. Numerous fractures strike southwestnortheast and dip very steeply to the northwest and southeast, respectively. There is a very large population of steeply dipping fractures, as indicated by the dense population of tadpoles on the right side of the tadpole plot; this is uncorrected for the vertical sampling bias. The majority of fractures dip towards $\mathrm{N} 237^{\circ} \mathrm{E}$ and strike and $\operatorname{dip} \mathrm{N} 147^{\circ} \mathrm{E}, 85^{\circ} \mathrm{SE}$. In general, the fracture orientation on or near Howard Mountain is more variable than on or near Miller Mountain or at the Transmitter Site. This variability in the Howard Mountain data may be attributed to the influence of the fault, which is directly northeast of the Howard Mountain summit (Gates, 1981).

A stereoplot of the 61 transmissive fractures (poles to fracture planes shown in dark blue circles and squares) from the 17 boreholes on or near Howard Mountain is similar to the overall fracture population for Howard Mountain (fig. 17). Contoured stereoplots show the clustering of poles to fracture planes for all fractures identified as transmissive (fig. 18). The transmissive fractures strike (and dip) in almost every direction, but most notably they do not strike west (and dip due north), as do many of the fractures, which dip due north, in the entire fracture population for Howard Mountain (fig. 17). This observation is confirmed by the lack of contours on the southern side of the stereoplot (fig. 18). The lithologic features identified in the Howard Mountain boreholes (coded in green) show a wide range of orientations, without a strong pattern of clustering of the poles to the planes (fig. 17).

An assessment of fracturing with depth indicates a strong sampling bias when all boreholes are included (fig. 17 and appendix 6, figs. 6B1-3). Because most of the boreholes are about $120 \mathrm{ft}$ deep, the fracture count in the total population appears to decline abruptly below a depth of about $120 \mathrm{ft}$ below land surface. However, the fracture density for the three deepest wells in the Howard Mountain area, WY-3, WY-3B, and WY-15, does not show a decline in fracturing with depth (appendix 6, fig. 6B-4). Most of the fractures below a depth of $200 \mathrm{ft}$ are moderately to steeply dipping, indicating a decline in the frequency of shallow-dipping unloading or sheeting fractures with depth.

\section{Transmitter Site}

A total of 275 fractures and lithologic features were identified in the six boreholes near the Transmitter Site on the southwest side of Howard Mountain (fig. 19). The fractures show a wide range of orientations in poles to fracture planes, with some minor clustering on the stereoplot. The stereo and tadpole plots for the Transmitter Site indicate fractures trend in two directions - southwest-northeast and southeastnorthwest. The fractures that strike southwest and northeast dip steeply towards the northwest and southeast, respectively. Another substantial cluster of poles to fracture planes indicates fractures strike south and southeast and dip toward the west-southwest.

A stereoplot of the 35 transmissive fractures (dark blue circles) is similar to the overall fracture population for the Transmitter Site (figs. 19 and 20). There are clusters of poles to transmissive fracture planes that dip steeply towards the southeast and towards the northwest (fig. 20). These fracture orientations appear to follow the regional pattern of northeastsouthwest striking fractures with dip directions towards the southeast and northwest. Another small cluster of poles to planes of transmissive fractures occurs near the center of the stereoplot, indicating a shallow dip towards the east (fig. 20). 

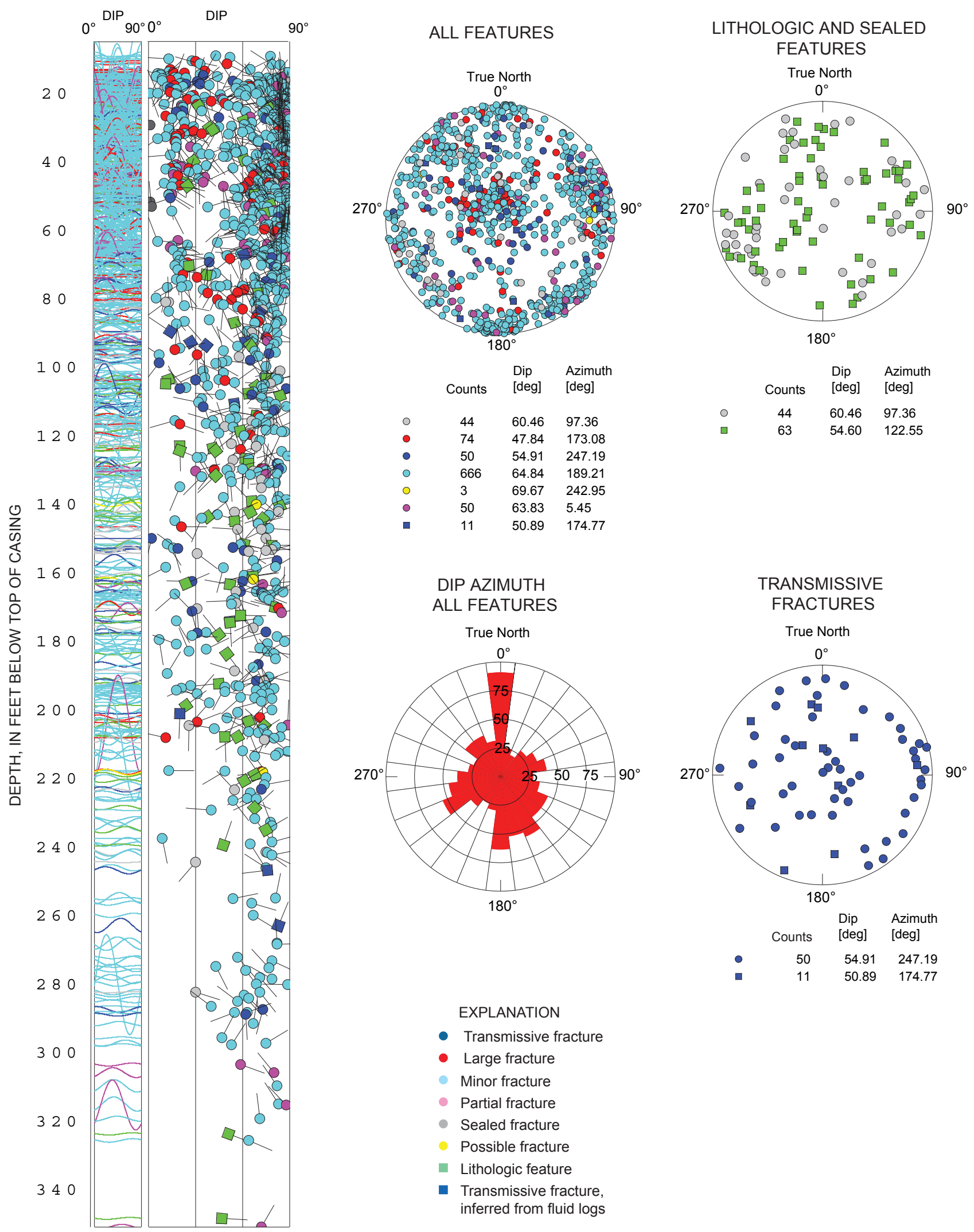

Figure 17. Tadpole plots, stereoplots, and rose diagram showing all fractures and lithologic features in 17 boreholes near the Air Force Radar Tracking Station on Howard Mountain, near Machiasport, Maine. Stereoplots are lower hemisphere Schmidt, equal area plots. Rose diagram shows direction of dip azimuth, which is 90 degrees to the right of the strike. (deg, degrees) 


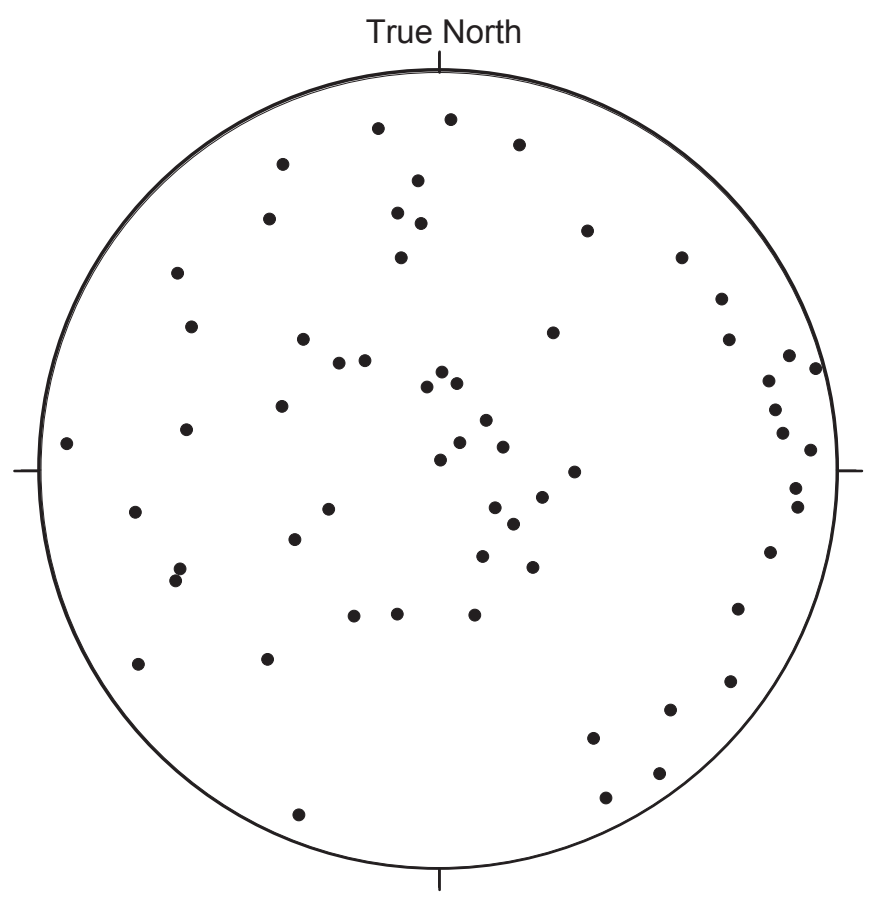

- Poles to planes

Number of poles $=61$

Maximum density 6.03 at $\mathrm{N}^{\circ} 8^{\circ} \mathrm{E}, 12^{\mathrm{O}}$

Contours at

$0.5,1.0,2.0,3.0,4.0,5.0$

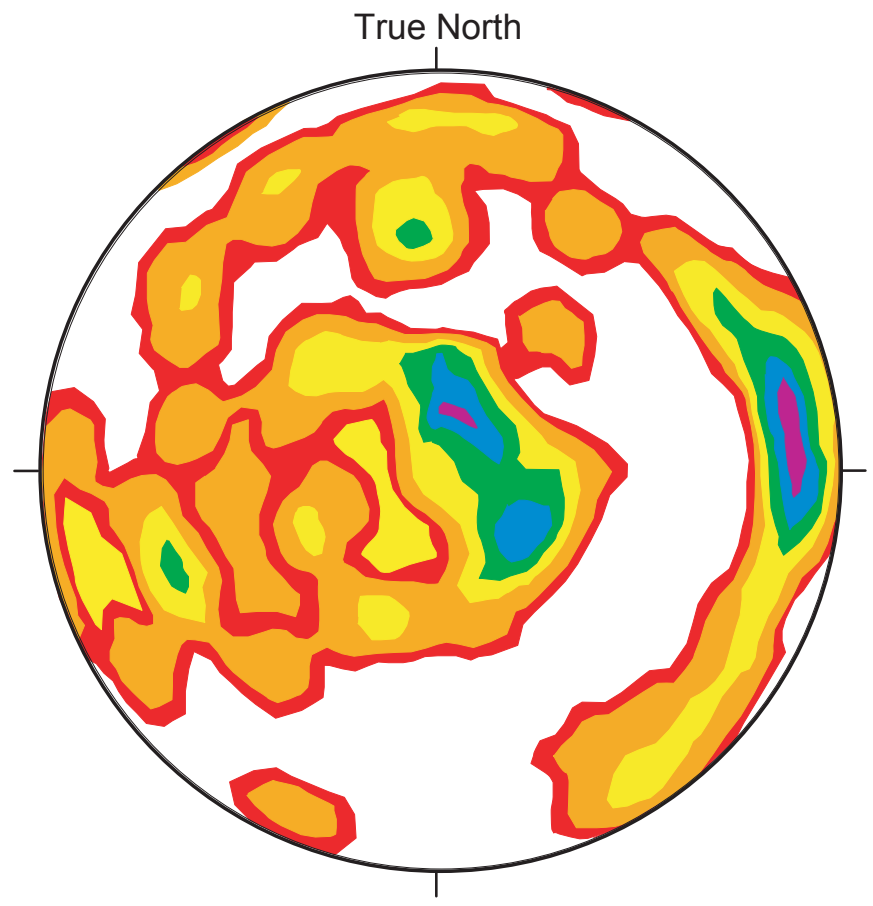

Equal area projection, lower hemisphere

Figure 18. Poles to planes of transmissive fractures in 17 boreholes near the Air Force Radar Tracking Station on Howard Mountain, near Machiasport, Maine. 

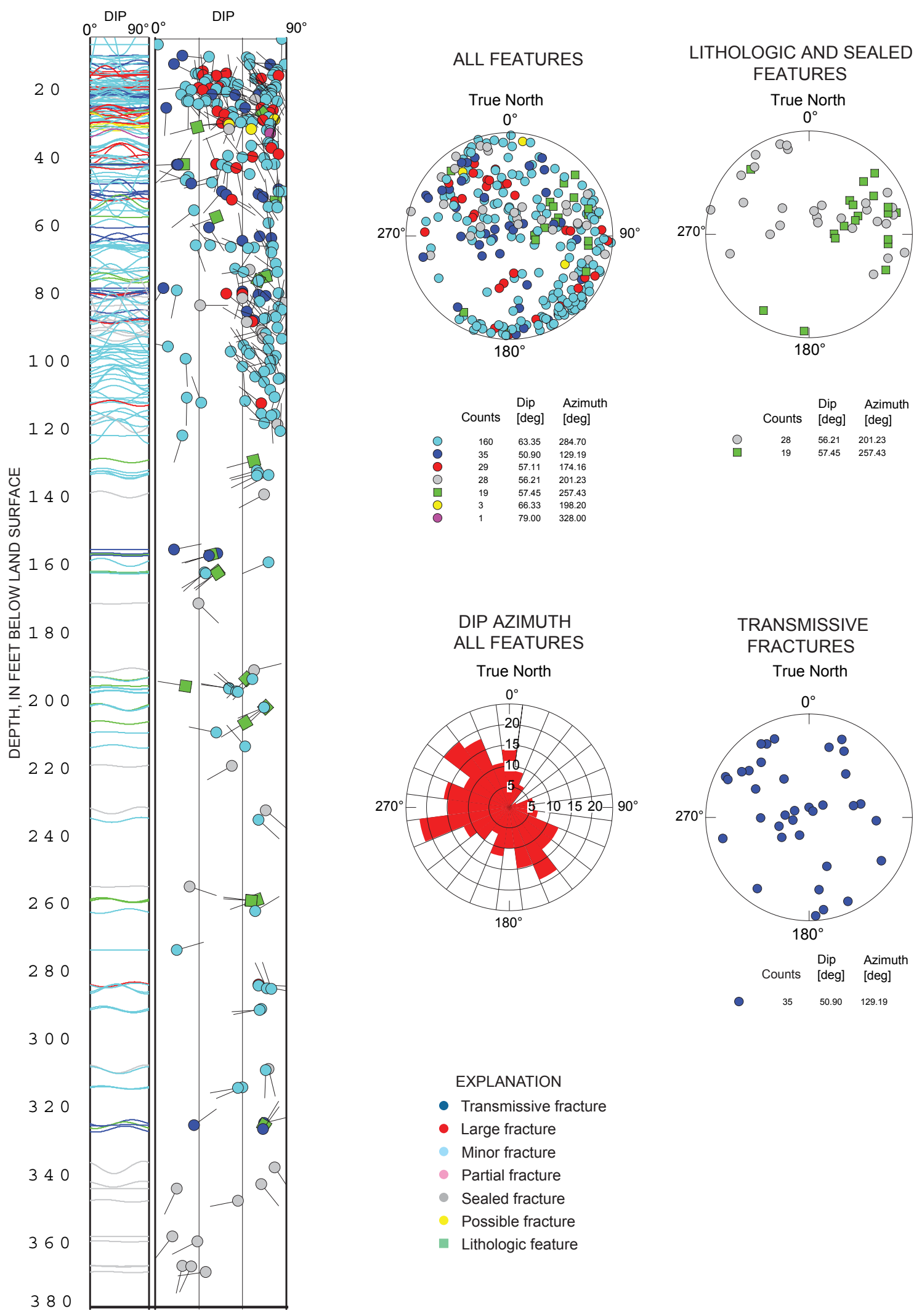

FEATURES
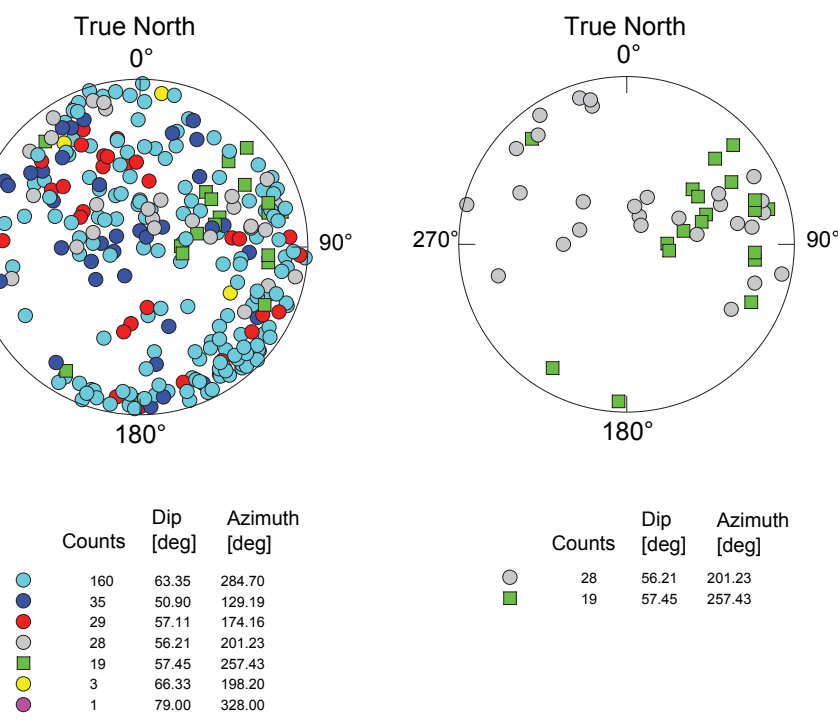

DIP AZIMUTH

ALL FEATURES

True North

TRANSMISSIVE

FRACTURES

True North
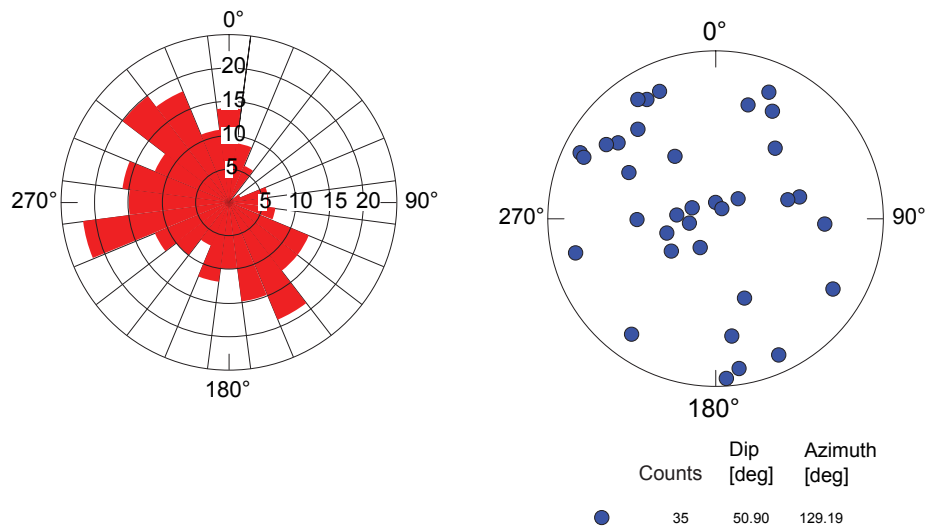

EXPLANATION

- Transmissive fracture

- Large fracture

Minor fracture

- Partial fracture

- Sealed fracture

- Possible fracture

Lithologic feature

Figure 19. Tadpole plots, stereoplots, and rose diagram showing all fractures and lithologic features in six boreholes near the Transmitter Site on Howard Mountain, near Machiasport, Maine. Stereoplots are lower hemisphere Schmidt, equal area plots. Rose diagram shows direction of dip azimuth, which is 90 degrees to the right of the strike. (deg, degrees) 

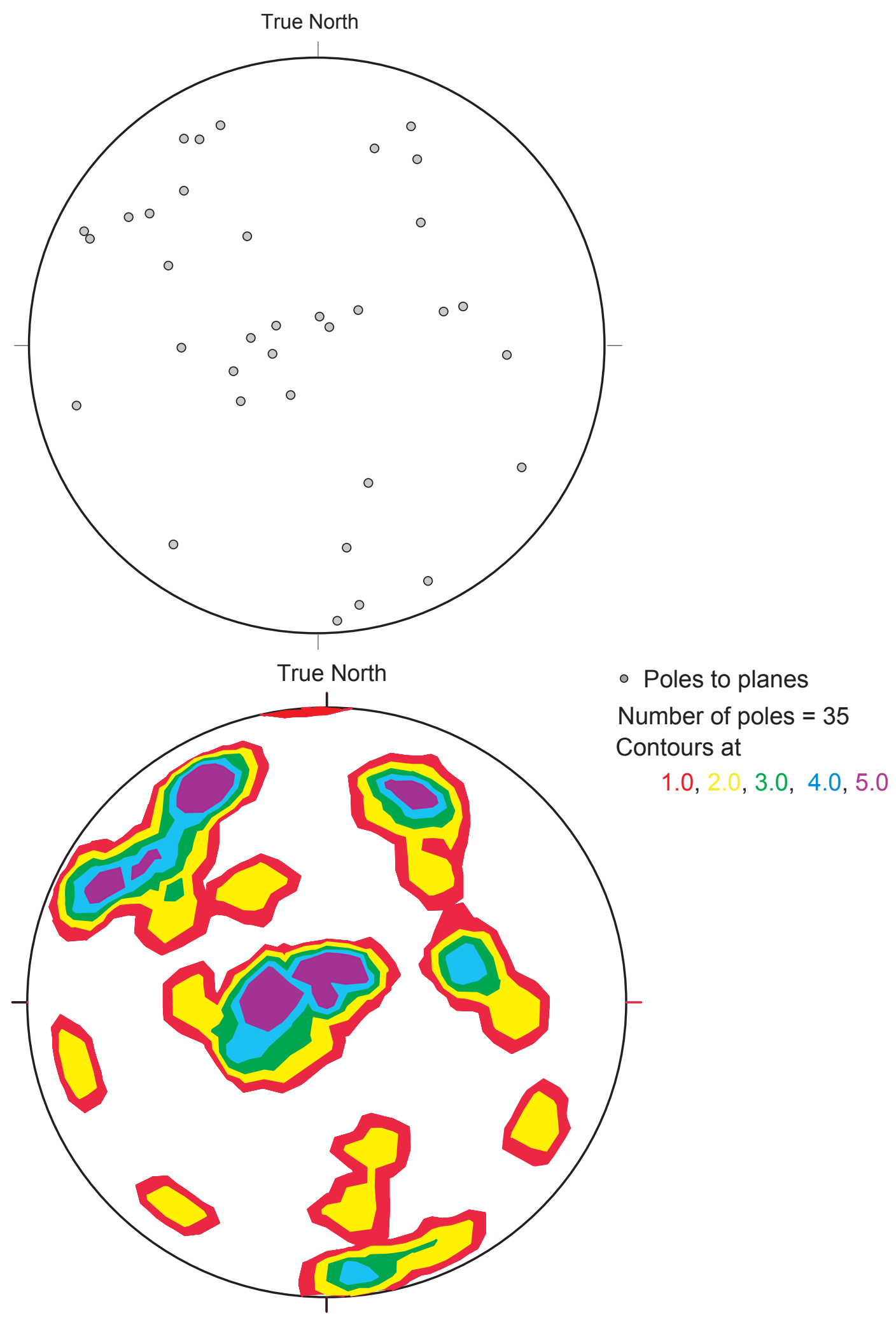

Equal area projection, lower hemisphere

Figure 20. Poles to planes of transmissive fractures in six boreholes near the Transmitter Site on Howard Mountain, near Machiasport, Maine. 
Mafic dikes strike to the south-southeast and dip moderately to steeply towards the west-southwest at an average dip azimuth of $\mathrm{N} 275^{\circ} \mathrm{E}$ (appendix 3 and fig. 19). Many of the mafic dikes generally parallel a subset of the transmissive fractures at the Transmitter Site. The lithologic features (coded in green, fig. 19) generally dip moderately to very steeply to the west. Sealed fractures dip at all angles towards the west and the east-southeast and were observed at all depths.

An assessment of fracturing with depth indicates fractures from a depth of 0 to $100 \mathrm{ft}$ below land surface at the Transmitter Site strike to the southwest and northeast and dip steeply towards the northwest and southeast (tadpole and stereoplots, appendix 6 , fig. $6 \mathrm{C}-2$ ). These fractures tend to parallel the regional structural northeast trend. From depths of 100 to $200 \mathrm{ft}$ below land surface, the fractures dip towards the northwest and southwest. Deeper than $200 \mathrm{ft}$ below land surface, the limited number of fractures dip towards the east and west. Because most of the boreholes are less than $120 \mathrm{ft}$ deep, the analysis with depth is limited to borehole DW-10 (appendix 6, fig. 6C-4). In general, the fracturing appears to be fairly uniform with depth.

In order to assess the pattern of the fracture populations with respect to proximity to the northwest-trending fault that bounds the northeast side of Howard Mountain, a series of stereoplots and rose diagrams are shown side-by-side for selected Howard Mountain boreholes (fig. 21). The plots represent a cross section extending from the southwest at the Transmitter Site towards the northeast, Howard Mountain, and the fault location. The stereoplots and rose diagrams show numerous fractures in these boreholes with a wide variation in fracture orientation. Many of the boreholes across this section have fractures that are parallel to the regional northeast trend. Boreholes MW-4, DW-6, MW-9, WY-15, MW-10, MW-15, MW-12, DW-2, DW-4, and WY-3C have dominant fracture sets that strike northeast and southwest and dip southeast and northwest, respectively. Other boreholes, including WY-3 and MW-17, have lesser amounts of northeast-southwest striking fractures. The fractures in boreholes MW-17, WY-4, MW-9, and DW-6 predominantly strike northwest-southeast, parallel to the northwest trending fault north of Howard Mountain. Most of the fractures in boreholes MW-10 and MW-11 strike north and south and dip towards the east and west, respectively; boreholes WY-3B, MW-9, and MW-4 show small numbers of north-south striking fractures. Boreholes DW-6, MW-12, WY-3, and WY-3B have prominent fracture sets that strike east and west and dip south and north, respectively. Also, boreholes DW-2 and WY-4 have minor fracture sets that strike east and west. Collectively, these observations indicate similarities in the orientations of fracture sets between the boreholes, but there does not appear to be a consistent pattern associated with topography or distance from the fault. When all the other Transmitter Site boreholes are included in the analysis (appendix 4), a general observation is that the fracture pattern goes from mostly southwest-northeast striking to more variable near the summit of Howard Mountain and in the boreholes near the fault.
A similar series of stereoplots and rose diagrams were plotted side-by-side for adjacent boreholes on or near Miller Mountain (fig. 22). Boreholes DW-39, DW-31, DW-33, DW-23, and DW-34 have dominant fracture orientations that strike northeast and southwest. Boreholes WY-GATR, MW-13, DW-32, and DW-24 have fracture orientations that strike to the northwest and southeast, and boreholes DW-25 and DW-40 have fracture sets that strike both northeast-southwest and northwest-southeast.

The stereoplots for Howard Mountain (fig. 21) show more variation in strike than the Miller Mountain stereoplots, but they also show less variation in dip. In general, the fracture populations in the Howard Mountain boreholes are dominated by steeply dipping fractures that dip at steeper angles than the Miller Mountain fractures.

\section{Hydraulic Characterization}

Hydraulic characterization included determination of ambient vertical flow, inflow and outflow zones under ambient and stressed hydraulic conditions, discrete-zone transmissivity and head within individual boreholes, and whole-well open-hole transmissivity. Ambient flow through a borehole is "artificial" in that the borehole serves as a conduit between fractures and "aquifers" with different heads; ambient vertical flow is, however, an indicator of the hydraulic potential within the aquifer. Usually, regional groundwater flow is inferred to follow land-surface topography; however, actual flow paths can vary because of the fracture network. Typically, downward flow occurs on mountain tops and in recharge zones, and upflow occurs where there is a break in the slope of the land surface and in discharge locations (Toth, 1963; Winter and others, 1998). The natural pattern of flow moves water from recharge locations with higher head to discharge locations with lower head. In this investigation, the direction of flow generally followed this pattern with a few localized variations in this conceptual site model.

The results of HPFM logging are summarized for all boreholes in this study, showing the direction of flow and a code for topographic setting (table 21). Within the study area, 9 boreholes had ambient upflow that could be measured with the HPFM, 13 boreholes had measurable ambient downflow, and 11 boreholes showed no measurable ambient flow or were affected by well interference or tidal influences. Differences in flow rates and flow directions in closely spaced boreholes indicate a difference in heads and (or) the presence of interconnected fractures and show the complexity and heterogeneity of fractured rock. In many of the boreholes logged for this investigation, the direction of vertical flow in the borehole was consistent with the conceptual groundwater flow model of recharge in topographic highs and discharge at topographic lows.

Two boreholes, DW-23 and WY-GATR on Miller Mountain, showed strong ambient flow with more than 100 gal moving through the borehole each day. One borehole, 

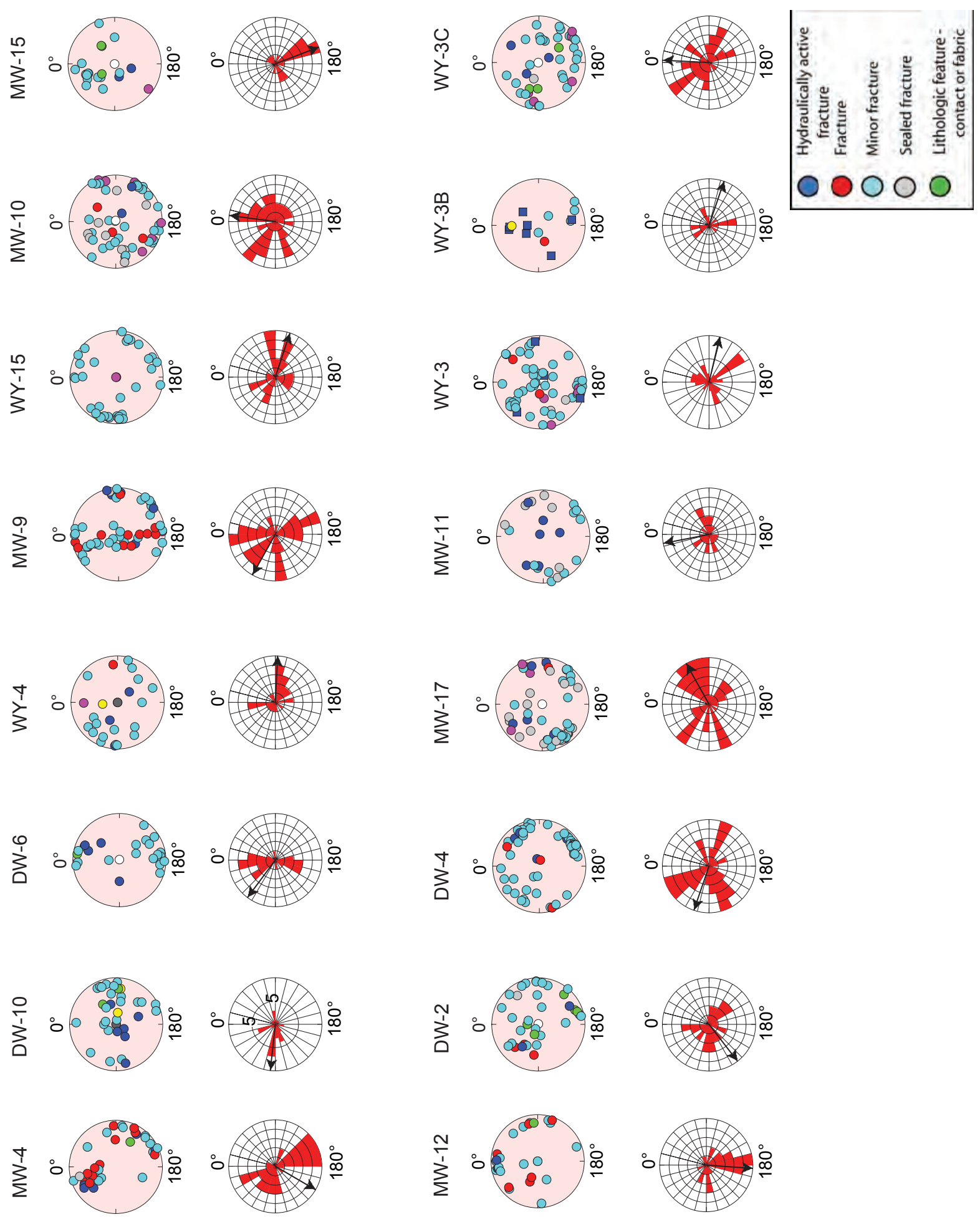


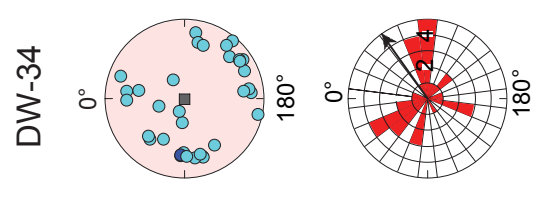

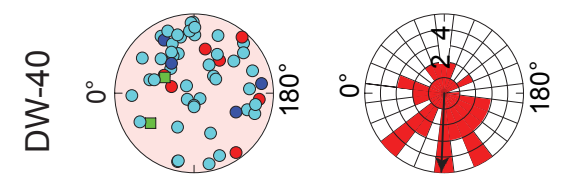
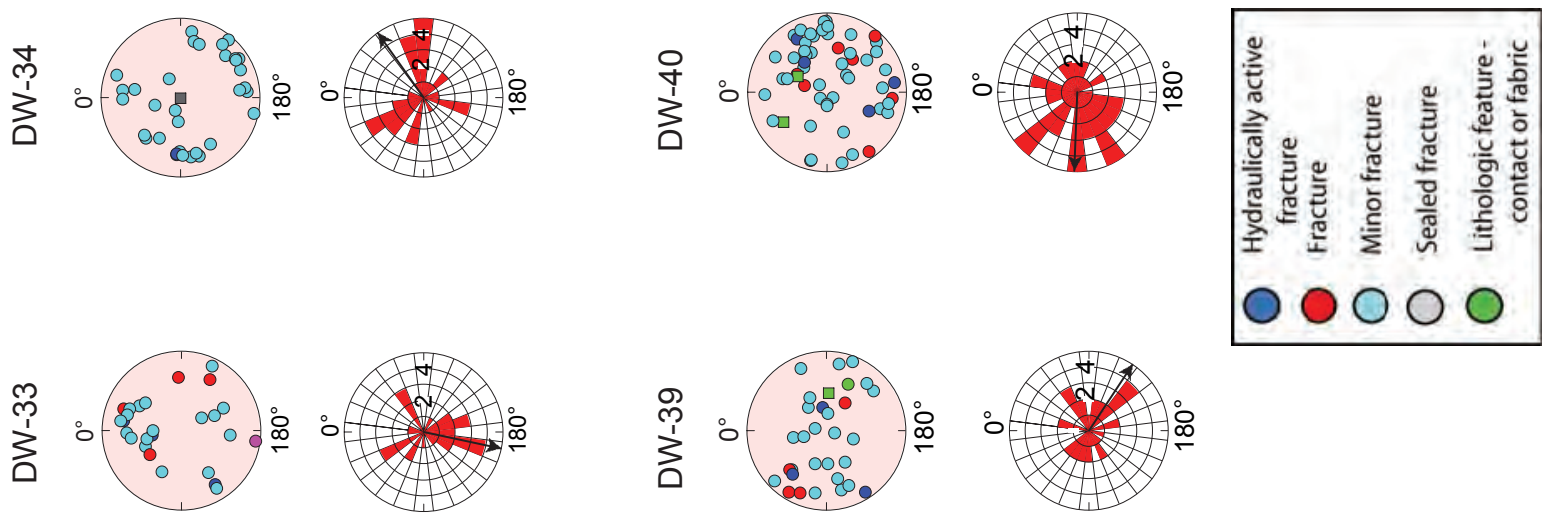

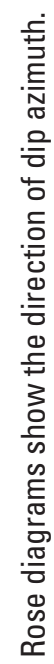
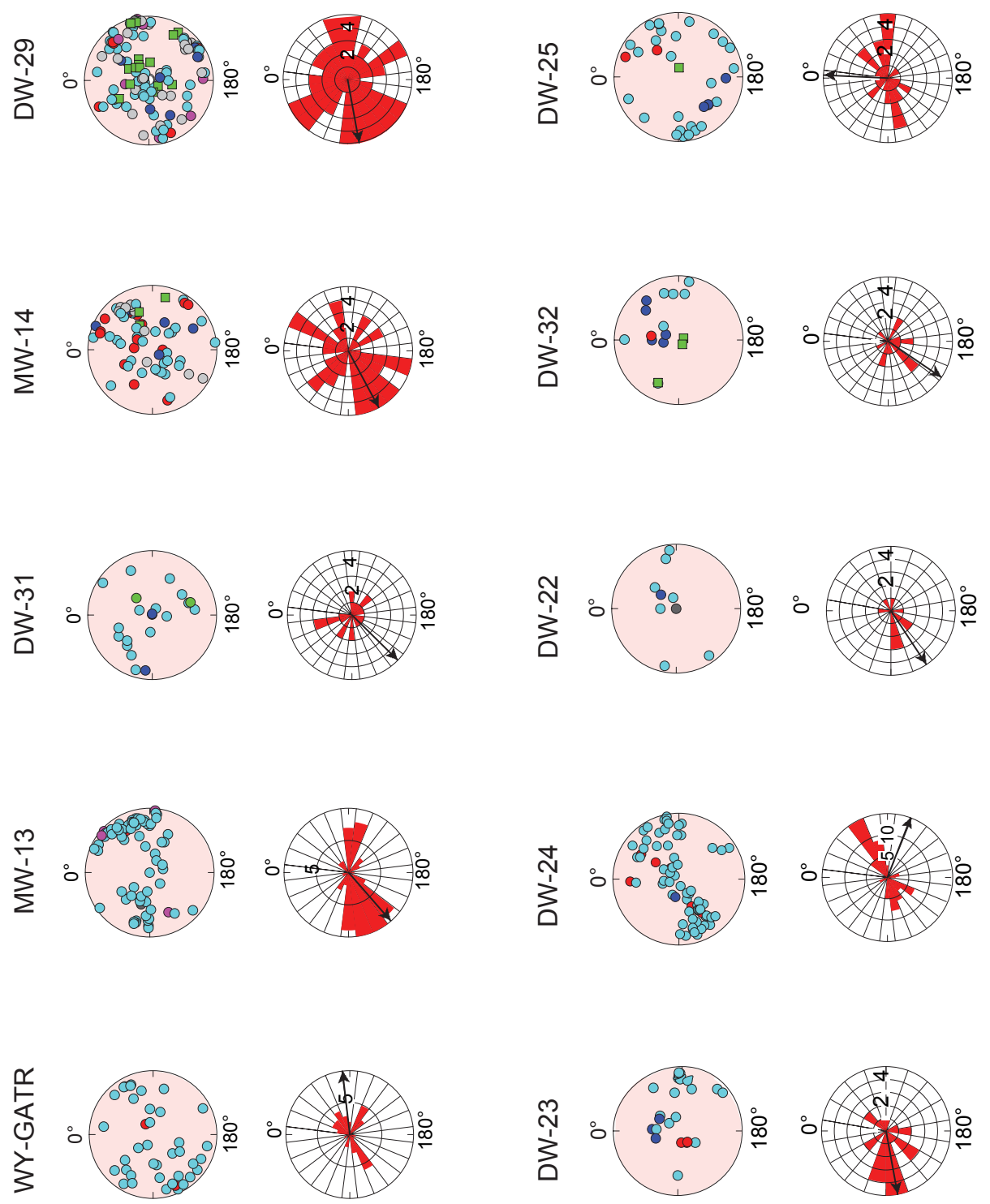
Table 21. Topographic setting and direction of ambient flow for boreholes near Machiasport, Maine, sorted by land-surface elevation.

[HPFM, heat-pulse flowmeter; LS, land surface; Top indicates a topographic hill; Slope indicates borehole is on a topographic slope; BS/V indicates break in slope or valley setting; Tidal indicates borehole was affected by tidal influences; Interference indicates an impact from a nearby borehole precluded measurements of ambient flow directions]

\begin{tabular}{|c|c|c|c|c|}
\hline Borehole & $\begin{array}{l}\text { Topo- } \\
\text { graphic } \\
\text { setting }\end{array}$ & $\begin{array}{l}\text { Direction of } \\
\text { ambient flow } \\
\text { identified } \\
\text { with HPFM }\end{array}$ & $\begin{array}{l}\text { Elevation } \\
\text { of land } \\
\text { surface } \\
\text { (feet) }\end{array}$ & $\begin{array}{c}\text { Depth of } \\
\text { borehole } \\
\text { from LS } \\
\text { (feet) }\end{array}$ \\
\hline \multicolumn{5}{|c|}{ Miller Mountain } \\
\hline WY-GATR & Top & Down & 251.81 & 415.4 \\
\hline MW-13 & Top & No flow & 250.42 & 204.5 \\
\hline DW-31 & Slope & Tidal & 206.60 & 242.8 \\
\hline DW-29 & Slope & Down & 97.26 & 114.5 \\
\hline MW-14 & Slope & Down & 74.47 & 95.0 \\
\hline DW-39 & Slope & Down & 136.07 & 218.8 \\
\hline DW-40 & $\mathrm{BS} / \mathrm{V}$ & No flow & 90.01 & 239.6 \\
\hline DW-34 & Slope & Up & 64.92 & 310.4 \\
\hline DW-32 & $\mathrm{BS} / \mathrm{V}$ & Down & 63.15 & 103.6 \\
\hline DW-24 & Slope & Interference & 58.45 & 189.5 \\
\hline DW-23 & $\mathrm{BS} / \mathrm{V}$ & Up & 52.59 & 179.2 \\
\hline DW-22 & $\mathrm{BS} / \mathrm{V}$ & Down & 57.10 & 109.7 \\
\hline DW-33 & $\mathrm{BS} / \mathrm{V}$ & No flow & 50.82 & 80.0 \\
\hline DW-25 & $\mathrm{BS} / \mathrm{V}$ & Up & 40.78 & 143.6 \\
\hline \multicolumn{5}{|c|}{ Howard Mountain, near the Air Force Radar Tracking Station } \\
\hline MW-10 & Top & No flow & 243.30 & 201.0 \\
\hline MW-15 & Top & No flow & 240.92 & 49.4 \\
\hline MW-16 & Top & No flow & 237.85 & 169.5 \\
\hline MW-9 & Slope & Down & 194.62 & 120.0 \\
\hline WY-15 & $\begin{array}{c}\text { Slope or } \\
\text { BS/V }\end{array}$ & $\mathrm{Up}$ & 187.22 & 292.6 \\
\hline WY-4 & $\mathrm{BS} / \mathrm{V}$ & Up & 170.77 & 179.3 \\
\hline MW-8 & Slope & Down & 161.74 & 55.0 \\
\hline MW-17 & Slope & Down & 72.64 & 248.7 \\
\hline WY-3C & $\mathrm{BS} / \mathrm{V}$ & Up & 68.34 & 351.6 \\
\hline DW-2 & Slope & Up & 63.71 & 219.7 \\
\hline MW-11 & $\mathrm{BS} / \mathrm{V}$ & $\mathrm{Up}$ & 55.93 & 200.0 \\
\hline WY-3 & $\mathrm{BS} / \mathrm{V}$ & No flow & 45.10 & 342.0 \\
\hline MW-12 & $\mathrm{BS} / \mathrm{V}$ & No flow & 43.23 & 243.0 \\
\hline \multicolumn{5}{|c|}{ Transmitter Site, on Howard Mountain } \\
\hline MW-5 & Top & No flow & 220.66 & 98.0 \\
\hline MW-6 & Top & Down & 220.45 & 120.0 \\
\hline DW-6 & Slope & Up & 173.20 & 121.7 \\
\hline DW-10 & Top & Down & 214.48 & 379.0 \\
\hline MW-4 & Top & Down & 214.22 & 98.0 \\
\hline MW-7 & Top & Down & 205.59 & 130.0 \\
\hline
\end{tabular}

DW-24 on Miller Mountain, was highly influenced by nearby pumping, and borehole DW-31, also on Miller Mountain, was verified to be affected by tidal fluctuations during flowmeter testing. These influences precluded the determination of an ambient flow and ambient heads in those boreholes. Some of the other ambient flows observed in the HPFM measurements might be related to tidal fluctuations, but this was not verified by the water-level data collected during HPFM logging. Water-level monitoring in borehole DW-2 near Howard Mountain indicated the influence of nearby pumping (James Vernon, ENSR International, written commun., September 2006) that was not observed, however, over the shortterm measurements during HPFM logging. These results support the observation that minor changes in water level or oscillations occurring over a long period of time cannot be measured with the HPFM if the change in head, when converted to a volumetric flow rate, is less than the resolution of the flowmeter.

In this investigation, transmissive fractures were identified with the HPFM or inferred from fluid logs. Fractures interpreted as transmissive were reported in tables and shown in projection, stereo, and tadpole plots. Open-hole transmissivity was estimated by analysis of open-hole water levels in response to hydraulic stress using either transient or steadystate analysis. The open-hole transmissivities ranged from 1.9 to $632 \mathrm{ft}^{2} / \mathrm{d}$. The transmissivity and head of individual transmissive fracture zones were estimated by numerically modeling the ambient and stressed HPFM profiles along with the hydraulically stressed water-level data (table 22). The discrete-interval transmissivities ranged from 0.16 to $330 \mathrm{ft}^{2} / \mathrm{d}$. The transmissivities of the individual transmissive zones were summed to determine a whole-well transmissivity. The total transmissivity values, which ranged from 2.4 to $511 \mathrm{ft}^{2} / \mathrm{d}$, were consistently lower than the estimates of open-hole transmissivity based only on water-level data. Twenty wells were used for this analysis: DW-2, DW-6, DW-22, DW-23, DW-24, DW-25, DW-31, DW-32, DW-33, DW-34, DW-39, DW-40, WY-15, WY-4, WY-GATR, MW-15, MW-16, MW-17, WY-3C, and DW-29. A correlation plot shows the two methods agree well, with a coefficient of determination of 0.9866 (fig. 23). The one-to-one line is shown as a dashed blue line. These results indicate that in most cases, the open-hole transmissivity can be used as a good starting estimate for modeling with FWRAP and possibly for expediting the process.

Results of the flowmeter models and HPFM logging can be used to identify places where there is ambient flow in the boreholes that might permit the spread of contamination. In addition, the identification of ambient-flow regimes and the location and proportion of transmissive zones is important for designing strategies to obtain representative samples or for understanding open-hole samples. A water sample collected from an open borehole represents a transmissivity-weighted combination of the individual fracture zones in the borehole, and open-hole water-quality sampling can yield ambiguous results (Shapiro, 2002). Consequently, if the results of open-hole samples show contamination, the results should be 
Table 22. Summary of transmissivity values derived from heat-pulse flowmeter data and hydraulic tests for boreholes near Machiasport, Maine.

[ft, feet; $\mathrm{ft}^{2} / \mathrm{d}$, feet squared per day; gal/min, gallons per minute; B\&R, Bradbury and Rothschild (1985); CJ, Cooper-Jacob straight-line test; CBP, Cooper and others (1967); --, no data]

\begin{tabular}{|c|c|c|c|c|c|c|c|c|c|c|}
\hline Well name & $\begin{array}{c}\text { Depth } \\
\text { (ft) }\end{array}$ & $\begin{array}{l}\text { Zone } \\
\text { transmis- } \\
\text { sivity } \\
\left(\mathrm{ft}^{2} / \mathrm{d}\right)\end{array}$ & $\begin{array}{c}\text { Zone } \\
\text { water } \\
\text { level } \\
\text { (ft) }\end{array}$ & $\begin{array}{l}\text { Elevation } \\
\text { of water } \\
\text { level } \\
\text { (ft) }\end{array}$ & $\begin{array}{l}\text { Percent } \\
\text { transmis- } \\
\text { sivity }\end{array}$ & $\begin{array}{c}\text { Depth to } \\
\text { ambient } \\
\text { water level } \\
\text { (ft) }\end{array}$ & $\begin{array}{l}\text { Total bore- } \\
\text { hole trans- } \\
\text { missivity } \\
\left(\mathrm{ft}^{2} / \mathrm{d}\right)\end{array}$ & $\begin{array}{l}\text { Root mean } \\
\text { square } \\
\text { error } \\
\text { (gal/min) }\end{array}$ & $\begin{array}{l}\text { Transmis- } \\
\text { sivity from } \\
\text { hydraulic } \\
\text { test } \\
\left(\mathrm{ft}^{2} / \mathrm{d}\right)\end{array}$ & Method \\
\hline \multicolumn{11}{|c|}{ Miller Mountain } \\
\hline DW-22 & 22.5 & 11.66 & 5.08 & 54.92 & 63 & 6.7 & 18.5 & 0.017 & 22.7 & $\mathrm{~B} \& \mathrm{R}$ \\
\hline \multirow[t]{3}{*}{ DW-23 } & 94.50 & 69.00 & 6.88 & 53.12 & 45 & 7.3 & 153.0 & 0.830 & 237 & $\mathrm{~B} \& \mathrm{R}$ \\
\hline & 150.00 & 24.00 & 6.98 & 53.02 & 16 & & & & & \\
\hline & 175.00 & 60.00 & -4.52 & 64.52 & 39 & & & & & \\
\hline DW-24 & 182.0 & 306.0 & 9.80 & 50.20 & 100 & 9.8 & 306.0 & 0.006 & 405 & $\mathrm{~B} \& \mathrm{R}$ \\
\hline \multirow[t]{4}{*}{ DW-29 } & 20.0 & 2.75 & 7.04 & 92.82 & 56 & 10.72 & 4.9 & 0.015 & 4.9 & $\mathrm{~B} \& \mathrm{R}$ \\
\hline & 40.8 & 0.60 & -3.96 & 103.82 & 12 & & & & & \\
\hline & 95.1 & 1.05 & 17.04 & 82.82 & 21 & & & & & \\
\hline & 108.0 & 0.55 & 33.04 & 66.82 & 0 & & & & & \\
\hline \multirow[t]{2}{*}{ DW-31 } & 146.0 & 0.8 & 134.45 & 73.55 & 8 & 134.45 & 10.2 & 0.006 & 1.8 & $\mathrm{CJ}$ \\
\hline & 235.0 & 9.4 & 134.45 & 73.55 & 92 & & & & & \\
\hline \multirow[t]{2}{*}{ DW-32 } & 26.0 & 82.5 & 16.95 & 45.05 & 16 & 17.04 & 511.5 & 0.020 & 632 & B\&R \\
\hline & 71.0 & 99.0 & 17.04 & 44.96 & 19 & & & & & \\
\hline \multirow{2}{*}{ DW-34 } & 145.0 & 1.50 & 7.65 & 59.25 & 19 & & & & & \\
\hline & 210.0 & 0.48 & 7.65 & 59.25 & 6 & & & & & \\
\hline \multirow[t]{3}{*}{ DW-39 } & 31.0 & 1.6 & -3.81 & 133.81 & 9 & 11.67 & 18.6 & 0.012 & 15.0 & B\&R \\
\hline & 75.0 & 13.0 & 12.19 & 117.81 & 70 & & & & & \\
\hline & 90.0 & 4.0 & 16.19 & 113.81 & 21 & & & & & \\
\hline \multirow[t]{3}{*}{ DW-40 } & 34 & 12.0 & 0.56 & 92.00 & 57 & 0.56 & 21.0 & 0.009 & 29.3 & B\&R \\
\hline & 112 & 3.0 & 0.56 & 92.00 & 14 & & & & & \\
\hline & 215 & 6.0 & 0.56 & 92.00 & 29 & & & & & \\
\hline \multirow[t]{2}{*}{ WY-GATR } & 186.0 & 12.0 & 150.51 & 121.49 & 11 & 153 & 108.0 & 0.007 & 96.0 & B\&R \\
\hline & 412.0 & 96.0 & 153.31 & 118.69 & 89 & & & & & \\
\hline
\end{tabular}


Table 22. Summary of transmissivity values derived from heat-pulse flowmeter data and hydraulic tests for boreholes near Machiasport, Maine.-Continued

[ft, feet; $\mathrm{ft}^{2} / \mathrm{d}$, feet squared per day; gal/min, gallons per minute; B\&R, Bradbury and Rothschild (1985); CJ, Cooper-Jacob straight-line test; CBP, Cooper and others (1967); --, no data]

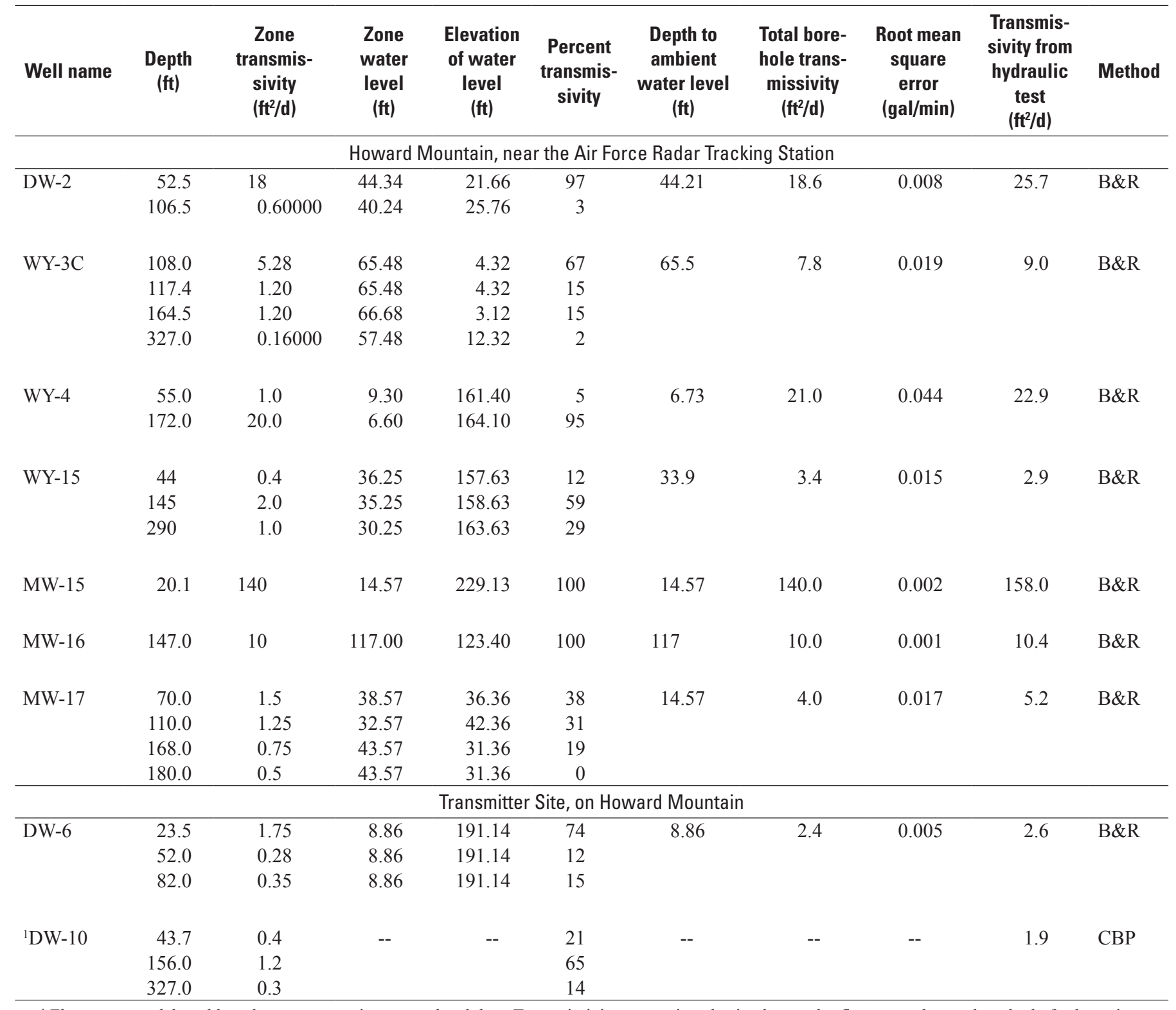

\footnotetext{
${ }^{1}$ Flowmeter model could not be run on transient water-level data. Transmissivity proportioned using heat-pulse flowmeter data and method of subtraction.
} 


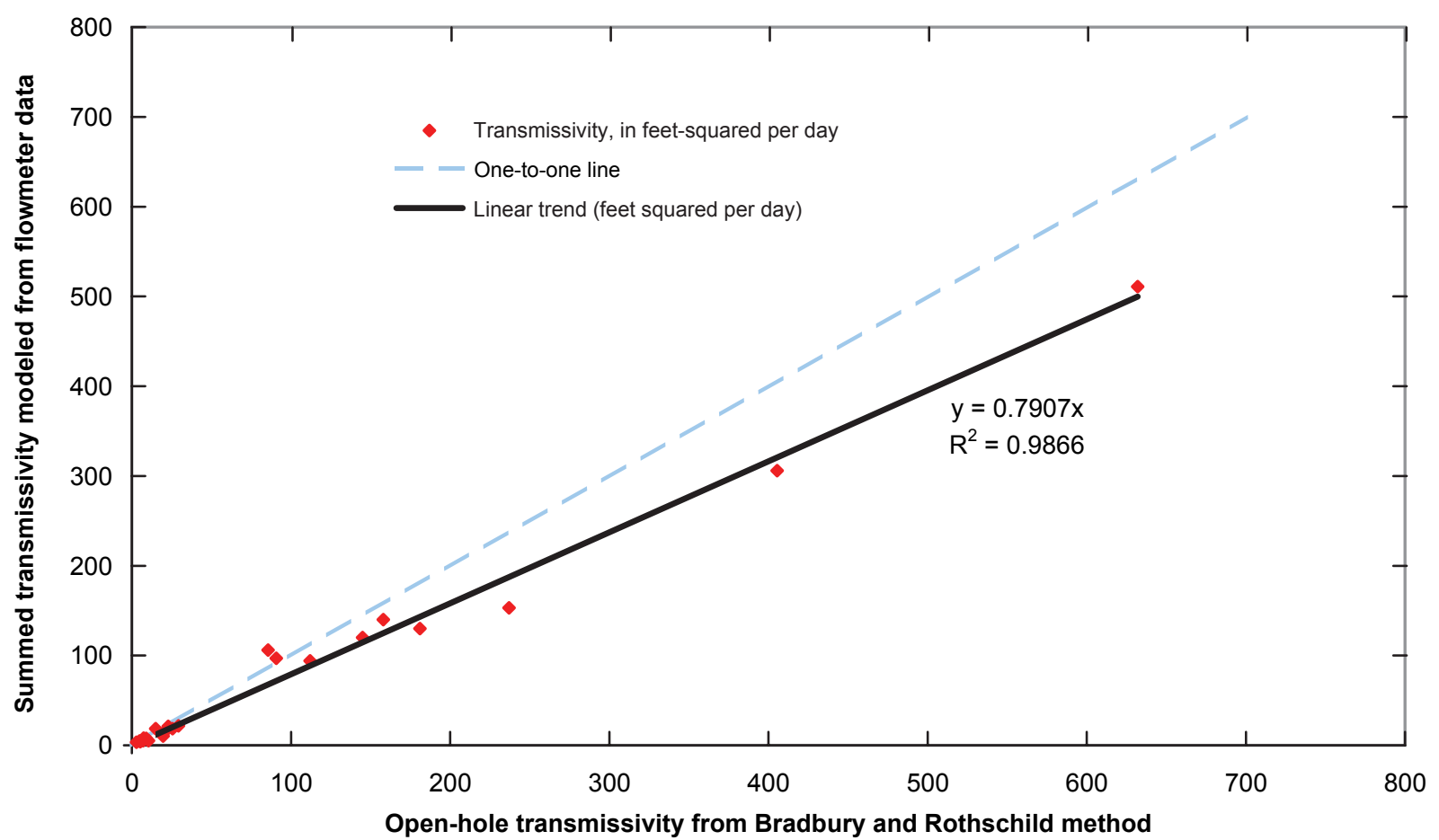

Figure 23. Comparison of open-hole transmissivity determined from Bradbury and Rothschild (1985) method and summed transmissivity determined from modeled heat-pulse flowmeter profiles and water levels. The black line indicates the best fit regression line, and the blue dashed line indicates a line showing one-to-one correlation.

considered within the measured flow regime, to help determine the sources of water in the sample and potentially identify where additional discrete-interval sampling is needed to determine the depth-dependent distribution of contamination.

The transmissivity values determined by hydraulic testing and flowmeter analysis also were compared to the results of packer tests collected at the site. None of the boreholes tested with the straddle-packers (boreholes MW-7, MW-10, MW-11, and MW-12), however, had sufficient water-level data for modeling to be used. In general, the transmissivities obtained for isolated depth intervals in these boreholes ranged from less than 0.07 to $5.3 \mathrm{ft}^{2} / \mathrm{d}$ (Weston Solutions, 2005). Packer testing has a much higher resolution for determining transmissivity than flowmeter logging. Depending on the equipment used, packer-test methods can measure transmissivity values as low as $10^{-8} \mathrm{ft}^{2} / \mathrm{s}$ or about $10^{-4} \mathrm{ft}^{2} / \mathrm{d}$ (Shapiro, 2001). The flowmeter can be used to identify zones that are within 1.5 to 2 orders of magnitude of the most transmissive fractures in the borehole, and the HPFM can measure flows as small as $0.01 \pm$ $0.005 \mathrm{gal} / \mathrm{min}$, which corresponds to a transmissivity of about $10^{-5} \mathrm{ft}^{2} / \mathrm{s}$ or $1 \mathrm{ft}^{2} / \mathrm{d}$. Although the flowmeter is not as sensitive as the packer-test method, it is relatively easy and quick compared to packer testing.

In another fractured-rock investigation, where transmissivity values were estimated using similar HPFM methods and analyses, the transmissivity estimates derived with flowmeter methods were most commonly greater than the packer-test methods (Johnson and others, 2005). In that investigation, the log transmissivity values determined with the HPFM were regressed against log transmissivity values determined by conventional straddle-packer testing and yielded a good coefficient of determination, indicating the HPFM is an effective tool for screening boreholes and for identifying the most transmissive fractures. Moreover, these results indicate that caution should be used when comparing the transmissivity results derived from different methods. The HPFM-derived 
estimates of transmissivity, although overestimated relative to packer-test estimates, were still effective for relative comparisons with other flowmeter-derived values.

A comparison of the HPFM-derived transmissivity values (table 22) shows a wide range of values. The four highest transmissivity values are associated with boreholes on Miller Mountain. One factor these four boreholes (DW-32, DW-24, DW-23, and DW-25) have in common is their topographic setting; they are either along the slope or are in a discharge location (table 21). A regression of open-hole transmissivity and elevation of land surface gives highly variable results with a heteroskedastic distribution. Moreover, the regression shows that low transmissivity values occurred over all elevations, yielding a poor linear correlation.

\section{Summary and Conclusions}

The U.S. Geological Survey (USGS), in cooperation with the U.S. Army Corps of Engineers (USACE), conducted two phases of borehole geophysical data collection at sites on and near Miller Mountain and Howard Mountain at a Formerly Used Defense Site in Machiasport, Maine. The first phase of data collection was in November 2004 and included 11 boreholes mostly used for domestic water supply. The second phase, conducted in March and April 2005, included seven boreholes that were both observation wells and domesticsupply wells. In addition to the geophysical logs collected by USGS, the USACE had geophysical logs collected by contractors in 12 boreholes in 2003 and 7 boreholes in 2006. To improve spatial coverage and the total statistical population of fractures, all available geophysical and hydraulic data from the 37 boreholes were interpreted and compared for an integrated analysis of the three environmental restoration sites. The data for these additional boreholes were not published in this report, but the methods and all interpretative results were included.

Characterization of individual boreholes included determination of geologic contacts, lithology, fractures, and hydraulically active fractures. All oriented data were corrected for magnetic declination and for deviation of the borehole. The results were tabulated and shown graphically for each borehole. In addition, the results were summarized for all 37 boreholes, and for each of the three restorations sites within the study area.

Rock types: Rock types were effectively determined with combined use of gamma, reflectivity, optical televiewer (OTV), and acoustic televiewer (ATV) logging. The interpretations of rock type were consistent with observations and mineralogical and textural descriptions of rock cores, observations on outcrop samples, and published maps. For this investigation, the mean and median acoustic amplitude values were computed for each depth increment in the ATV reflectivity log, producing logs that can be compared directly with other logs. Correlations between log parameters were explored using cross-plots. Cross-plots of gamma and electromagnetic induction (EMI), resistivity, and singlepoint resistance values do not show a clear correspondence between rock type and electric properties, whereas crossplots of gamma and mean ATV reflectivity were effective in identifying changes in rock types.

In general, the rock types identified in the boreholes were consistent with the local mapping. The summit of Miller Mountain was verified to be gabbro or diabase. Along the flanks of Miller Mountain and at depth on Miller Mountain, quartz monzonite was observed. Along the eastern side of Miller Mountain and just onshore, there is a large block of metasedimentary rocks, thought to be part of the Eastport Formation, which crops out along the flank of the mountain and is bounded above and below by gabbro or diabase. To the north of Miller Mountain, gabbro was observed in the near surface overlying the metasediments. On Howard Mountain, at the Air Force Radar Tracking Station site and at the Transmitter Site, the rock types are dominated by rhyolite of varying composition and (or) texture. Mafic dikes that generally strike to the southeast and dip towards the southwest have intruded all rock units, especially the rhyolites on Howard Mountain.

Fracturing: Borehole-imaging methods were used to identify and map the location and orientation of fractures in the boreholes. The interpreted image logs are shown in tabular and graphic forms. Projection plots were used to overlay structural interpretations directly on the borehole images. Stereoplots of poles to planar features, fractures, and rock contacts were used to assess the clustering of poles and to determine possible sets of fractures. Tadpole, projection, and fractureintensity plots were used to assess fracturing with depth. Rose diagrams were used to assess dip direction. Results were summarized by borehole, site-wide, and for the three environmental restoration sites.

A stereoplot of all fractures indicates numerous fractures, a high proportion of steeply dipping fractures, and considerable variation in fracture orientation. Low-dip-angle fractures associated with unloading and exfoliation also are present, especially at depths of less than $100 \mathrm{ft}$ below the top of casing. These low-angle fractures help to connect the steeply dipping fractures, resulting in a highly connected fracture network. The high variability in fracture orientation increases the probability of fracture intersections and junctions, thereby also increasing the connectivity of the fracture network. The fracture patterns for Miller Mountain appeared to be more uniform; whereas for Howard Mountain, the fracture pattern exhibited more variation.

When considering all the boreholes in the study area or all the boreholes in each of the three restoration sites, the intensity of fracturing appears to decline dramatically with depth. Because all the boreholes were not drilled to the same depth, there is a clear sampling bias that suggests there are more fractures near the surface and less with depth. But, when the deepest boreholes are analyzed separately for fracture density, the intensity of fracturing in each 10 -ft interval does not decline substantially with depth. This analysis includes 
all the fractures - transmissive, open-looking, and minor or tight-looking fractures. Theoretically, fracture occurrence and fracture aperture, which are correlated to local stress, regional stress, and confining pressure, decrease with depth (Trainer, 1987). It is possible the fractures observed in these boreholes become progressively tighter or closed with depth, but it is difficult to verify with the methods used in this investigation. The fact that there are more sealed fractures at depth (observed in OTV logs in some of the boreholes) may indicate less opening of the sealed fractures, less water moving through the rock, and less weathering of the fracture-infilling minerals.

The fracture orientations at each of the restoration sites remained fairly constant with depth. Similar results have been reported at other crystalline rock sites. Raven and Gale (1977) observed uniform orientations in joint sets in the near surface down to hundreds of feet in depth. Although the fracture orientation remained fairly constant with depth, the fracture patterns for the three sites showed minor variations, indicating a lateral change in the fracture orientation with location. The fractures on Miller Mountain primarily strike to the northwest and southeast and, to a lesser amount, strike to the northeast. The fractures on or near the summit of Howard Mountain trend in two directions, predominantly east-west and northeast-southwest. On the Transmitter Site, further to the southwest and further away from the fault, the fractures strike predominantly northeast-southwest and northwest-southeast. The fracture pattern on Howard Mountain, although similar to the orientation of fractures on Miller Mountain, is more variable than the fracture patterns for Miller Mountain and the Transmitter Site.

\section{Evaluation of geophysical methods applied at the}

site: Characterizing and remediating fractured-rock aquifers remains a difficult challenge. However, advances in geophysical equipment and interpretive methods have helped improve the characterization of the subsurface and identification of heterogeneities that affect flow in the aquifer.

The combined use of borehole geophysical logs, limited core sampling, and outcrop mapping was an effective approach for mapping the rock units at depth at this site. Although mechanical breakage and plucking of some fractures in boreholes precludes an accurate measurement of fracture aperture, borehole imaging logs provided information on fracture and lithology orientations not easily determined in core samples because of core loss, mechanical breakage, rotation, and lack of oriented core samples. Core samples from selected boreholes, however, were valuable for identifying rock types in hand samples for direct comparison with borehole logs. For this investigation, a few boreholes were cored, providing direct observation of the rocks and an interpretation of rock types that were essential for verifying geophysical tool response to various rock types.

These analyses indicate acoustic reflectivity and gamma logs can be used to aid in the interpretation of rock type in the boreholes. The use of cross-plots and side-by-side comparison of logs between boreholes demonstrates the importance of having calibrated tools to produce logs that can be compared directly. Where multiple gamma logs were collected in the same borehole with different tools, the counts per second were normalized to a single tool response. Because some logs, such as ATV reflectivity, do not have a typical calibration, it would be helpful to establish a "calibration" well at the site that would be logged by all tools each time they are used. The ideal borehole for site calibration would contain multiple rock types to show a variety of tool responses and would be considered a background well that is not subject to change in water level or water chemistry over time. Logs collected by different tools or the same tool at different times could be adjusted for variation in tool response or for drift. Such a site calibration borehole, which is not subject to change, would provide a useful standard for each geophysical logging effort, especially if remediation efforts are to be initiated at the site.

Fractures were identified with caliper, ATV, and OTV imaging tools, and to a lesser extent with the normal resistivity tool. The OTV and ATV tools generally identified all the major fractures and most of the transmissive fractures. Tight fractures, however, were better identified in the ATV logs, and sealed fractures and lithology features were identified more clearly in the OTV logs. The orientations of fractures determined with the OTV generally agreed with orientations determined with the ATV.

Normal resistivity values at this site were very high and beyond the functional range of the tool. The calibration checks indicated the tool was working properly within the operable range. Hence, the resistivity values that were collected could only be used in a relative sense to identify zones with higher or lower resistivity, which either corresponded to a change in rock type or the presence of fractures.

EMI, which measures electrical conductivity of the formation and fluids in the formation, was not effective for identifying changes in rock type in this environment of highly resistive (minimally conductive) rock units. However, EMI logs were helpful for identifying the bottom of steel casing.

The temperature, fluid conductivity, and water-quality logs were effective in determining hydraulically active fractures and potential ambient flow in the borehole. Ambient flow occurs whenever two fractures with different heads intersect the borehole. The water flows through the borehole from the fracture with higher head to the fracture with the lower head. Because flowmeters can only measure flow rates above their detection limit, sometimes signs of vertical flow were only identified in the fluid conductivity and temperature logs. However, the direction and rate of flow cannot be determined with the fluid logs alone. In the field, temperature, fluid conductivity, and water-quality logs were used to determine measurement locations for the heat-pulse flowmeter (HPFM).

HPFM logs were used to identify transmissive intervals of the borehole and to assess the relative transmissivity of the zones intersecting a borehole. Although HPFM methods are effective for identifying the most transmissive zones in the borehole, it is important to realize that other methods, including discrete-zone packer testing, discrete-zone monitoring with hydraulic testing, and hydrophysical logging, can identify 
transmissive zones below the detection limit of the HPFM. Packer-testing methods can measure transmissivity over 6 orders of magnitude, whereas flowmeter methods can measure 1.5 to 2 orders of magnitude. Thus, the HPFM is an effective screening tool for determining the most transmissive zones. Other hydraulic tests would be required to determine the distribution of transmissivity that is less than the detection limit of the HPFM, about $10^{-5} \mathrm{ft}^{2} / \mathrm{s}$ or $1 \mathrm{ft}^{2} / \mathrm{d}$.

Modeling the head and transmissivity of discrete intervals to match the observed water level and measured ambient and pumped flowmeter profiles provides quantitative estimates of hydraulic parameters and defines the variability of these parameters along the borehole. Vertical flow within the borehole indicates the potential for cross-contamination, dilution, or misleading samples. Determining the flow regime within a borehole is critically important for understanding what a water-quality sample collected from that borehole represents. Hence, the flowmeter data and hydraulic-modeling results are important for planning sampling, monitoring, and remediation strategies.

Cross-hole flowmeter logging, which was not used in this investigation, may be helpful in future efforts. The method involves collecting transient flowmeter profiles in one borehole while hydraulically stressing another borehole (Paillet, 1998). The cross-hole flowmeter results produce information about aquifer properties, identify interconnectivity, and provide information valuable for understanding well-field hydraulics, designing well completions, and understanding water-chemistry results. This method would be appropriate if any new boreholes were installed adjacent to existing or other new boreholes.

Conceptual site model for groundwater flow: Details of fracture location, orientation, and characterization are important for site description. But to understand these fracture characteristics in the context of the site conceptual model requires a brief discussion of the factors controlling flow and transport in fractured bedrock. The mechanisms for fluid and solute transport in fractured media are advection, dispersion, and diffusion. Advection occurs primarily through the secondary porosity, which is comprised of a network of fractures. The more interconnected and open the fractures, the more water that can be transported through the fracture network in the aquifer. Fractures that are oriented at multiple angles are more likely to cross or abut one another and, therefore, increase the potential for interconnectivity. Also, the longer the fracture length, the greater the likelihood a fracture will intersect other fractures. With a highly interconnected fracture network, water and solutes can flow more readily through the aquifer than in a sparsely or poorly connected fracture network. Moreover, when there is a highly connected fracture network and when the orientation of the fracture set varies in orientation from the hydraulic gradient, then there are more intersections in the field of transport and an increased opportunity for solutes to mix (Long and others, 1982; Endo and others, 1984; Berkowitz and others, 1988). Collectively, these fracture characteristics indicate a highly connected fracture network is more likely to behave like an equivalent porous media and allow fluid flow to be described by continuum methods. Although these factors suggest flow through the highly connected fracture systems can be described by continuum methods, this approach is likely to be oversimplified and insufficient for describing mass transport because effective porosity in fractured rocks is heterogeneous and directionally dependent (Endo and others, 1984). Hence, the discussion of the conceptual site model is limited to groundwater flow.

The borehole geophysical data from this site indicate extensive fracturing, with numerous and variable fracture orientations in the near surface and over the depths intersected by the boreholes. The conceptual model is that the fractures form a three-dimensional network of blocks and fractures that act at some scale as a continuum. In general, water flows from the recharge areas towards discharge areas, and regional groundwater flow is inferred to follow land-surface topography. Analysis of hydraulic testing and HPFM data indicates the vertical flow within the boreholes generally supports the concept of downward movement in recharge locations and upward flow in discharge locations. Locally, the direction of groundwater flow is affected by small-scale topographic features, direction of fractures relative to the hydraulic gradient, effects of pumping, and, in some cases, tidal influences. The actual flowpaths that water and (or) contaminants follow can differ from the inferred regional flow. To expand the site conceptual groundwater flow model to describe contaminant flow, the data in this report would have to be coupled with geologic, hydrologic, and geochemical data to refine the site conceptual flow model and determine contaminant pathways (Shapiro and others, 1999).

The fractures on Miller Mountain predominantly strike northwest and southeast and, to a much lesser extent, northeast. The dominant fracture pattern on Miller Mountain is parallel to local faulting and parallel to the incised valley between Miller and Bucks Mountains. The contaminant distribution, which has been identified southeast of the source area at the summit of Miller Mountain, also is parallel to this dominant orientation of fractures for Miller Mountain.

The fractures on or near the summit of Howard Mountain predominantly trend in two directions: east-west and northeast-southwest. The contaminant distribution for the AFRTS site on Howard Mountain is thought to be towards the northeast, which is in the direction of that predominant fracture set, along the pathway of the greatest change in topographic relief, and towards actively pumped boreholes.

Further to the southwest and further from the fault, the fractures at the Transmitter Site strike predominantly northeast-southwest and northwest-southeast. The observed contaminant distribution from this site is to the northeast and southwest, parallel to the strike of a predominant fracture set.

For each of these sites, there is a large proportion of steeply dipping fractures. These fractures provide recharge to the bedrock and increase connectivity with sub-horizontal fractures. The analysis of fracture orientation with depth 
indicates that the frequency of sub-horizontal sheeting fractures declines with depth, but the fracture orientation of the moderately to steeply dipping fractures remains fairly constant over the depths of the boreholes.

The data and interpretation presented in this report should provide information useful to the site investigators as they refine the conceptual site model. Collectively, the results and the conceptual site model are important for evaluating remediation options and planning or implementing design of a well field and borehole completions that will be adequate for monitoring flow, remediation efforts, groundwater levels, and (or) water quality.

\section{Acknowledgments}

This project was supported by the U.S. Army Corps of Engineers (USACE), New England District, under MIPRs W13G8642965424 and W13G8653296728. We also acknowledge support from the USGS Toxic Substances Hydrology Program. The authors are especially grateful to the homeowners who permitted access to their wells and allowed us to work on their properties as part of this investigation. We appreciate the assistance of Jeff Huntley of J.L. Huntley, Inc., and his staff for facilitating this work by providing logistical assistance and access to domestic wells. We especially thank Mark Blackey of Geophysical Applications, Inc., and Robert Garfield of Hager-Richter Geoscience, Inc., for providing data they collected at the site and for their willingness to share data and information for the site-wide summary of geophysical data. The authors would like to acknowledge the support, assistance, and guidance of Drew Clemens and Robert Leitch of the USACE. Drew Clemens, along with James Vernon of ENSR International, was extremely helpful in describing the lithology and structural geology of the area. Additionally, the authors appreciate the technical assistance of Frederick DayLewis, Frederick L. Paillet, Alton Anderson, and Christopher Kochiss of the USGS. Finally, the authors are grateful to George Harlow and Kristen McSwain for technical reviews of this work and to Sandra Cooper of the USGS for her final review of the manuscript.

\section{References}

ABB Environmental Services, Inc., 1995, Final fracture trace analysis report, Bucks Harbor Former Air Force Radar Tracking Station, Machiasport, Maine: Portland, Maine, Environmental Services, Inc.

ABB Environmental Services, Inc., 1997, Geophysical study for alternative water supply, Bucks Harbor Former Air Force Radar Tracking Station, Machiasport, Maine: Portland, Maine, Environmental Services, Inc., 76 p.
Berkowitz, B., Bear, J., and Braester, C., 1988, Continuum models for contaminant transport in fractured porous formations: Water Resources Research, v. 24, no. 8, p. 1225-1236.

Borns, H.W. Jr., 1974, Surficial geology of the Machias quadrangle, Maine: Maine Geological Survey, Department of Conservation, Open File No. 74-4.

Bradbury, K.R., and Rothschild, E.R., 1985, A computerized technique for estimating hydraulic conductivity of aquifers from specific capacity data: Ground Water, v. 23, no. 2, p. $240-245$.

Bradley, P.M., 2003, History and ecology of choloroethene biodegradation-A review: Bioremediation Journal, v. 7, no. 2, p. 81-109.

Chapelle, F.H., 1993, Ground-water microbiology and geochemistry: New York, N.Y., John Wiley and Sons, Inc., $424 \mathrm{p}$.

Cooper, H.H., Bredehoeft, J.D., and Papadopulos, I.S., 1967, Response of a finite-diameter well to an instantaneous charge of water: Water Resources Research, v. 3, no. 1, p. 263-269.

Endo, H.K., Long, J.C.S., Wilson, C.R., and Witherspoon, P.A., 1984, A model for investigating mechanical transport in fracture networks: Water Resources Research, v. 20, no. 10, p. 1390-1400.

ENSR, 2006, Feasibility study, Bucks Harbor Former Air Force Radar Tracking Station, Machiasport Maine (preliminary draft), prepared for the U.S. Army Corps of Engineers New England District: Westford, Mass., ENSR AECOM, 2 Technology Park Drive, Westford, Mass.

Freeze, R.A., and Cherry, J.A., 1979, Ground water: Englewood Cliffs, N.J., Prentice Hall, Inc., 603 p.

Gates, Olcott, 1981, Bedrock geology of the Machias, Columbia Falls, and Great Wass Island quadrangles: Maine Geological Survey, Department of Conservation, Open File no. 81-11.

Gates, Olcott, and Moench, R.H., 1981, Bimodal Silurian and Lower Devonian volcanic rock assemblages in the MachiasEastport area, Maine: U.S. Geological Survey Professional Paper 1184, 32 p., map at scale 1:62,500.

Hem, J.D., 1985, Study and interpretation of the chemical characteristics of natural water (3d ed.): U.S. Geological Survey Water-Supply Paper 2254, 263 p.

Hess, A.E., and Paillet, F.L., 1990, Applications of the thermal-pulse flowmeter in the hydraulic characterization of fractured rocks: West Conshohocken, Pa., American Society for Testing and Materials, Standard Technical Publications 1101, p. 99-112. 
Idronaut, Srl, 2006, Ocean Seven 303 CTD multi-parameter probe operator's manual-v 7.1_05: Brugherio, Italy, Idronaut, 58 p.

Johnson, C.D., and Joesten, P.K., 2005, Analysis of boreholeradar reflection data from Machiasport, Maine, December 2003: U.S. Geological Survey Scientific Investigations Report 2005-5087, 44 p.

Johnson, C.D., Kochiss, C.K., and Dawson, C.B., 2005, Use of discrete-zone monitoring systems for hydraulic characterization of a fractured-rock aquifer at the University of Connecticut landfill, Storrs, Connecticut, 1999 to 2002: U.S. Geological Survey Water-Resources Investigations Report 03-4338, 105 p.

Keys, W.S., 1990, Borehole geophysics applied to groundwater investigations: U.S. Geological Survey Techniques of Water-Resources Investigations, book 2, chap. E2, 150 p.

Leitch, R., and Clemens, D., 2006, Efficient approach determines nature, extents of TCE in a bedrock aquifer: The Corps Environment, January, v. 17, no. 1, p. 8-9.

Lohman, S.W., 1979, Ground-water hydraulics: U.S. Geological Survey Professional Paper 708, 70 p.

Long, J.C.S., Remer, J.S., Wilson, C.R., and Witherspoon, P.A., 1982, Porous media equivalents for networks of discontinuous fractures: Water Resources Research, v. 18, no. 3, p. 645-658.

Moore, R.B., 2004, Quality of water in the fractured bedrock aquifer of New Hampshire: U.S. Geological Survey Scientific Investigations Report 2004-5093, 30 p.

Paillet, F.L., 1995, Using borehole flowmeter logging to optimize hydraulic test procedures in heterogeneous fractured aquifers: Hydrogeology Journal, v. 3, no. 3, p. 4-20.

Paillet, F.L., 1998, Flow modeling and permeability estimation using borehole flow logs in heterogeneous fractured formations: Water Resources Research, v. 34, no. 5, p. 997-1010.

Paillet, F.L., 2000, A field technique for estimating aquifer parameters using flow log data: Ground Water, v. 38, no. 4, p. 510-521.

Paillet, F.L., 2004, Borehole flowmeter applications in irregular and large-diameter boreholes: Journal of Applied Geophysics, v. 55, no. 1-2, p. 4-39.

Pedler, W.H., Head, C.L., and Williams, L.L., 1992, Hydrophysical logging - A new wellbore technology for hydrogeologic and contaminant characterization of aquifers, in Sixth National Outdoor Action Conference, Proceedings: Westerville, Ohio, National Ground Water Association, p. 701-715.
Raven, K.G., and Gale, J.E., 1977, Project 740057, subsurface containment of solid radioactive waste-A study of the surface and subsurface structural and groundwater conditions at selected underground mines and excavation: Ottawa, Geological Survey of Canada, EMR-GSC-RW Internal Report 1-77, 105 p.

Robinson, K.W., Flanagan, S.M., Ayotte, J.D., Campo, K.W., Chalmers, Ann, Coles, J.F., and Cuffney, T.F., 2004, Water quality in the New England Coastal Basins, Maine, New Hampshire, Massachusetts, and Rhode Island, 1999-2001: U.S. Geological Survey Circular 1226, 38 p., available at http://pubs.water.usgs.gov/circ1226

Shapiro, A.M., 2001, Characterizing ground-water chemistry and hydraulic properties of fractured rock aquifers using the multifunction Bedrock-Aquifer Transportable Testing Tool (BAT3): U.S. Geological Survey Fact Sheet FS-075-01, $4 \mathrm{p}$.

Shapiro, A.M., 2002, Cautions and suggestions for geochemical sampling in fractured rock: Ground Water Monitoring and Remediation, v. 22, no. 3, p. 151-164.

Shapiro, A.M., Hsieh, P.A., and Haeni, F.P., 1999, Integrating multidisciplinary investigations in the characterization of fractured rock, in Morganwalp, D.W., and Buxton, H.T., eds., U.S. Geological Survey Toxic Substances Hydrology Program-Proceedings of the Technical Meeting, Charleston, South Carolina, March 8-12, 1999: U.S. Geological Survey Water-Resources Investigations Report 99-4018C, v. 3, p. 669-680.

Terzaghi, R.D., 1965, Sources of error in joint surveys: Geotechnique, v. 15, p. 287-304.

The Johnson Company, 2006, Field report for spring 2006 activities, Bucks Harbor Former Air Force Radar Tracking Station, Machiasport, Maine, volumes 1 and 2, prepared for the U.S. Army Corps of Engineers New England District under contract W912WJ-05-D0006 Task Order 1: Montpelier, Vt., The Johnson Company.

Thompson, M.D., Miller, S.F., and Davies, W.E., 2005, Geophysical investigation of the Formerly Used Defense Site-Machiasport, Maine: Argonne, Ill., Energy Systems Division Argonne National Laboratory, Sponsor Report, $141 \mathrm{p}$.

Toth, J., 1963, A theoretical analysis of groundwater flow in small drainage basins: Journal of Geophysical Research, v. 68 , p. $4795-4812$.

Trainer, F.W., 1987, Hydrogeology of the plutonic and metamophic rocks, in Back, W., Rosenshein, J.S., and Seaber, P.R., eds., Hydrogeology: Boulder, Colo., Geological Society of America, The Geology of North America, v. O-2, p. 367-380. 
Tsang, C.F., Hufschmied, P., and Hale, F.V., 1990, Determination of fracture inflow parameters with a borehole fluid conductivity method: Water Resources Research, v. 26, no. 4 , p. 561-578.

U.S. Army Corps of Engineers, 2004, Howard Mountain site plan, prepared for the Formerly Used Defense Site Program: Concord, Mass., U.S. Army Corps of Engineers New England District, $1 \mathrm{p}$.

Weston Solutions, 2005, Remedial investigation report former Bucks Harbor Air Force Radar Tracking Station, Machiasport, Maine: Manchester, N.H., Weston Solutions, $617 \mathrm{p}$.

White, E.A., Thompson, M.D., Johnson, C.D., Abraham, J.D., Miller, S.F., and Lane, J.W. Jr., 2005, Surfacegeophysical investigation of a Formerly Used Defense Site, Machiasport, Maine_February 2003: U.S. Geological Survey Scientific Investigations Report 2004-5099, 48 p.

Williams, J.H., and Conger, R.W., 1990, Preliminary delineation of contaminated water-bearing fractures intersected by open-hole bedrock wells: Ground Water Monitoring Review, v. 10, no. 4, p. 118-126.

Williams, J.H., and Johnson, C.D., 2004, Acoustic and optical borehole-wall imaging for fractured-rock aquifer studies: Journal of Applied Geophysics, v. 55, no. 1-2, p. 151-159.

Williams, J.H., Lapham, W.W., and Barringer, T.H., 1993, Application of electromagnetic logging to contamination investigations in glacial sand and gravel aquifers: Ground Water Monitoring and Remediation Review, v. 13, no. 3, p. 129-138.

Winter, T.C., Harvey, J.W., Franke, O.L., and Alley, W.M., 1998, Ground water and surface water-A single resource: U.S. Geological Survey Circular 1139, 79 p. 


\section{Appendixes}

Explanation information for appendixes

Appendix 1. Borehole geophysical logs from boreholes on or near Miller Mountain, near Machiasport, Maine

Appendix 2. Borehole geophysical logs from boreholes near the Air Force Radar Tracking Station on Howard Mountain, near Machiasport, Maine

Appendix 3. Borehole geophysical logs from boreholes near the Transmitter Site on Howard Mountain, near Machiasport, Maine

Appendix 4. Plots and interpretations of borehole geophysical logs collected by Geophysical Applications, Inc., for boreholes near Machiasport, Maine

Appendix 5. Plots and interpretations of borehole geophysical logs collected by Hager-Richter Geoscience, Inc., for boreholes near Machiasport, Maine

Appendix 6. Summary of structure interpreted from geophysical logs for boreholes near Machiasport, Maine 


\section{Explanation Information for Appendixes}

\section{Abbreviations on log plots:}

Acou Caliper, in inch

ATV

ATV Amp

ATV Amp, in mV

Azi

Caliper, in inch

deg

dev

DO

Eh, in $\mathrm{mV}$

EMI Cond, in mmho/m

Frax

FRX

$\mathrm{gal} / \mathrm{min}$

gpm

Fl Cond, in $\mu \mathrm{S} / \mathrm{cm}$

Gamma, in CPS

HPFM Amb, in gal $/ \mathrm{min}$

HPFM Pump, in gal/min

LH

Lith

ls

Max

Min

Mtn

O2 ppm

OTV

$\mathrm{pH}$

R8, in Ohm-m

R16, in Ohm-m

$\mathrm{R} 32$, in Ohm-m

R64, in Ohm-m

$\mathrm{SP}$, in $\mathrm{mV}$

SP Cond, in $\mu S / \mathrm{cm}$

SPR, in Ohm

Std. Dev.

T-Frax

tad

Temp, in deg F

TN

toc

tt

Tx caliper measured by acoustic televiewer, in inches acoustic televiewer traveltime acoustic televiewer amplitude

acoustic televiewer amplitude, in millivolts

azimuth

3-arm mechanical caliper, in inches

degrees

deviation

dissolved oxygen

electromotive potential, in millivolts

electromagnetic induction conductivity, in millimhos per meter

fracture

fracture

gallon(s) per minute

gallon(s) per minute

fluid conductivity, in microsiemens per centimeter

natural gamma radiation, in counts per second

heat-pulse flowmeter, under ambient conditions, in gallons per minute heat-pulse flowmeter, under pumped conditions, in gallons per minute lower hemisphere

lithologic feature

land surface

maximum

minimum

Mountain

dissolved oxygen, in parts per million

optical televiewer image

$\mathrm{pH}$

normal resistivity with electrode spacing of 8 inches, in ohm-meters normal resistivity with electrode spacing of 16 inches, in ohm-meters normal resistivity with electrode spacing of 32 inches, in ohm-meters normal resistivity with electrode spacing of 64 inches, in ohm-meters spontaneous potential, in millivolts

specific conductivity, in microsiemens per centimeter single point resistance, in ohms

standard deviation

transmissive fracture

tadpole

temperature, in degrees Fahrenheit

true north

top of casing

travel time

transmissive 


\section{Image log interpretation:}

Interpretations of structure from the image logs are shown in three forms, including projection, stereo, and tadpole plots. A consistent color code was used for all three plots. In addition, lithologic features are shown in the tadpole and stereoplots with squares, so as to distinguish them from interpreted fractures.

Fractures interpreted as transmissive and shown with blue dots, were determined to be transmissive using the heat-pulse flowmeter. Transmissive fractures coded with blue squares were inferred to be transmissive from fluid conductivity, temperature, or other water-quality parameter logs.

- Transmissive fracture

- Large fracture

Minor fracture

Partial fracture

- Sealed fracture

O Possible fracture

Lithologic feature

- Transmissive fracture, inferred from fluid logs 


\section{Example of interpretation of borehole imaging data:}

(A) Optical Televiewer

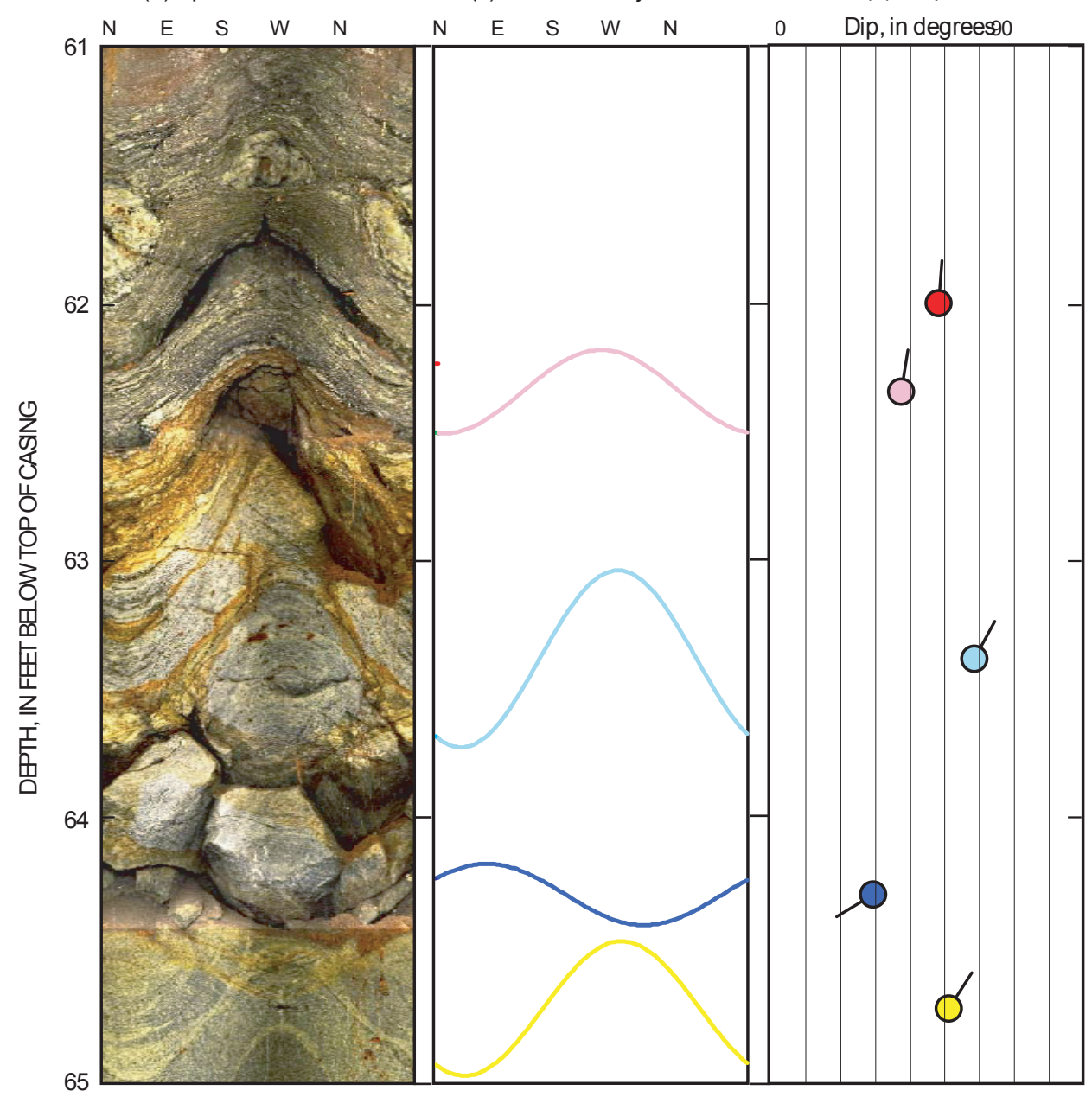

(D) Stereoplot

(E) Rose diagram
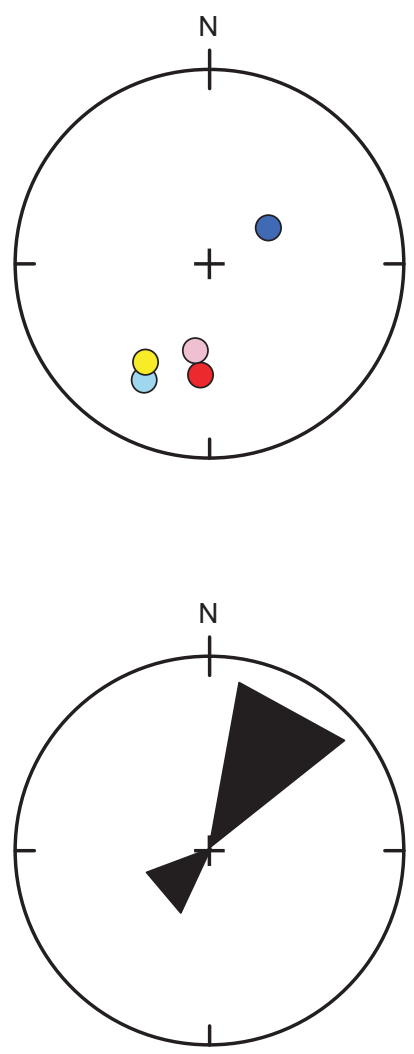

Figure. Example of interpretation of borehole imaging data.

(A) Optical televiewer image and the corresponding interpretation of planar data in (B) structural, (C) tadpole, and (D) stereographic projection plots. The trace of the features on the structural projection (B) directly overlays on the image (A). In the tadpole plot (C), depth is plotted along the $y$ axis, and the magnitude of dip is plotted on the $x$ axis. The tail of the tadpole points in the direction of dip relative to True North, which is at the top of the page. The poles to the planar features are shown in a lower-hemisphere equal-area stereonet (stereoplot) (D), which reduces the plane to a point. (E) Rose diagram, which shows frequency of dip direction. 


\section{Appendix 1. Borehole geophysical logs from boreholes on or near Miller Mountain, near Machiasport, Maine}




\section{Appendix 1.}

\section{Borehole geophysical logs from boreholes on or near Miller Mountain, near Machiasport, Maine}

\section{A. Borehole MW-13}

Figure 1A-1. Caliper, acoustic caliper, gamma, electromagnetic conductivity, fluid temperature, specific conductance, dissolved oxygen, $\mathrm{pH}$, reduction oxidation, multi-space resistivity, oriented acoustic and optical borehole images, and heatpulse flowmeter logs for borehole MW-13, near Machiasport, Maine.

Figure 1A-2. Borehole deviation logs for borehole MW-13, near Machiasport, Maine.

Table 1A-1. Interpretation of acoustic televiewer logs for borehole MW-13, near Machiasport, Maine.

Figure 1A-3. Projection, tadpole, and stereoplots of interpretation of borehole image data for borehole MW-13, near Machiasport, Maine.

\section{B. Borehole DW-22}

Figure 1B-1. Caliper, acoustic caliper, gamma, electromagnetic conductivity, fluid temperature, specific conductance, dissolved oxygen, $\mathrm{pH}$, reduction oxidation, multi-space resistivity, oriented acoustic and optical borehole images, and heatpulse flowmeter logs for borehole DW-22, near Machiasport, Maine.

Figure 1B-2. Borehole deviation logs for borehole DW-22, near Machiasport, Maine.

Table 1B-1. Interpretation of acoustic televiewer logs for borehole DW-22, near Machiasport, Maine.

Table 1B-2. Interpretation of optical televiewer logs for borehole DW-22, near Machiasport, Maine.

Figure 1B-3. Projection, tadpole, and stereoplots of interpretation of borehole image data for borehole DW-22, near Machiasport, Maine.

Figure 1B-4. Interpretation and modeling of heat-pulse flowmeter logs for borehole DW-22, near Machiasport, Maine.

\section{Borehole DW-23}

Figure 1C-1. Caliper, acoustic caliper, gamma, electromagnetic conductivity, fluid temperature, specific conductance, dissolved oxygen, $\mathrm{pH}$, reduction oxidation, multi-space resistivity, oriented acoustic and optical borehole images, and heatpulse flowmeter logs for borehole DW-23, near Machiasport, Maine.

Figure 1C-2. Borehole deviation logs for borehole DW-23, near Machiasport, Maine.

Table 1C-1. Interpretation of acoustic televiewer logs for borehole DW-23, near Machiasport, Maine.

Table 1C-2. Interpretation of optical televiewer logs for borehole DW-23, near Machiasport, Maine.

Figure 1C-3. Projection, tadpole, and stereoplots of interpretation of borehole image data for borehole DW-23, near Machiasport, Maine.

Figure 1C-4. Interpretation and modeling of heat-pulse flowmeter logs for borehole DW-23, near Machiasport, Maine.

\section{Borehole DW-24}

Figure 1D-1. Caliper, acoustic caliper, gamma, electromagnetic conductivity, fluid temperature, specific conductance, dissolved oxygen, $\mathrm{pH}$, reduction oxidation, multi-space resistivity, oriented acoustic and optical borehole images, and heatpulse flowmeter logs for borehole DW-24, near Machiasport, Maine.

Figure 1D-2. Borehole deviation logs for borehole DW-24, near Machiasport, Maine.

Table 1D-1. Interpretation of acoustic televiewer logs for borehole DW-24, near Machiasport, Maine.

Figure 1D-3. Projection, tadpole, and stereoplots of interpretation of borehole image data for borehole DW-24, near Machiasport, Maine. 
Figure 1D-4. Interpretation and modeling of heat-pulse flowmeter logs for borehole DW-24, near Machiasport, Maine.

\section{E. Borehole DW-25}

Figure 1E-1. Caliper, acoustic caliper, gamma, electromagnetic conductivity, fluid temperature, specific conductance, dissolved oxygen, $\mathrm{pH}$, reduction oxidation, multi-space resistivity, oriented acoustic and optical borehole images, and heatpulse flowmeter logs for borehole DW-25, near Machiasport, Maine.

Figure 1E-2. Borehole deviation logs for borehole DW-25, near Machiasport, Maine.

Table 1E-1. Interpretation of acoustic televiewer logs for borehole DW-25, near Machiasport, Maine.

Figure 1E-3. Projection, tadpole, and stereoplots of interpretation of borehole image data for borehole DW-25, near Machiasport, Maine.

Figure 1E-4. Interpretation and modeling of heat-pulse flowmeter logs for borehole DW-25, near Machiasport, Maine.

\section{F. Borehole DW-31}

Figure 1F-1. Caliper, acoustic caliper, gamma, electromagnetic conductivity, fluid temperature, specific conductance, dissolved oxygen, $\mathrm{pH}$, reduction oxidation, multi-space resistivity, oriented acoustic and optical borehole images, and heatpulse flowmeter logs for borehole DW-31, near Machiasport, Maine.

Figure 1F-2. Borehole deviation logs for borehole DW-31, near Machiasport, Maine.

Table 1F-1. Interpretation of acoustic televiewer logs for borehole DW-31, near Machiasport, Maine.

Table 1F-2. Interpretation of optical televiewer logs for borehole DW-31, near Machiasport, Maine.

Figure 1F-3. Projection, tadpole, and stereoplots of interpretation of borehole image data for borehole DW-31, near Machiasport, Maine.

Figure 1F-4. Interpretation and modeling of heat-pulse flowmeter logs for borehole DW-31, near Machiasport, Maine.

\section{G. Borehole DW-32}

Figure 1G-1. Caliper, acoustic caliper, gamma, electromagnetic conductivity, fluid temperature, specific conductance, dissolved oxygen, $\mathrm{pH}$, reduction oxidation, multi-space resistivity, oriented acoustic and optical borehole images, and heatpulse flowmeter logs for borehole DW-32, near Machiasport, Maine.

Figure 1G-2. Borehole deviation logs for borehole DW-32, near Machiasport, Maine.

Table 1G-1. Interpretation of acoustic televiewer logs for borehole DW-32, near Machiasport, Maine.

Figure 1G-3. Projection, tadpole, and stereoplots of interpretation of borehole image data for borehole DW-32, near Machiasport, Maine.

Figure 1G-4. Interpretation and modeling of heat-pulse flowmeter logs for borehole DW-32, near Machiasport, Maine.

\section{H. Borehole DW-33}

Figure 1H-1. Caliper, acoustic caliper, gamma, electromagnetic conductivity, fluid temperature, specific conductance, dissolved oxygen, $\mathrm{pH}$, reduction oxidation, multi-space resistivity, oriented acoustic and optical borehole images, and heatpulse flowmeter logs for borehole DW-33, near Machiasport, Maine.

Figure 1H-2. Borehole deviation logs for borehole DW-33, near Machiasport, Maine.

Table 1H-1. Interpretation of acoustic televiewer logs for borehole DW-33, near Machiasport, Maine.

Figure 1H-3. Projection, tadpole, and stereoplots of interpretation of borehole image data for borehole DW-33, near Machiasport, Maine.

Figure 1H-4. Interpretation and modeling of heat-pulse flowmeter logs for borehole DW-33, near Machiasport, Maine. 


\section{Borehole DW-34}

Figure 1I-1. Caliper, acoustic caliper, gamma, electromagnetic conductivity, fluid temperature, specific conductance, dissolved oxygen, $\mathrm{pH}$, reduction oxidation, multi-space resistivity, oriented acoustic and optical borehole images, and heatpulse flowmeter logs for borehole DW-34, near Machiasport, Maine.

Figure 1I-2. Borehole deviation logs for borehole DW-34, near Machiasport, Maine. Deviation (tilt) data interpolated from 95 to 295 feet below top of casing.

Table 1I-1. Interpretation of acoustic televiewer logs for borehole DW-34, near Machiasport, Maine.

Figure 1I-3. Projection, tadpole, and stereoplots of interpretation of borehole image data for borehole DW-34, near Machiasport, Maine.

Figure 1I-4. Interpretation and modeling of heat-pulse flowmeter logs for borehole DW-34, near Machiasport, Maine.

\section{J. Borehole DW-39}

Figure 1J-1. Caliper, acoustic caliper, gamma, electromagnetic conductivity, fluid temperature, specific conductance, dissolved oxygen, $\mathrm{pH}$, reduction oxidation, multi-space resistivity, oriented acoustic and optical borehole images, and heatpulse flowmeter logs for borehole DW-39, near Machiasport, Maine.

Figure 1J-2. Borehole deviation logs for borehole DW-39, near Machiasport, Maine.

Table 1J-1. Interpretation of acoustic televiewer logs for borehole DW-39, near Machiasport, Maine.

Figure 1J-3. Projection, tadpole, and stereoplots of interpretation of borehole image data for borehole DW-39, near Machiasport, Maine.

Figure 1J-4. Interpretation and modeling of heat-pulse flowmeter logs for borehole DW-39, near Machiasport, Maine.

\section{K. Borehole DW-40}

Figure 1K-1. Caliper, acoustic caliper, gamma, electromagnetic conductivity, fluid temperature, specific conductance, dissolved oxygen, $\mathrm{pH}$, reduction oxidation, multi-space resistivity, oriented acoustic and optical borehole images, and heatpulse flowmeter logs for borehole DW-40, near Machiasport, Maine.

Figure 1K-2. Borehole deviation logs for borehole DW-40, near Machiasport, Maine.

Table 1K-1. Interpretation of acoustic televiewer logs for borehole DW-40, near Machiasport, Maine.

Figure 1K-3. Projection, tadpole, and stereoplots of interpretation of borehole image data for borehole DW-40, near Machiasport, Maine.

Figure 1K-4. Interpretation and modeling of heat-pulse flowmeter logs for borehole DW-40, near Machiasport, Maine.

\section{Borehole WY-GATR}

Figure 1L-1. Caliper, acoustic caliper, gamma, electromagnetic conductivity, fluid temperature, specific conductance, dissolved oxygen, $\mathrm{pH}$, reduction oxidation, multi-space resistivity, oriented acoustic and optical borehole images, and heatpulse flowmeter logs for borehole WY-GATR, near Machiasport, Maine.

Figure 1L-2. Borehole deviation logs for borehole WY-GATR, near Machiasport, Maine.

Table 1L-1. Interpretation of acoustic televiewer logs for borehole WY-GATR, near Machiasport, Maine.

Table 1L-2. Interpretation of optical televiewer logs for borehole WY-GATR, near Machiasport, Maine.

Figure 1L-3. Projection, tadpole, and stereoplots of interpretation of borehole image data for borehole WY-GATR, near Machiasport, Maine.

Figure 1L-4. Interpretation and modeling of heat-pulse flowmeter logs for borehole WY-GATR, near Machiasport, Maine. 


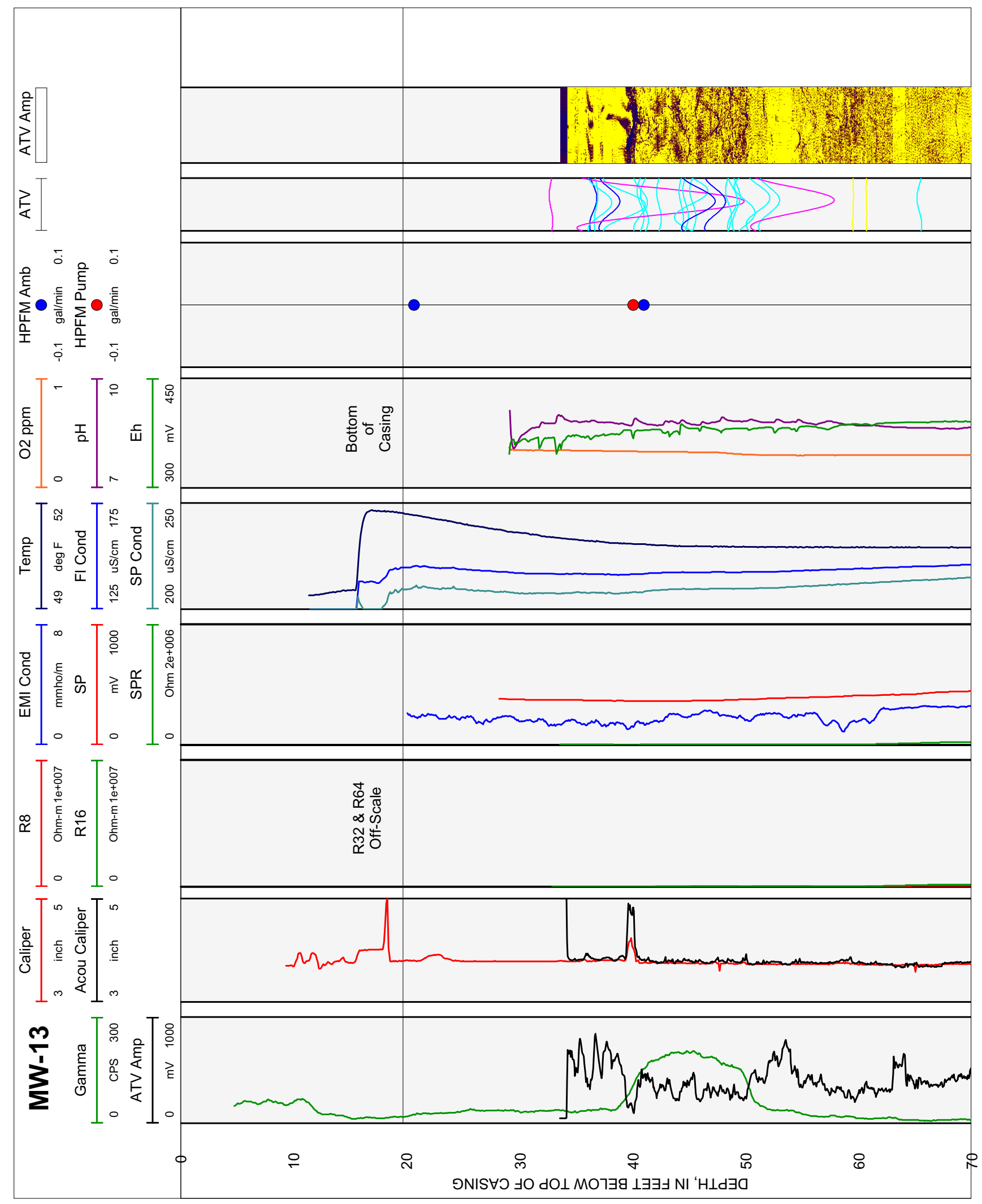

Figure 1A-1. Caliper, acoustic caliper, gamma, electromagnetic conductivity, fluid temperature, specific conductance, $\mathrm{DO}, \mathrm{pH}$, reduction oxidation, multi-space resistivity, oriented acoustic and optical borehole images, and heat-pulse flowmeter logs for borehole MW-13, near Machiasport, Maine. 


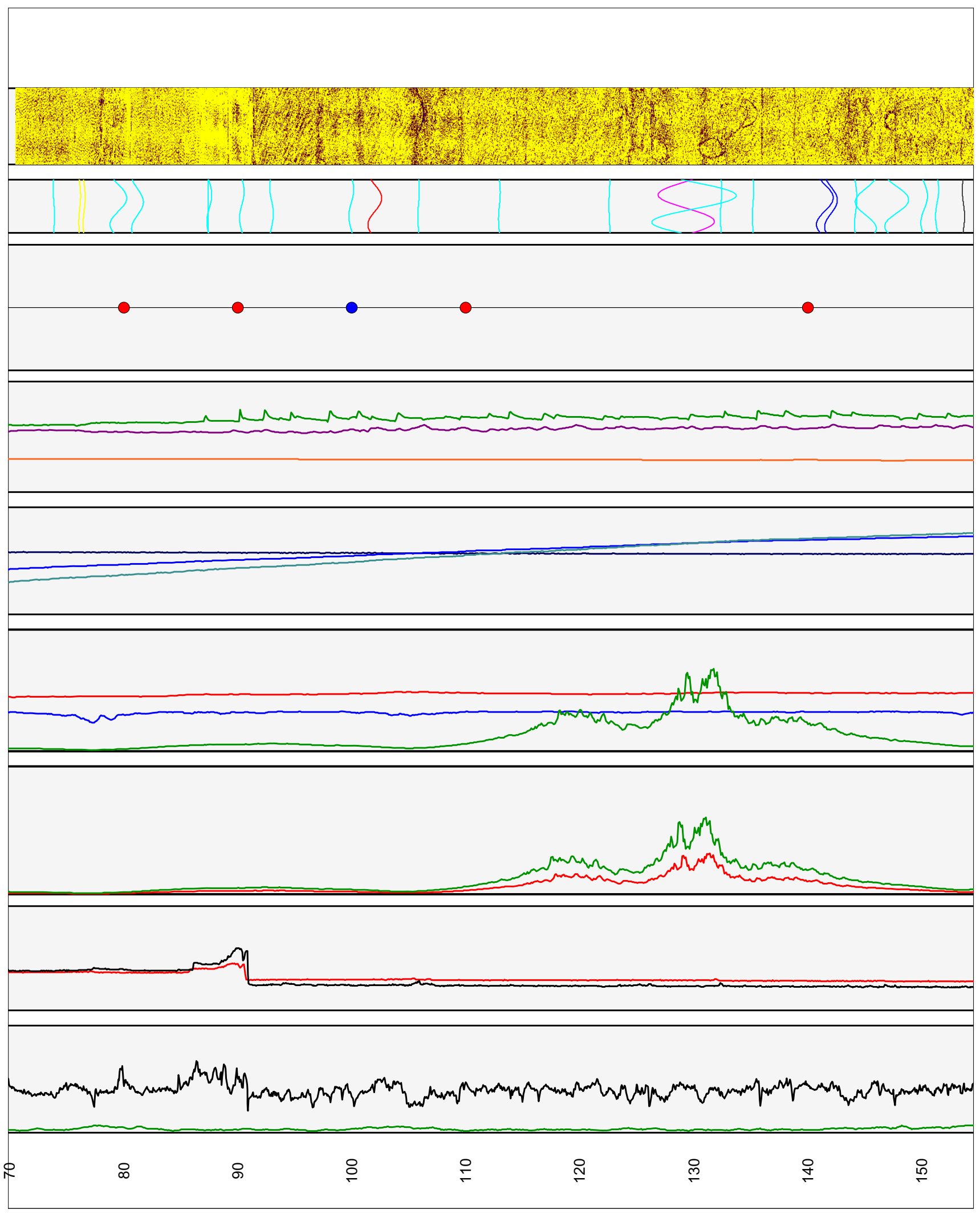

Figure 1A-1. Caliper, acoustic caliper, gamma, electromagnetic conductivity, fluid temperature, specific conductance, $\mathrm{DO}, \mathrm{pH}$, reduction oxidation, multi-space resistivity, oriented acoustic and optical borehole images, and heat-pulse flowmeter logs for borehole MW-13, near Machiasport, Maine.-Continued 


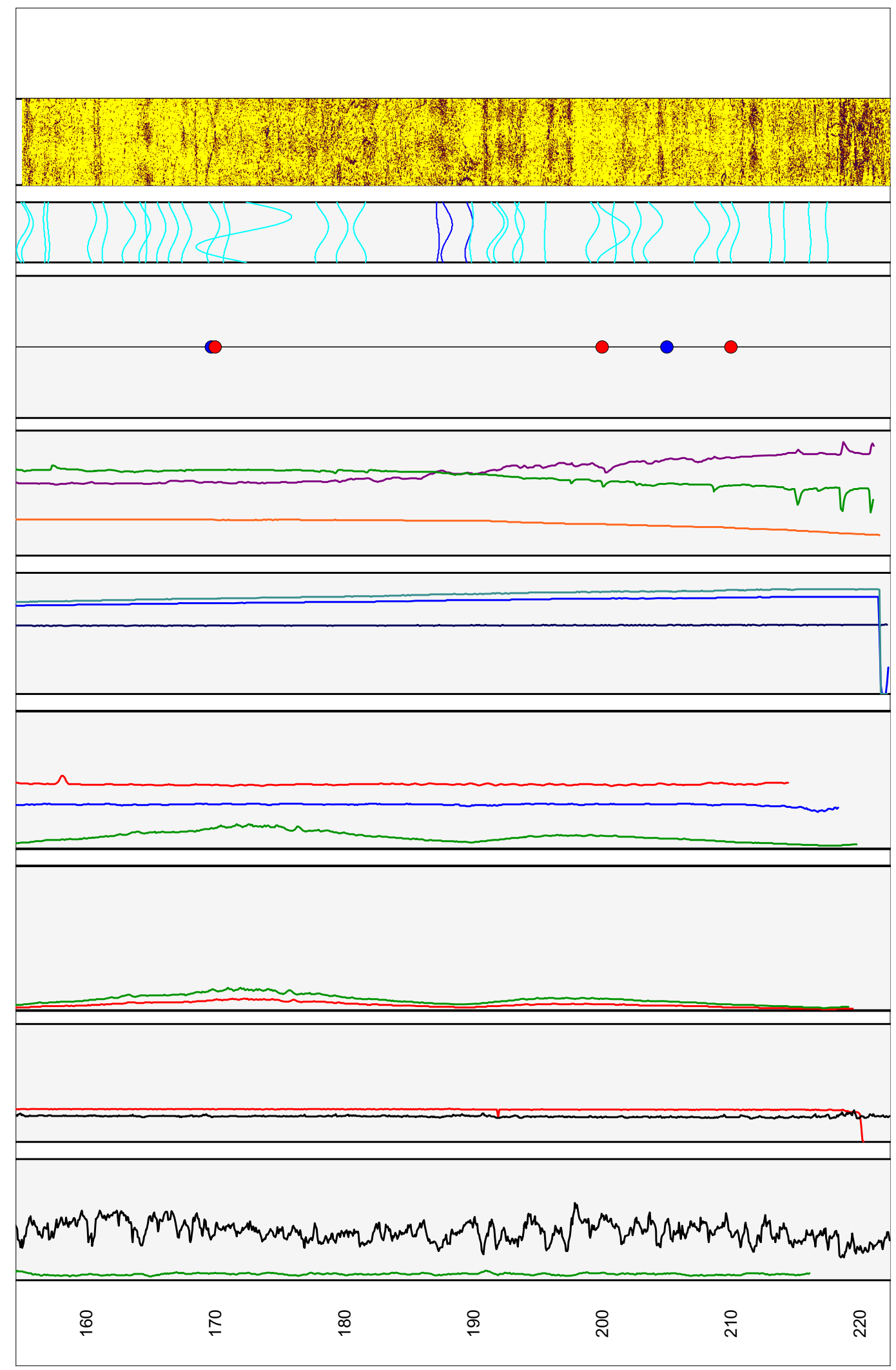

Figure 1A-1. Caliper, acoustic caliper, gamma, electromagnetic conductivity, fluid temperature, specific conductance, $\mathrm{DO}, \mathrm{pH}$, reduction oxidation, multi-space resistivity, oriented acoustic and optical borehole images, and heat-pulse flowmeter logs for borehole MW-13, near Machiasport, Maine.-Continued 

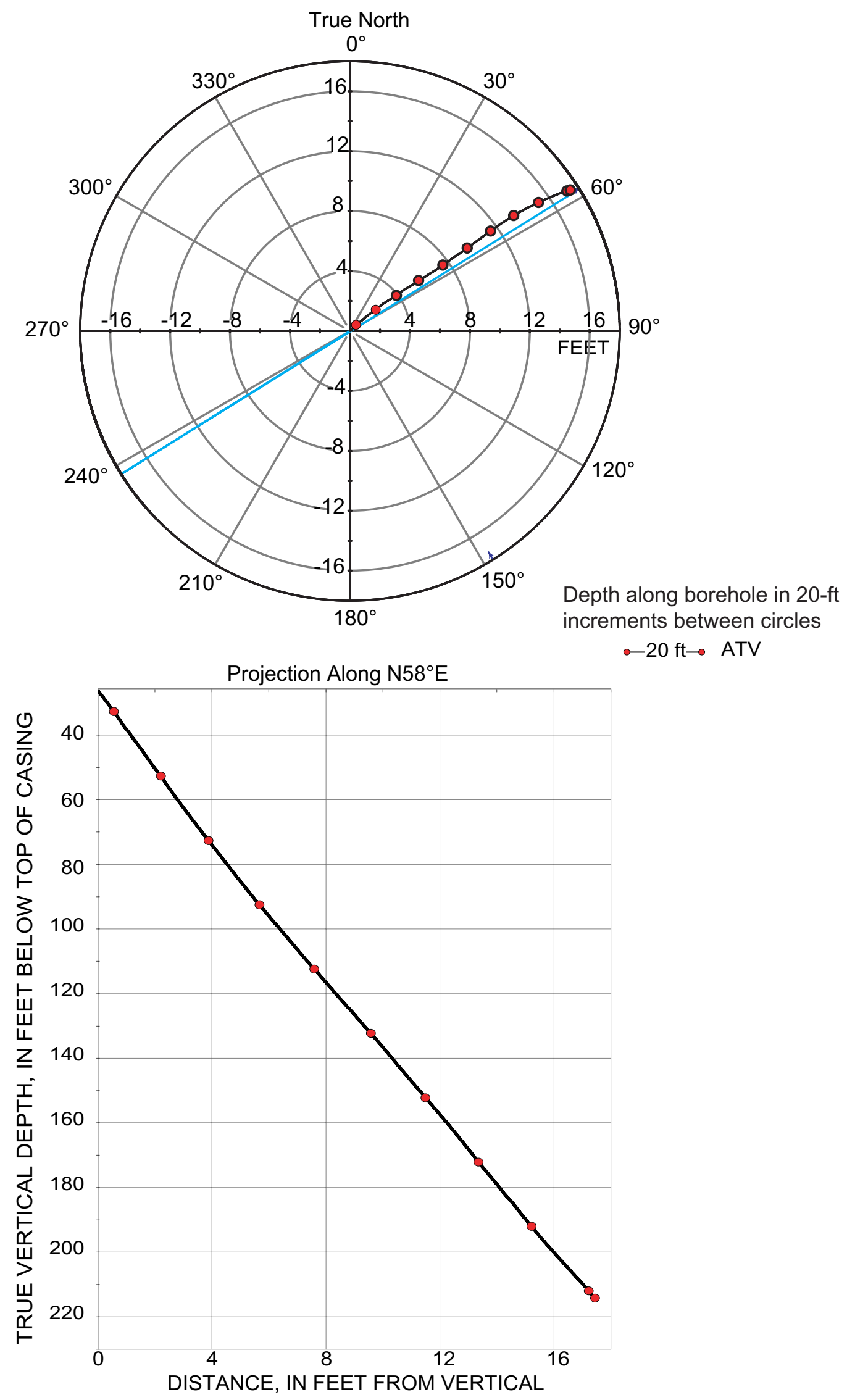

Figure 1A-2. Borehole deviation logs for borehole MW-13, near Machiasport, Maine. Blue line on radial plot (top) is line of projection for vertical plot (bottom).

[ft, foot; ATV, acoustic televiewer] 
Table 1A-1. Interpretation of acoustic televiewer logs for borehole MW-13, near Machiasport, Maine.

[Televiewer data are corrected for deviation and magnetic declination, so orientations are relative to true north; depths are below top of casing, which is 3.48 feet above land surface; dip azimuth is given in degrees east of true north; strike is reported in right-hand-rule (RHR)-azimuthal degrees east of true north and where the direction of dip is 90 degrees to the right of strike]

\begin{tabular}{|c|c|c|c|c|c|c|c|}
\hline $\begin{array}{l}\text { Depth, } \\
\text { in feet }\end{array}$ & $\begin{array}{l}\text { Depth, } \\
\text { in meters }\end{array}$ & $\begin{array}{c}\text { Dip } \\
\text { azimuth }\end{array}$ & $\begin{array}{l}\text { Strike, } \\
\text { in RHR }\end{array}$ & Dip & $\begin{array}{c}\text { Dip } \\
\text { direction }\end{array}$ & Dip descriptor & Comment \\
\hline 34.13 & 10.40 & 240 & 150 & 5 & SW & Nearly horizontal & Minor fracture \\
\hline 36.22 & 11.04 & 64 & 334 & 51 & $\mathrm{NE}$ & Steep & Partial fracture \\
\hline 39.94 & 12.17 & 222 & 132 & 68 & SW & Steep & $\begin{array}{l}\text { Transmissive fracture, } \\
\text { inferred from fluid logs }\end{array}$ \\
\hline 40.18 & 12.25 & 242 & 152 & 53 & SW & Steep & Minor fracture \\
\hline 40.56 & 12.36 & 192 & 102 & 83 & $\mathrm{~S}$ & Nearly vertical & Minor fracture \\
\hline 41.37 & 12.61 & 201 & 111 & 82 & S & Nearly vertical & $\begin{array}{l}\text { Transmissive fracture, } \\
\text { inferred from fluid logs }\end{array}$ \\
\hline 42.72 & 13.02 & 178 & 88 & 86 & $\mathrm{~s}$ & Nearly vertical & Minor fracture \\
\hline 44.13 & 13.45 & 92 & 2 & 67 & $\mathrm{E}$ & Steep & Minor fracture \\
\hline 44.14 & 13.45 & 194 & 104 & 78 & $\bar{S}$ & Nearly vertical & Minor fracture \\
\hline 44.45 & 13.55 & 72 & 342 & 70 & $E$ & Nearly vertical & Minor fracture \\
\hline 45.75 & 13.94 & 86 & 356 & 58 & $E$ & Steep & Minor fracture \\
\hline 45.92 & 14.00 & 200 & 110 & 89 & S & Nearly vertical & Partial fracture \\
\hline 47.70 & 14.54 & 89 & 359 & 55 & $\mathrm{E}$ & Steep & Minor fracture \\
\hline 48.12 & 14.67 & 99 & 9 & 62 & $\bar{E}$ & Steep & Minor fracture \\
\hline 48.60 & 14.81 & 272 & 182 & 85 & W & Nearly vertical & Minor fracture \\
\hline 48.77 & 14.86 & 96 & 6 & 65 & $\mathrm{E}$ & Steep & Minor fracture \\
\hline 49.25 & 15.01 & 203 & 113 & 85 & SW & Nearly vertical & $\begin{array}{l}\text { Transmissive fracture, } \\
\text { inferred from fluid logs }\end{array}$ \\
\hline 50.72 & 15.46 & 200 & 110 & 82 & S & Nearly vertical & $\begin{array}{l}\text { Transmissive fracture, } \\
\text { inferred from fluid logs }\end{array}$ \\
\hline 51.92 & 15.82 & 96 & 6 & 64 & $E$ & Steep & Minor fracture \\
\hline 52.23 & 15.92 & 211 & 121 & 73 & SW & Nearly vertical & Minor fracture \\
\hline 52.57 & 16.02 & 230 & 140 & 69 & SW & Steep & Minor fracture \\
\hline 53.33 & 16.25 & 123 & 33 & 82 & SE & Nearly vertical & Minor fracture \\
\hline 54.53 & 16.62 & 224 & 134 & 83 & SW & Nearly vertical & Minor fracture \\
\hline 55.49 & 16.91 & 209 & 119 & 82 & SW & Nearly vertical & Minor fracture \\
\hline 57.55 & 17.54 & 209 & 119 & 88 & SW & Nearly vertical & Partial fracture \\
\hline 62.95 & 19.19 & 233 & 143 & 12 & SW & Shallow & Possible fracture \\
\hline 64.12 & 19.54 & 115 & 25 & 11 & SE & Shallow & Possible fracture \\
\hline 68.78 & 20.96 & 42 & 312 & 59 & NE & Steep & Minor fracture \\
\hline 77.34 & 23.57 & 116 & 26 & 23 & SE & Shallow & Minor fracture \\
\hline 79.62 & 24.27 & 250 & 160 & 31 & W & Moderate & Possible fracture \\
\hline 80.00 & 24.38 & 241 & 151 & 36 & SW & Moderate & Possible fracture \\
\hline 83.00 & 25.30 & 236 & 146 & 80 & SW & Nearly vertical & Minor fracture \\
\hline 84.69 & 25.81 & 209 & 119 & 76 & SW & Nearly vertical & Minor fracture \\
\hline 90.88 & 27.70 & 261 & 171 & 5 & W & Nearly horizontal & Minor fracture \\
\hline 90.98 & 27.73 & 256 & 166 & 59 & W & Steep & Minor fracture \\
\hline 93.85 & 28.60 & 279 & 189 & 57 & W & Steep & Minor fracture \\
\hline 96.44 & 29.39 & 128 & 38 & 51 & SE & Steep & Minor fracture \\
\hline 103.44 & 31.53 & 293 & 203 & 59 & NW & Steep & Minor fracture \\
\hline 105.49 & 32.15 & 235 & 145 & 78 & SW & Nearly vertical & Minor fracture \\
\hline 109.33 & 33.32 & 288 & 198 & 29 & W & Shallow & Minor fracture \\
\hline 116.43 & 35.49 & 274 & 184 & 30 & W & Shallow & Minor fracture \\
\hline 126.07 & 38.42 & 7 & 277 & 16 & $\mathrm{~N}$ & Shallow & Minor fracture \\
\hline 132.82 & 40.48 & 77 & 347 & 87 & $\mathrm{E}$ & Nearly vertical & Partial fracture \\
\hline 133.49 & 40.69 & 252 & 162 & 88 & W & Nearly vertical & Minor fracture \\
\hline 135.86 & 41.41 & 285 & 195 & 22 & W & Shallow & Minor fracture \\
\hline 138.68 & 42.27 & 289 & 199 & 22 & W & Shallow & Minor fracture \\
\hline 144.98 & 44.19 & 237 & 147 & 80 & SW & Nearly vertical & $\begin{array}{l}\text { Transmissive fracture, } \\
\text { inferred from fluid logs }\end{array}$ \\
\hline 145.52 & 44.35 & 221 & 131 & 77 & SW & Nearly vertical & $\begin{array}{l}\text { Transmissive fracture, } \\
\text { inferred from fluid logs }\end{array}$ \\
\hline 147.65 & 45.00 & 236 & 146 & 38 & SW & Moderate & Minor fracture \\
\hline 148.55 & 45.28 & 30 & 300 & 82 & $\mathrm{NE}$ & Nearly vertical & Minor fracture \\
\hline
\end{tabular}


Table 1A-1. Interpretation of acoustic televiewer logs for borehole MW-13, near Machiasport, Maine.-Continued [Televiewer data are corrected for deviation and magnetic declination, so orientations are relative to true north; depths are below top of casing, which is 3.48 feet above land surface; dip azimuth is given in degrees east of true north; strike is reported in right-hand-rule (RHR)-azimuthal degrees east of true north and where the direction of dip is 90 degrees to the right of strike]

\begin{tabular}{|c|c|c|c|c|c|c|c|}
\hline $\begin{array}{l}\text { Depth, } \\
\text { in feet }\end{array}$ & $\begin{array}{l}\text { Depth, } \\
\text { in meters }\end{array}$ & $\begin{array}{c}\text { Dip } \\
\text { azimuth }\end{array}$ & $\begin{array}{l}\text { Strike, } \\
\text { in RHR }\end{array}$ & Dip & $\begin{array}{l}\text { Dip } \\
\text { direction }\end{array}$ & Dip descriptor & Comment \\
\hline 151.29 & 46.11 & 224 & 134 & 83 & SW & Nearly vertical & Minor fracture \\
\hline 153.69 & 46.84 & 249 & 159 & 66 & W & Steep & Minor fracture \\
\hline 154.80 & 47.18 & 292 & 202 & 47 & W & Moderate & Minor fracture \\
\hline 157.13 & 47.89 & 110 & 20 & 37 & $\mathrm{E}$ & Moderate & Lithlogic/foliation \\
\hline 158.53 & 48.32 & 253 & 163 & 75 & $\mathrm{~W}$ & Nearly vertical & Minor fracture \\
\hline 158.89 & 48.43 & 233 & 143 & 74 & SW & Nearly vertical & Minor fracture \\
\hline 160.24 & 48.84 & 79 & 349 & 31 & $E$ & Moderate & Minor fracture \\
\hline 160.53 & 48.93 & 93 & 3 & 33 & $\mathrm{E}$ & Moderate & Minor fracture \\
\hline 163.90 & 49.95 & 266 & 176 & 69 & W & Steep & Minor fracture \\
\hline 164.89 & 50.26 & 233 & 143 & 59 & SW & Steep & Minor fracture \\
\hline 166.75 & 50.82 & 221 & 131 & 76 & SW & Nearly vertical & Minor fracture \\
\hline 168.02 & 51.21 & 213 & 123 & 74 & SW & Nearly vertical & Minor fracture \\
\hline 168.08 & 51.23 & 117 & 27 & 27 & SE & Shallow & Minor fracture \\
\hline 169.28 & 51.59 & 211 & 121 & 70 & SW & Nearly vertical & Minor fracture \\
\hline 170.22 & 51.88 & 203 & 113 & 71 & SW & Nearly vertical & Minor fracture \\
\hline 171.27 & 52.20 & 198 & 108 & 71 & $\mathrm{~S}$ & Nearly vertical & Minor fracture \\
\hline 173.29 & 52.82 & 223 & 133 & 75 & SW & Nearly vertical & Minor fracture \\
\hline 174.34 & 53.14 & 198 & 108 & 62 & $\mathrm{~S}$ & Steep & Minor fracture \\
\hline 175.68 & 53.54 & 273 & 183 & 88 & W & Nearly vertical & Minor fracture \\
\hline 181.72 & 55.39 & 212 & 122 & 76 & SW & Nearly vertical & Minor fracture \\
\hline 183.30 & 55.87 & 210 & 120 & 74 & SW & Nearly vertical & Minor fracture \\
\hline 184.70 & 56.29 & 25 & 295 & 75 & $\mathrm{NE}$ & Nearly vertical & Minor fracture \\
\hline 190.73 & 58.13 & 128 & 38 & 41 & SE & Moderate & $\begin{array}{l}\text { Transmissive fracture, } \\
\text { inferred from fluid logs }\end{array}$ \\
\hline 191.44 & 58.35 & 226 & 136 & 73 & sW & Nearly vertical & $\begin{array}{l}\text { Transmissive fracture, } \\
\text { inferred from fluid logs }\end{array}$ \\
\hline 193.14 & 58.87 & 237 & 147 & 67 & sw & Steep & $\begin{array}{l}\text { Transmissive fracture, } \\
\text { inferred from fluid logs }\end{array}$ \\
\hline 193.32 & 58.92 & 279 & 189 & 46 & W & Moderate & Minor fracture \\
\hline 195.23 & 59.50 & 239 & 149 & 79 & SW & Nearly vertical & Minor fracture \\
\hline 195.62 & 59.62 & 236 & 146 & 77 & SW & Nearly vertical & Minor fracture \\
\hline 197.00 & 60.04 & 226 & 136 & 74 & SW & Nearly vertical & Minor fracture \\
\hline 197.02 & 60.05 & 89 & 359 & 66 & $E$ & Steep & Minor fracture \\
\hline 199.07 & 60.67 & 314 & 224 & 22 & NW & Shallow & Minor fracture \\
\hline 202.75 & 61.80 & 253 & 163 & 76 & W & Nearly vertical & Minor fracture \\
\hline 204.35 & 62.28 & 184 & 94 & 84 & $\mathrm{~S}$ & Nearly vertical & Minor fracture \\
\hline 204.41 & 62.30 & 84 & 354 & 50 & $\mathrm{E}$ & Steep & Minor fracture \\
\hline 206.16 & 62.83 & 248 & 158 & 70 & W & Steep & Minor fracture \\
\hline 207.43 & 63.22 & 244 & 154 & 80 & SW & Nearly vertical & Minor fracture \\
\hline 211.21 & 64.37 & 200 & 110 & 78 & $\mathrm{~S}$ & Nearly vertical & Minor fracture \\
\hline 212.89 & 64.89 & 234 & 144 & 75 & SW & Nearly vertical & Minor fracture \\
\hline 213.75 & 65.15 & 224 & 134 & 69 & SW & Steep & Minor fracture \\
\hline 216.52 & 65.99 & 129 & 39 & 38 & SE & Moderate & Minor fracture \\
\hline 217.58 & 66.32 & 81 & 351 & 18 & $\mathrm{E}$ & Shallow & Minor fracture \\
\hline 219.57 & 66.92 & 121 & 31 & 32 & SE & Moderate & Minor fracture \\
\hline 220.90 & 67.33 & 71 & 341 & 42 & $E$ & Moderate & Minor fracture \\
\hline
\end{tabular}




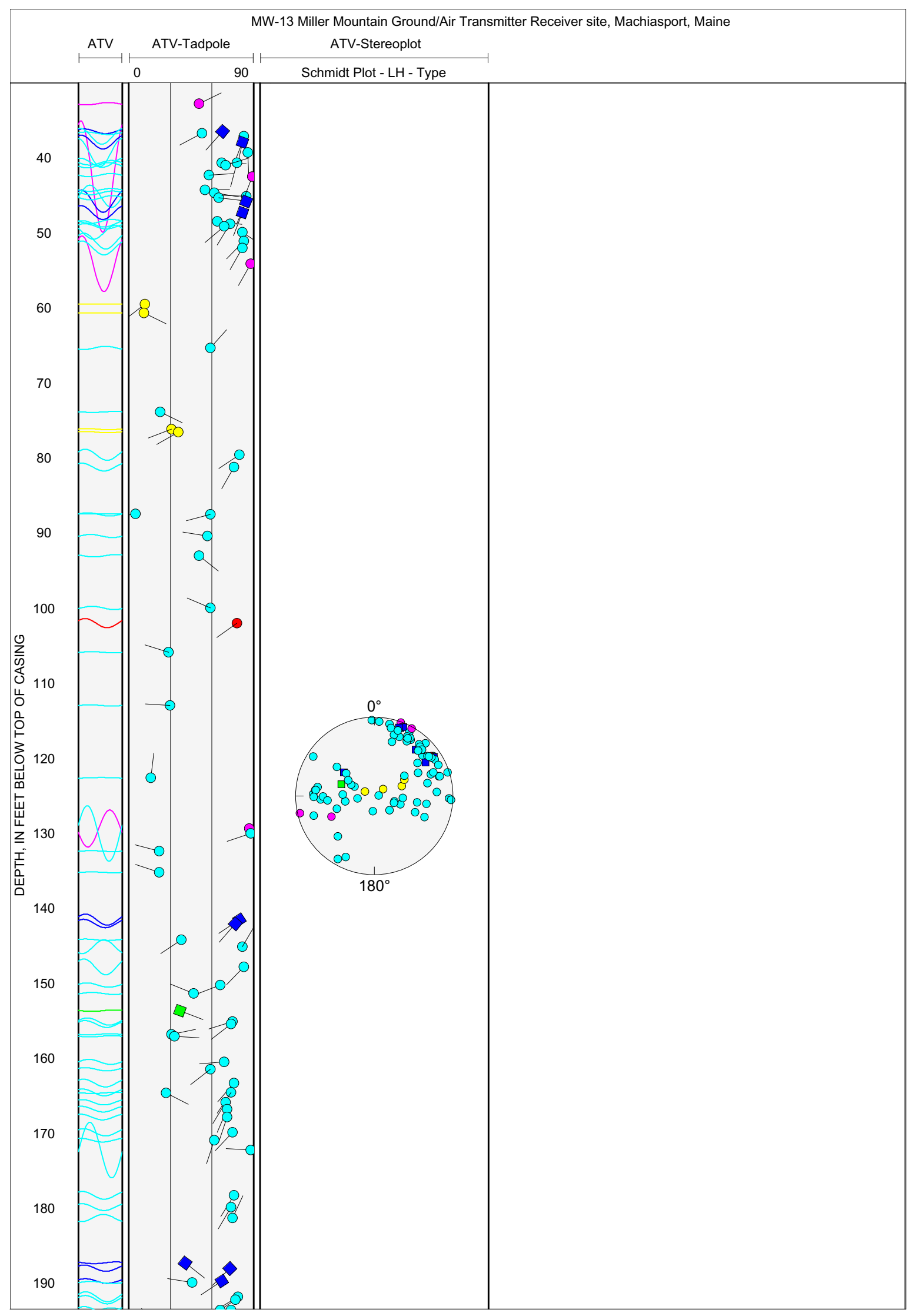

Figure 1A-3. Projection, tadpole, and stereoplots of interpretation of borehole image data for borehole MW-13, near Machiasport, Maine. 


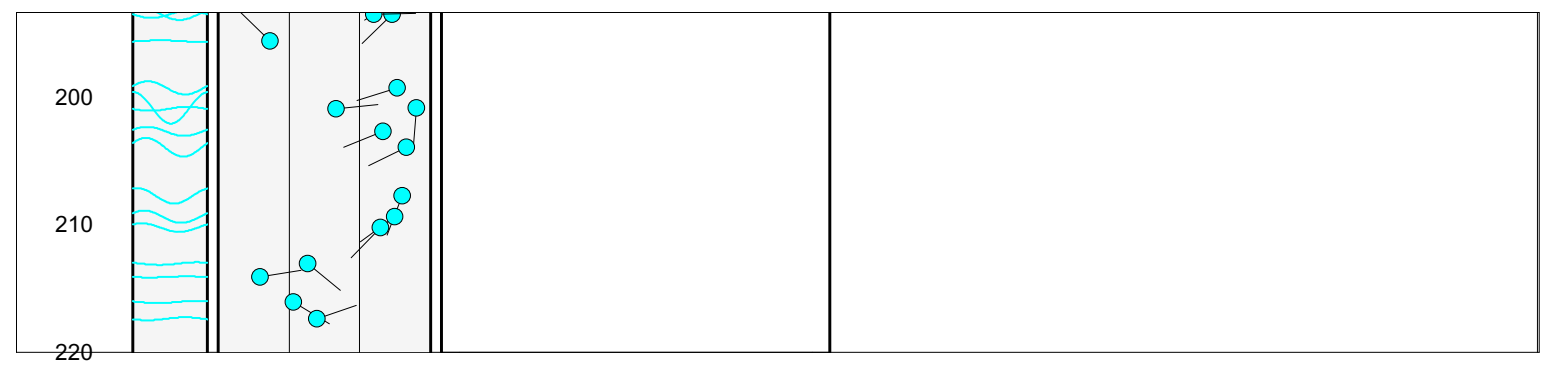

Figure 1A-3. Projection, tadpole, and stereoplots of interpretation of borehole image data for borehole MW-13, near Machiasport, Maine.-Continued 


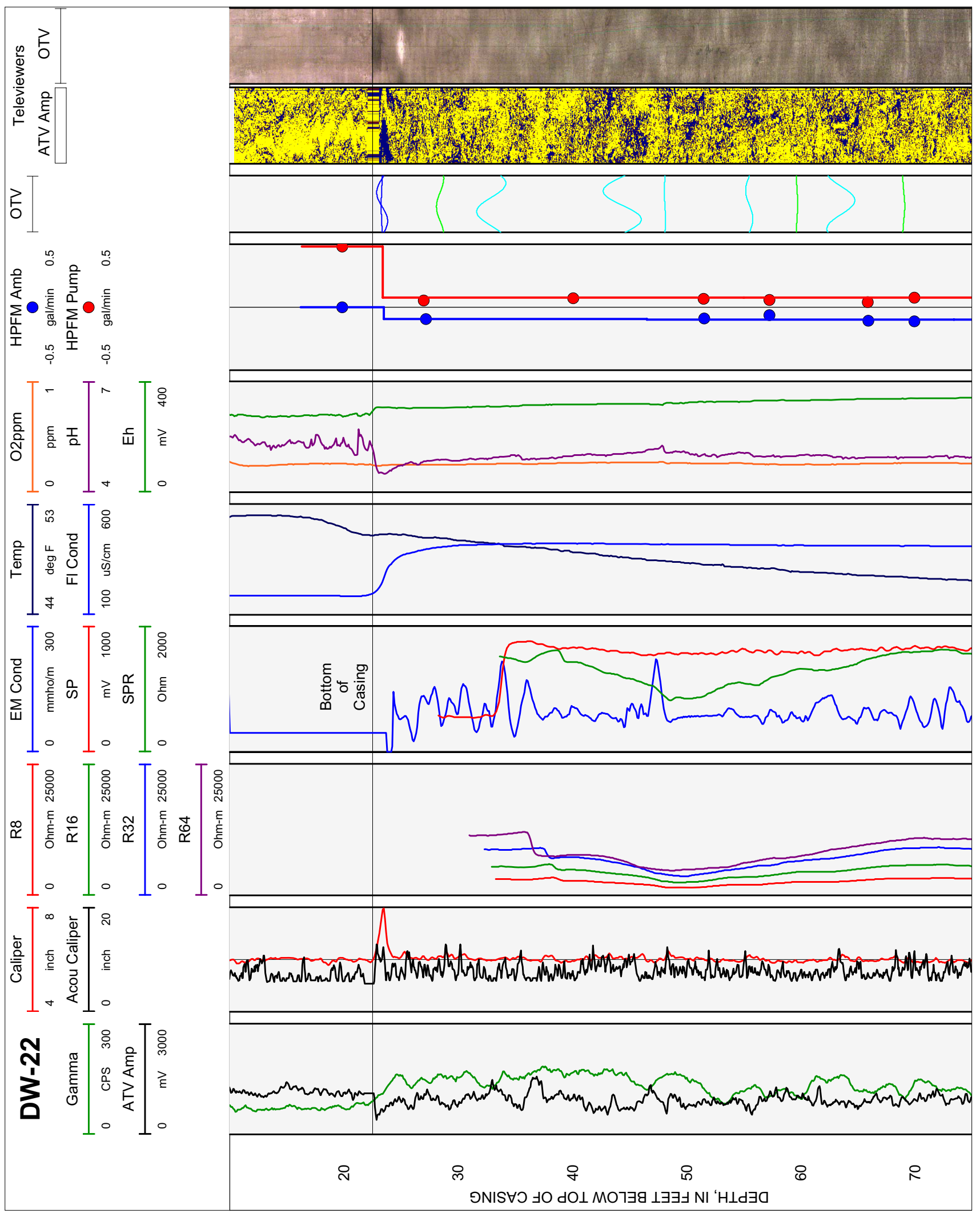

Figure 1B-1. Caliper, acoustic caliper, gamma, electromagnetic conductivity, fluid temperature, specific conductance, $\mathrm{DO}, \mathrm{pH}$, reduction oxidation, multi-space resistivity, oriented acoustic and optical borehole images, and heat-pulse flowmeter logs for borehole DW-22, near Machiasport, Maine. 


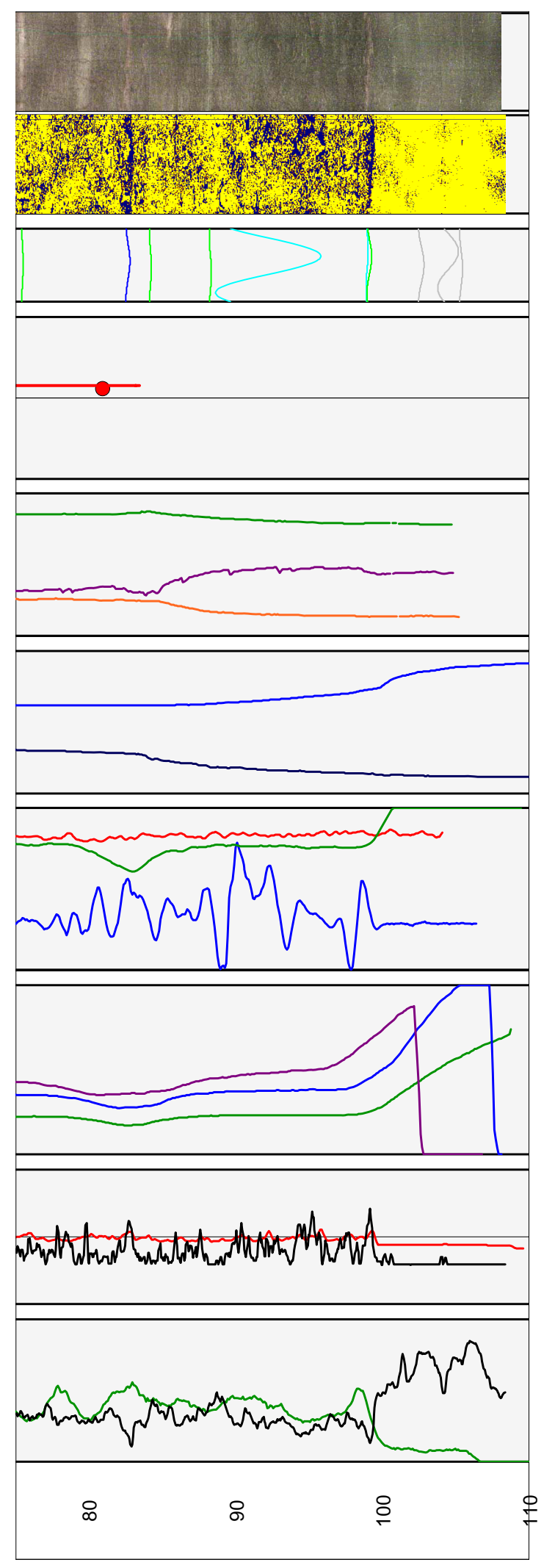

Figure 1B-1. Caliper, acoustic caliper, gamma, electromagnetic conductivity, fluid temperature, specific conductance, $\mathrm{DO}, \mathrm{pH}$, reduction oxidation, multi-space resistivity, oriented acoustic and optical borehole images, and heat-pulse flowmeter logs for borehole DW-22, near Machiasport, Maine.-Continued 

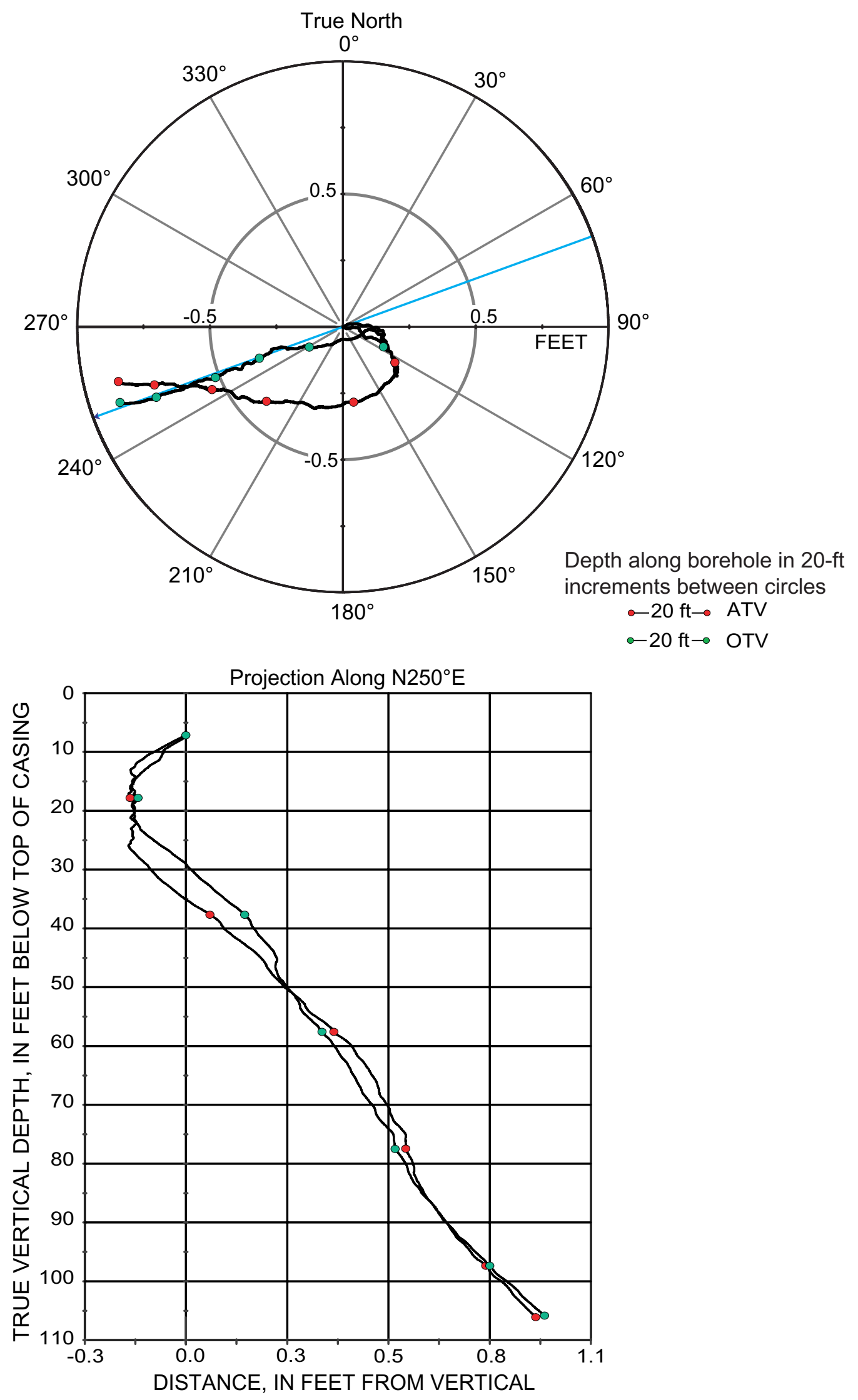

Figure 1B-2. Borehole deviation logs for borehole DW-22, near Machiasport, Maine. Blue line on radial plot (top) is line of projection for vertical plot (bottom).

[ft, foot; ATV, acoustic televiewer; OTV, optical televiewer] 
Table 1B-1. Interpretation of acoustic televiewer logs for borehole DW-22, near Machiasport, Maine.

[Televiewer data are corrected for deviation and magnetic declination, so orientations are relative to true north; depths are below top of casing, which is 0.34 feet above land surface; dip azimuth is given in degrees east of true north; strike is reported in right-hand-rule (RHR)-azimuthal degrees east of true north and where the direction of dip is 90 degrees to the right of strike]

\begin{tabular}{rrrrrccl}
\hline $\begin{array}{c}\text { Depth, } \\
\text { in feet }\end{array}$ & $\begin{array}{c}\text { Depth, } \\
\text { in meters }\end{array}$ & $\begin{array}{c}\text { Dip } \\
\text { azimuth }\end{array}$ & $\begin{array}{c}\text { Strike, } \\
\text { in RHR }\end{array}$ & Dip & $\begin{array}{c}\text { Dip } \\
\text { direction }\end{array}$ & Dip descriptor & Comment \\
\hline 22.71 & 6.92 & 0 & 270 & 0 & N & Horizontal & Bottom of casing \\
23.08 & 7.03 & 63 & 333 & 66 & NE & Steep & Transmissive fracture \\
44.66 & 13.61 & 94 & 4 & 80 & E & Nearly vertical & Fracture \\
48.17 & 14.68 & 180 & 90 & 21 & S & Shallow & Minor fracture \\
51.92 & 15.82 & 230 & 140 & 39 & SW & Moderate & Minor fracture \\
56.25 & 17.14 & 256 & 166 & 68 & W & Steep & Minor fracture \\
82.89 & 25.26 & 208 & 118 & 27 & SW & Shallow & Transmissive fracture \\
90.52 & 27.59 & 242 & 152 & 81 & SW & Nearly vertical & Minor fracture \\
95.08 & 28.98 & 49 & 319 & 78 & NE & Nearly vertical & Minor fracture \\
99.02 & 30.18 & 261 & 171 & 14 & W & Shallow & Fracture \\
99.26 & 30.25 & 264 & 174 & 25 & W & Shallow & Lithologic feature \\
104.54 & 31.86 & 255 & 165 & 72 & W & Nearly vertical & Sealed feature \\
\hline
\end{tabular}

Table 1B-2. Interpretation of optical televiewer logs for borehole DW-22, near Machiasport, Maine.

[Televiewer data are corrected for deviation and magnetic declination, so orientations are relative to true north; depths are below top of casing, which is 0.34 feet above land surface; dip azimuth is given in degrees east of true north; strike is reported in right-hand-rule (RHR)-azimuthal degrees east of true north and where the direction of dip is 90 degrees to the right of strike]

\begin{tabular}{|c|c|c|c|c|c|c|c|}
\hline $\begin{array}{l}\text { Depth, } \\
\text { in feet }\end{array}$ & $\begin{array}{l}\text { Depth, } \\
\text { in meters }\end{array}$ & $\begin{array}{c}\text { Dip } \\
\text { azimuth }\end{array}$ & $\begin{array}{l}\text { Strike, } \\
\text { in RHR }\end{array}$ & Dip & $\begin{array}{c}\text { Dip } \\
\text { direction }\end{array}$ & Dip descriptor & Comment \\
\hline 22.46 & 6.85 & 5 & 275 & 0 & $\mathrm{~N}$ & Horizontal & Bottom of casing \\
\hline 23.31 & 7.10 & 349 & 259 & 9 & N & Nearly horizontal & $\begin{array}{l}\text { Transmissive, } \\
\text { not well defined fracture }\end{array}$ \\
\hline 23.32 & 7.11 & 72 & 342 & 62 & E & Steep & $\begin{array}{l}\text { Transmissive, } \\
\text { not well defined fracture }\end{array}$ \\
\hline 28.40 & 8.66 & 343 & 253 & 52 & $\mathrm{~N}$ & Steep & Lithologic feature \\
\hline 32.89 & 10.02 & 311 & 221 & 79 & NW & Nearly vertical & Minor fracture \\
\hline 44.35 & 13.52 & 82 & 352 & 81 & $\mathrm{E}$ & Nearly vertical & Minor fracture \\
\hline 48.08 & 14.65 & 77 & 347 & 11 & $E$ & Shallow & Minor fracture \\
\hline 55.49 & 16.91 & 86 & 356 & 51 & $E$ & Steep & Minor fracture \\
\hline 59.64 & 18.18 & 180 & 90 & 11 & $\bar{S}$ & Shallow & Lithologic feature \\
\hline 63.51 & 19.36 & 203 & 113 & 78 & SW & Nearly vertical & Minor fracture \\
\hline 69.03 & 21.04 & 166 & 76 & 18 & $\mathrm{~S}$ & Shallow & Lithologic feature \\
\hline 75.39 & 22.98 & 184 & 94 & 10 & S & Shallow & Lithologic feature \\
\hline 82.59 & 25.17 & 199 & 109 & 27 & S & Shallow & Transmissive fracture \\
\hline 84.12 & 25.64 & 168 & 78 & 14 & $\mathrm{~S}$ & Shallow & Lithologic feature \\
\hline 88.20 & 26.88 & 141 & 51 & 16 & SE & Shallow & Lithologic feature \\
\hline 92.15 & 28.09 & 225 & 135 & 86 & SW & Nearly vertical & Minor fracture \\
\hline 98.88 & 30.14 & 251 & 161 & 16 & w & Shallow & Minor fracture \\
\hline 99.04 & 30.19 & 222 & 132 & 32 & SW & Moderate & Lithologic feature \\
\hline 102.54 & 31.25 & 182 & 92 & 35 & $\mathrm{~S}$ & Moderate & Sealed feature \\
\hline 104.39 & 31.82 & 248 & 158 & 70 & W & Nearly vertical & Sealed feature \\
\hline 105.29 & 32.09 & 164 & 74 & 22 & $\mathrm{~S}$ & Shallow & Sealed feature \\
\hline
\end{tabular}




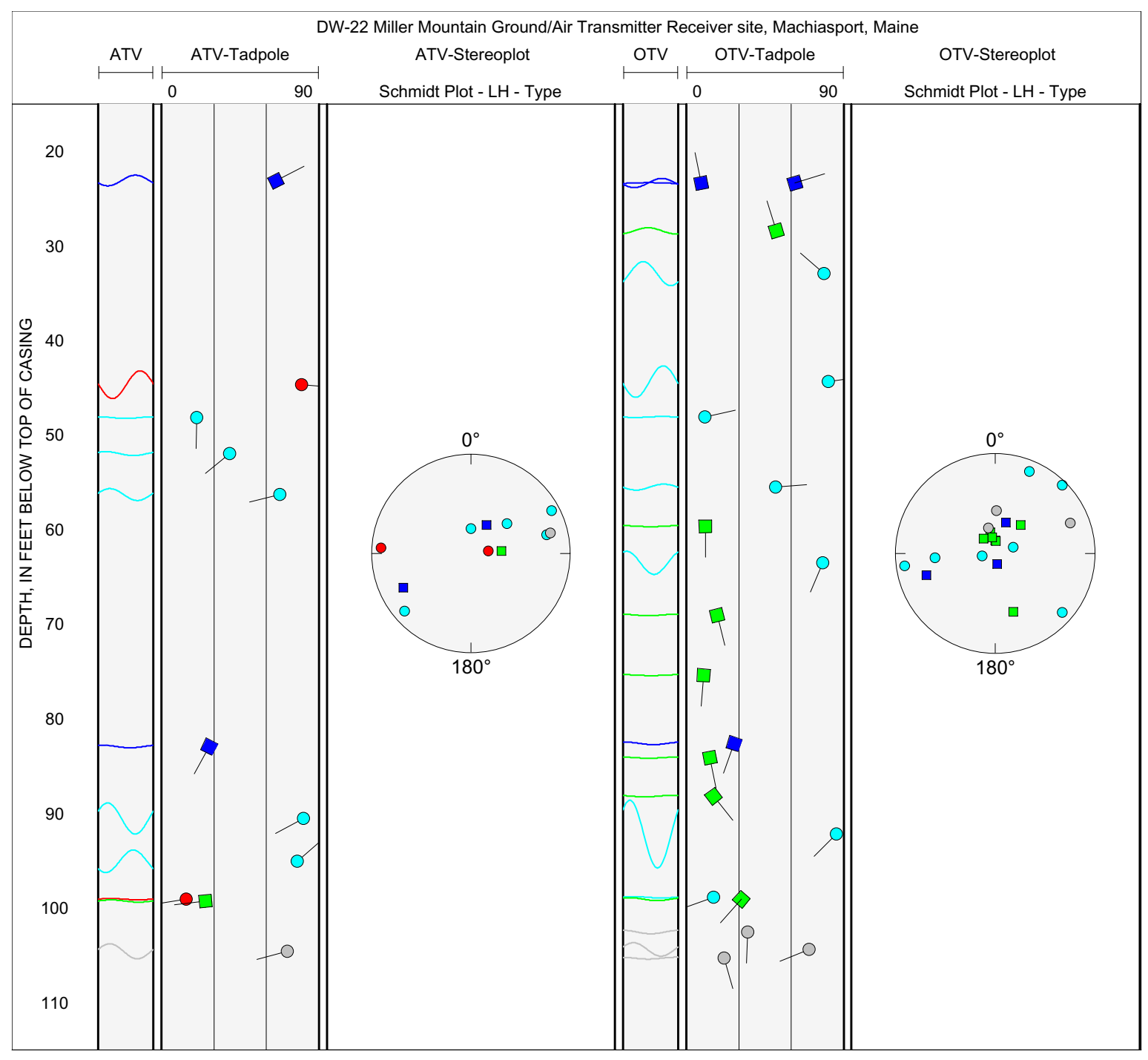

Figure 1B-3. Projection, tadpole, and stereoplots of interpretation of borehole image data for borehole DW-22, near Machiasport, Maine. 

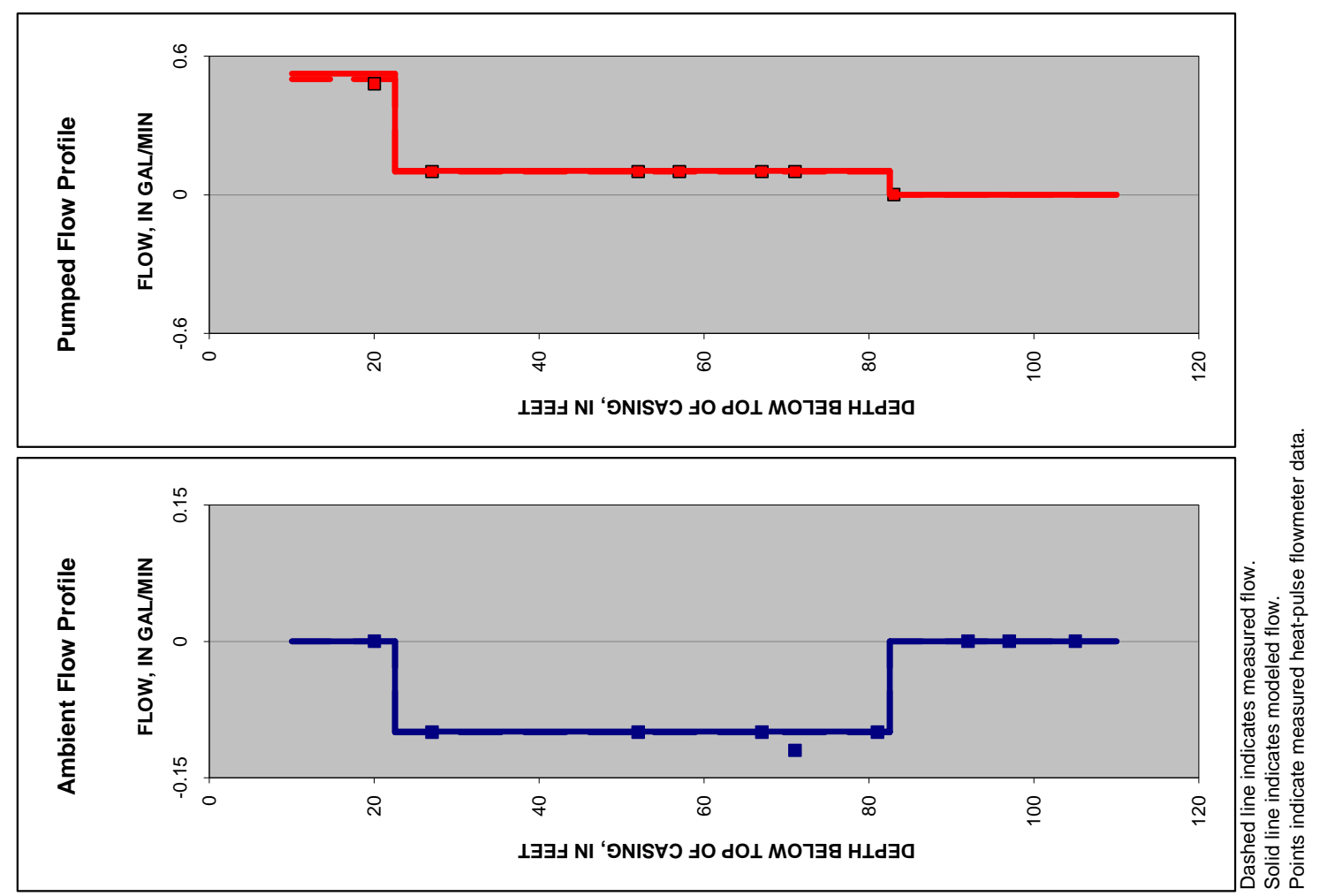

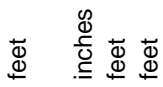
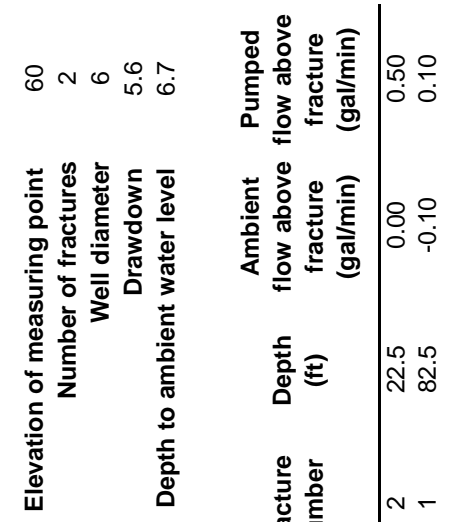

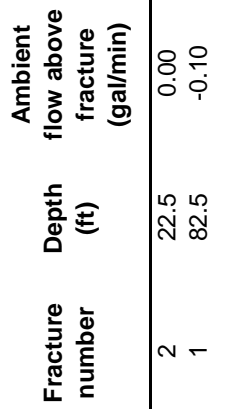

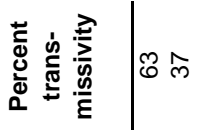

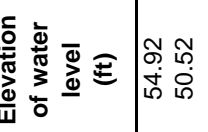

㐫

مீ

窵

\section{可}

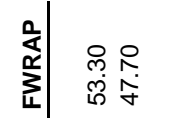

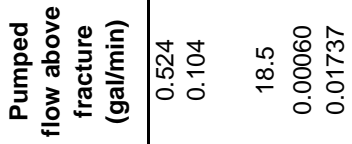

욤

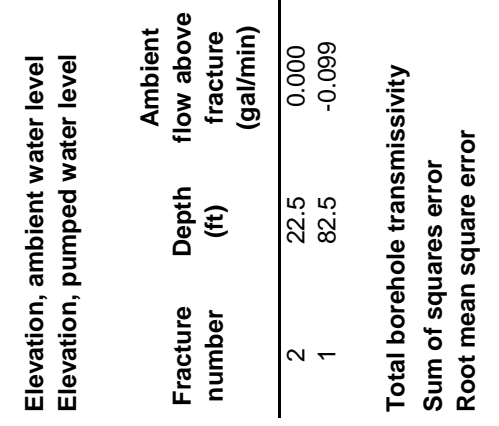




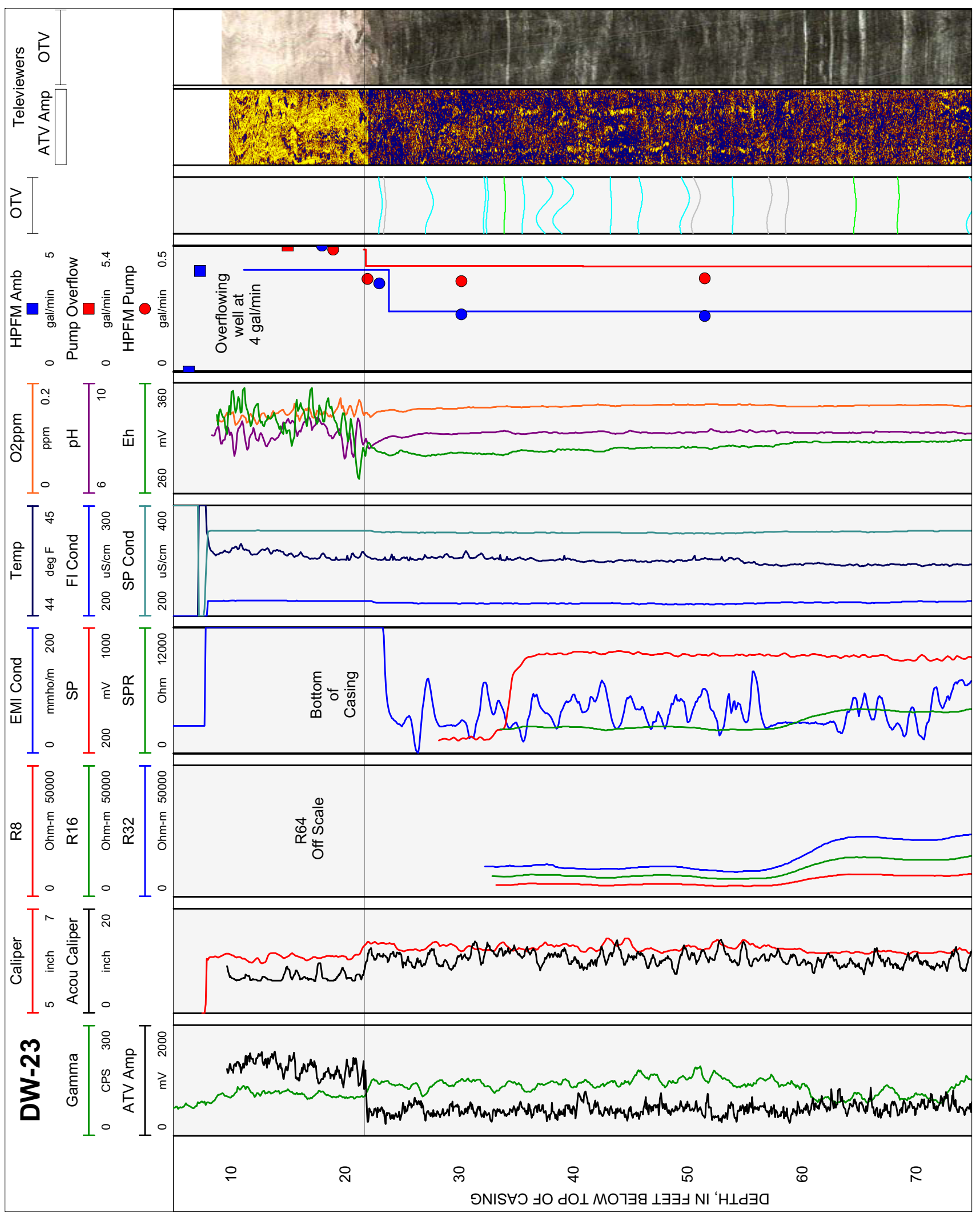

Figure 1C-1. Caliper, acoustic caliper, gamma, electromagnetic conductivity, fluid temperature, specific conductance, $\mathrm{DO}, \mathrm{pH}$, reduction oxidation, multi-space resistivity, oriented acoustic and optical borehole images, and heat-pulse flowmeter logs for borehole DW-23, near Machiasport, Maine. 


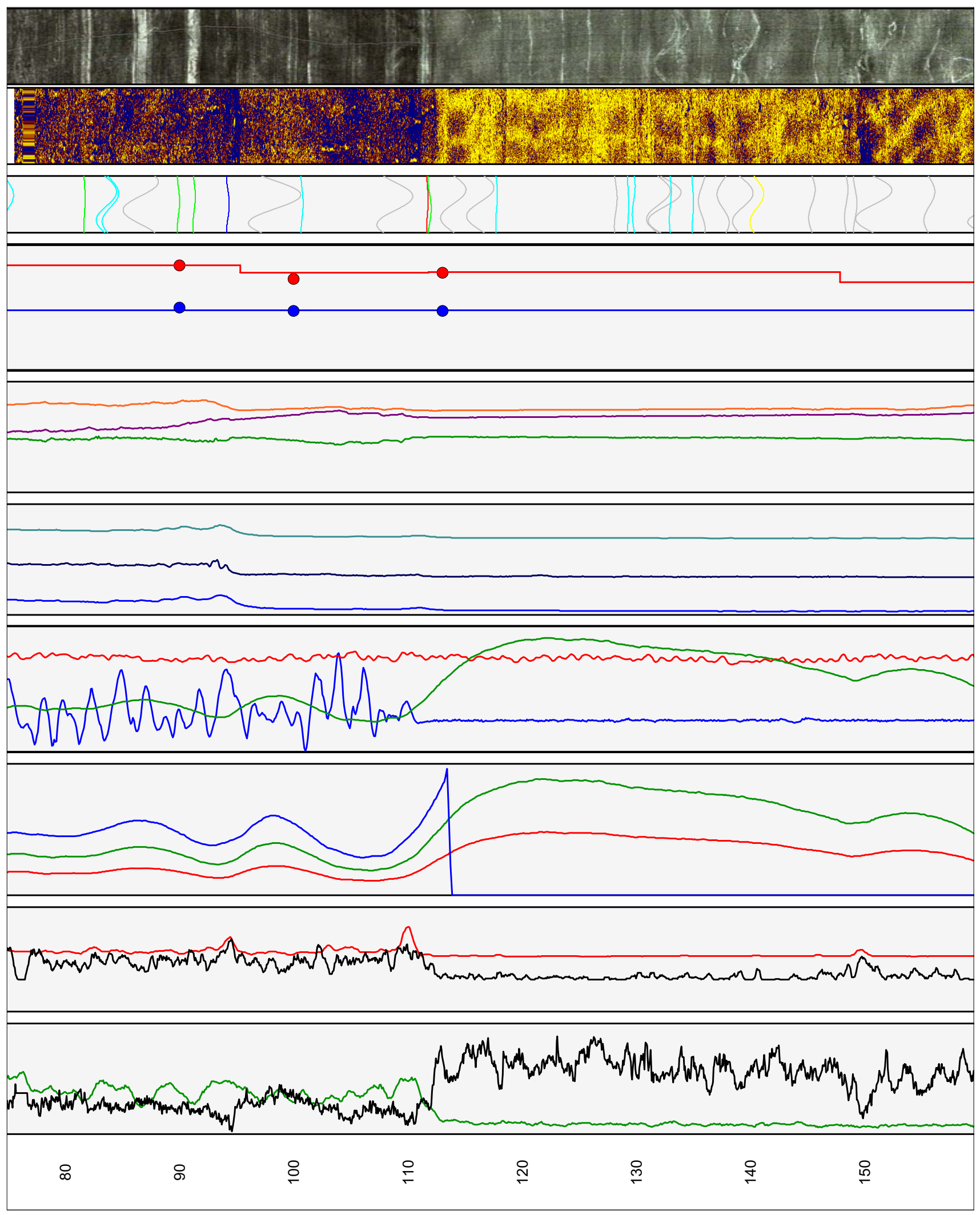

Figure 1C-1. Caliper, acoustic caliper, gamma, electromagnetic conductivity, fluid temperature, specific conductance, $\mathrm{DO}, \mathrm{pH}$, reduction oxidation, multi-space resistivity, oriented acoustic and optical borehole images, and heat-pulse flowmeter logs for borehole DW-23, near Machiasport, Maine.-Continued 


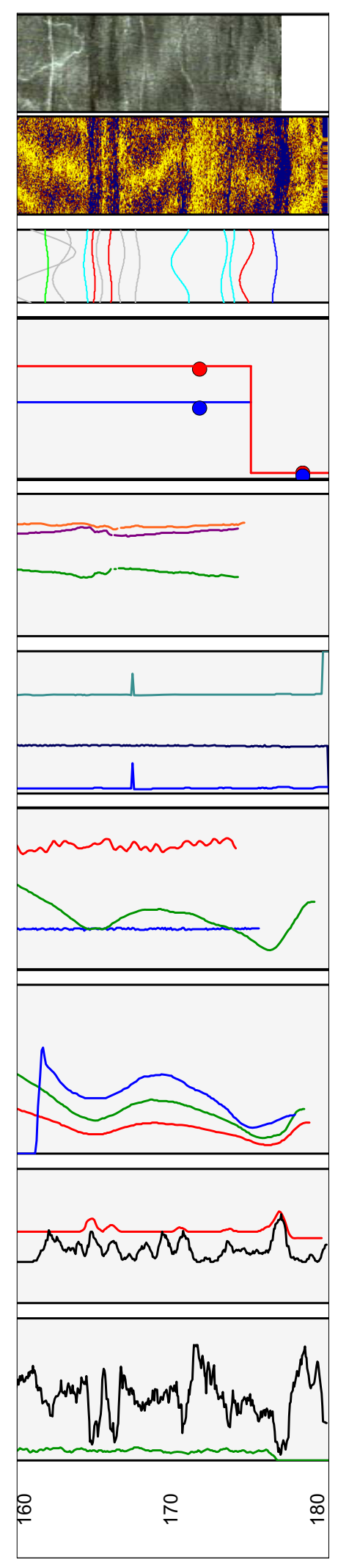

Figure 1C-1. Caliper, acoustic caliper, gamma, electromagnetic conductivity, fluid temperature, specific conductance, $\mathrm{DO}, \mathrm{pH}$, reduction oxidation, multi-space resistivity, oriented acoustic and optical borehole images, and heat-pulse flowmeter logs for borehole DW-23, near Machiasport, Maine.-Continued 

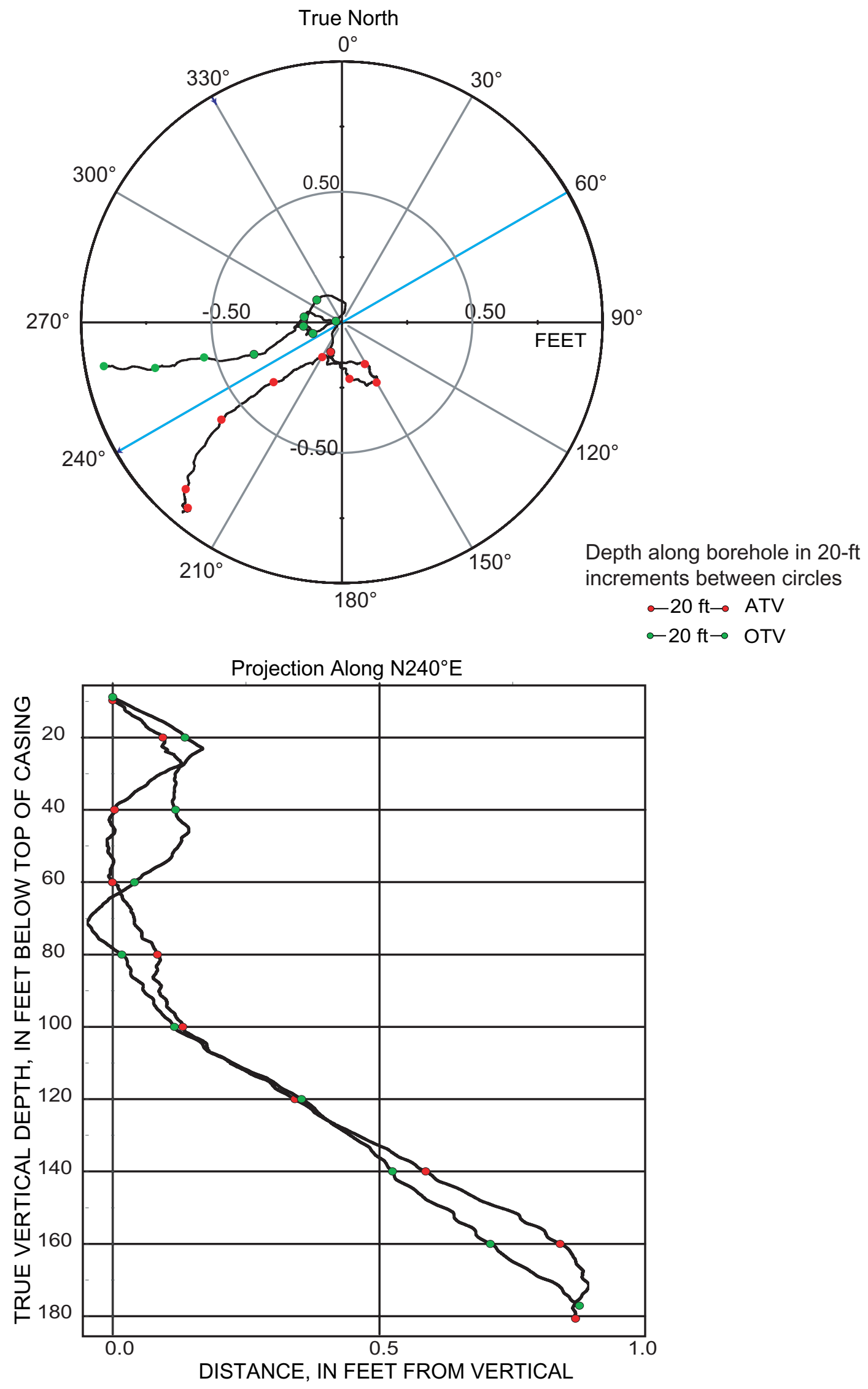

Figure 1C-2. Borehole deviation logs for borehole DW-23 near Machiasport, Maine. Blue line on radial plot (top) is line of projection for vertical plot (bottom).

[ft, foot; ATV, acoustic televiewer; OTV, optical televiewer] 
Table 1C-1. Interpretation of acoustic televiewer logs for borehole DW-23, near Machiasport, Maine.

[Televiewer data are corrected for deviation and magnetic declination, so orientations are relative to true north; depths are below top of casing, which is 1.95 feet above land surface; dip azimuth is given in degrees east of true north; strike is reported in right-hand-rule (RHR)-azimuthal degrees east of true north and where the direction of dip is 90 degrees to the right of strike]

\begin{tabular}{|c|c|c|c|c|c|c|c|}
\hline $\begin{array}{l}\text { Depth, } \\
\text { in feet }\end{array}$ & $\begin{array}{l}\text { Depth, } \\
\text { in meters }\end{array}$ & $\begin{array}{c}\text { Dip } \\
\text { azimuth }\end{array}$ & $\begin{array}{l}\text { Strike, } \\
\text { in RHR }\end{array}$ & Dip & $\begin{array}{c}\text { Dip } \\
\text { direction }\end{array}$ & Dip descriptor & Comment \\
\hline 23.09 & 7.04 & 184 & 94 & 31 & $\mathrm{~S}$ & Moderate & Minor fracture \\
\hline 23.50 & 7.16 & 183 & 93 & 18 & $\mathrm{~S}$ & Shallow & Fabric \\
\hline 27.37 & 8.34 & 195 & 105 & 54 & $\mathrm{~S}$ & Steep & Minor fracture \\
\hline 32.22 & 9.82 & 241 & 151 & 20 & SW & Shallow & Minor fracture \\
\hline 32.48 & 9.90 & 237 & 147 & 19 & SW & Shallow & Minor fracture \\
\hline 34.00 & 10.36 & 198 & 108 & 14 & $\mathrm{~s}$ & Shallow & Possible fracture \\
\hline 35.61 & 10.85 & 196 & 106 & 24 & $\mathrm{~S}$ & Shallow & Minor fracture \\
\hline 37.50 & 11.43 & 269 & 179 & 71 & W & Nearly vertical & Minor fracture \\
\hline 39.09 & 11.91 & 258 & 168 & 74 & W & Nearly vertical & Minor fracture \\
\hline 43.28 & 13.19 & 156 & 66 & 14 & SE & Shallow & Minor fracture \\
\hline 45.87 & 13.98 & 228 & 138 & 37 & SW & Moderate & Minor fracture \\
\hline 49.73 & 15.16 & 221 & 131 & 59 & SW & Steep & Minor fracture \\
\hline 50.71 & 15.46 & 229 & 139 & 56 & SW & Steep & Fabric \\
\hline 53.98 & 16.45 & 167 & 77 & 12 & $\mathrm{~S}$ & Shallow & Minor fracture \\
\hline 57.15 & 17.42 & 243 & 153 & 41 & SW & Moderate & Fabric \\
\hline 58.68 & 17.88 & 237 & 147 & 32 & SW & Moderate & Fabric \\
\hline 64.67 & 19.71 & 177 & 87 & 22 & $\mathrm{~S}$ & Shallow & Possible fracture \\
\hline 68.43 & 20.86 & 230 & 140 & 17 & sw & Shallow & Possible fracture \\
\hline 72.60 & 22.13 & 183 & 140 & 13 & SW & Shallow & Minor fracture \\
\hline 74.91 & 22.83 & 231 & 141 & 64 & SW & Steep & Minor fracture \\
\hline 81.67 & 24.89 & 210 & 120 & 12 & SW & Shallow & Possible fracture \\
\hline 83.58 & 25.47 & 254 & 164 & 74 & W & Nearly vertical & Minor fracture \\
\hline 83.95 & 25.59 & 245 & 155 & 71 & SW & Nearly vertical & Minor fracture \\
\hline 86.60 & 26.39 & 317 & 227 & 81 & NW & Nearly vertical & Fabric \\
\hline 89.91 & 27.40 & 192 & 102 & 22 & $\mathrm{~S}$ & Shallow & Possible fracture \\
\hline 91.27 & 27.82 & 224 & 134 & 22 & SW & Shallow & Possible fracture \\
\hline 94.22 & 28.72 & 175 & 85 & 25 & $\mathrm{~S}$ & Shallow & Minor fracture \\
\hline 98.31 & 29.96 & 235 & 145 & 84 & SW & Nearly vertical & Fabric \\
\hline 100.73 & 30.70 & 178 & 88 & 19 & $\mathrm{~S}$ & Shallow & Minor fracture \\
\hline 108.83 & 33.17 & 225 & 135 & 81 & SW & Nearly vertical & Fabric \\
\hline 111.69 & 34.04 & 202 & 112 & 13 & $\mathrm{~S}$ & Shallow & Fracture \\
\hline 111.88 & 34.10 & 147 & 57 & 29 & SE & Shallow & Possible fracture \\
\hline 113.94 & 34.73 & 268 & 178 & 77 & W & Nearly vertical & Fabric \\
\hline 116.33 & 35.46 & 280 & 190 & 78 & W & Nearly vertical & Fabric \\
\hline 117.77 & 35.89 & 232 & 142 & 16 & SW & Shallow & Minor fracture \\
\hline 128.20 & 39.07 & 214 & 124 & 26 & SW & Shallow & Fabric \\
\hline 129.27 & 39.40 & 172 & 82 & 11 & $\mathrm{~s}$ & Shallow & Minor fracture \\
\hline 129.75 & 39.55 & 290 & 200 & 26 & W & Shallow & Minor fracture \\
\hline 131.94 & 40.21 & 260 & 170 & 76 & W & Nearly vertical & Fabric \\
\hline 132.47 & 40.37 & 249 & 159 & 80 & W & Nearly vertical & Fabric \\
\hline 132.93 & 40.52 & 257 & 167 & 18 & W & Shallow & Minor fracture \\
\hline 134.94 & 41.13 & 182 & 92 & 14 & $\mathrm{~S}$ & Shallow & Minor fracture \\
\hline 135.69 & 41.36 & 16 & 286 & 49 & $\mathrm{~N}$ & Moderate & Fabric \\
\hline 137.59 & 41.94 & 57 & 327 & 64 & NE & Steep & Fabric \\
\hline 139.31 & 42.46 & 246 & 156 & 74 & SW & Nearly vertical & Fabric \\
\hline 140.55 & 42.84 & 240 & 150 & 67 & SW & Steep & Lithologic feature \\
\hline 145.34 & 44.30 & 268 & 178 & 48 & W & Moderate & Fabric \\
\hline 148.35 & 45.21 & 268 & 178 & 30 & W & Moderate & Fabric \\
\hline 149.14 & 45.46 & 178 & 88 & 31 & $\mathrm{~S}$ & Moderate & Fabric \\
\hline 150.77 & 45.95 & 263 & 173 & 81 & W & Nearly vertical & Fabric \\
\hline 155.65 & 47.44 & 254 & 164 & 62 & W & Steep & Fabric \\
\hline 161.24 & 49.14 & 243 & 153 & 84 & SW & Nearly vertical & Fabric \\
\hline 161.56 & 49.24 & 172 & 82 & 23 & $\mathrm{~S}$ & Shallow & Possible fracture \\
\hline 162.58 & 49.55 & 289 & 199 & 68 & W & Steep & Fabric \\
\hline
\end{tabular}


Table 1C-1. Interpretation of acoustic televiewer logs for borehole DW-23, near Machiasport, Maine.-Continued [Televiewer data are corrected for deviation and magnetic declination, so orientations are relative to true north; depths are below top of casing, which is 1.95 feet above land surface; dip azimuth is given in degrees east of true north; strike is reported in right-hand-rule (RHR)-azimuthal degrees east of true north and where the direction of dip is 90 degrees to the right of strike]

\begin{tabular}{crrrrcrl}
\hline $\begin{array}{c}\text { Depth, } \\
\text { in feet }\end{array}$ & $\begin{array}{c}\text { Depth, } \\
\text { in meters }\end{array}$ & $\begin{array}{c}\text { Dip } \\
\text { azimuth }\end{array}$ & $\begin{array}{c}\text { Strike, } \\
\text { in RHR }\end{array}$ & Dip & $\begin{array}{c}\text { Dip } \\
\text { direction }\end{array}$ & Dip descriptor & Comment \\
\hline 164.22 & 50.05 & 0 & 270 & 27 & $\mathrm{~N}$ & Shallow & Minor fracture \\
164.72 & 50.20 & 87 & 357 & 21 & $\mathrm{E}$ & Shallow & Fracture \\
165.15 & 50.34 & 72 & 342 & 40 & $\mathrm{E}$ & Moderate & Fabric \\
165.86 & 50.55 & 50 & 320 & 24 & $\mathrm{NE}$ & Shallow & Fracture \\
166.68 & 50.80 & 241 & 151 & 38 & $\mathrm{SW}$ & Moderate & Fabric \\
167.75 & 51.13 & 195 & 105 & 30 & $\mathrm{~S}$ & Moderate & Fabric \\
170.64 & 52.01 & 15 & 285 & 67 & $\mathrm{~N}$ & Steep & Minor fracture \\
173.66 & 52.93 & 259 & 169 & 40 & $\mathrm{~W}$ & Moderate & Minor fracture \\
174.20 & 53.09 & 339 & 249 & 31 & $\mathrm{~N}$ & Moderate & Minor fracture \\
175.16 & 53.39 & 285 & 195 & 62 & $\mathrm{~W}$ & Steep & Fracture \\
177.12 & 53.98 & 189 & 99 & 30 & $\mathrm{~S}$ & Moderate & Transmissive fracture \\
\hline
\end{tabular}


Table 1C-2. Interpretation of optical televiewer logs for borehole DW-23, near Machiasport, Maine.

[Televiewer data are corrected for deviation and magnetic declination, so orientations are relative to true north; depths are below top of casing, which is 1.95 feet above land surface; dip azimuth is given in degrees east of true north; strike is reported in right-hand-rule (RHR)-azimuthal degrees east of true north and where the direction of dip is 90 degrees to the right of strike]

\begin{tabular}{|c|c|c|c|c|c|c|c|}
\hline $\begin{array}{l}\text { Depth, } \\
\text { in feet }\end{array}$ & $\begin{array}{l}\text { Depth, } \\
\text { in meters }\end{array}$ & $\begin{array}{c}\text { Dip } \\
\text { azimuth }\end{array}$ & $\begin{array}{l}\text { Strike, } \\
\text { in RHR }\end{array}$ & Dip & $\begin{array}{c}\text { Dip } \\
\text { direction }\end{array}$ & Dip descriptor & Comment \\
\hline 23.09 & 7.04 & 184 & 94 & 31 & $\mathrm{~S}$ & Moderate & Minor fracture \\
\hline 23.50 & 7.16 & 183 & 93 & 18 & $\mathrm{~s}$ & Shallow & Fabric or foliation \\
\hline 27.37 & 8.34 & 195 & 105 & 54 & $\mathrm{~S}$ & Steep & Minor fracture \\
\hline 32.22 & 9.82 & 241 & 151 & 20 & SW & Shallow & Minor fracture \\
\hline 32.48 & 9.90 & 237 & 147 & 19 & SW & Shallow & Minor fracture \\
\hline 34.00 & 10.36 & 198 & 108 & 14 & $\mathrm{~S}$ & Shallow & Possible fracture \\
\hline 35.61 & 10.85 & 196 & 106 & 24 & $\mathrm{~S}$ & Shallow & Minor fracture \\
\hline 37.50 & 11.43 & 269 & 179 & 71 & W & Nearly vertical & Minor fracture \\
\hline 39.09 & 11.91 & 258 & 168 & 74 & W & Nearly vertical & Minor fracture \\
\hline 43.28 & 13.19 & 156 & 66 & 14 & SE & Shallow & Minor fracture \\
\hline 45.87 & 13.98 & 228 & 138 & 37 & SW & Moderate & Minor fracture \\
\hline 49.73 & 15.16 & 221 & 131 & 59 & SW & Steep & Minor fracture \\
\hline 50.71 & 15.46 & 229 & 139 & 56 & SW & Steep & Fabric or foliation \\
\hline 53.98 & 16.45 & 167 & 77 & 12 & $\mathrm{~S}$ & Shallow & Minor fracture \\
\hline 57.15 & 17.42 & 243 & 153 & 41 & SW & Moderate & Fabric or foliation \\
\hline 58.68 & 17.88 & 237 & 147 & 32 & SW & Moderate & Fabric or foliation \\
\hline 64.67 & 19.71 & 177 & 87 & 22 & $\mathrm{~S}$ & Shallow & Possible fracture \\
\hline 68.43 & 20.86 & 230 & 140 & 17 & SW & Shallow & Possible fracture \\
\hline 74.91 & 22.83 & 231 & 141 & 64 & SW & Steep & Minor fracture \\
\hline 81.67 & 24.89 & 210 & 120 & 12 & SW & Shallow & Possible fracture \\
\hline 83.58 & 25.47 & 254 & 164 & 74 & W & Nearly vertical & Minor fracture \\
\hline 83.95 & 25.59 & 245 & 155 & 71 & sw & Nearly vertical & Minor fracture \\
\hline 86.60 & 26.39 & 317 & 227 & 81 & NW & Nearly vertical & Fabric or foliation \\
\hline 89.91 & 27.40 & 192 & 102 & 22 & $\mathrm{~S}$ & Shallow & Possible fracture \\
\hline 91.27 & 27.82 & 224 & 134 & 22 & sw & Shallow & Possible fracture \\
\hline 94.22 & 28.72 & 175 & 85 & 25 & $\mathrm{~S}$ & Shallow & Minor fracture \\
\hline 98.31 & 29.96 & 235 & 145 & 84 & sw & Nearly vertical & Fabric or foliation \\
\hline 100.73 & 30.70 & 178 & 88 & 19 & $\mathrm{~S}$ & Shallow & Minor fracture \\
\hline 108.83 & 33.17 & 225 & 135 & 81 & SW & Nearly vertical & Fabric or foliation \\
\hline 111.69 & 34.04 & 202 & 112 & 13 & $\mathrm{~S}$ & Shallow & Fracture \\
\hline 111.88 & 34.10 & 147 & 57 & 29 & SE & Shallow & Possible fracture \\
\hline 113.94 & 34.73 & 268 & 178 & 77 & W & Nearly vertical & Fabric or foliation \\
\hline 116.33 & 35.46 & 280 & 190 & 78 & W & Nearly vertical & Fabric or foliation \\
\hline 117.77 & 35.89 & 232 & 142 & 16 & SW & Shallow & Minor fracture \\
\hline 128.20 & 39.07 & 214 & 124 & 26 & SW & Shallow & Fabric or foliation \\
\hline 129.27 & 39.40 & 172 & 82 & 11 & $\mathrm{~S}$ & Shallow & Minor fracture \\
\hline 129.75 & 39.55 & 290 & 200 & 26 & W & Shallow & Minor fracture \\
\hline 131.94 & 40.21 & 260 & 170 & 76 & W & Nearly vertical & Fabric or foliation \\
\hline 132.47 & 40.37 & 249 & 159 & 80 & W & Nearly vertical & Fabric or foliation \\
\hline 132.93 & 40.52 & 257 & 167 & 18 & W & Shallow & Minor fracture \\
\hline 134.94 & 41.13 & 182 & 92 & 14 & $\mathrm{~S}$ & Shallow & Minor fracture \\
\hline 135.69 & 41.36 & 16 & 286 & 49 & $\mathrm{~N}$ & Moderate & Fabric or foliation \\
\hline 137.59 & 41.94 & 57 & 327 & 64 & $\mathrm{NE}$ & Steep & Fabric or foliation \\
\hline 139.31 & 42.46 & 246 & 156 & 74 & SW & Nearly vertical & Fabric or foliation \\
\hline 140.55 & 42.84 & 240 & 150 & 67 & SW & Steep & Lithologic feature \\
\hline 145.34 & 44.30 & 268 & 178 & 48 & W & Moderate & Fabric or foliation \\
\hline 148.35 & 45.21 & 268 & 178 & 30 & W & Moderate & Fabric or foliation \\
\hline 149.14 & 45.46 & 178 & 88 & 31 & $\mathrm{~S}$ & Moderate & Fabric or foliation \\
\hline 150.77 & 45.95 & 263 & 173 & 81 & W & Nearly vertical & Fabric or foliation \\
\hline 155.65 & 47.44 & 254 & 164 & 62 & W & Steep & Fabric or foliation \\
\hline 161.24 & 49.14 & 243 & 153 & 84 & SW & Nearly vertical & Fabric or foliation \\
\hline 161.56 & 49.24 & 172 & 82 & 23 & $\mathrm{~s}$ & Shallow & Possible fracture \\
\hline 162.58 & 49.55 & 289 & 199 & 68 & W & Steep & Fabric or foliation \\
\hline
\end{tabular}


Table 1C-2. Interpretation of optical televiewer logs for borehole DW-23, near Machiasport, Maine.-Continued [Televiewer data are corrected for deviation and magnetic declination, so orientations are relative to true north; depths are below top of casing, which is 1.95 feet above land surface; dip azimuth is given in degrees east of true north; strike is reported in right-hand-rule (RHR)-azimuthal degrees east of true north and where the direction of dip is 90 degrees to the right of strike]

\begin{tabular}{crrrrcrl}
\hline $\begin{array}{c}\text { Depth, } \\
\text { in feet }\end{array}$ & $\begin{array}{c}\text { Depth, } \\
\text { in meters }\end{array}$ & $\begin{array}{c}\text { Dip } \\
\text { azimuth }\end{array}$ & $\begin{array}{c}\text { Strike, } \\
\text { in RHR }\end{array}$ & Dip & $\begin{array}{c}\text { Dip } \\
\text { direction }\end{array}$ & Dip descriptor & Comment \\
\hline 164.22 & 50.05 & 0 & 270 & 27 & $\mathrm{~N}$ & Shallow & Minor fracture \\
164.72 & 50.20 & 87 & 357 & 21 & $\mathrm{E}$ & Shallow & Fracture \\
165.15 & 50.34 & 72 & 342 & 40 & $\mathrm{E}$ & Moderate & Fabric or foliation \\
165.86 & 50.55 & 50 & 320 & 24 & $\mathrm{NE}$ & Shallow & Fracture \\
166.68 & 50.80 & 241 & 151 & 38 & $\mathrm{SW}$ & Moderate & Fabric or foliation \\
167.75 & 51.13 & 195 & 105 & 30 & $\mathrm{~S}$ & Moderate & Fabric or foliation \\
170.64 & 52.01 & 15 & 285 & 67 & $\mathrm{~N}$ & Steep & Minor fracture \\
173.66 & 52.93 & 259 & 169 & 40 & $\mathrm{~W}$ & Moderate & Minor fracture \\
174.20 & 53.09 & 339 & 249 & 31 & $\mathrm{~N}$ & Moderate & Minor fracture \\
175.16 & 53.39 & 285 & 195 & 62 & $\mathrm{~W}$ & Steep & Fracture \\
177.12 & 53.98 & 189 & 99 & 30 & $\mathrm{~S}$ & Moderate & Transmissive fracture \\
\hline
\end{tabular}




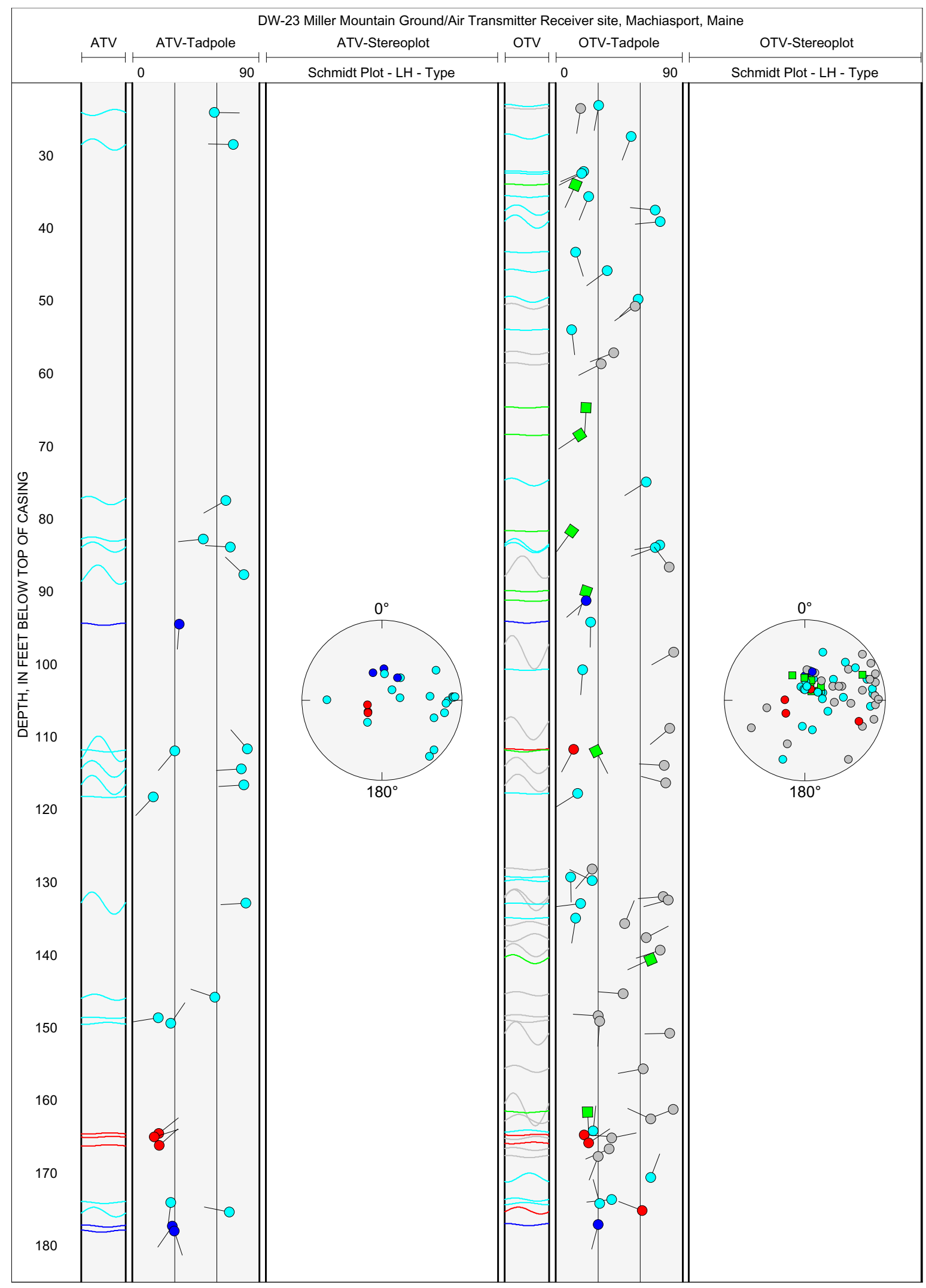

Figure 1C-3. Projection, tadpole, and stereoplots of interpretation of borehole image data for borehole DW-23, near Machiasport, Maine. 

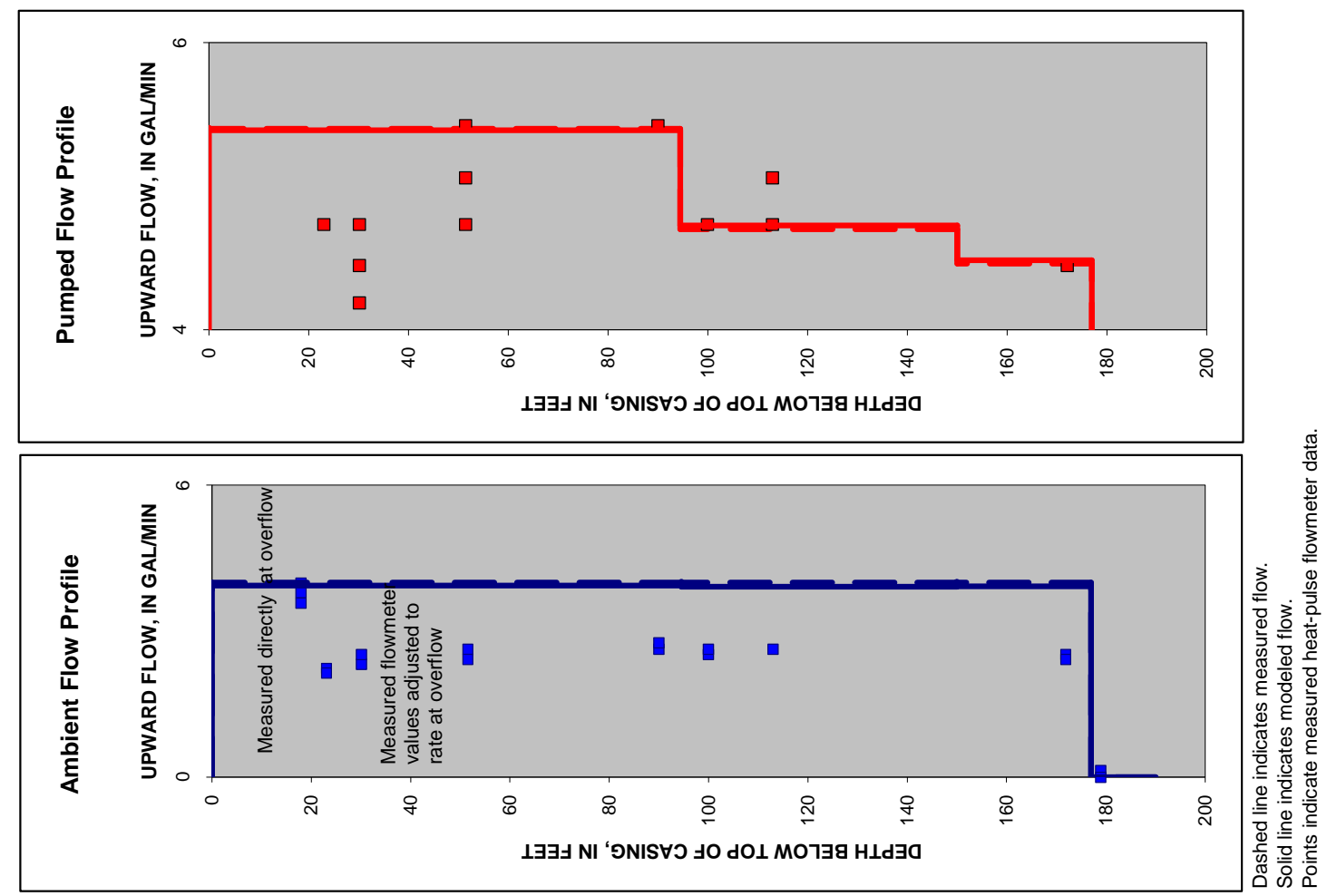

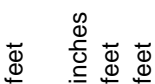

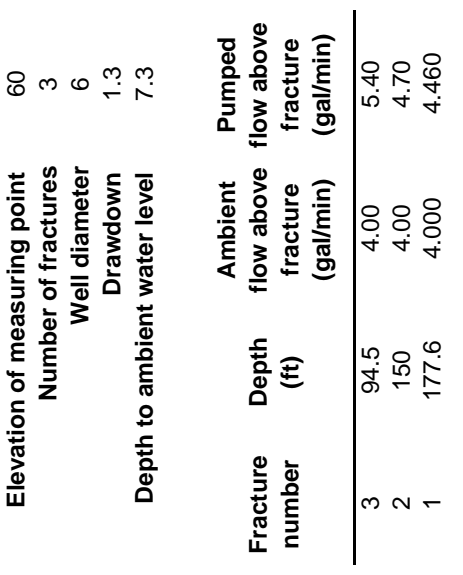

苞的竞

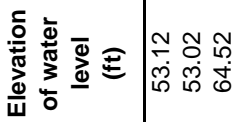

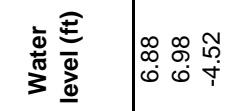

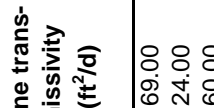

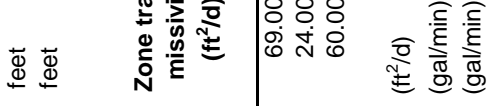

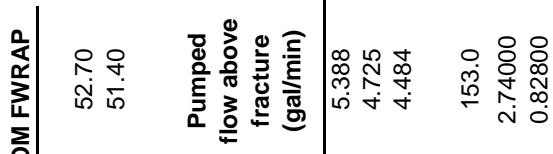

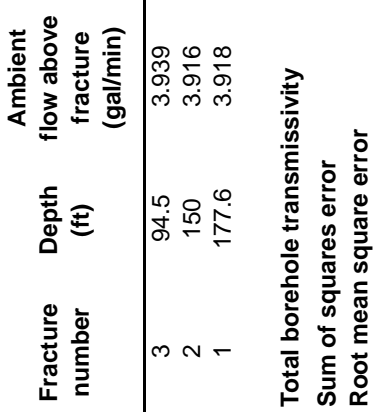

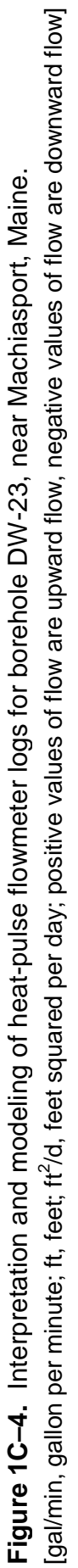




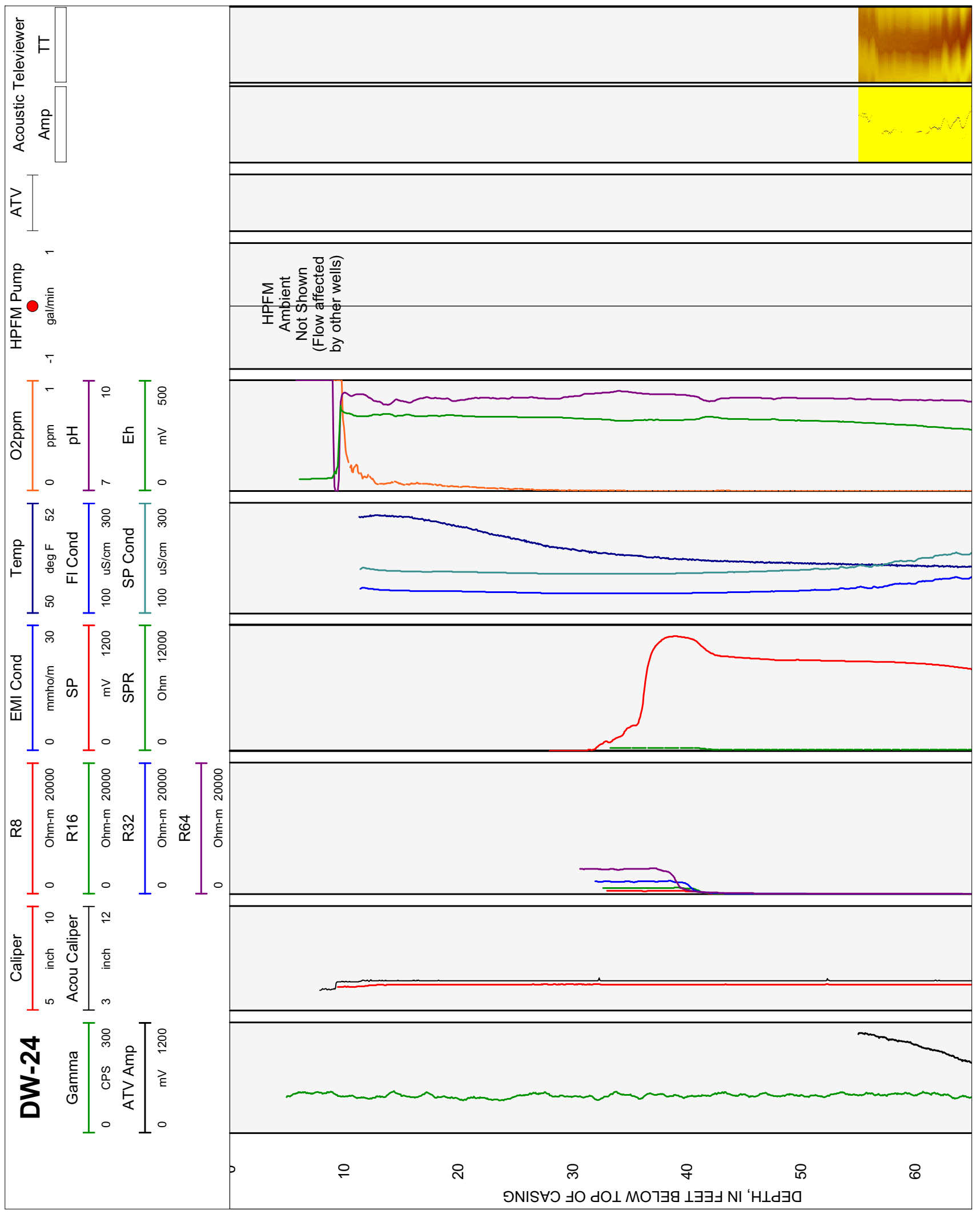

Figure 1D-1. Caliper, acoustic caliper, gamma, electromagnetic conductivity, fluid temperature, specific conductance, $\mathrm{DO}, \mathrm{pH}$, reduction oxidation, multi-space resistivity, oriented acoustic and optical borehole images, and heat-pulse flowmeter logs for borehole DW-24, near Machiasport, Maine. 


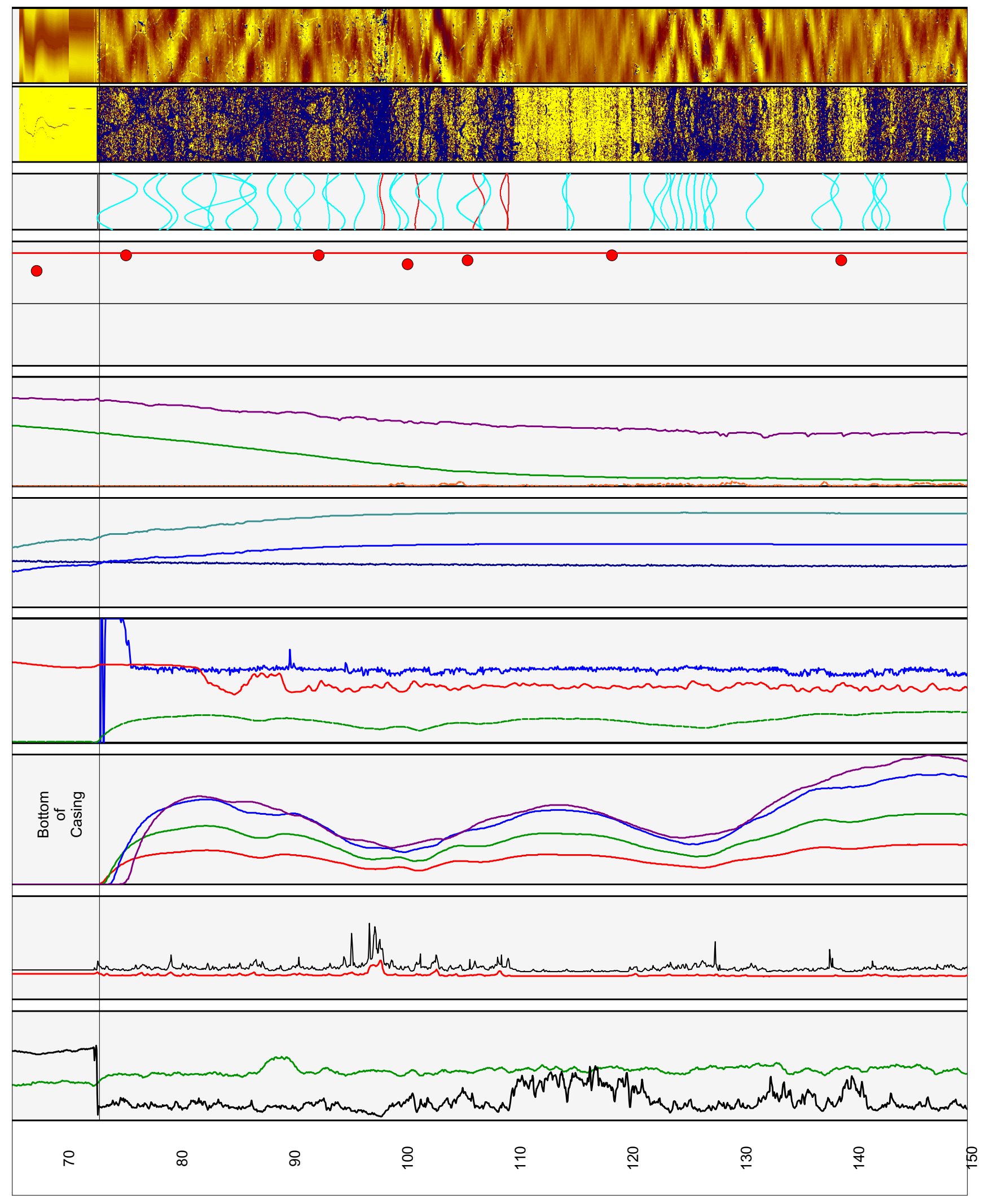

Figure 1D-1. Caliper, acoustic caliper, gamma, electromagnetic conductivity, fluid temperature, specific conductance, $\mathrm{DO}, \mathrm{pH}$, reduction oxidation, multi-space resistivity, oriented acoustic and optical borehole images, and heat-pulse flowmeter logs for borehole DW-24, near Machiasport, Maine.-Continued 


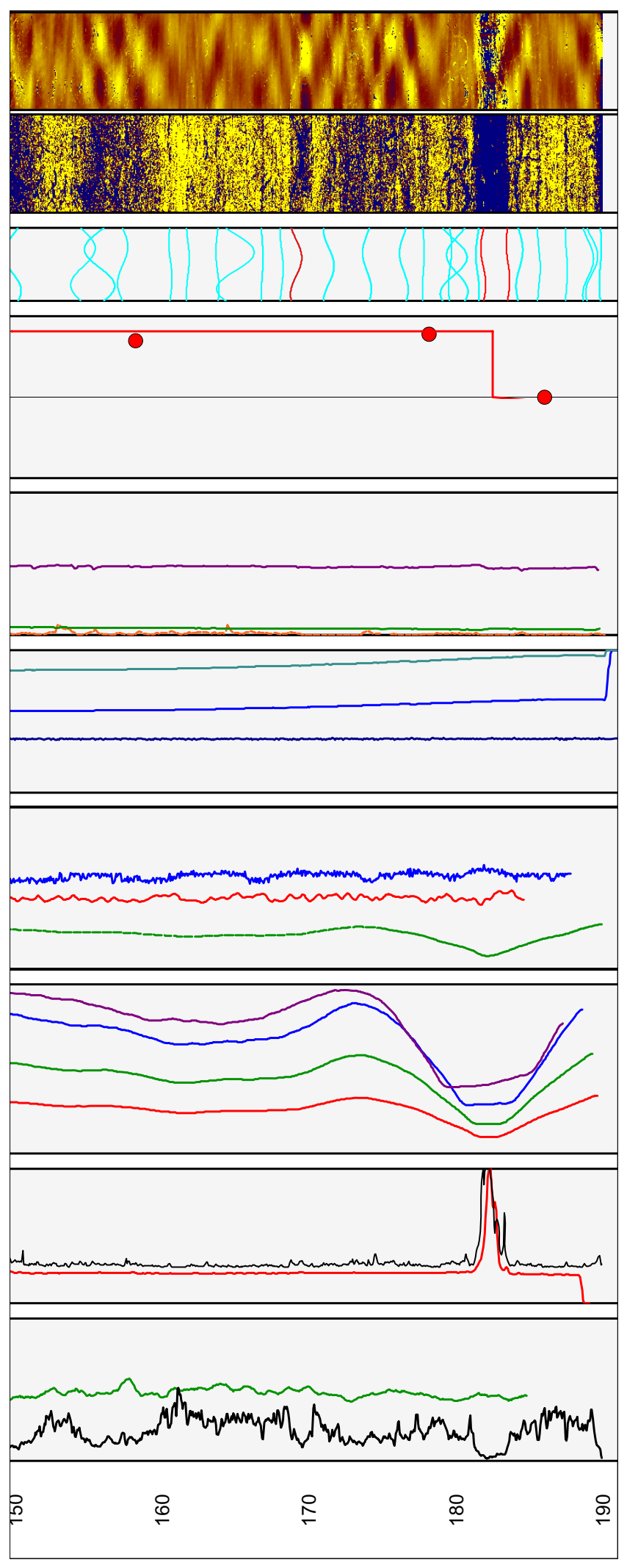

Figure 1D-1. Caliper, acoustic caliper, gamma, electromagnetic conductivity, fluid temperature, specific conductance, $\mathrm{DO}, \mathrm{pH}$, reduction oxidation, multi-space resistivity, oriented acoustic and optical borehole images, and heat-pulse flowmeter logs for borehole DW-24, near Machiasport, Maine.-Continued 

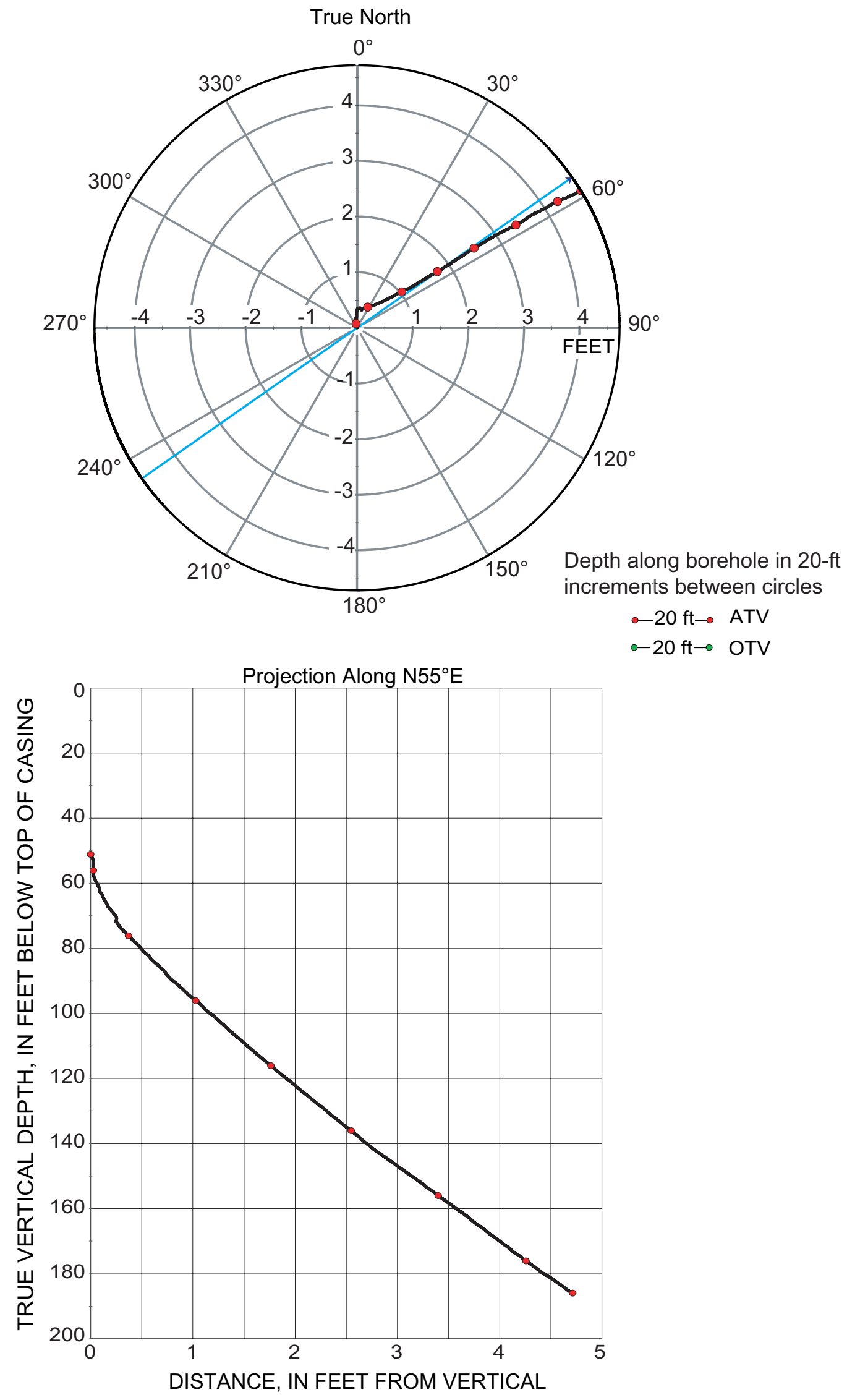

Figure 1D-2. Borehole deviation logs for borehole DW-24, near Machiasport, Maine. Blue line on radial plot (top) is line of projection for vertical plot (bottom).

[ft, foot; ATV, acoustic televiewer; OTV, optical televiewer] 
Table 1D-1. Interpretation of acoustic televiewer logs for borehole DW-24, near Machiasport, Maine.

[Televiewer data are corrected for deviation and magnetic declination, so orientations are relative to true north; depths are below top of casing, which is 1.52 feet above land surface; dip azimuth is given in degrees east of true north; strike is reported in right-hand-rule (RHR)-azimuthal degrees east of true north and where the direction of dip is 90 degrees to the right of strike]

\begin{tabular}{|c|c|c|c|c|c|c|c|}
\hline $\begin{array}{l}\text { Depth, } \\
\text { in feet }\end{array}$ & $\begin{array}{l}\text { Depth, } \\
\text { in meters }\end{array}$ & $\begin{array}{c}\text { Dip } \\
\text { azimuth }\end{array}$ & $\begin{array}{c}\text { Strike, } \\
\text { in RHR }\end{array}$ & Dip & $\begin{array}{c}\text { Dip } \\
\text { direction }\end{array}$ & Dip descriptor & Comment \\
\hline 72.53 & 22.11 & 0 & 270 & 0 & $\mathrm{~N}$ & Horizontal & Foliation \\
\hline 74.28 & 22.64 & 256 & 166 & 82 & W & Nearly vertical & Minor fracture \\
\hline 77.85 & 23.73 & 83 & 353 & 78 & $E$ & Nearly vertical & Minor fracture \\
\hline 78.68 & 23.98 & 88 & 358 & 75 & E & Nearly vertical & Minor fracture \\
\hline 81.38 & 24.80 & 71 & 341 & 80 & $E$ & Nearly vertical & Minor fracture \\
\hline 82.70 & 25.21 & 273 & 183 & 55 & W & Steep & Minor fracture \\
\hline 83.42 & 25.43 & 259 & 169 & 85 & W & Nearly vertical & Minor fracture \\
\hline 85.22 & 25.97 & 234 & 144 & 79 & SW & Nearly vertical & Minor fracture \\
\hline 85.91 & 26.18 & 67 & 337 & 72 & NE & Nearly vertical & Minor fracture \\
\hline 88.17 & 26.87 & 69 & 339 & 68 & $E$ & Steep & Minor fracture \\
\hline 89.80 & 27.37 & 74 & 344 & 69 & $E$ & Steep & Minor fracture \\
\hline 90.83 & 27.68 & 259 & 169 & 74 & $\bar{W}$ & Nearly vertical & Minor fracture \\
\hline 92.92 & 28.32 & 68 & 338 & 30 & $\mathrm{E}$ & Shallow & Minor fracture \\
\hline 93.44 & 28.48 & 56 & 326 & 76 & NE & Nearly vertical & Minor fracture \\
\hline 95.73 & 29.18 & 207 & 117 & 60 & SW & Steep & Minor fracture \\
\hline 97.74 & 29.79 & 65 & 335 & 40 & $\mathrm{NE}$ & Moderate & Fracture \\
\hline 98.89 & 30.14 & 55 & 325 & 61 & NE & Steep & Minor fracture \\
\hline 99.26 & 30.25 & 61 & 331 & 72 & NE & Nearly vertical & Minor fracture \\
\hline 100.84 & 30.73 & 214 & 124 & 34 & SW & Moderate & Fracture \\
\hline 101.64 & 30.98 & 65 & 335 & 74 & $\mathrm{NE}$ & Nearly vertical & Minor fracture \\
\hline 102.91 & 31.37 & 47 & 317 & 46 & NE & Moderate & Minor fracture \\
\hline 105.61 & 32.19 & 329 & 239 & 78 & NW & Nearly vertical & Minor fracture \\
\hline 106.32 & 32.40 & 176 & 86 & 63 & $\mathrm{~S}$ & Steep & Fracture \\
\hline 106.86 & 32.57 & 247 & 157 & 64 & SW & Steep & Minor fracture \\
\hline 108.56 & 33.09 & 56 & 326 & 54 & $\mathrm{NE}$ & Steep & Fracture \\
\hline 108.88 & 33.19 & 232 & 142 & 15 & SW & Shallow & Fracture \\
\hline 114.12 & 34.78 & 74 & 344 & 12 & $\mathrm{E}$ & Shallow & Minor fracture \\
\hline 114.20 & 34.81 & 67 & 337 & 63 & NE & Steep & Minor fracture \\
\hline 119.73 & 36.49 & 205 & 115 & 6 & SW & Nearly horizontal & Minor fracture \\
\hline 121.40 & 37.00 & 85 & 355 & 61 & $\mathrm{E}$ & Steep & Minor fracture \\
\hline 122.38 & 37.30 & 326 & 236 & 68 & NW & Steep & Minor fracture \\
\hline 122.88 & 37.45 & 318 & 228 & 59 & NW & Steep & Minor fracture \\
\hline 123.59 & 37.67 & 59 & 329 & 49 & $\mathrm{NE}$ & Moderate & Minor fracture \\
\hline 124.20 & 37.85 & 55 & 325 & 42 & $\mathrm{NE}$ & Moderate & Minor fracture \\
\hline 124.94 & 38.08 & 72 & 342 & 46 & $E$ & Moderate & Minor fracture \\
\hline 125.49 & 38.25 & 57 & 327 & 25 & $\mathrm{NE}$ & Shallow & Minor fracture \\
\hline 126.22 & 38.47 & 51 & 321 & 40 & NE & Moderate & Minor fracture \\
\hline 126.82 & 38.65 & 59 & 329 & 48 & $\mathrm{NE}$ & Moderate & Minor fracture \\
\hline 126.83 & 38.66 & 254 & 164 & 66 & W & Steep & Minor fracture \\
\hline 130.74 & 39.85 & 273 & 183 & 71 & W & Nearly vertical & Minor fracture \\
\hline 137.02 & 41.76 & 258 & 168 & 78 & W & Nearly vertical & Minor fracture \\
\hline 138.00 & 42.06 & 54 & 324 & 62 & NE & Steep & Minor fracture \\
\hline 140.82 & 42.92 & 230 & 140 & 64 & SW & Steep & Minor fracture \\
\hline 141.62 & 43.16 & 70 & 340 & 57 & $\mathrm{E}$ & Steep & Minor fracture \\
\hline 141.78 & 43.21 & 270 & 180 & 69 & $\bar{W}$ & Steep & Minor fracture \\
\hline 142.08 & 43.30 & 74 & 344 & 69 & $\mathrm{E}$ & Steep & Minor fracture \\
\hline 147.82 & 45.05 & 236 & 146 & 49 & SW & Moderate & Minor fracture \\
\hline 149.75 & 45.64 & 50 & 320 & 67 & $\mathrm{NE}$ & Steep & Minor fracture \\
\hline 154.58 & 47.11 & 259 & 169 & 73 & W & Nearly vertical & Minor fracture \\
\hline 155.70 & 47.46 & 74 & 344 & 76 & $\mathrm{E}$ & Nearly vertical & Minor fracture \\
\hline 157.29 & 47.94 & 267 & 177 & 54 & W & Steep & Minor fracture \\
\hline 160.53 & 48.93 & 109 & 19 & 24 & $\mathrm{E}$ & Shallow & Minor fracture \\
\hline 161.71 & 49.29 & 209 & 119 & 21 & SW & Shallow & Minor fracture \\
\hline 163.72 & 49.90 & 62 & 332 & 22 & $\mathrm{NE}$ & Shallow & Minor fracture \\
\hline 164.94 & 50.27 & 239 & 149 & 79 & SW & Nearly vertical & Minor fracture \\
\hline
\end{tabular}


Table 1D-1. Interpretation of acoustic televiewer logs for borehole DW-24, near Machiasport, Maine.-Continued [Televiewer data are corrected for deviation and magnetic declination, so orientations are relative to true north; depths are below top of casing, which is 1.52 feet above land surface; dip azimuth is given in degrees east of true north; strike is reported in right-hand-rule (RHR)-azimuthal degrees east of true north and where the direction of dip is 90 degrees to the right of strike]

\begin{tabular}{crrrrcrl}
\hline $\begin{array}{c}\text { Depth, } \\
\text { in feet }\end{array}$ & $\begin{array}{c}\text { Depth, } \\
\text { in meters }\end{array}$ & $\begin{array}{c}\text { Dip } \\
\text { azimuth }\end{array}$ & $\begin{array}{c}\text { Strike, } \\
\text { in RHR }\end{array}$ & Dip & $\begin{array}{c}\text { Dip } \\
\text { direction }\end{array}$ & Dip descriptor & Comment \\
\hline 166.80 & 50.84 & 210 & 120 & 12 & SW & Shallow & Minor fracture \\
168.10 & 51.23 & 158 & 68 & 22 & S & Shallow & Minor fracture \\
169.11 & 51.54 & 212 & 122 & 56 & SW & Steep & Fracture \\
171.30 & 52.21 & 173 & 83 & 55 & S & Steep & Minor fracture \\
173.92 & 53.01 & 57 & 327 & 50 & NE & Moderate & Minor fracture \\
176.45 & 53.78 & 55 & 325 & 49 & NE & Moderate & Minor fracture \\
177.75 & 54.18 & 237 & 147 & 14 & SW & Shallow & Minor fracture \\
179.59 & 54.74 & 256 & 166 & 25 & W & Shallow & Minor fracture \\
179.82 & 54.81 & 215 & 125 & 74 & SW & Nearly vertical & Minor fracture \\
180.06 & 54.88 & 46 & 316 & 71 & NE & Nearly vertical & Minor fracture \\
181.46 & 55.31 & 48 & 318 & 24 & NE & Shallow & Minor fracture \\
183.51 & 55.93 & 101 & 11 & 26 & $\mathrm{E}$ & Shallow & Transmissive fracture \\
184.30 & 56.17 & 251 & 161 & 42 & W & Moderate & Minor fracture \\
185.64 & 56.58 & 164 & 74 & 19 & S & Shallow & Minor fracture \\
187.48 & 57.14 & 149 & 59 & 13 & SE & Shallow & Minor fracture \\
188.99 & 57.60 & 208 & 118 & 56 & SW & Steep & Minor fracture \\
189.21 & 57.67 & 220 & 130 & 58 & SW & Steep & Minor fracture \\
189.82 & 57.85 & 266 & 176 & 15 & W & Shallow & Minor fracture \\
\hline
\end{tabular}




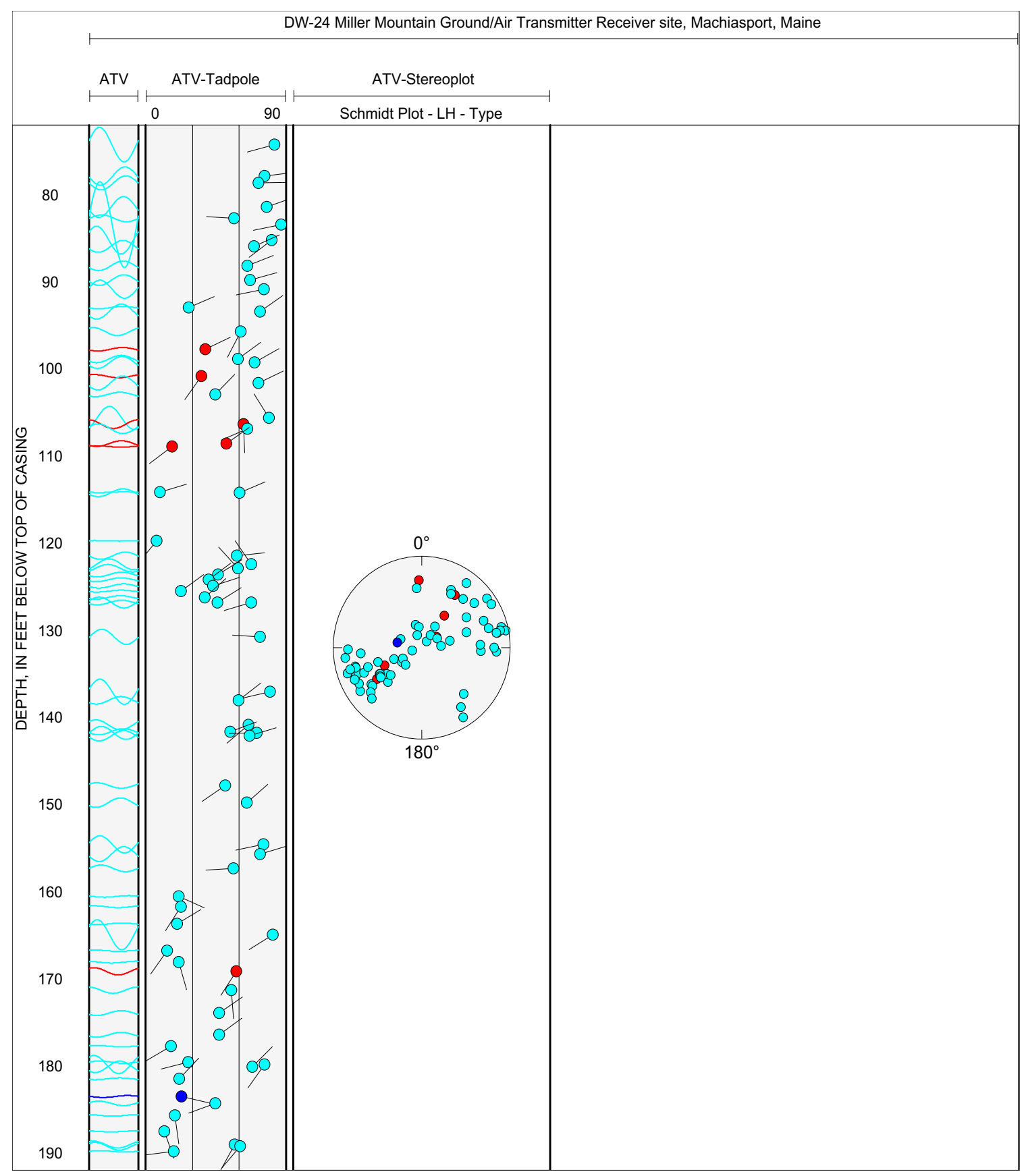

Figure 1D-3. Projection, tadpole, and stereoplots of interpretation of borehole image data for borehole DW-24, near Machiasport, Maine. 

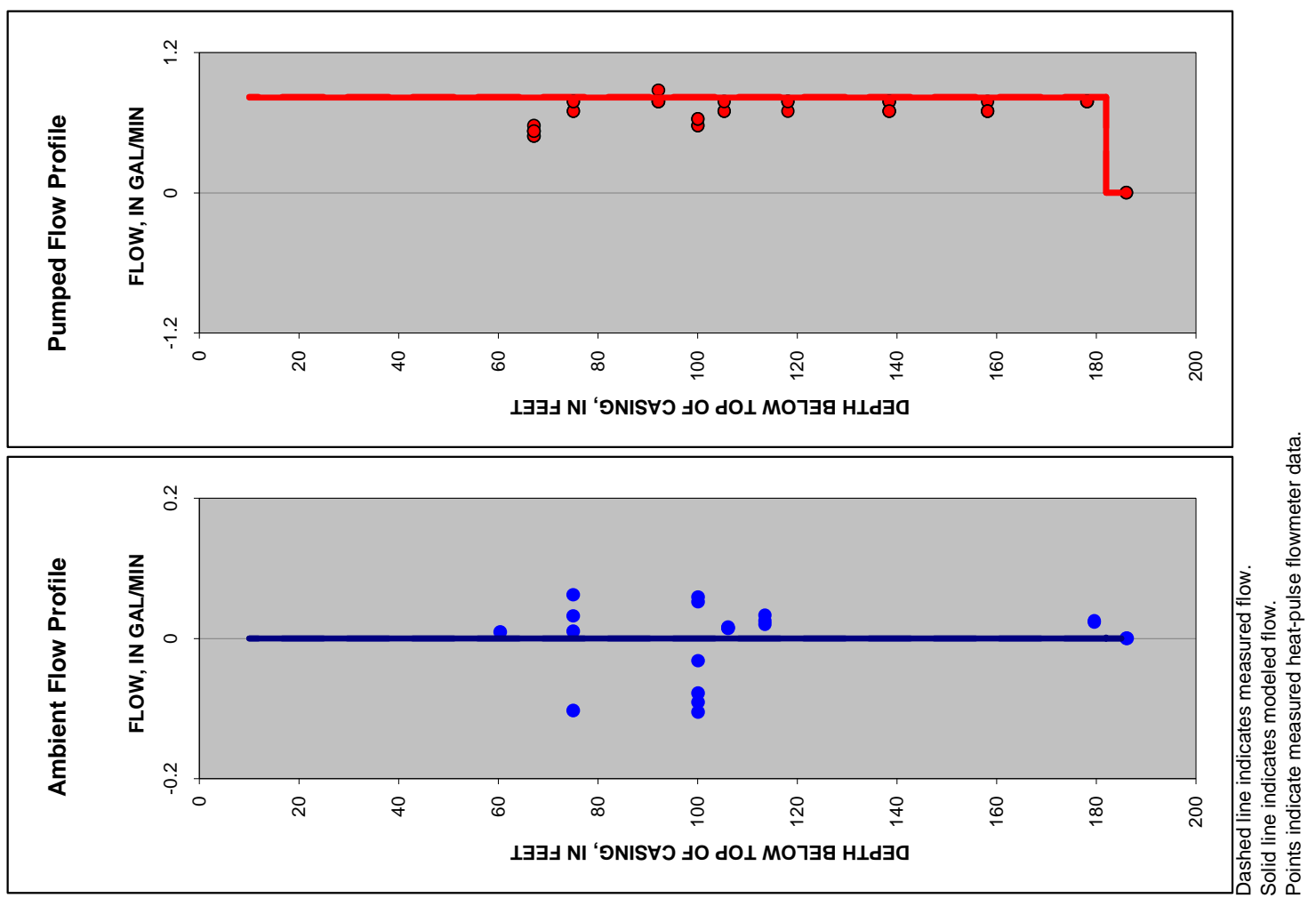

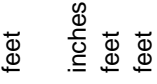
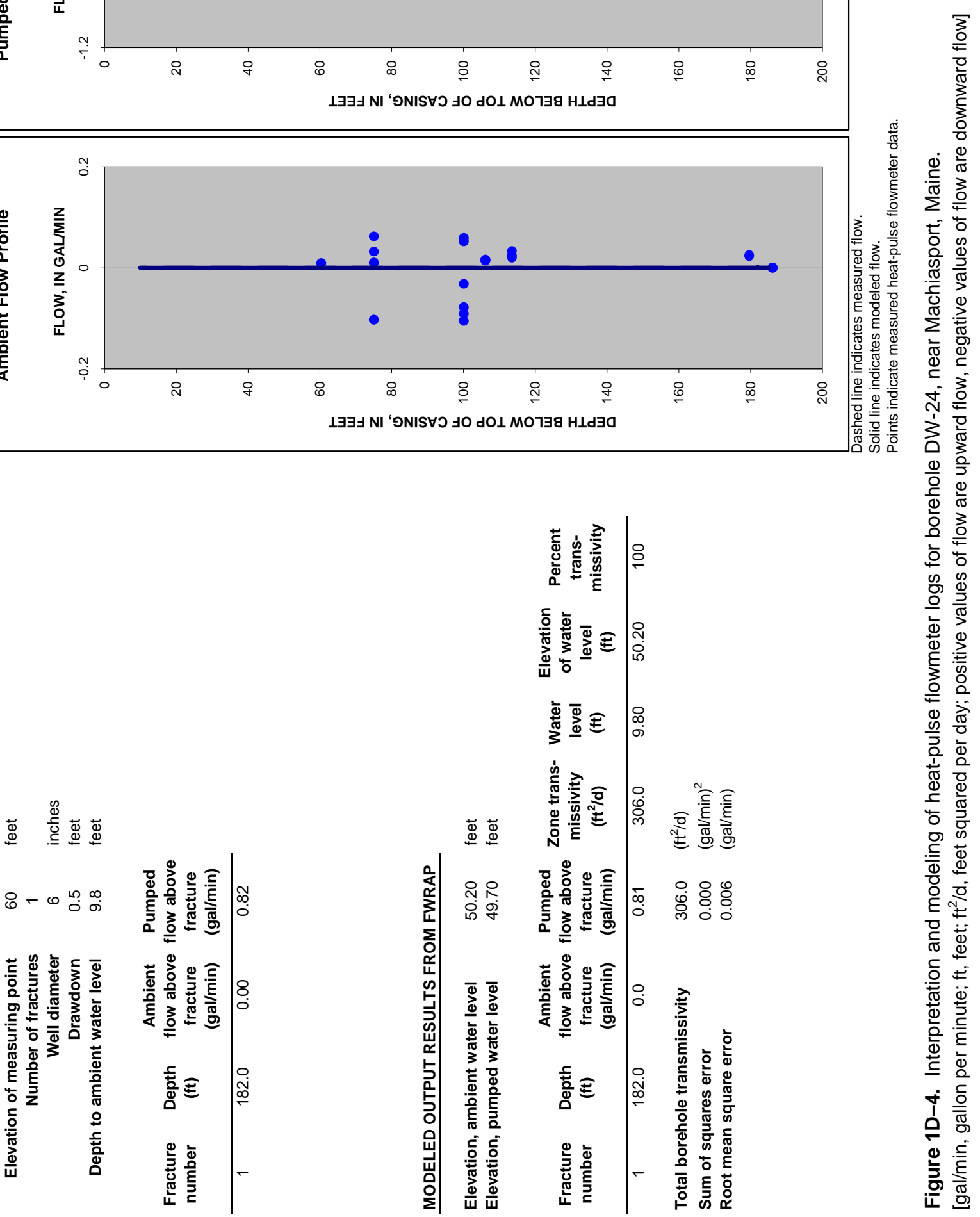

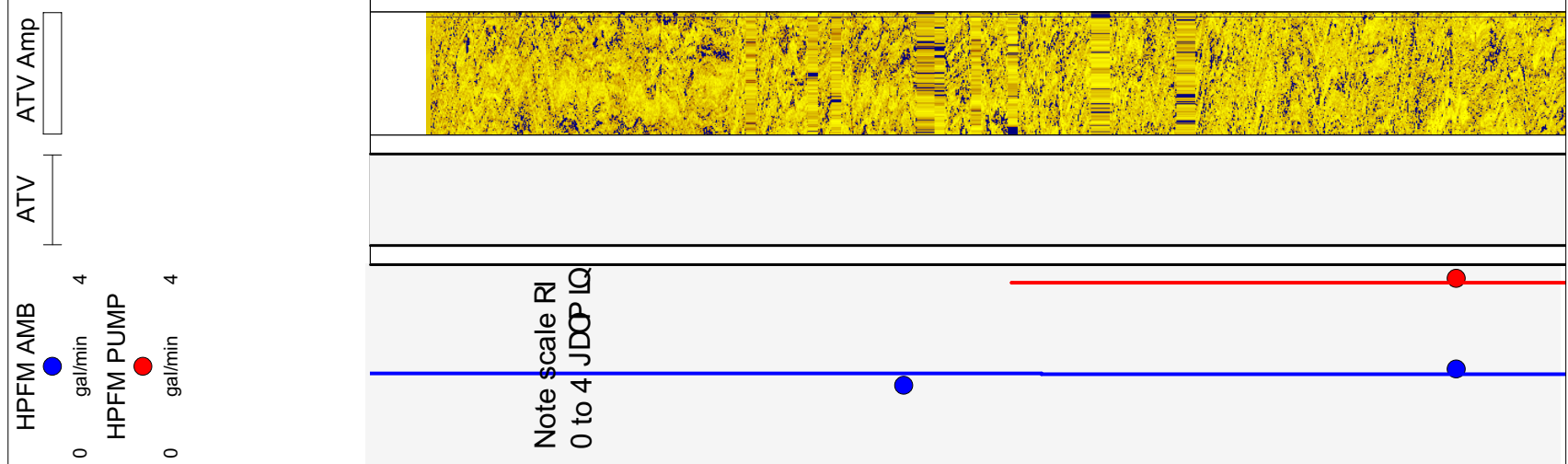

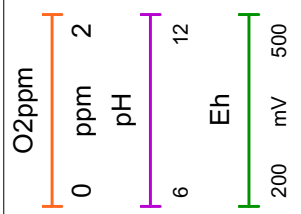

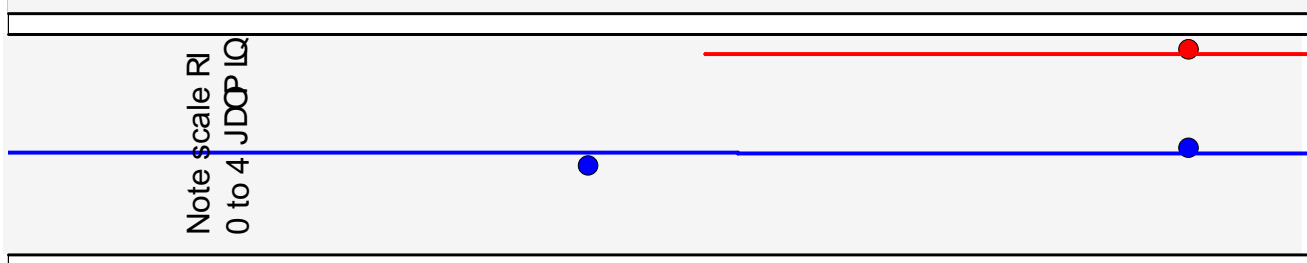

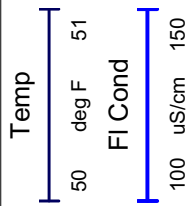

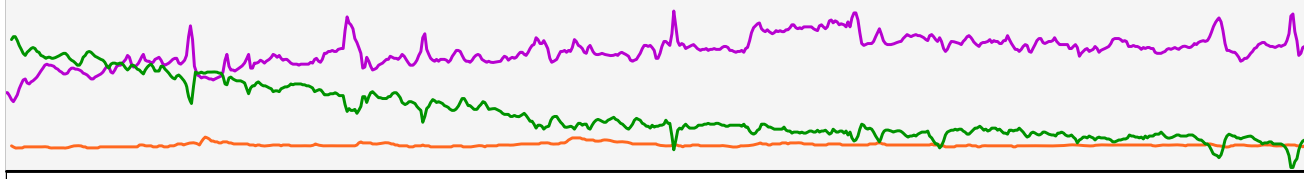

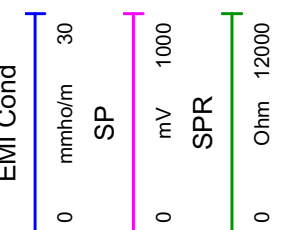

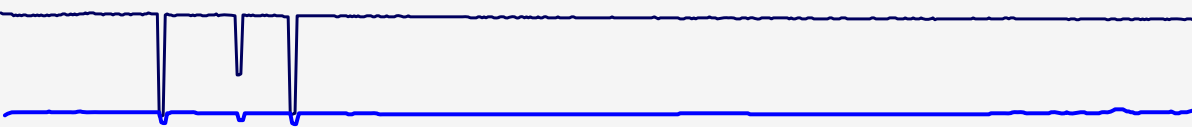

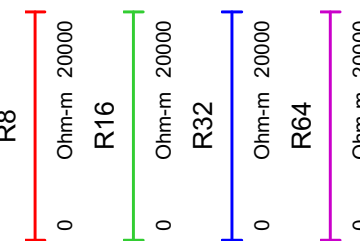

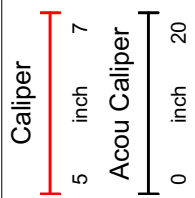

\م)

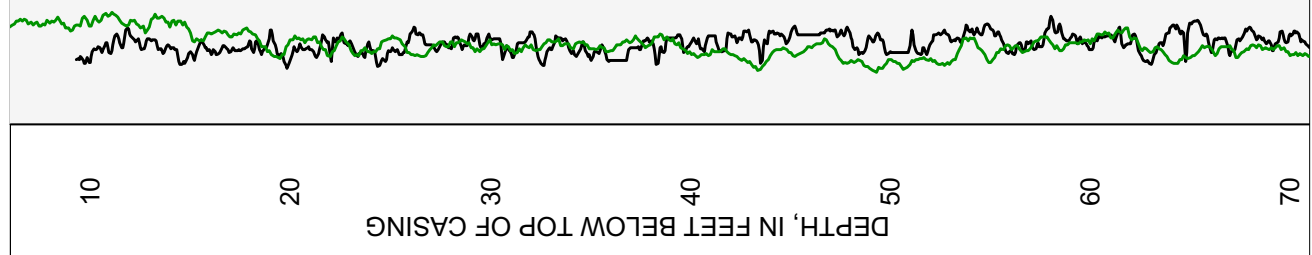

Figure 1E-1. Caliper, acoustic caliper, gamma, electromagnetic conductivity, fluid temperature, specific conductance, $\mathrm{DO}, \mathrm{pH}$, reduction oxidation, multi-space resistivity, oriented acoustic and optical borehole images, and heat-pulse flowmeter logs for borehole DW-25, near Machiasport, Maine. 


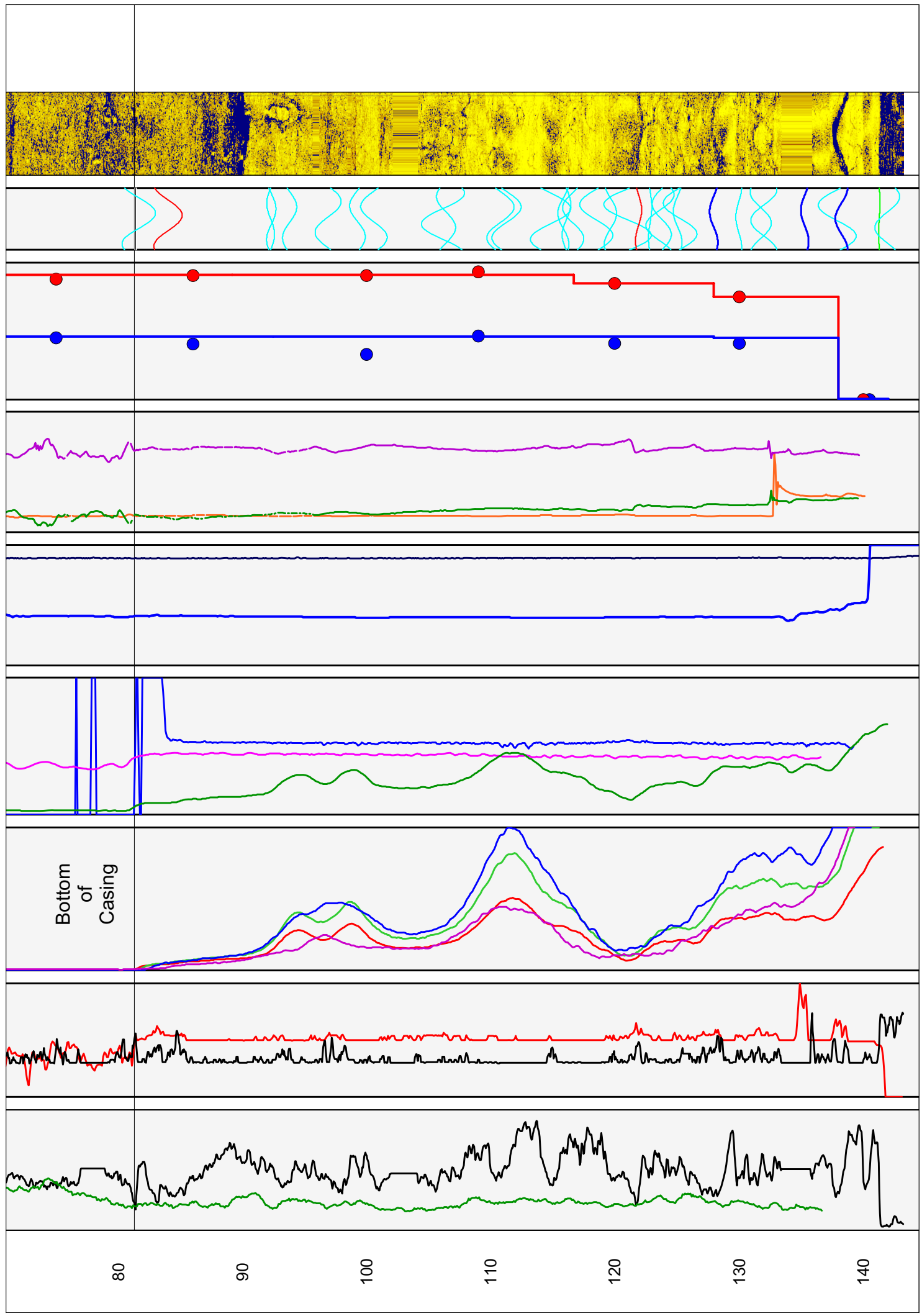

Figure 1E-1. Caliper, acoustic caliper, gamma, electromagnetic conductivity, fluid temperature, specific conductance, $\mathrm{DO}, \mathrm{pH}$, reduction oxidation, multi-space resistivity, oriented acoustic and optical borehole images, and heat-pulse flowmeter logs for borehole DW-25, near Machiasport, Maine.-Continued 

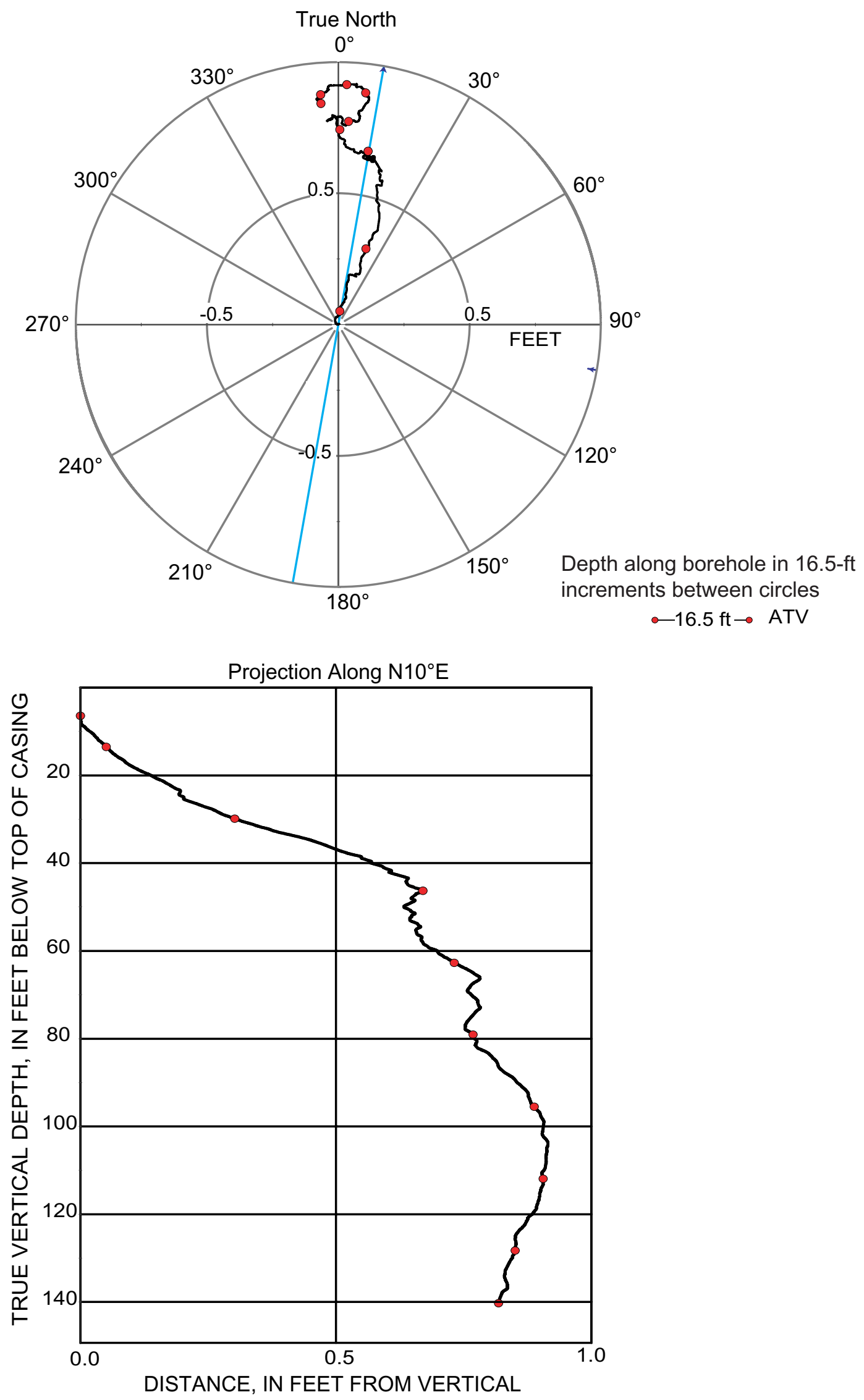

Figure 1E-2. Borehole deviation logs for borehole DW-25, near Machiasport, Maine. Blue line on radial plot (top) is line of projection for vertical plot (bottom).

[ft, foot; ATV, acoustic televiewer] 
Table 1E-1. Interpretation of acoustic televiewer logs for borehole DW-25, near Machiasport, Maine.

[Televiewer data are corrected for deviation and magnetic declination, so orientations are relative to true north; depths are below top of casing, which is 0.78 feet above land surface; dip azimuth is given in degrees east of true north; strike is reported in right-hand-rule (RHR)-azimuthal degrees east of true north and where the direction of dip is 90 degrees to the right of strike]

\begin{tabular}{|c|c|c|c|c|c|c|c|}
\hline $\begin{array}{l}\text { Depth, } \\
\text { in feet }\end{array}$ & $\begin{array}{l}\text { Depth, } \\
\text { in meters }\end{array}$ & $\begin{array}{c}\text { Dip } \\
\text { azimuth }\end{array}$ & $\begin{array}{c}\text { Strike, } \\
\text { in RHR }\end{array}$ & Dip & $\begin{array}{c}\text { Dip } \\
\text { direction }\end{array}$ & Dip descriptor & Comment \\
\hline 81.38 & 24.80 & 227 & 137 & 1 & SW & Nearly horizontal & Bottom of casing \\
\hline 81.40 & 24.81 & 227 & 137 & 2 & sw & Nearly horizontal & Other \\
\hline 81.64 & 24.88 & 214 & 124 & 80 & sw & Nearly vertical & Minor fracture \\
\hline 84.01 & 25.60 & 201 & 111 & 78 & $\mathrm{~S}$ & Nearly vertical & Large fracture \\
\hline 92.28 & 28.13 & 90 & 0 & 52 & $E$ & Steep & Minor fracture \\
\hline 92.33 & 28.14 & 238 & 148 & 56 & sw & Steep & Minor fracture \\
\hline 93.79 & 28.59 & 250 & 160 & 66 & w & Steep & Minor fracture \\
\hline 96.89 & 29.53 & 281 & 191 & 77 & W & Nearly vertical & Minor fracture \\
\hline 99.28 & 30.26 & 76 & 346 & 68 & $\mathrm{E}$ & Steep & Minor fracture \\
\hline 100.58 & 30.66 & 72 & 342 & 77 & $E$ & Nearly vertical & Minor fracture \\
\hline 106.15 & 32.35 & 330 & 240 & 82 & NW & Nearly vertical & Minor fracture \\
\hline 106.37 & 32.42 & 130 & 40 & 72 & SE & Nearly vertical & Minor fracture \\
\hline 110.80 & 33.77 & 249 & 159 & 77 & W & Nearly vertical & Minor fracture \\
\hline 111.28 & 33.92 & 250 & 160 & 78 & W & Nearly vertical & Minor fracture \\
\hline 114.79 & 34.99 & 241 & 151 & 81 & SW & Nearly vertical & Minor fracture \\
\hline 115.84 & 35.31 & 33 & 303 & 61 & $\mathrm{NE}$ & Steep & Minor fracture \\
\hline 116.07 & 35.38 & 266 & 176 & 54 & W & Steep & Minor fracture \\
\hline 116.65 & 35.55 & 65 & 335 & 74 & $\mathrm{NE}$ & Nearly vertical & Minor fracture \\
\hline 118.50 & 36.12 & 84 & 354 & 79 & $E$ & Nearly vertical & Minor fracture \\
\hline 119.63 & 36.46 & 212 & 122 & 63 & sw & Steep & Minor fracture \\
\hline 121.01 & 36.88 & 85 & 355 & 83 & $\mathrm{E}$ & Nearly vertical & Minor fracture \\
\hline 121.88 & 37.15 & 231 & 141 & 44 & sw & Moderate & Large fracture \\
\hline 122.83 & 37.44 & 249 & 159 & 28 & W & Shallow & Minor fracture \\
\hline 123.60 & 37.67 & 322 & 232 & 78 & NW & Nearly vertical & Minor fracture \\
\hline 123.77 & 37.72 & 88 & 358 & 72 & $E$ & Nearly vertical & Minor fracture \\
\hline 125.06 & 38.12 & 43 & 313 & 54 & $\mathrm{NE}$ & Steep & Minor fracture \\
\hline 125.24 & 38.17 & 92 & 2 & 80 & $E$ & Nearly vertical & Minor fracture \\
\hline 127.95 & 39.00 & 43 & 313 & 53 & $\mathrm{NE}$ & Steep & Transmissive fracture \\
\hline 129.98 & 39.62 & 11 & 281 & 43 & $\mathrm{~N}$ & Moderate & Minor fracture \\
\hline 131.73 & 40.15 & 156 & 66 & 74 & SE & Nearly vertical & Minor fracture \\
\hline 131.97 & 40.22 & 351 & 261 & 77 & $\mathrm{~N}$ & Nearly vertical & Minor fracture \\
\hline 135.29 & 41.23 & 49 & 319 & 52 & $\mathrm{NE}$ & Steep & Transmissive fracture \\
\hline 137.90 & 42.03 & 80 & 350 & 81 & $E$ & Nearly vertical & Minor fracture \\
\hline 138.22 & 42.13 & 2 & 272 & 63 & $\mathrm{~N}$ & Steep & Transmissive fracture \\
\hline 141.30 & 43.07 & 275 & 185 & 12 & W & Shallow & Lithologic feature \\
\hline 141.91 & 43.25 & 310 & 220 & 76 & NW & Nearly vertical & Minor fracture \\
\hline
\end{tabular}




(1)

Figure 1E-3. Projection, tadpole, and stereoplots of interpretation of borehole image data for borehole DW-25, near Machiasport, Maine. 


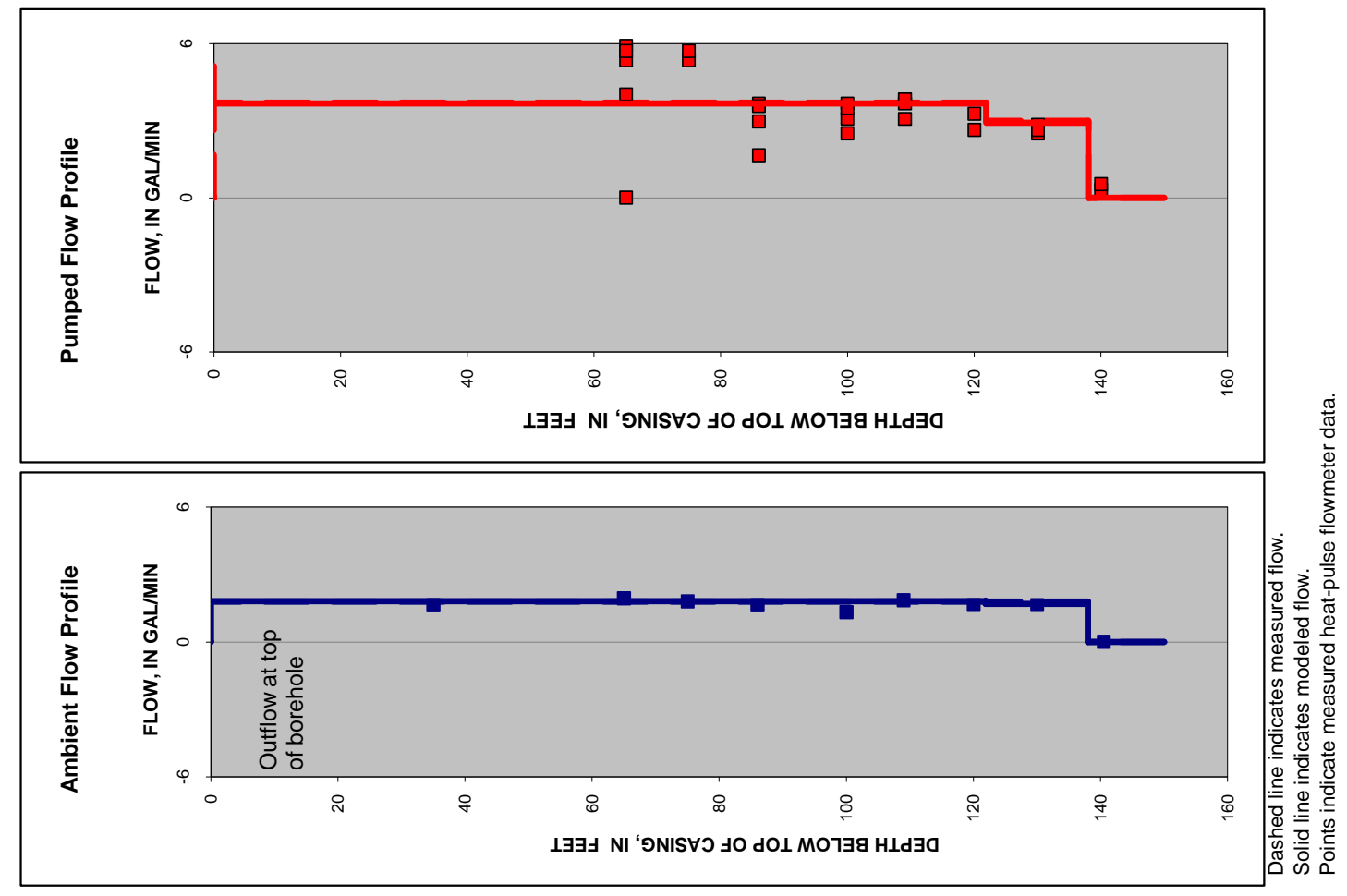

蛋
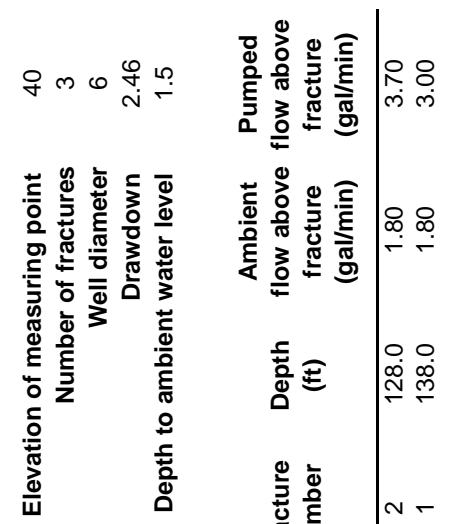

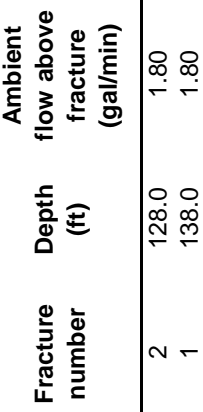

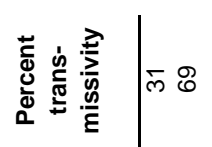

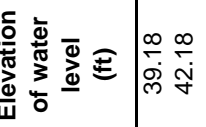

离

商皇

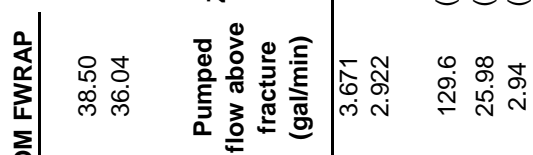

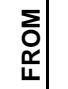

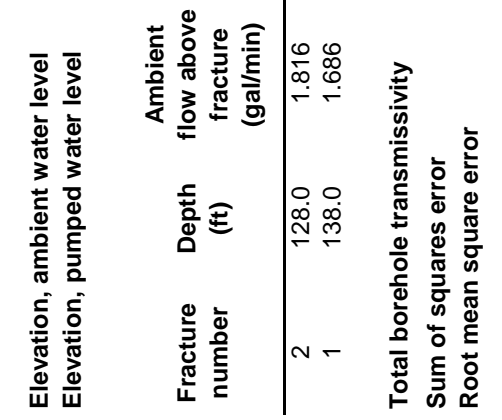




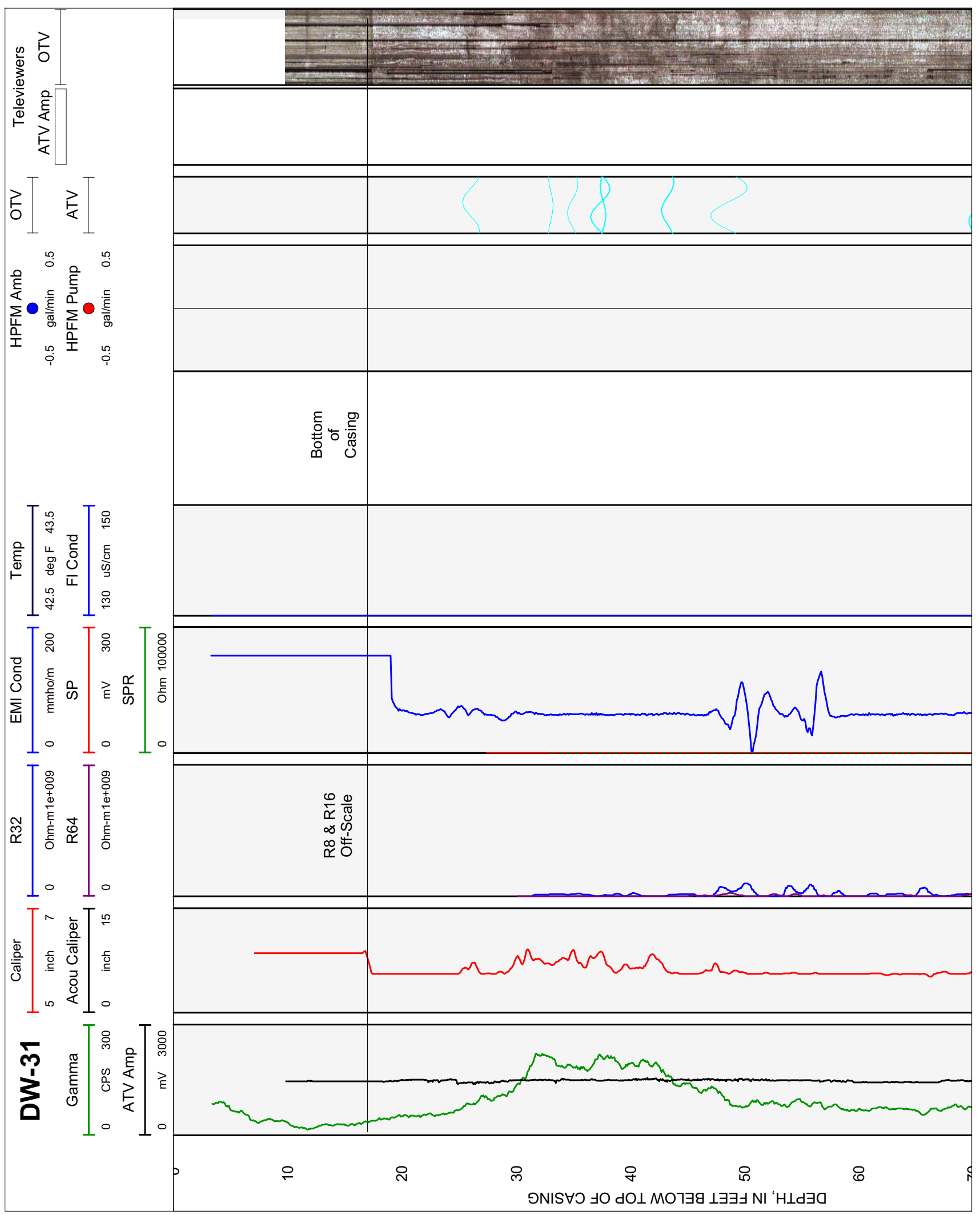

Figure 1F-1. Caliper, acoustic caliper, gamma, electromagnetic conductivity, fluid temperature, specific conductance, $\mathrm{DO}, \mathrm{pH}$, reduction oxidation, multi-space resistivity, oriented acoustic and optical borehole images, and heat-pulse flowmeter logs for borehole DW-31, near Machiasport, Maine. 


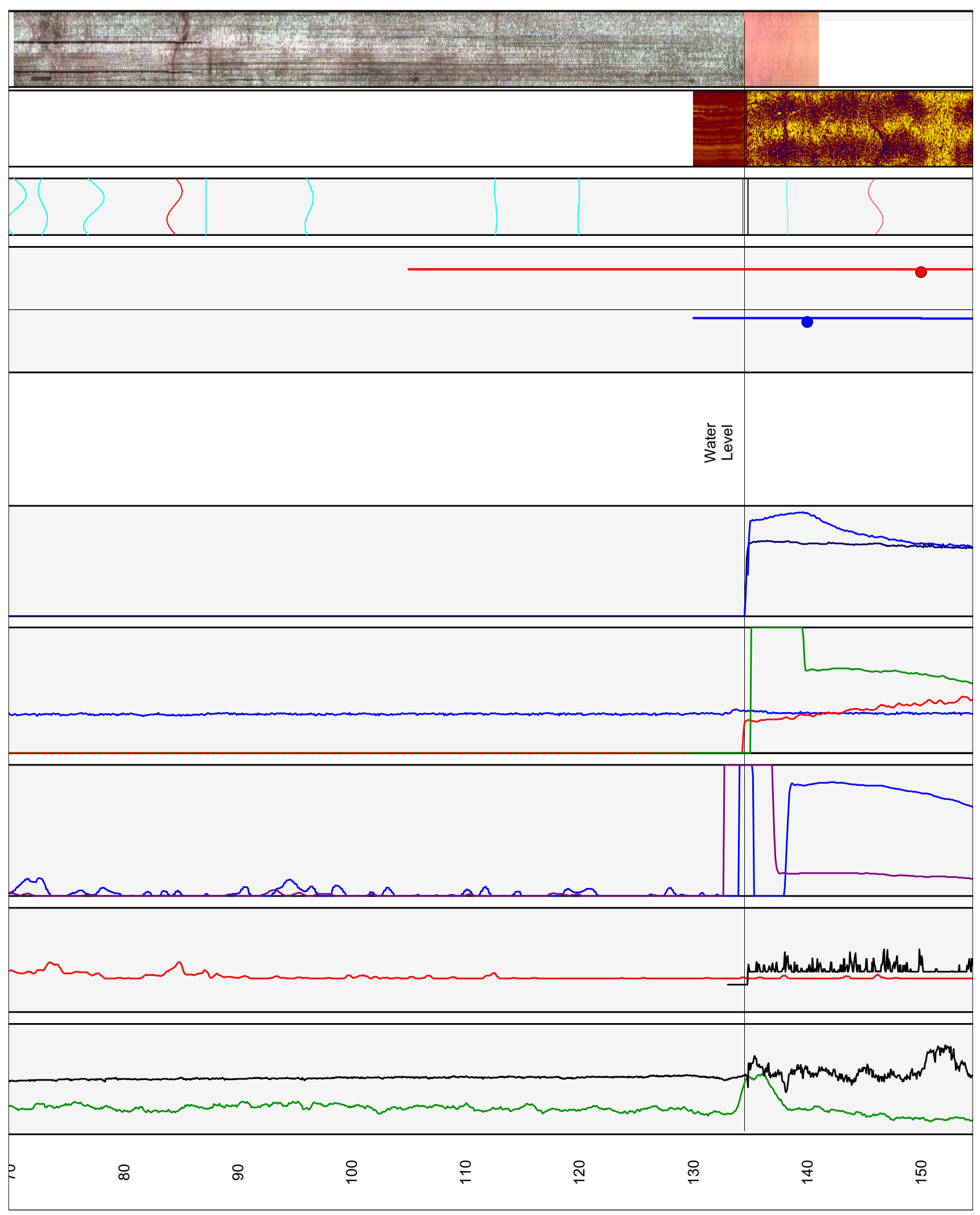

Figure 1F-1. Caliper, acoustic caliper, gamma, electromagnetic conductivity, fluid temperature, specific conductance, $\mathrm{DO}, \mathrm{pH}$, reduction oxidation, multi-space resistivity, oriented acoustic and optical borehole images, and heat-pulse flowmeter logs for borehole DW-31, near Machiasport, Maine.-Continued 


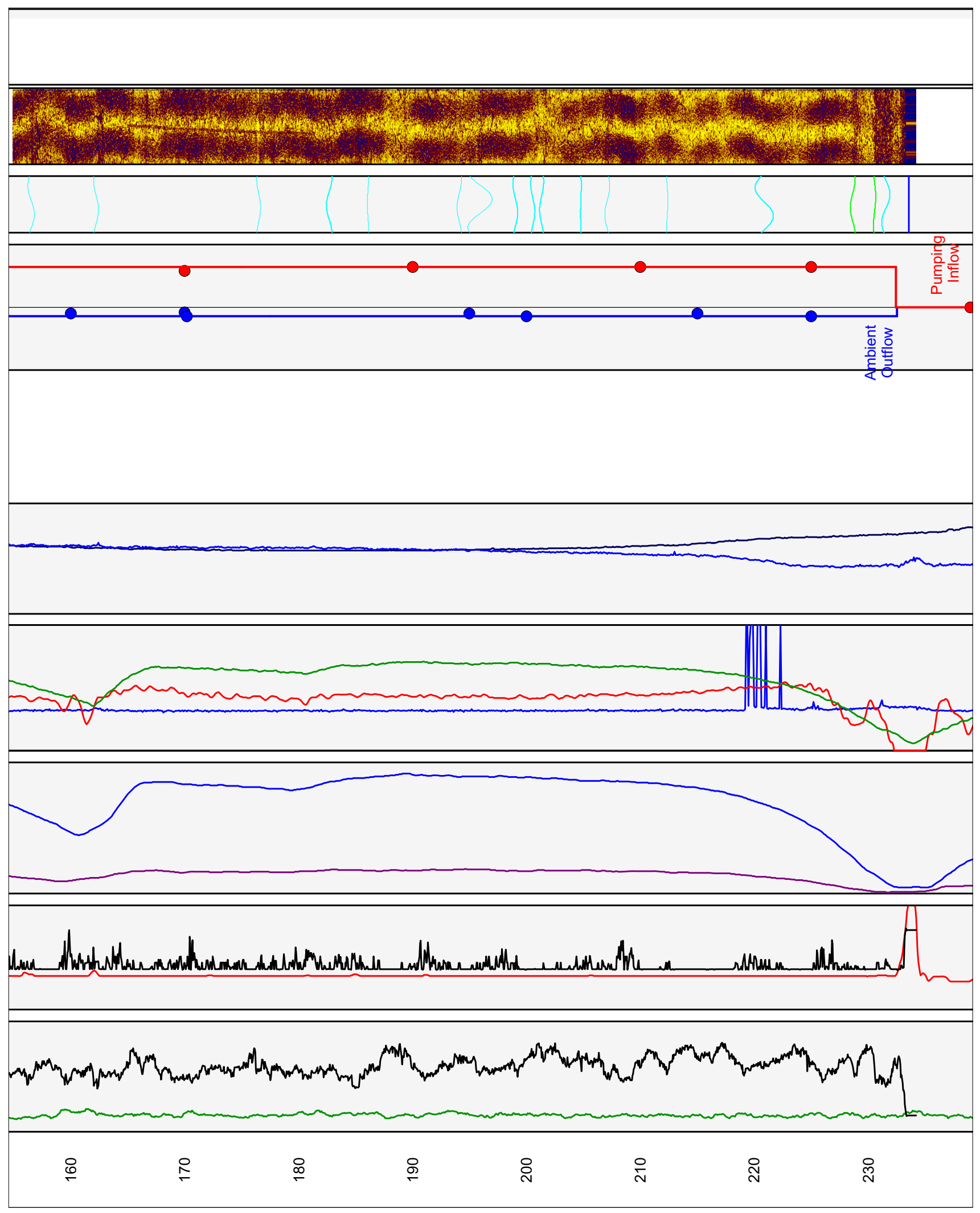

Figure 1F-1. Caliper, acoustic caliper, gamma, electromagnetic conductivity, fluid temperature, specific conductance, $\mathrm{DO}, \mathrm{pH}$, reduction oxidation, multi-space resistivity, oriented acoustic and optical borehole images, and heat-pulse flowmeter logs for borehole DW-31, near Machiasport, Maine.-Continued 


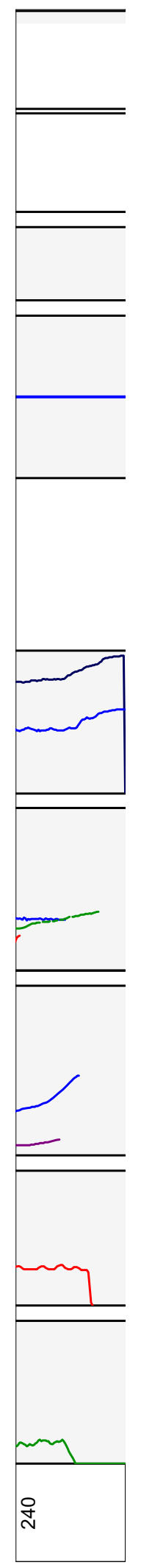

Figure 1F-1. Caliper, acoustic caliper, gamma, electromagnetic conductivity, fluid temperature, specific conductance, $\mathrm{DO}, \mathrm{pH}$, reduction oxidation, multi-space resistivity, oriented acoustic and optical borehole images, and heat-pulse flowmeter logs for borehole DW-31, near Machiasport, Maine.-Continued 

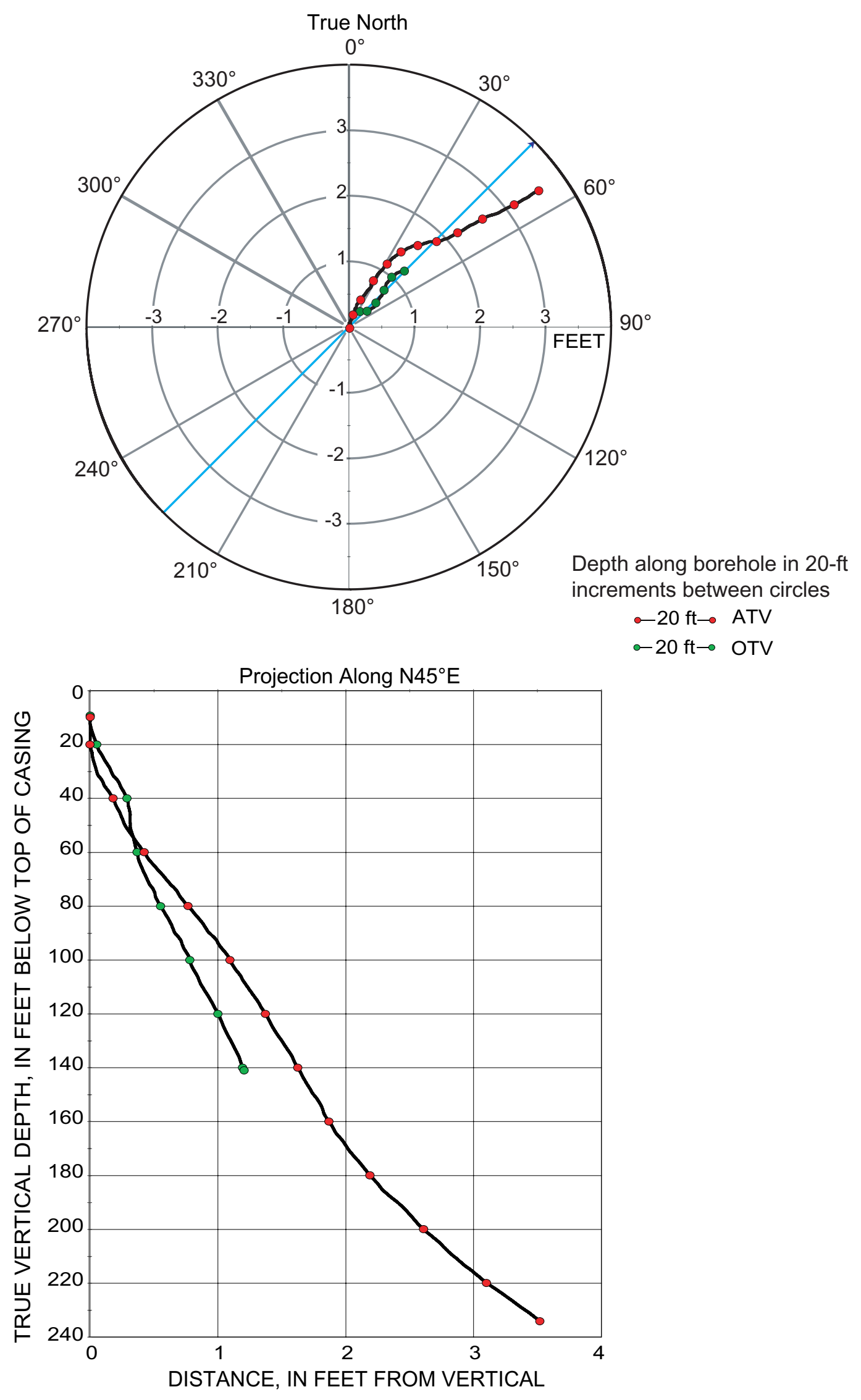

Figure 1F-2. Borehole deviation logs for borehole DW-31, near Machiasport, Maine. Blue line on radial plot (top) is line of projection for vertical plot (bottom).

[ft, foot; ATV, acoustic televiewer; OTV, optical televiewer] 
Table 1F-1. Interpretation of acoustic televiewer logs for borehole DW-31, near Machiasport, Maine.

[Televiewer data are corrected for deviation and magnetic declination, so orientations are relative to true north; depths are below top of casing, which is 2.2 feet above land surface; dip azimuth is given in degrees east of true north; strike is reported in right-hand-rule (RHR)-azimuthal degrees east of true north and where the direction of dip is 90 degrees to the right of strike; -- , orientation of fracture could not be determined]

\begin{tabular}{crrrrrrl}
\hline $\begin{array}{c}\text { Depth, } \\
\text { in feet }\end{array}$ & $\begin{array}{c}\text { Depth, } \\
\text { in meters }\end{array}$ & $\begin{array}{c}\text { Dip } \\
\text { azimuth }\end{array}$ & $\begin{array}{c}\text { Strike, } \\
\text { in RHR }\end{array}$ & Dip & $\begin{array}{c}\text { Dip } \\
\text { direction }\end{array}$ & Dip descriptor & Comment \\
\hline 134.79 & 41.08 & 265 & 175 & 1 & W & Nearly horizontal & Water level \\
138.22 & 42.13 & 96 & 6 & 22 & E & Shallow & Minor fracture \\
146.02 & 44.50 & 97 & 7 & 76 & E & Nearly vertical & Fracture \\
156.48 & 47.69 & 117 & 27 & 60 & SE & Steep & Minor fracture \\
162.19 & 49.43 & 148 & 58 & 52 & SE & Steep & Minor fracture \\
176.45 & 53.78 & 159 & 69 & 47 & S & Moderate & Minor fracture \\
182.70 & 55.68 & 352 & 262 & 57 & N & Steep & Minor fracture \\
186.06 & 56.71 & 5 & 275 & 19 & N & Shallow & Minor fracture \\
194.09 & 59.16 & 341 & 251 & 50 & N & Steep & Minor fracture \\
195.91 & 59.71 & 213 & 123 & 81 & SW & Nearly vertical & Minor fracture \\
199.02 & 60.66 & 130 & 40 & 52 & SE & Steep & Minor fracture \\
200.53 & 61.12 & 134 & 44 & 47 & SE & Moderate & Minor fracture \\
201.33 & 61.36 & 326 & 236 & 47 & NW & Moderate & Minor fracture \\
204.79 & 62.42 & 299 & 209 & 10 & NW & Shallow & Minor fracture \\
207.10 & 63.12 & 296 & 206 & 53 & NW & Steep & Minor fracture \\
212.38 & 64.73 & 202 & 112 & 18 & S & Shallow & Minor fracture \\
220.86 & 67.31 & 107 & 17 & 79 & E & Nearly vertical & Minor fracture \\
228.64 & 69.69 & 341 & 251 & 53 & N & Steep & Possible fracture \\
230.54 & 70.27 & 228 & 138 & 30 & SW & Shallow & Possible fracture \\
231.56 & 70.58 & 244 & 154 & 66 & SW & Steep & Minor fracture \\
233.56 & 71.19 & -- & -- & -- & -- & Horizontal & Transmissive fracture \\
\hline
\end{tabular}

Table 1F-2. Interpretation of optical televiewer logs for borehole DW-31, near Machiasport, Maine.

[Televiewer data are corrected for deviation and magnetic declination, so orientations are relative to true north; depths are below top of casing, which is 2.2 feet above land surface; dip azimuth is given in degrees east of true north; strike is reported in right-hand-rule (RHR)-azimuthal degrees east of true north and where the direction of dip is 90 degrees to the right of strike]

\begin{tabular}{rrrrrccl}
\hline $\begin{array}{c}\text { Depth, } \\
\text { in feet }\end{array}$ & $\begin{array}{c}\text { Depth, } \\
\text { in meters }\end{array}$ & $\begin{array}{c}\text { Dip } \\
\text { azimuth }\end{array}$ & $\begin{array}{c}\text { Strike, } \\
\text { in RHR }\end{array}$ & Dip & $\begin{array}{c}\text { Dip } \\
\text { direction }\end{array}$ & Dip descriptor & Comment \\
\hline 17.00 & 5.18 & 346 & 256 & 1 & $\mathrm{~N}$ & Nearly horizontal & Bottom of casing \\
26.02 & 7.93 & 18 & 288 & 72 & $\mathrm{~N}$ & Nearly vertical & Minor fracture \\
33.01 & 10.06 & 175 & 85 & 38 & $\mathrm{~S}$ & Moderate & Minor fracture \\
34.96 & 10.66 & 309 & 219 & 62 & NW & Steep & Minor fracture \\
37.35 & 11.38 & 285 & 195 & 74 & W & Nearly vertical & Minor fracture \\
37.62 & 11.47 & 117 & 27 & 43 & SE & Moderate & Minor fracture \\
43.27 & 13.19 & 325 & 235 & 65 & NW & Steep & Minor fracture \\
48.65 & 14.83 & 292 & 202 & 81 & W & Nearly vertical & Minor fracture \\
70.53 & 21.50 & 256 & 166 & 75 & W & Nearly vertical & Minor fracture \\
72.86 & 22.21 & 103 & 13 & 59 & $\mathrm{E}$ & Steep & Minor fracture \\
77.36 & 23.58 & 237 & 147 & 75 & SW & Nearly vertical & Minor fracture \\
84.46 & 25.74 & 279 & 189 & 70 & W & Nearly vertical & Fracture \\
87.19 & 26.57 & 215 & 125 & 0 & SW & Nearly horizontal & Minor fracture \\
96.25 & 29.34 & 237 & 147 & 56 & SW & Steep & Minor fracture \\
112.63 & 34.33 & 108 & 18 & 23 & $\mathrm{E}$ & Shallow & Minor fracture \\
119.93 & 36.55 & 272 & 182 & 15 & W & Shallow & Minor fracture \\
134.36 & 40.95 & 262 & 172 & 1 & W & Nearly horizontal & Water level \\
\hline
\end{tabular}




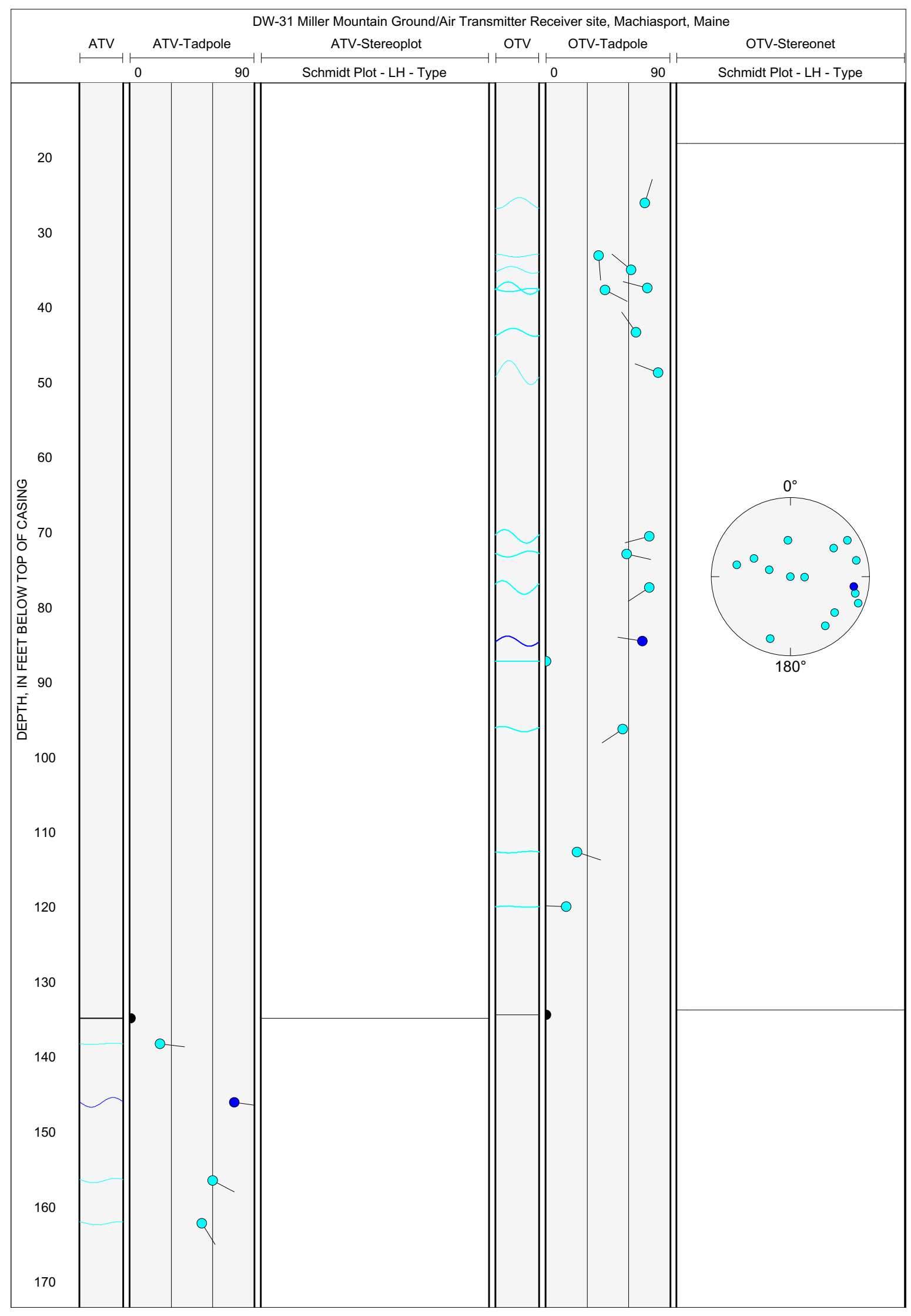

Figure 1F-3. Projection, tadpole, and stereoplots of interpretation of borehole image data for borehole DW-31, near Machiasport, Maine. 


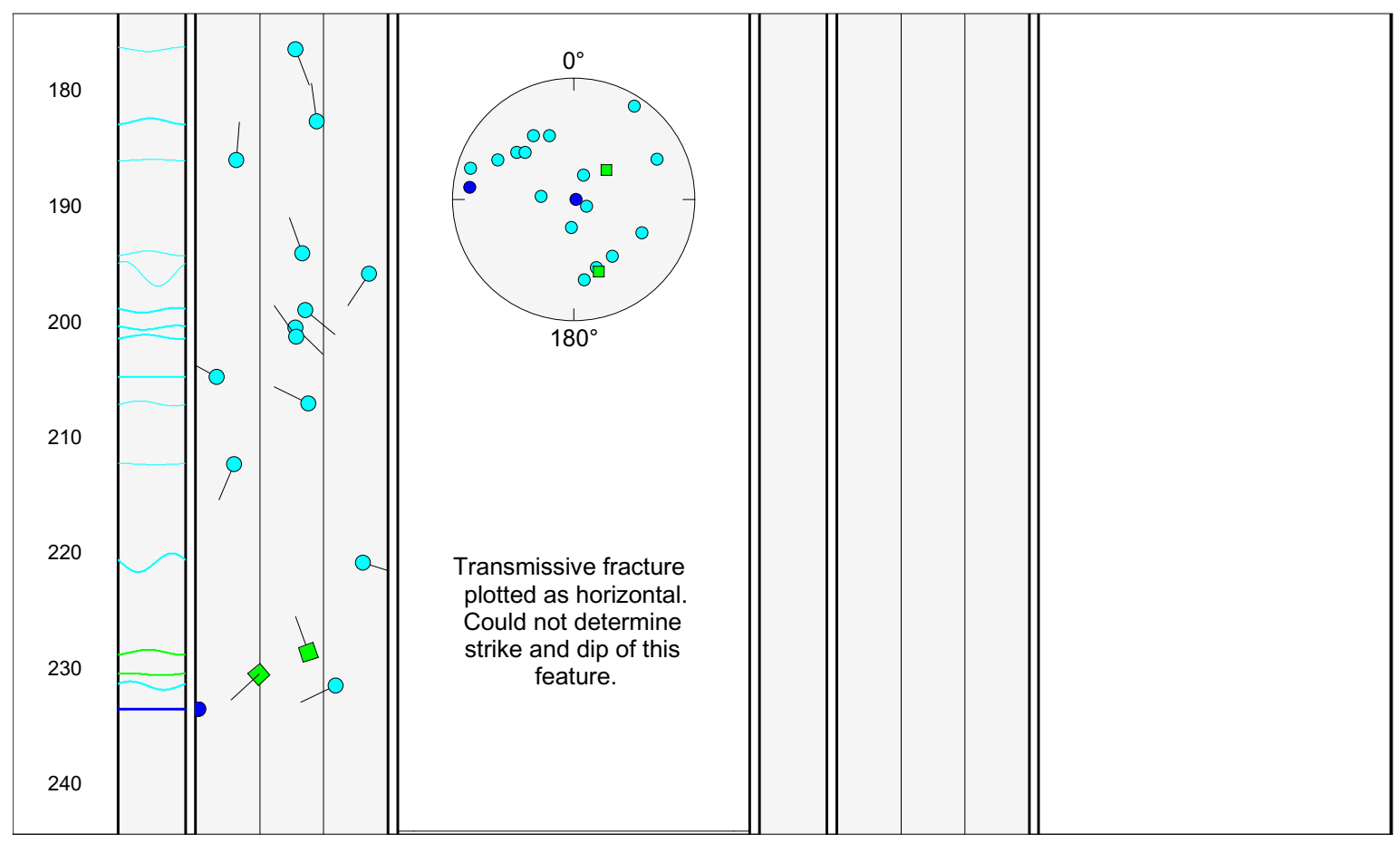

Figure 1F-3. Projection, tadpole, and stereoplots of interpretation of borehole image data for borehole DW-31, near Machiasport, Maine.-Continued 

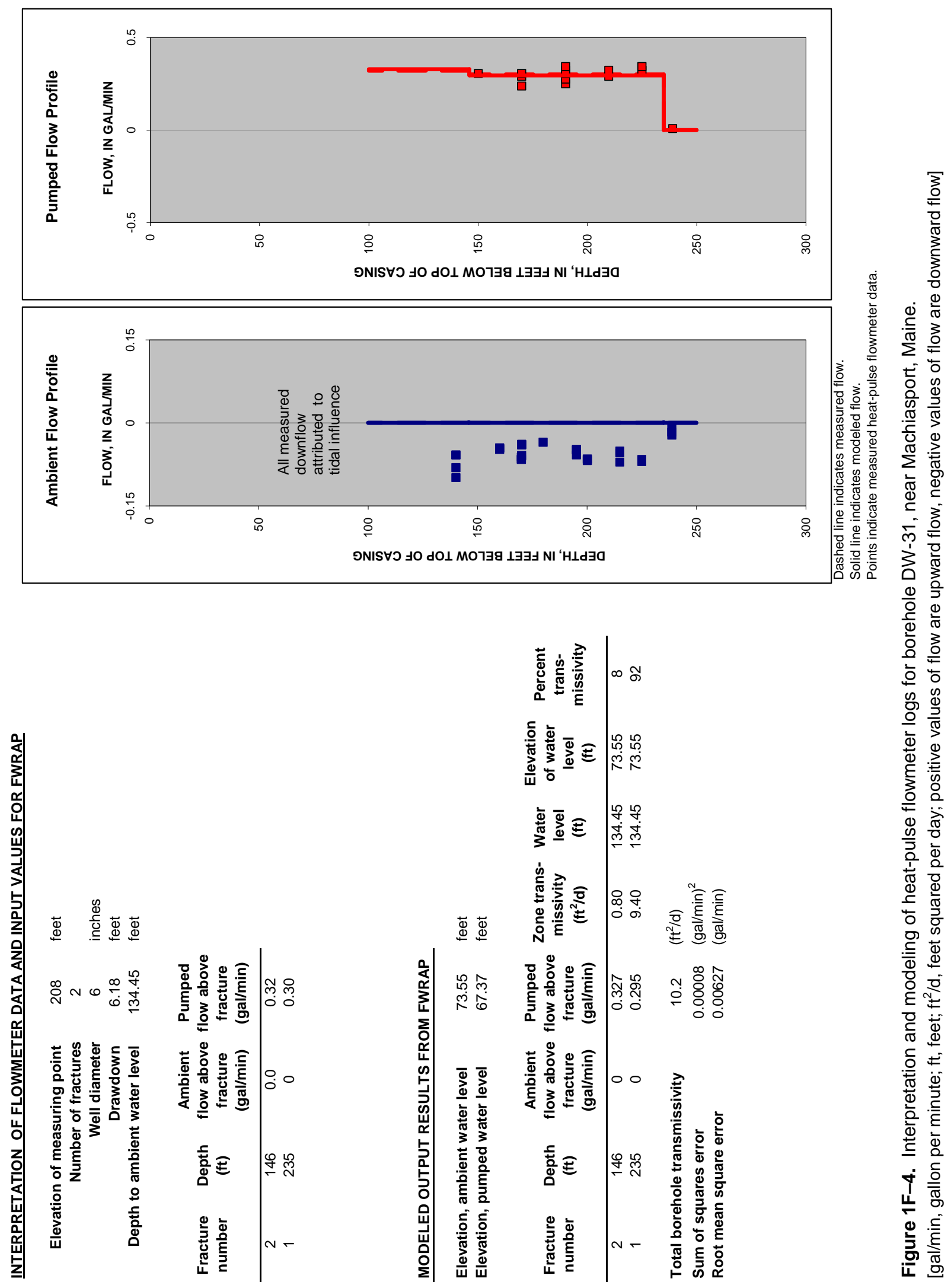


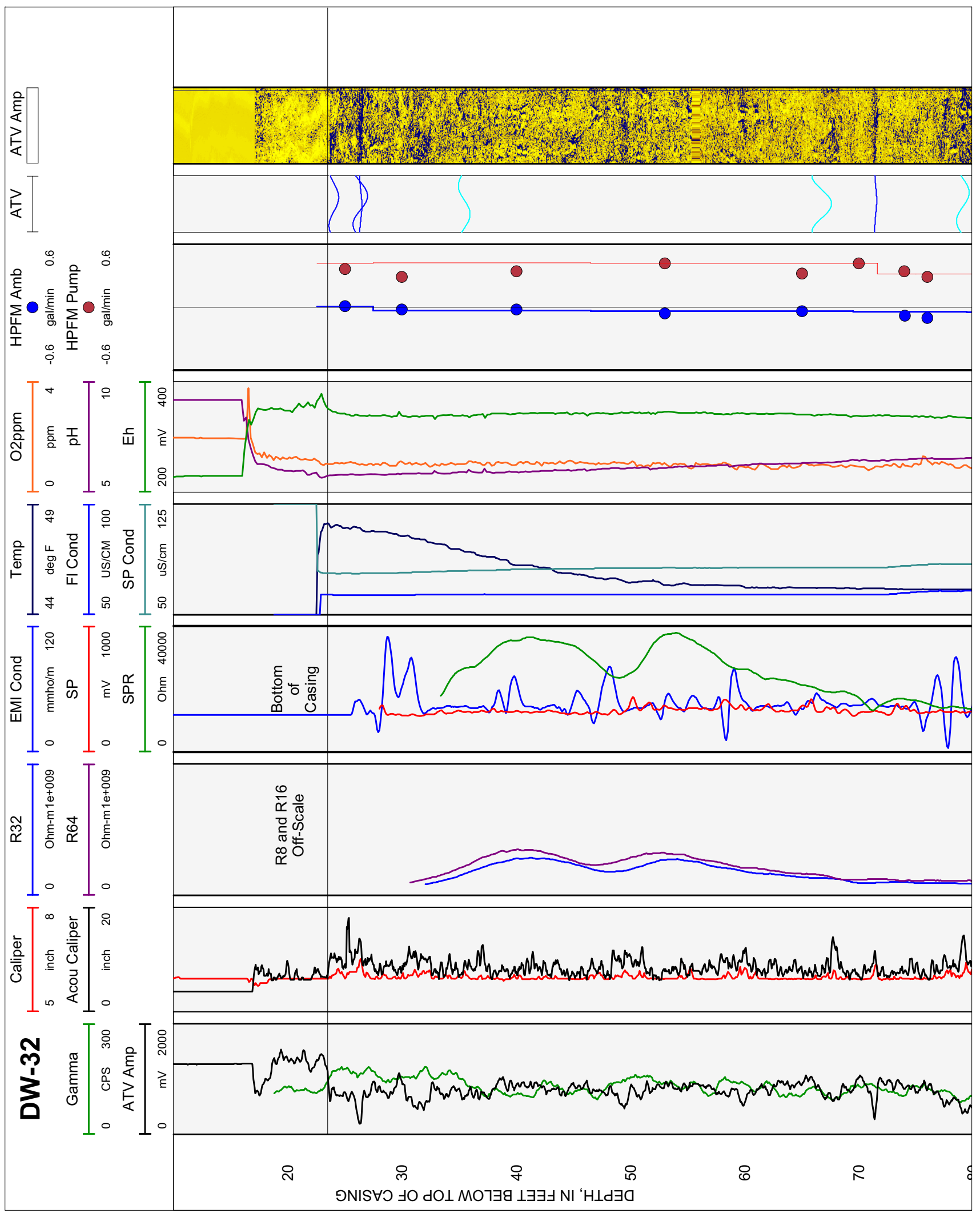

Figure 1G-1. Caliper, acoustic caliper, gamma, electromagnetic conductivity, fluid temperature, specific conductance, $\mathrm{DO}, \mathrm{pH}$, reduction oxidation, multi-space resistivity, oriented acoustic and optical borehole images, and heat-pulse flowmeter logs for borehole DW-32, near Machiasport, Maine. 


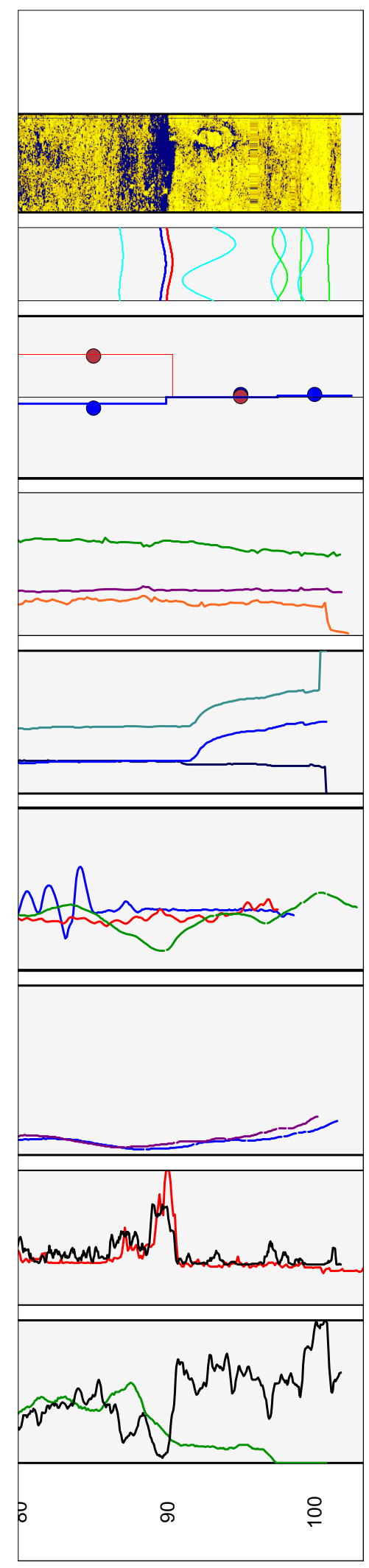

Figure 1G-1. Caliper, acoustic caliper, gamma, electromagnetic conductivity, fluid temperature, specific conductance, $\mathrm{DO}, \mathrm{pH}$, reduction oxidation, multi-space resistivity, oriented acoustic and optical borehole images, and heat-pulse flowmeter logs for borehole DW-32, near Machiasport, Maine.-Continued 

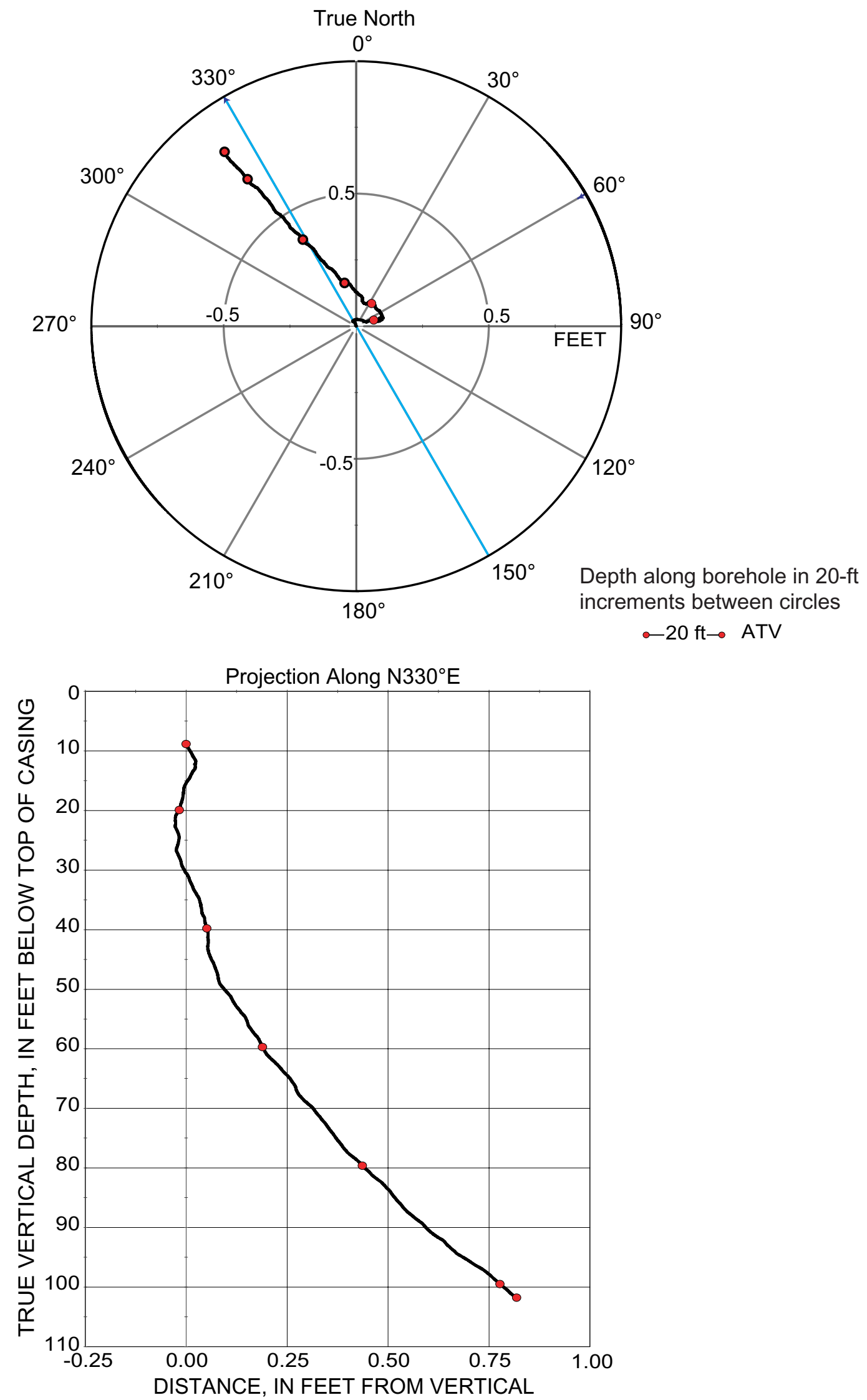

Figure 1G-2. Borehole deviation logs for borehole DW-32, near Machiasport, Maine. Blue line on radial plot (top) is line of projection for vertical plot (bottom).

[ft, foot; ATV, acoustic televiewer] 
Table 1G-1. Interpretation of acoustic televiewer logs for borehole DW-32, near Machiasport, Maine.

[Televiewer data are corrected for deviation and magnetic declination, so orientations are relative to true north; depths are below top of casing, which is 1.4 feet above land surface; dip azimuth is given in degrees east of true north; strike is reported in right-hand-rule (RHR)-azimuthal degrees east of true north and where the direction of dip is 90 degrees to the right of strike; ,-- no measurement]

\begin{tabular}{rrrccccl}
\hline $\begin{array}{c}\text { Depth, } \\
\text { in feet }\end{array}$ & $\begin{array}{c}\text { Depth, } \\
\text { in meters }\end{array}$ & $\begin{array}{c}\text { Dip } \\
\text { azimuth }\end{array}$ & $\begin{array}{c}\text { Strike, } \\
\text { in RHR }\end{array}$ & Dip & $\begin{array}{c}\text { Dip } \\
\text { direction }\end{array}$ & Dip descriptor & Comment \\
\hline 17.00 & 5.18 & 336 & 246 & 0 & -- & Horizontal & Water level \\
23.61 & 7.20 & 89 & 359 & 89 & E & Nearly vertical & Bottom of casing \\
24.04 & 7.33 & 232 & 132 & 59 & SW & Steep & Transmissive fracture \\
26.33 & 8.02 & 231 & 141 & 68 & SW & Steep & Transmissive fracture \\
26.38 & 8.04 & 171 & 81 & 20 & S & Shallow & Transmissive fracture \\
35.46 & 10.81 & 128 & 38 & 66 & SE & Steep & Minor fracture \\
36.50 & 11.12 & 124 & 34 & 22 & SE & Shallow & Minor fracture \\
66.75 & 20.34 & 197 & 107 & 47 & S & Moderate & Minor fracture \\
71.47 & 21.78 & 282 & 192 & 15 & W & Shallow & Transmissive fracture \\
79.09 & 24.11 & 263 & 173 & 70 & W & Nearly vertical & Minor fracture \\
86.86 & 26.47 & 268 & 178 & 26 & W & Shallow & Minor fracture \\
89.73 & 27.35 & 256 & 166 & 23 & W & Shallow & Transmissive fracture \\
90.16 & 27.48 & 190 & 100 & 33 & S & Moderate & Fracture \\
92.84 & 28.30 & 281 & 191 & 88 & W & Nearly vertical & Minor fracture \\
97.53 & 29.73 & 271 & 181 & 65 & W & Steep & Minor fracture \\
97.63 & 29.76 & 260 & 170 & 2 & W & Nearly horizontal & Lithologic feature \\
99.10 & 30.20 & 339 & 249 & 27 & N & Shallow & Lithologic feature \\
99.36 & 30.28 & 272 & 182 & 70 & W & Steep & Minor fracture \\
100.96 & 30.77 & 336 & 246 & 38 & NW & Moderate & Lithologic feature \\
\hline
\end{tabular}




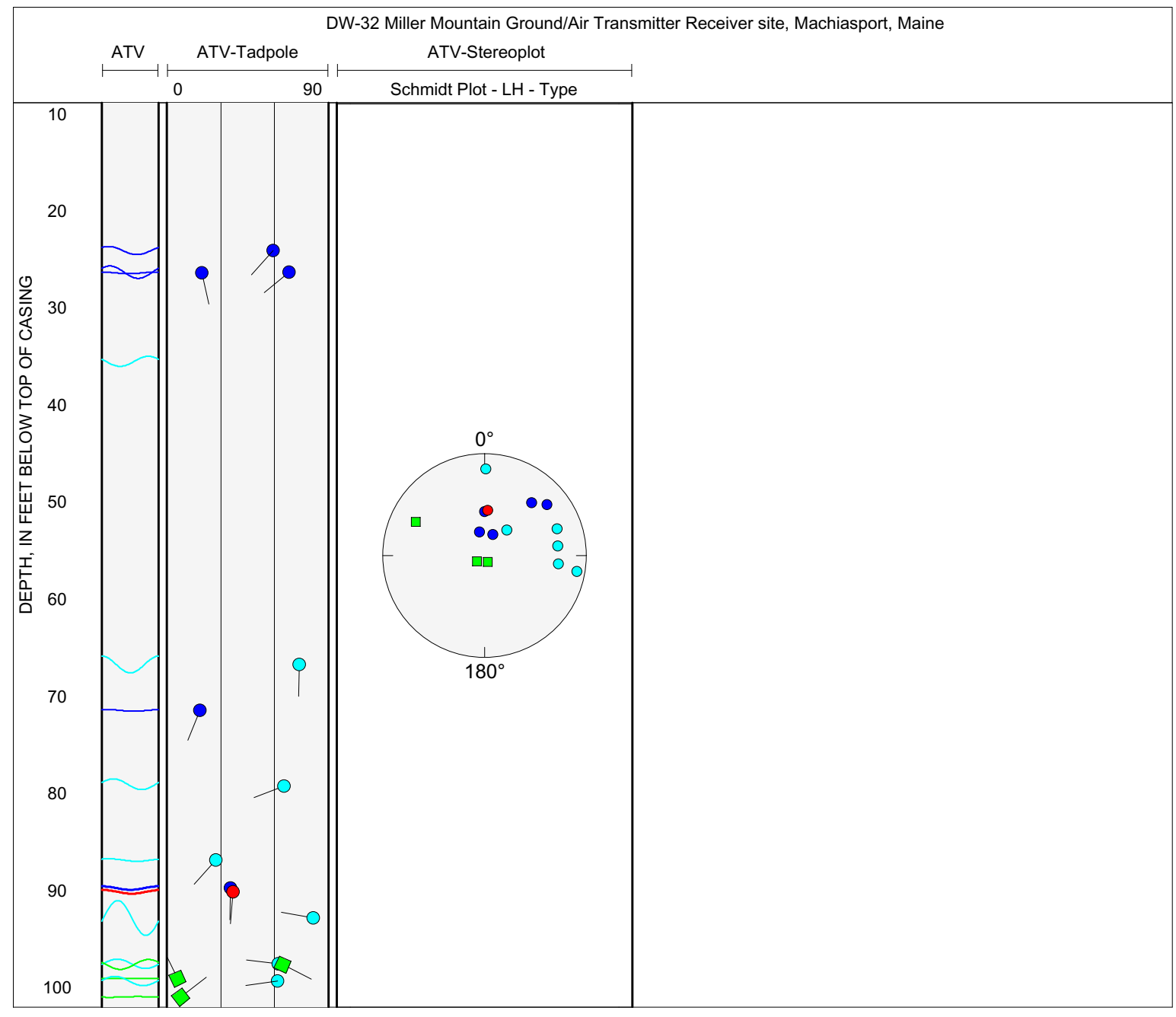

Figure 1G-3. Projection, tadpole, and stereoplots of interpretation of borehole image data for borehole DW-32, near Machiasport, Maine. 

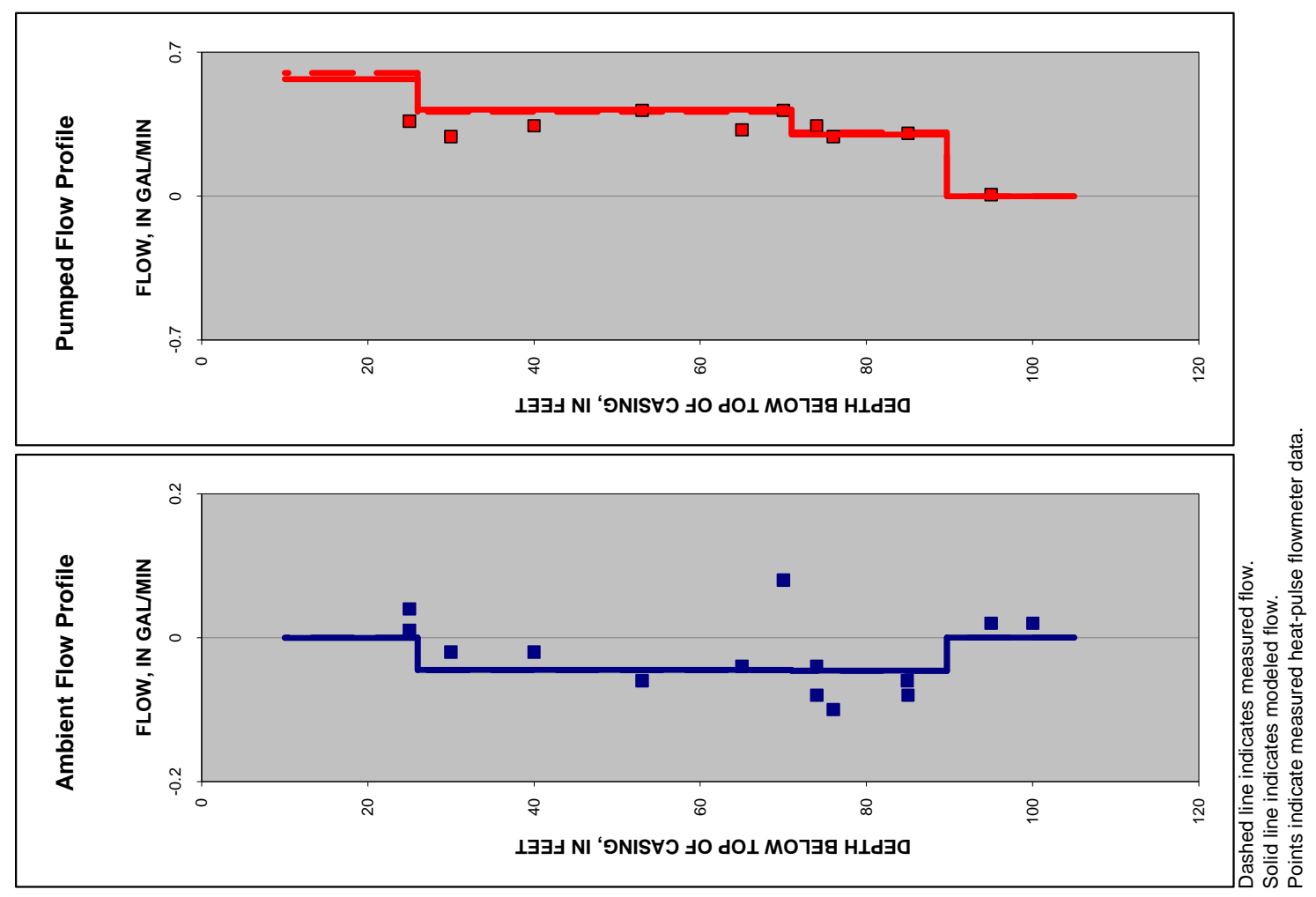

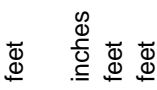

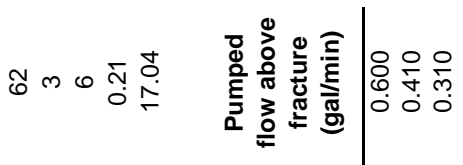

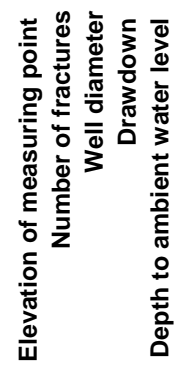

蒙旁

言经次灾

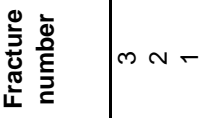

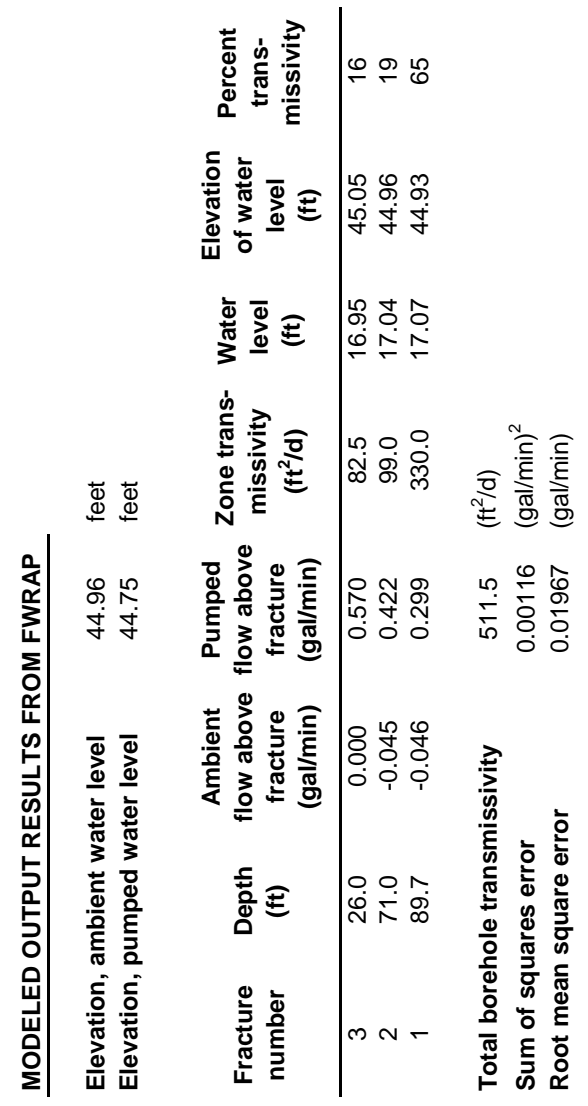

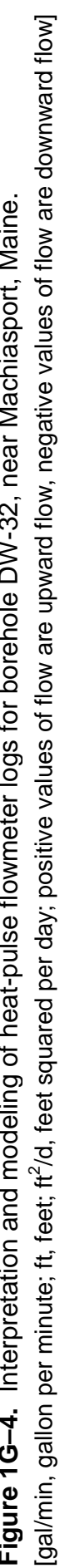




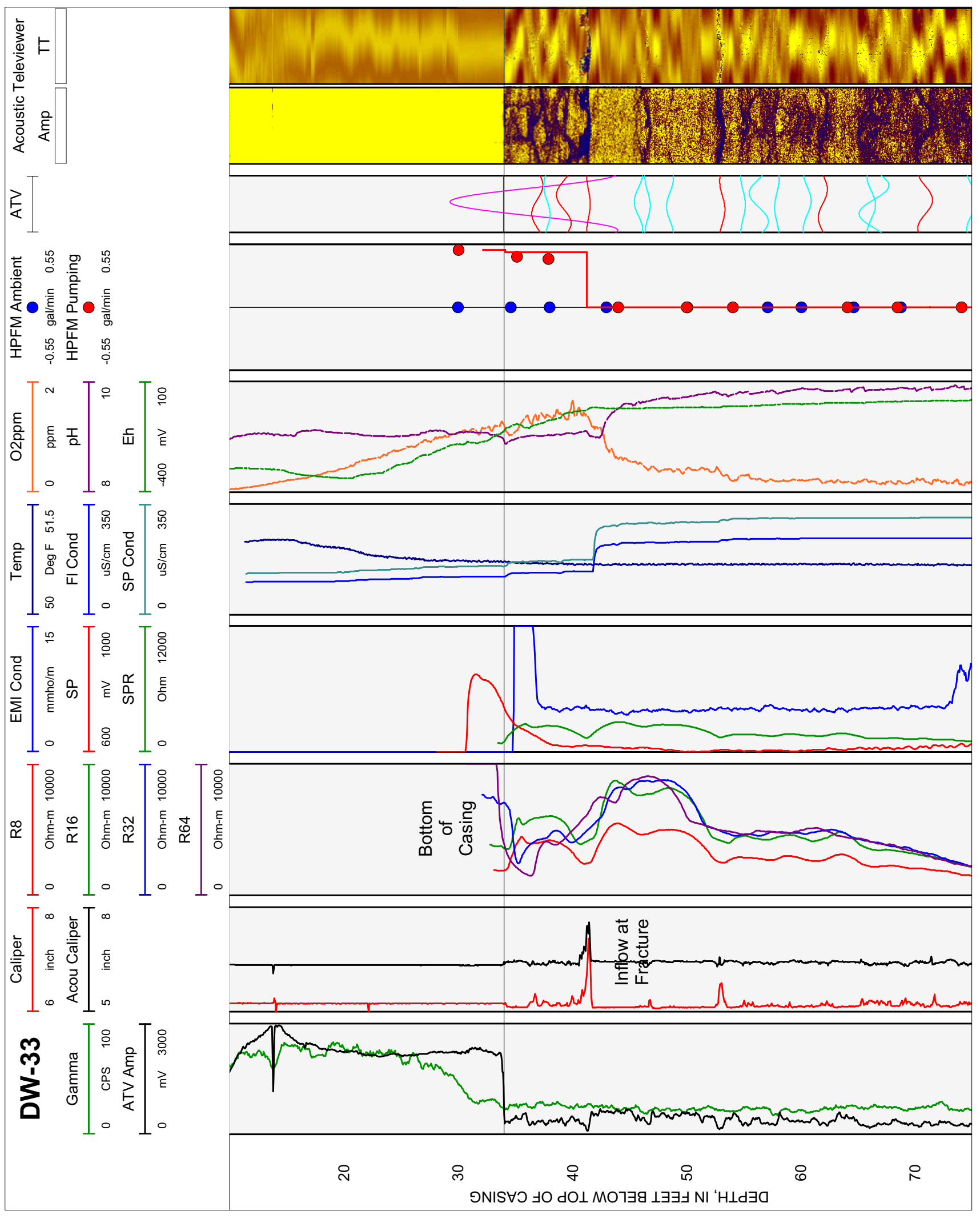

Figure 1H-1. Caliper, acoustic caliper, gamma, electromagnetic conductivity, fluid temperature, specific conductance, $\mathrm{DO}, \mathrm{pH}$, reduction oxidation, multi-space resistivity, oriented acoustic and optical borehole images, and heat-pulse flowmeter logs for borehole DW-33, near Machiasport, Maine. 


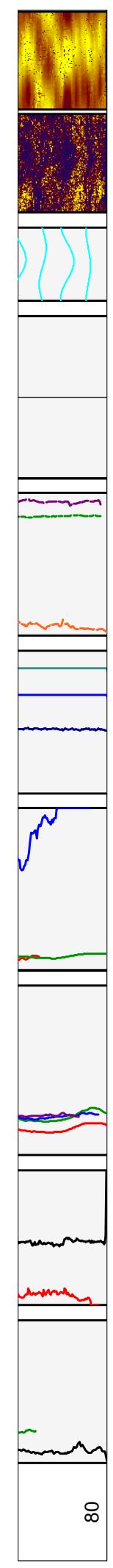

Figure 1H-1. Caliper, acoustic caliper, gamma, electromagnetic conductivity, fluid temperature, specific conductance, $\mathrm{DO}, \mathrm{pH}$, reduction oxidation, multi-space resistivity, oriented acoustic and optical borehole images, and heat-pulse flowmeter logs for borehole DW-33, near Machiasport, Maine.-Continued 

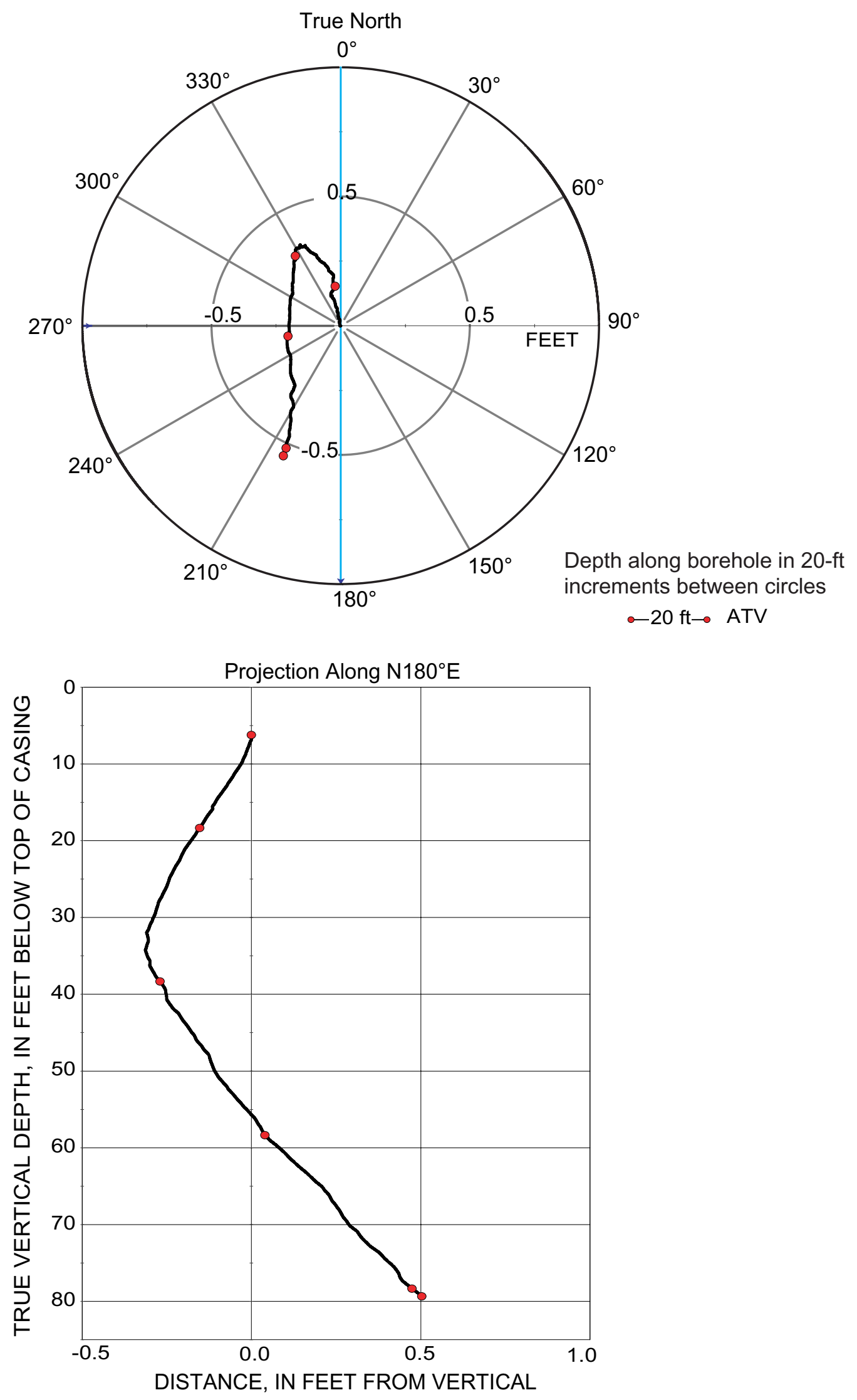

Figure 1H-2. Borehole deviation logs for borehole DW-33, near Machiasport, Maine. Blue line on radial plot (top) is line of projection for vertical plot (bottom).

[ft, foot; ATV, acoustic televiewer] 
Table 1H-1. Interpretation of acoustic televiewer logs for borehole DW-33, near Machiasport, Maine.

[Televiewer data are corrected for deviation and magnetic declination, so orientations are relative to true north; depths are below top of casing, which is 1.98 feet above land surface; dip azimuth is given in degrees east of true north; strike is reported in right-hand-rule (RHR)-azimuthal degrees east of true north and where the direction of dip is 90 degrees to the right of strike]

\begin{tabular}{crrrrcll}
\hline $\begin{array}{c}\text { Depth, } \\
\text { in feet }\end{array}$ & $\begin{array}{c}\text { Depth, } \\
\text { in meters }\end{array}$ & $\begin{array}{c}\text { Dip } \\
\text { azimuth }\end{array}$ & $\begin{array}{c}\text { Strike, } \\
\text { in RHR }\end{array}$ & Dip & $\begin{array}{c}\text { Dip } \\
\text { direction }\end{array}$ & Dip descriptor & Comment \\
\hline 33.98 & 10.36 & 76.5 & 347 & 1 & E & Nearly horizontal & Bottom of casing \\
34.69 & 10.57 & 177.1 & 87 & 58 & S & Steep & Minor fracture \\
34.80 & 10.61 & 8.04 & 278 & 84 & N & Nearly vertical & Partial trace of fracture \\
36.92 & 11.25 & 299.26 & 209 & 63 & NW & Steep & Fracture \\
37.77 & 11.51 & 115.16 & 25 & 48 & SE & Moderate & Minor fracture \\
39.24 & 11.96 & 57.77 & 328 & 69 & NE & Steep & Transmissive fracture \\
39.31 & 11.98 & 327.19 & 237 & 25 & NW & Shallow & Minor fracture \\
40.87 & 12.46 & 190.17 & 100 & 64 & S & Steep & Transmissive fracture \\
41.40 & 12.62 & 170.65 & 81 & 31 & S & Moderate & Transmissive fracture \\
45.84 & 13.97 & 5.82 & 276 & 52 & N & Steep & Minor fracture \\
46.56 & 14.19 & 156.18 & 66 & 42 & SE & Moderate & Minor fracture \\
48.49 & 14.78 & 331.43 & 241 & 51 & NW & Steep & Minor fracture \\
53.12 & 16.19 & 142.8 & 53 & 42 & SE & Moderate & Fracture \\
54.82 & 16.71 & 166.14 & 76 & 37 & S & Moderate & Minor fracture \\
56.36 & 17.18 & 58.37 & 328 & 74 & NE & Nearly vertical & Minor fracture \\
57.86 & 17.63 & 334.96 & 245 & 38 & NW & Moderate & Minor fracture \\
60.59 & 18.47 & 210.52 & 121 & 52 & SW & Steep & Minor fracture \\
61.92 & 18.87 & 266.33 & 176 & 57 & W & Steep & Fracture \\
66.15 & 20.16 & 170.87 & 81 & 54 & S & Steep & Minor fracture \\
66.40 & 20.24 & 295.33 & 205 & 80 & NW & Nearly vertical & Minor fracture \\
70.84 & 21.59 & 201.04 & 111 & 68 & S & Steep & Fracture \\
75.00 & 22.86 & 202.83 & 113 & 60 & SW & Steep & Minor fracture \\
75.91 & 23.14 & 56.81 & 327 & 54 & NE & Steep & Minor fracture \\
76.57 & 23.34 & 217.87 & 128 & 49 & SW & Moderate & Minor fracture \\
78.21 & 23.84 & 196.49 & 106 & 60 & S & Steep & Minor fracture \\
79.24 & 24.15 & 189.56 & 100 & 66 & S & Steep & Minor fracture \\
79.74 & 24.30 & 180.92 & 91 & 30 & S & Shallow & Minor fracture \\
\hline
\end{tabular}




\begin{tabular}{|lll|l|l|l|l|}
\hline & & \\
\hline
\end{tabular}

Figure 1H-3. Projection, tadpole, and stereoplots of interpretation of borehole image data for borehole DW-33, near Machiasport, Maine. 

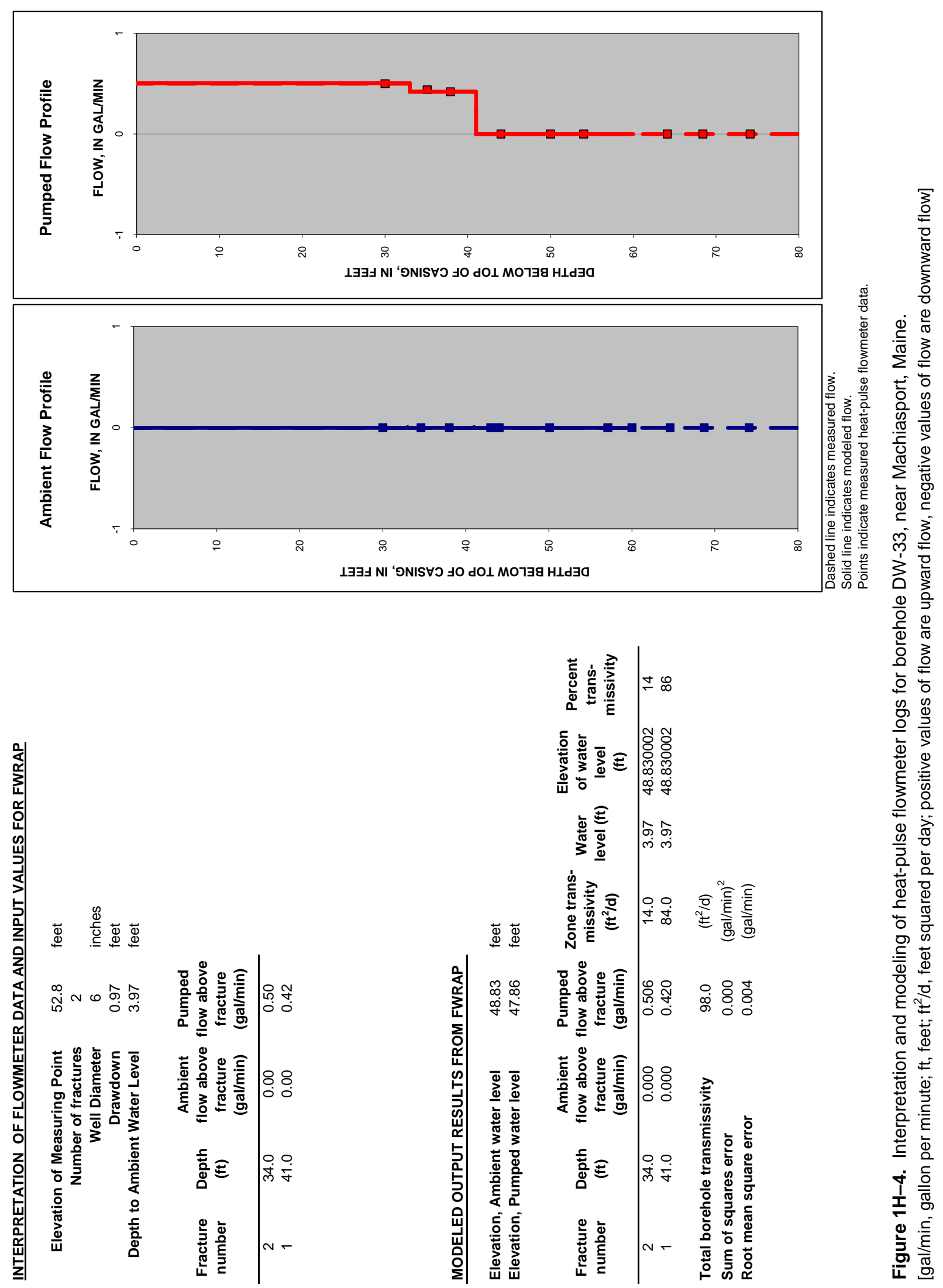


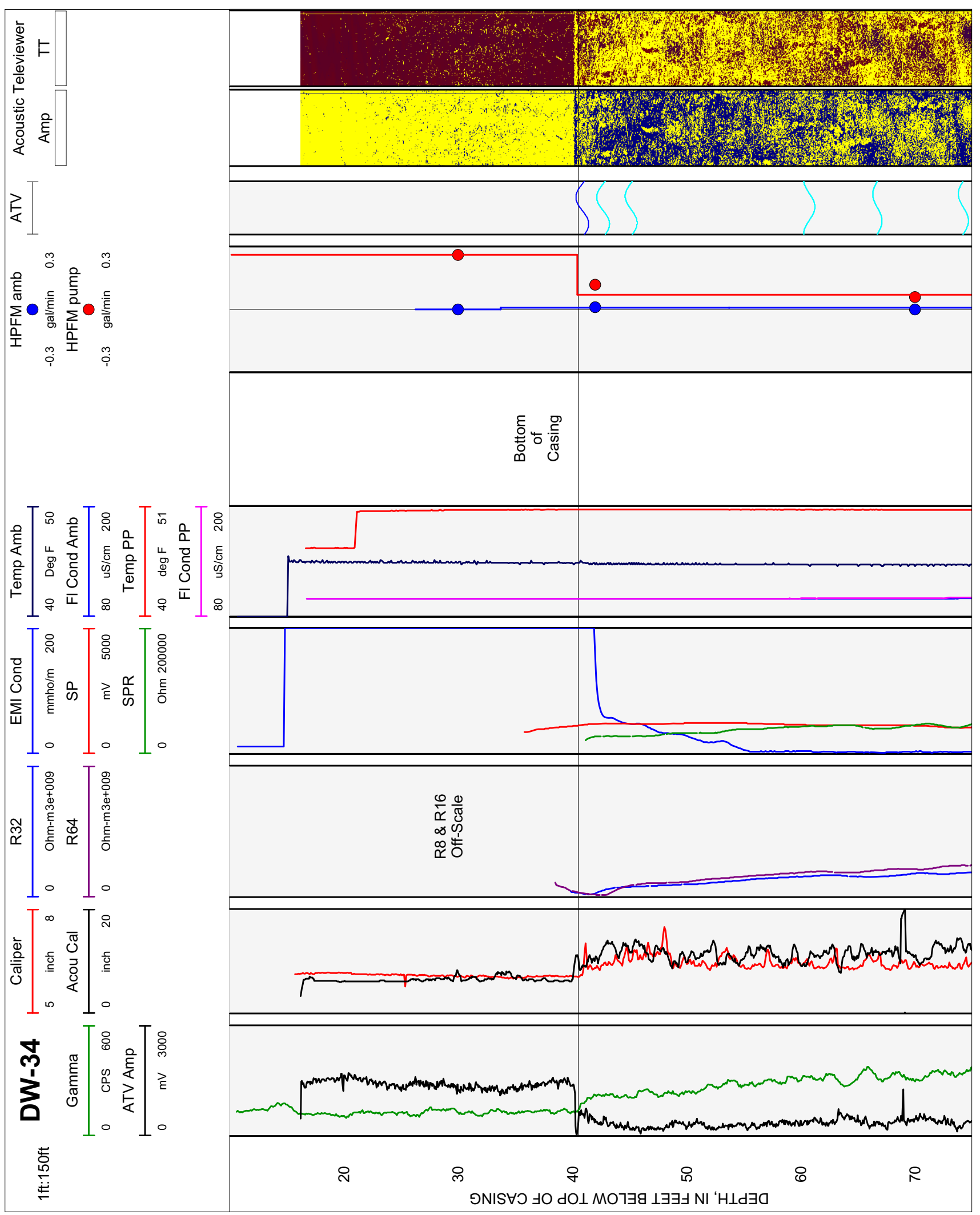

Figure 11-1. Caliper, acoustic caliper, gamma, electromagnetic conductivity, fluid temperature, specific conductance, $\mathrm{DO}, \mathrm{pH}$, reduction oxidation, multi-space resistivity, oriented acoustic and optical borehole images, and heat-pulse flowmeter logs for borehole DW-34, near Machiasport, Maine. 


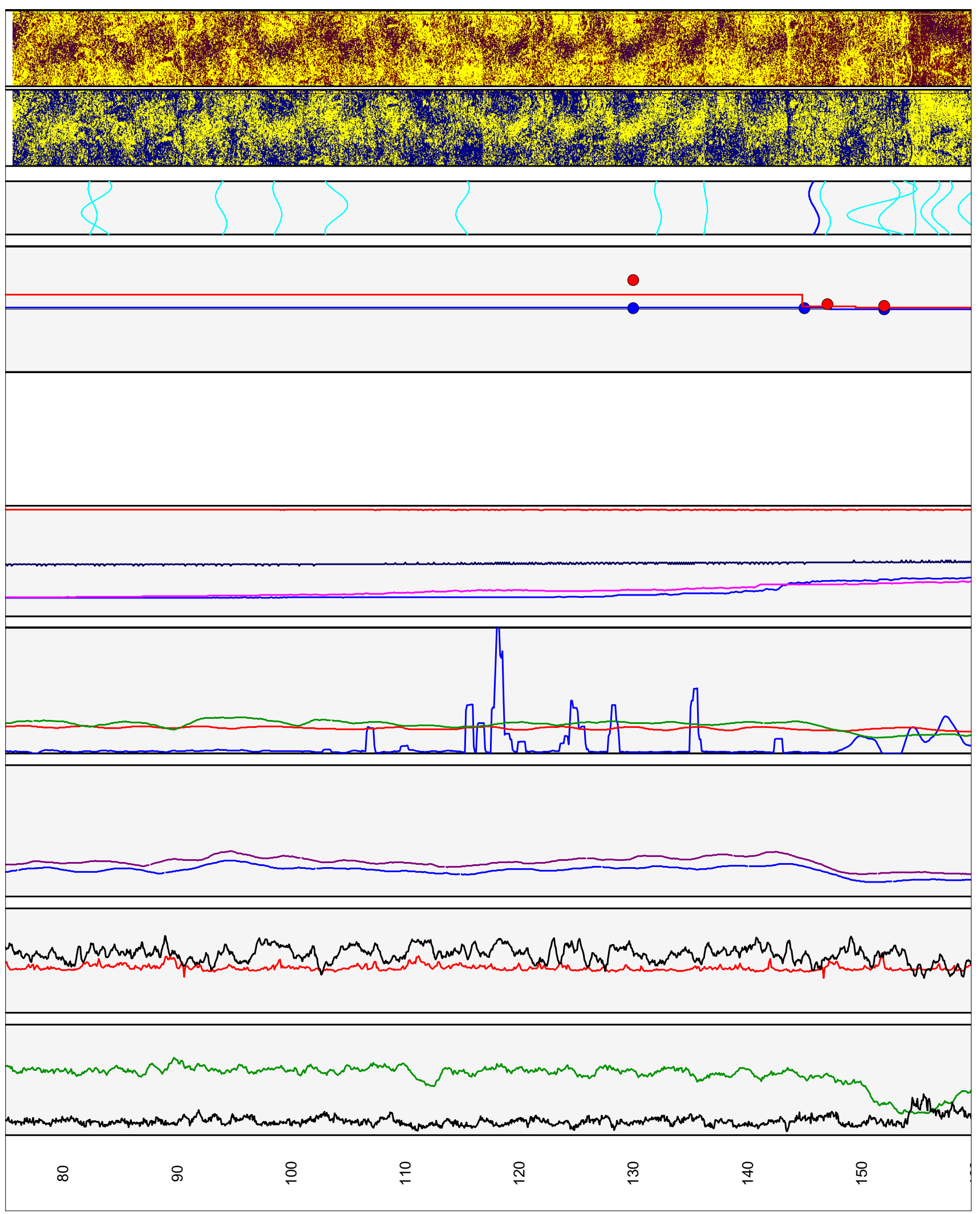

Figure 11-1. Caliper, acoustic caliper, gamma, electromagnetic conductivity, fluid temperature, specific conductance, $\mathrm{DO}, \mathrm{pH}$, reduction oxidation, multi-space resistivity, oriented acoustic and optical borehole images, and heat-pulse flowmeter logs for borehole DW-34, near Machiasport, Maine.-Continued 

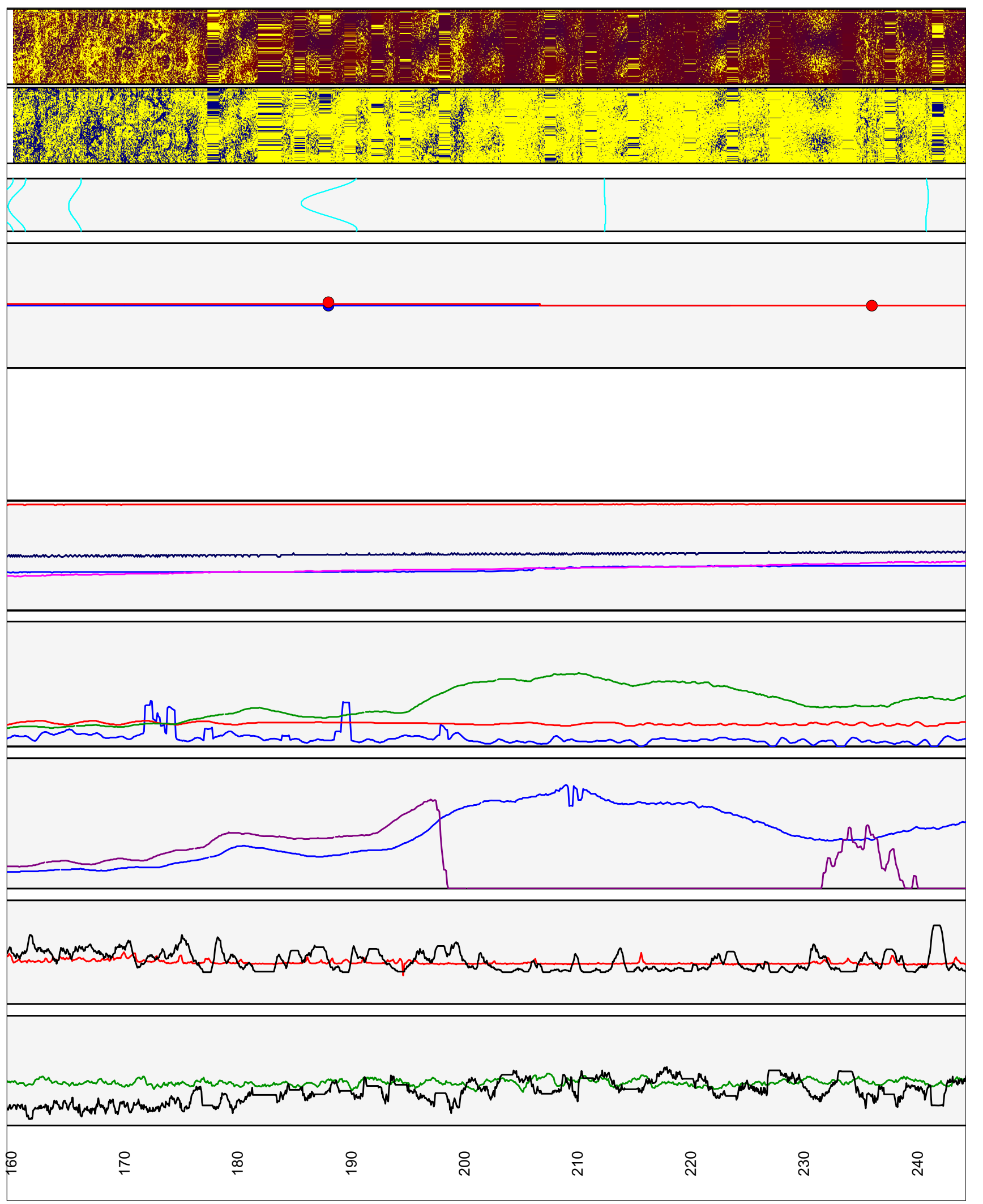

Figure 1I-1. Caliper, acoustic caliper, gamma, electromagnetic conductivity, fluid temperature, specific conductance, $\mathrm{DO}, \mathrm{pH}$, reduction oxidation, multi-space resistivity, oriented acoustic and optical borehole images, and heat-pulse flowmeter logs for borehole DW-34, near Machiasport, Maine.-Continued 


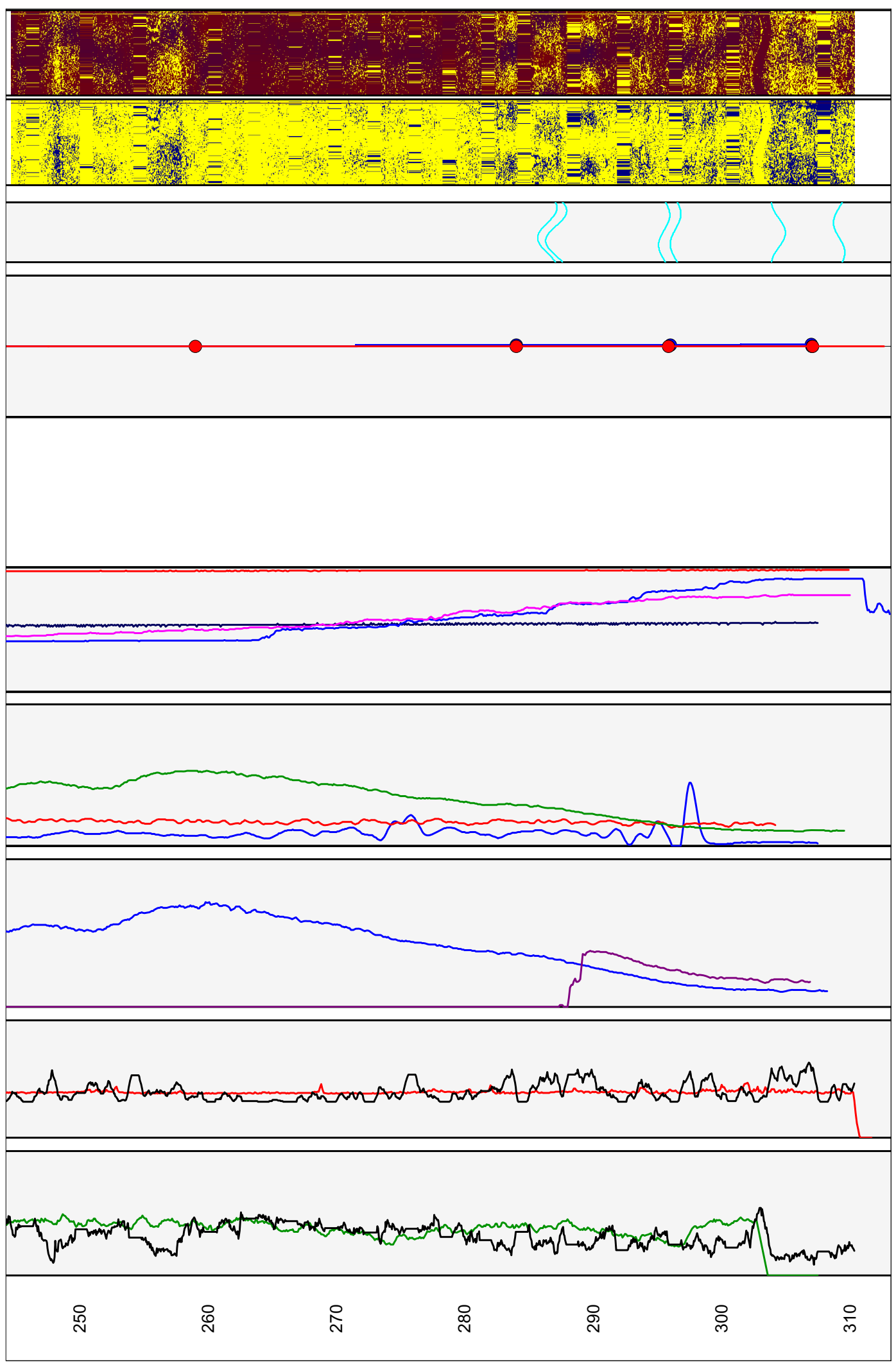

Figure 11-1. Caliper, acoustic caliper, gamma, electromagnetic conductivity, fluid temperature, specific conductance, $\mathrm{DO}, \mathrm{pH}$, reduction oxidation, multi-space resistivity, oriented acoustic and optical borehole images, and heat-pulse flowmeter logs for borehole DW-34, near Machiasport, Maine.-Continued 

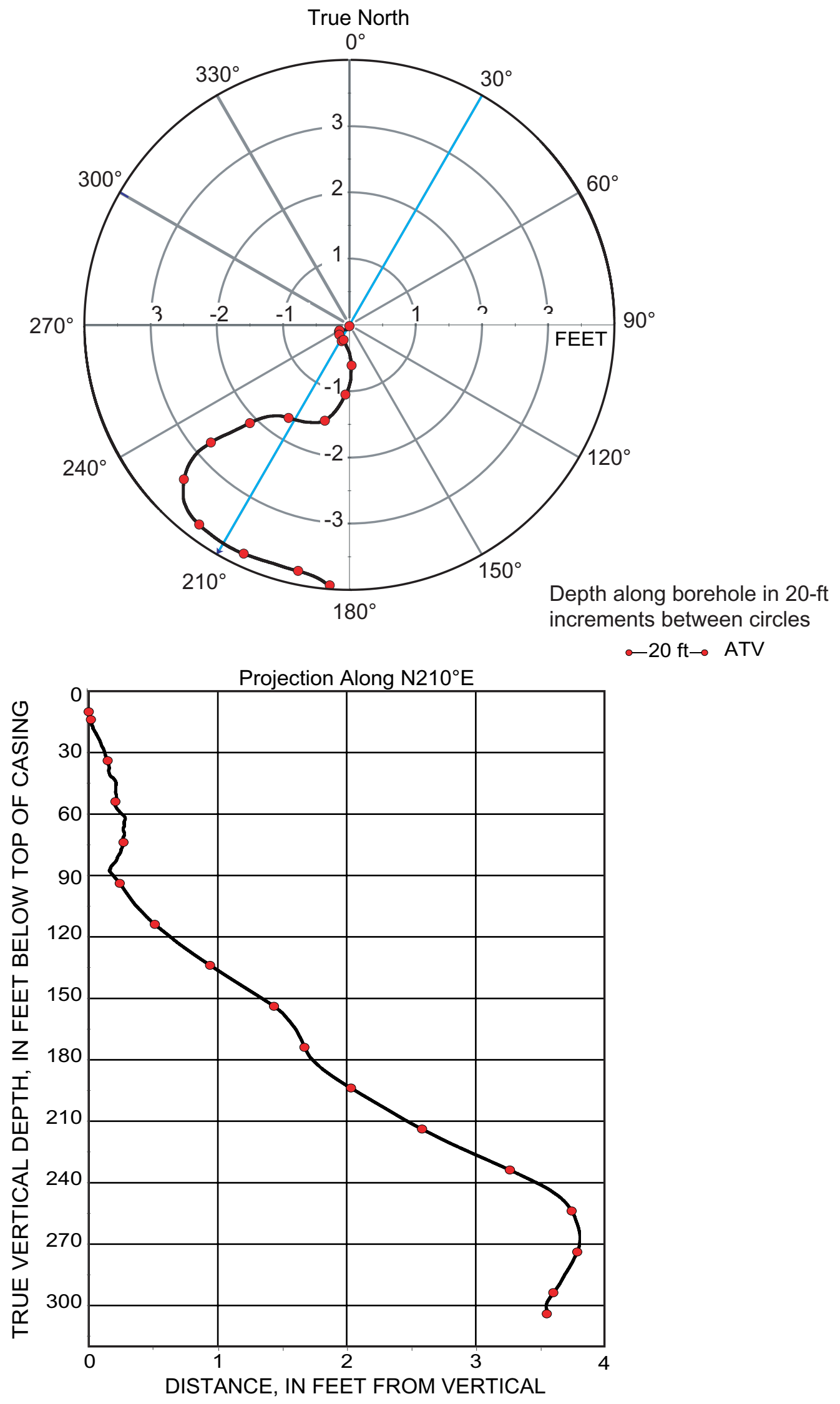

Figure 1I-2. Borehole deviation logs for borehole DW-34, near Machiasport, Maine. Blue line on radial plot (top is line of projection for vertical plot (bottom). Deviation (tilt) data interpolated from 95 to 295 feet below top of casing. [ft, foot; ATV, acoustic televiewer] 
Table 1I-1. Interpretation of acoustic televiewer logs for borehole DW-34, near Machiasport, Maine.

[Televiewer data are corrected for deviation and magnetic declination, so orientations are relative to true north; depths are below top of casing, which is 2.25 feet above land surface; dip azimuth is given in degrees east of true north; strike is reported in right-hand-rule (RHR)-azimuthal degrees east of true north and where the direction of dip is 90 degrees to the right of strike; ,-- no measurement]

\begin{tabular}{|c|c|c|c|c|c|c|c|}
\hline $\begin{array}{l}\text { Depth, } \\
\text { in feet }\end{array}$ & $\begin{array}{l}\text { Depth, } \\
\text { in meters }\end{array}$ & $\begin{array}{c}\text { Dip } \\
\text { azimuth }\end{array}$ & $\begin{array}{l}\text { Strike, } \\
\text { in RHR }\end{array}$ & Dip & $\begin{array}{c}\text { Dip } \\
\text { direction }\end{array}$ & Dip descriptor & Comment \\
\hline 40.50 & 12.34 & -- & -- & -- & -- & -- & Bottom of casing \\
\hline 40.87 & 12.46 & 72 & 342 & 66 & $E$ & Steep & Transmissive fracture \\
\hline 42.67 & 13.01 & 72 & 342 & 67 & $E$ & Steep & Minor fracture \\
\hline 45.16 & 13.76 & 80 & 350 & 65 & $E$ & Steep & Minor fracture \\
\hline 60.73 & 18.51 & 188 & 98 & 63 & $\mathrm{~S}$ & Steep & Minor fracture \\
\hline 66.71 & 20.33 & 91 & 1 & 58 & $E$ & Steep & Minor fracture \\
\hline 74.21 & 22.62 & 94 & 4 & 61 & $E$ & Steep & Minor fracture \\
\hline 82.59 & 25.17 & 131 & 41 & 57 & SE & Steep & Minor fracture \\
\hline 82.92 & 25.27 & 326 & 236 & 78 & NW & Nearly vertical & Minor fracture \\
\hline 93.85 & 28.60 & 74 & 344 & 63 & $E$ & Steep & Minor fracture \\
\hline 98.79 & 30.11 & 134 & 44 & 56 & SE & Steep & Minor fracture \\
\hline 103.94 & 31.68 & 199 & 109 & 75 & $\mathrm{~S}$ & Nearly vertical & Minor fracture \\
\hline 115.01 & 35.05 & 317 & 227 & 67 & NW & Steep & Minor fracture \\
\hline 132.14 & 40.27 & 118 & 28 & 49 & SE & Moderate & Minor fracture \\
\hline 136.34 & 41.55 & 164 & 74 & 28 & $\mathrm{~S}$ & Shallow & Minor fracture \\
\hline 145.83 & 44.45 & 95 & 5 & 61 & $\mathrm{E}$ & Steep & Transmissive fracture \\
\hline 146.80 & 44.74 & 87 & 357 & 62 & $\bar{E}$ & Steep & Minor fracture \\
\hline 151.78 & 46.26 & 310 & 220 & 85 & NW & Nearly vertical & Minor fracture \\
\hline 152.42 & 46.46 & 280 & 190 & 73 & W & Nearly vertical & Minor fracture \\
\hline 154.62 & 47.13 & 97 & 7 & 26 & $E$ & Shallow & Minor fracture \\
\hline 156.02 & 47.55 & 335 & 245 & 73 & NW & Nearly vertical & Minor fracture \\
\hline 157.06 & 47.87 & 324 & 234 & 74 & NW & Nearly vertical & Minor fracture \\
\hline 159.30 & 48.55 & 355 & 265 & 74 & $\mathrm{~N}$ & Nearly vertical & Minor fracture \\
\hline 160.48 & 48.91 & 351 & 261 & 72 & $\mathrm{~N}$ & Nearly vertical & Minor fracture \\
\hline 165.62 & 50.48 & 352 & 262 & 65 & $\mathrm{~N}$ & Steep & Minor fracture \\
\hline 188.05 & 57.31 & 12 & 282 & 84 & $\mathrm{~N}$ & Nearly vertical & Minor fracture \\
\hline 212.39 & 64.73 & 112 & 22 & 14 & $E$ & Shallow & Minor fracture \\
\hline 240.87 & 73.41 & 239 & 149 & 23 & sw & Shallow & Minor fracture \\
\hline 286.45 & 87.31 & 326 & 236 & 74 & NW & Nearly vertical & Minor fracture \\
\hline 287.13 & 87.51 & 308 & 218 & 75 & NW & Nearly vertical & Minor fracture \\
\hline 295.53 & 90.07 & 284 & 194 & 62 & W & Steep & Minor fracture \\
\hline 296.44 & 90.35 & 290 & 200 & 61 & W & Steep & Minor fracture \\
\hline 304.42 & 92.78 & 178 & 88 & 62 & $\mathrm{~S}$ & Steep & Minor fracture \\
\hline 309.17 & 94.23 & 57 & 327 & 60 & $\mathrm{NE}$ & Steep & Minor fracture \\
\hline
\end{tabular}




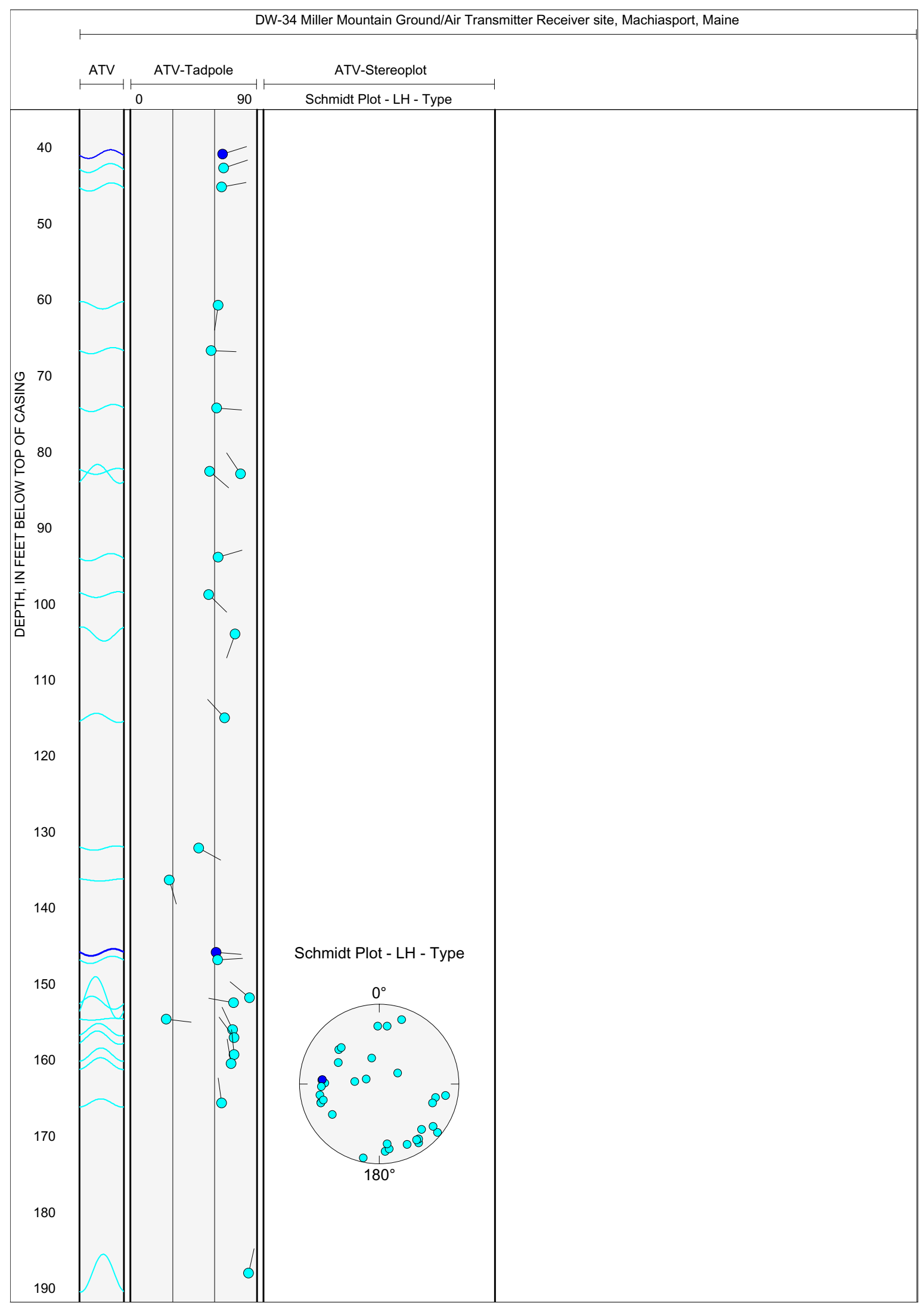

Figure 1I-3. Projection, tadpole, and stereoplots of interpretation of borehole image data for borehole DW-34, near Machiasport, Maine. 


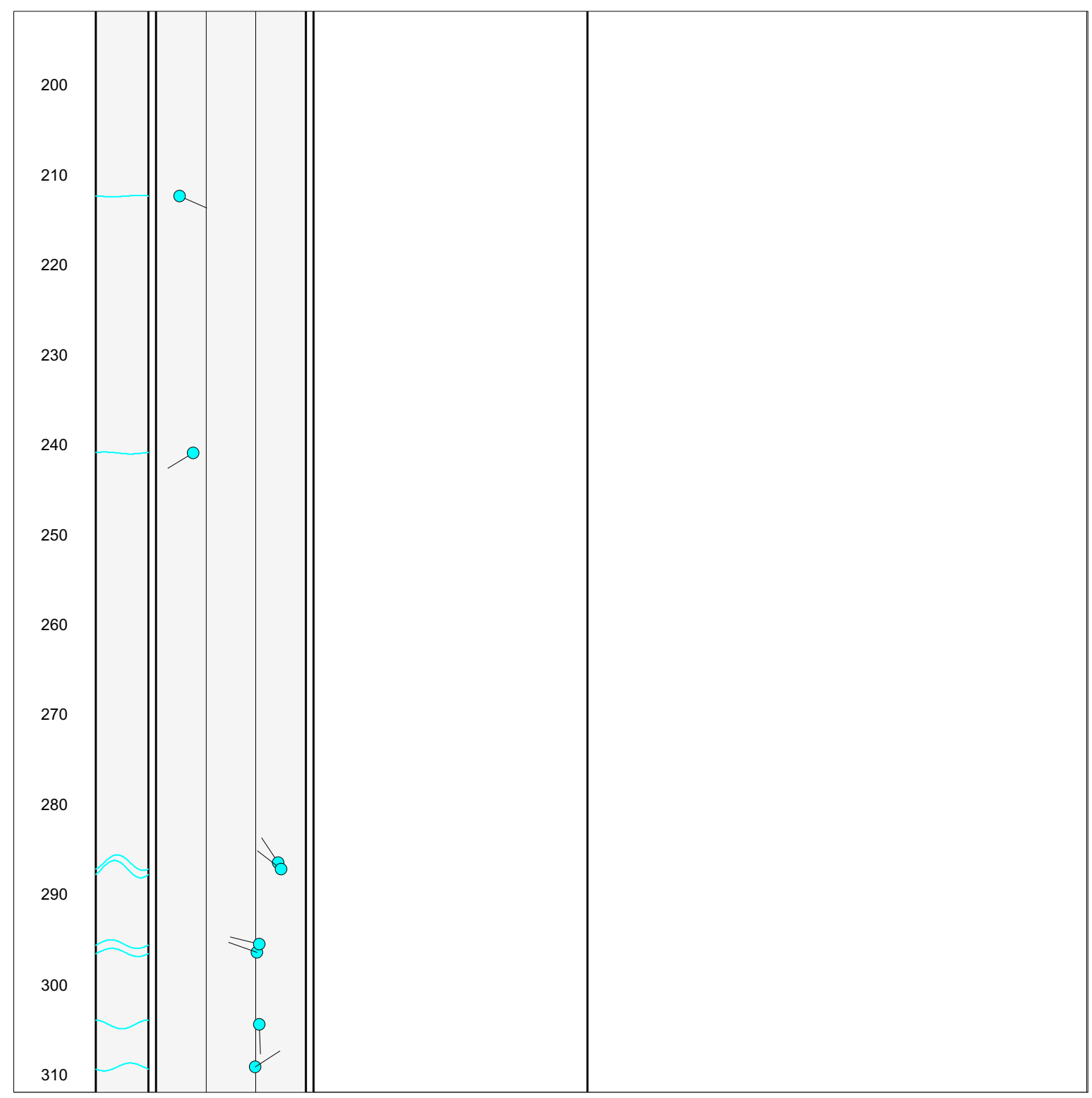

Figure 11-3. Projection, tadpole, and stereoplots of interpretation of borehole image data for borehole DW-34, near Machiasport, Maine.-Continued 

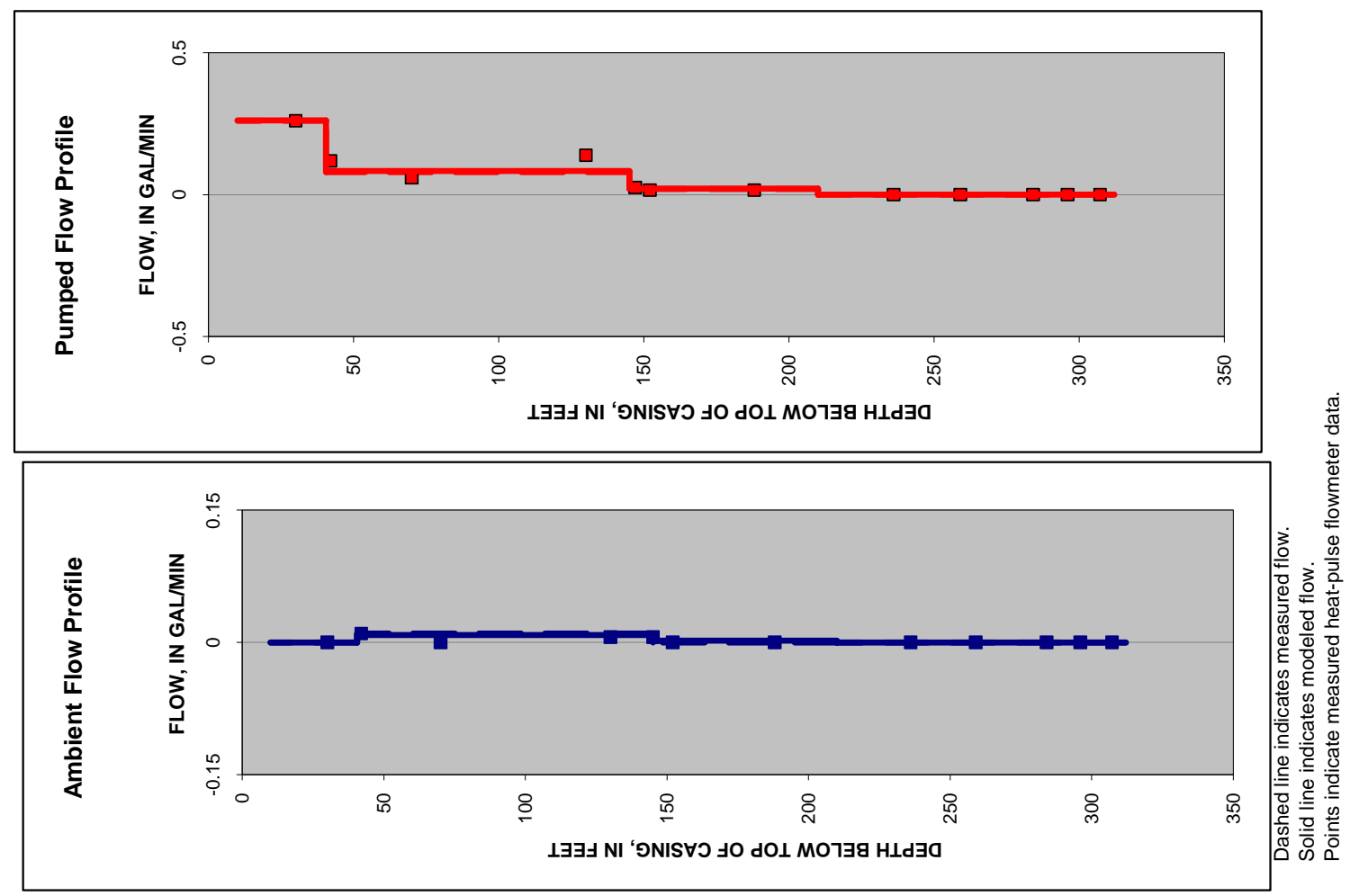

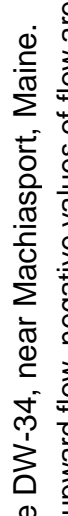

응 음

잉 은

흐 "

응 금

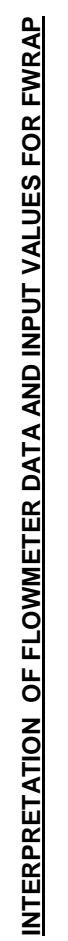

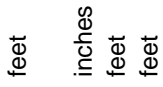
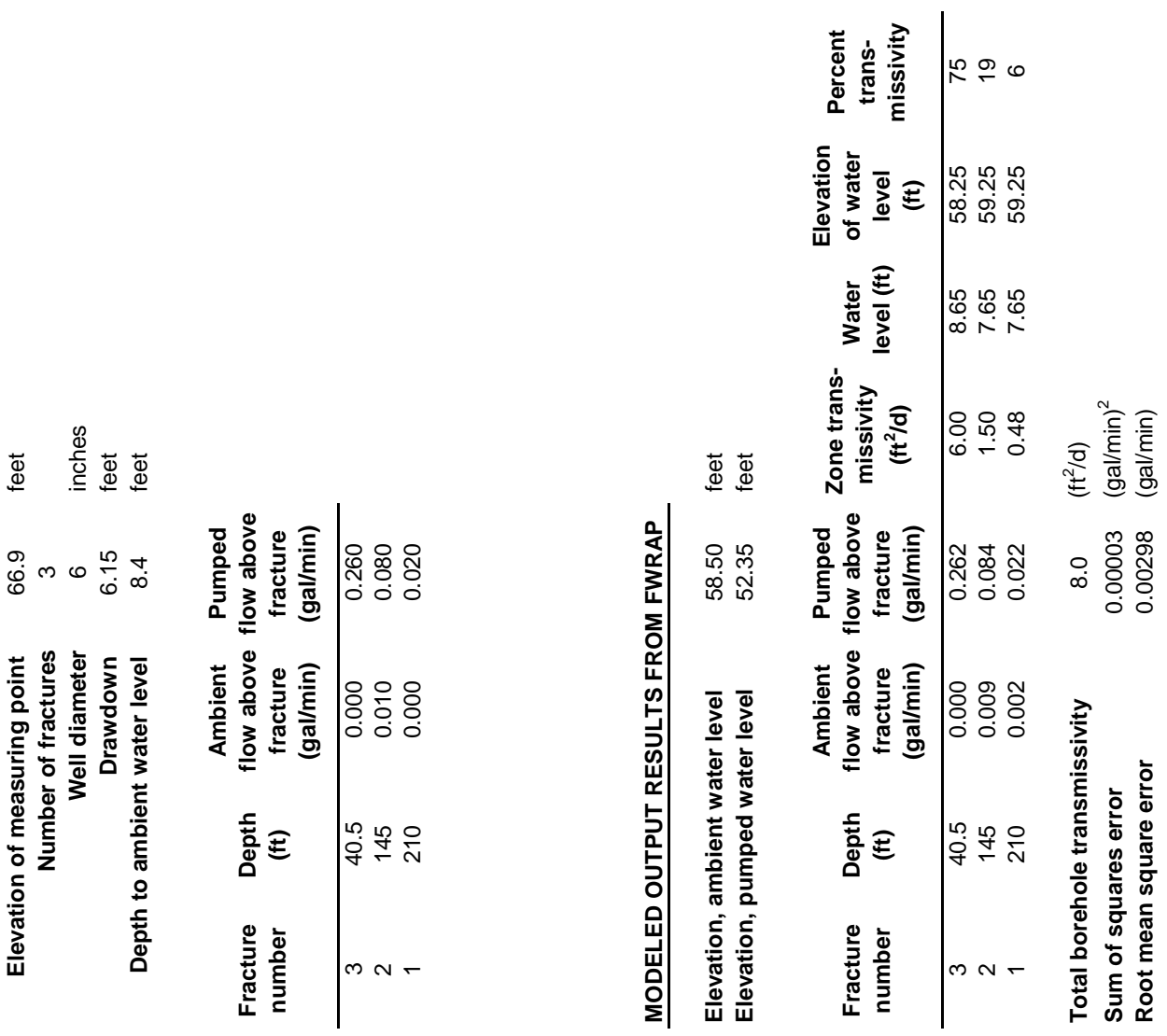

产

过

은

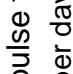

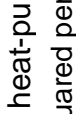

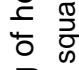

을

을

동

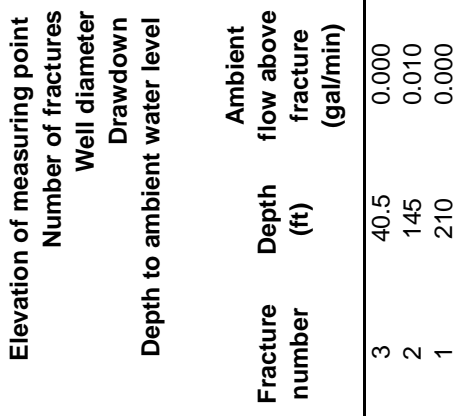

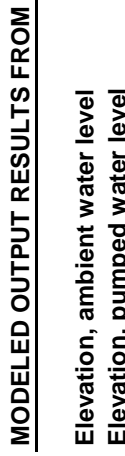

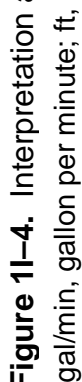




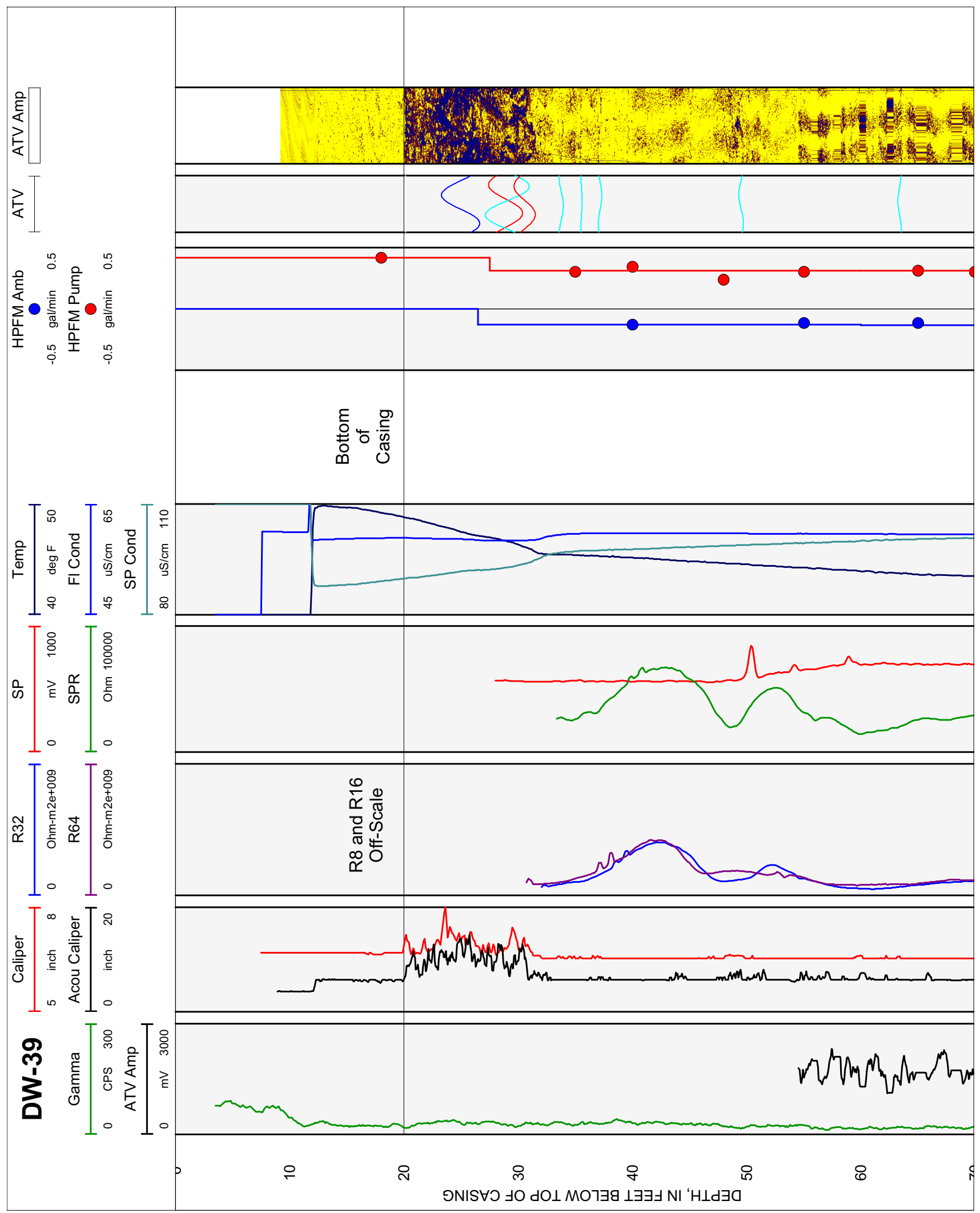

Figure 1J-1. Caliper, acoustic caliper, gamma, electromagnetic conductivity, fluid temperature, specific conductance, $\mathrm{DO}, \mathrm{pH}$, reduction oxidation, multi-space resistivity, oriented acoustic and optical borehole images, and heat-pulse flowmeter logs for borehole DW-39, near Machiasport, Maine. 


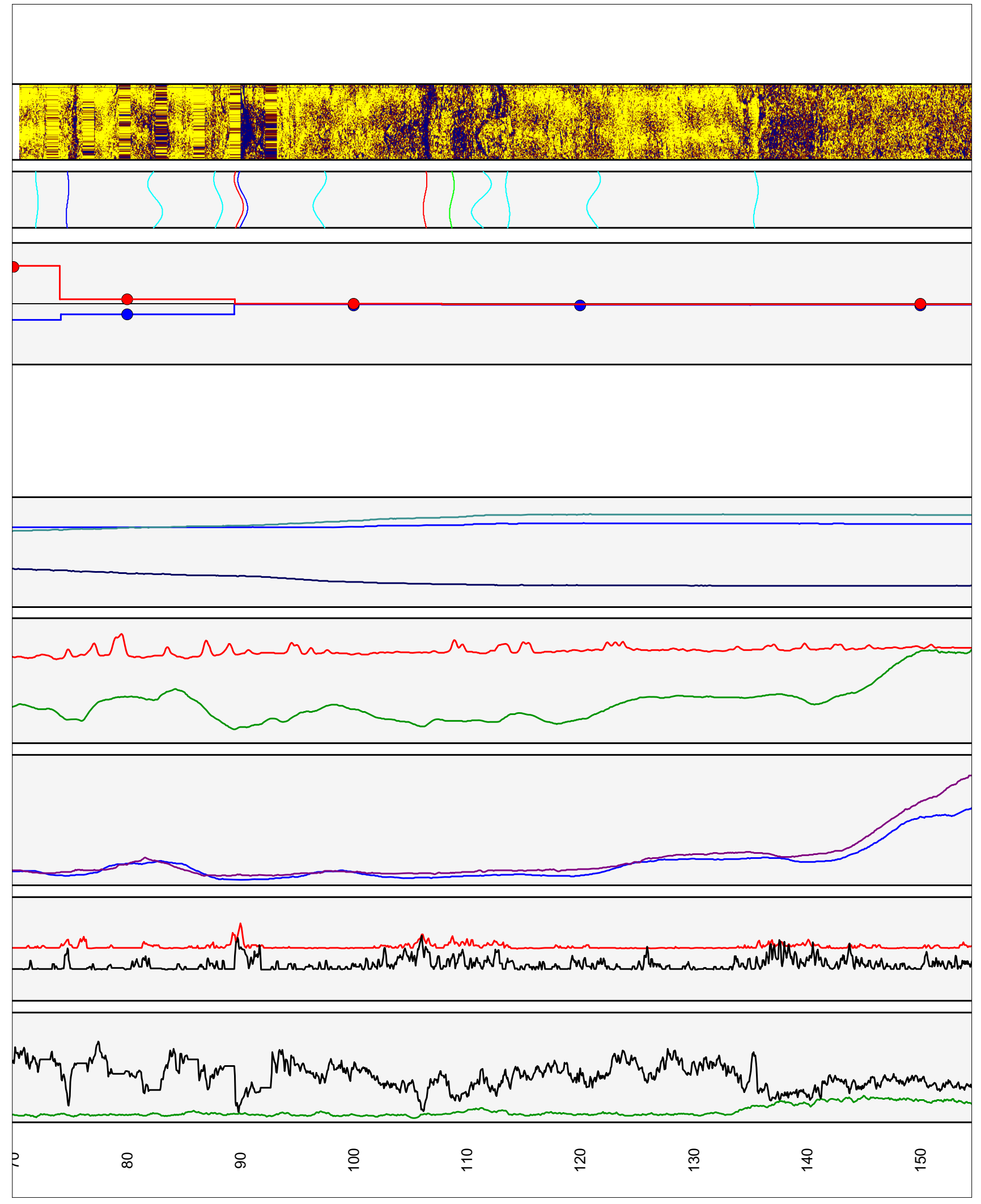

Figure 1J-1. Caliper, acoustic caliper, gamma, electromagnetic conductivity, fluid temperature, specific conductance, $\mathrm{DO}, \mathrm{pH}$, reduction oxidation, multi-space resistivity, oriented acoustic and optical borehole images, and heat-pulse flowmeter logs for borehole DW-39, near Machiasport, Maine.-Continued 


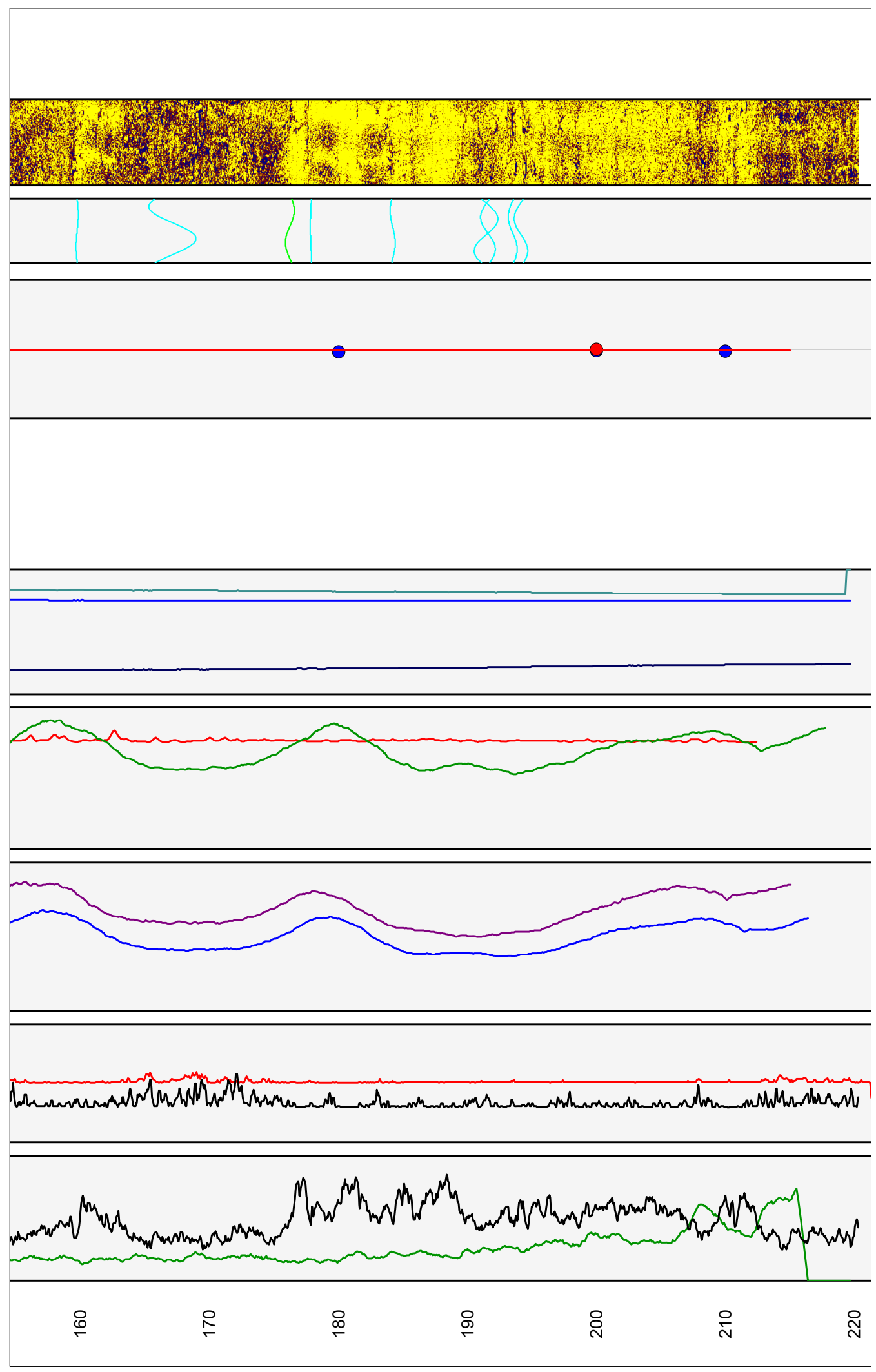

Figure 1J-1. Caliper, acoustic caliper, gamma, electromagnetic conductivity, fluid temperature, specific conductance, $\mathrm{DO}, \mathrm{pH}$, reduction oxidation, multi-space resistivity, oriented acoustic and optical borehole images, and heat-pulse flowmeter logs for borehole DW-39, near Machiasport, Maine.-Continued 

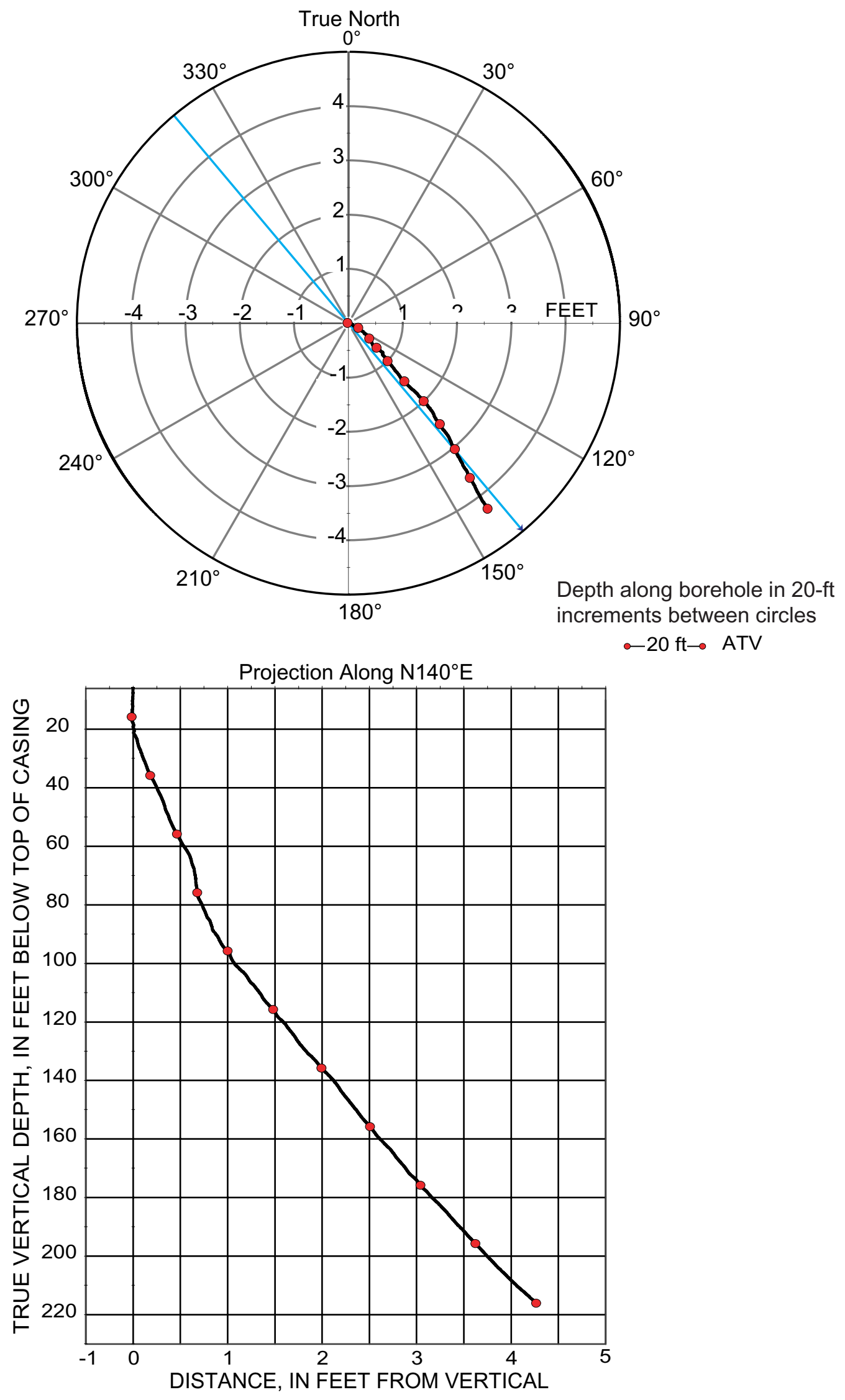

Figure 1J-2. Borehole deviation logs for borehole DW-39, near Machiasport, Maine. Blue line on radial plot (top) is line of projection for vertical plot (bottom).

[ft, foot; ATV, acoustic televiewer] 
Table 1J-1. Interpretation of acoustic televiewer logs for borehole DW-39, near Machiasport, Maine.

[Televiewer data are corrected for deviation and magnetic declination, so orientations are relative to true north; depths are below top of casing, which is 2.18 feet above land surface; dip azimuth is given in degrees east of true north; strike is reported in right-hand-rule (RHR)-azimuthal degrees east of true north and where the direction of dip is 90 degrees to the right of strike]

\begin{tabular}{|c|c|c|c|c|c|c|c|}
\hline $\begin{array}{l}\text { Depth, } \\
\text { in feet }\end{array}$ & $\begin{array}{l}\text { Depth, } \\
\text { in meters }\end{array}$ & $\begin{array}{c}\text { Dip } \\
\text { azimuth }\end{array}$ & $\begin{array}{c}\text { Strike, } \\
\text { in RHR }\end{array}$ & Dip & $\begin{array}{c}\text { Dip } \\
\text { direction }\end{array}$ & Dip descriptor & Comment \\
\hline 20.14 & 6.14 & 0 & 270 & 0 & $\mathrm{~N}$ & Horizontal & Bottom of casing \\
\hline 24.93 & 7.60 & 57 & 327 & 81 & $\mathrm{NE}$ & Nearly vertical & Transmissive fracture \\
\hline 28.88 & 8.80 & 122 & 32 & 80 & SE & Nearly vertical & Large fracture \\
\hline 29.03 & 8.85 & 291 & 201 & 82 & W & Nearly vertical & Minor fracture \\
\hline 30.56 & 9.31 & 113 & 23 & 75 & SE & Nearly vertical & Large fracture \\
\hline 33.77 & 10.29 & 168 & 78 & 35 & $\mathrm{~S}$ & Moderate & Minor fracture \\
\hline 35.52 & 10.83 & 191 & 101 & 12 & $\mathrm{~S}$ & Shallow & Minor fracture \\
\hline 37.13 & 11.32 & 232 & 142 & 31 & sW & Moderate & Minor fracture \\
\hline 49.50 & 15.09 & 59 & 329 & 38 & $\mathrm{NE}$ & Moderate & Minor fracture \\
\hline 63.37 & 19.31 & 18 & 288 & 30 & $\mathrm{~N}$ & Shallow & Minor fracture \\
\hline 72.03 & 21.95 & 164 & 74 & 25 & $\mathrm{~S}$ & Shallow & Minor fracture \\
\hline 74.74 & 22.78 & 259 & 169 & 25 & W & Shallow & Transmissive fracture \\
\hline 82.49 & 25.14 & 101 & 11 & 69 & $E$ & Steep & Minor fracture \\
\hline 88.06 & 26.84 & 132 & 42 & 56 & SE & Steep & Minor fracture \\
\hline 89.88 & 27.39 & 133 & 43 & 57 & SE & Steep & Large fracture \\
\hline 90.19 & 27.49 & 128 & 38 & 59 & SE & Steep & Transmissive fracture \\
\hline 97.01 & 29.57 & 320 & 230 & 67 & NW & Steep & Minor fracture \\
\hline 106.28 & 32.39 & 305 & 215 & 35 & NW & Moderate & Large fracture \\
\hline 108.66 & 33.12 & 274 & 184 & 39 & W & Moderate & Lithologic feature \\
\hline 111.29 & 33.92 & 281 & 191 & 75 & W & Nearly vertical & Minor fracture \\
\hline 113.60 & 34.62 & 87 & 357 & 34 & $E$ & Moderate & Minor fracture \\
\hline 121.14 & 36.92 & 310 & 220 & 68 & NW & Steep & Minor fracture \\
\hline 135.49 & 41.30 & 243 & 153 & 39 & SW & Moderate & Minor fracture \\
\hline 159.77 & 48.70 & 276 & 186 & 18 & W & Shallow & Minor fracture \\
\hline 167.11 & 50.93 & 136 & 46 & 81 & SE & Nearly vertical & Minor fracture \\
\hline 176.22 & 53.71 & 295 & 205 & 55 & NW & Steep & Lithologic feature \\
\hline 177.85 & 54.21 & 19 & 289 & 10 & $\mathrm{~N}$ & Nearly horizontal & Minor fracture \\
\hline 184.20 & 56.14 & 110 & 20 & 36 & $E$ & Moderate & Minor fracture \\
\hline 191.42 & 58.34 & 247 & 157 & 75 & SW & Nearly vertical & Minor fracture \\
\hline 191.56 & 58.38 & 76 & 346 & 66 & $E$ & Steep & Minor fracture \\
\hline 193.51 & 58.98 & 76 & 346 & 53 & $E$ & Steep & Minor fracture \\
\hline 194.13 & 59.17 & 67 & 337 & 64 & $\mathrm{NE}$ & Steep & Minor fracture \\
\hline
\end{tabular}




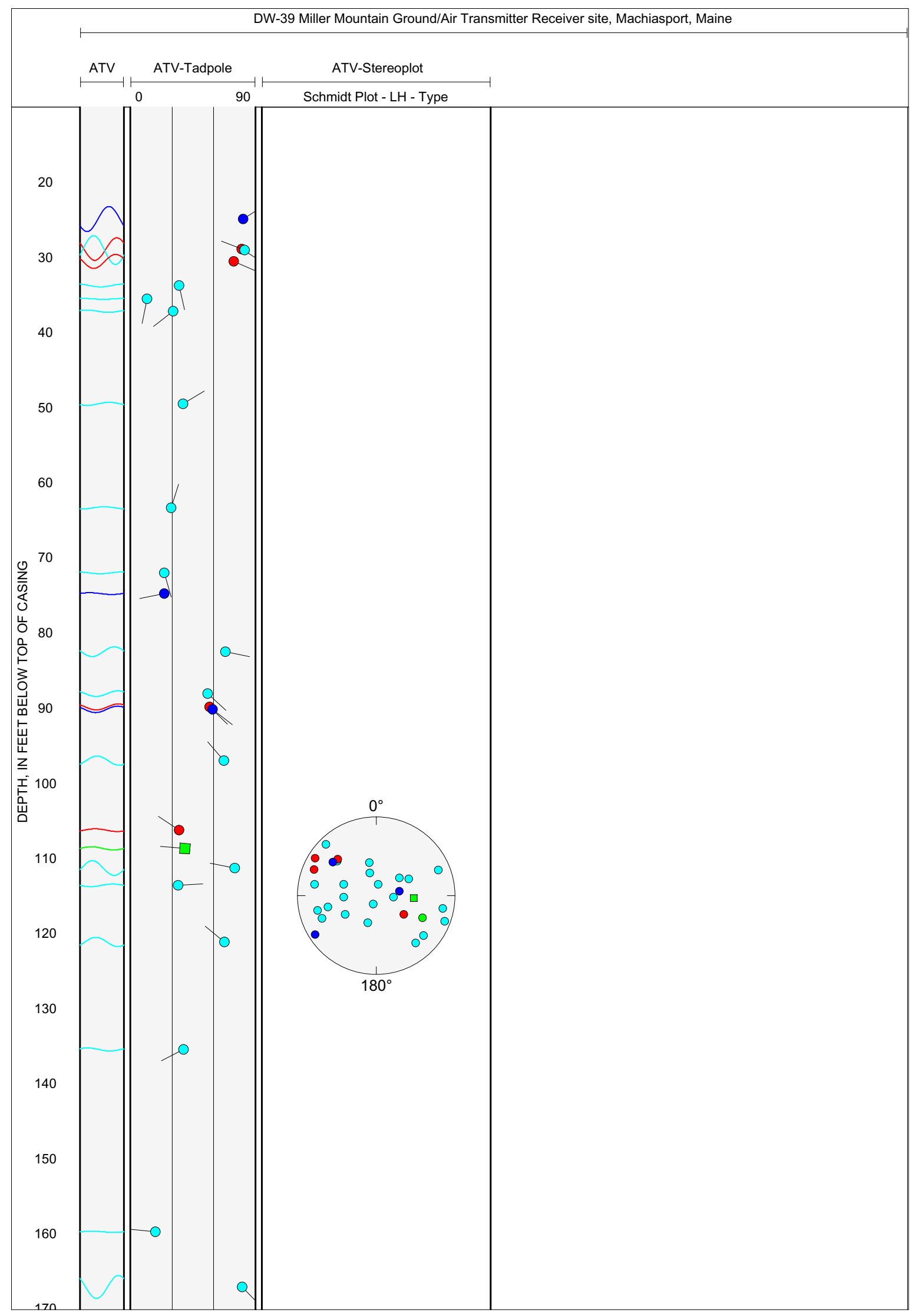

Figure 1J-3. Projection, tadpole, and stereoplots of interpretation of borehole image data for borehole DW-39, near Machiasport, Maine. 


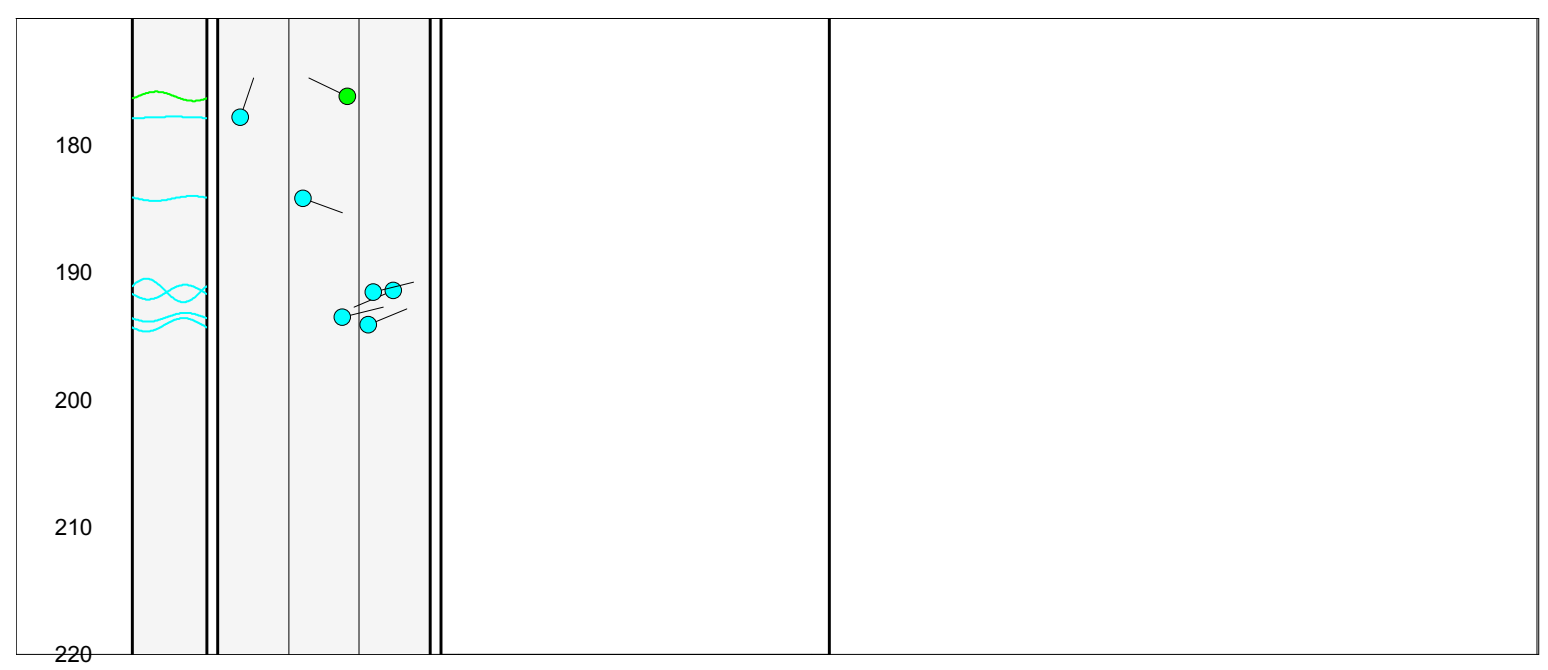

Figure 1J-3. Projection, tadpole, and stereoplots of interpretation of borehole image data for borehole DW-39, near Machiasport, Maine.-Continued 

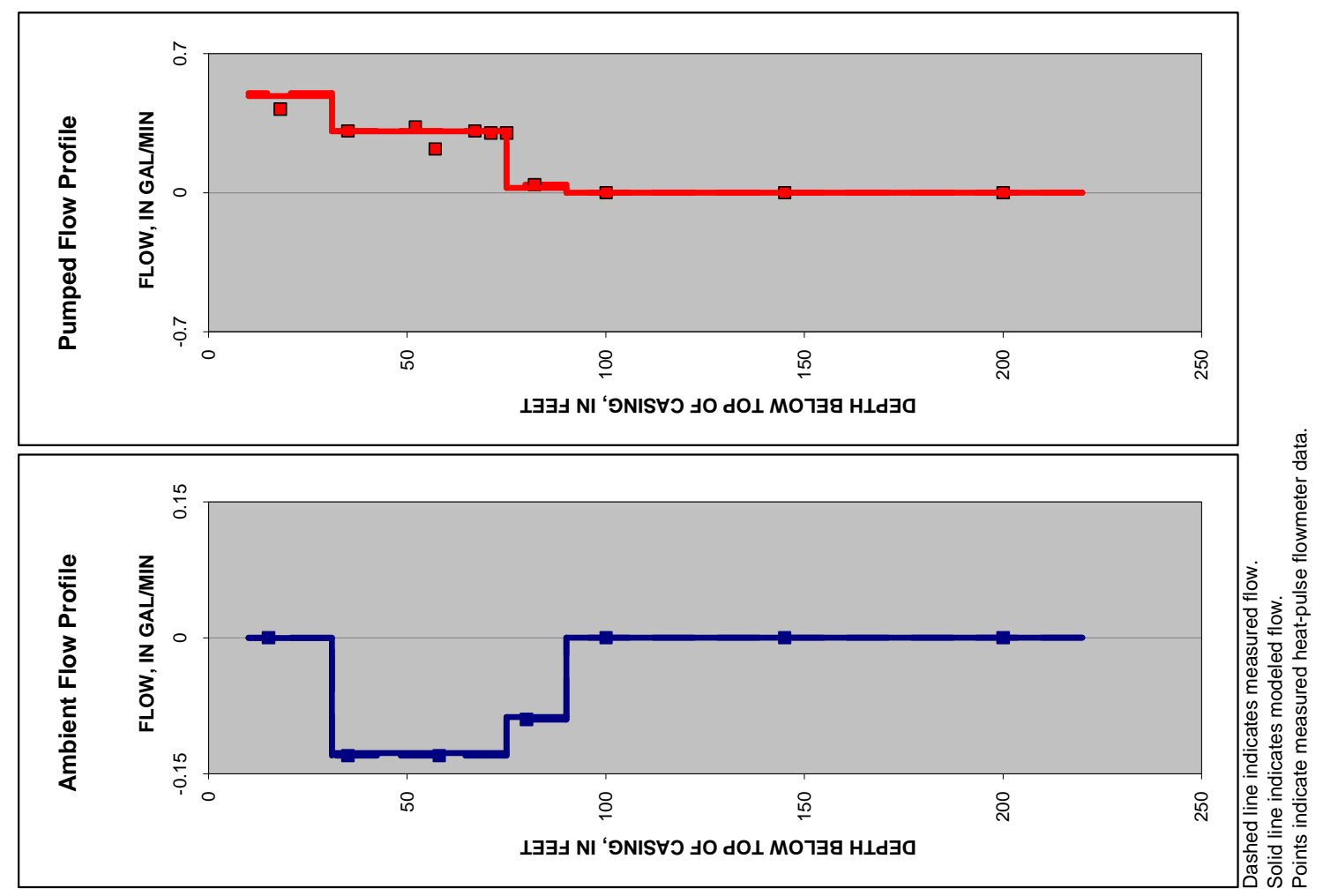

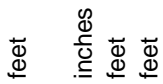
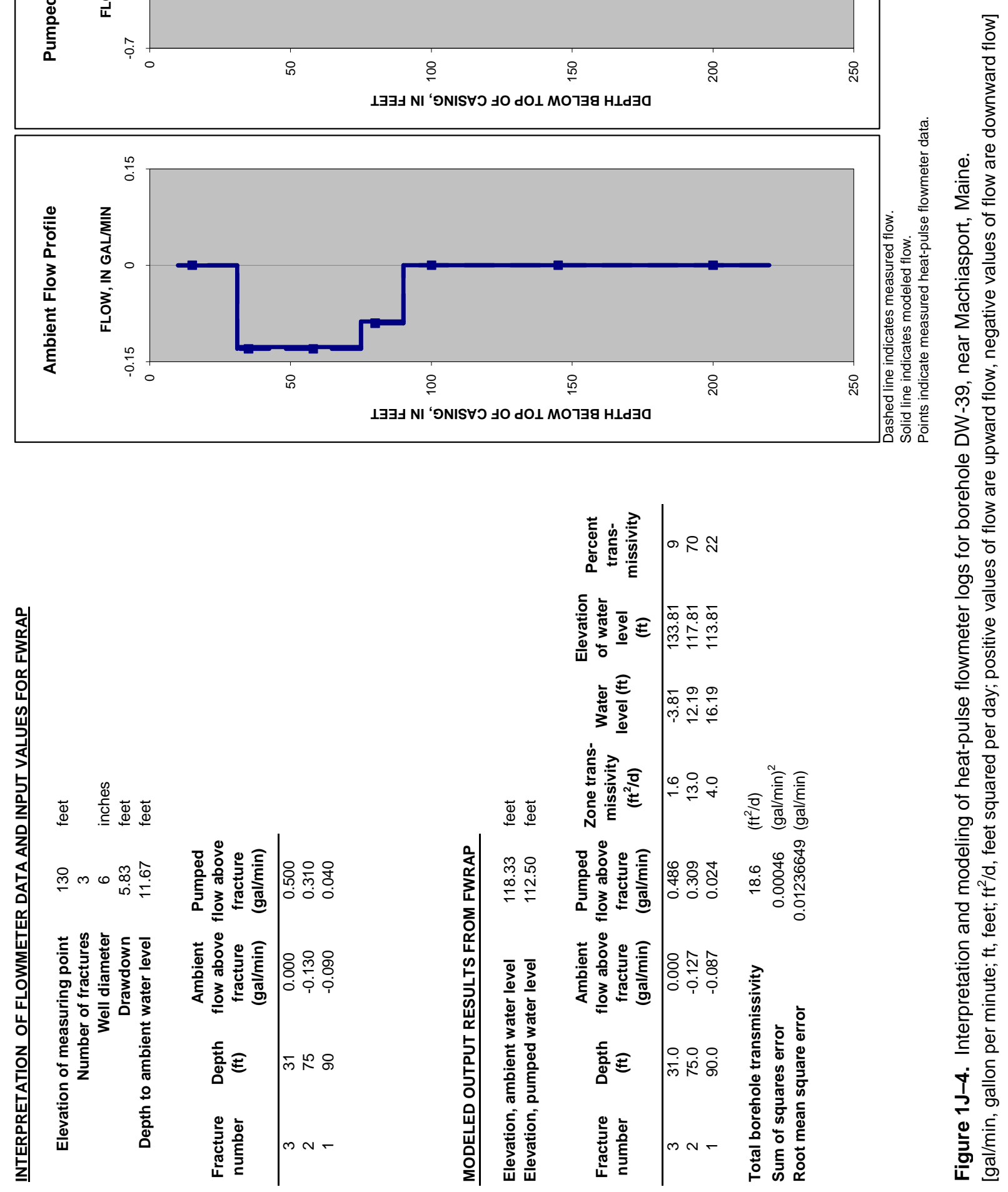


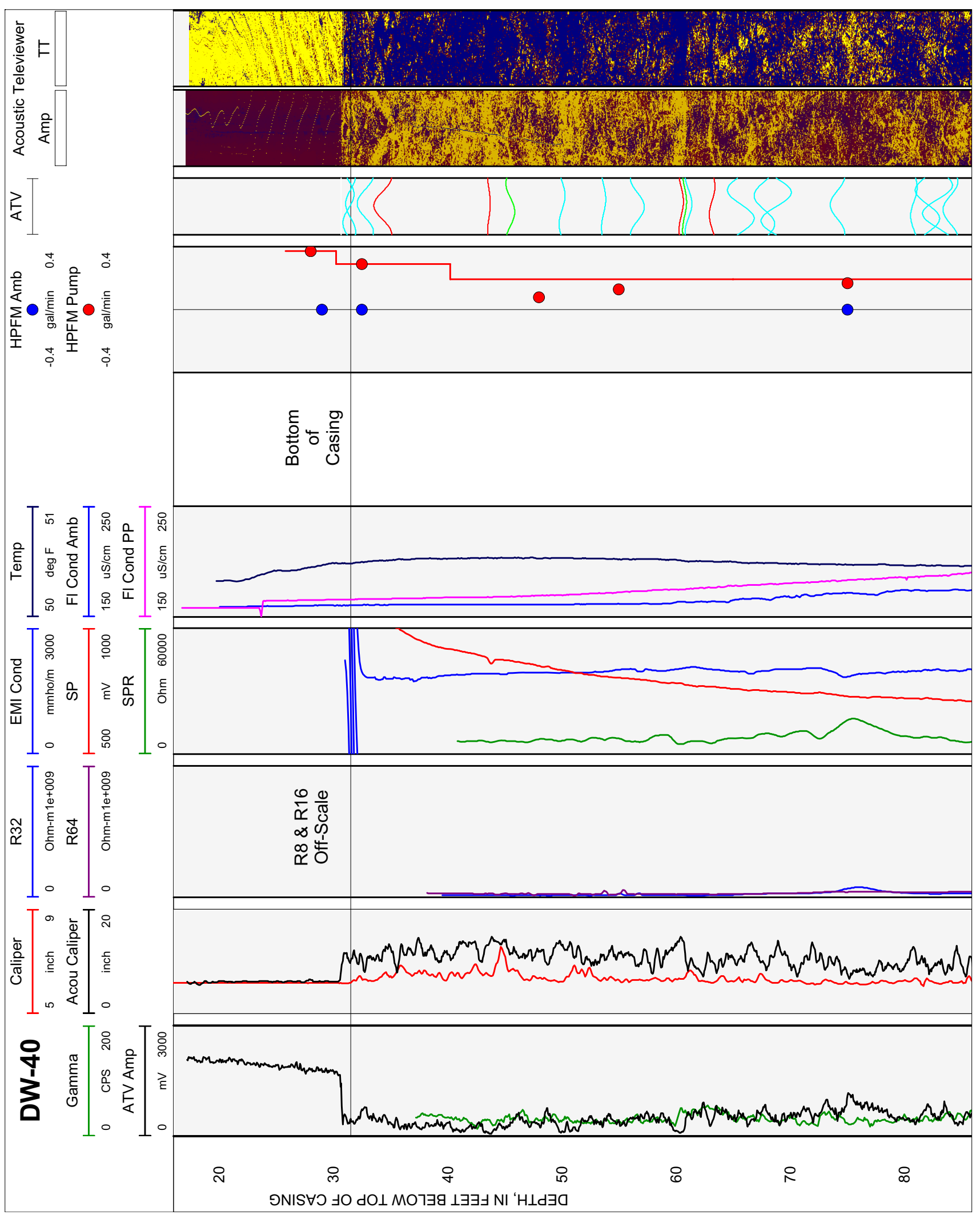

Figure 1K-1. Caliper, acoustic caliper, gamma, electromagnetic conductivity, fluid temperature, specific conductance, $\mathrm{DO}, \mathrm{pH}$, reduction oxidation, multi-space resistivity, oriented acoustic and optical borehole images, and heat-pulse flowmeter logs for borehole DW-40, near Machiasport, Maine. 


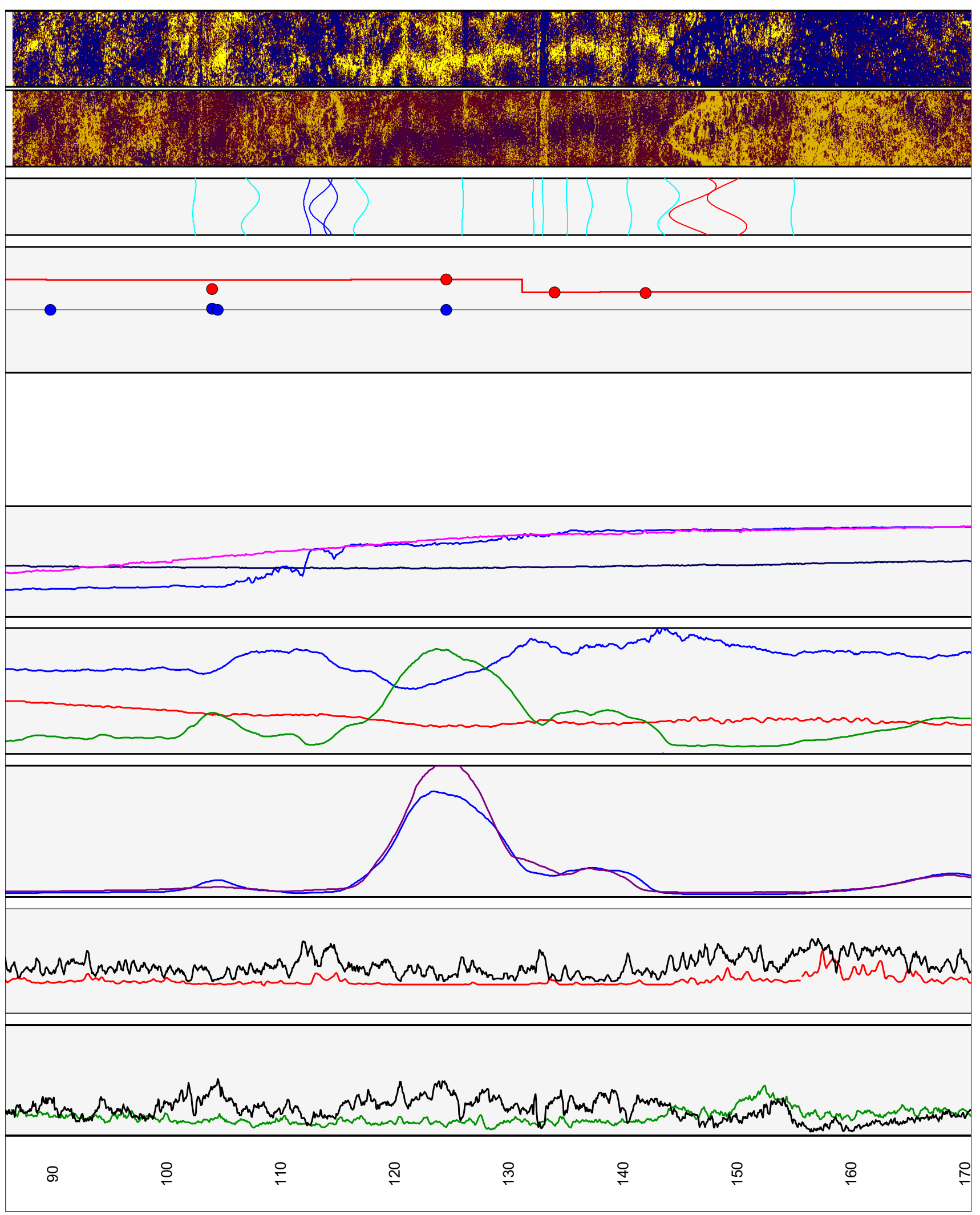

Figure 1K-1. Caliper, acoustic caliper, gamma, electromagnetic conductivity, fluid temperature, specific conductance, $\mathrm{DO}, \mathrm{pH}$, reduction oxidation, multi-space resistivity, oriented acoustic and optical borehole images, and heat-pulse flowmeter logs for borehole DW-40, near Machiasport, Maine.-Continued 

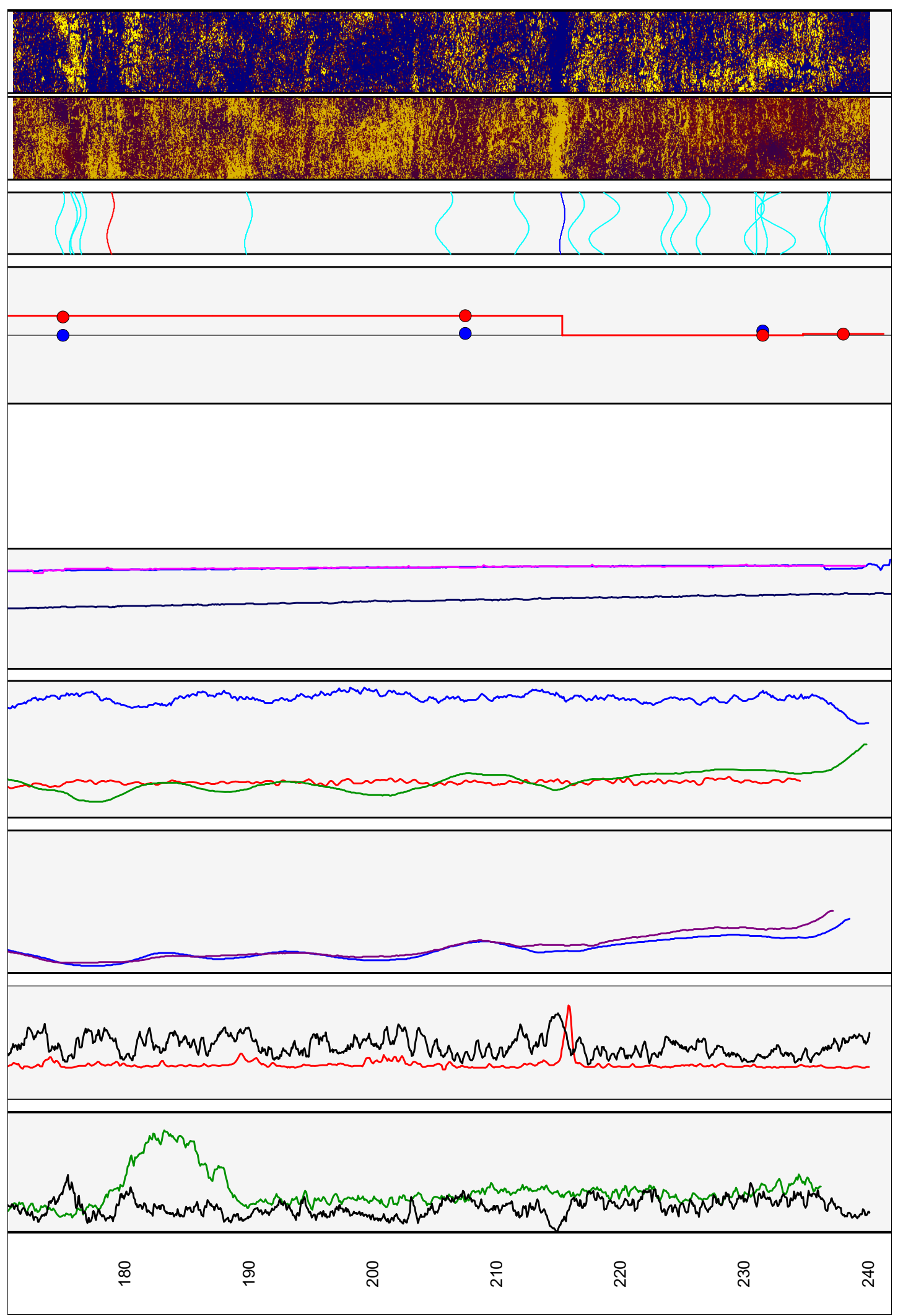

Figure 1K-1. Caliper, acoustic caliper, gamma, electromagnetic conductivity, fluid temperature, specific conductance, $\mathrm{DO}, \mathrm{pH}$, reduction oxidation, multi-space resistivity, oriented acoustic and optical borehole images, and heat-pulse flowmeter logs for borehole DW-40, near Machiasport, Maine.-Continued 

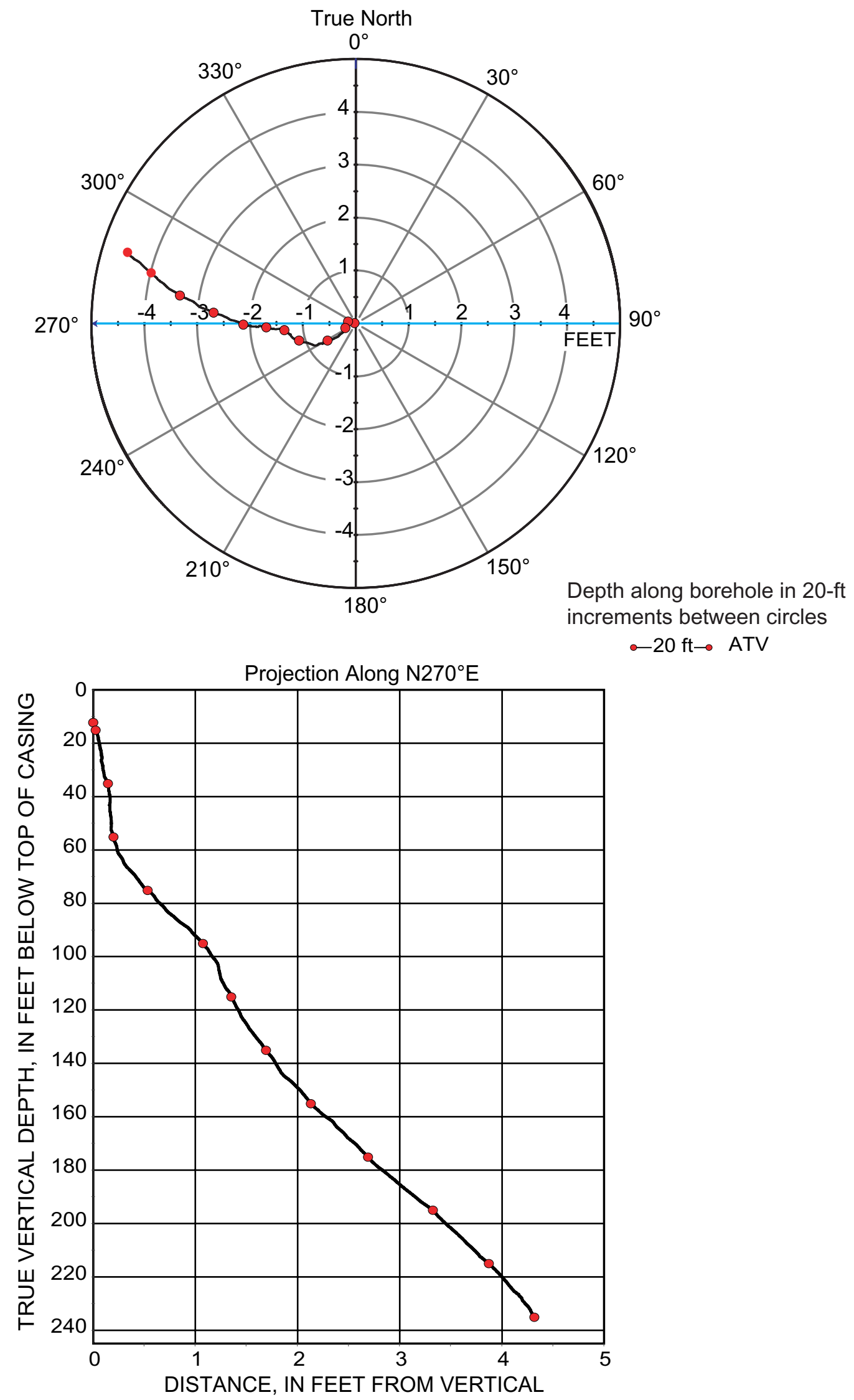

Figure 1K-2. Borehole deviation logs for borehole DW-40, near Machiasport, Maine. Blue line on radial plot (top) is line of projection for vertical plot (bottom).

[ft, foot; ATV, acoustic televiewer] 
Table 1K-1. Interpretation of acoustic televiewer logs for borehole DW-40, near Machiasport, Maine.

[Televiewer data are corrected for deviation and magnetic declination, so orientations are relative to true north; depths are below top of casing, which is 2.45 feet above land surface; dip azimuth is given in degrees east of true north; strike is reported in right-hand-rule (RHR)-azimuthal degrees east of true north and where the direction of dip is 90 degrees to the right of strike]

\begin{tabular}{|c|c|c|c|c|c|c|c|}
\hline $\begin{array}{l}\text { Depth, } \\
\text { in feet }\end{array}$ & $\begin{array}{l}\text { Depth, } \\
\text { in meters }\end{array}$ & $\begin{array}{c}\text { Dip } \\
\text { azimuth }\end{array}$ & $\begin{array}{l}\text { Strike, } \\
\text { in RHR }\end{array}$ & Dip & $\begin{array}{c}\text { Dip } \\
\text { direction }\end{array}$ & Dip descriptor & Comment \\
\hline 30.68 & 9.35 & 207 & 117 & 1 & SW & Nearly horizontal & Other \\
\hline 31.31 & 9.54 & 256 & 166 & 62 & W & Steep & Minor fracture \\
\hline 31.50 & 9.60 & 17 & 287 & 60 & $\mathrm{~N}$ & Steep & Minor fracture \\
\hline 32.76 & 9.98 & 19 & 289 & 70 & $\mathrm{~N}$ & Nearly vertical & Minor fracture \\
\hline 34.29 & 10.45 & 6 & 276 & 72 & $\mathrm{~N}$ & Nearly vertical & Fracture \\
\hline 43.62 & 13.29 & 198 & 108 & 25 & $\mathrm{~S}$ & Shallow & Fracture \\
\hline 45.49 & 13.86 & 146 & 56 & 57 & SE & Steep & Lithologic feature \\
\hline 50.03 & 15.25 & 248 & 158 & 45 & W & Moderate & Minor fracture \\
\hline 53.63 & 16.35 & 226 & 136 & 36 & SW & Moderate & Minor fracture \\
\hline 56.58 & 17.24 & 178 & 88 & 67 & $\mathrm{~S}$ & Steep & Minor fracture \\
\hline 60.43 & 18.42 & 211 & 121 & 37 & SW & Moderate & Fracture \\
\hline 60.73 & 18.51 & 209 & 119 & 35 & SW & Moderate & Lithologic feature \\
\hline 61.08 & 18.62 & 197 & 107 & 49 & $\mathrm{~s}$ & Moderate & Minor fracture \\
\hline 63.16 & 19.25 & 308 & 218 & 44 & NW & Moderate & Fracture \\
\hline 65.65 & 20.01 & 104 & 14 & 78 & $E$ & Nearly vertical & Minor fracture \\
\hline 67.70 & 20.63 & 68 & 338 & 74 & $E$ & Nearly vertical & Minor fracture \\
\hline 68.77 & 20.96 & 269 & 179 & 79 & w & Nearly vertical & Minor fracture \\
\hline 74.14 & 22.60 & 11 & 281 & 68 & $\mathrm{~N}$ & Steep & Minor fracture \\
\hline 80.83 & 24.64 & 301 & 211 & 48 & NW & Moderate & Minor fracture \\
\hline 81.97 & 24.98 & 103 & 13 & 77 & $\mathrm{E}$ & Nearly vertical & Minor fracture \\
\hline 82.90 & 25.27 & 315 & 225 & 79 & NW & Nearly vertical & Minor fracture \\
\hline 84.00 & 25.60 & 339 & 249 & 69 & $\mathrm{~N}$ & Steep & Minor fracture \\
\hline 102.42 & 31.22 & 319 & 229 & 27 & NW & Shallow & Minor fracture \\
\hline 107.34 & 32.72 & 240 & 150 & 72 & SW & Nearly vertical & Minor fracture \\
\hline 112.31 & 34.23 & 24 & 294 & 49 & NE & Moderate & Transmissive fracture \\
\hline 113.47 & 34.58 & 351 & 261 & 75 & $\mathrm{~N}$ & Nearly vertical & Transmissive fracture \\
\hline 114.40 & 34.87 & 241 & 151 & 67 & SW & Steep & Transmissive fracture \\
\hline 117.06 & 35.68 & 214 & 124 & 68 & SW & Steep & Minor fracture \\
\hline 125.92 & 38.38 & 227 & 137 & 11 & SW & Shallow & Minor fracture \\
\hline 132.13 & 40.27 & 43 & 313 & 9 & NE & Nearly horizontal & Minor fracture \\
\hline 132.98 & 40.53 & 135 & 45 & 10 & SE & Nearly horizontal & Minor fracture \\
\hline 135.11 & 41.18 & 89 & 359 & 13 & $E$ & Shallow & Minor fracture \\
\hline 137.08 & 41.78 & 199 & 109 & 44 & $\bar{S}$ & Moderate & Minor fracture \\
\hline 140.57 & 42.84 & 116 & 26 & 40 & SE & Moderate & Minor fracture \\
\hline 144.01 & 43.89 & 247 & 157 & 75 & SW & Nearly vertical & Minor fracture \\
\hline 146.11 & 44.53 & 311 & 221 & 83 & NW & Nearly vertical & Fracture \\
\hline 149.12 & 45.45 & 55 & 325 & 82 & NE & Nearly vertical & Fracture \\
\hline 154.88 & 47.21 & 298 & 208 & 34 & NW & Moderate & Minor fracture \\
\hline 174.77 & 53.27 & 320 & 230 & 55 & NW & Steep & Minor fracture \\
\hline 175.83 & 53.59 & 227 & 137 & 51 & SW & Steep & Minor fracture \\
\hline 176.02 & 53.65 & 246 & 156 & 58 & SW & Steep & Minor fracture \\
\hline 176.63 & 53.83 & 241 & 151 & 46 & SW & Moderate & Minor fracture \\
\hline 178.82 & 54.50 & 285 & 195 & 48 & W & Moderate & Fracture \\
\hline 189.94 & 57.89 & 241 & 151 & 50 & SW & Moderate & Minor fracture \\
\hline 205.77 & 62.72 & 320 & 230 & 70 & NW & Nearly vertical & Minor fracture \\
\hline 212.00 & 64.61 & 152 & 62 & 67 & SE & Steep & Minor fracture \\
\hline 215.29 & 65.62 & 233 & 143 & 40 & SW & Moderate & Transmissive fracture \\
\hline 216.43 & 65.96 & 293 & 203 & 69 & NW & Steep & Minor fracture \\
\hline 218.68 & 66.65 & 267 & 177 & 78 & w & Nearly vertical & Minor fracture \\
\hline 223.76 & 68.20 & 271 & 181 & 63 & W & Steep & Minor fracture \\
\hline 224.70 & 68.49 & 266 & 176 & 68 & w & Steep & Minor fracture \\
\hline 226.70 & 69.09 & 254 & 164 & 66 & W & Steep & Minor fracture \\
\hline 230.82 & 70.35 & 271 & 181 & 73 & W & Nearly vertical & Minor fracture \\
\hline 230.98 & 70.40 & 88 & 358 & 14 & $E$ & Shallow & Minor fracture \\
\hline 231.58 & 70.58 & 67 & 337 & 45 & $\overline{N E}$ & Moderate & Minor fracture \\
\hline 232.56 & 70.88 & 78 & 348 & 81 & $\mathrm{E}$ & Nearly vertical & Minor fracture \\
\hline 236.52 & 72.09 & 355 & 265 & 60 & $\mathrm{~N}$ & Steep & Minor fracture \\
\hline 236.64 & 72.12 & 327 & 237 & 27 & NW & Shallow & Minor fracture \\
\hline
\end{tabular}




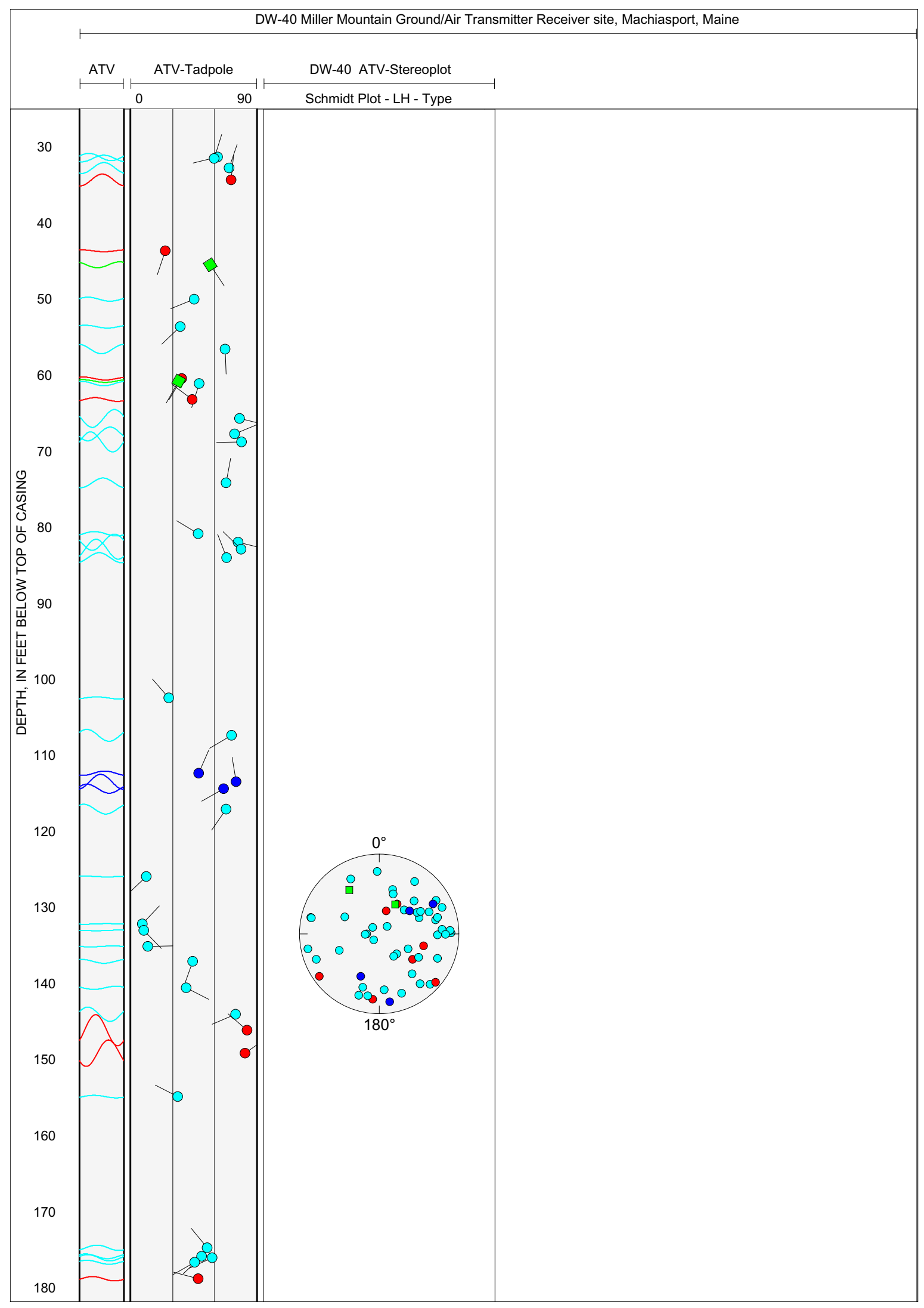

Figure 1K-3. Projection, tadpole, and stereoplots of interpretation of borehole image data for borehole DW-40, near Machiasport, Maine. 


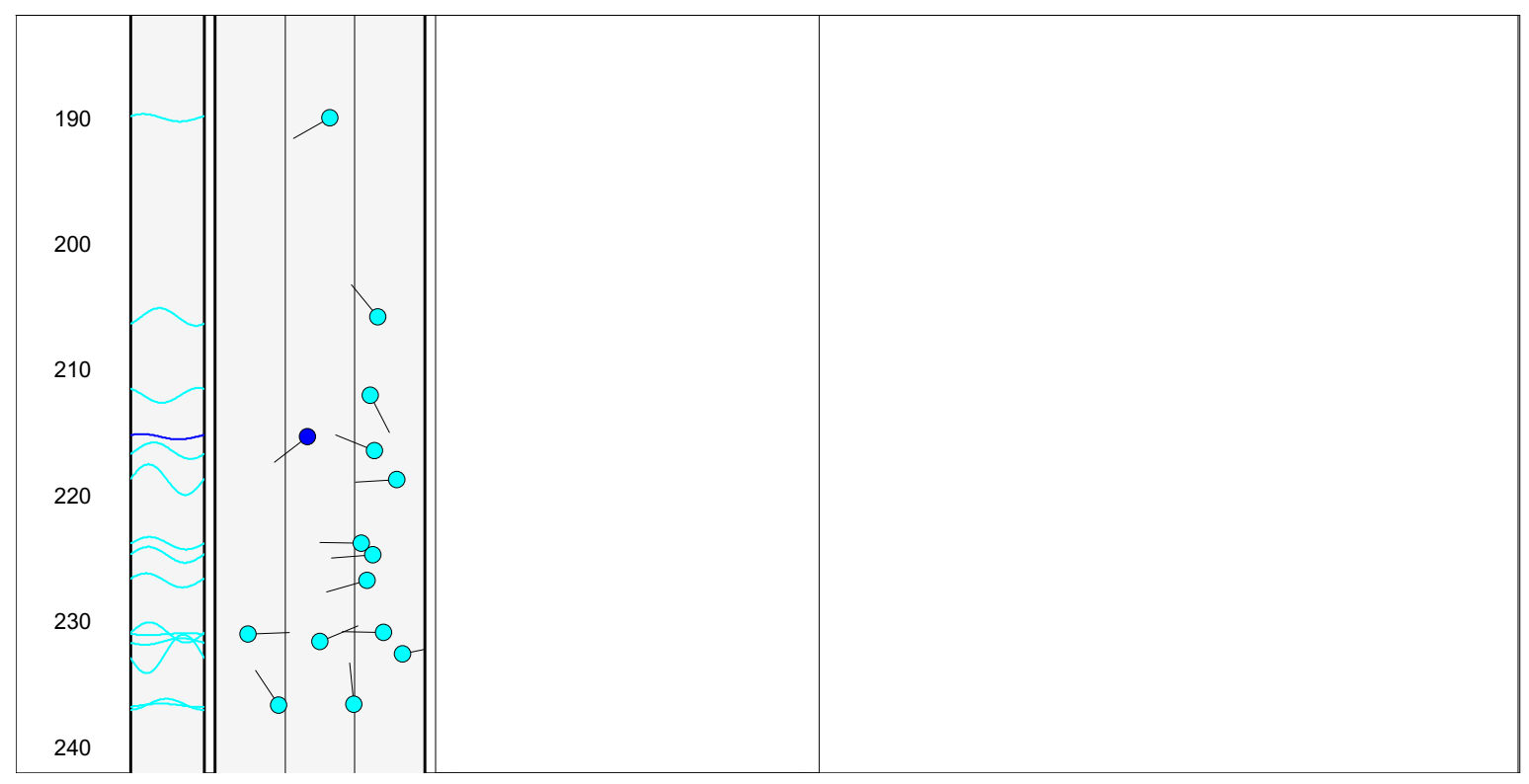

Figure 1K-3. Projection, tadpole, and stereoplots of interpretation of borehole image data for borehole DW-40, near Machiasport, Maine.-Continued 

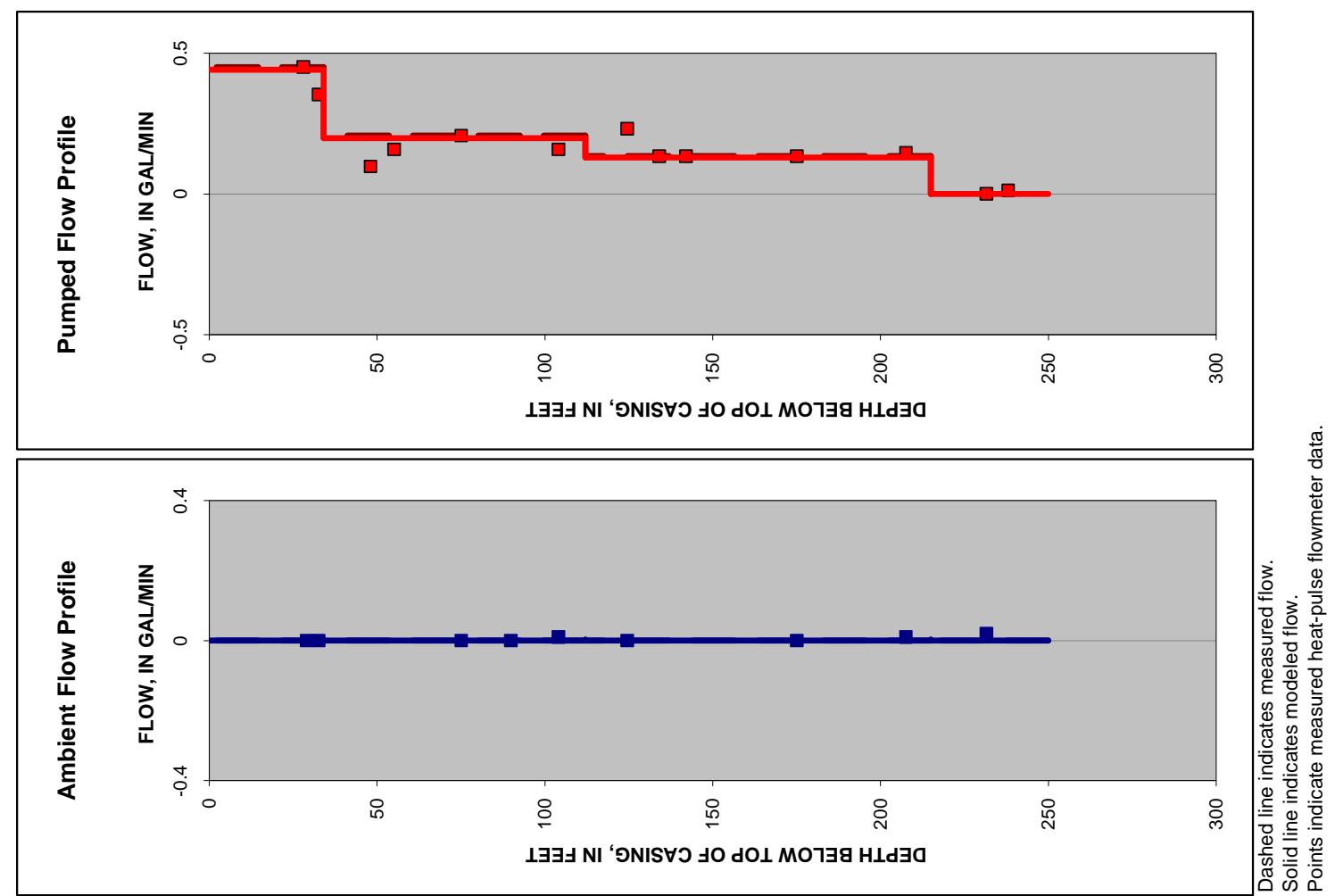

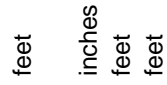
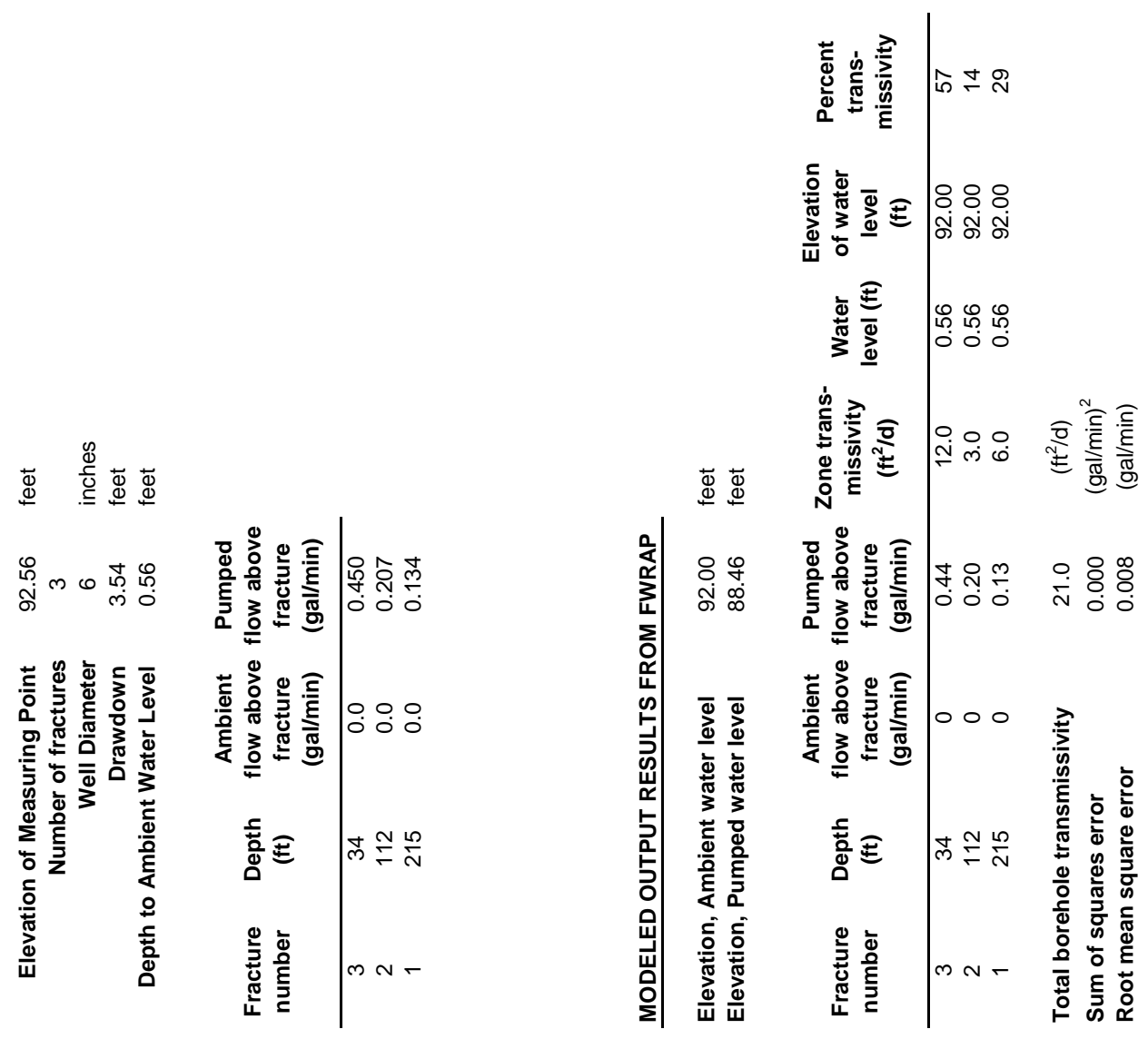

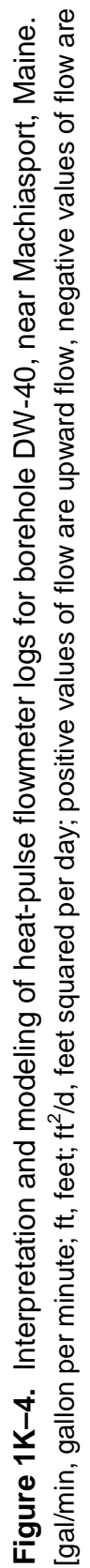




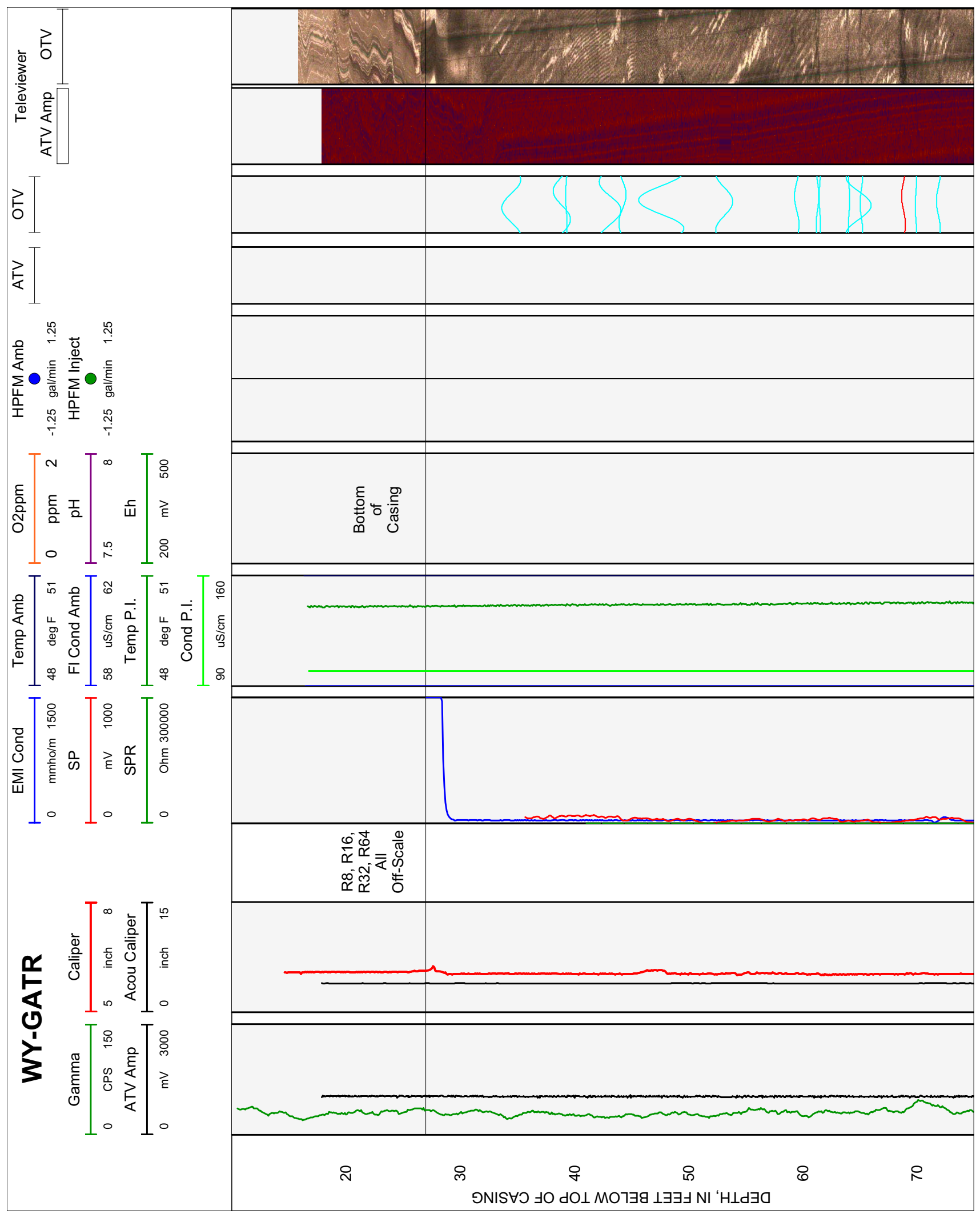

Figure 1L-1. Caliper, acoustic caliper, gamma, electromagnetic conductivity, fluid temperature, specific conductance, $\mathrm{DO}, \mathrm{pH}$, reduction oxidation, multi-space resistivity, oriented acoustic and optical borehole images, and heat-pulse flowmeter logs for borehole WY-GATR, near Machiasport, Maine. 


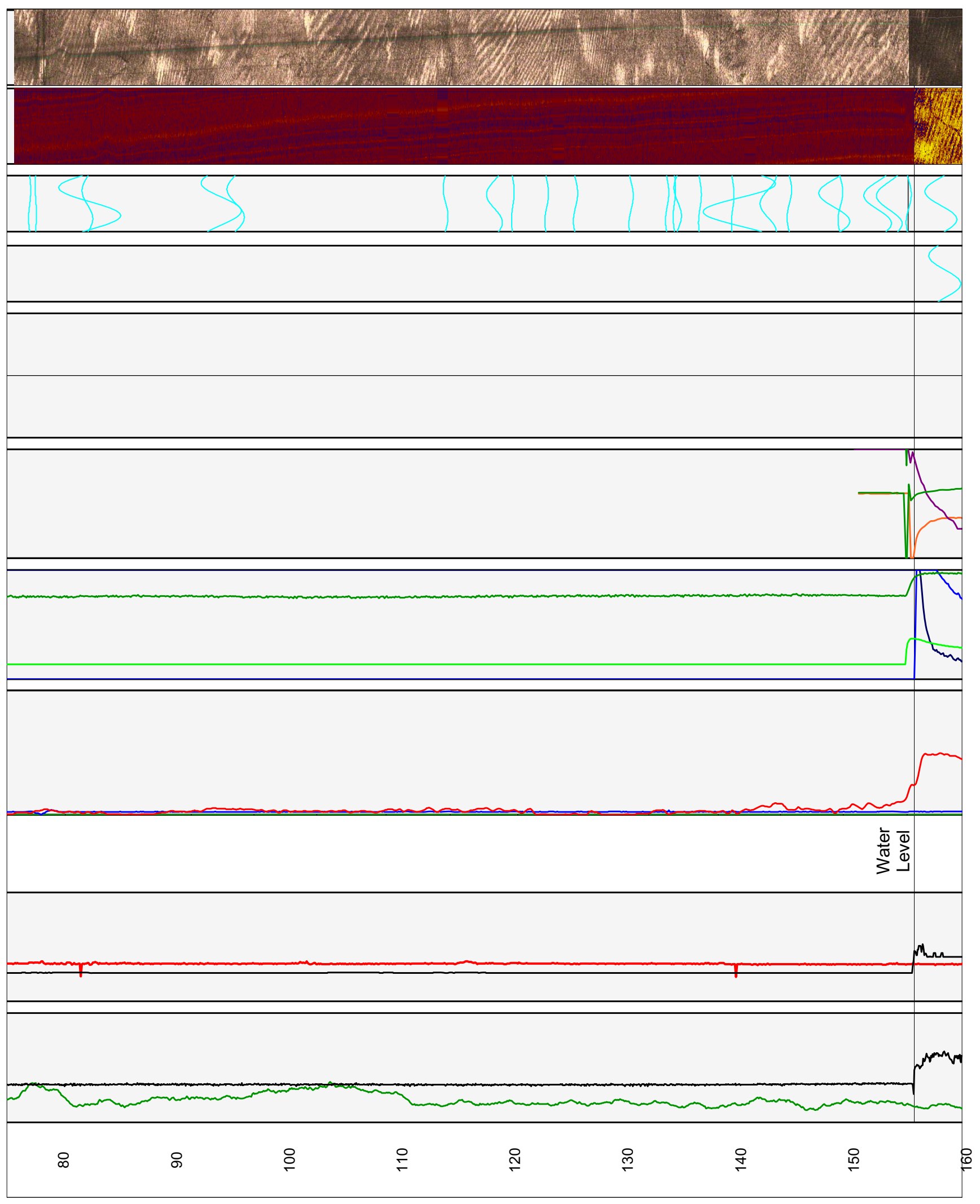

Figure 1L-1. Caliper, acoustic caliper, gamma, electromagnetic conductivity, fluid temperature, specific conductance, $\mathrm{DO}, \mathrm{pH}$, reduction oxidation, multi-space resistivity, oriented acoustic and optical borehole images, and heat-pulse flowmeter logs for borehole WY-GATR, near Machiasport, Maine.-Continued 


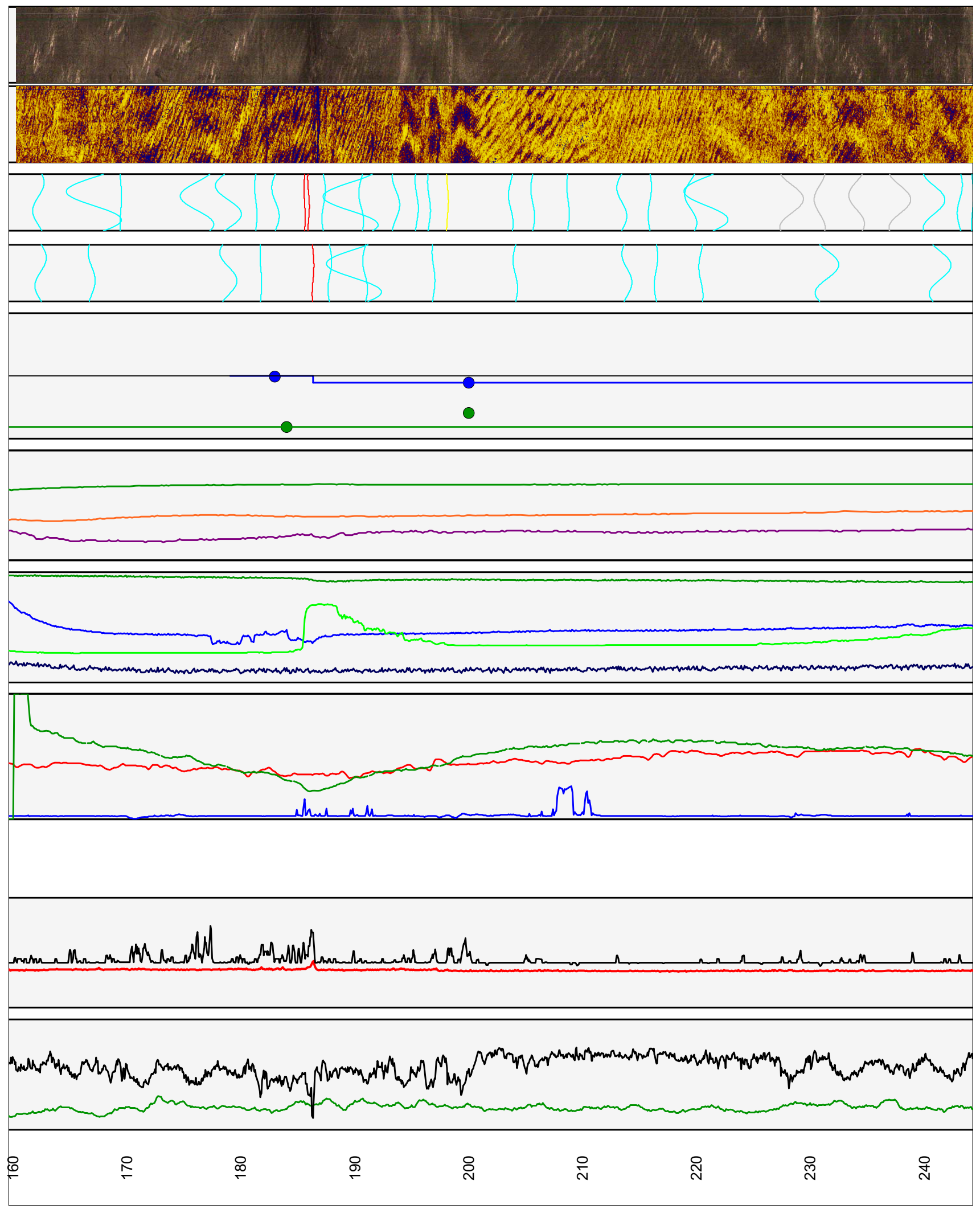

Figure 1L-1. Caliper, acoustic caliper, gamma, electromagnetic conductivity, fluid temperature, specific conductance, $\mathrm{DO}, \mathrm{pH}$, reduction oxidation, multi-space resistivity, oriented acoustic and optical borehole images, and heat-pulse flowmeter logs for borehole WY-GATR, near Machiasport, Maine.-Continued 


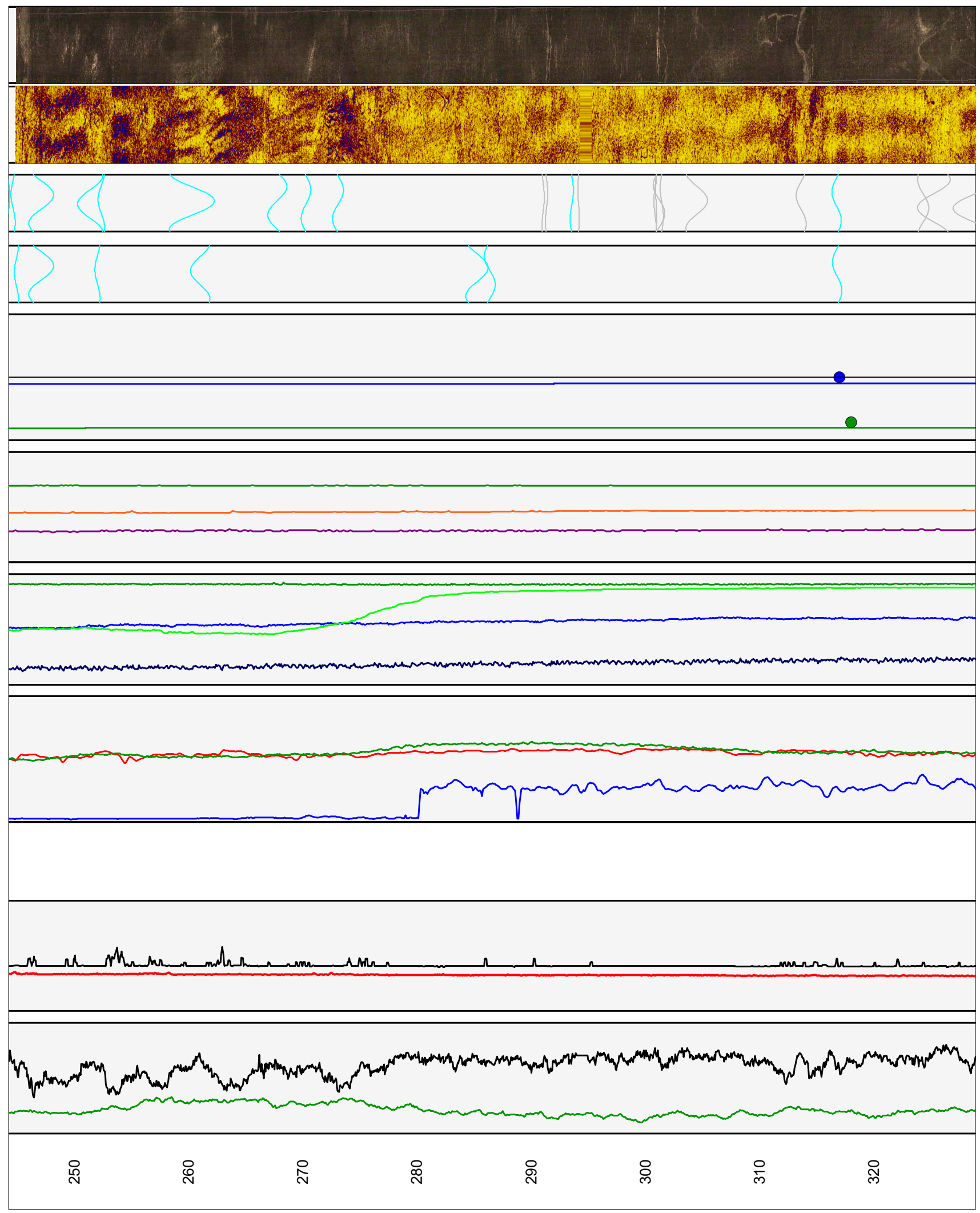

Figure 1L-1. Caliper, acoustic caliper, gamma, electromagnetic conductivity, fluid temperature, specific conductance, $\mathrm{DO}, \mathrm{pH}$, reduction oxidation, multi-space resistivity, oriented acoustic and optical borehole images, and heat-pulse flowmeter logs for borehole WY-GATR, near Machiasport, Maine.-Continued 


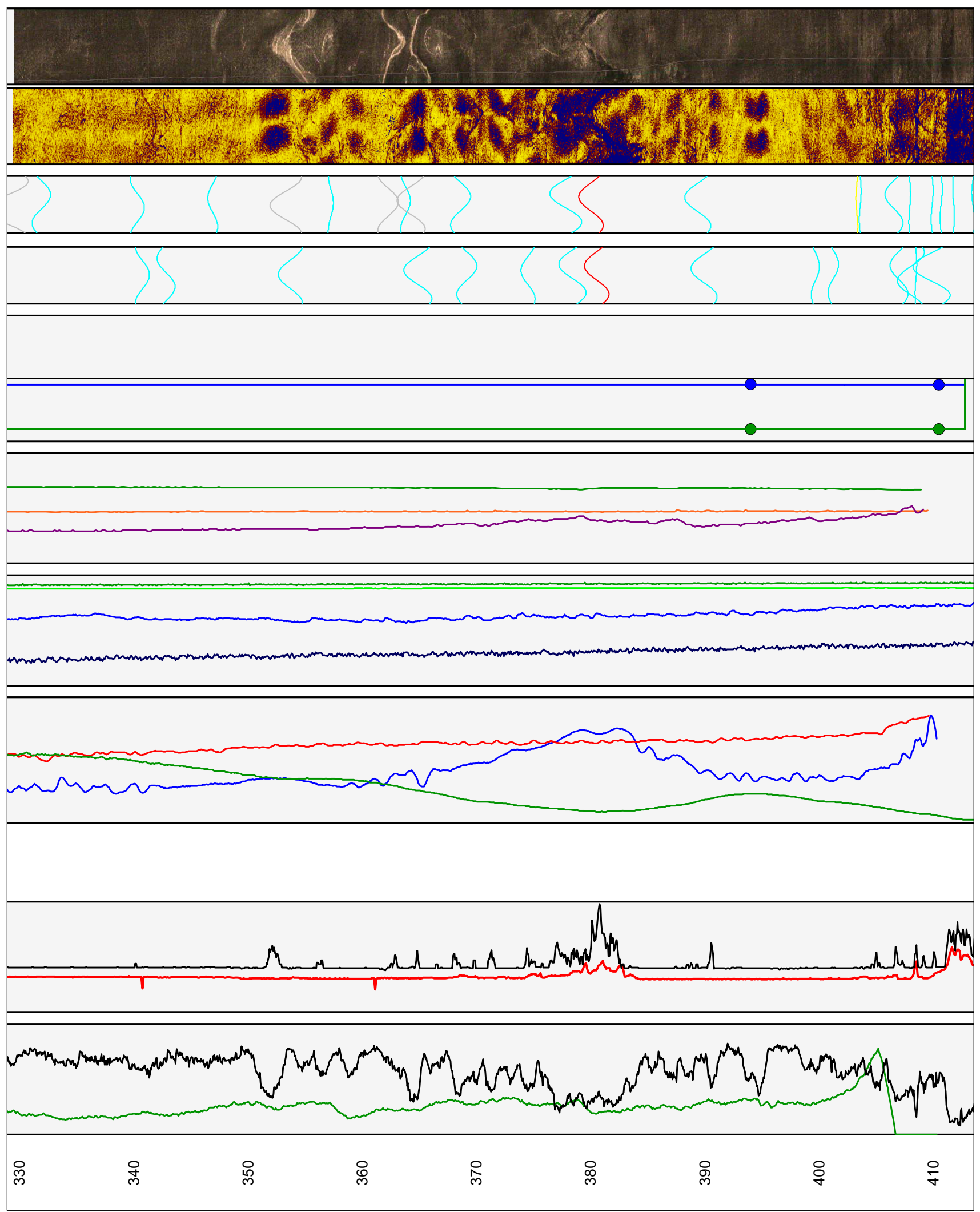

Figure 1L-1. Caliper, acoustic caliper, gamma, electromagnetic conductivity, fluid temperature, specific conductance, $\mathrm{DO}, \mathrm{pH}$, reduction oxidation, multi-space resistivity, oriented acoustic and optical borehole images, and heat-pulse flowmeter logs for borehole WY-GATR, near Machiasport, Maine.-Continued 


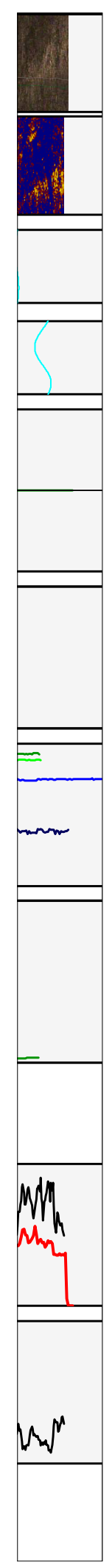

Figure 1L-1. Caliper, acoustic caliper, gamma, electromagnetic conductivity, fluid temperature, specific conductance, $\mathrm{DO}, \mathrm{pH}$, reduction oxidation, multi-space resistivity, oriented acoustic and optical borehole images, and heat-pulse flowmeter logs for borehole WY-GATR, near Machiasport, Maine.-Continued 


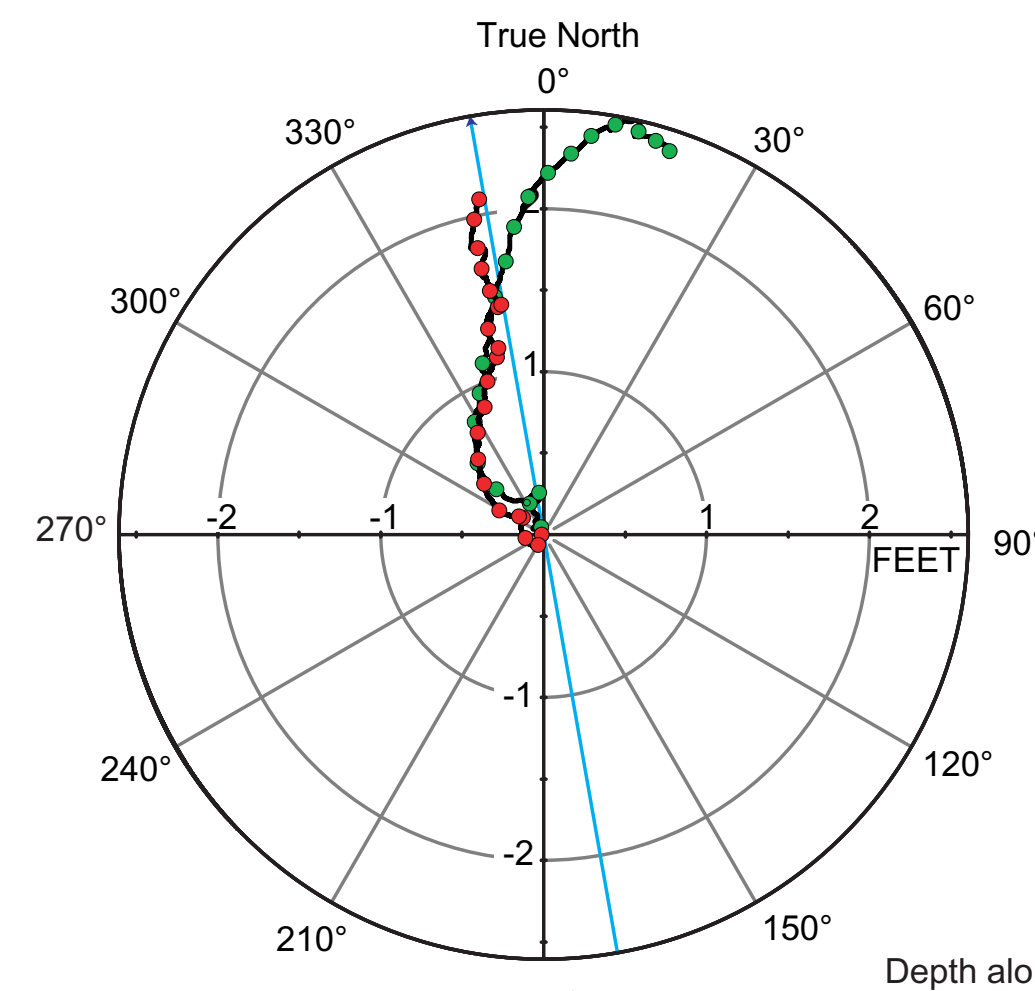

Depth along borehole in 20-ft $180^{\circ}$ increments between circles

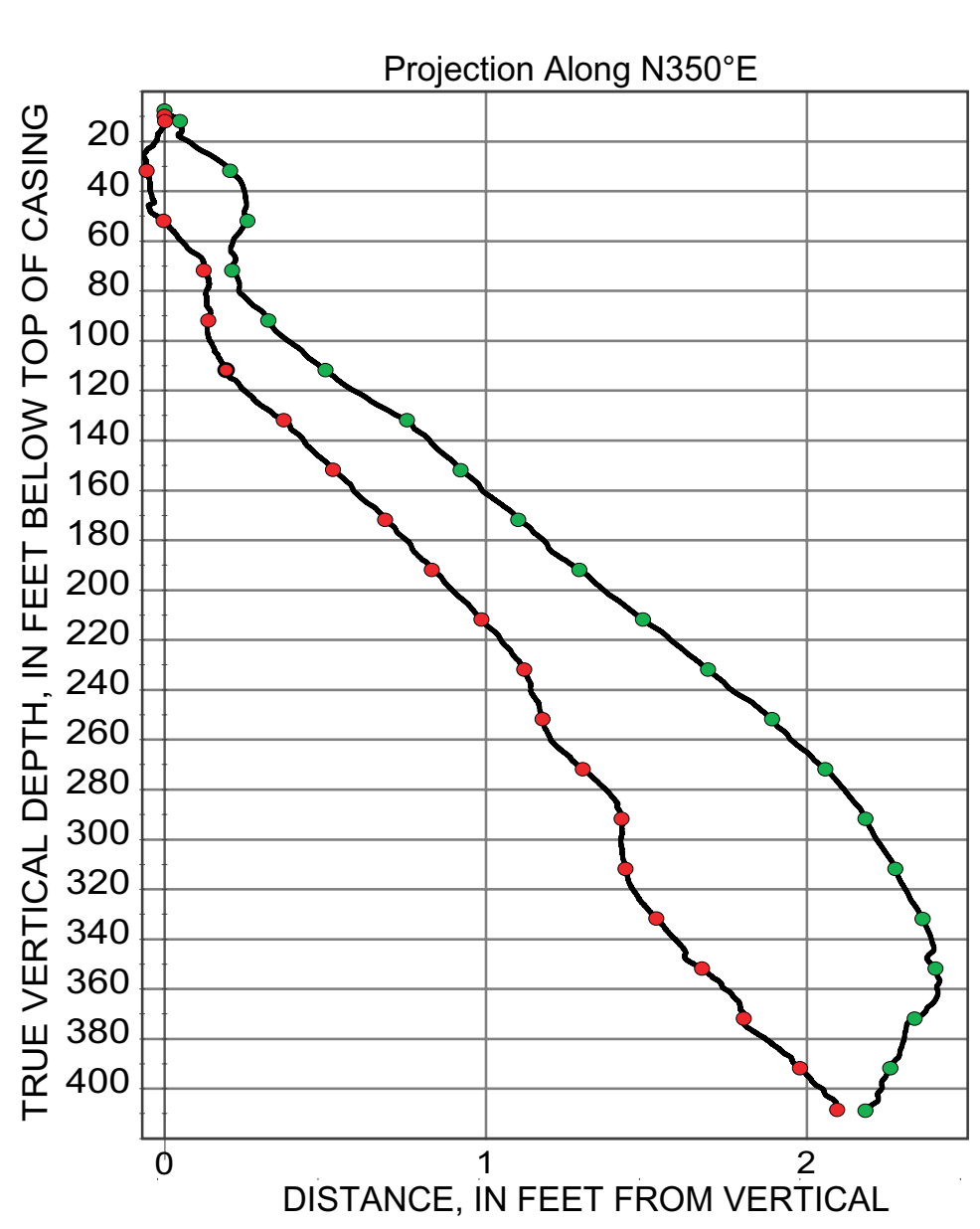

$\bullet-20 \mathrm{ft} \rightarrow$ ATV 
Table 1L-1. Interpretation of acoustic televiewer logs for borehole WY-GATR, near Machiasport, Maine. [Televiewer data are corrected for deviation and magnetic declination, so orientations are relative to true north; depths are below top of casing, which is 3.45 feet above land surface; dip azimuth is given in degrees east of true north; strike is reported in right-hand-rule (RHR)-azimuthal degrees east of true north and where the direction of dip is 90 degrees to the right of strike]

\begin{tabular}{|c|c|c|c|c|c|c|c|}
\hline $\begin{array}{l}\text { Depth, } \\
\text { in feet }\end{array}$ & $\begin{array}{l}\text { Depth, } \\
\text { in meters }\end{array}$ & $\begin{array}{c}\text { Dip } \\
\text { azimuth }\end{array}$ & $\begin{array}{l}\text { Strike, } \\
\text { in RHR }\end{array}$ & Dip & $\begin{array}{c}\text { Dip } \\
\text { direction }\end{array}$ & Dip descriptor & Comment \\
\hline 158.10 & 48.19 & 114.82 & 25 & 80 & SE & Nearly vertical & Minor fracture \\
\hline 162.41 & 49.50 & 277.43 & 187 & 64 & W & Steep & Minor fracture \\
\hline 166.87 & 50.86 & 132.29 & 42 & 50 & SE & Moderate & Minor fracture \\
\hline 178.90 & 54.53 & 130.11 & 40 & 73 & SE & Nearly vertical & Minor fracture \\
\hline 181.74 & 55.39 & 115.11 & 25 & 15 & SE & Shallow & Minor fracture \\
\hline 186.35 & 56.80 & 224.23 & 134 & 17 & SW & Shallow & Transmissive fracture \\
\hline 187.81 & 57.24 & 255.59 & 166 & 34 & W & Moderate & Minor fracture \\
\hline 189.94 & 57.89 & 59.5 & 330 & 84 & NE & Nearly vertical & Minor fracture \\
\hline 190.93 & 58.19 & 77.55 & 348 & 41 & $\mathrm{E}$ & Moderate & Minor fracture \\
\hline 196.93 & 60.02 & 132.79 & 43 & 26 & SE & Shallow & Minor fracture \\
\hline 204.11 & 62.21 & 82.09 & 352 & 39 & $E$ & Moderate & Minor fracture \\
\hline 213.87 & 65.18 & 121.79 & 32 & 59 & SE & Steep & Minor fracture \\
\hline 216.44 & 65.97 & 281.71 & 192 & 31 & W & Moderate & Minor fracture \\
\hline 220.36 & 67.16 & 37.35 & 307 & 34 & NE & Moderate & Minor fracture \\
\hline 231.44 & 70.54 & 233.38 & 143 & 76 & SW & Nearly vertical & Minor fracture \\
\hline 241.38 & 73.57 & 228.98 & 139 & 75 & SW & Nearly vertical & Minor fracture \\
\hline 244.96 & 74.66 & 10.91 & 281 & 35 & $\mathrm{~N}$ & Moderate & Minor fracture \\
\hline 247.10 & 75.31 & 231.74 & 142 & 77 & SW & Nearly vertical & Minor fracture \\
\hline 252.05 & 76.82 & 26.61 & 297 & 41 & NE & Moderate & Minor fracture \\
\hline 261.04 & 79.56 & 20.69 & 291 & 73 & $\mathrm{~N}$ & Nearly vertical & Minor fracture \\
\hline 285.24 & 86.94 & 219.61 & 130 & 77 & SW & Nearly vertical & Minor fracture \\
\hline 286.38 & 87.28 & 112.68 & 23 & 62 & SE & Steep & Minor fracture \\
\hline 316.80 & 96.56 & 74.55 & 345 & 58 & $\mathrm{E}$ & Steep & Minor fracture \\
\hline 340.78 & 103.86 & 183.16 & 93 & 67 & S & Steep & Minor fracture \\
\hline 342.82 & 104.49 & 107.68 & 18 & 73 & $E$ & Nearly vertical & Minor fracture \\
\hline 353.70 & 107.80 & 5.96 & 276 & 76 & $\mathrm{~N}$ & Nearly vertical & Minor fracture \\
\hline 364.87 & 111.21 & 32.35 & 302 & 77 & $\mathrm{NE}$ & Nearly vertical & Minor fracture \\
\hline 369.17 & 112.52 & 239.01 & 149 & 74 & SW & Nearly vertical & Minor fracture \\
\hline 374.51 & 114.15 & 30.04 & 300 & 68 & NE & Steep & Minor fracture \\
\hline 378.43 & 115.34 & 69.86 & 340 & 79 & $E$ & Nearly vertical & Minor fracture \\
\hline 380.54 & 115.98 & 59.81 & 330 & 78 & NE & Nearly vertical & Large fracture \\
\hline 389.90 & 118.84 & 42.85 & 313 & 77 & $\mathrm{NE}$ & Nearly vertical & Minor fracture \\
\hline 399.67 & 121.81 & 234.54 & 145 & 56 & SW & Steep & Minor fracture \\
\hline 401.23 & 122.29 & 248.46 & 158 & 62 & W & Steep & Minor fracture \\
\hline 407.01 & 124.05 & 62.62 & 333 & 71 & NE & Nearly vertical & Minor fracture \\
\hline 408.05 & 124.37 & 325.65 & 236 & 77 & NW & Nearly vertical & Minor fracture \\
\hline 408.47 & 124.50 & 246.75 & 157 & 17 & SW & Shallow & Minor fracture \\
\hline 409.85 & 124.92 & 52.56 & 323 & 81 & NE & Nearly vertical & Minor fracture \\
\hline 415.25 & 126.56 & 52.39 & 322 & 65 & $\mathrm{NE}$ & Steep & Transmissive fracture \\
\hline
\end{tabular}


Table 1L-2. Interpretation of optical televiewer logs for borehole WY-GATR, near Machiasport, Maine.

[Televiewer data are corrected for deviation and magnetic declination, so orientations are relative to true north; depths are below top of casing, which is 3.45 feet above land surface; dip azimuth is given in degrees east of true north; strike is reported in right-hand-rule (RHR)-azimuthal degrees east of true north and where the direction of dip is 90 degrees to the right of strike]

\begin{tabular}{|c|c|c|c|c|c|c|c|}
\hline $\begin{array}{l}\text { Depth, } \\
\text { in feet }\end{array}$ & $\begin{array}{l}\text { Depth, } \\
\text { in meters }\end{array}$ & $\begin{array}{c}\text { Dip } \\
\text { azimuth }\end{array}$ & $\begin{array}{l}\text { Strike, } \\
\text { in RHR }\end{array}$ & Dip & $\begin{array}{c}\text { Dip } \\
\text { direction }\end{array}$ & Dip descriptor & Comment \\
\hline 26.90 & 8.20 & 178.8 & 89 & 1 & $\mathrm{~S}$ & Nearly horizontal & Bottom of casing \\
\hline 34.47 & 10.51 & 338.18 & 248 & 72 & $\mathrm{~N}$ & Nearly vertical & Minor fracture \\
\hline 38.88 & 11.85 & 85.84 & 356 & 72 & $E$ & Nearly vertical & Minor fracture \\
\hline 39.27 & 11.97 & 58.41 & 328 & 13 & $\mathrm{NE}$ & Shallow & Minor fracture \\
\hline 42.39 & 12.92 & 59.08 & 329 & 4 & $\mathrm{NE}$ & Nearly horizontal & Minor fracture \\
\hline 43.14 & 13.15 & 143.61 & 54 & 75 & SE & Nearly vertical & Minor fracture \\
\hline 44.19 & 13.47 & 241.88 & 152 & 51 & SW & Steep & Minor fracture \\
\hline 47.61 & 14.51 & 28.19 & 298 & 82 & NE & Nearly vertical & Minor fracture \\
\hline 53.13 & 16.19 & 198.67 & 109 & 71 & $\mathrm{~S}$ & Nearly vertical & Minor fracture \\
\hline 59.45 & 18.12 & 51.92 & 322 & 38 & $\mathrm{NE}$ & Moderate & Minor fracture \\
\hline 61.26 & 18.67 & 234.48 & 144 & 25 & sW & Shallow & Minor fracture \\
\hline 61.47 & 18.74 & 44.73 & 315 & 14 & NE & Shallow & Minor fracture \\
\hline 64.06 & 19.52 & 212.89 & 123 & 15 & SW & Shallow & Minor fracture \\
\hline 64.85 & 19.77 & 174.4 & 84 & 77 & $\mathrm{~S}$ & Nearly vertical & Minor fracture \\
\hline 65.13 & 19.85 & 5.86 & 276 & 25 & $\mathrm{~N}$ & Shallow & Minor fracture \\
\hline 68.82 & 20.98 & 53.9 & 324 & 33 & $\mathrm{NE}$ & Moderate & Large fracture \\
\hline 69.91 & 21.31 & 351.48 & 261 & 15 & $\mathrm{~N}$ & Shallow & Minor fracture \\
\hline 71.87 & 21.90 & 22.19 & 292 & 34 & $\mathrm{~N}$ & Moderate & Minor fracture \\
\hline 76.97 & 23.46 & 265.91 & 176 & 19 & W & Shallow & Minor fracture \\
\hline 77.52 & 23.63 & 108.92 & 19 & 12 & $\mathrm{E}$ & Shallow & Minor fracture \\
\hline 82.12 & 25.03 & 83.34 & 353 & 62 & $\mathrm{E}$ & Steep & Minor fracture \\
\hline 82.29 & 25.08 & 103.05 & 13 & 85 & $E$ & Nearly vertical & Minor fracture \\
\hline 93.98 & 28.64 & 132.95 & 43 & 82 & SE & Nearly vertical & Minor fracture \\
\hline 95.26 & 29.03 & 92.8 & 3 & 72 & $\mathrm{E}$ & Nearly vertical & Minor fracture \\
\hline 113.83 & 34.69 & 97.49 & 7 & 41 & $\bar{E}$ & Moderate & Minor fracture \\
\hline 118.18 & 36.02 & 58.75 & 329 & 70 & $\mathrm{NE}$ & Steep & Minor fracture \\
\hline 119.77 & 36.50 & 251.69 & 162 & 25 & W & Shallow & Minor fracture \\
\hline 122.78 & 37.42 & 244.22 & 154 & 34 & sw & Moderate & Minor fracture \\
\hline 125.37 & 38.21 & 246.65 & 157 & 37 & sw & Moderate & Minor fracture \\
\hline 130.28 & 39.71 & 228.52 & 139 & 37 & sw & Moderate & Minor fracture \\
\hline 133.48 & 40.68 & 249.54 & 160 & 29 & w & Shallow & Minor fracture \\
\hline 134.09 & 40.87 & 272.31 & 182 & 22 & W & Shallow & Minor fracture \\
\hline 134.41 & 40.97 & 102.02 & 12 & 52 & $E$ & Steep & Minor fracture \\
\hline 136.39 & 41.57 & 236.27 & 146 & 27 & sw & Shallow & Minor fracture \\
\hline 139.26 & 42.44 & 234.1 & 144 & 26 & sw & Shallow & Minor fracture \\
\hline 139.87 & 42.63 & 307.58 & 218 & 85 & NW & Nearly vertical & Minor fracture \\
\hline 142.43 & 43.41 & 359.23 & 269 & 70 & $\mathrm{~N}$ & Nearly vertical & Minor fracture \\
\hline 144.31 & 43.98 & 268.54 & 179 & 38 & W & Moderate & Minor fracture \\
\hline 148.27 & 45.19 & 66.9 & 337 & 79 & NE & Nearly vertical & Minor fracture \\
\hline 148.85 & 45.37 & 254.36 & 164 & 40 & W & Moderate & Minor fracture \\
\hline 152.13 & 46.37 & 53 & 323 & 78 & $\mathrm{NE}$ & Nearly vertical & Minor fracture \\
\hline 153.18 & 46.69 & 50.9 & 321 & 77 & $\mathrm{NE}$ & Nearly vertical & Minor fracture \\
\hline 154.85 & 47.20 & 203.47 & 113 & 1 & SW & Nearly horizontal & Water level \\
\hline 154.90 & 47.21 & 238.85 & 149 & 43 & SW & Moderate & Minor fracture \\
\hline 157.76 & 48.08 & 77.91 & 348 & 80 & $\mathrm{E}$ & Nearly vertical & Minor fracture \\
\hline 162.22 & 49.44 & 306.6 & 217 & 63 & NW & Steep & Minor fracture \\
\hline 167.08 & 50.92 & 69.31 & 339 & 84 & $E$ & Nearly vertical & Minor fracture \\
\hline 169.46 & 51.65 & 214.35 & 124 & 15 & sw & Shallow & Minor fracture \\
\hline 176.13 & 53.68 & 40 & 310 & 79 & NE & Nearly vertical & Minor fracture \\
\hline 178.92 & 54.53 & 106.34 & 16 & 77 & $E$ & Nearly vertical & Minor fracture \\
\hline 181.33 & 55.27 & 100.16 & 10 & 22 & $\mathrm{E}$ & Shallow & Minor fracture \\
\hline 183.05 & 55.79 & 93.46 & 3 & 52 & $\mathrm{E}$ & Steep & Minor fracture \\
\hline 185.58 & 56.56 & 88.46 & 358 & 11 & $\mathrm{E}$ & Shallow & Transmissive fracture \\
\hline 185.94 & 56.67 & 154.72 & 65 & 17 & SE & Shallow & Transmissive fracture \\
\hline 187.24 & 57.07 & 256.68 & 167 & 31 & W & Moderate & Minor fracture \\
\hline 189.61 & 57.79 & 37.23 & 307 & 84 & NE & Nearly vertical & Minor fracture \\
\hline 190.55 & 58.08 & 58.68 & 329 & 40 & $\mathrm{NE}$ & Moderate & Minor fracture \\
\hline 193.62 & 59.01 & 165.46 & 75 & 52 & $\mathrm{~S}$ & Steep & Minor fracture \\
\hline
\end{tabular}


Table 1L-2. Interpretation of optical televiewer logs for borehole WY-GATR, near Machiasport, Maine.-Continued [Televiewer data are corrected for deviation and magnetic declination, so orientations are relative to true north; depths are below top of casing, which is 3.45 feet above land surface; dip azimuth is given in degrees east of true north; strike is reported in right-hand-rule (RHR)-azimuthal degrees east of true north and where the direction of dip is 90 degrees to the right of strike]

\begin{tabular}{|c|c|c|c|c|c|c|c|}
\hline $\begin{array}{l}\text { Depth, } \\
\text { in feet }\end{array}$ & $\begin{array}{l}\text { Depth, } \\
\text { in meters }\end{array}$ & $\begin{array}{c}\text { Dip } \\
\text { azimuth }\end{array}$ & $\begin{array}{l}\text { Strike, } \\
\text { in RHR }\end{array}$ & Dip & $\begin{array}{c}\text { Dip } \\
\text { direction }\end{array}$ & Dip descriptor & Comment \\
\hline 195.41 & 59.56 & 142.14 & 52 & 29 & SE & Shallow & Minor fracture \\
\hline 196.51 & 59.89 & 130.35 & 40 & 26 & SE & Shallow & Minor fracture \\
\hline 198.16 & 60.40 & 188.05 & 98 & 17 & $\mathrm{~S}$ & Shallow & Lithologic feature \\
\hline 203.69 & 62.08 & 46.53 & 317 & 38 & NE & Moderate & Minor fracture \\
\hline 205.60 & 62.66 & 88.02 & 358 & 33 & $E$ & Moderate & Minor fracture \\
\hline 208.74 & 63.62 & 106.88 & 17 & 22 & $\bar{E}$ & Shallow & Minor fracture \\
\hline 213.44 & 65.05 & 93.43 & 3 & 60 & $\mathrm{E}$ & Steep & Minor fracture \\
\hline 215.92 & 65.81 & 277.25 & 187 & 31 & W & Moderate & Minor fracture \\
\hline 219.52 & 66.91 & 50.09 & 320 & 64 & NE & Steep & Minor fracture \\
\hline 220.84 & 67.31 & 70.87 & 341 & 82 & $E$ & Nearly vertical & Minor fracture \\
\hline 228.34 & 69.59 & 202.73 & 113 & 77 & SW & Nearly vertical & Sealed fracture - felsic \\
\hline 230.82 & 70.35 & 18.58 & 289 & 62 & $\mathrm{~N}$ & Steep & Sealed fracture - felsic \\
\hline 234.05 & 71.33 & 44.56 & 315 & 69 & NE & Steep & Sealed fracture - felsic \\
\hline 237.84 & 72.49 & 199.31 & 109 & 76 & $\mathrm{~S}$ & Nearly vertical & Sealed fracture - felsic \\
\hline 240.87 & 73.41 & 196.23 & 106 & 76 & $\mathrm{~S}$ & Nearly vertical & Minor fracture \\
\hline 243.12 & 74.10 & 291.44 & 201 & 42 & W & Moderate & Minor fracture \\
\hline 244.26 & 74.45 & 221.9 & 132 & 21 & SW & Shallow & Minor fracture \\
\hline 244.66 & 74.57 & 57.27 & 327 & 35 & $\mathrm{NE}$ & Moderate & Minor fracture \\
\hline 247.10 & 75.31 & 231.85 & 142 & 78 & SW & Nearly vertical & Minor fracture \\
\hline 251.38 & 76.62 & 354.56 & 265 & 76 & $\mathrm{~N}$ & Nearly vertical & Minor fracture \\
\hline 252.36 & 76.92 & 23.01 & 293 & 48 & $\mathrm{NE}$ & Moderate & Minor fracture \\
\hline 260.28 & 79.33 & 194.05 & 104 & 83 & $\mathrm{~S}$ & Nearly vertical & Minor fracture \\
\hline 267.77 & 81.61 & 284.89 & 195 & 73 & W & Nearly vertical & Minor fracture \\
\hline 270.29 & 82.38 & 263.76 & 174 & 59 & W & Steep & Minor fracture \\
\hline 273.08 & 83.23 & 262.03 & 172 & 63 & W & Steep & Minor fracture \\
\hline 291.05 & 88.71 & 216.92 & 127 & 21 & sw & Shallow & Sealed fracture - felsic \\
\hline 291.35 & 88.80 & 241.38 & 151 & 22 & sW & Shallow & Sealed fracture - felsic \\
\hline 293.55 & 89.47 & 259.85 & 170 & 30 & W & Moderate & Minor fracture \\
\hline 294.15 & 89.65 & 85.65 & 356 & 15 & $\mathrm{E}$ & Shallow & Sealed fracture - felsic \\
\hline 300.85 & 91.69 & 14.23 & 284 & 22 & $\mathrm{~N}$ & Shallow & Sealed fracture - felsic \\
\hline 300.95 & 91.73 & 72.41 & 342 & 8 & $\mathrm{E}$ & Nearly horizontal & Sealed fracture - felsic \\
\hline 301.21 & 91.80 & 115.06 & 25 & 63 & SE & Steep & Sealed fracture - felsic \\
\hline 301.45 & 91.88 & 94.14 & 4 & 28 & $\mathrm{E}$ & Shallow & Sealed fracture - felsic \\
\hline 304.49 & 92.80 & 198.34 & 108 & 75 & $\bar{S}$ & Nearly vertical & Sealed fracture - felsic \\
\hline 313.62 & 95.59 & 48.31 & 318 & 59 & NE & Steep & Sealed fracture - felsic \\
\hline 316.75 & 96.54 & 70.55 & 341 & 58 & $\mathrm{E}$ & Steep & Minor fracture \\
\hline 324.32 & 98.85 & 150.34 & 60 & 62 & SE & Steep & Sealed fracture - felsic \\
\hline 325.25 & 99.13 & 330.42 & 240 & 80 & NW & Nearly vertical & Sealed fracture - felsic \\
\hline 328.86 & 100.23 & 327.7 & 238 & 82 & NW & Nearly vertical & Sealed fracture - felsic \\
\hline 331.88 & 101.15 & 241.29 & 151 & 73 & SW & Nearly vertical & Minor fracture \\
\hline 340.33 & 103.73 & 159.64 & 70 & 67 & $\mathrm{~S}$ & Steep & Minor fracture \\
\hline 346.90 & 105.73 & 39.16 & 309 & 59 & $\mathrm{NE}$ & Steep & Minor fracture \\
\hline 353.32 & 107.69 & 353.64 & 264 & 80 & $\mathrm{~N}$ & Nearly vertical & Sealed fracture - felsic \\
\hline 357.25 & 108.88 & 189.52 & 100 & 42 & S & Moderate & Minor fracture \\
\hline 362.24 & 110.41 & 194.58 & 105 & 74 & $\mathrm{~S}$ & Nearly vertical & Sealed fracture - felsic \\
\hline 363.80 & 110.88 & 203.88 & 114 & 60 & SW & Steep & Minor fracture \\
\hline 364.28 & 111.03 & 25.12 & 295 & 78 & $\mathrm{NE}$ & Nearly vertical & Sealed fracture - felsic \\
\hline 368.62 & 112.35 & 230.02 & 140 & 74 & SW & Nearly vertical & Minor fracture \\
\hline 377.81 & 115.15 & 68.02 & 338 & 80 & $\mathrm{E}$ & Nearly vertical & Minor fracture \\
\hline 380.03 & 115.83 & 47.32 & 317 & 78 & NE & Nearly vertical & Large fracture \\
\hline 389.39 & 118.68 & 43.94 & 314 & 77 & NE & Nearly vertical & Minor fracture \\
\hline 403.29 & 122.92 & 37.1 & 307 & 17 & NE & Shallow & Lithologic feature \\
\hline 403.62 & 123.02 & 264.95 & 175 & 17 & W & Shallow & Minor fracture \\
\hline 406.54 & 123.91 & 62.44 & 332 & $\begin{array}{l}11 \\
72\end{array}$ & $\mathrm{NE}$ & Nearly vertical & Minor fracture \\
\hline 407.93 & 124.33 & 247.96 & 158 & 17 & W & Shallow & Minor fracture \\
\hline 409.91 & 124.93 & 267.6 & 178 & 19 & W & Shallow & Minor fracture \\
\hline 410.68 & 125.17 & 274.33 & 184 & 21 & W & Shallow & Minor fracture \\
\hline 411.78 & 125.50 & 106.27 & 16 & 15 & $\mathrm{E}$ & Shallow & Transmissive fracture \\
\hline 413.47 & 126.02 & 73.31 & 343 & 26 & $\mathrm{E}$ & Shallow & Transmissive fracture \\
\hline
\end{tabular}




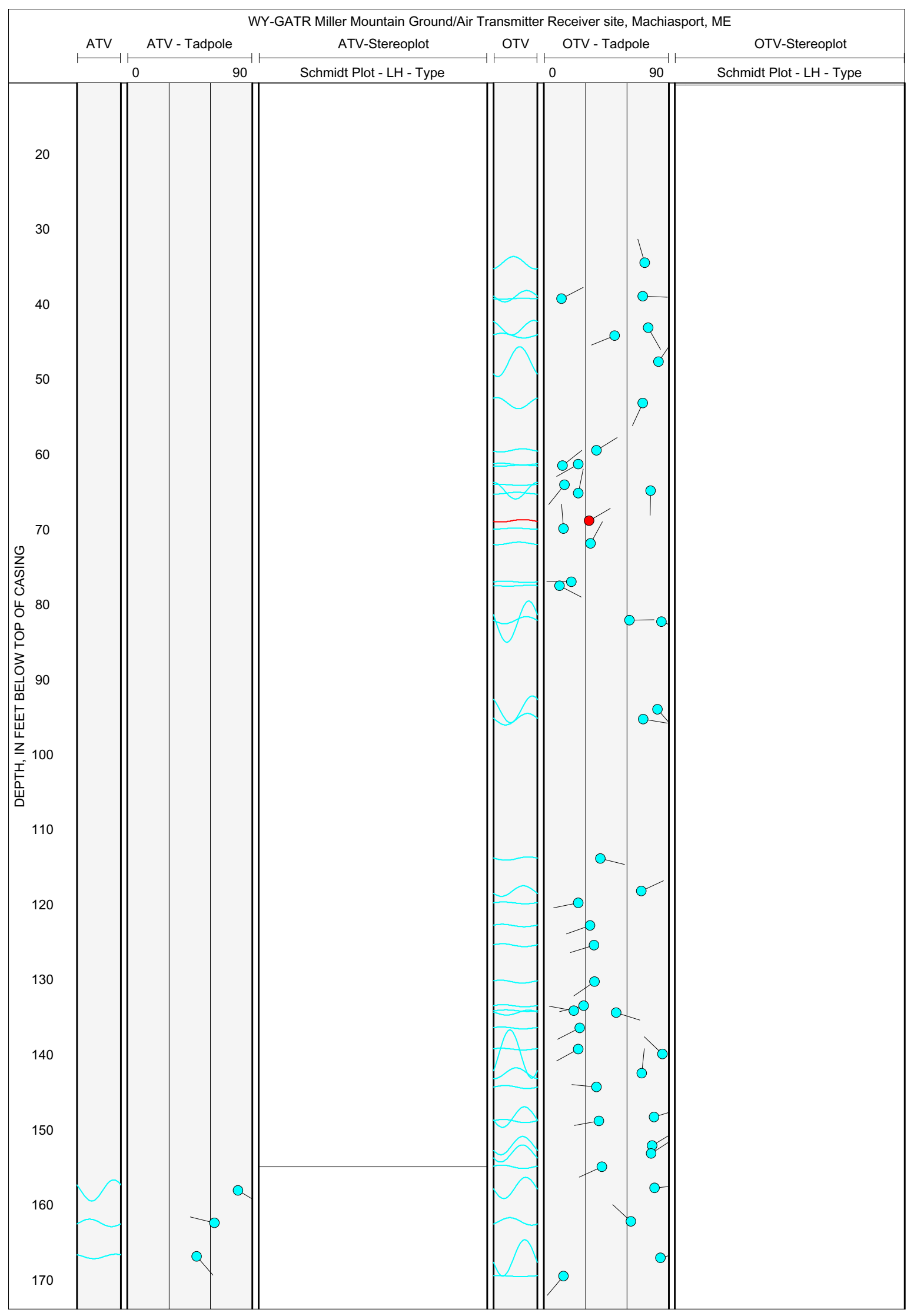

Figure 1L-3. Projection, tadpole, and stereoplots of interpretation of borehole image data for borehole WY-GATR, near Machiasport, Maine. 


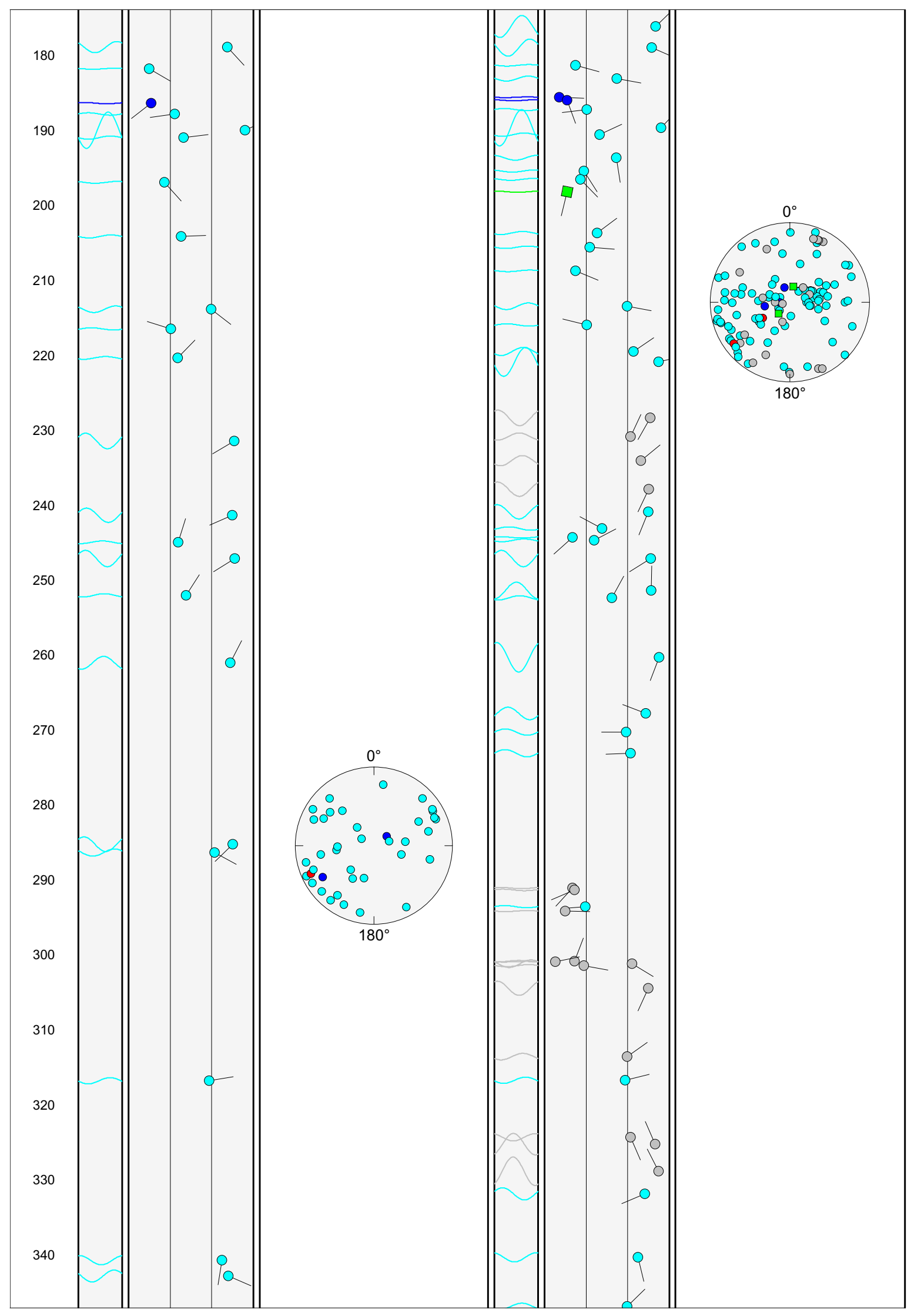

Figure 1L-3. Projection, tadpole, and stereoplots of interpretation of borehole image data for borehole WY-GATR, near Machiasport, Maine.-Continued 


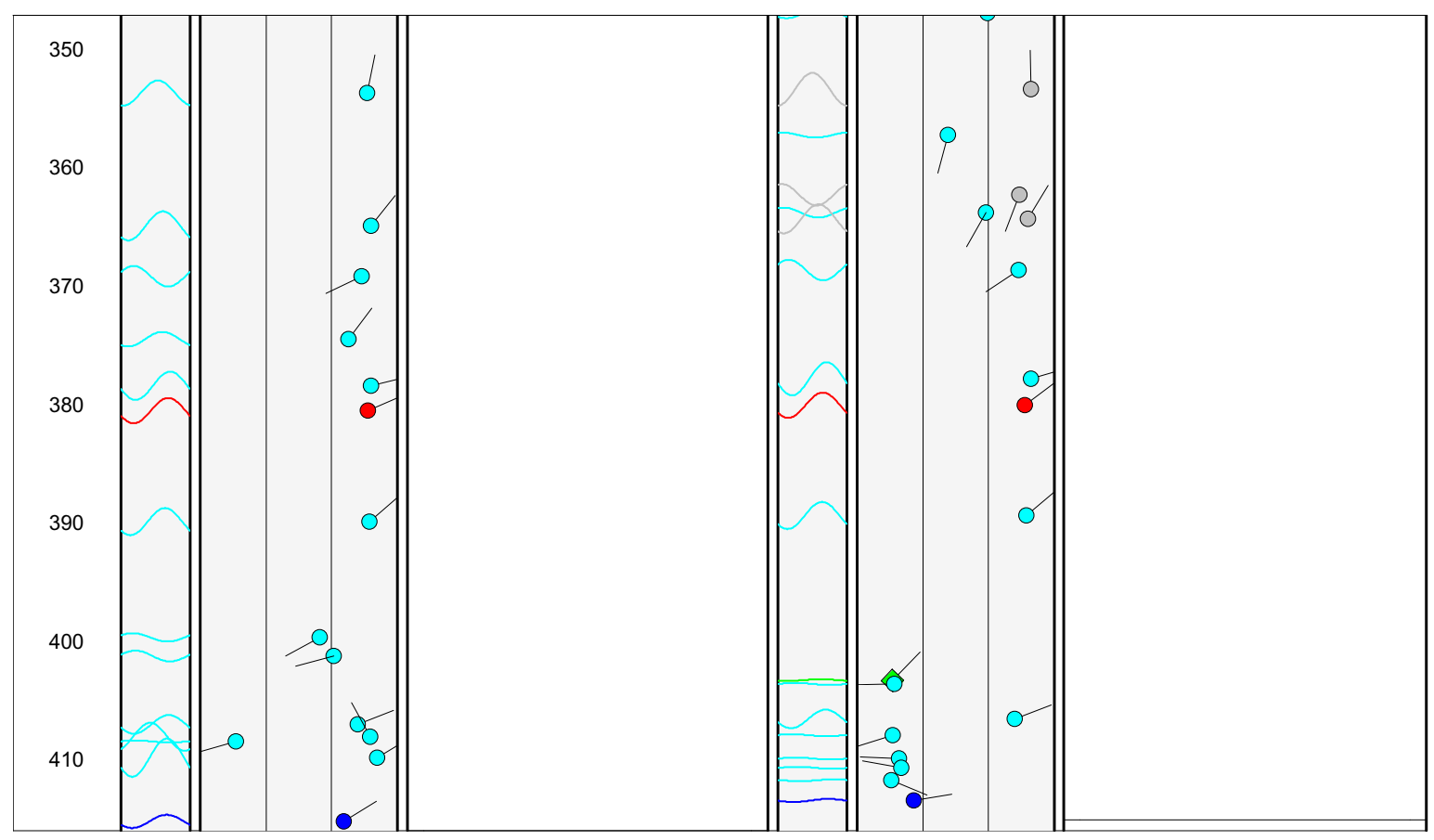

Figure 1L-3. Projection, tadpole, and stereoplots of interpretation of borehole image data for borehole WY-GATR, near Machiasport, Maine.-Continued 

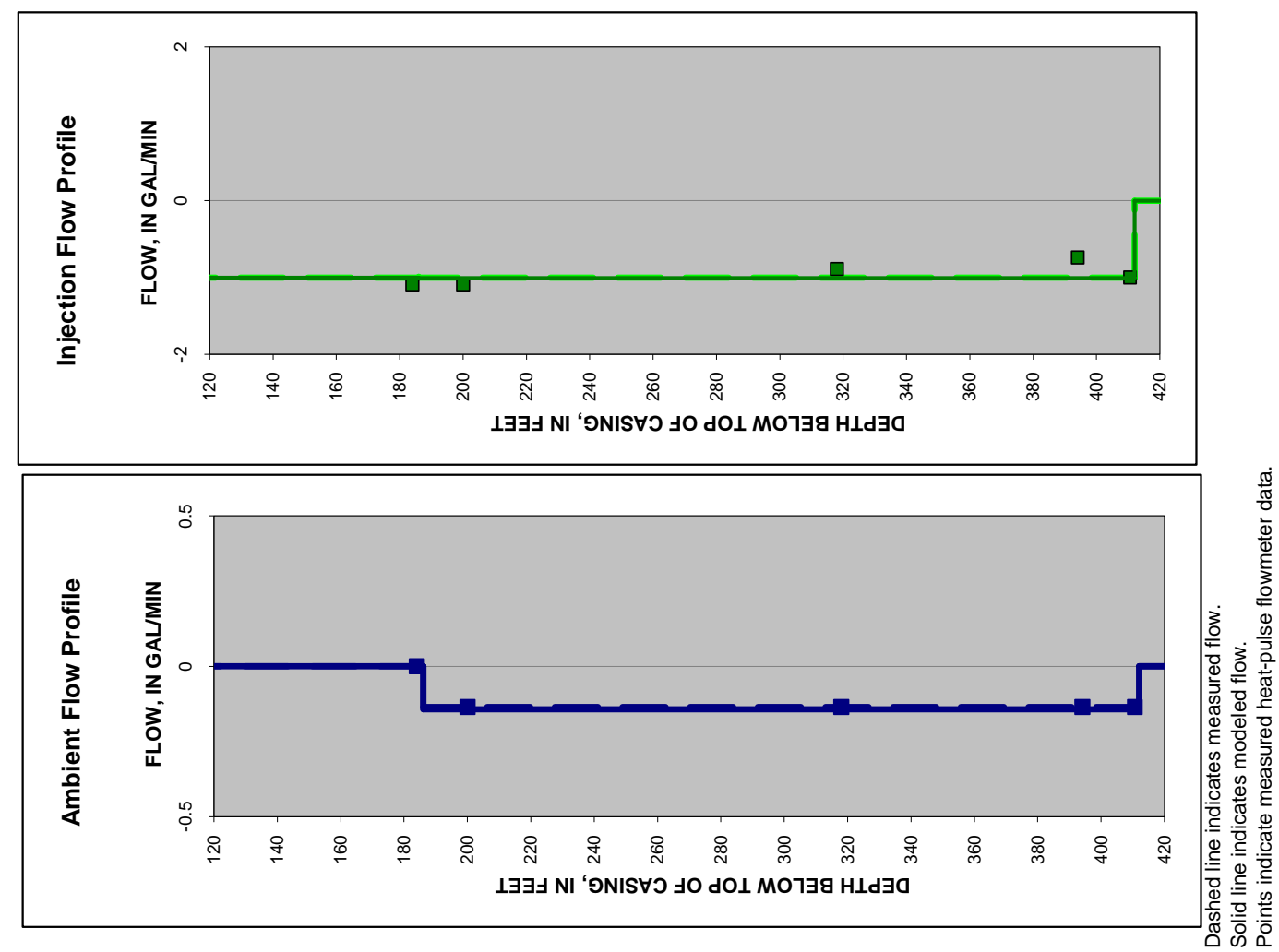

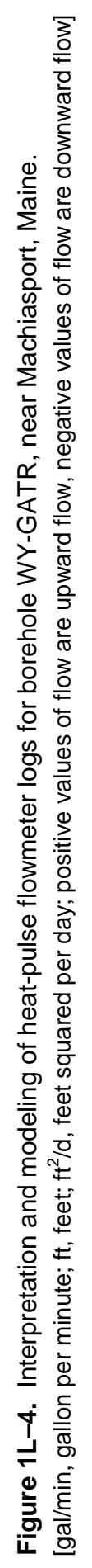




\section{Appendix 2. Borehole geophysical logs from boreholes near the Air Force Radar Tracking Station on Howard Mountain, near Machiasport, Maine}




\section{Appendix 2.}

\section{Borehole geophysical logs from boreholes near the Air Force Radar Tracking Station on Howard Mountain, near Machiasport, Maine}

\section{A. Borehole DW-2}

Figure 2A-1. Caliper, acoustic caliper, gamma, electromagnetic conductivity, fluid temperature, specific conductance, dissolved oxygen, $\mathrm{pH}$, reduction oxidation, multi-space resistivity, oriented acoustic and optical borehole images, and heatpulse flowmeter logs for borehole DW-2, near Machiasport, Maine.

Figure 2A-2. Borehole deviation logs for borehole DW-2, near Machiasport, Maine.

Table 2A-1. Interpretation of acoustic televiewer logs for borehole DW-2, near Machiasport, Maine.

Figure 2A-3. Projection, tadpole, and stereoplots of interpretation of borehole image data for borehole DW-2, near Machiasport, Maine.

Figure 2A-4. Interpretation and modeling of heat-pulse flowmeter logs for borehole DW-2, near Machiasport, Maine.

\section{B. Borehole WY-3B}

Figure 2B-1. Caliper, acoustic caliper, gamma, electromagnetic conductivity, fluid temperature, specific conductance, dissolved oxygen, $\mathrm{pH}$, reduction oxidation, multi-space resistivity, oriented acoustic and optical borehole images, and heatpulse flowmeter logs for borehole WY-3B, near Machiasport, Maine.

Figure 2B-2. Borehole deviation logs for borehole WY-3B, near Machiasport, Maine.

Table 2B-1. Interpretation of acoustic televiewer logs for borehole WY-3B, near Machiasport, Maine.

Figure 2B-3. Projection, tadpole, and stereoplots of interpretation of borehole image data for borehole WY-3B, near Machiasport, Maine.

\section{Borehole WY-4}

Figure 2C-1. Caliper, acoustic caliper, gamma, electromagnetic conductivity, fluid temperature, specific conductance, dissolved oxygen, $\mathrm{pH}$, reduction oxidation, multi-space resistivity, oriented acoustic and optical borehole images, and heatpulse flowmeter logs for borehole WY-4, near Machiasport, Maine.

Figure 2C-2. Borehole deviation logs for borehole WY-4, near Machiasport, Maine.

Table 2C-1. Interpretation of acoustic televiewer logs for borehole WY-4, near Machiasport, Maine.

Figure 2C-3. Projection, tadpole, and stereoplots of interpretation of borehole image data for borehole WY-4, near Machiasport, Maine.

Figure 2C-4. Interpretation and modeling of heat-pulse flowmeter logs for borehole WY-4, near Machiasport, Maine.

\section{Borehole WY-15}

Figure 2D-1. Caliper, acoustic caliper, gamma, electromagnetic conductivity, fluid temperature, specific conductance, dissolved oxygen, $\mathrm{pH}$, reduction oxidation, multi-space resistivity, oriented acoustic and optical borehole images, and heatpulse flowmeter logs for borehole WY-15, near Machiasport, Maine.

Figure 2D-2. Borehole deviation logs for borehole WY-15, near Machiasport, Maine.

Table 2D-1. Interpretation of acoustic televiewer logs for borehole WY-15, near Machiasport, Maine.

Figure 2D-3. Projection, tadpole, and stereoplots of interpretation of borehole image data for borehole WY-15, near Machiasport, Maine.

Figure 2D-4. Interpretation and modeling of heat-pulse flowmeter logs for borehole WY-15, near Machiasport, Maine. 


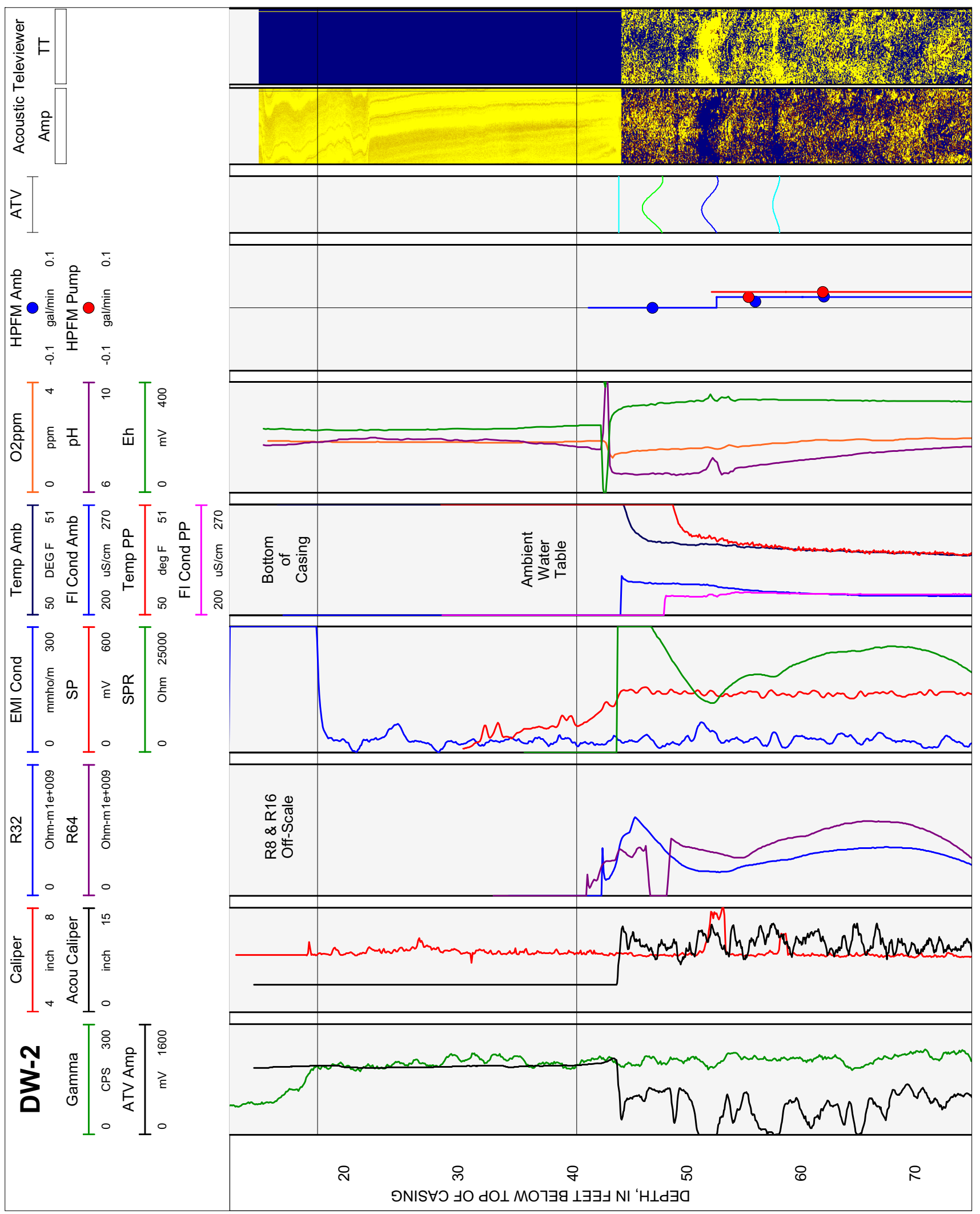

Figure 2A-1. Caliper, acoustic caliper, gamma, electromagnetic conductivity, fluid temperature, specific conductance, $\mathrm{DO}, \mathrm{pH}$, reduction oxidation, multi-space resistivity, oriented acoustic and optical borehole images, and heat-pulse flowmeter logs for borehole DW-2, near Machiasport, Maine. 


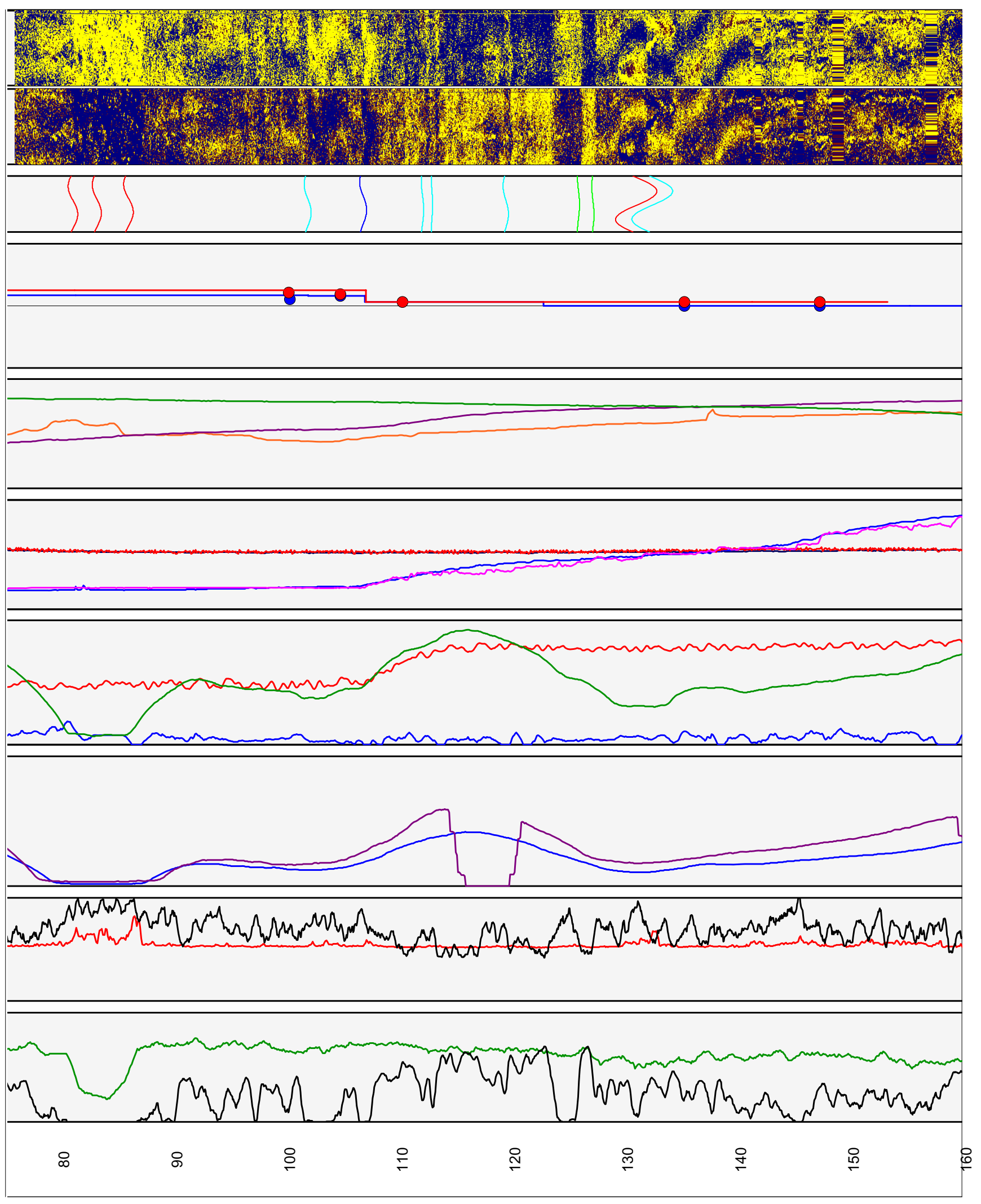

Figure 2A-1. Caliper, acoustic caliper, gamma, electromagnetic conductivity, fluid temperature, specific conductance, $\mathrm{DO}, \mathrm{pH}$, reduction oxidation, multi-space resistivity, oriented acoustic and optical borehole images, and heat-pulse flowmeter logs for borehole DW-2, near Machiasport, Maine.-Continued 


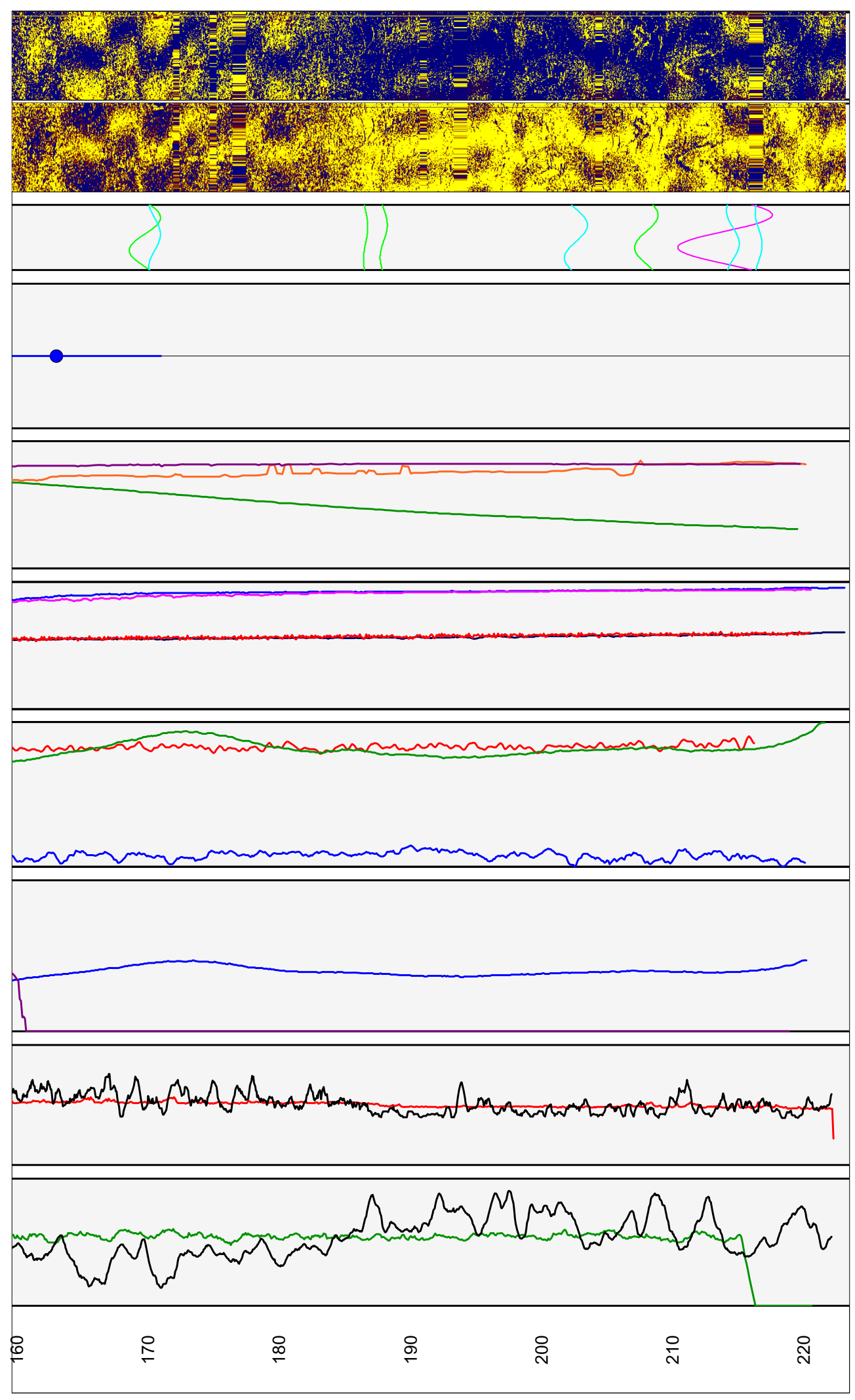

Figure 2A-1. Caliper, acoustic caliper, gamma, electromagnetic conductivity, fluid temperature, specific conductance, $\mathrm{DO}, \mathrm{pH}$, reduction oxidation, multi-space resistivity, oriented acoustic and optical borehole images, and heat-pulse flowmeter logs for borehole DW-2, near Machiasport, Maine.-Continued 

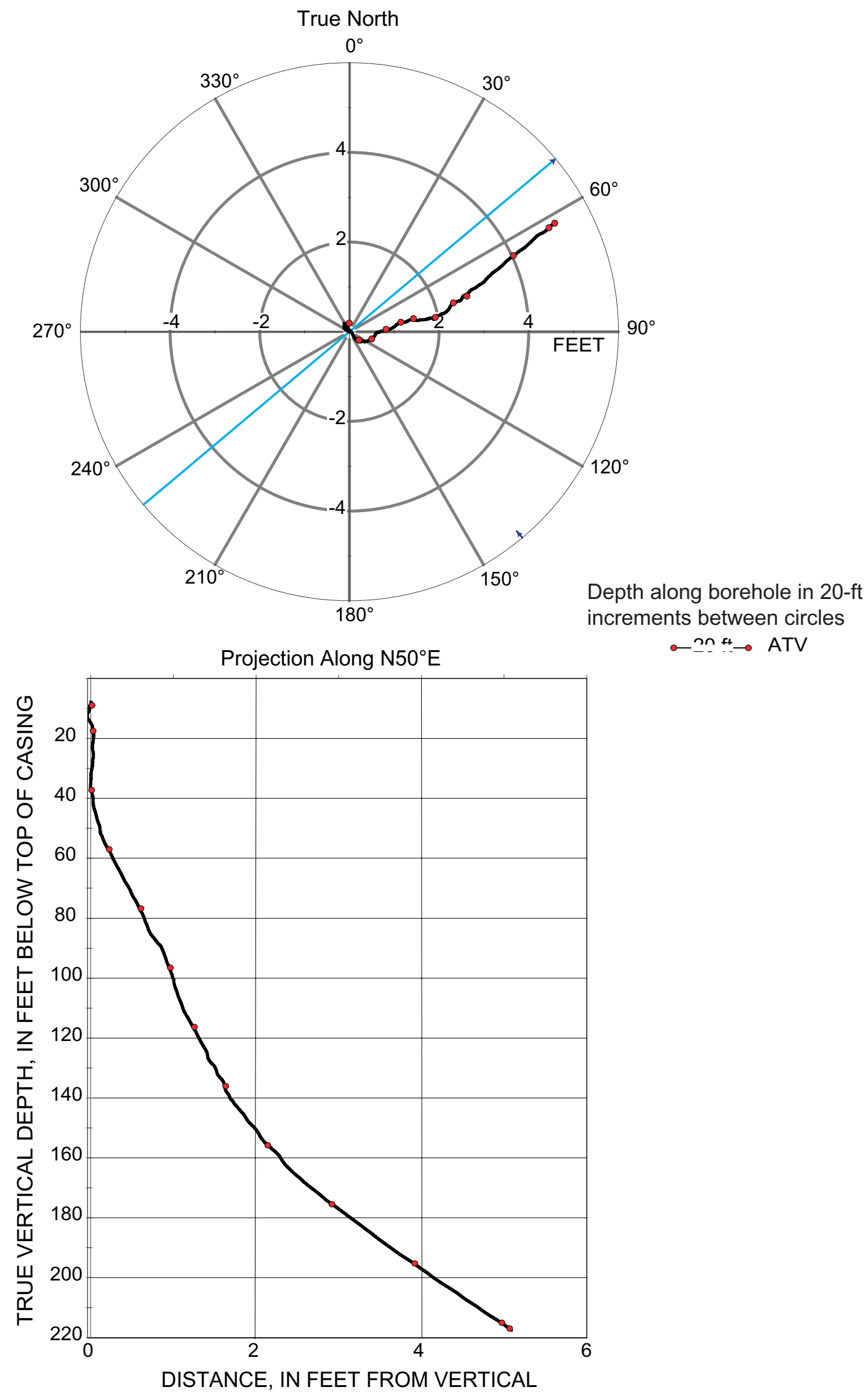

$\because$ on ${ }_{-} \rightarrow$ ATV is line of projection for vertical plot (bottom).

[ft, foot; ATV, acoustic televiewer] 
Table 2A-1. Interpretation of acoustic televiewer logs for borehole DW-2, near Machiasport, Maine.

[Televiewer data are corrected for deviation and magnetic declination, so orientations are relative to true north; depths are below top of casing, which is 2.7 feet above land surface; dip azimuth is given in degrees east of true north; strike is reported in right-hand-rule (RHR)-azimuthal degrees east of true north and where the direction of dip is 90 degrees to the right of strike]

\begin{tabular}{|c|c|c|c|c|c|c|c|}
\hline $\begin{array}{l}\text { Depth, } \\
\text { in feet }\end{array}$ & $\begin{array}{l}\text { Depth, } \\
\text { in meters }\end{array}$ & $\begin{array}{c}\text { Dip } \\
\text { azimuth }\end{array}$ & $\begin{array}{l}\text { Strike, } \\
\text { in RHR }\end{array}$ & Dip & $\begin{array}{l}\text { Dip } \\
\text { direction }\end{array}$ & Dip descriptor & Comment \\
\hline 44.09 & 13.44 & 298 & 208 & 1 & NW & Nearly horizontal & Water level \\
\hline 47.00 & 14.33 & 338 & 248 & 74 & $\mathrm{~N}$ & Nearly vertical & Lithologic feature \\
\hline 49.01 & 14.94 & 123 & 33 & 10 & SE & Shallow & Minor fracture \\
\hline 50.57 & 15.41 & 346 & 256 & 81 & $\mathrm{~N}$ & Nearly vertical & Minor fracture \\
\hline 52.17 & 15.90 & 330 & 240 & 67 & NW & Steep & Transmissive fracture \\
\hline 55.08 & 16.79 & 342 & 252 & 78 & $\mathrm{~N}$ & Nearly vertical & Lithologic feature \\
\hline 57.74 & 17.60 & 356 & 266 & 49 & $\mathrm{~N}$ & Moderate & Transmissive fracture \\
\hline 80.78 & 24.62 & 98 & 8 & 57 & $E$ & Steep & Fracture \\
\hline 82.94 & 25.28 & 125 & 35 & 44 & SE & Moderate & Fracture \\
\hline 85.65 & 26.11 & 136 & 46 & 60 & SE & Steep & Fracture \\
\hline 97.02 & 29.57 & 79 & 349 & 20 & $E$ & Shallow & Minor fracture \\
\hline 101.44 & 30.92 & 119 & 29 & 43 & SE & Moderate & Minor fracture \\
\hline 106.49 & 32.46 & 126 & 36 & 49 & SE & Moderate & Fracture, probably transmissive \\
\hline 111.88 & 34.10 & 161 & 71 & 34 & $\mathrm{~S}$ & Moderate & Minor fracture \\
\hline 112.81 & 34.38 & 281 & 191 & 32 & W & Moderate & Minor fracture \\
\hline 119.11 & 36.30 & 96 & 6 & 37 & $E$ & Moderate & Minor fracture \\
\hline 125.50 & 38.25 & 179 & 89 & 20 & S & Shallow & Lithologic feature \\
\hline 126.9 & 38.68 & 112 & 22 & 20 & $E$ & Shallow & Lithologic feature \\
\hline 130.66 & 39.83 & 252 & 162 & 82 & W & Nearly vertical & Minor fracture \\
\hline 132.31 & 40.33 & 267 & 177 & 83 & W & Nearly vertical & Minor fracture \\
\hline 136.38 & 41.57 & 267 & 177 & 81 & W & Nearly vertical & Minor fracture \\
\hline 137.53 & 41.92 & 203 & 113 & 20 & SW & Shallow & Minor fracture \\
\hline 144.00 & 43.89 & 349 & 259 & 83 & $\mathrm{~N}$ & Nearly vertical & $\begin{array}{l}\text { Minor fracture, possible } \\
\text { transmissive fracture }\end{array}$ \\
\hline 161.07 & 49.09 & 195 & 105 & 48 & S & Moderate & $\begin{array}{l}\text { Minor fracture - weak feature } \\
\text { possible transmissive fracture }\end{array}$ \\
\hline 169.46 & 51.65 & 284 & 194 & 75 & W & Nearly vertical & Minor fracture \\
\hline 170.78 & 52.05 & 268 & 178 & 53 & W & Steep & Minor fracture \\
\hline 178.65 & 54.45 & 234 & 144 & 67 & SW & Steep & Sealed fracture \\
\hline 186.22 & 56.76 & 275 & 185 & 80 & W & Nearly vertical & Minor fracture \\
\hline 199.45 & 60.79 & 226 & 136 & 79 & SW & Nearly vertical & Minor fracture \\
\hline 202.56 & 61.74 & 246 & 156 & 79 & SW & Nearly vertical & Minor fracture \\
\hline 207.19 & 63.15 & 311 & 221 & 74 & NW & Nearly vertical & Lithologic feature \\
\hline 209.92 & 63.98 & 204 & 114 & 76 & SW & Nearly vertical & Minor fracture \\
\hline 214.64 & 65.42 & 144 & 54 & 60 & SE & Steep & Minor fracture \\
\hline 214.79 & 65.47 & 310 & 220 & 89 & NW & Nearly vertical & Minor fracture \\
\hline 216.27 & 65.92 & 144 & 54 & 68 & SE & Steep & Minor fracture \\
\hline
\end{tabular}




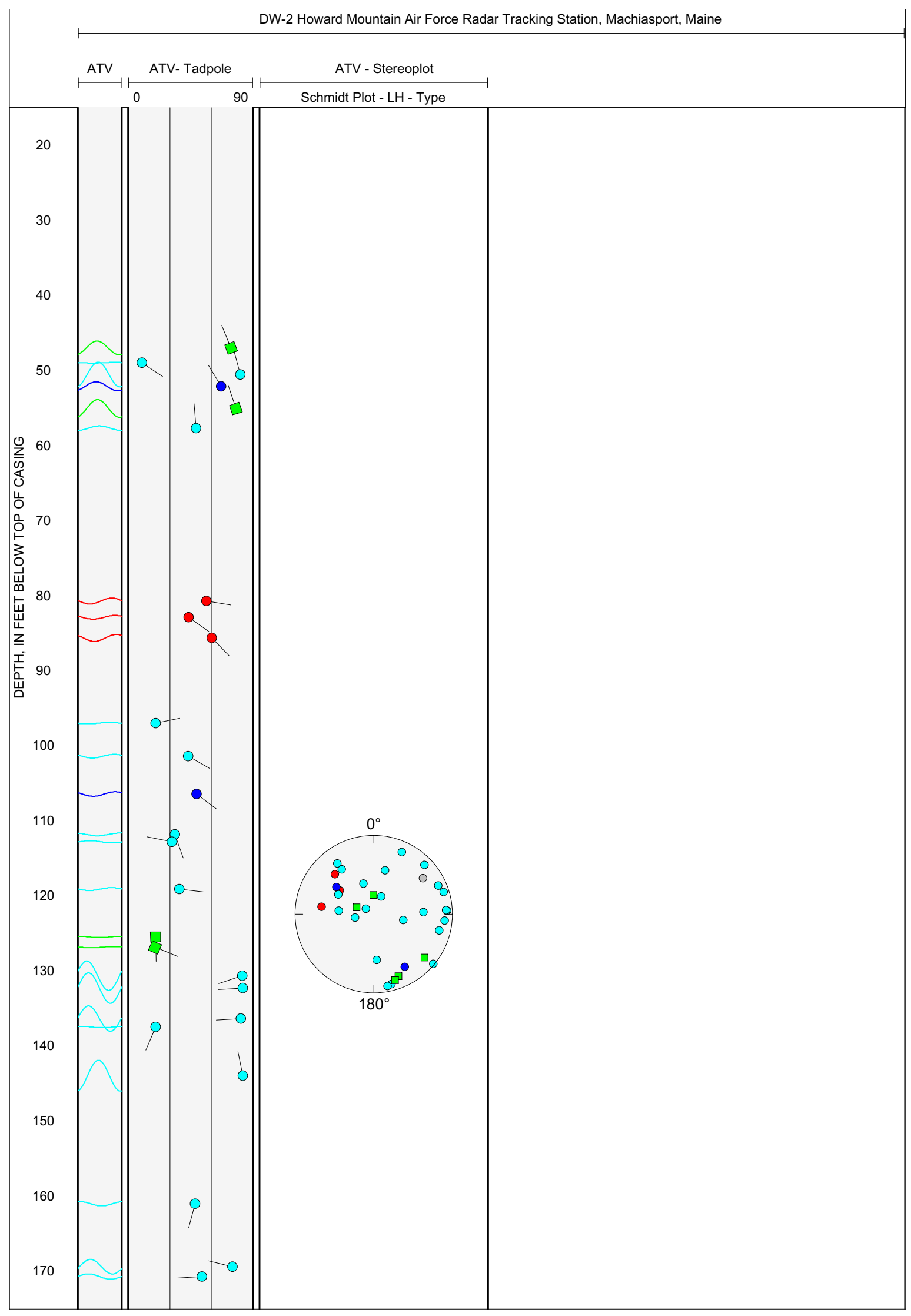

Figure 2A-3. Projection, tadpole, and stereoplots of interpretation of borehole image data for borehole DW-2 near Machiasport, Maine. 


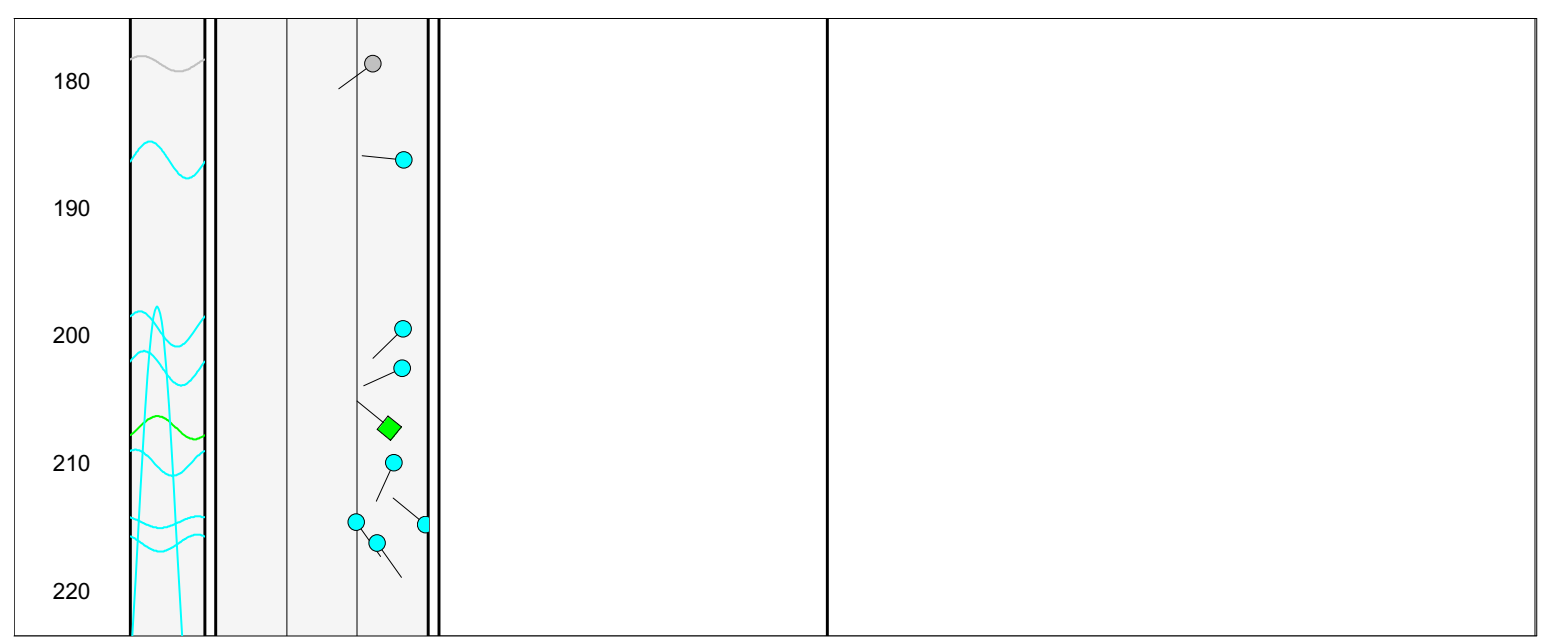

Figure 2A-3. Projection, tadpole, and stereoplots of interpretation of borehole image data for borehole DW-2 near Machiasport, Maine.-Continued 

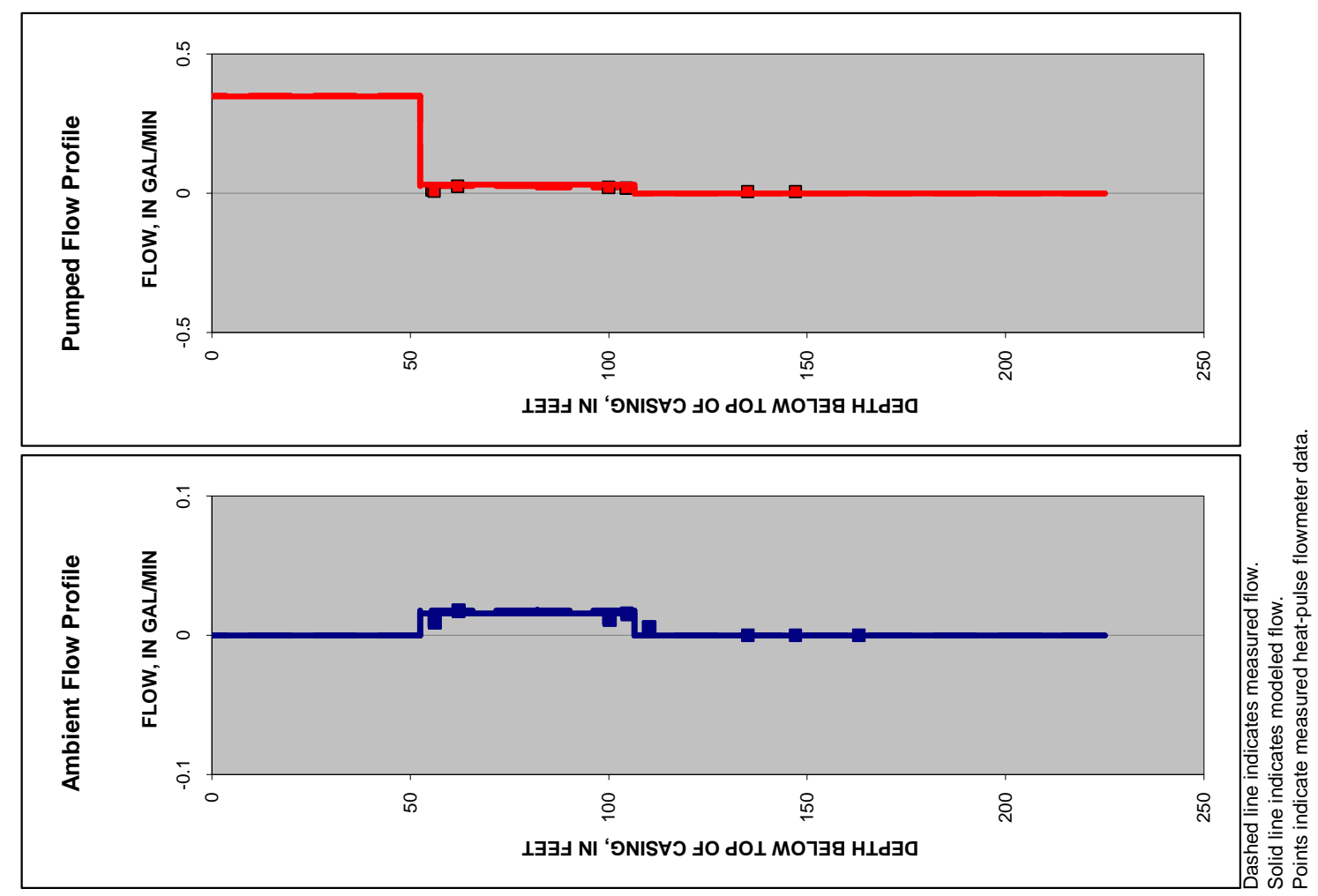

悉

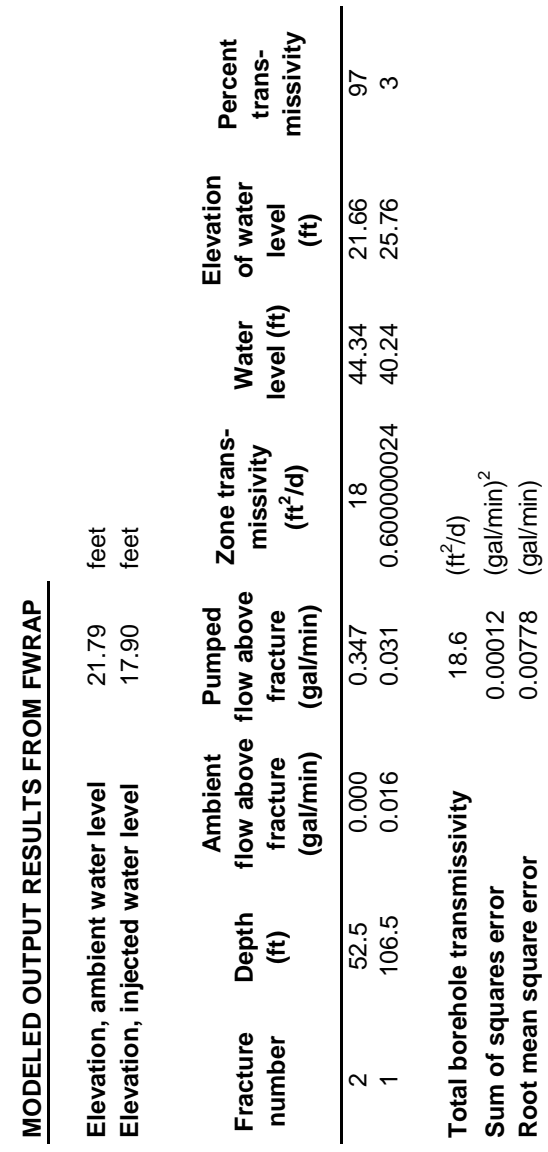




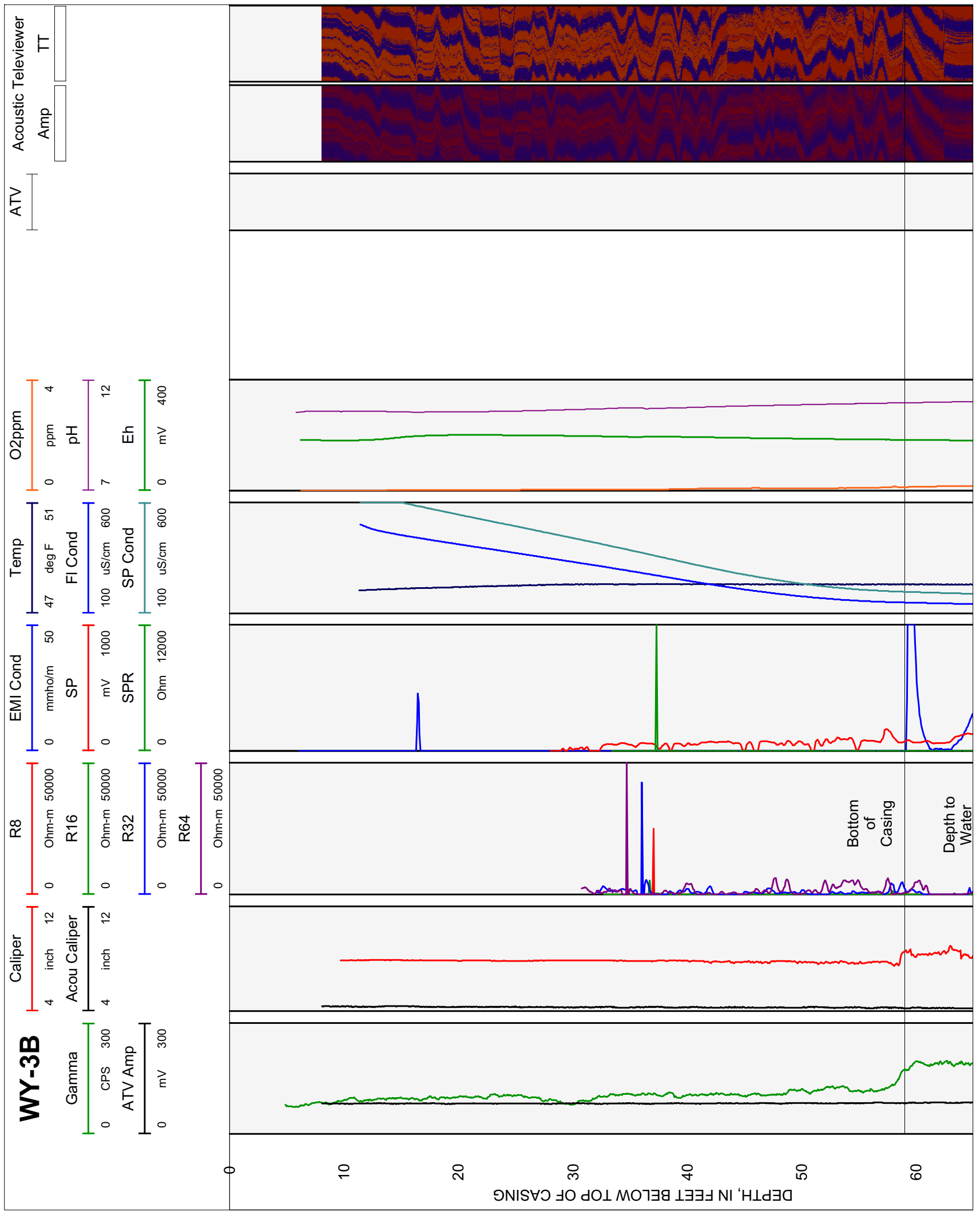

Figure 2B-1. Caliper, acoustic caliper, gamma, electromagnetic conductivity, fluid temperature, specific conductance, $\mathrm{DO}, \mathrm{pH}$, reduction oxidation, multi-space resistivity, oriented acoustic and optical borehole images, and heat-pulse flowmeter logs for borehole WY-3B, near Machiasport, Maine. 

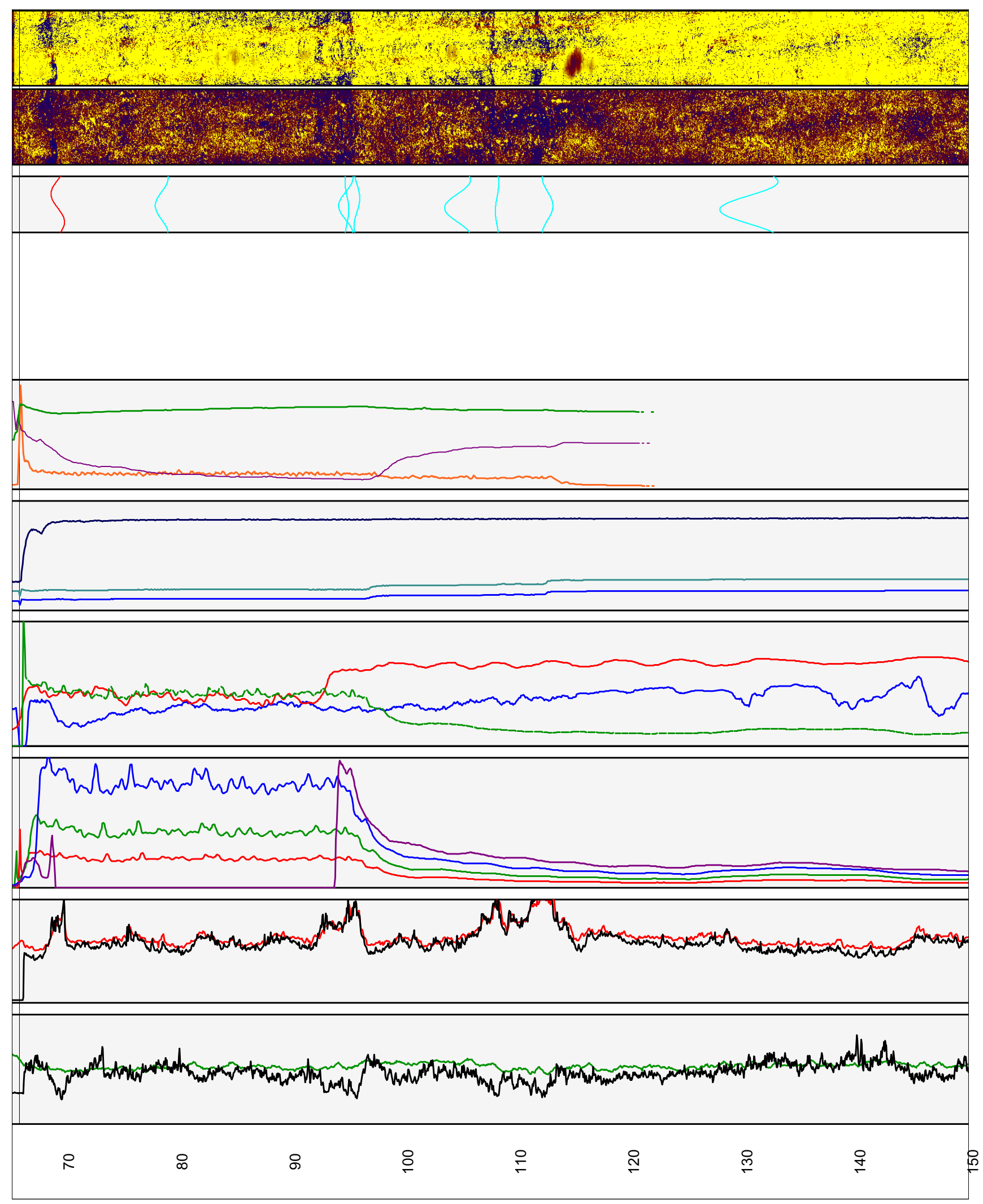

Figure 2B-1. Caliper, acoustic caliper, gamma, electromagnetic conductivity, fluid temperature, specific conductance, $\mathrm{DO}, \mathrm{pH}$, reduction oxidation, multi-space resistivity, oriented acoustic and optical borehole images, and heat-pulse flowmeter logs for borehole WY-3B, near Machiasport, Maine._Continued 

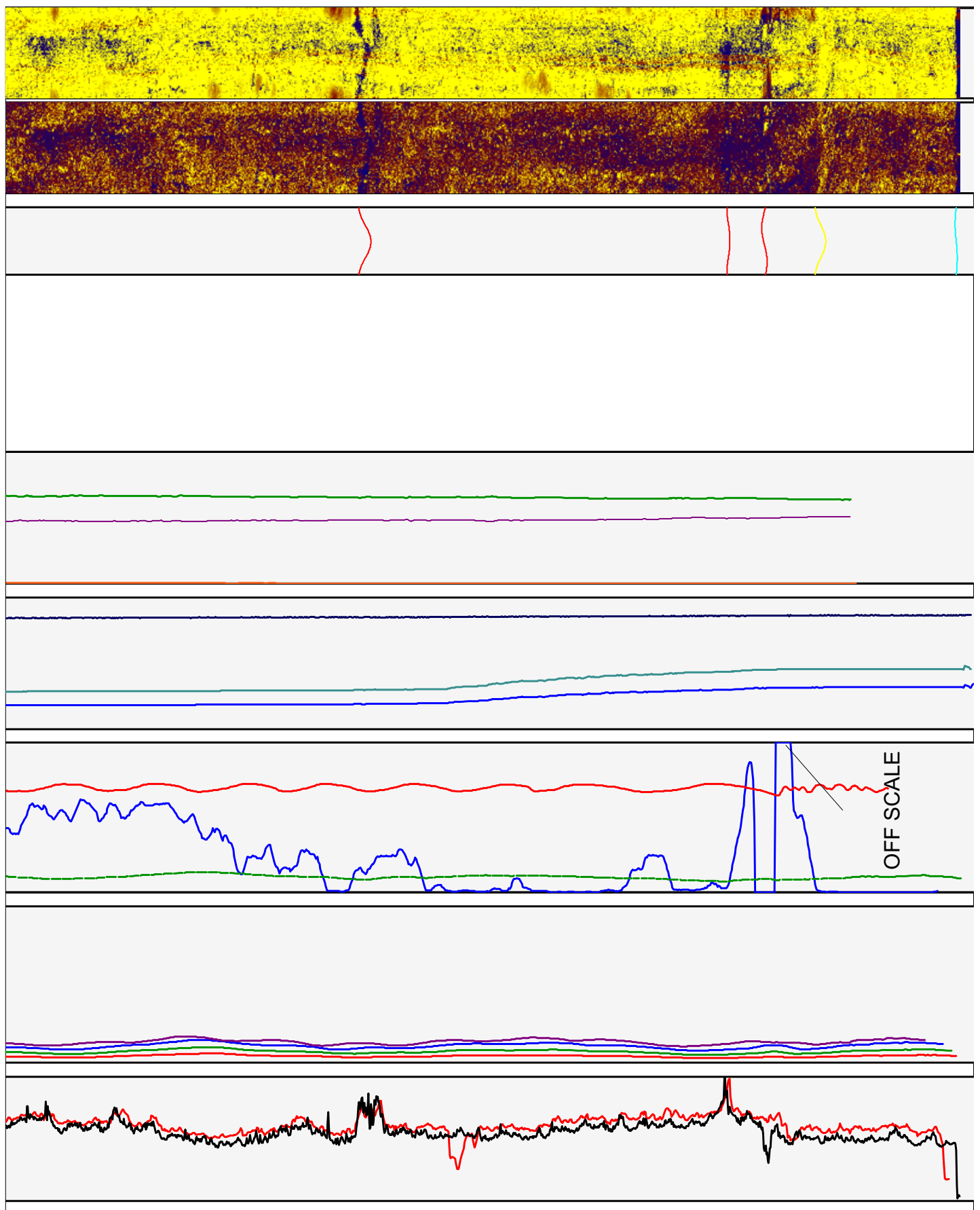

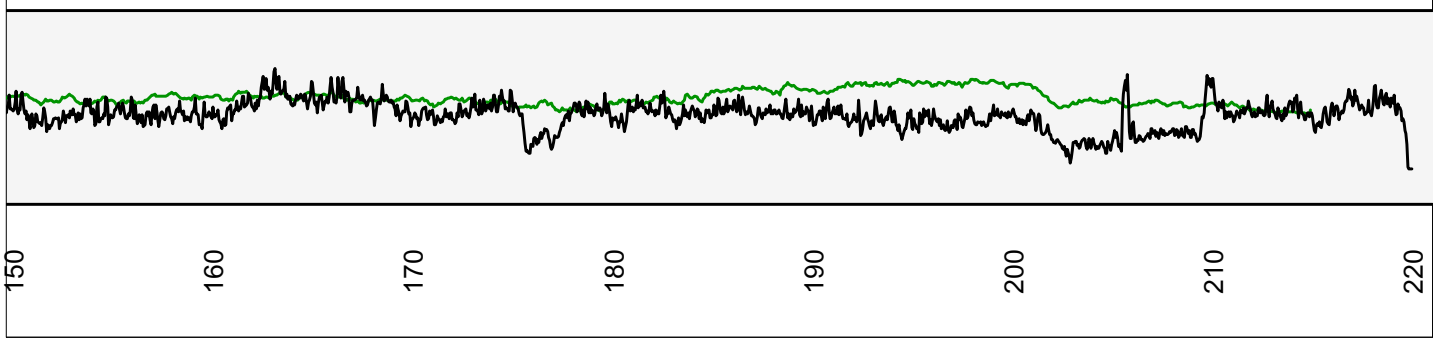

Figure 2B-1. Caliper, acoustic caliper, gamma, electromagnetic conductivity, fluid temperature, specific conductance, $\mathrm{DO}, \mathrm{pH}$, reduction oxidation, multi-space resistivity, oriented acoustic and optical borehole images, and heat-pulse flowmeter logs for borehole WY-3B, near Machiasport, Maine.-Continued 

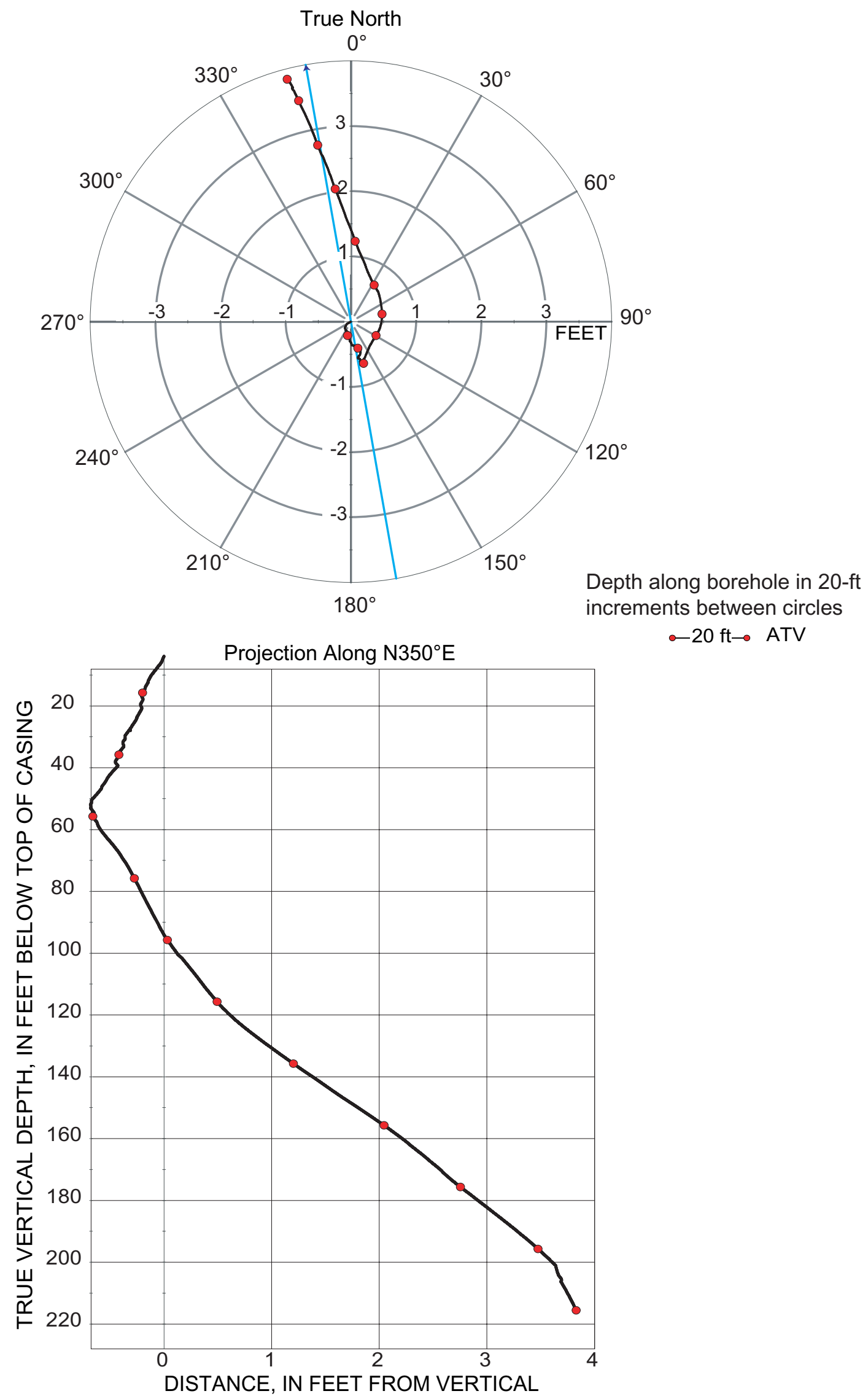

$\bullet 20 \mathrm{ft} \rightarrow$ ATV 
Table 2B-1. Interpretation of acoustic televiewer logs for borehole WY-3B, near Machiasport, Maine.

[Televiewer data are corrected for deviation and magnetic declination, so orientations are relative to true north; depths are below top of casing, which is 1.87 feet above land surface; dip azimuth is given in degrees east of true north; strike is reported in right-hand-rule (RHR)-azimuthal degrees east of true north and where the direction of dip is 90 degrees to the right of strike]

\begin{tabular}{|c|c|c|c|c|c|c|c|}
\hline $\begin{array}{l}\text { Depth, } \\
\text { in feet }\end{array}$ & $\begin{array}{l}\text { Depth, } \\
\text { in meters }\end{array}$ & $\begin{array}{c}\text { Dip } \\
\text { azimuth }\end{array}$ & $\begin{array}{l}\text { Strike, } \\
\text { in RHR }\end{array}$ & Dip & $\begin{array}{l}\text { Dip } \\
\text { direction }\end{array}$ & Dip descriptor & Comment \\
\hline 34.13 & 10.40 & 240 & 150 & 5 & SW & Nearly horizontal & Minor fracture \\
\hline 69.01 & 21.03 & 67 & 337 & 61 & NE & Steep & $\begin{array}{l}\text { Transmissive fracture, } \\
\text { inferred from fluid logs }\end{array}$ \\
\hline 78.20 & 23.83 & 351 & 261 & 60 & $\mathrm{~N}$ & Steep & minor fracture \\
\hline 94.47 & 28.79 & 351 & 261 & 62 & $\mathrm{~N}$ & Steep & $\begin{array}{l}\text { Transmissive fracture, } \\
\text { inferred from fluid logs }\end{array}$ \\
\hline 94.58 & 28.83 & 146 & 56 & 27 & SE & Shallow & $\begin{array}{l}\text { Transmissive fracture, } \\
\text { inferred from fluid logs }\end{array}$ \\
\hline 95.46 & 29.09 & 220 & 130 & 37 & SW & Moderate & $\begin{array}{l}\text { Transmissive fracture, } \\
\text { inferred from fluid logs }\end{array}$ \\
\hline 104.39 & 31.82 & 337 & 247 & 74 & NW & Nearly vertical & Minor fracture \\
\hline 107.85 & 32.87 & 316 & 226 & 24 & NW & Shallow & Minor fracture \\
\hline 112.36 & 34.25 & 171 & 81 & 55 & S & Steep & $\begin{array}{l}\text { Transmissive fracture, } \\
\text { inferred from fluid logs }\end{array}$ \\
\hline 130.18 & 39.68 & 326 & 236 & 83 & NW & Nearly vertical & Minor fracture \\
\hline 176.06 & 53.66 & 176 & 86 & 52 & S & Steep & $\begin{array}{l}\text { Transmissive fracture, } \\
\text { inferred from fluid logs }\end{array}$ \\
\hline 202.86 & 61.83 & 182 & 92 & 20 & S & Shallow & $\begin{array}{l}\text { Transmissive fracture, } \\
\text { inferred from fluid logs }\end{array}$ \\
\hline 205.51 & 62.64 & 69 & 339 & 31 & $E$ & Moderate & Fracture \\
\hline 209.67 & 63.90 & 178 & 88 & 49 & S & Moderate & Lithologic feature \\
\hline 219.62 & 66.94 & 90 & 360 & 13 & $E$ & Shallow & Minor fracture \\
\hline
\end{tabular}




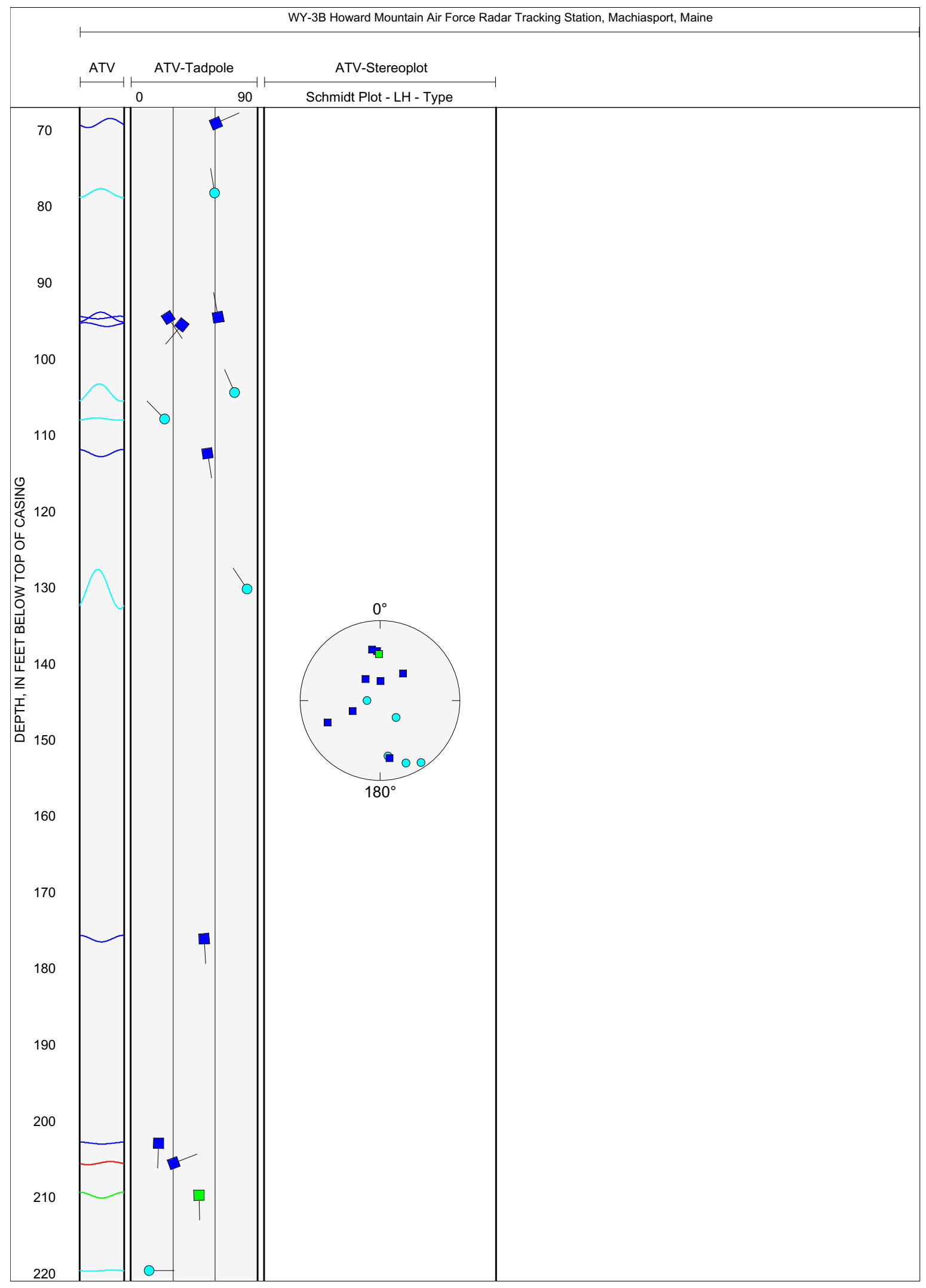

Figure 2B-3. Projection, tadpole, and stereoplots of interpretation of borehole image data for borehole WY-3B, near Machiasport, Maine. 


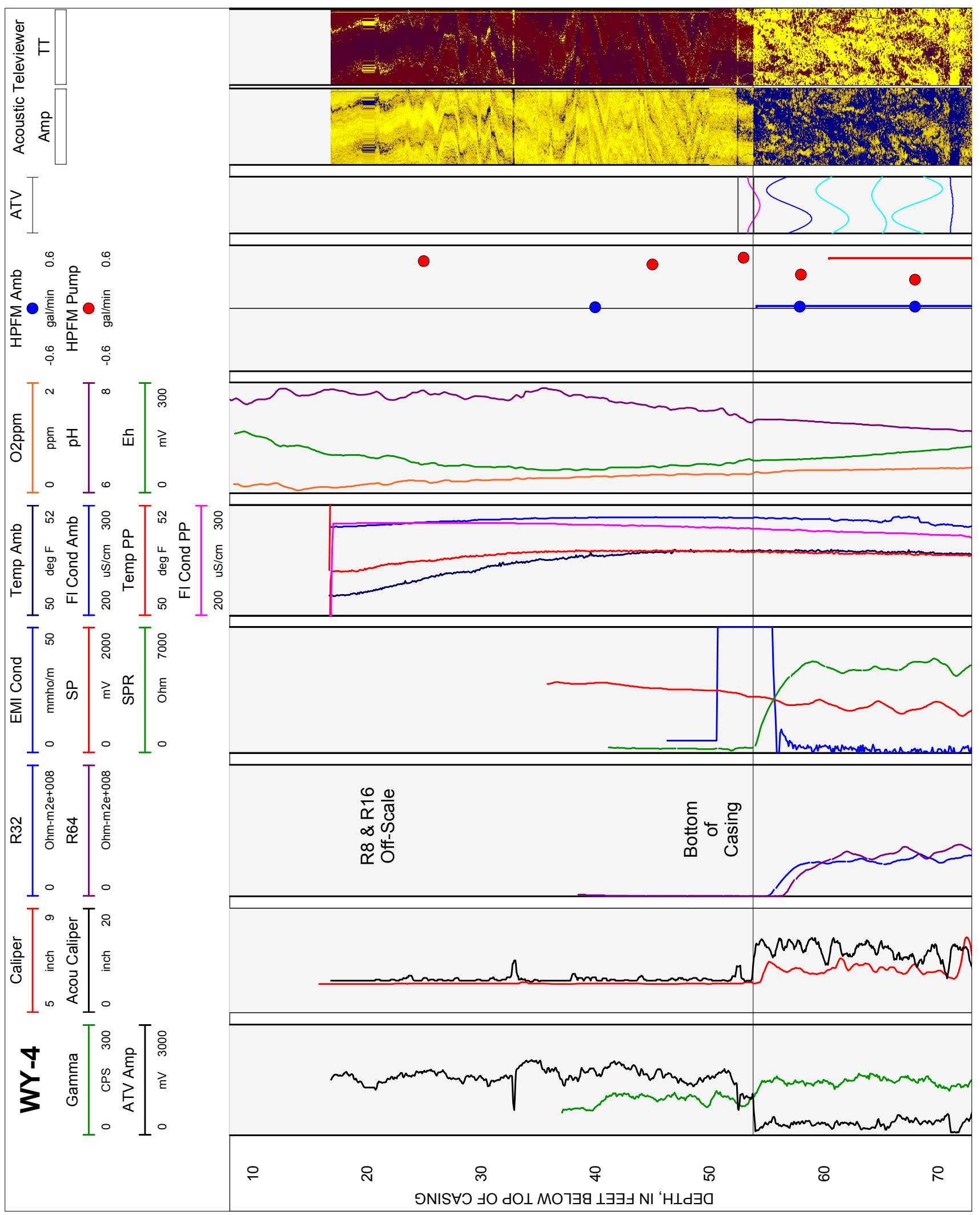

Figure 2C-1. Caliper, acoustic caliper, gamma, electromagnetic conductivity, fluid temperature, specific conductance, $\mathrm{DO}, \mathrm{pH}$, reduction oxidation, multi-space resistivity, oriented acoustic and optical borehole images, and heat-pulse flowmeter logs for borehole WY-4, near Machiasport, Maine. 


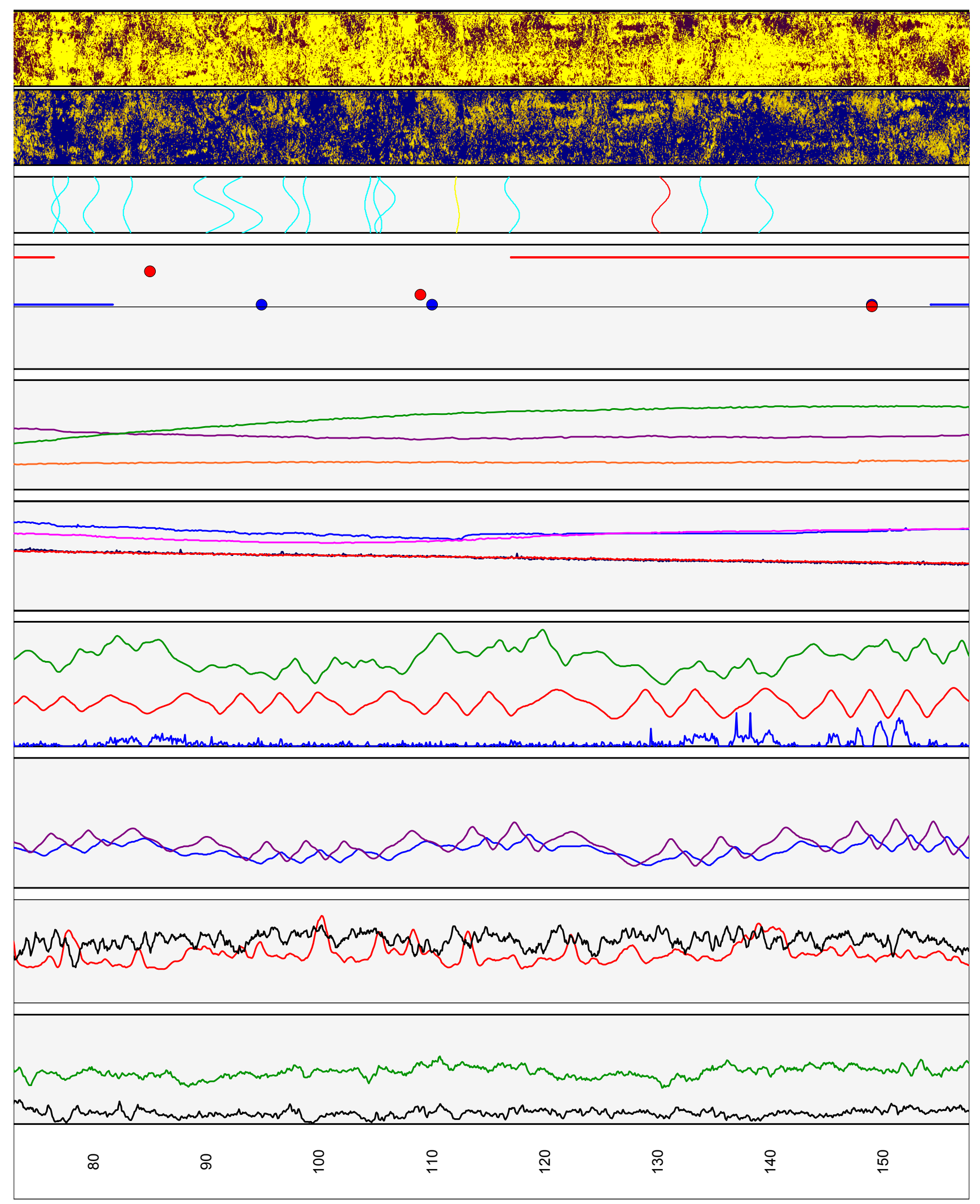

Figure 2C-1. Caliper, acoustic caliper, gamma, electromagnetic conductivity, fluid temperature, specific conductance, $\mathrm{DO}, \mathrm{pH}$, reduction oxidation, multi-space resistivity, oriented acoustic and optical borehole images, and heat-pulse flowmeter logs for borehole WY-4, near Machiasport, Maine.-Continued 


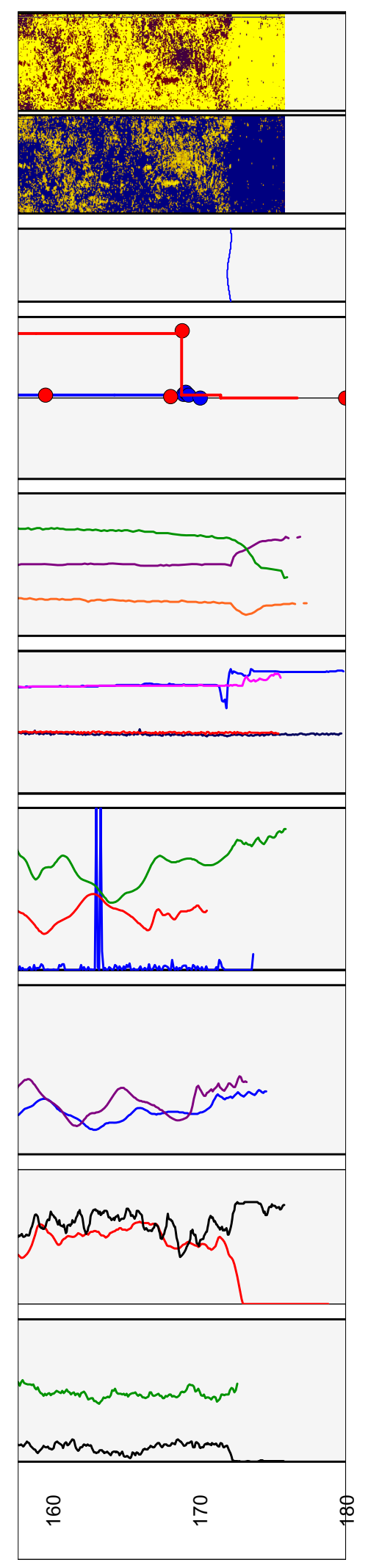

Figure 2C-1. Caliper, acoustic caliper, gamma, electromagnetic conductivity, fluid temperature, specific conductance, $\mathrm{DO}, \mathrm{pH}$, reduction oxidation, multi-space resistivity, oriented acoustic and optical borehole images, and heat-pulse flowmeter logs for borehole WY-4, near Machiasport, Maine.-Continued 


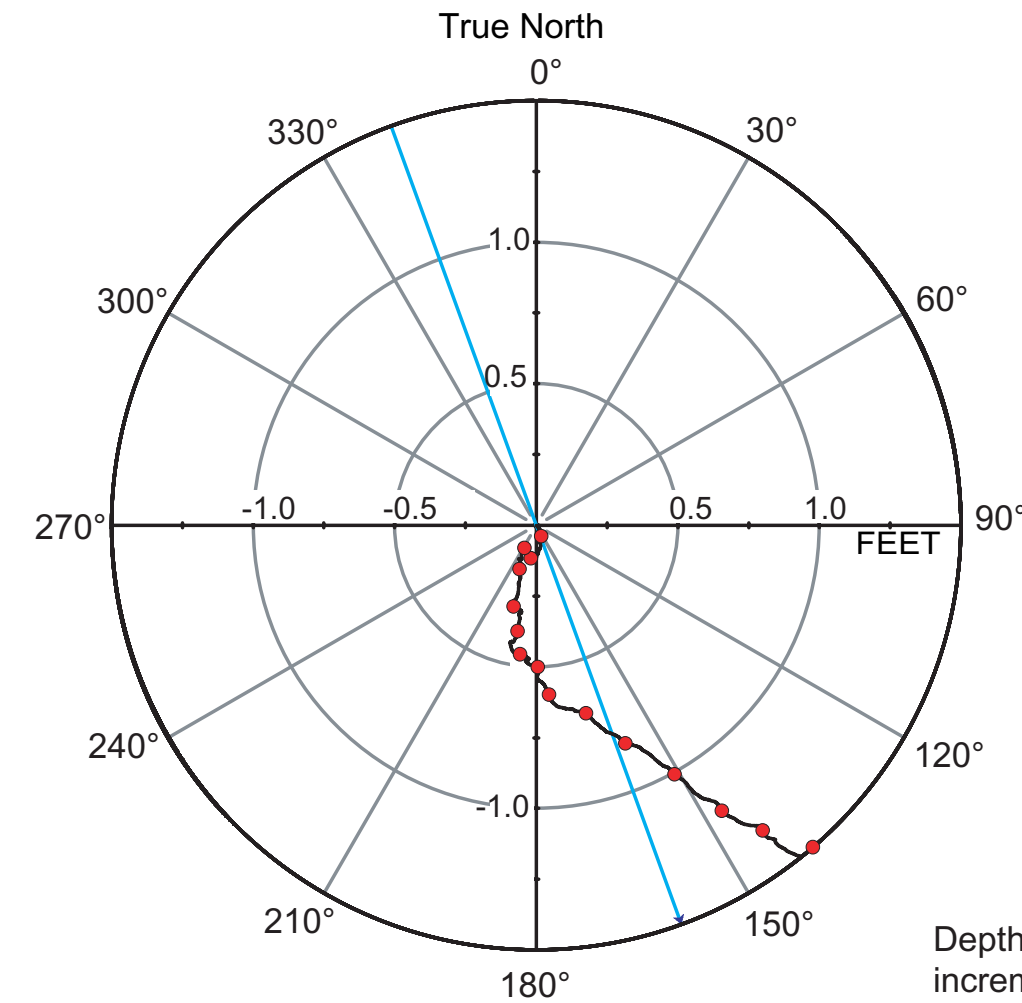

Depth along borehole in $10-\mathrm{ft}$ increments between circles

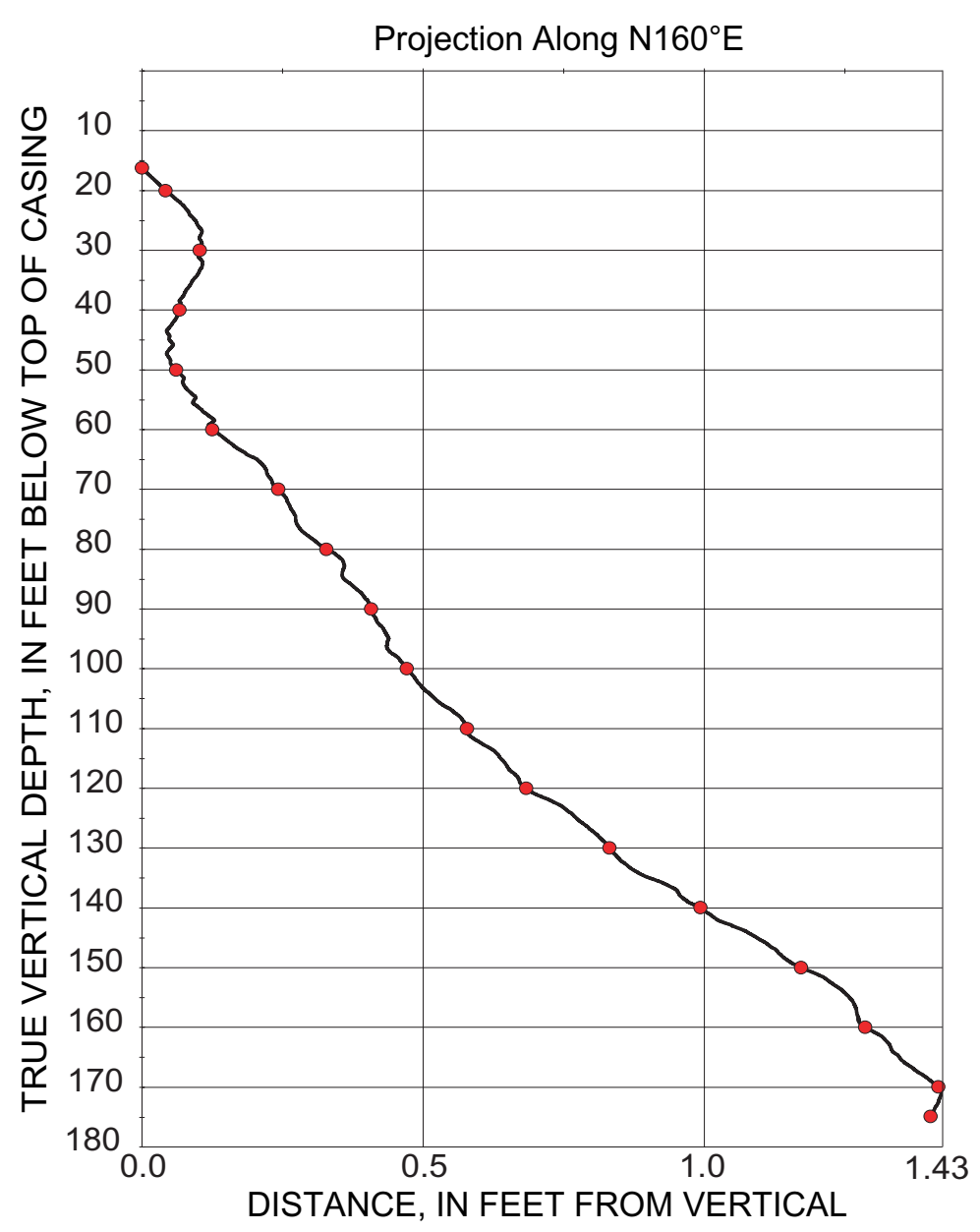

$\bullet-10 \mathrm{ft} \rightarrow$ ATV

Figure 2C-2. Borehole deviation logs for borehole WY-4, near Machiasport, Maine. Blue line on radial plot (top) is line of projection for vertical plot (bottom).

[ft, foot; ATV, acoustic televiewer] 
Table 2C-1. Interpretation of acoustic televiewer logs for borehole WY-4, near Machiasport, Maine.

[Televiewer data are corrected for deviation and magnetic declination, so orientations are relative to true north; depths are below top of casing, which is 0.7 feet above land surface; dip azimuth is given in degrees east of true north; strike is reported in right-hand-rule (RHR)-azimuthal degrees east of true north and where the direction of dip is 90 degrees to the right of strike]

\begin{tabular}{rrrrrrll}
\hline $\begin{array}{c}\text { Depth, } \\
\text { in feet }\end{array}$ & $\begin{array}{c}\text { Depth, } \\
\text { in meters }\end{array}$ & $\begin{array}{c}\text { Dip } \\
\text { azimuth }\end{array}$ & $\begin{array}{c}\text { Strike, } \\
\text { in RHR }\end{array}$ & Dip & $\begin{array}{c}\text { Dip } \\
\text { direction }\end{array}$ & Dip descriptor & Comment \\
\hline 52.49 & 16.00 & 207 & 117 & 1 & SW & Nearly horizontal & Joint in casing \\
53.87 & 16.42 & 178 & 88 & 64 & S & Steep & Fracture intersecting base of \\
& & & & & & & casing - possibly transmissive \\
53.88 & 16.42 & 355 & 265 & 2 & N & Nearly horizontal & Bottom of casing \\
56.95 & 17.36 & 94 & 4 & 83 & E & Nearly vertical & Transmissive fracture \\
60.74 & 18.51 & 92 & 2 & 80 & E & Nearly vertical & Minor fracture \\
64.84 & 19.76 & 63 & 333 & 68 & NE & Steep & Minor fracture \\
68.20 & 20.79 & 284 & 194 & 83 & W & Nearly vertical & Minor fracture \\
71.17 & 21.69 & 176 & 86 & 26 & S & Shallow & Lithologic feature \\
76.71 & 23.38 & 149 & 59 & 50 & SE & Moderate & Minor fracture \\
77.04 & 23.48 & 338 & 248 & 71 & N & Nearly vertical & Minor fracture \\
79.80 & 24.32 & 293 & 203 & 70 & NW & Steep & Minor fracture \\
83.07 & 25.32 & 312 & 222 & 57 & NW & Steep & Minor fracture \\
90.69 & 27.64 & 113 & 23 & 82 & SE & Nearly vertical & Minor fracture \\
93.23 & 28.42 & 91 & 1 & 82 & E & Nearly vertical & Minor fracture \\
97.54 & 29.73 & 141 & 51 & 70 & SE & Nearly vertical & Minor fracture \\
98.89 & 30.14 & 96 & 6 & 50 & E & Moderate & Minor fracture \\
104.32 & 31.80 & 360 & 270 & 45 & N & Moderate & Minor fracture \\
105.18 & 32.06 & 54 & 324 & 55 & NE & Steep & Minor fracture \\
105.84 & 32.26 & 222 & 132 & 74 & SW & Nearly vertical & Minor fracture \\
112.23 & 34.21 & 112 & 22 & 35 & E & Moderate & Possible transmissive fracture \\
117.12 & 35.70 & 113 & 23 & 69 & SE & Steep & Minor fracture \\
130.28 & 39.71 & 263 & 173 & 72 & W & Nearly vertical & Large fracture \\
134.08 & 40.87 & 135 & 45 & 53 & SE & Steep & Minor fracture \\
139.43 & 42.50 & 130 & 40 & 72 & SE & Nearly vertical & Minor fracture \\
171.98 & 52.42 & 316 & 226 & 28 & NW & Shallow & Transmissive fracture \\
\hline
\end{tabular}




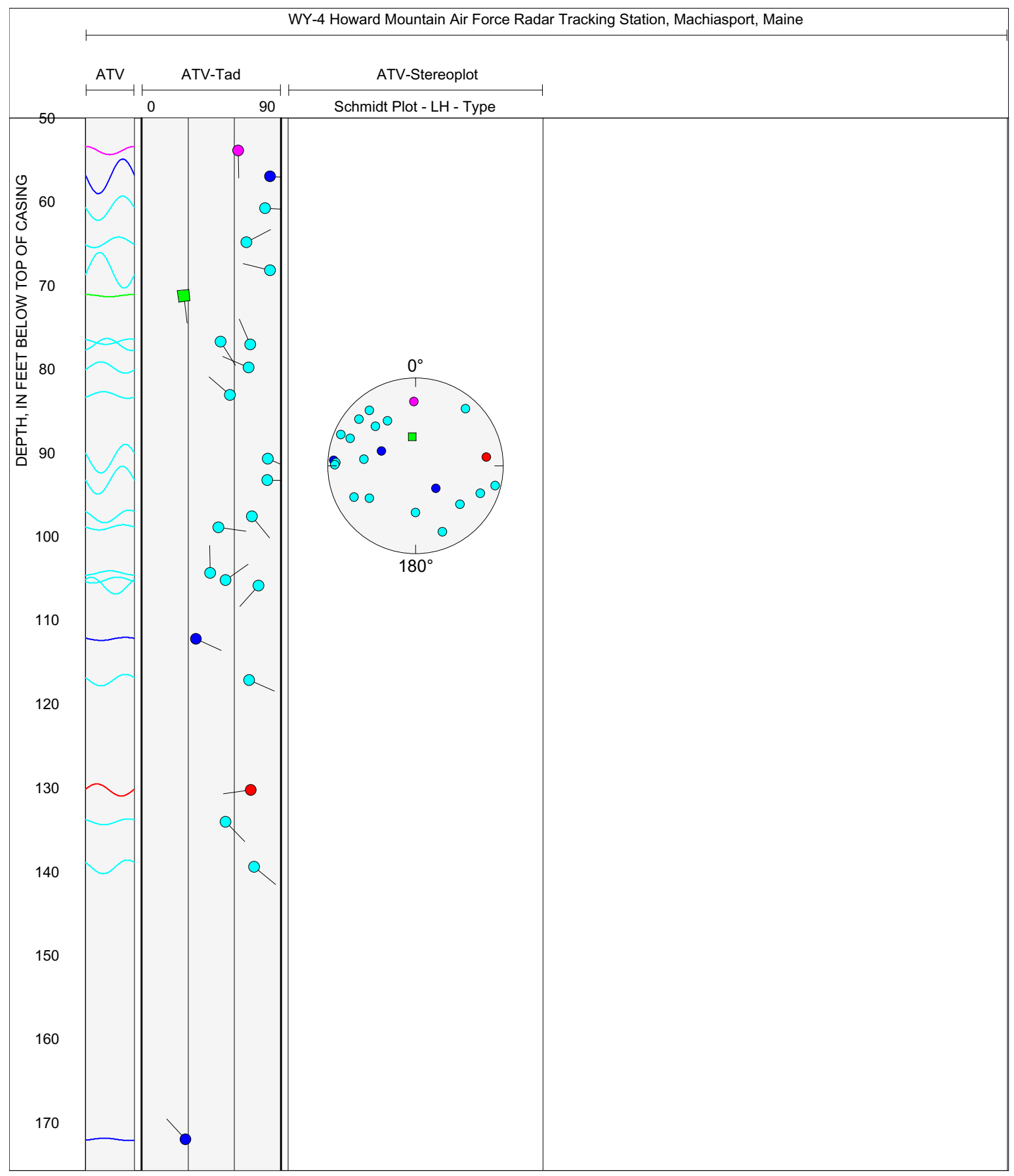

Figure 2C-3. Projection, tadpole, and stereoplots of interpretation of borehole image data for borehole WY-4, near Machiasport, Maine. 

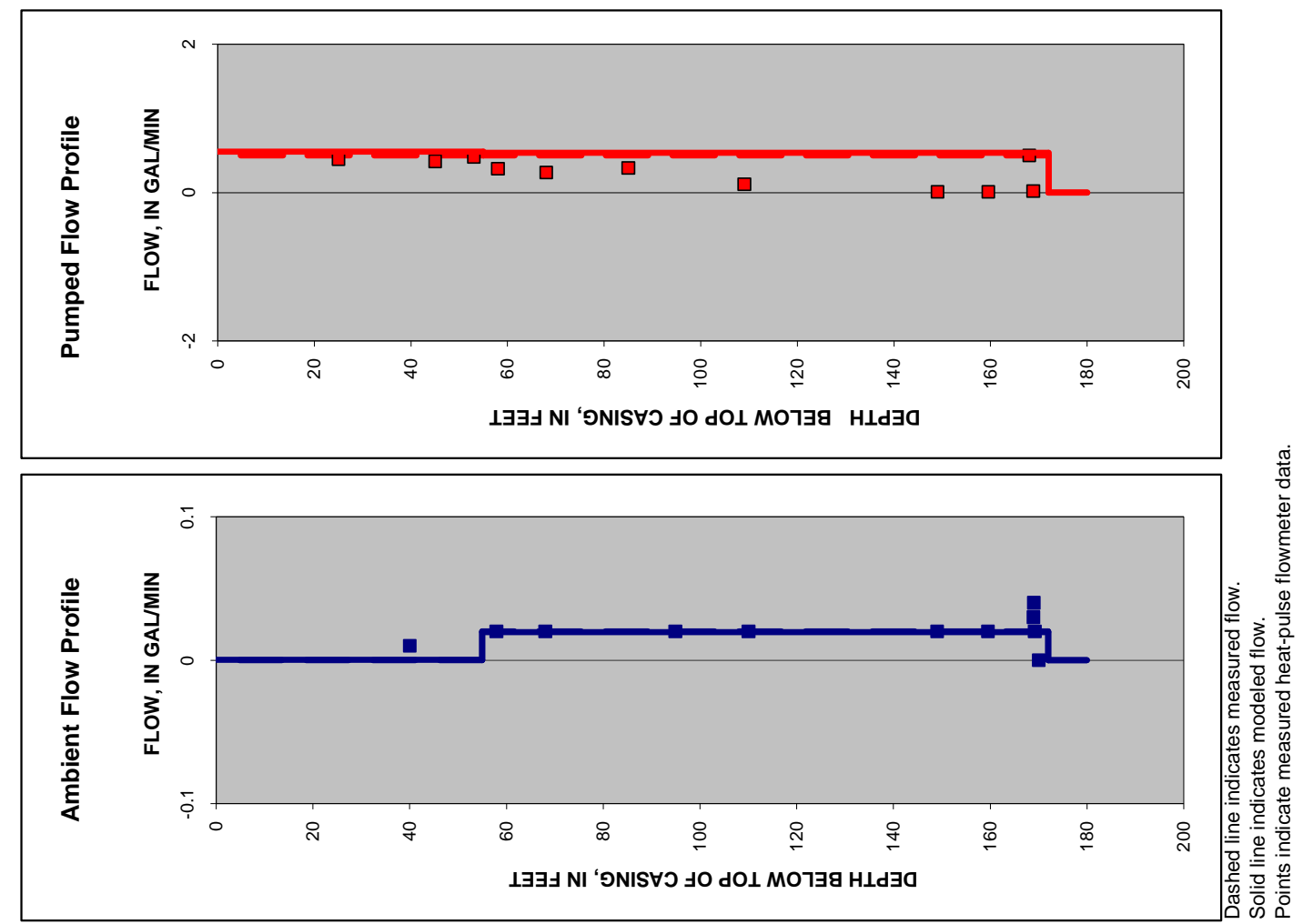

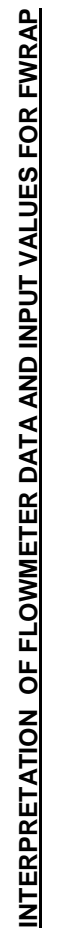

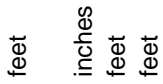

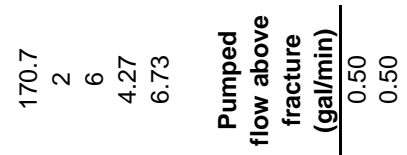

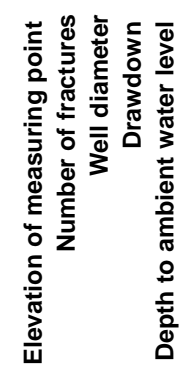

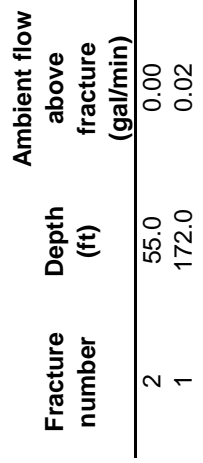

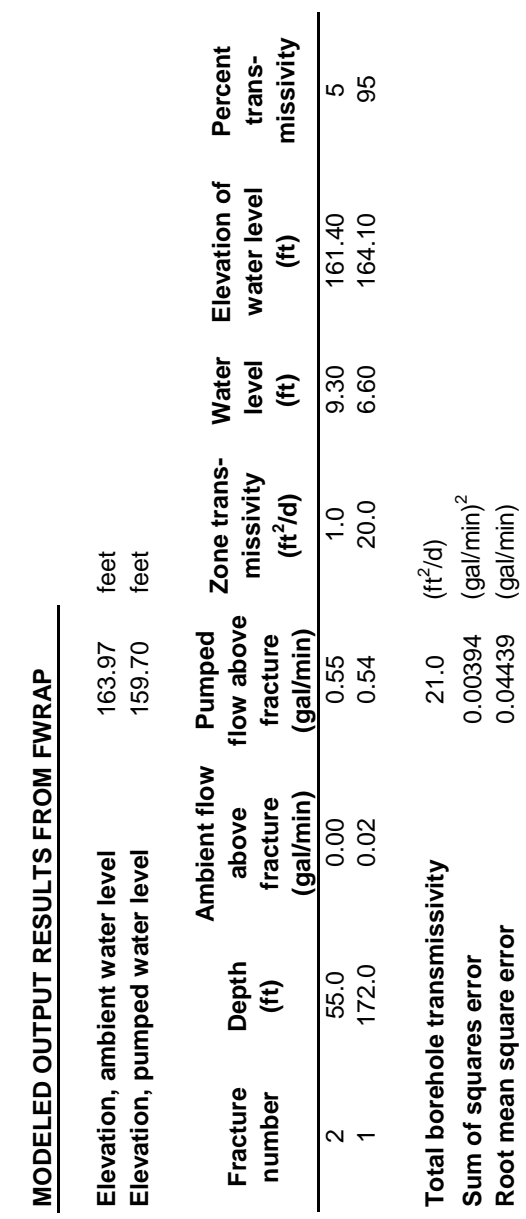

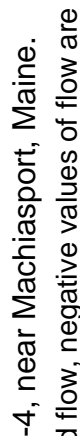

3

응

응

흐

응 을

$\bar{\omega}$

$\pm$

은

(1) 充

울

党

일

음

跣

등

운

중

흔

㐫

ปั

N

은 은 


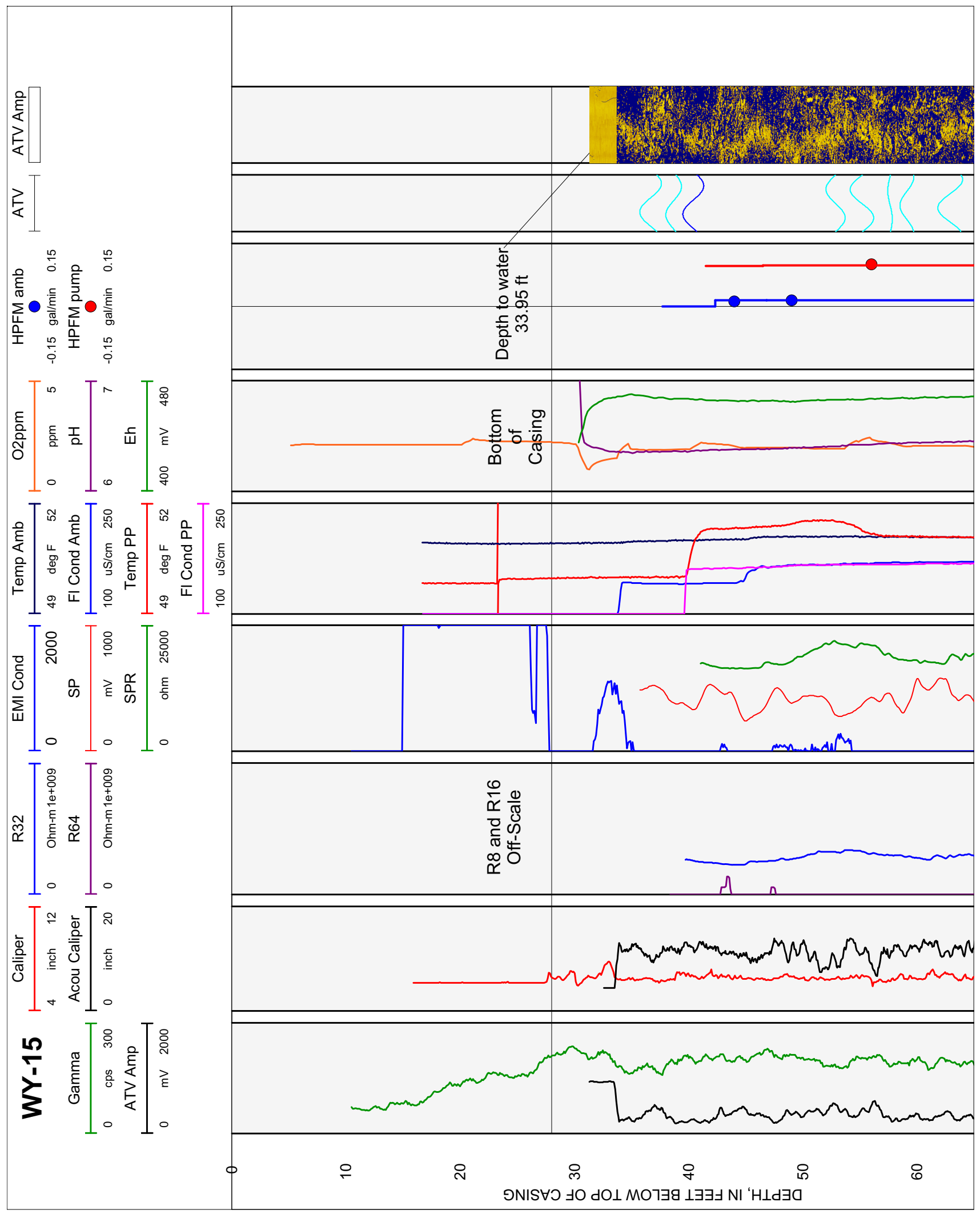

Figure 2D-1. Caliper, acoustic caliper, gamma, electromagnetic conductivity, fluid temperature, specific conductance, $\mathrm{DO}, \mathrm{pH}$, reduction oxidation, multi-space resistivity, oriented acoustic and optical borehole images, and heat-pulse flowmeter logs for borehole WY-15, near Machiasport, Maine. 


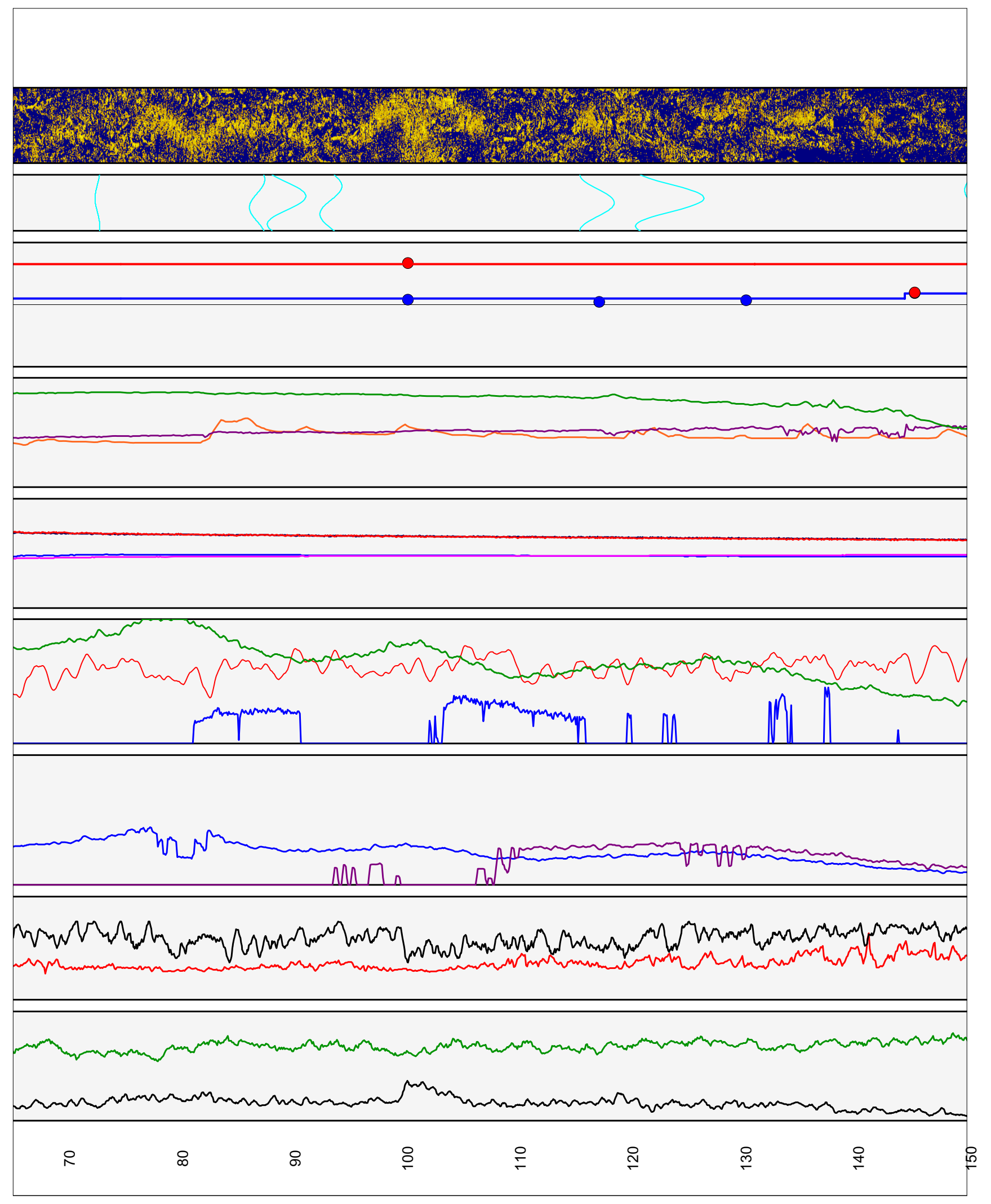

Figure 2D-1. Caliper, acoustic caliper, gamma, electromagnetic conductivity, fluid temperature, specific conductance, $\mathrm{DO}, \mathrm{pH}$, reduction oxidation, multi-space resistivity, oriented acoustic and optical borehole images, and heat-pulse flowmeter logs for borehole WY-15, near Machiasport, Maine.-Continued 


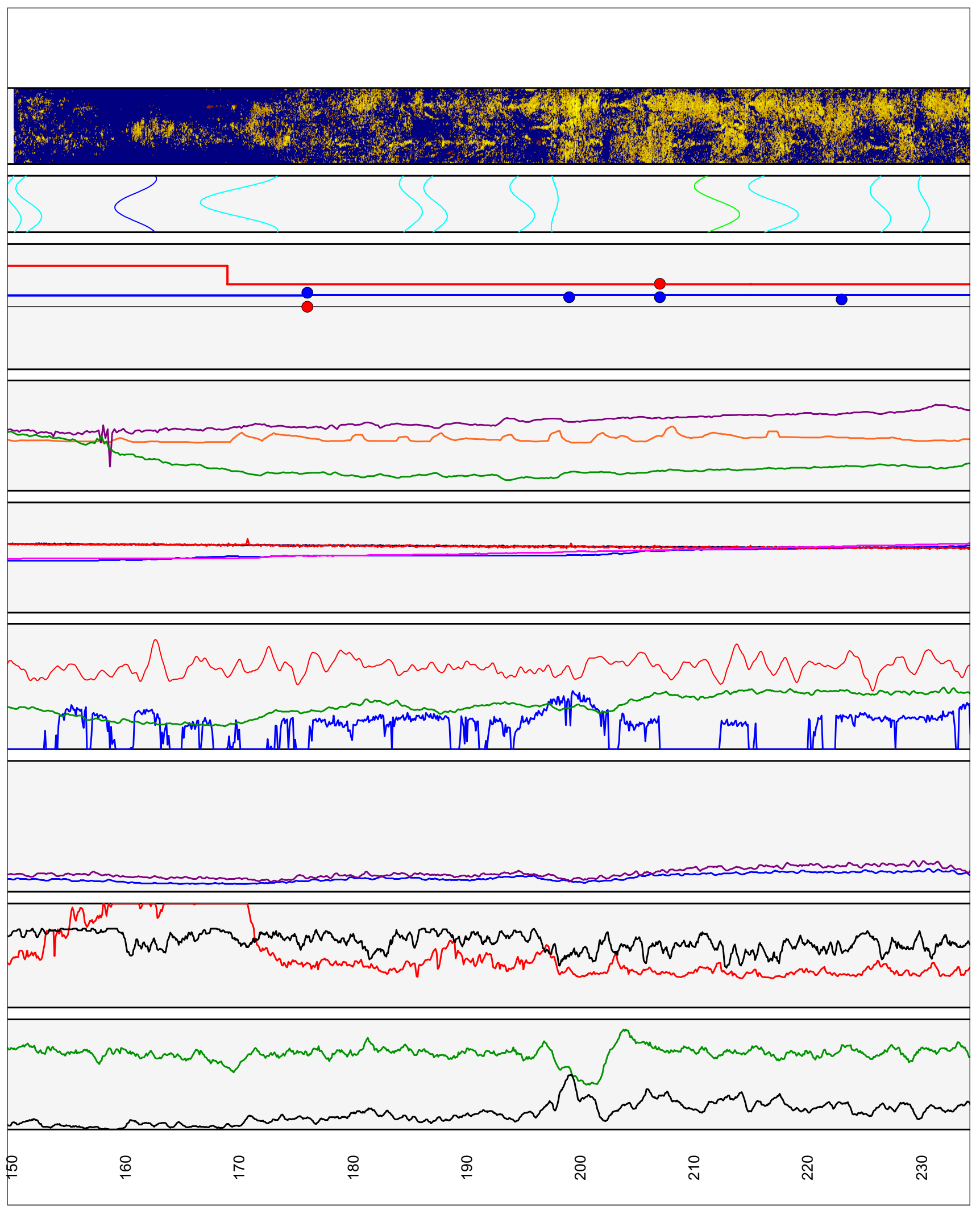

Figure 2D-1. Caliper, acoustic caliper, gamma, electromagnetic conductivity, fluid temperature, specific conductance, $\mathrm{DO}, \mathrm{pH}$, reduction oxidation, multi-space resistivity, oriented acoustic and optical borehole images, and heat-pulse flowmeter logs for borehole WY-15, near Machiasport, Maine.-Continued 


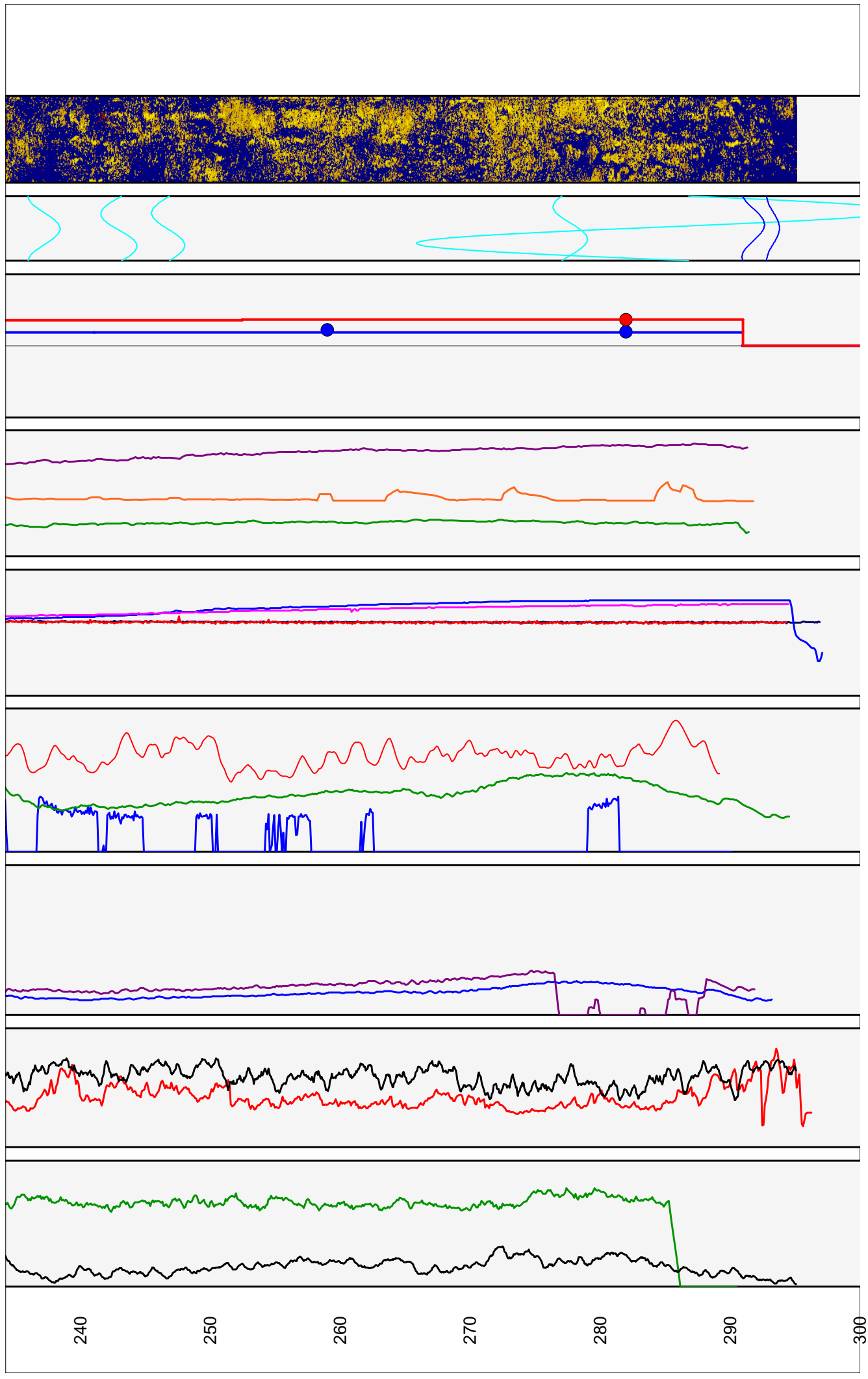

Figure 2D-1. Caliper, acoustic caliper, gamma, electromagnetic conductivity, fluid temperature, specific conductance, $\mathrm{DO}, \mathrm{pH}$, reduction oxidation, multi-space resistivity, oriented acoustic and optical borehole images, and heat-pulse flowmeter logs for borehole WY-15, near Machiasport, Maine.-Continued 


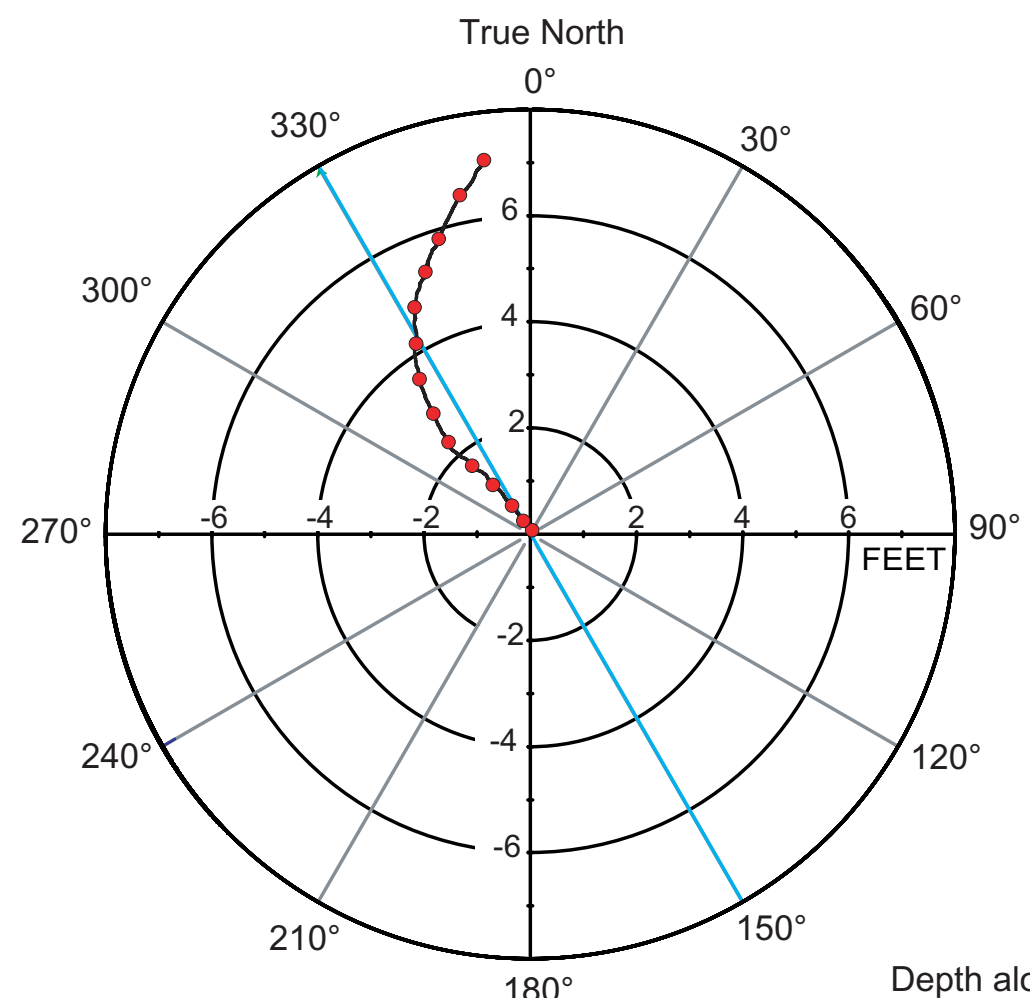

$90^{\circ}$

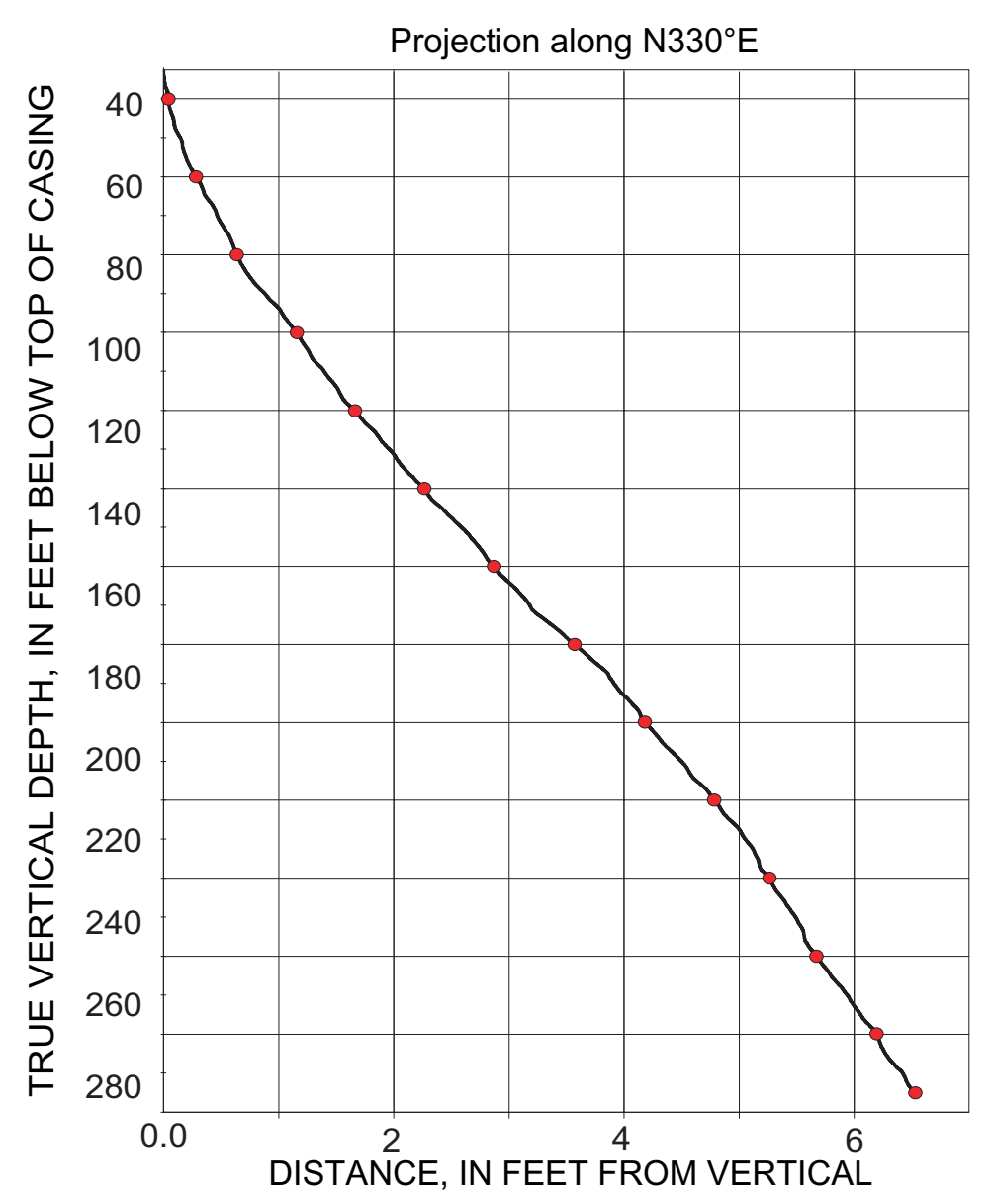

Figure 2D-2. Borehole deviation logs for borehole WY-15, near Machiasport, Maine. Blue line on radial plot (top) is line of projection for vertical plot (bottom).

[ft, foot; ATV, acoustic televiewer] 
Table 2D-1. Interpretation of acoustic televiewer logs for borehole WY-15, near Machiasport, Maine.

[Televiewer data are corrected for deviation and magnetic declination, so orientations are relative to true north; depths are below top of casing, which is 4.4 feet above land surface; dip azimuth is given in degrees east of true north; strike is reported in right-hand-rule (RHR)-azimuthal degrees east of true north and where the direction of dip is 90 degrees to the right of strike]

\begin{tabular}{|c|c|c|c|c|c|c|c|}
\hline $\begin{array}{l}\text { Depth, } \\
\text { in feet }\end{array}$ & $\begin{array}{l}\text { Depth, } \\
\text { in meters }\end{array}$ & $\begin{array}{c}\text { Dip } \\
\text { azimuth }\end{array}$ & $\begin{array}{l}\text { Strike, } \\
\text { in RHR }\end{array}$ & Dip & $\begin{array}{c}\text { Dip } \\
\text { direction }\end{array}$ & Dip descriptor & Comment \\
\hline 33.69 & 10.27 & 314.38 & 224 & 0.85 & NW & Nearly horizontal & Water level \\
\hline 36.67 & 11.18 & 298.22 & 208 & 75.06 & NW & Nearly vertical & Minor fracture \\
\hline 38.70 & 11.80 & 280.17 & 190 & 69.67 & W & Steep & Minor fracture \\
\hline 40.41 & 12.32 & 284.29 & 194 & 74.57 & W & Nearly vertical & Transmissive fracture \\
\hline 43.95 & 13.40 & 339.42 & 249 & 60.52 & $\mathrm{~N}$ & Steep & Possible fracture \\
\hline 52.84 & 16.10 & 82.63 & 353 & 73.11 & $E$ & Nearly vertical & Minor fracture \\
\hline 55.15 & 16.81 & 81.31 & 351 & 76.12 & $\mathrm{E}$ & Nearly vertical & Minor fracture \\
\hline 57.38 & 17.49 & 282.21 & 192 & 62.18 & W & Steep & Minor fracture \\
\hline 57.63 & 17.56 & 73.21 & 343 & 37.78 & $\mathrm{E}$ & Moderate & Minor fracture \\
\hline 59.10 & 18.01 & 340.01 & 250 & 67.30 & $\mathrm{~N}$ & Steep & Minor fracture \\
\hline 61.16 & 18.64 & 329.21 & 239 & 60.56 & NW & Steep & Minor fracture \\
\hline 62.90 & 19.17 & 324.45 & 234 & 76.75 & NW & Nearly vertical & Minor fracture \\
\hline 72.46 & 22.08 & 22.20 & 292 & 39.07 & $\mathrm{~N}$ & Moderate & Minor fracture \\
\hline 81.17 & 24.74 & 306.44 & 216 & 79.64 & NW & Nearly vertical & Minor fracture \\
\hline 86.59 & 26.39 & 324.36 & 234 & 69.54 & NW & Steep & Minor fracture \\
\hline 89.20 & 27.19 & 216.24 & 126 & 81.71 & SW & Nearly vertical & Minor fracture \\
\hline 93.16 & 28.39 & 280.83 & 191 & 75.55 & w & Nearly vertical & Minor fracture \\
\hline 116.77 & 35.59 & 174.26 & 84 & 80.66 & $\mathrm{~S}$ & Nearly vertical & Minor fracture \\
\hline 119.45 & 36.41 & 355.05 & 265 & 76.80 & $\mathrm{~N}$ & Nearly vertical & Minor fracture \\
\hline 123.23 & 37.56 & 203.87 & 114 & 85.32 & sw & Nearly vertical & Minor fracture \\
\hline 130.32 & 39.72 & 92.50 & 3 & 88.69 & $E$ & Nearly vertical & Minor fracture \\
\hline 150.08 & 45.74 & 75.33 & 345 & 69.51 & $E$ & Steep & Minor fracture \\
\hline 151.48 & 46.17 & 94.12 & 4 & 77.16 & $E$ & Nearly vertical & Minor fracture \\
\hline 154.45 & 47.07 & 192.59 & 103 & 1.93 & $\mathrm{~s}$ & Nearly horizontal & Partial fracture \\
\hline 160.88 & 49.03 & 333.47 & 243 & 82.08 & NW & Nearly vertical & Minor fracture \\
\hline 169.97 & 51.80 & 4.14 & 274 & 85.70 & $\mathrm{~N}$ & Nearly vertical & Minor fracture \\
\hline 185.07 & 56.41 & 123.76 & 34 & 75.73 & SE & Nearly vertical & Minor fracture \\
\hline 187.26 & 57.07 & 96.51 & 7 & 75.95 & $E$ & Nearly vertical & Minor fracture \\
\hline 194.89 & 59.40 & 101.01 & 11 & 76.94 & $\mathrm{E}$ & Nearly vertical & Minor fracture \\
\hline 197.74 & 60.27 & 207.89 & 118 & 48.95 & sw & Moderate & Minor fracture \\
\hline 202.30 & 61.66 & 221.73 & 132 & 39.11 & SW & Moderate & Minor fracture \\
\hline 212.22 & 64.68 & 109.62 & 20 & 84.47 & $\mathrm{E}$ & Nearly vertical & Minor fracture \\
\hline 216.98 & 66.13 & 105.39 & 15 & 83.12 & $E$ & Nearly vertical & Minor fracture \\
\hline 226.35 & 68.99 & 79.65 & 350 & 73.62 & $\mathrm{E}$ & Nearly vertical & Minor fracture \\
\hline 230.21 & 70.16 & 114.35 & 24 & 62.98 & SE & Steep & Minor fracture \\
\hline 237.18 & 72.29 & 172.16 & 82 & 78.25 & $\mathrm{~S}$ & Nearly vertical & Minor fracture \\
\hline 242.94 & 74.04 & 74.73 & 345 & 79.47 & $\mathrm{E}$ & Nearly vertical & Minor fracture \\
\hline 246.77 & 75.21 & 79.25 & 349 & 79.33 & $E$ & Nearly vertical & Minor fracture \\
\hline 277.72 & 84.64 & 113.89 & 24 & 78.66 & SE & Nearly vertical & Minor fracture \\
\hline 284.54 & 86.72 & 270.94 & 181 & 89.43 & W & Nearly vertical & Minor fracture \\
\hline 291.77 & 88.93 & 194.30 & 104 & 73.43 & $\mathrm{~S}$ & Nearly vertical & Transmissive fracture \\
\hline 293.32 & 89.40 & 175.75 & 86 & 62.03 & S & Steep & Transmissive fracture \\
\hline
\end{tabular}




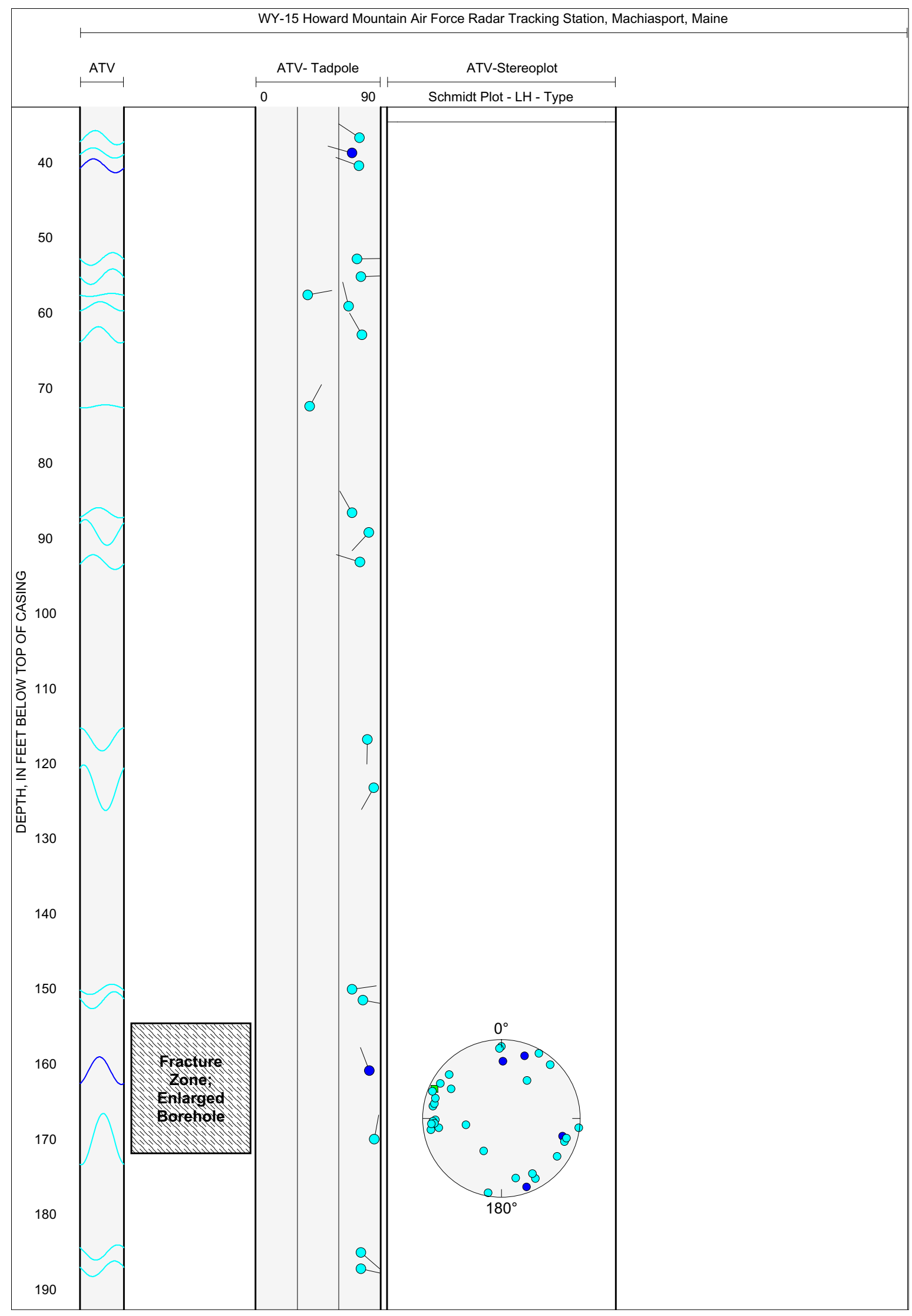

Figure 2D-3. Projection, tadpole, and stereoplots of interpretation of borehole image data for borehole WY-15, near Machiasport, Maine. 


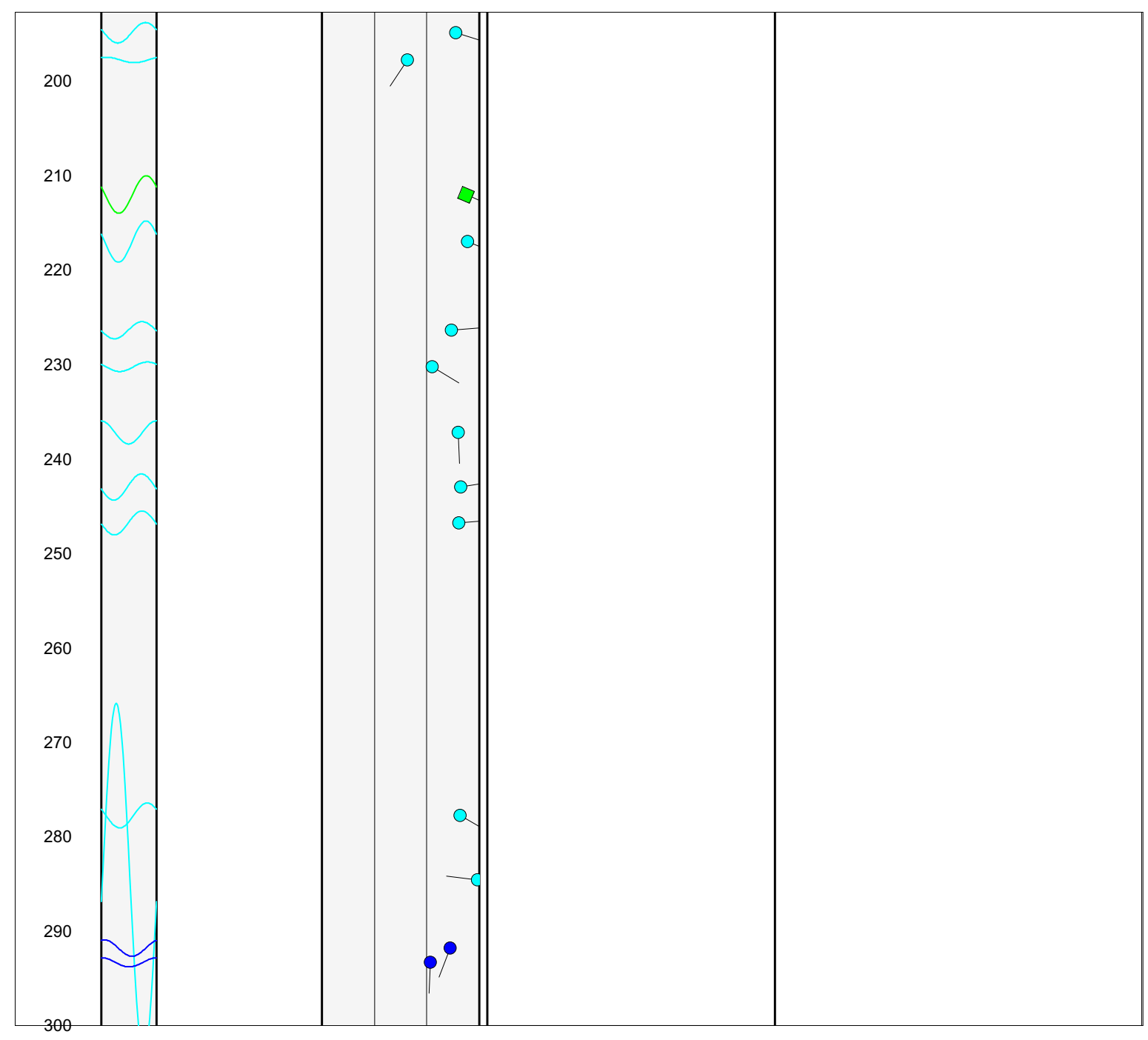

Figure 2D-3. Projection, tadpole, and stereoplots of interpretation of borehole image data for borehole WY-15, near Machiasport, Maine.-Continued 

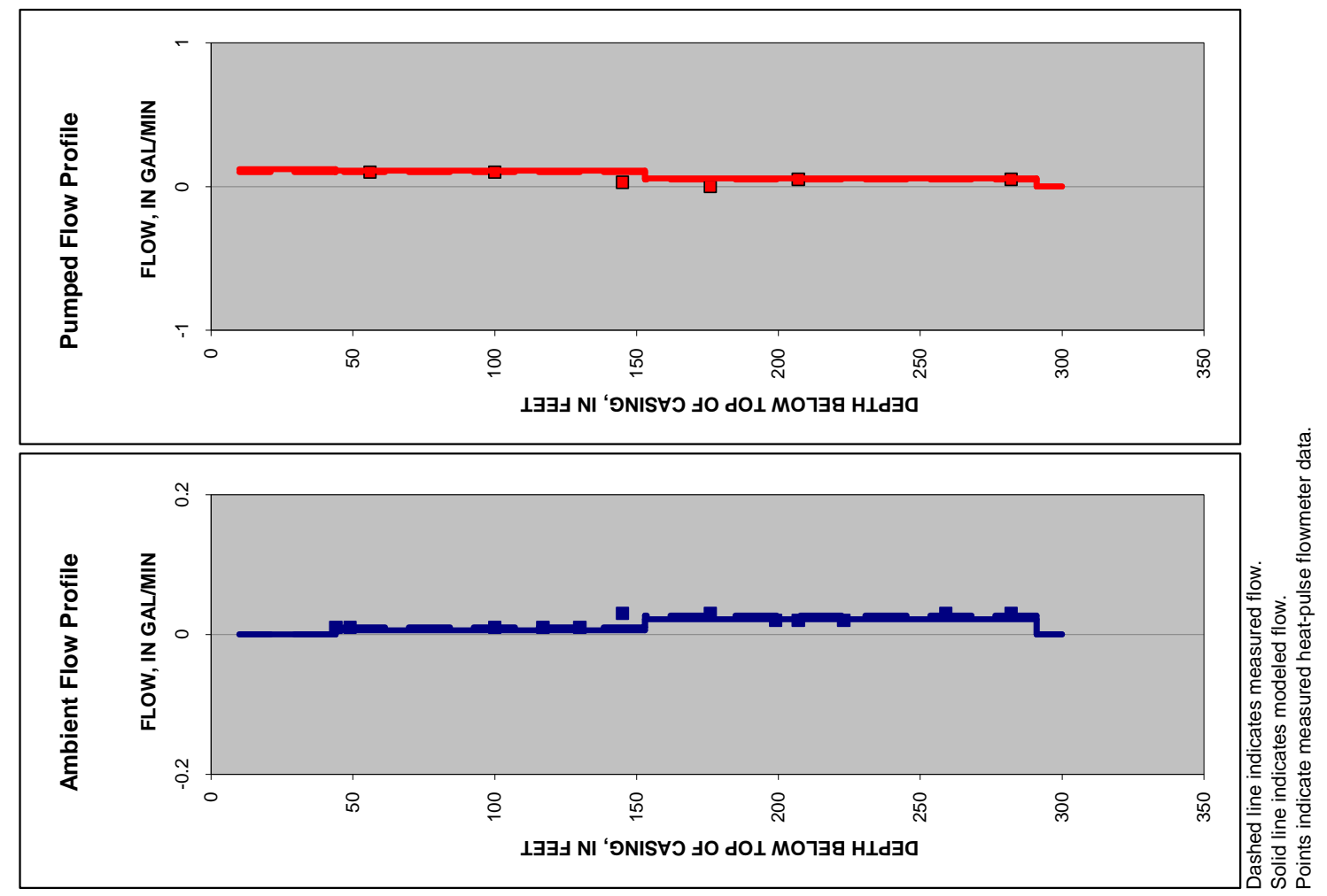

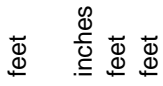

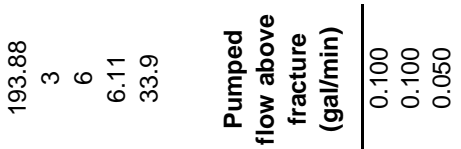

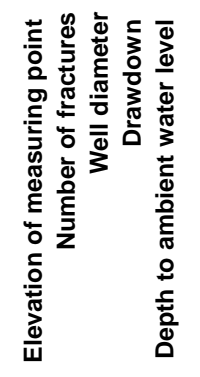

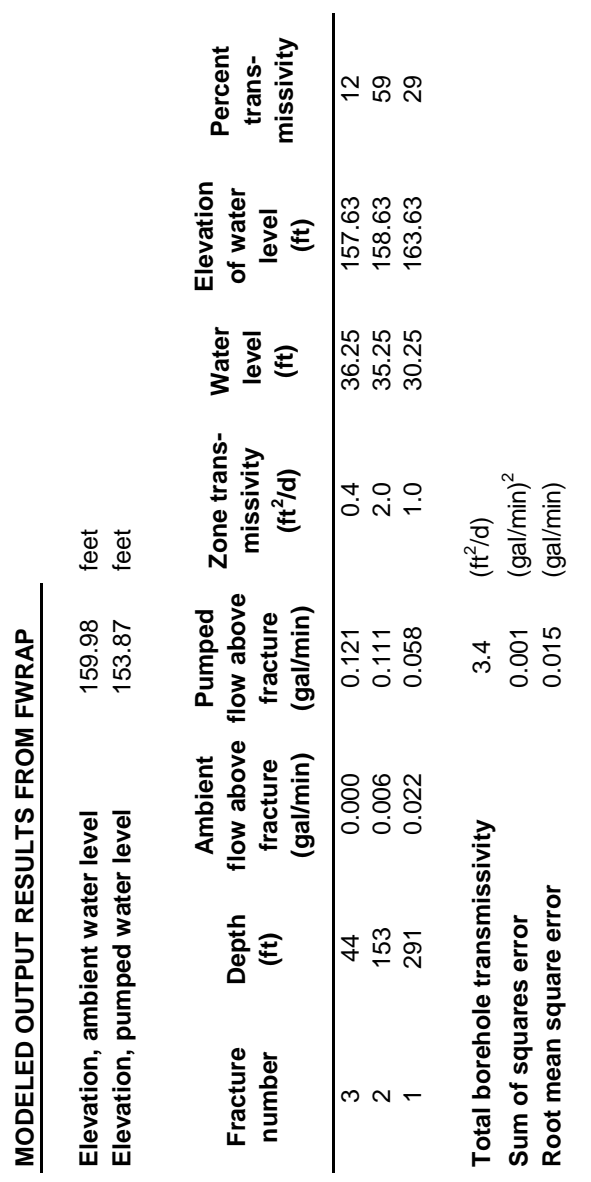

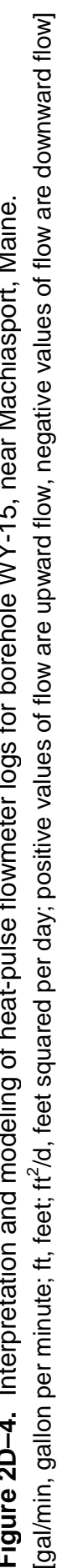




\section{Appendix 3. Borehole geophysical logs from boreholes near the Transmitter Site on Howard Mountain, near Machiasport, Maine}




\section{Appendix 3.}

\section{Borehole geophysical logs from boreholes near the Transmitter Site on Howard Mountain, near Machiasport, Maine}

\section{A. Borehole DW-6}

Figure 3A-1. Caliper, acoustic caliper, gamma, electromagnetic conductivity, fluid temperature, specific conductance, dissolved oxygen, $\mathrm{pH}$, reduction oxidation, multi-space resistivity, oriented acoustic and optical borehole images, and heatpulse flowmeter logs for borehole DW-6, near Machiasport, Maine.

Figure 3A-2. Borehole deviation logs for borehole DW-6, near Machiasport, Maine.

Table 3A-1. Interpretation of acoustic televiewer logs for borehole DW-6, near Machiasport, Maine.

Figure 3A-3. Projection, tadpole, and stereoplots of interpretation of borehole image data for borehole DW-6, near Machiasport, Maine.

Figure 3A-4. Interpretation and modeling of heat-pulse flowmeter logs for borehole DW-6, near Machiasport, Maine.

\section{B. Borehole DW-10}

Figure 3B-1. Caliper, acoustic caliper, gamma, electromagnetic conductivity, fluid temperature, specific conductance, dissolved oxygen, $\mathrm{pH}$, reduction oxidation, multi-space resistivity, oriented acoustic and optical borehole images, and heatpulse flowmeter logs for borehole DW-10, near Machiasport, Maine.

Figure 3B-2. Borehole deviation logs for borehole DW-10, near Machiasport, Maine.

Table 3B-1. Interpretation of acoustic televiewer logs for borehole DW-10, near Machiasport, Maine.

Table 3B-2. Interpretation of optical televiewer logs for borehole DW-10, near Machiasport, Maine.

Figure 3B-3. Projection, tadpole, and stereoplots of interpretation of borehole image data for borehole DW-10, near Machiasport, Maine. 


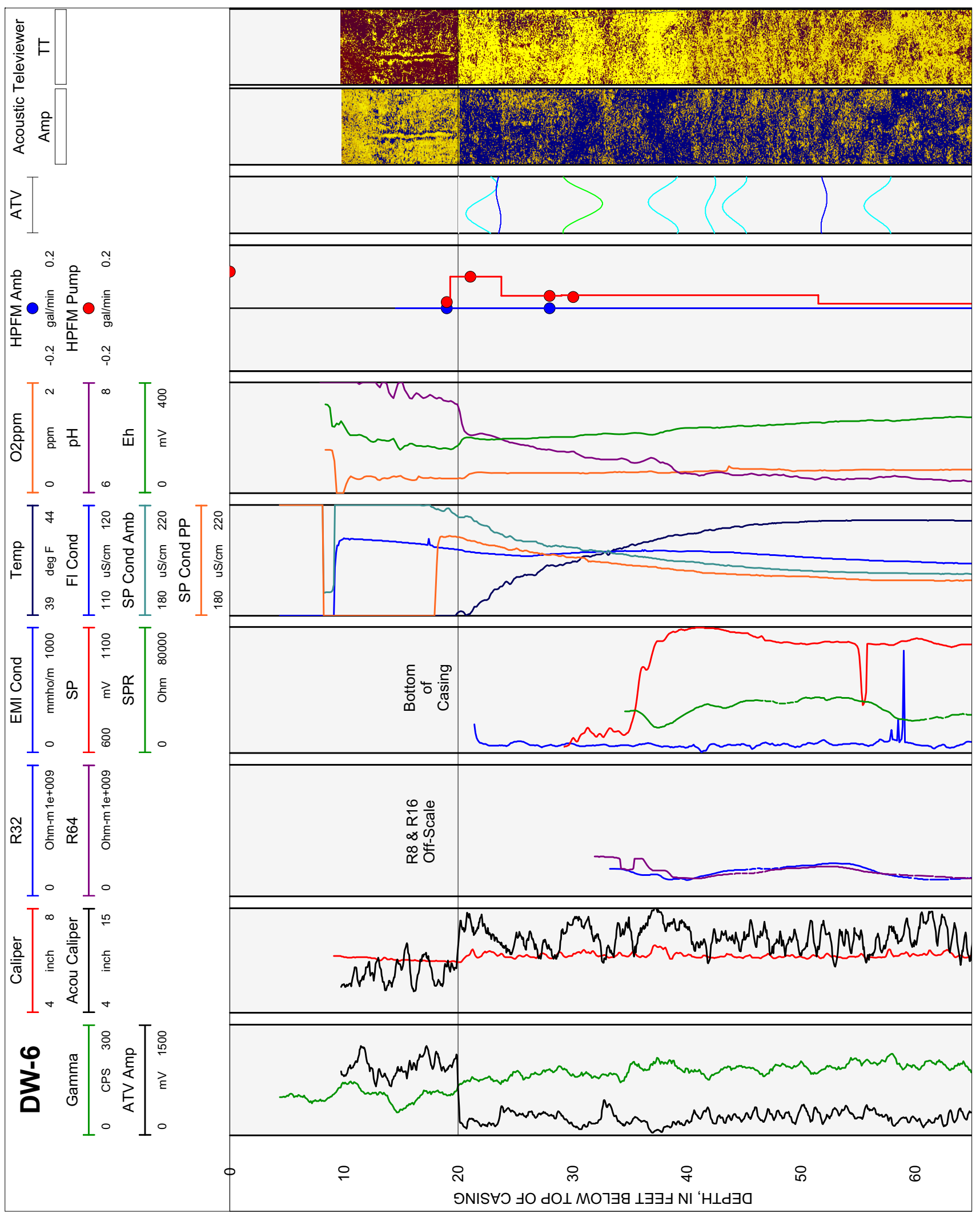

Figure 3A-1. Caliper, acoustic caliper, gamma, electromagnetic conductivity, fluid temperature, specific conductance, $\mathrm{DO}, \mathrm{pH}$, reduction oxidation, multi-space resistivity, oriented acoustic and optical borehole images, and heat-pulse flowmeter logs for borehole DW-6, near Machiasport, Maine. 


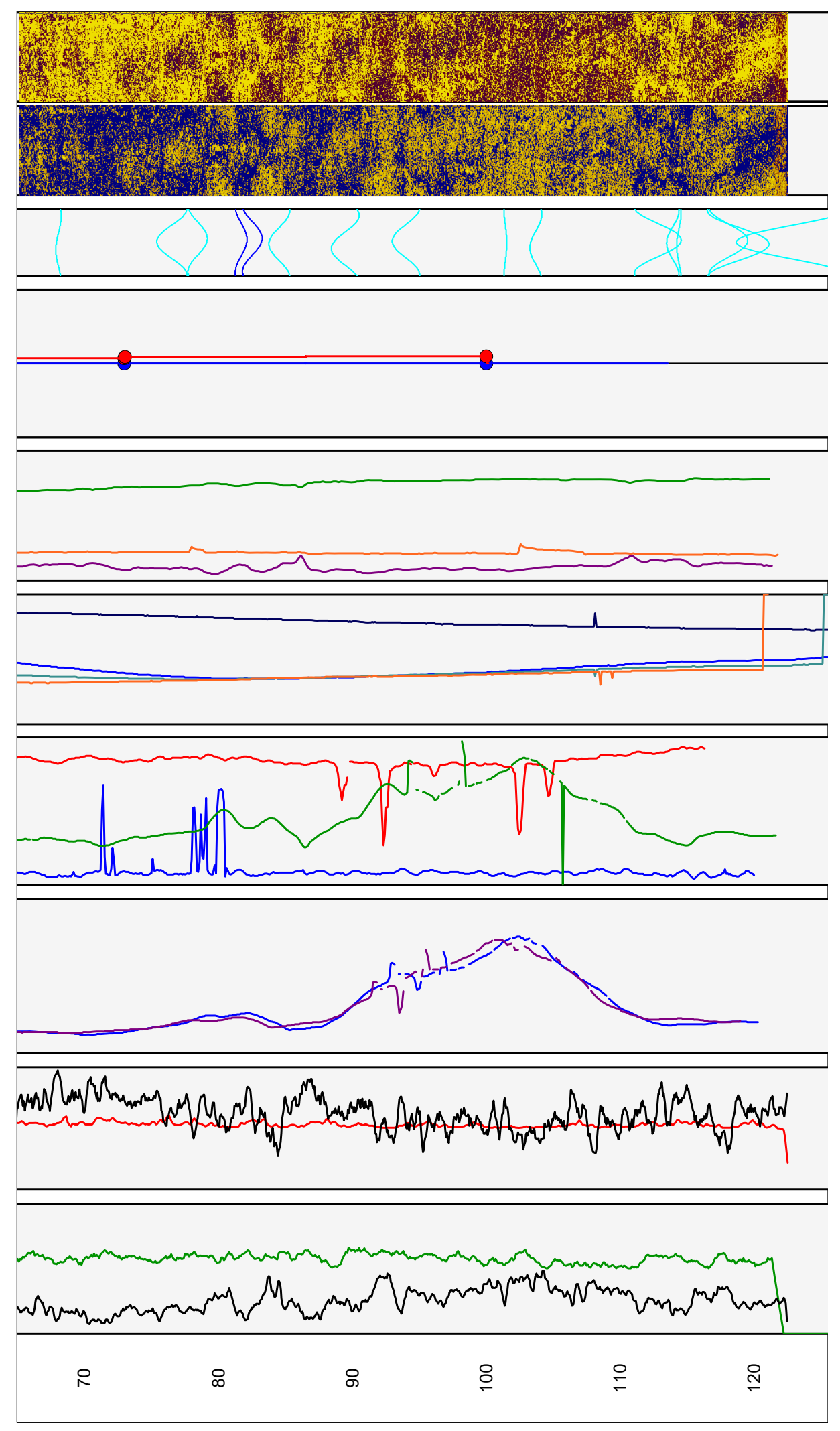

Figure 3A-1. Caliper, acoustic caliper, gamma, electromagnetic conductivity, fluid temperature, specific conductance, $\mathrm{DO}, \mathrm{pH}$, reduction oxidation, multi-space resistivity, oriented acoustic and optical borehole images, and heat-pulse flowmeter logs for borehole DW-6, near Machiasport, Maine.-Continued 


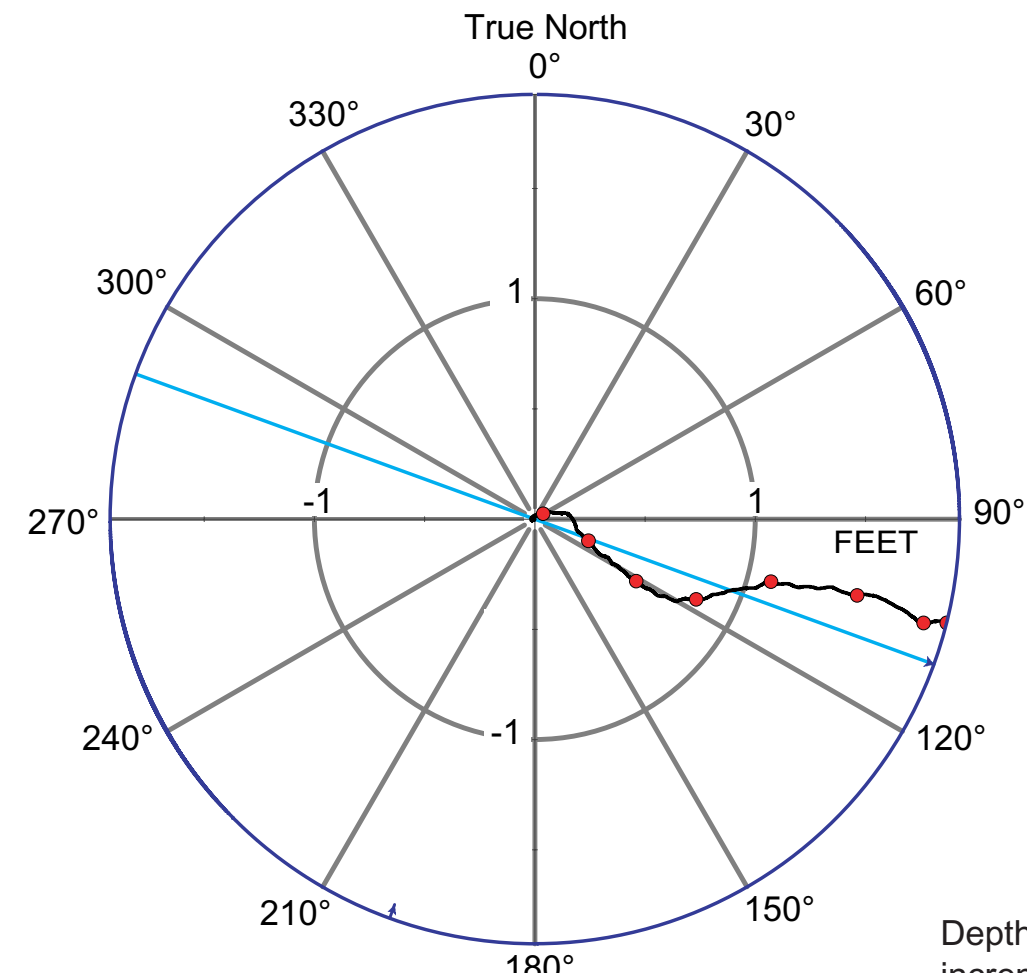

Depth along borehole in 16.4-ft increments between circles

$-16.4 \mathrm{ft} \rightarrow$ ATV

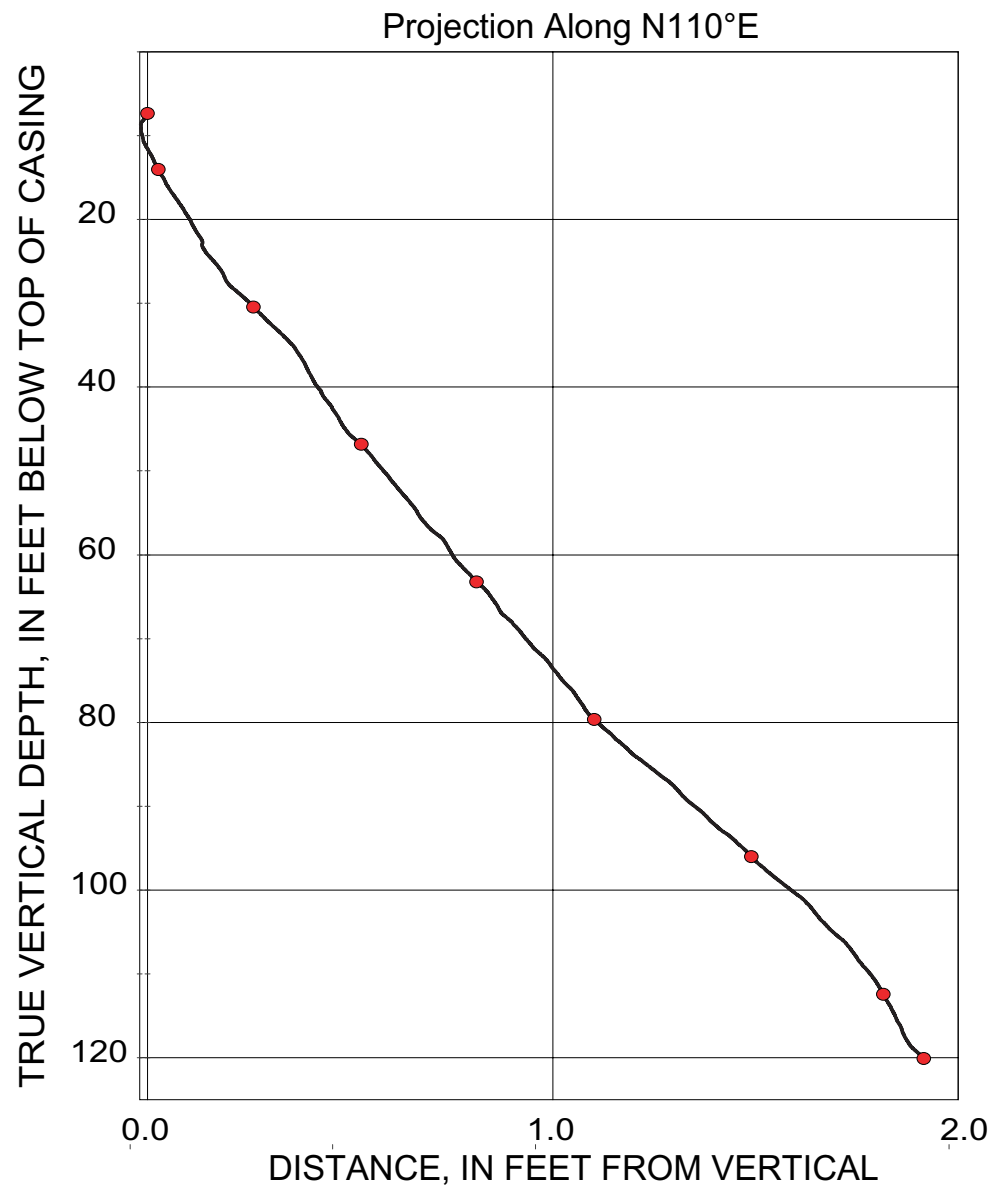

Figure 3A-2. Borehole deviation logs for borehole DW-6, near Machiasport, Main. Blue line on radial plot (top) is line of projection for vertical plot (bottom).

[ft, foot; ATV, acoustic televiewer] 
Table 3A-1. Interpretation of acoustic televiewer logs for borehole DW-6, near Machiasport, Maine.

[Televiewer data are corrected for deviation and magnetic declination, so orientations are relative to true north; depths are below top of casing, which is 1.8 feet above land surface; dip azimuth is given in degrees east of true north; strike is reported in right-hand-rule (RHR)-azimuthal degrees east of true north and where the direction of dip is 90 degrees to the right of strike; ,-- no measurement]

\begin{tabular}{rrrrrcrl}
\hline $\begin{array}{c}\text { Depth, } \\
\text { in feet }\end{array}$ & $\begin{array}{c}\text { Depth, } \\
\text { in meters }\end{array}$ & $\begin{array}{c}\text { Dip } \\
\text { azimuth }\end{array}$ & $\begin{array}{c}\text { Strike, } \\
\text { in RHR }\end{array}$ & Dip & $\begin{array}{c}\text { Dip } \\
\text { direction }\end{array}$ & Dip descriptor & Comment \\
\hline 20.03 & 6.10 & 0 & 270 & 0 & -- & Horizontal & Bottom of casing \\
22.03 & 6.71 & 305 & 215 & 79.53 & NW & Nearly vertical & Minor fracture \\
23.53 & 7.17 & 89 & 359 & 39.11 & $\mathrm{E}$ & Moderate & Transmissive fracture \\
30.92 & 9.42 & 188 & 98 & 81.60 & $\mathrm{~S}$ & Nearly vertical & $\begin{array}{l}\text { Possible fracture } \\
37.95\end{array}$ \\
\hline 11.57 & 18 & 288 & 79.00 & $\mathrm{~N}$ & Nearly vertical & Minor fracture \\
42.08 & 12.83 & 323 & 233 & 60.48 & $\mathrm{NW}$ & Steep & Minor fracture \\
44.17 & 13.46 & 349 & 259 & 76.50 & $\mathrm{~N}$ & Nearly vertical & Minor fracture \\
52.01 & 15.85 & 220 & 130 & 46.26 & $\mathrm{SW}$ & Moderate & Transmissive fracture \\
56.68 & 17.28 & 354 & 264 & 77.66 & $\mathrm{~N}$ & Nearly vertical & Minor fracture \\
68.04 & 20.74 & 321 & 231 & 37.75 & $\mathrm{NW}$ & Moderate & Minor fracture \\
76.55 & 23.33 & 4 & 274 & 77.22 & $\mathrm{~N}$ & Nearly vertical & Minor fracture \\
78.45 & 23.91 & 201 & 111 & 70.59 & $\mathrm{~S}$ & Nearly vertical & Minor fracture \\
81.68 & 24.89 & 196 & 106 & 59.58 & $\mathrm{~S}$ & Steep & Transmissive fracture \\
82.53 & 25.15 & 203 & 113 & 70.75 & $\mathrm{SW}$ & Nearly vertical & Transmissive fracture \\
84.54 & 25.77 & 352 & 262 & 71.88 & $\mathrm{~N}$ & Nearly vertical & Minor fracture \\
89.45 & 27.26 & 327 & 237 & 76.24 & $\mathrm{NW}$ & Nearly vertical & Minor fracture \\
94.01 & 28.65 & 7 & 277 & 75.96 & $\mathrm{~N}$ & Nearly vertical & Minor fracture \\
101.41 & 30.91 & 177 & 87 & 21.16 & $\mathrm{~S}$ & Shallow & Minor fracture \\
103.67 & 31.60 & 332 & 242 & 60.07 & $\mathrm{NW}$ & Steep & Minor fracture \\
112.77 & 34.37 & 193 & 103 & 81.72 & $\mathrm{~S}$ & Nearly vertical & Minor fracture \\
113.92 & 34.72 & 357 & 267 & 61.50 & $\mathrm{~N}$ & Steep & Minor fracture \\
114.36 & 34.86 & 341 & 251 & 31.77 & $\mathrm{~N}$ & Moderate & Minor fracture \\
118.21 & 36.03 & 176 & 86 & 80.01 & $\mathrm{~S}$ & Nearly vertical & Minor fracture \\
122.77 & 37.42 & 2 & 272 & 86.47 & $\mathrm{~N}$ & Nearly vertical & Minor fracture \\
\hline
\end{tabular}




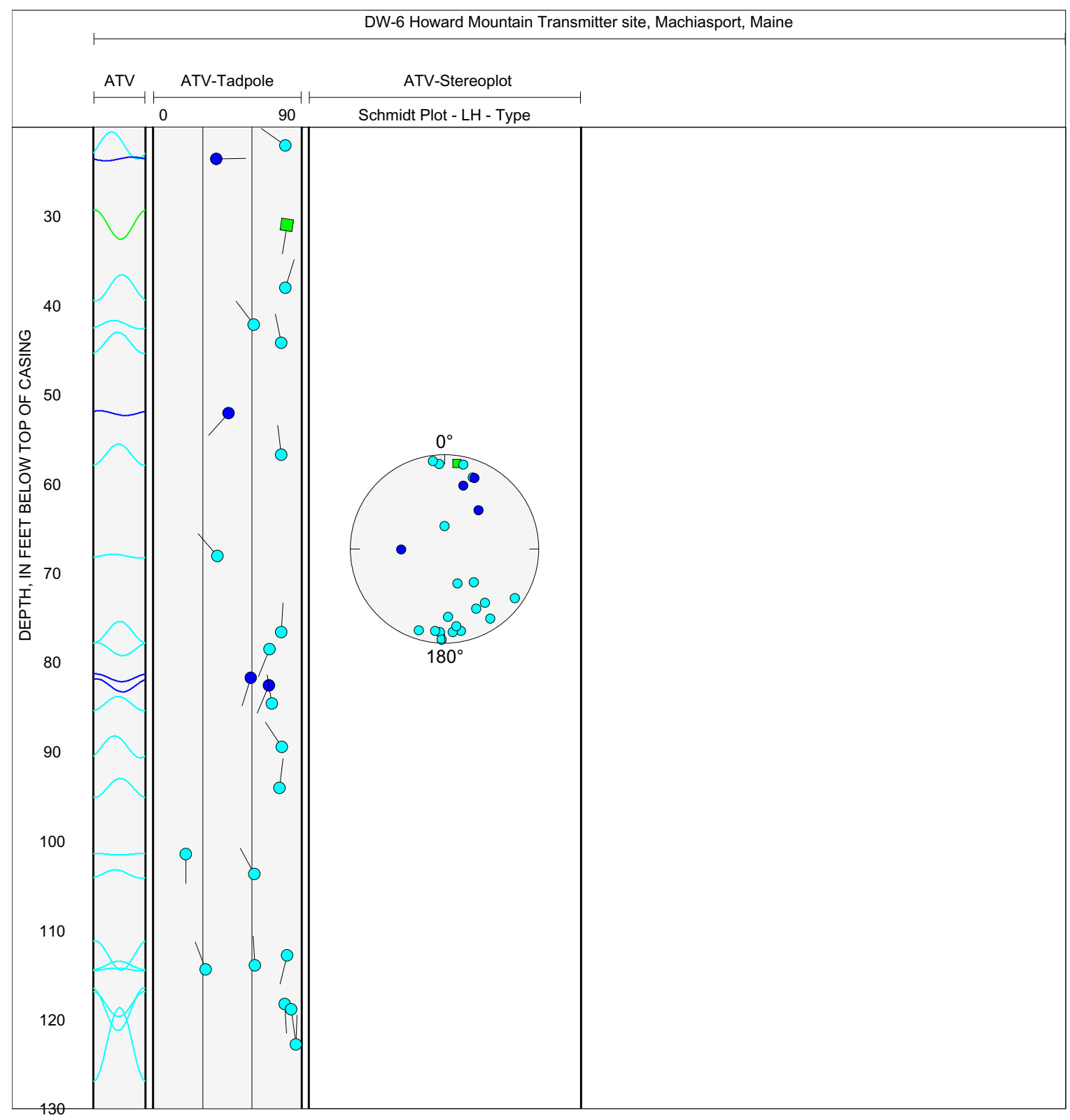

Figure 3A-3. Projection, tadpole, and stereoplots of interpretation of borehole image data for borehole DW-6, near Machiasport, Maine. 

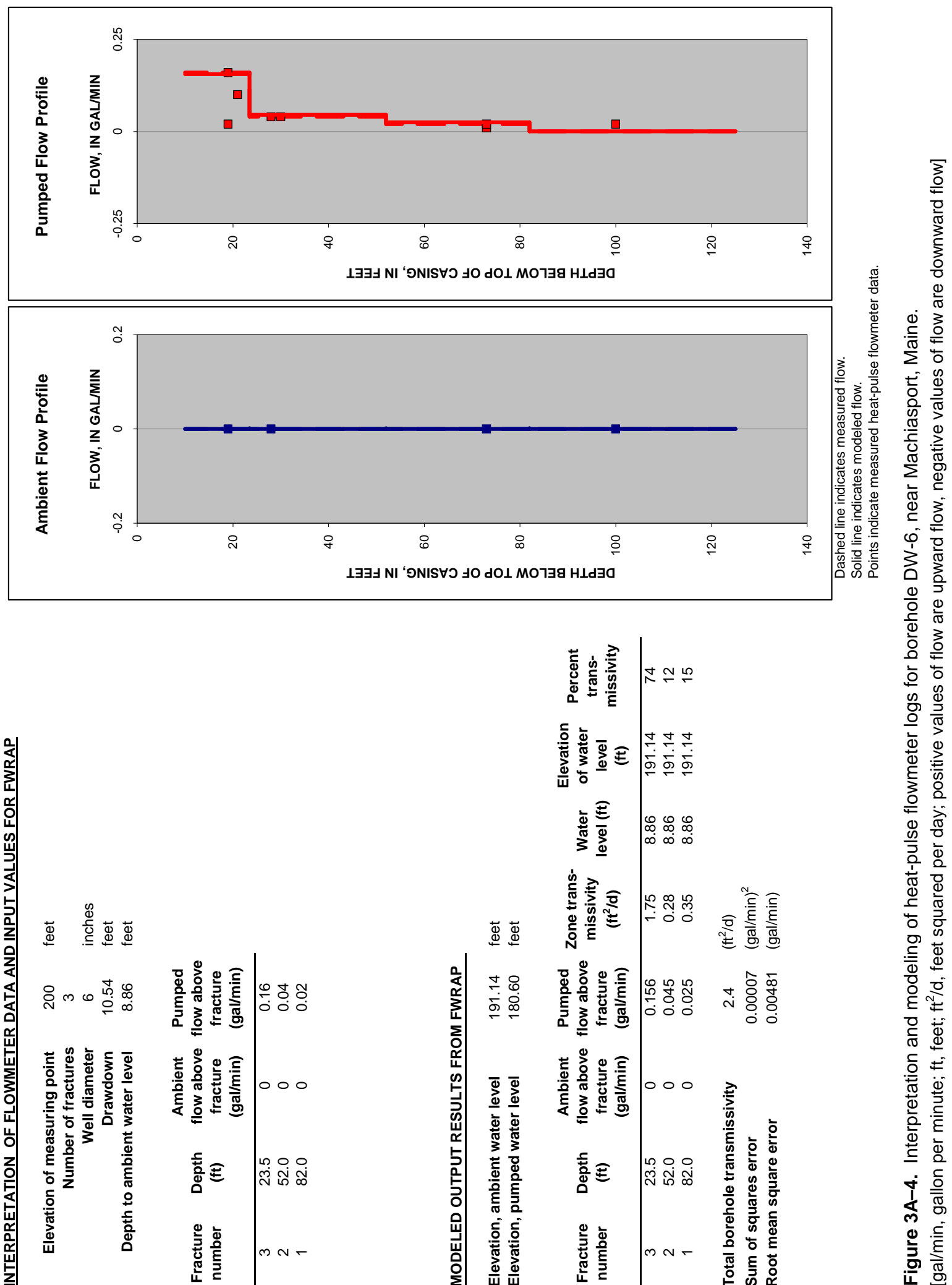


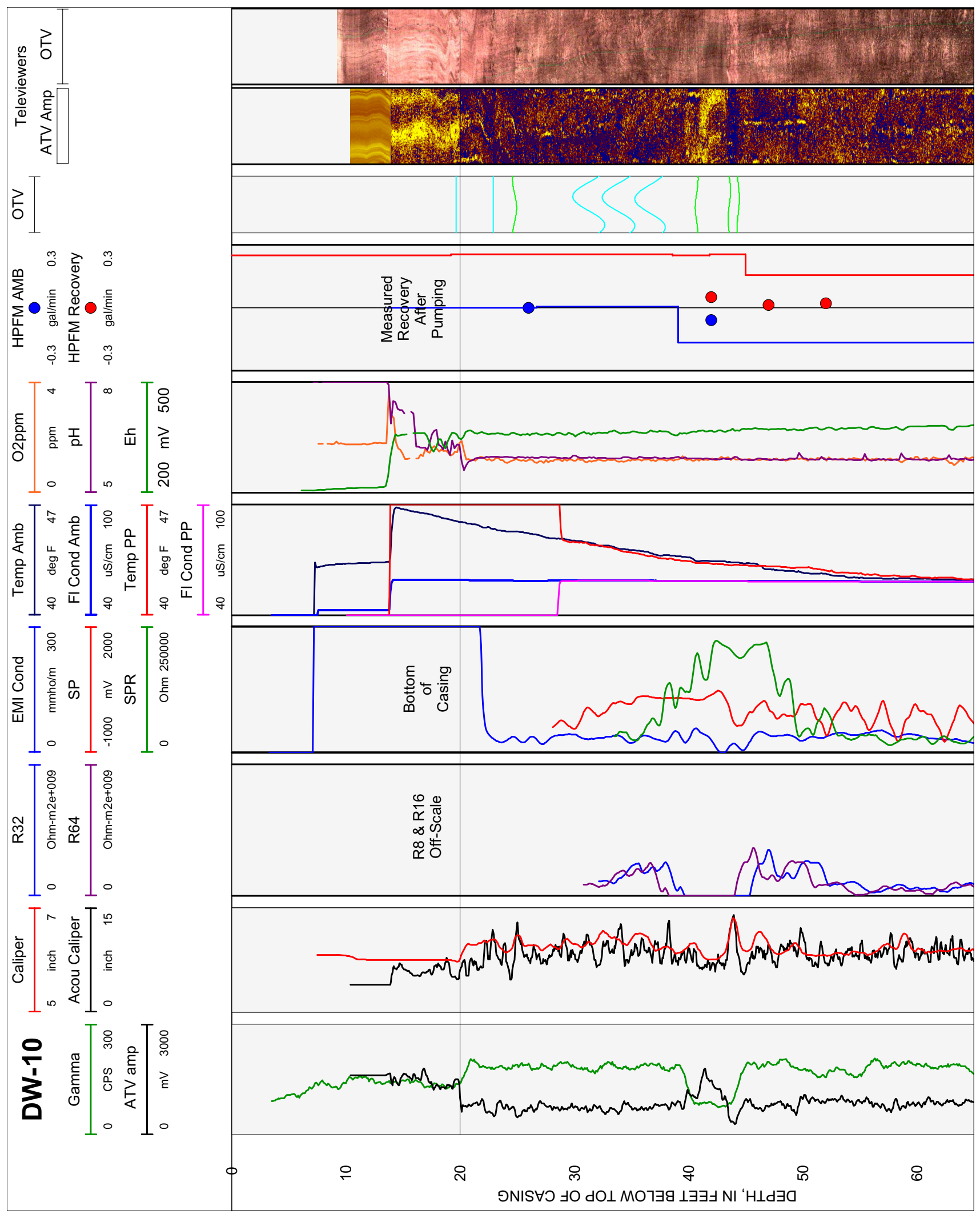

Figure 3B-1. Caliper, acoustic caliper, gamma, electromagnetic conductivity, fluid temperature, specific conductance, $\mathrm{DO}, \mathrm{pH}$, reduction oxidation, multi-space resistivity, oriented acoustic and optical borehole images, and heat-pulse flowmeter logs for borehole DW-10, near Machiasport, Maine. 


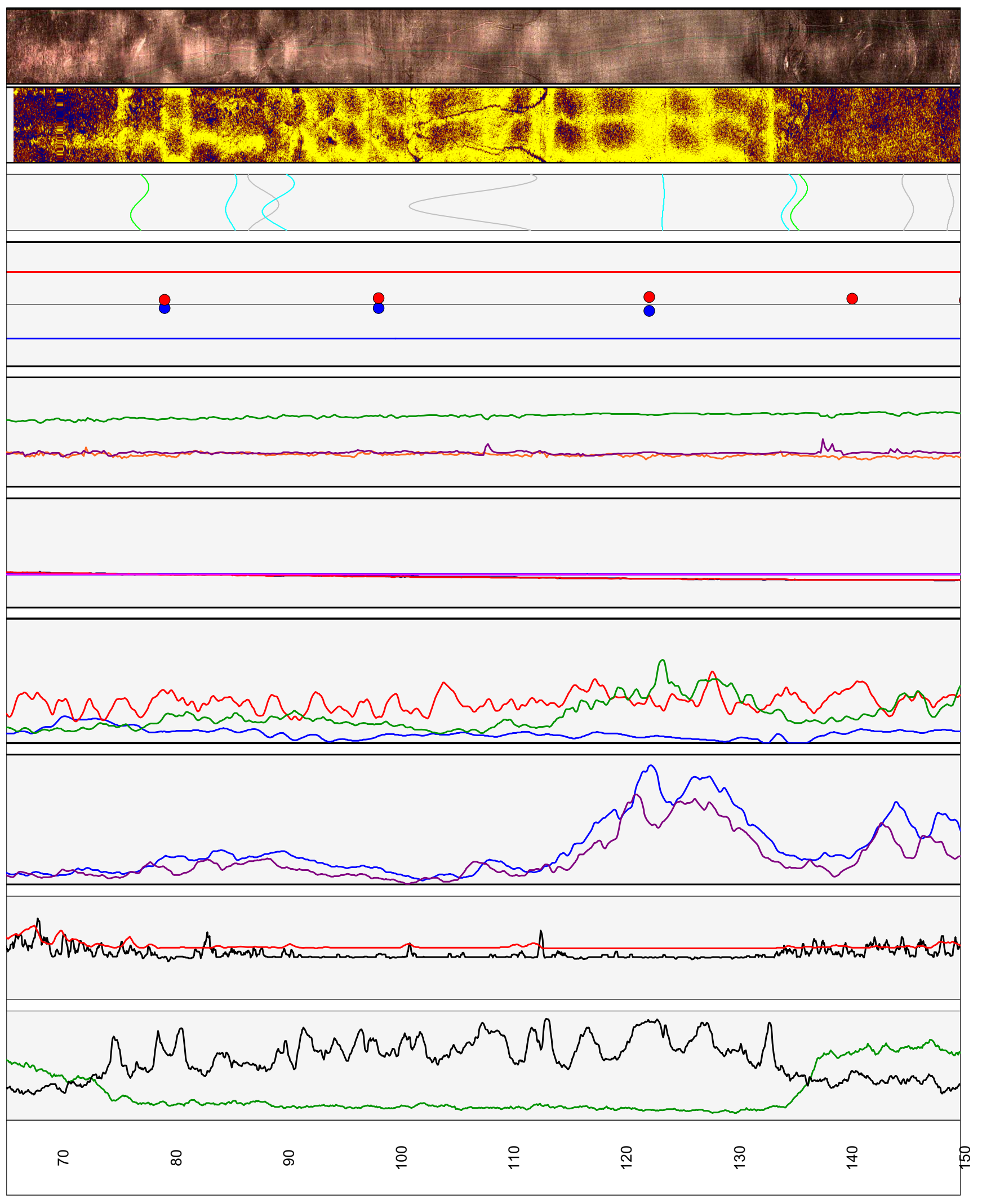

Figure 3B-1. Caliper, acoustic caliper, gamma, electromagnetic conductivity, fluid temperature, specific conductance, $\mathrm{DO}, \mathrm{pH}$, reduction oxidation, multi-space resistivity, oriented acoustic and optical borehole images, and heat-pulse flowmeter logs for borehole DW-10, near Machiasport, Maine.-Continued 


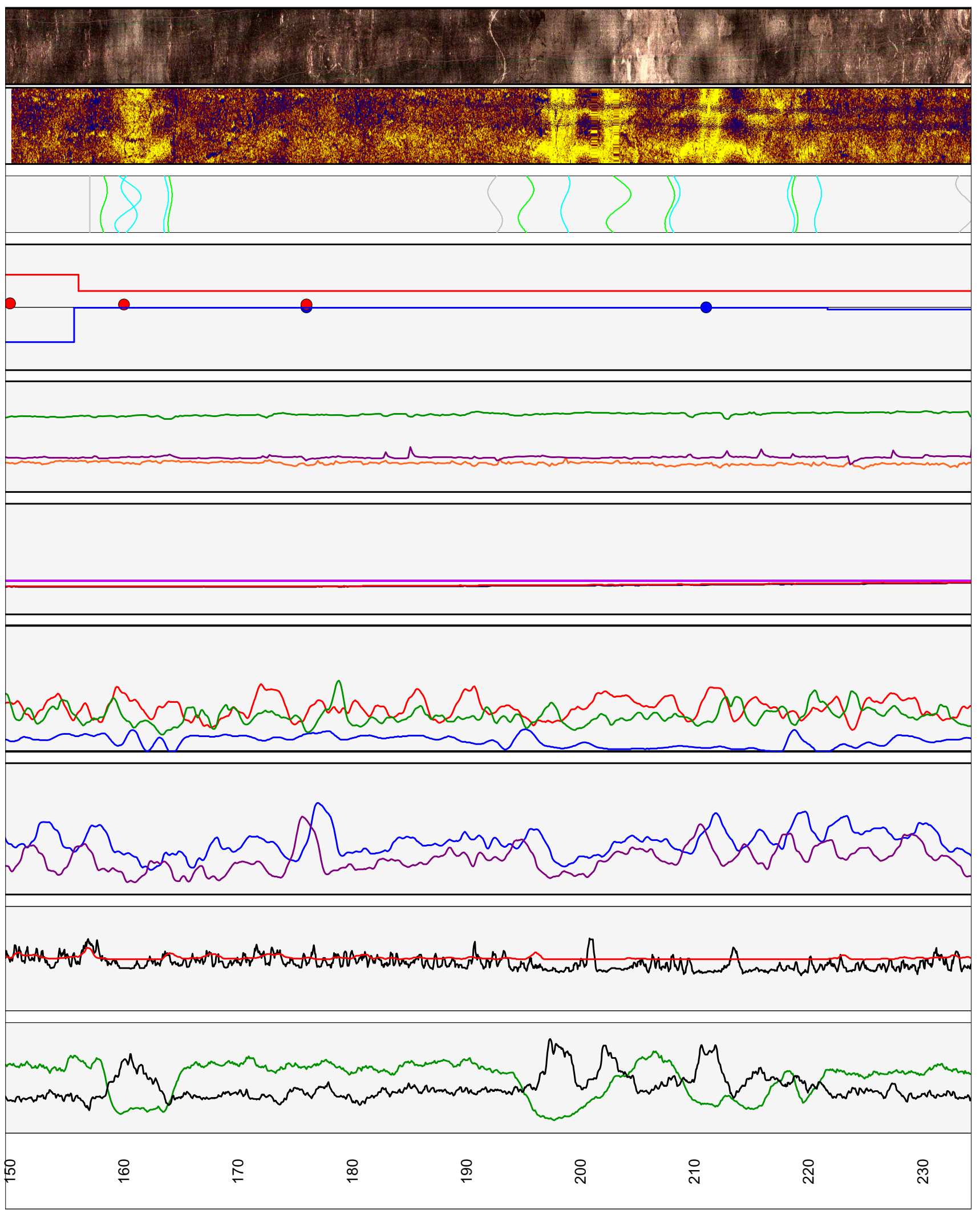

Figure 3B-1. Caliper, acoustic caliper, gamma, electromagnetic conductivity, fluid temperature, specific conductance, $\mathrm{DO}, \mathrm{pH}$, reduction oxidation, multi-space resistivity, oriented acoustic and optical borehole images, and heat-pulse flowmeter logs for borehole DW-10, near Machiasport, Maine.-Continued 


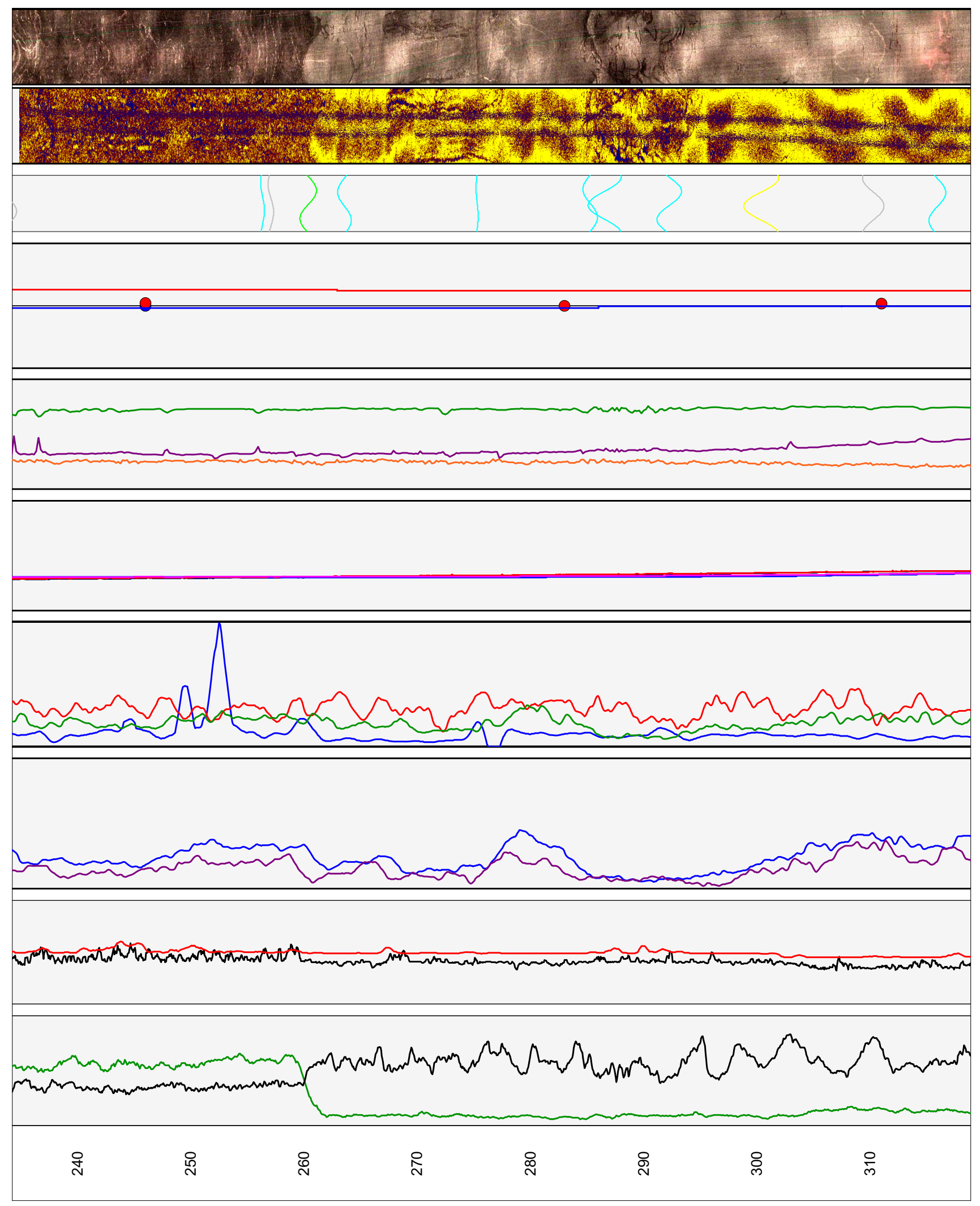

Figure 3B-1. Caliper, acoustic caliper, gamma, electromagnetic conductivity, fluid temperature, specific conductance, $\mathrm{DO}, \mathrm{pH}$, reduction oxidation, multi-space resistivity, oriented acoustic and optical borehole images, and heat-pulse flowmeter logs for borehole DW-10, near Machiasport, Maine.-Continued 


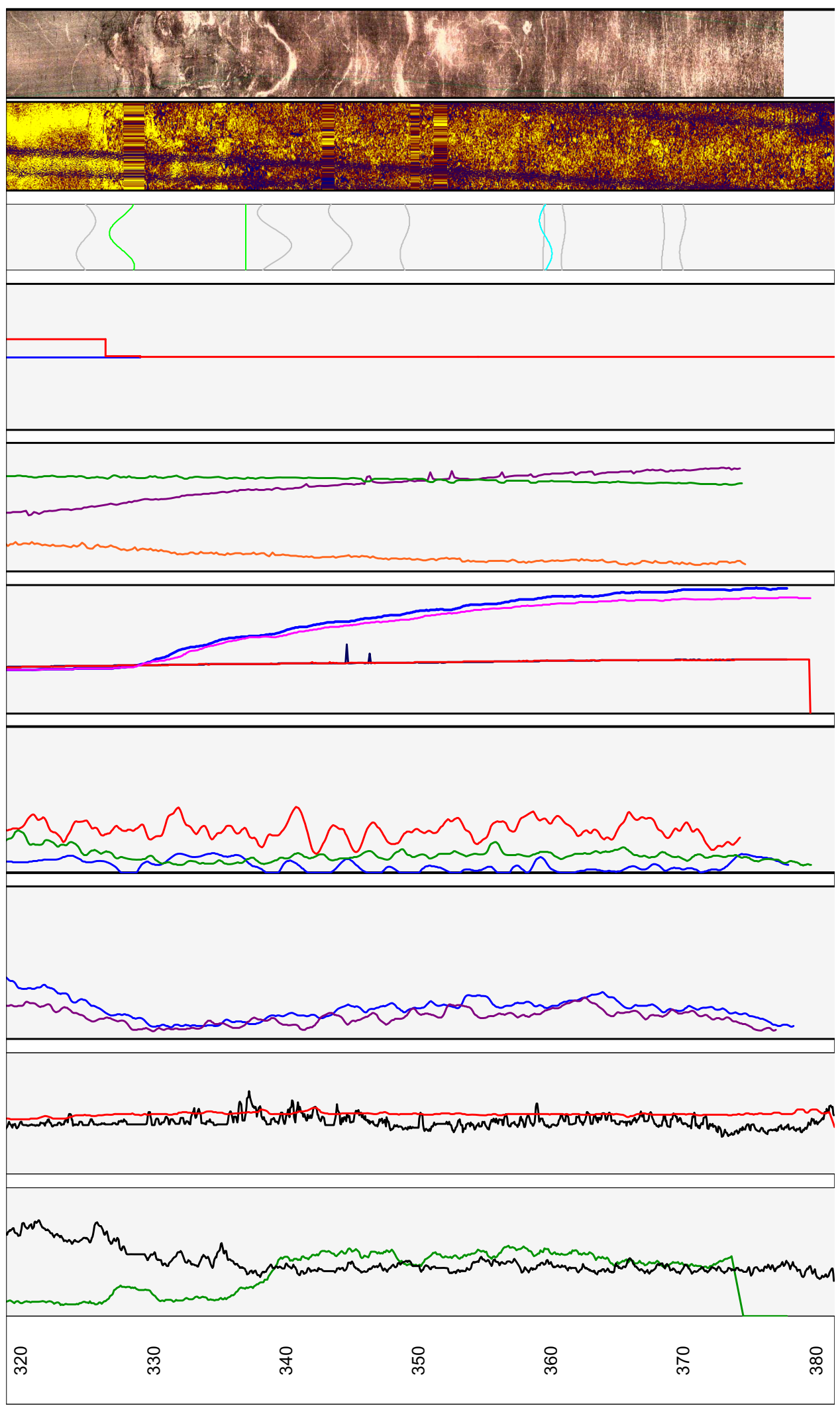

Figure 3B-1. Caliper, acoustic caliper, gamma, electromagnetic conductivity, fluid temperature, specific conductance, $\mathrm{DO}, \mathrm{pH}$, reduction oxidation, multi-space resistivity, oriented acoustic and optical borehole images, and heat-pulse flowmeter logs for borehole DW-10, near Machiasport, Maine.-Continued 

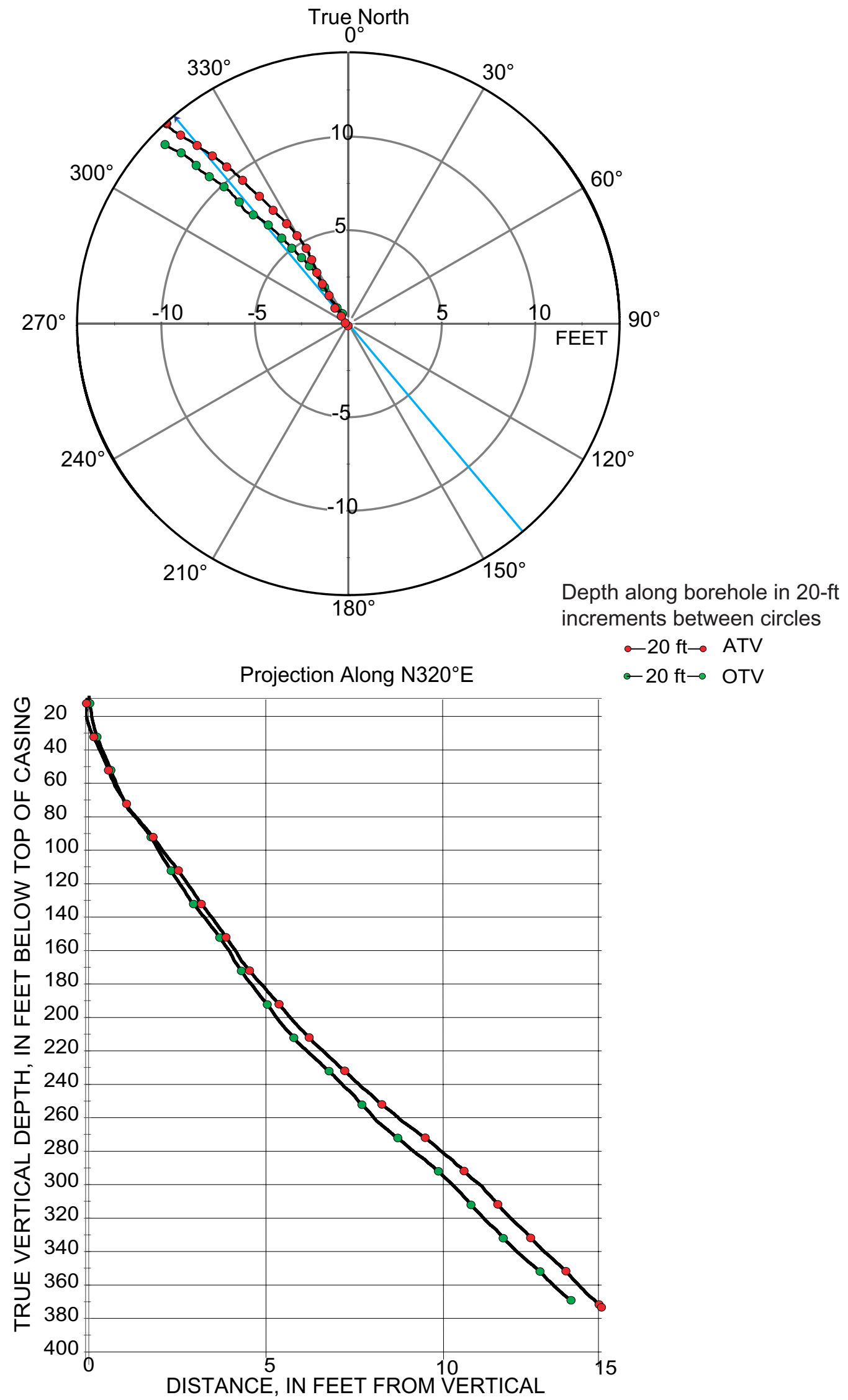

$-20 \mathrm{ft} \rightarrow$ ATV

$-20 \mathrm{ft} \rightarrow$ OTV

Figure 3B-2. Borehole deviation logs for borehole DW-10, near Machiasport, Maine. Blue line on radial plot (top) is line of projection for vertical plot (bottom).

[ft, foot; ATV, acoustic televiewer; OTV, optical televiewer] 
Table 3B-1. Interpretation of acoustic televiewer logs for borehole DW-10, near Machiasport, Maine.

[Televiewer data are corrected for deviation and magnetic declination, so orientations are relative to true north; depths are below top of casing, which is 0.97 feet above land surface; dip azimuth is given in degrees east of true north; strike is reported in right-hand-rule (RHR)-azimuthal degrees east of true north and where the direction of dip is 90 degrees to the right of strike]

\begin{tabular}{|c|c|c|c|c|c|c|c|}
\hline $\begin{array}{l}\text { Depth, } \\
\text { in feet }\end{array}$ & $\begin{array}{l}\text { Depth, } \\
\text { in meters }\end{array}$ & $\begin{array}{c}\text { Dip } \\
\text { azimuth }\end{array}$ & $\begin{array}{c}\text { Strike, } \\
\text { in RHR }\end{array}$ & Dip & $\begin{array}{c}\text { Dip } \\
\text { direction }\end{array}$ & Dip descriptor & Comment \\
\hline 13.97 & 4.26 & 336 & 246 & 1 & NW & Nearly horizontal & Top of cement? \\
\hline 20.01 & 6.10 & 40 & 310 & 1 & $\mathrm{NE}$ & Nearly horizontal & Bottom of casing \\
\hline 22.98 & 7.00 & 141 & 51 & 18 & SE & Shallow & Minor fracture \\
\hline 37.75 & 11.51 & 81 & 351 & 66 & $E$ & Steep & Minor fracture \\
\hline 43.14 & 13.15 & 340 & 250 & 42 & $\mathrm{~N}$ & Moderate & Transmissive fracture \\
\hline 43.42 & 13.23 & 29 & 299 & 16 & $\mathrm{NE}$ & Shallow & Transmissive fracture \\
\hline 67.49 & 20.57 & 272 & 182 & 81 & W & Nearly vertical & Minor fracture \\
\hline 96.95 & 29.55 & 282 & 192 & 9 & W & Nearly horizontal & Minor fracture \\
\hline 101.36 & 30.89 & 255 & 165 & 79 & W & Nearly vertical & Minor fracture \\
\hline 106.45 & 32.44 & 333 & 243 & 85 & NW & Nearly vertical & Minor fracture \\
\hline 112.11 & 34.17 & 181 & 91 & 22 & $\mathrm{~S}$ & Shallow & Minor fracture \\
\hline 123.20 & 37.55 & 197 & 107 & 19 & $\mathrm{~S}$ & Shallow & Minor fracture \\
\hline 134.96 & 41.13 & 242 & 152 & 78 & SW & Nearly vertical & Minor fracture \\
\hline 156.92 & 47.83 & 79 & 349 & 13 & $E$ & Shallow & Transmissive fracture \\
\hline 158.75 & 48.38 & 255 & 165 & 37 & W & Moderate & Transmissive fracture \\
\hline 160.61 & 48.95 & 247 & 157 & 78 & SW & Nearly vertical & Minor fracture \\
\hline 163.78 & 49.92 & 236 & 146 & 43 & SW & Moderate & Lithologic feature \\
\hline 163.93 & 49.96 & 239 & 149 & 35 & SW & Moderate & Minor fracture \\
\hline 197.09 & 60.07 & 279 & 189 & 21 & W & Shallow & Lithologic feature \\
\hline 197.92 & 60.32 & 280 & 190 & 51 & W & Steep & Minor fracture \\
\hline 198.93 & 60.63 & 315 & 225 & 57 & NW & Steep & Minor fracture \\
\hline 203.40 & 61.99 & 248 & 158 & 75 & W & Nearly vertical & Minor fracture \\
\hline 210.94 & 64.29 & 282 & 192 & 42 & W & Moderate & Minor fracture \\
\hline 214.98 & 65.52 & 319 & 229 & 62 & NW & Steep & Minor fracture \\
\hline 236.60 & 72.11 & 132 & 42 & 71 & SE & Nearly vertical & Minor fracture \\
\hline 260.39 & 79.36 & 277 & 187 & 66 & W & Steep & Lithologic feature \\
\hline 260.44 & 79.38 & 274 & 184 & 66 & W & Steep & Lithologic feature \\
\hline 285.56 & 87.03 & 100 & 10 & 71 & $\mathrm{E}$ & Nearly vertical & Minor fracture \\
\hline 286.43 & 87.30 & 342 & 252 & 80 & $\mathrm{~N}$ & Nearly vertical & Minor fracture \\
\hline 292.66 & 89.20 & 267 & 177 & 72 & W & Nearly vertical & Minor fracture \\
\hline 310.37 & 94.60 & 182 & 92 & 76 & $\mathrm{~S}$ & Nearly vertical & Minor fracture \\
\hline 315.76 & 96.24 & 260 & 170 & 57 & W & Steep & Minor fracture \\
\hline 326.02 & 99.37 & 76 & 346 & 75 & $\mathrm{E}$ & Nearly vertical & Transmissive fracture \\
\hline 326.73 & 99.58 & 54 & 324 & 27 & $\mathrm{NE}$ & Shallow & Transmissive fracture \\
\hline
\end{tabular}


Table 3B-2. Interpretation of optical televiewer logs for borehole DW-10, near Machiasport, Maine.

[Televiewer data are corrected for deviation and magnetic declination, so orientations are relative to true north; depths are below top of casing, which is 0.97 feet above land surface; dip azimuth is given in degrees east of true north; strike is reported in right-hand-rule (RHR)-azimuthal degrees east of true north and where the direction of dip is 90 degrees to the right of strike]

\begin{tabular}{|c|c|c|c|c|c|c|c|}
\hline $\begin{array}{l}\text { Depth, } \\
\text { in feet }\end{array}$ & $\begin{array}{l}\text { Depth, } \\
\text { in meters }\end{array}$ & $\begin{array}{c}\text { Dip } \\
\text { azimuth }\end{array}$ & $\begin{array}{c}\text { Strike, } \\
\text { in RHR }\end{array}$ & Dip & $\begin{array}{c}\text { Dip } \\
\text { direction }\end{array}$ & Dip descriptor & Comment \\
\hline 13.97 & 4.26 & 336 & 246 & 1 & NW & Nearly horizontal & Top of cement \\
\hline 13.52 & 4.12 & 72 & 342 & 1 & $E$ & Nearly horizontal & Bottom of casing \\
\hline 22.68 & 6.91 & 140 & 50 & 18 & SE & Shallow & Minor fracture \\
\hline 24.70 & 7.53 & 181 & 91 & 23 & $\mathrm{~S}$ & Shallow & Minor fracture \\
\hline 31.37 & 9.56 & 19 & 289 & 79 & $\mathrm{~N}$ & Nearly vertical & Minor fracture \\
\hline 33.57 & 10.23 & 30 & 300 & 79 & NE & Nearly vertical & Minor fracture \\
\hline 36.73 & 11.19 & 24 & 294 & 78 & NE & Nearly vertical & Minor fracture \\
\hline 43.21 & 13.17 & 268 & 178 & 20 & W & Shallow & Lithologic feature \\
\hline 43.41 & 13.23 & 229 & 139 & 15 & sw & Shallow & Transmissive fracture \\
\hline 46.05 & 14.04 & 293 & 203 & 65 & NW & Steep & Minor fracture \\
\hline 48.61 & 14.82 & 259 & 169 & 39 & W & Moderate & Minor fracture \\
\hline 76.27 & 23.25 & 256 & 166 & 76 & W & Nearly vertical & Lithologic feature \\
\hline 84.05 & 25.62 & 104 & 14 & 88 & $E$ & Nearly vertical & Fabric or layering in rock \\
\hline 87.76 & 26.75 & 162 & 72 & 81 & $\mathrm{~S}$ & Nearly vertical & Fabric or layering in rock \\
\hline 88.73 & 27.04 & 289 & 199 & 75 & W & Nearly vertical & Minor fracture \\
\hline 106.43 & 32.44 & 342 & 252 & 86 & $\mathrm{~N}$ & Nearly vertical & Minor fracture \\
\hline 119.96 & 36.56 & 281 & 191 & 84 & W & Nearly vertical & Fabric or layering in rock \\
\hline 130.68 & 39.83 & 255 & 165 & 68 & W & Steep & Lithologic feature \\
\hline 133.61 & 40.72 & 254 & 164 & 70 & W & Nearly vertical & Minor fracture \\
\hline 134.37 & 40.95 & 257 & 167 & 71 & W & Nearly vertical & Minor fracture \\
\hline 135.14 & 41.19 & 245 & 155 & 70 & sw & Steep & Minor fracture \\
\hline 140.61 & 42.86 & 242 & 152 & 75 & SW & Nearly vertical & Fabric or layering in rock \\
\hline 158.05 & 48.17 & 255 & 165 & 43 & W & Moderate & Transmissive fracture \\
\hline 158.28 & 48.24 & 253 & 163 & 39 & W & Moderate & Lithologic feature \\
\hline 163.52 & 49.84 & 230 & 140 & 43 & sw & Moderate & Lithologic feature \\
\hline 163.64 & 49.88 & 228 & 138 & 34 & SW & Moderate & Minor fracture \\
\hline 172.87 & 52.69 & 134 & 44 & 30 & SE & Shallow & Fabric or layering in rock \\
\hline 192.50 & 58.67 & 76 & 346 & 68 & $\mathrm{E}$ & Steep & Fabric or layering in rock \\
\hline 194.88 & 59.40 & 226 & 136 & 63 & sw & Steep & Lithologic feature \\
\hline 195.07 & 59.45 & 223 & 133 & 67 & SW & Steep & Minor fracture \\
\hline 197.66 & 60.24 & 277 & 187 & 51 & W & Steep & Minor fracture \\
\hline 198.73 & 60.57 & 308 & 218 & 56 & NW & Steep & Minor fracture \\
\hline 203.37 & 61.98 & 227 & 137 & 76 & SW & Nearly vertical & Lithologic feature \\
\hline 203.45 & 62.01 & 235 & 145 & 75 & SW & Nearly vertical & Minor fracture \\
\hline 207.94 & 63.38 & 239 & 149 & 62 & SW & Steep & Lithologic feature \\
\hline 220.77 & 67.29 & 241 & 151 & 53 & SW & Steep & Fabric or layering in rock \\
\hline 233.84 & 71.27 & 131 & 41 & 76 & SE & Nearly vertical & Fabric or layering in rock \\
\hline 256.37 & 78.14 & 108 & 18 & 24 & $E$ & Shallow & Fabric or layering in rock \\
\hline 260.28 & 79.33 & 251 & 161 & 70 & W & Steep & Lithologic feature \\
\hline 263.53 & 80.32 & 59 & 329 & 69 & NE & Steep & Minor fracture \\
\hline 275.02 & 83.82 & 74 & 344 & 15 & $E$ & Shallow & Minor fracture \\
\hline 285.20 & 86.92 & 93 & 3 & 71 & $E$ & Nearly vertical & Fracture \\
\hline 286.39 & 87.29 & 336 & 246 & 77 & NW & Nearly vertical & Minor fracture \\
\hline 292.33 & 89.10 & 259 & 169 & 73 & W & Nearly vertical & Minor fracture \\
\hline 310.17 & 94.54 & 166 & 76 & 78 & $\mathrm{~S}$ & Nearly vertical & Fabric or layering in rock \\
\hline 315.59 & 96.19 & 247 & 157 & 60 & sw & Steep & Minor fracture \\
\hline 326.70 & 99.57 & 31 & 301 & 75 & NE & Nearly vertical & Lithologic feature \\
\hline 327.84 & 99.92 & 36 & 306 & 74 & $\mathrm{NE}$ & Nearly vertical & Transmissive fracture \\
\hline 339.15 & 103.37 & 146 & 56 & 82 & SE & Nearly vertical & Fabric or layering in rock \\
\hline 344.10 & 104.88 & 141 & 51 & 73 & SE & Nearly vertical & Fabric or layering in rock \\
\hline 345.31 & 105.25 & 205 & 115 & 15 & SW & Shallow & Fabric or layering in rock \\
\hline 349.00 & 106.37 & 259 & 169 & 57 & W & Steep & Fabric or layering in rock \\
\hline 359.44 & 109.55 & 218 & 128 & 12 & SW & Shallow & Fabric or layering in rock \\
\hline 360.91 & 110.00 & 243 & 153 & 29 & SW & Shallow & Fabric or layering in rock \\
\hline 368.22 & 112.23 & 192 & 102 & 19 & $\mathrm{~S}$ & Shallow & Fabric or layering in rock \\
\hline 368.41 & 112.29 & 204 & 114 & 25 & SW & Shallow & Fabric or layering in rock \\
\hline 369.92 & 112.75 & 262 & 172 & 35 & w & Moderate & Fabric or layering in rock \\
\hline
\end{tabular}




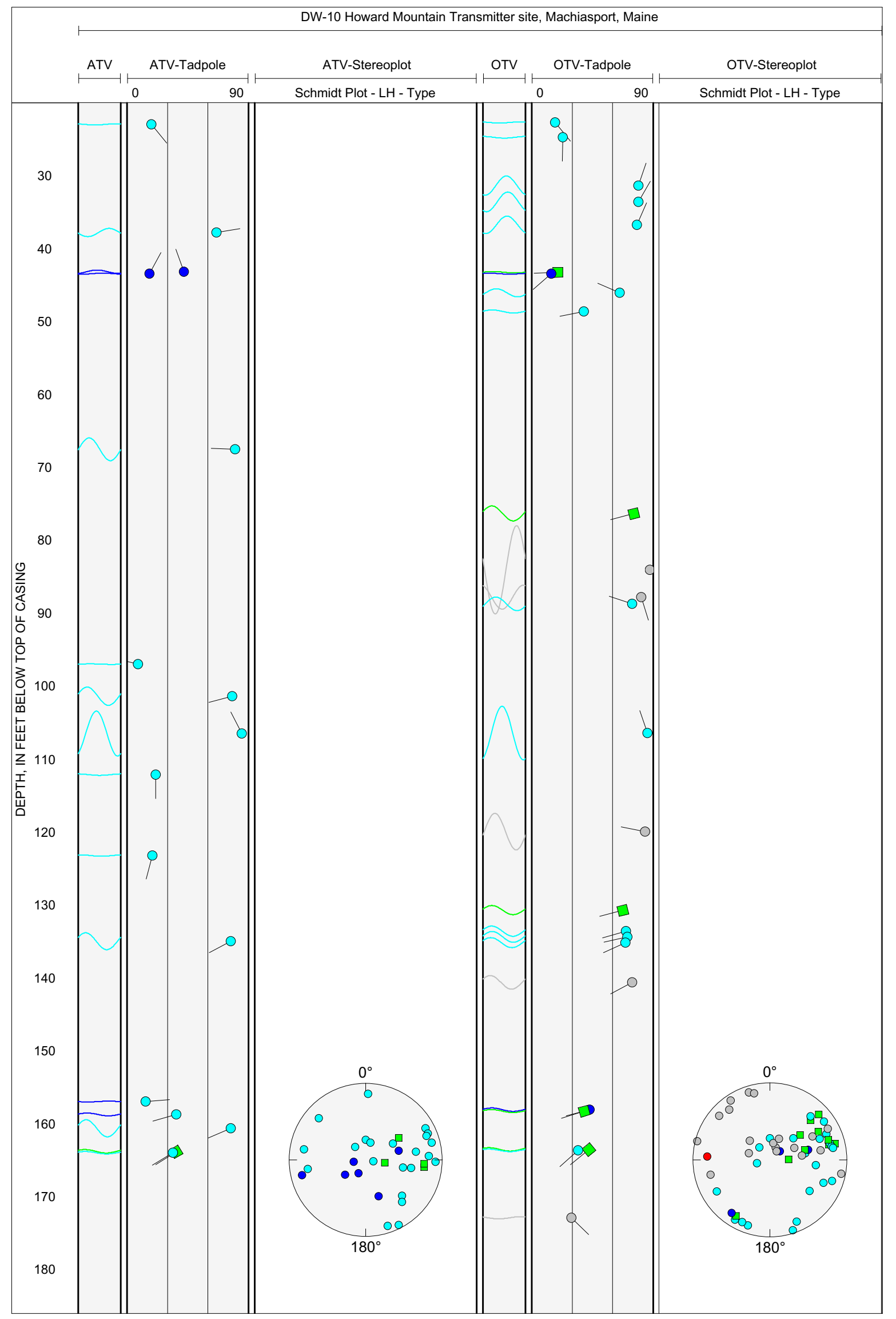

Figure 3B-3. Projection, tadpole, and stereoplots of interpretation of borehole image data for borehole DW-10, near Machiasport, Maine. 


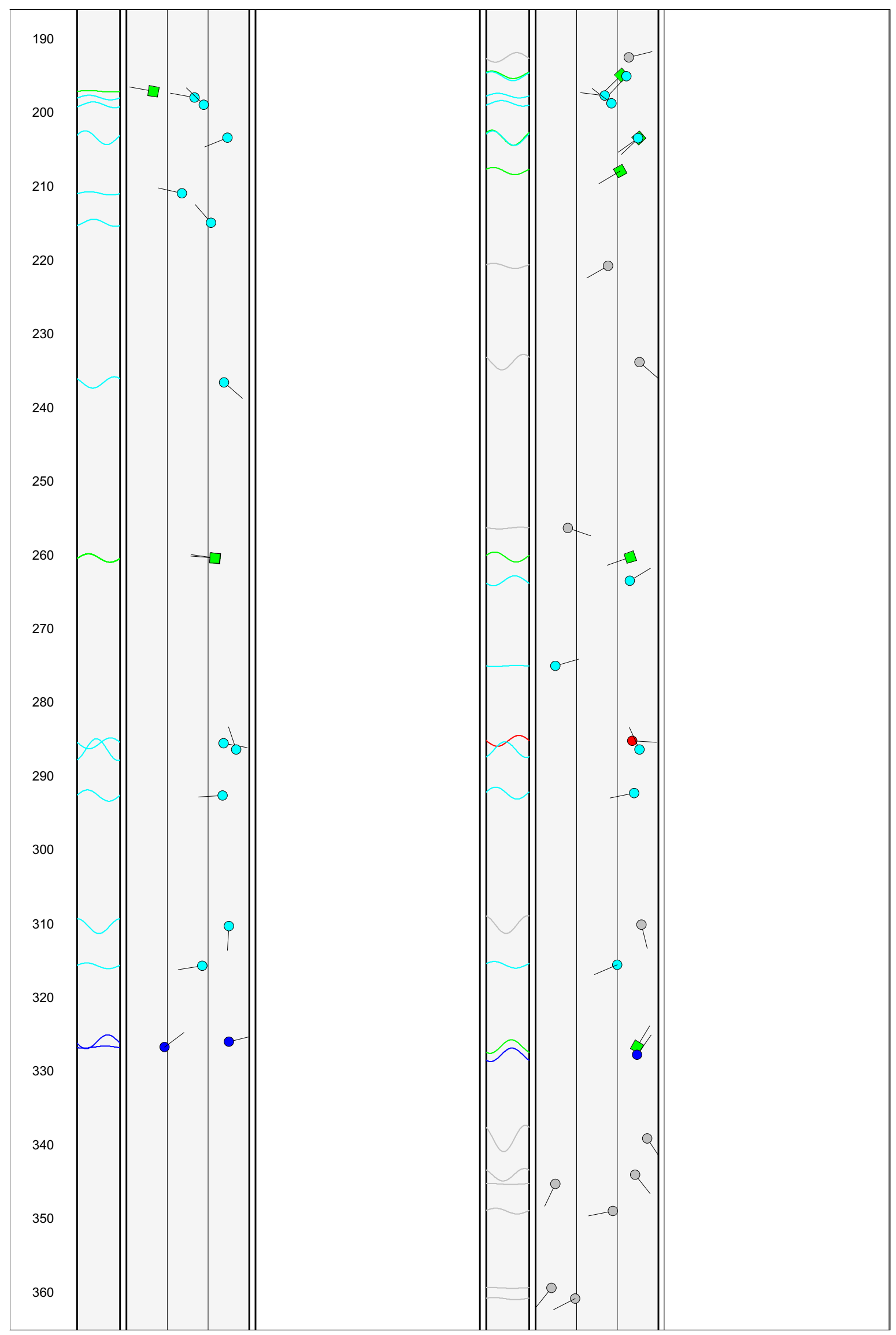

Figure 3B-3. Projection, tadpole, and stereoplots of interpretation of borehole image data for borehole DW-10, near Machiasport, Maine.-Continued 


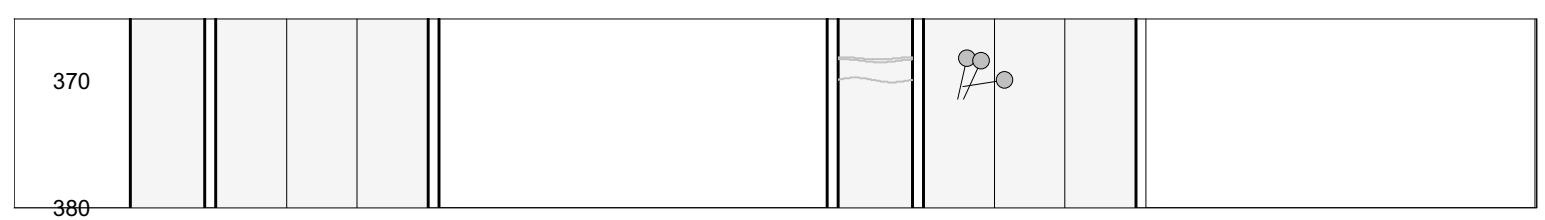

Figure 3B-3. Projection, tadpole, and stereoplots of interpretation of borehole image data for borehole DW-10, near Machiasport, Maine.-Continued 


\section{Appendix 4. Plots and interpretations of borehole geophysical logs collected by Geophysical Applications, Inc., for boreholes near Machiasport, Maine}




\section{Appendix 4.}

\section{Plots and interpretations of borehole geophysical logs collected by Geophysical Applications, Inc., near Machiasport, Maine}

A. Borehole MW-14 (near the Ground-to-Air Transmitter/Receiver Site on Miller Mountain)

Figure 4A-1. Borehole deviation logs for borehole MW-14, near Machiasport, Maine.

Table 4A-1. Interpretation of acoustic televiewer logs for borehole MW-14, near Machiasport, Maine.

Figure 4A-2. Projection, tadpole, and stereoplots of interpretation of borehole image data for borehole MW-14, near Machiasport, Maine.

B. Borehole MW-8 (in the Air Force Radar Tracking Station area on Howard Mountain)

Figure 4B-1. Borehole deviation logs for borehole MW-8, near Machiasport, Maine.

Table 4B-1. Interpretation of acoustic televiewer logs for borehole MW-8, near Machiasport, Maine.

Figure 4B-2. Projection, tadpole, and stereoplots of interpretation of borehole image data for borehole MW-8, near Machiasport, Maine.

C. Borehole MW-9 (in the Air Force Radar Tracking Station area on Howard Mountain)

Figure 4C-1. Borehole deviation logs for borehole MW-9, near Machiasport, Maine.

Table 4C-1. Interpretation of acoustic televiewer logs for borehole MW-9, near Machiasport, Maine.

Figure 4C-2. Projection, tadpole, and stereoplots of interpretation of borehole image data for borehole MW-9, near Machiasport, Maine.

D. Borehole MW-10 (in the Air Force Radar Tracking Station area on Howard Mountain)

Figure 4D-1. Borehole deviation logs for borehole MW-10, near Machiasport, Maine.

Table 4D-1. Interpretation of combined acoustic and optical televiewer logs for borehole MW-10, near Machiasport, Maine.

Figure 4D-2. Projection, tadpole, and stereoplots of interpretation of borehole image data for borehole MW-10, near Machiasport, Maine.

E. Borehole MW-11 (in the Air Force Radar Tracking Station area on Howard Mountain)

Figure 4E-1. Borehole deviation logs for borehole MW-11, near Machiasport, Maine.

Table 4E-1. Interpretation of acoustic televiewer logs for borehole MW-11, near Machiasport, Maine.

Figure 4E-2. Projection, tadpole, and stereoplots of interpretation of borehole image data for borehole MW-11, near Machiasport, Maine.

F. Borehole MW-12 (in the Air Force Radar Tracking Station area on Howard Mountain)

Figure 4F-1. Borehole deviation logs for borehole MW-12, near Machiasport, Maine.

Table 4F-1. Interpretation of acoustic televiewer logs for borehole MW-12, near Machiasport, Maine.

Figure 4F-2. Projection, tadpole, and stereoplots of interpretation of borehole image data for borehole MW-12, near Machiasport, Maine.

G. Borehole WY-3 (in the Air Force Radar Tracking Station area on Howard Mountain)

Figure 4G-1. Borehole deviation logs for borehole WY-3, near Machiasport, Maine.

Table 4G-1. Interpretation of acoustic televiewer logs for borehole WY-3, near Machiasport, Maine.

Figure 4G-2. Projection, tadpole, and stereoplots of interpretation of borehole image data for borehole WY-3, near Machiasport, Maine.

H. Borehole DW-4 (in the Air Force Radar Tracking Station area on Howard Mountain)

Figure 4H-1. Borehole deviation logs for borehole DW-4, near Machiasport, Maine.

Table 4H-1. Interpretation of acoustic televiewer logs for borehole DW-4, near Machiasport, Maine.

Figure 4H-2. Projection, tadpole, and stereoplots of interpretation of borehole image data for borehole DW-4, near Machiasport, Maine. 
I. Borehole MW-4 (near the Transmitter Site on Howard Mountain)

Figure 4I-1. Borehole deviation logs for borehole MW-4, near Machiasport, Maine.

Table 4I-1. Interpretation of acoustic televiewer logs for borehole MW-4, near Machiasport, Maine.

Table 4I-2. Interpretation of optical televiewer logs for borehole MW-4, near Machiasport, Maine.

Figure 4I-2. Projection, tadpole, and stereoplots of interpretation of borehole image data for borehole MW-4, near Machiasport, Maine.

J. Borehole MW-5 (near the Transmitter Site on Howard Mountain)

Figure 4J-1. Borehole deviation logs for borehole MW-5, near Machiasport, Maine.

Table 4J-1. Interpretation of acoustic televiewer logs for borehole MW-5, near Machiasport, Maine.

Figure 4J-2. Projection, tadpole, and stereoplots of interpretation of borehole image data for borehole MW-5, near Machiasport, Maine.

K. Borehole MW-6 (near the Transmitter Site on Howard Mountain)

Figure 4K-1. Borehole deviation logs for borehole MW-6, near Machiasport, Maine.

Table 4K-1. Interpretation of acoustic televiewer logs for borehole MW-6, near Machiasport, Maine.

Figure 4K-2. Projection, tadpole, and stereoplots of interpretation of borehole image data for borehole MW-6, near Machiasport, Maine.

L. Borehole MW-7 (near the Transmitter Site on Howard Mountain)

Figure 4L-1. Borehole deviation logs for borehole MW-7, near Machiasport, Maine.

Table 4L-1. Interpretation of acoustic televiewer logs for borehole MW-7, near Machiasport, Maine.

Figure 4L-2. Projection, tadpole, and stereoplots of interpretation of borehole image data for borehole MW-7, near Machiasport, Maine. 

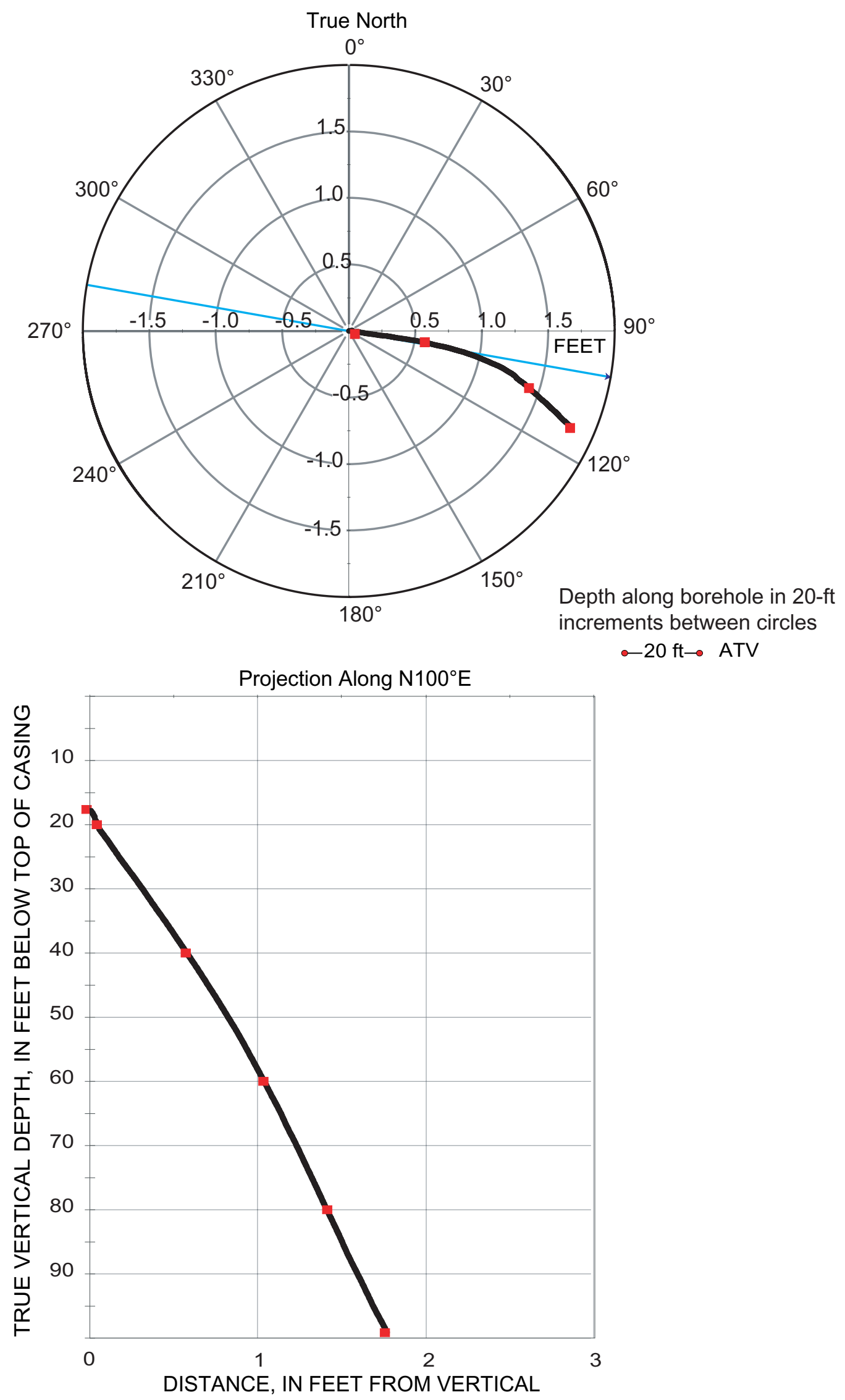

Figure 4A-1. Borehole deviation logs for borehole MW-14, near Machiasport, Maine. Blue line on radial plot (top) is line of projection for vertical plot (bottom).

[ft, foot; ATV, acoustic televiewer] 
Table 4A-1. Interpretation of acoustic televiewer logs for borehole MW-14, near Machiasport, Maine. [Televiewer data are corrected for deviation and magnetic declination, so orientations are relative to true north; depths are below top of casing, which is 4.10 feet above land surface; dip azimuth is given in degrees east of true north; strike is reported in right-hand-rule (RHR)-azimuthal degrees east of true north and where the direction of dip is 90 degrees to the right of strike]

\begin{tabular}{|c|c|c|c|c|c|c|c|}
\hline $\begin{array}{l}\text { Depth, } \\
\text { in feet }\end{array}$ & $\begin{array}{l}\text { Depth, } \\
\text { in meters }\end{array}$ & $\begin{array}{c}\text { Dip } \\
\text { azimuth }\end{array}$ & $\begin{array}{l}\text { Strike, } \\
\text { in RHR }\end{array}$ & Dip & $\begin{array}{c}\text { Dip } \\
\text { direction }\end{array}$ & Dip descriptor & Comment \\
\hline 25.42 & 7.75 & 203 & 113 & 86 & SW & Nearly vertical & Transmissive fracture \\
\hline 28.39 & 8.65 & 318 & 228 & 34 & NW & Moderate & Minor fracture \\
\hline 28.88 & 8.80 & 196 & 106 & 48 & $\mathrm{~s}$ & Moderate & Minor fracture \\
\hline 29.22 & 8.91 & 332 & 242 & 61 & NW & Steep & Transmissive fracture \\
\hline 29.83 & 9.09 & 63 & 333 & 36 & NE & Moderate & Minor fracture \\
\hline 29.93 & 9.12 & 353 & 263 & 88 & $\mathrm{~N}$ & Nearly vertical & Minor fracture \\
\hline 30.55 & 9.31 & 317 & 227 & 41 & NW & Moderate & Minor fracture \\
\hline 30.82 & 9.39 & 49 & 319 & 23 & NE & Shallow & Minor fracture \\
\hline 32.70 & 9.97 & 153 & 63 & 41 & SE & Moderate & Fracture \\
\hline 34.61 & 10.55 & 302 & 212 & 81 & NW & Nearly vertical & Minor fracture \\
\hline 35.73 & 10.89 & 152 & 62 & 31 & SE & Moderate & Minor fracture \\
\hline 36.20 & 11.03 & 146 & 56 & 39 & SE & Moderate & Minor fracture \\
\hline 39.32 & 11.98 & 305 & 215 & 78 & NW & Nearly vertical & Fracture \\
\hline 40.46 & 12.33 & 139 & 49 & 75 & SE & Nearly vertical & Minor fracture \\
\hline 42.26 & 12.88 & 192 & 102 & 84 & $\mathrm{~S}$ & Nearly vertical & Minor fracture \\
\hline 44.12 & 13.45 & 309 & 219 & 79 & NW & Nearly vertical & Fracture \\
\hline 45.37 & 13.83 & 199 & 109 & 75 & $\mathrm{~S}$ & Nearly vertical & Fracture \\
\hline 45.79 & 13.96 & 198 & 108 & 74 & $\mathrm{~S}$ & Nearly vertical & Fracture \\
\hline 47.77 & 14.56 & 118 & 28 & 52 & SE & Steep & Fracture \\
\hline 48.93 & 14.91 & 219 & 129 & 26 & SW & Shallow & Minor fracture \\
\hline 50.27 & 15.32 & 77 & 347 & 27 & $\mathrm{E}$ & Shallow & Minor fracture \\
\hline 52.47 & 15.99 & 186 & 96 & 23 & $\mathrm{~S}$ & Shallow & Fracture \\
\hline 53.38 & 16.27 & 115 & 25 & 33 & SE & Moderate & Minor fracture \\
\hline 54.11 & 16.49 & 214 & 124 & 24 & SW & Shallow & Fracture \\
\hline 55.35 & 16.87 & 330 & 240 & 78 & NW & Nearly vertical & Minor fracture \\
\hline 57.59 & 17.55 & 22 & 292 & 39 & $\mathrm{~N}$ & Moderate & Minor fracture \\
\hline 58.92 & 17.96 & 31 & 301 & 40 & NE & Moderate & Minor fracture \\
\hline 59.45 & 18.12 & 67 & 337 & 31 & NE & Moderate & Minor fracture \\
\hline 60.33 & 18.39 & 246 & 156 & 50 & SW & Moderate & Fracture \\
\hline 60.50 & 18.44 & 241 & 151 & 55 & SW & Steep & Minor fracture \\
\hline 61.01 & 18.59 & 239 & 149 & 58 & SW & Steep & Fracture \\
\hline 61.27 & 18.67 & 239 & 149 & 61 & SW & Steep & Transmissive fracture \\
\hline 61.90 & 18.87 & 249 & 159 & 60 & W & Steep & Minor fracture \\
\hline 62.37 & 19.01 & 235 & 145 & 63 & SW & Steep & Transmissive fracture \\
\hline 62.83 & 19.15 & 249 & 159 & 53 & W & Steep & Transmissive fracture \\
\hline 63.33 & 19.30 & 248 & 158 & 36 & W & Moderate & Fracture \\
\hline 63.36 & 19.31 & 242 & 152 & 36 & sw & Moderate & Fracture \\
\hline 63.63 & 19.39 & 191 & 101 & 42 & $\mathrm{~S}$ & Moderate & Minor fracture \\
\hline 64.18 & 19.56 & 234 & 144 & 35 & sw & Moderate & Minor fracture \\
\hline 64.68 & 19.71 & 73 & 343 & 72 & $\mathrm{E}$ & Nearly vertical & Fracture \\
\hline 65.03 & 19.82 & 221 & 131 & 17 & SW & Shallow & Minor fracture \\
\hline 65.25 & 19.89 & 245 & 155 & 56 & SW & Steep & Sealed feature \\
\hline 66.59 & 20.30 & 69 & 339 & 68 & $\mathrm{E}$ & Steep & Minor fracture \\
\hline 66.90 & 20.39 & 229 & 139 & 58 & sw & Steep & Minor fracture \\
\hline 67.36 & 20.53 & 244 & 154 & 64 & SW & Steep & Sealed feature \\
\hline 68.49 & 20.87 & 81 & 351 & 25 & $\mathrm{E}$ & Shallow & Minor fracture \\
\hline 70.71 & 21.55 & 229 & 139 & 74 & sw & Nearly vertical & Minor fracture \\
\hline 72.18 & 22.00 & 198 & 108 & 60 & $\mathrm{~S}$ & Steep & Minor fracture \\
\hline 73.35 & 22.36 & 34 & 304 & 58 & $\mathrm{NE}$ & Steep & Sealed feature \\
\hline 74.10 & 22.58 & 233 & 143 & 71 & SW & Nearly vertical & Minor fracture \\
\hline 75.90 & 23.13 & 213 & 123 & 78 & SW & Nearly vertical & Fracture \\
\hline 77.33 & 23.57 & 244 & 154 & 67 & SW & Steep & Sealed feature \\
\hline 78.05 & 23.79 & 233 & 143 & 72 & SW & Nearly vertical & Sealed feature \\
\hline 78.71 & 23.99 & 228 & 138 & 68 & SW & Steep & Sealed feature \\
\hline 79.91 & 24.36 & 250 & 160 & 65 & W & Steep & Minor fracture \\
\hline 80.65 & 24.58 & 280 & 190 & 23 & W & Shallow & Minor fracture \\
\hline
\end{tabular}


Table 4A-1. Interpretation of acoustic televiewer logs for borehole MW-14, near Machiasport, Maine.-Continued [Televiewer data are corrected for deviation and magnetic declination, so orientations are relative to true north; depths are below top of casing, which is 4.10 feet above land surface; dip azimuth is given in degrees east of true north; strike is reported in right-hand-rule (RHR)-azimuthal degrees east of true north and where the direction of dip is 90 degrees to the right of strike]

\begin{tabular}{ccccccll}
\hline $\begin{array}{c}\text { Depth, } \\
\text { in feet }\end{array}$ & $\begin{array}{c}\text { Depth, } \\
\text { in meters }\end{array}$ & $\begin{array}{c}\text { Dip } \\
\text { azimuth }\end{array}$ & $\begin{array}{c}\text { Strike, } \\
\text { in RHR }\end{array}$ & Dip & $\begin{array}{c}\text { Dip } \\
\text { direction }\end{array}$ & Dip descriptor & Comment \\
\hline 81.39 & 24.81 & 284 & 194 & 73 & W & Nearly vertical & Lithologic feature \\
82.75 & 25.22 & 250 & 160 & 53 & W & Steep & Lithologic feature \\
85.14 & 25.95 & 359 & 269 & 13 & N & Shallow & Fracture \\
86.67 & 26.42 & 315 & 225 & 30 & NW & Moderate & Minor fracture \\
87.86 & 26.78 & 14 & 284 & 19 & N & Shallow & Minor fracture \\
88.15 & 26.87 & 115 & 25 & 17 & SE & Shallow & Sealed feature \\
88.29 & 26.91 & 30 & 300 & 80 & NE & Nearly vertical & Sealed feature \\
88.93 & 27.10 & 247 & 157 & 27 & SW & Shallow & Sealed feature \\
90.64 & 27.63 & 237 & 147 & 67 & SW & Steep & Sealed feature \\
95.81 & 29.20 & 36 & 306 & 24 & NE & Shallow & Minor fracture \\
98.05 & 29.88 & 229 & 139 & 65 & SW & Steep & Minor fracture \\
104.65 & 31.90 & 295 & 205 & 39 & NW & Moderate & Transmissive fracture \\
105.01 & 32.01 & 35 & 305 & 11 & NE & Shallow & Transmissive fracture \\
\hline
\end{tabular}




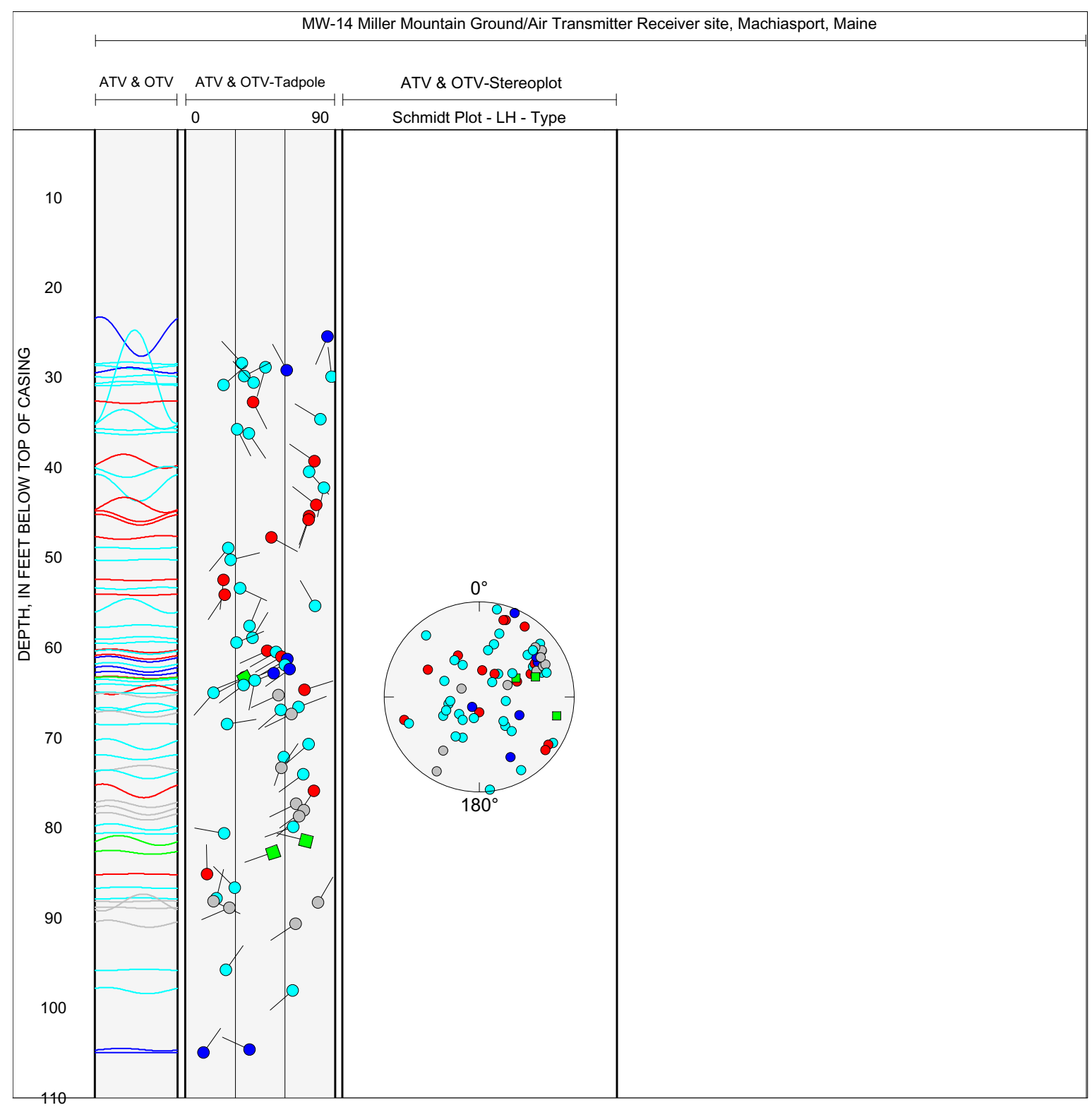

Figure 4A-2. Projection, tadpole, and stereoplots of interpretation of borehole image data for borehole MW-14, near Machiasport, Maine. 

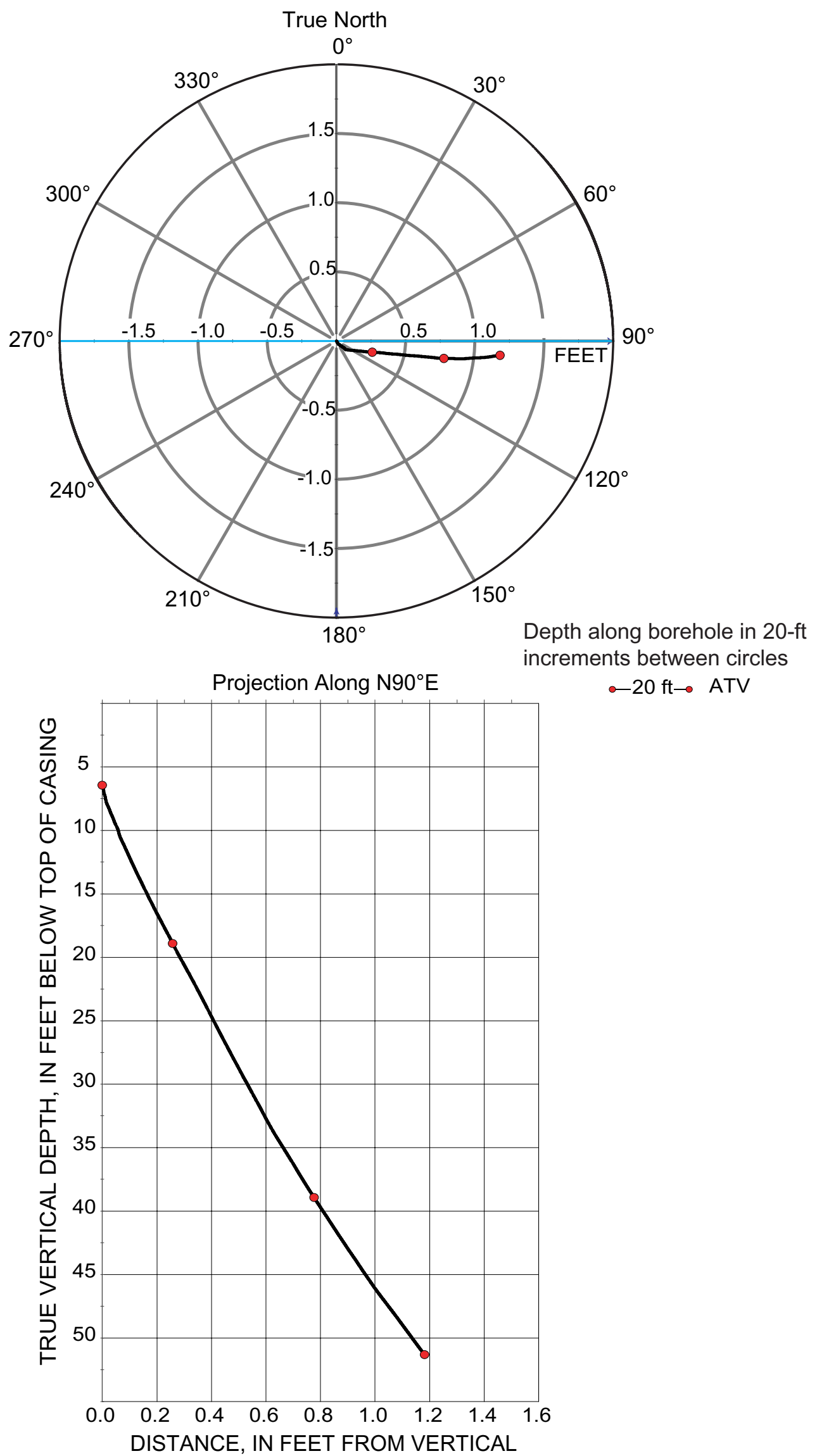

Figure 4B-1. Borehole deviation logs for borehole MW-8, near Machiasport, Maine. Blue line on radial plot (top) is line of projection for vertical plot (bottom).

[ft, foot; ATV, acoustic televiewer] 
Table 4B-1. Interpretation of acoustic televiewer logs for borehole MW-8, near Machiasport, Maine. [Televiewer data are corrected for deviation and magnetic declination, so orientations are relative to true north; depths are below top of casing, which is 3.42 feet above land surface; dip azimuth is given in degrees east of true north; strike is reported in right-hand-rule (RHR)-azimuthal degrees east of true north and where the direction of dip is 90 degrees to the right of strike]

\begin{tabular}{|c|c|c|c|c|c|c|c|}
\hline $\begin{array}{l}\text { Depth, } \\
\text { in feet }\end{array}$ & $\begin{array}{c}\text { Depth, } \\
\text { in meters }\end{array}$ & $\begin{array}{c}\text { Dip } \\
\text { azimuth }\end{array}$ & $\begin{array}{l}\text { Strike, } \\
\text { in RHR }\end{array}$ & Dip & $\begin{array}{c}\text { Dip } \\
\text { direction }\end{array}$ & Dip descriptor & Comment \\
\hline 12.09 & 3.68 & 172 & 82 & 17 & $\mathrm{~S}$ & Shallow & Fracture \\
\hline 12.50 & 3.81 & 146 & 56 & 43 & SE & Moderate & Minor fracture \\
\hline 12.76 & 3.89 & 179 & 89 & 78 & $S$ & Nearly vertical & Minor fracture \\
\hline 12.97 & 3.95 & 124 & 34 & 52 & SE & Steep & Minor fracture \\
\hline 13.47 & 4.11 & 274 & 184 & 13 & W & Shallow & Minor fracture \\
\hline 13.98 & 4.26 & 101 & 11 & 28 & $E$ & Shallow & Minor fracture \\
\hline 14.24 & 4.34 & 120 & 30 & 30 & SE & Shallow & Fracture \\
\hline 14.85 & 4.53 & 116 & 26 & 50 & SE & Moderate & Fracture \\
\hline 14.97 & 4.56 & 286 & 196 & 33 & W & Moderate & Minor fracture \\
\hline 15.27 & 4.65 & 114 & 24 & 84 & SE & Nearly vertical & Minor fracture \\
\hline 16.48 & 5.02 & 193 & 103 & 14 & $S$ & Shallow & Fracture \\
\hline 16.91 & 5.15 & 220 & 130 & 36 & SW & Moderate & Fracture \\
\hline 17.43 & 5.31 & 196 & 106 & 16 & $S$ & Shallow & Fracture \\
\hline 17.75 & 5.41 & 282 & 192 & 6 & W & Nearly horizontal & Minor fracture \\
\hline 18.16 & 5.53 & 179 & 89 & 8 & $S$ & Nearly horizontal & Minor fracture \\
\hline 18.83 & 5.74 & 21 & 291 & 17 & $\mathrm{~N}$ & Shallow & Minor fracture \\
\hline 19.14 & 5.83 & 47 & 317 & 9 & NE & Nearly horizontal & Minor fracture \\
\hline 19.57 & 5.96 & 212 & 122 & 14 & SW & Shallow & Fracture \\
\hline 19.78 & 6.03 & 202 & 112 & 9 & $S$ & Nearly horizontal & Minor fracture \\
\hline 20.48 & 6.24 & 251 & 161 & 21 & W & Shallow & Minor fracture \\
\hline 20.64 & 6.29 & 215 & 125 & 20 & SW & Shallow & Minor fracture \\
\hline 21.09 & 6.43 & 173 & 83 & 39 & $S$ & Moderate & Minor fracture \\
\hline 21.20 & 6.46 & 186 & 96 & 17 & $S$ & Shallow & Fracture \\
\hline 21.55 & 6.57 & 231 & 141 & 22 & SW & Shallow & Minor fracture \\
\hline 21.74 & 6.63 & 116 & 26 & 12 & SE & Shallow & Minor fracture \\
\hline 22.03 & 6.71 & 224 & 134 & 14 & SW & Shallow & Transmissive fracture \\
\hline 23.25 & 7.09 & 116 & 26 & 14 & SE & Shallow & Fracture \\
\hline 23.40 & 7.13 & 135 & 45 & 70 & SE & Steep & Minor fracture \\
\hline 23.58 & 7.19 & 137 & 47 & 58 & SE & Steep & Minor fracture \\
\hline 24.06 & 7.33 & 194 & 104 & 29 & $S$ & Shallow & Fracture \\
\hline 24.65 & 7.51 & 166 & 76 & 36 & $S$ & Moderate & Minor fracture \\
\hline 25.22 & 7.69 & 178 & 88 & 25 & $S$ & Shallow & Fracture \\
\hline 26.40 & 8.05 & 213 & 123 & 49 & SW & Moderate & Fracture \\
\hline 27.08 & 8.25 & 174 & 84 & 21 & $S$ & Shallow & Minor fracture \\
\hline 27.61 & 8.42 & 165 & 75 & 22 & $S$ & Shallow & Minor fracture \\
\hline 28.74 & 8.76 & 145 & 55 & 62 & SE & Steep & Minor fracture \\
\hline 28.75 & 8.76 & 285 & 195 & 22 & W & Shallow & Transmissive fracture \\
\hline 28.88 & 8.80 & 192 & 102 & 18 & $S$ & Shallow & Transmissive fracture \\
\hline 30.51 & 9.30 & 170 & 80 & 45 & $S$ & Moderate & Transmissive fracture \\
\hline 30.92 & 9.42 & 153 & 63 & 75 & SE & Nearly vertical & Transmissive fracture \\
\hline 31.89 & 9.72 & 215 & 125 & 23 & SW & Shallow & Minor fracture \\
\hline 33.18 & 10.11 & 131 & 41 & 83 & SE & Nearly vertical & Minor fracture \\
\hline 33.98 & 10.36 & 149 & 59 & 23 & SE & Shallow & Fracture \\
\hline 34.53 & 10.52 & 171 & 81 & 29 & $S$ & Shallow & Fracture \\
\hline 35.37 & 10.78 & 144 & 54 & 80 & SE & Nearly vertical & Minor fracture \\
\hline 35.47 & 10.81 & 133 & 43 & 20 & SE & Shallow & Fracture \\
\hline 35.82 & 10.92 & 191 & 101 & 18 & $S$ & Shallow & Fracture \\
\hline 37.47 & 11.42 & 163 & 73 & 17 & $S$ & Shallow & Fracture \\
\hline 37.76 & 11.51 & 325 & 235 & 86 & NW & Nearly vertical & Minor fracture \\
\hline 39.21 & 11.95 & 150 & 60 & 18 & SE & Shallow & Minor fracture \\
\hline 41.44 & 12.63 & 266 & 176 & 14 & W & Shallow & Minor fracture \\
\hline 42.40 & 12.92 & 123 & 33 & 75 & SE & Nearly vertical & Minor fracture \\
\hline 43.90 & 13.38 & 151 & 61 & 76 & SE & Nearly vertical & Minor fracture \\
\hline 44.15 & 13.46 & 121 & 31 & 75 & SE & Nearly vertical & Minor fracture \\
\hline 45.29 & 13.80 & 12 & 282 & 18 & $\mathrm{~N}$ & Shallow & Minor fracture \\
\hline 46.18 & 14.07 & 153 & 63 & 77 & SE & Nearly vertical & Minor fracture \\
\hline
\end{tabular}


Table 4B-1. Interpretation of acoustic televiewer logs for borehole MW-8, near Machiasport, Maine.-Continued [Televiewer data are corrected for deviation and magnetic declination, so orientations are relative to true north; depths are below top of casing, which is 3.42 feet above land surface; dip azimuth is given in degrees east of true north; strike is reported in right-hand-rule (RHR)-azimuthal degrees east of true north and where the direction of dip is 90 degrees to the right of strike]

\begin{tabular}{rrrrrcrl}
\hline $\begin{array}{c}\text { Depth, } \\
\text { in feet }\end{array}$ & $\begin{array}{c}\text { Depth, } \\
\text { in meters }\end{array}$ & $\begin{array}{c}\text { Dip } \\
\text { azimuth }\end{array}$ & $\begin{array}{c}\text { Strike, } \\
\text { in RHR }\end{array}$ & Dip & $\begin{array}{c}\text { Dip } \\
\text { direction }\end{array}$ & Dip descriptor & Comment \\
\hline 47.03 & 14.33 & 150 & 60 & 83 & SE & Nearly vertical & Minor fracture \\
47.48 & 14.47 & 159 & 69 & 67 & S & Steep & Fracture \\
47.53 & 14.49 & 236 & 146 & 19 & SW & Shallow & Fracture \\
48.36 & 14.74 & 178 & 88 & 32 & S & Moderate & Minor fracture \\
49.37 & 15.05 & 148 & 58 & 64 & SE & Steep & Fracture \\
49.68 & 15.14 & 158 & 68 & 80 & S & Nearly vertical & other \\
51.07 & 15.57 & 136 & 46 & 60 & SE & Steep & Fracture \\
53.06 & 16.17 & 170 & 80 & 13 & S & Shallow & Fracture \\
\hline
\end{tabular}




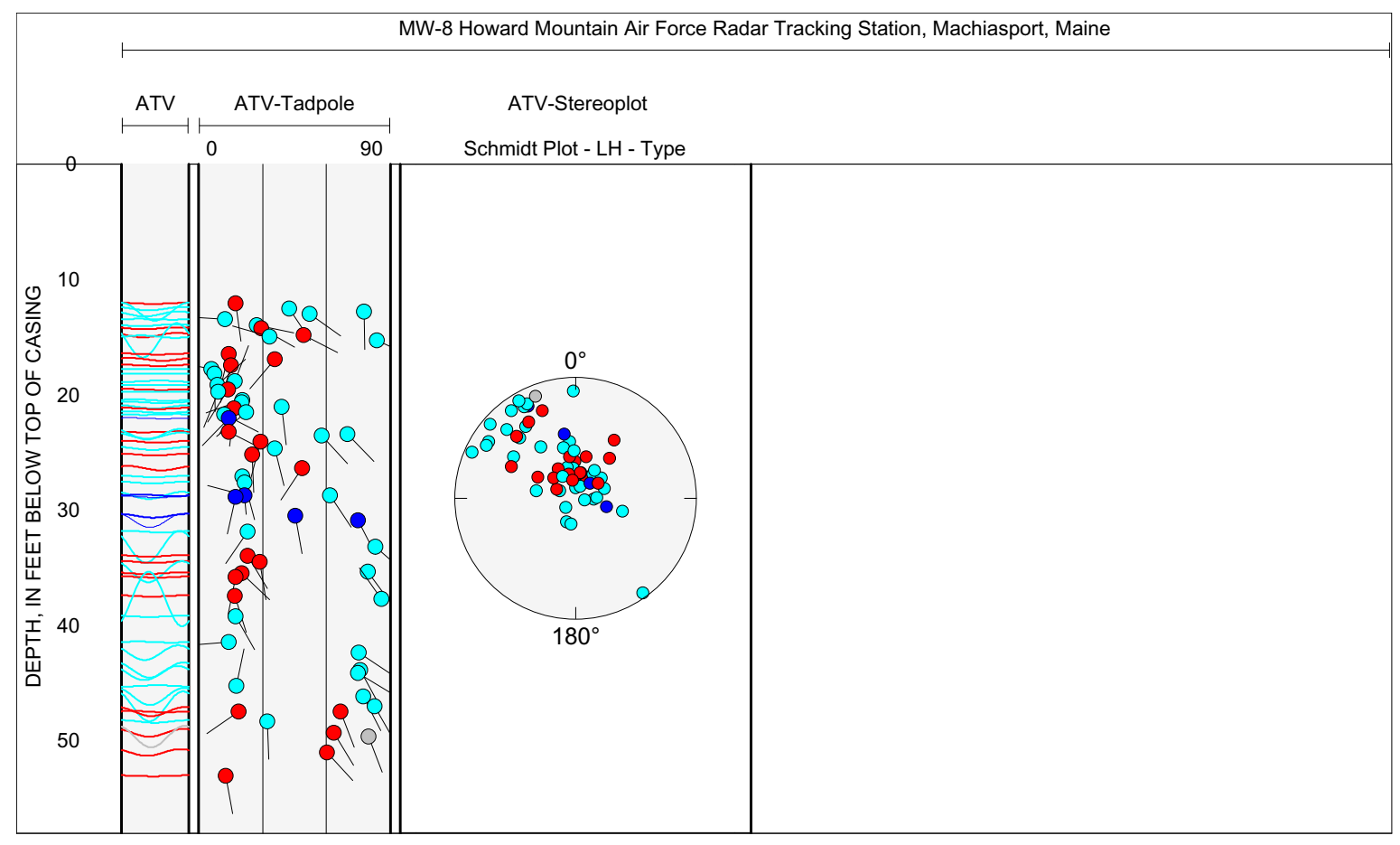

Figure 4B-2. Projection, tadpole, and stereoplots of interpretation of borehole image data for borehole MW-8, near Machiasport, Maine. 

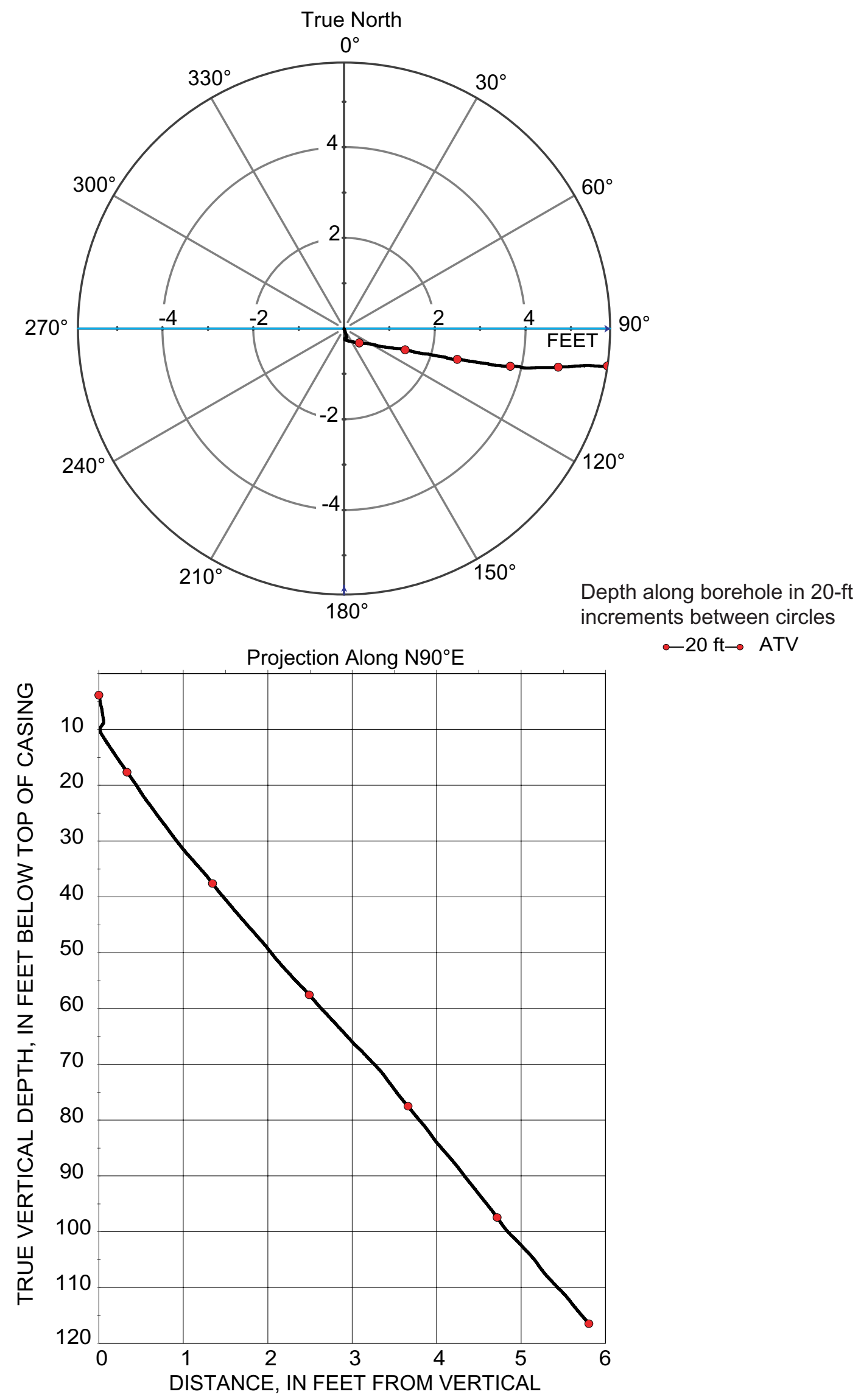

$-20 \mathrm{ft} \rightarrow$ ATV 
Table 4C-1. Interpretation of acoustic televiewer logs for borehole MW-9, near Machiasport, Maine.

[Televiewer data are corrected for deviation and magnetic declination, so orientations are relative to true north; depths are below top of casing, which is 2.89 feet above land surface; dip azimuth is given in degrees east of true north; strike is reported in right-hand-rule (RHR)-azimuthal degrees east of true north and where the direction of dip is 90 degrees to the right of strike]

\begin{tabular}{|c|c|c|c|c|c|c|c|}
\hline $\begin{array}{l}\text { Depth, } \\
\text { in feet }\end{array}$ & $\begin{array}{l}\text { Depth, } \\
\text { in meters }\end{array}$ & $\begin{array}{c}\text { Dip } \\
\text { azimuth }\end{array}$ & $\begin{array}{c}\text { Strike, } \\
\text { in RHR }\end{array}$ & Dip & $\begin{array}{c}\text { Dip } \\
\text { direction }\end{array}$ & Dip descriptor & Comment \\
\hline 14.59 & 4.45 & 303 & 213 & 79 & NW & Nearly vertical & Minor fracture \\
\hline 17.85 & 5.44 & 30 & 300 & 35 & NE & Moderate & Transmissive fracture \\
\hline 18.29 & 5.57 & 356 & 266 & 85 & $\mathrm{~N}$ & Nearly vertical & Partial trace - upper toe \\
\hline 20.06 & 6.11 & 354 & 264 & 85 & $\mathrm{~N}$ & Nearly vertical & Minor fracture \\
\hline 20.63 & 6.29 & 328 & 238 & 70 & NW & Steep & Minor fracture \\
\hline 24.78 & 7.55 & 317 & 227 & 86 & NW & Nearly vertical & Minor fracture \\
\hline 26.57 & 8.10 & 25 & 295 & 79 & NE & Nearly vertical & Minor fracture \\
\hline 27.82 & 8.48 & 319 & 229 & 83 & NW & Nearly vertical & Minor fracture \\
\hline 30.68 & 9.35 & 324 & 234 & 84 & NW & Nearly vertical & Transmissive fracture \\
\hline 35.15 & 10.71 & 312 & 222 & 90 & NW & Nearly vertical & Minor fracture \\
\hline 36.16 & 11.02 & 54 & 324 & 18 & $\mathrm{NE}$ & Shallow & Minor fracture \\
\hline 41.54 & 12.66 & 269 & 179 & 85 & W & Nearly vertical & Fracture \\
\hline 45.74 & 13.94 & 188 & 98 & 84 & $\mathrm{~S}$ & Nearly vertical & Minor fracture \\
\hline 49.08 & 14.96 & 18 & 288 & 24 & $\mathrm{~N}$ & Shallow & Contact \\
\hline 49.52 & 15.09 & 305 & 215 & 89 & NW & Nearly vertical & Minor fracture \\
\hline 50.01 & 15.24 & 52 & 322 & 25 & NE & Shallow & Contact \\
\hline 53.13 & 16.19 & 191 & 101 & 68 & $\mathrm{~S}$ & Steep & Minor fracture \\
\hline 57.44 & 17.51 & 150 & 60 & 79 & SE & Nearly vertical & Minor fracture \\
\hline 60.38 & 18.40 & 141 & 51 & 81 & SE & Nearly vertical & Minor fracture \\
\hline 61.86 & 18.85 & 170 & 80 & 84 & $\mathrm{~S}$ & Nearly vertical & Fracture \\
\hline 62.73 & 19.12 & 179 & 89 & 84 & S & Nearly vertical & Minor fracture \\
\hline 63.19 & 19.26 & 161 & 71 & 81 & $S$ & Nearly vertical & Fracture \\
\hline 67.69 & 20.63 & 181 & 91 & 83 & $S$ & Nearly vertical & Minor fracture \\
\hline 68.25 & 20.80 & 11 & 281 & 86 & $\mathrm{~N}$ & Nearly vertical & Minor fracture \\
\hline 75.93 & 23.14 & 280 & 190 & 37 & W & Moderate & Contact \\
\hline 76.01 & 23.17 & 65 & 335 & 22 & NE & Shallow & Fracture \\
\hline 76.71 & 23.38 & 43 & 313 & 31 & NE & Moderate & Fracture \\
\hline 77.33 & 23.57 & 241 & 151 & 18 & SW & Shallow & Minor fracture \\
\hline 77.81 & 23.72 & 260 & 170 & 75 & W & Nearly vertical & Transmissive fracture \\
\hline 78.58 & 23.95 & 273 & 183 & 79 & W & Nearly vertical & Transmissive fracture \\
\hline 78.85 & 24.03 & 266 & 176 & 68 & W & Steep & Minor fracture \\
\hline 80.22 & 24.45 & 10 & 280 & 35 & $\mathrm{~N}$ & Moderate & Minor fracture \\
\hline 80.26 & 24.46 & 157 & 67 & 61 & SE & Steep & Fracture \\
\hline 81.33 & 24.79 & 360 & 270 & 38 & $\mathrm{~N}$ & Moderate & Fracture \\
\hline 82.75 & 25.22 & 60 & 330 & 5 & NE & Nearly horizontal & Minor fracture \\
\hline 83.21 & 25.36 & 358 & 268 & 53 & $\mathrm{~N}$ & Steep & Fracture \\
\hline 84.52 & 25.76 & 157 & 67 & 46 & SE & Moderate & Minor fracture \\
\hline 84.94 & 25.89 & 101 & 11 & 23 & $E$ & Shallow & Minor fracture \\
\hline 86.58 & 26.39 & 139 & 49 & 13 & SE & Shallow & Minor fracture \\
\hline 88.48 & 26.97 & 0 & 270 & 69 & $\mathrm{~N}$ & Steep & Fracture \\
\hline 89.09 & 27.15 & 151 & 61 & 39 & SE & Moderate & Minor fracture \\
\hline 89.46 & 27.27 & 138 & 48 & 23 & SE & Shallow & Minor fracture \\
\hline 89.57 & 27.30 & 349 & 259 & 70 & $\mathrm{~N}$ & Steep & Fracture \\
\hline 90.29 & 27.52 & 347 & 257 & 81 & $\mathrm{~N}$ & Nearly vertical & Minor fracture \\
\hline 92.39 & 28.16 & 159 & 69 & 63 & $\mathrm{~S}$ & Steep & Minor fracture \\
\hline 94.49 & 28.80 & 273 & 183 & 76 & W & Nearly vertical & Fracture \\
\hline 97.80 & 29.81 & 6 & 276 & 17 & $\mathrm{~N}$ & Shallow & Fracture \\
\hline 99.22 & 30.24 & 303 & 213 & 7 & NW & Nearly horizontal & Minor fracture \\
\hline 99.33 & 30.27 & 178 & 88 & 31 & $\mathrm{~S}$ & Moderate & Fracture \\
\hline 103.96 & 31.69 & 258 & 168 & 84 & W & Nearly vertical & Sealed fracture \\
\hline 106.58 & 32.48 & 68 & 338 & 13 & $E$ & Shallow & Contact \\
\hline 107.76 & 32.84 & 92 & 2 & 11 & $E$ & Shallow & Contact \\
\hline 109.21 & 33.29 & 255 & 165 & 88 & W & Nearly vertical & Transmissive fracture \\
\hline 114.38 & 34.86 & 268 & 178 & 88 & W & Nearly vertical & Minor fracture \\
\hline 119.88 & 36.54 & 159 & 69 & 42 & $\mathrm{~S}$ & Moderate & Minor fracture \\
\hline 120.43 & 36.71 & 160 & 70 & 54 & S & Steep & Minor fracture \\
\hline
\end{tabular}




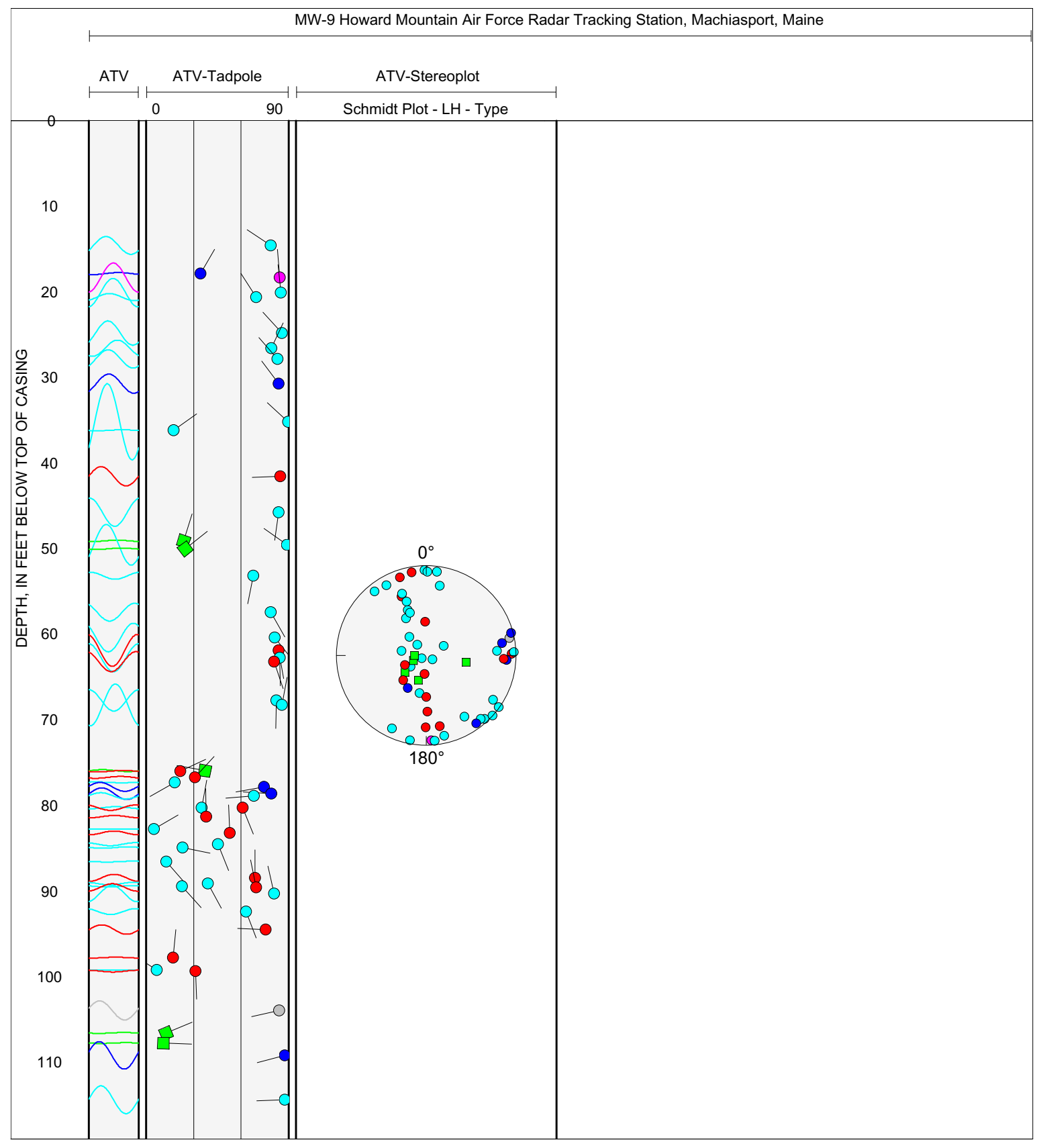

Figure 4C-2. Projection, tadpole, and stereoplots of interpretation of borehole image data for borehole MW-9, near Machiasport, Maine. 


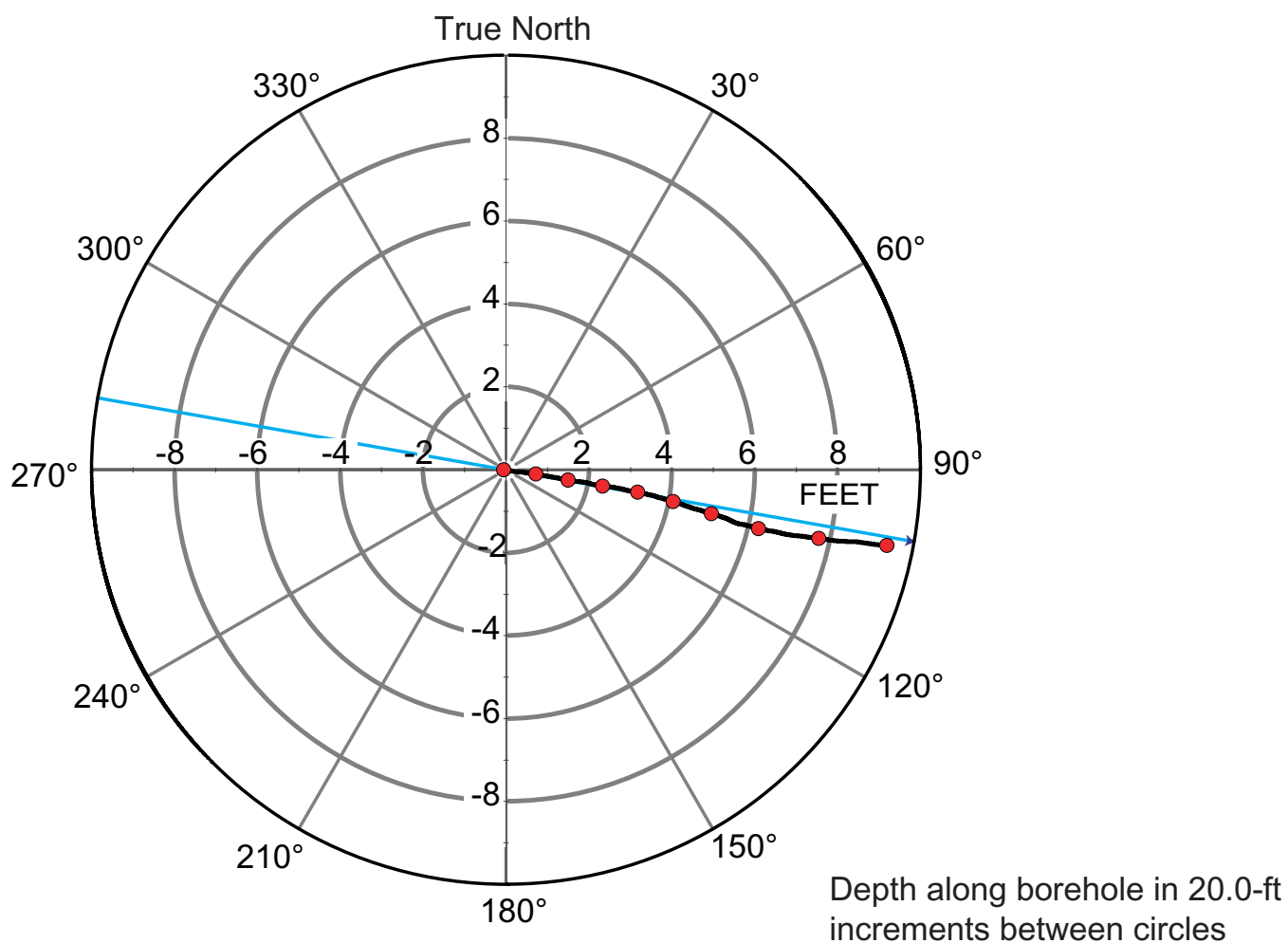

increments between circles

$\sim 20.0 \mathrm{ft} \longrightarrow$ ATV

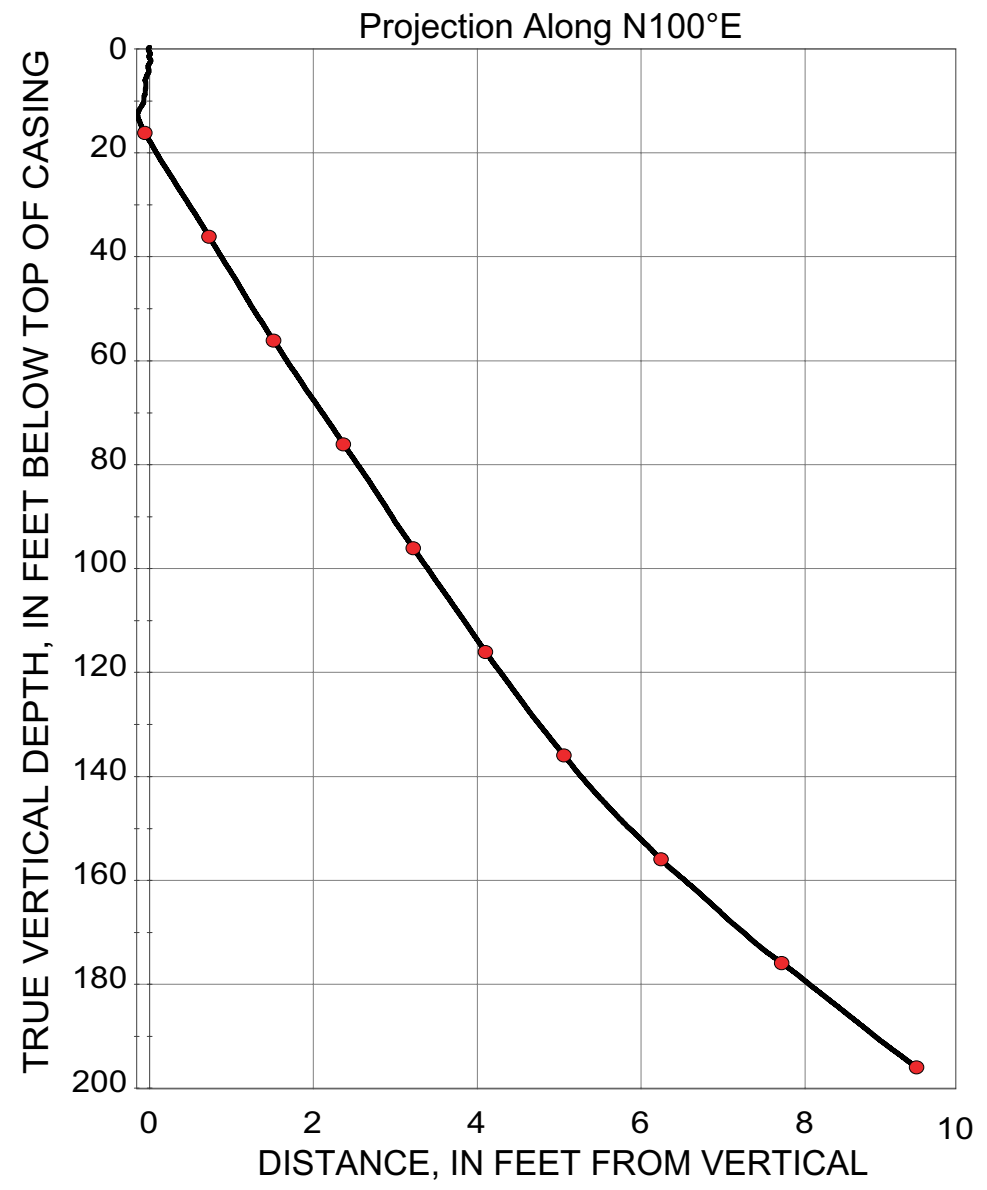

Figure 4D-1. Borehole deviation logs for borehole MW-10, near Machiasport, Maine. Blue line on radial plot (top) is line of projection for vertical plot (bottom).

[ft, foot; ATV, acoustic televiewer] 
Table 4D-1. Interpretation of combined acoustic and optical televiewer logs for borehole MW-10, near Machiasport, Maine. [Televiewer data are corrected for deviation and magnetic declination, so orientations are relative to true north; depths are below top of casing, which is 2.66 feet above land surface; dip azimuth is given in degrees east of true north; strike is reported in right-hand-rule (RHR)-azimuthal degrees east of true north and where the direction of dip is 90 degrees to the right of strike]

\begin{tabular}{|c|c|c|c|c|c|c|c|}
\hline $\begin{array}{l}\text { Depth, } \\
\text { in feet }\end{array}$ & $\begin{array}{l}\text { Depth, } \\
\text { in meters }\end{array}$ & $\begin{array}{c}\text { Dip } \\
\text { azimuth }\end{array}$ & $\begin{array}{c}\text { Strike, } \\
\text { in RHR }\end{array}$ & Dip & $\begin{array}{c}\text { Dip } \\
\text { direction }\end{array}$ & Dip descriptor & Comment \\
\hline 21.15 & 6.45 & 239 & 149 & 2 & SW & Nearly horizontal & Bottom of casing \\
\hline 24.63 & 7.51 & 80 & 350 & 30 & $E$ & Moderate & Minor fracture \\
\hline 28.94 & 8.82 & 247 & 157 & 88 & SW & Nearly vertical & Partial fracture \\
\hline 40.34 & 12.30 & 256 & 166 & 80 & W & Nearly vertical & Partial fracture \\
\hline 53.06 & 16.17 & 57 & 327 & 57 & NE & Steep & Minor fracture \\
\hline 60.00 & 18.29 & 116 & 26 & 54 & SE & Steep & Minor fracture \\
\hline 64.88 & 19.77 & 296 & 206 & 84 & NW & Nearly vertical & Partial fracture \\
\hline 66.76 & 20.35 & 124 & 34 & 82 & SE & Nearly vertical & Minor fracture \\
\hline 69.13 & 21.07 & 321 & 231 & 80 & NW & Nearly vertical & Minor fracture \\
\hline 72.55 & 22.11 & 29 & 299 & 18 & $\mathrm{NE}$ & Shallow & Minor fracture \\
\hline 75.49 & 23.01 & 308 & 218 & 85 & NW & Nearly vertical & Minor fracture \\
\hline 75.86 & 23.12 & 31 & 301 & 81 & $\mathrm{NE}$ & Nearly vertical & Minor fracture \\
\hline 76.57 & 23.34 & 247 & 157 & 79 & SW & Nearly vertical & Minor fracture \\
\hline 79.36 & 24.19 & 192 & 102 & 12 & $\mathrm{~S}$ & Shallow & Minor fracture \\
\hline 80.29 & 24.47 & 300 & 210 & 82 & NW & Nearly vertical & Minor fracture \\
\hline 82.92 & 25.27 & 5 & 275 & 83 & $\mathrm{~N}$ & Nearly vertical & Minor fracture \\
\hline 84.49 & 25.75 & 185 & 95 & 48 & $\mathrm{~S}$ & Moderate & Minor fracture \\
\hline 85.73 & 26.13 & 26 & 296 & 80 & NE & Nearly vertical & Minor fracture \\
\hline 89.02 & 27.13 & 12 & 282 & 85 & $\mathrm{~N}$ & Nearly vertical & Minor fracture \\
\hline 93.83 & 28.60 & 25 & 295 & 75 & NE & Nearly vertical & Partial fracture \\
\hline 95.08 & 28.98 & 48 & 318 & 76 & NE & Nearly vertical & Partial fracture \\
\hline 95.95 & 29.24 & 310 & 220 & 80 & NW & Nearly vertical & Minor fracture \\
\hline 97.23 & 29.63 & 304 & 214 & 78 & NW & Nearly vertical & Minor fracture \\
\hline 98.37 & 29.98 & 243 & 153 & 81 & SW & Nearly vertical & Minor fracture \\
\hline 105.94 & 32.29 & 301 & 211 & 80 & NW & Nearly vertical & Minor fracture \\
\hline 107.81 & 32.86 & 13 & 283 & 74 & $\mathrm{~N}$ & Nearly vertical & Minor fracture \\
\hline 108.92 & 33.20 & 31 & 301 & 73 & NE & Nearly vertical & Minor fracture \\
\hline 109.86 & 33.48 & 75 & 345 & 67 & $\mathrm{E}$ & Steep & Minor fracture \\
\hline 119.25 & 36.35 & 109 & 19 & 20 & E & Shallow & Fracture \\
\hline 121.47 & 37.02 & 340 & 250 & 87 & $\mathrm{~N}$ & Nearly vertical & Minor fracture \\
\hline 123.69 & 37.70 & 287 & 197 & 2 & W & Nearly horizontal & Other \\
\hline 126.62 & 38.59 & 32 & 302 & 59 & NE & Steep & Fracture \\
\hline 129.78 & 39.56 & 73 & 343 & 54 & $E$ & Steep & Sealed fracture \\
\hline 132.15 & 40.28 & 77 & 347 & 52 & $\mathrm{E}$ & Steep & Sealed fracture \\
\hline 132.55 & 40.40 & 219 & 129 & 42 & SW & Moderate & Fracture \\
\hline 134.08 & 40.87 & 73 & 343 & 65 & $\mathrm{E}$ & Steep & Minor fracture \\
\hline 140.66 & 42.87 & 155 & 65 & 48 & SE & Moderate & Minor fracture \\
\hline 142.81 & 43.53 & 119 & 29 & 69 & SE & Steep & Possible fracture \\
\hline 145.76 & 44.43 & 104 & 14 & 44 & $E$ & Moderate & Minor fracture \\
\hline 150.05 & 45.73 & 273 & 183 & 57 & $\mathrm{~W}$ & Steep & Sealed fracture \\
\hline 155.60 & 47.42 & 306 & 216 & 19 & NW & Shallow & Transmissive fracture \\
\hline 155.87 & 47.51 & 77 & 347 & 79 & $\mathrm{E}$ & Nearly vertical & Sealed fracture \\
\hline 156.42 & 47.67 & 331 & 241 & 64 & NW & Steep & Sealed fracture \\
\hline 157.02 & 47.86 & 126 & 36 & 31 & SE & Moderate & Sealed fracture \\
\hline 163.47 & 49.82 & 252 & 162 & 61 & W & Steep & Minor fracture \\
\hline 164.65 & 50.18 & 271 & 181 & 67 & W & Steep & Possible fracture \\
\hline 165.75 & 50.52 & 67 & 337 & 24 & NE & Shallow & Contact \\
\hline 168.17 & 51.26 & 157 & 67 & 56 & SE & Steep & Sealed fracture \\
\hline 168.49 & 51.35 & 295 & 205 & 72 & NW & Nearly vertical & Transmissive fracture \\
\hline 171.51 & 52.27 & 148 & 58 & 56 & SE & Steep & Sealed fracture \\
\hline 171.76 & 52.35 & 141 & 51 & 53 & SE & Steep & Minor fracture \\
\hline 173.22 & 52.79 & 176 & 86 & 31 & $\mathrm{~S}$ & Moderate & Sealed fracture \\
\hline 175.01 & 53.34 & 91 & 1 & 59 & $\mathrm{E}$ & Steep & Contact \\
\hline 177.16 & 54.00 & 82 & 352 & 52 & $\mathrm{E}$ & Steep & Contact \\
\hline 180.17 & 54.91 & 92 & 2 & 37 & $\mathrm{E}$ & Moderate & Minor fracture \\
\hline 182.71 & 55.69 & 239 & 149 & 87 & SW & Nearly vertical & Minor fracture \\
\hline 207.13 & 63.13 & 2 & 272 & 89 & $\mathrm{~N}$ & Nearly vertical & Partial fracture \\
\hline
\end{tabular}




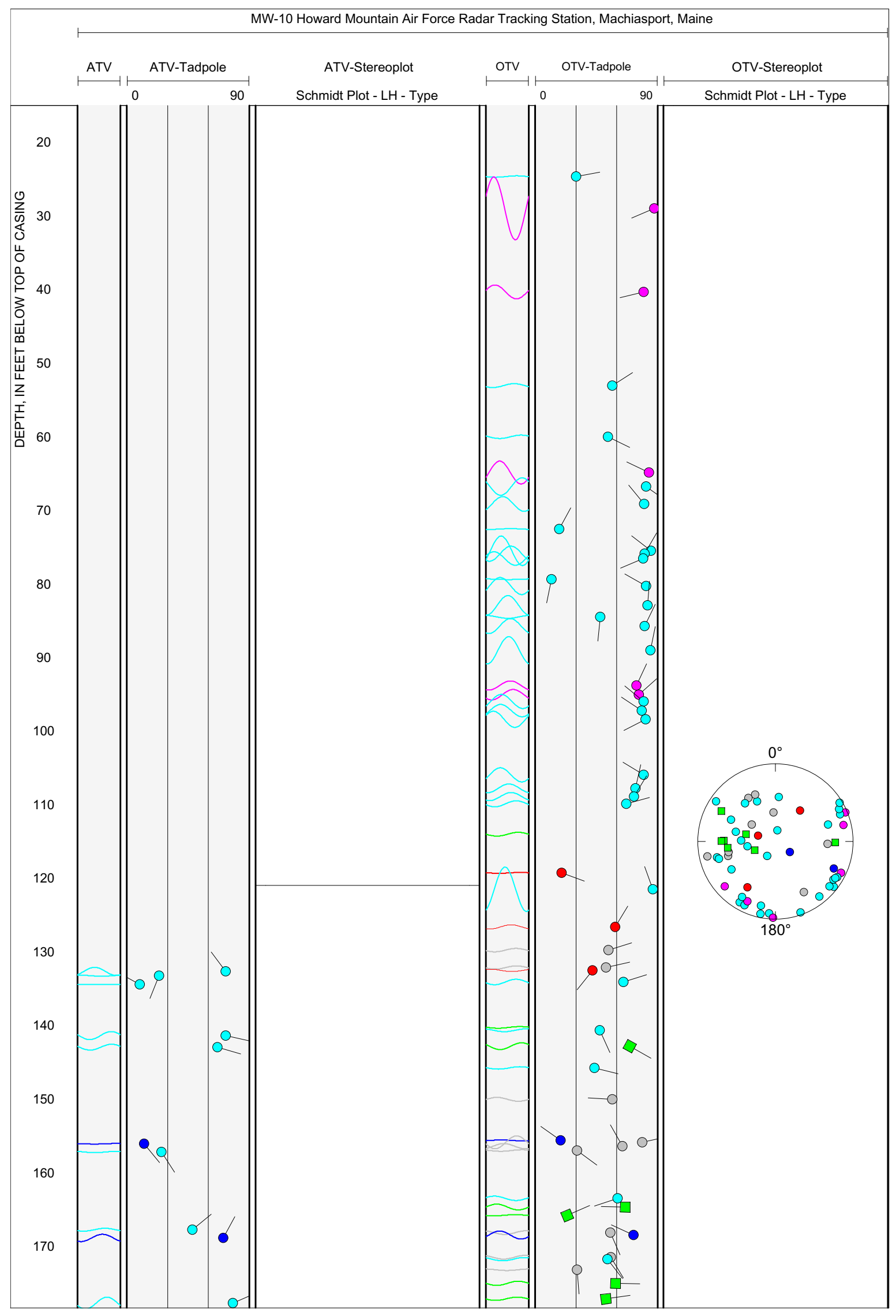

Figure 4D-2. Projection, tadpole, and stereoplots of interpretation of borehole image data for borehole MW-10, near Machiasport, Maine. 


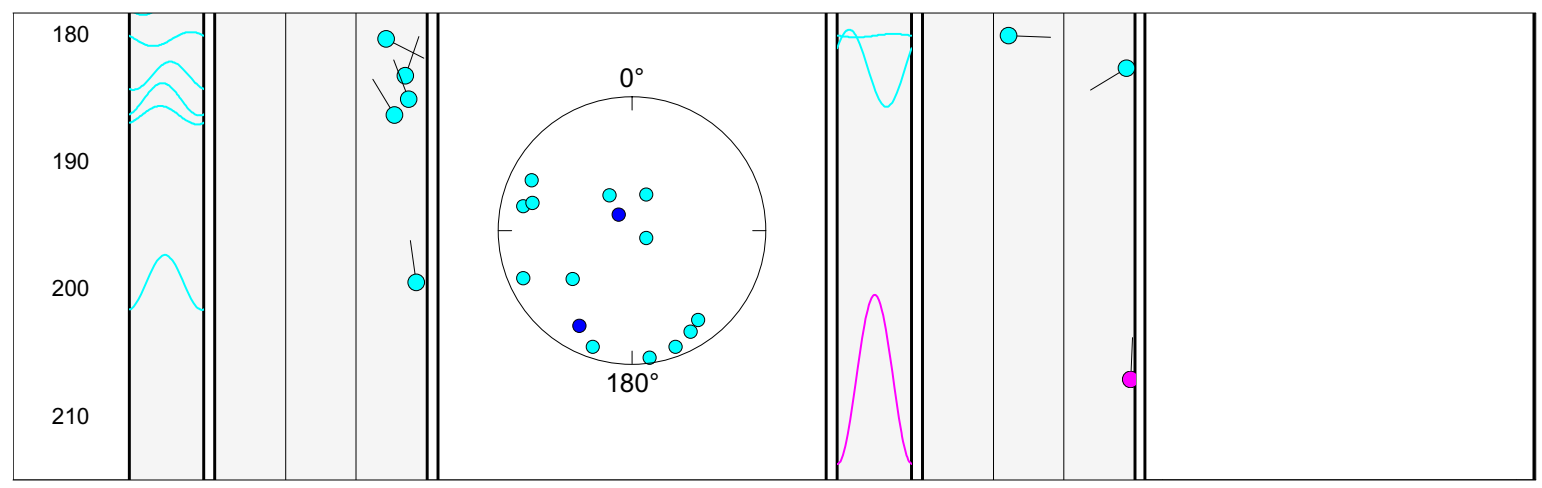

Figure 4D-2. Projection, tadpole, and stereoplots of interpretation of borehole image data for borehole MW-10, near Machiasport, Maine.-Continued 


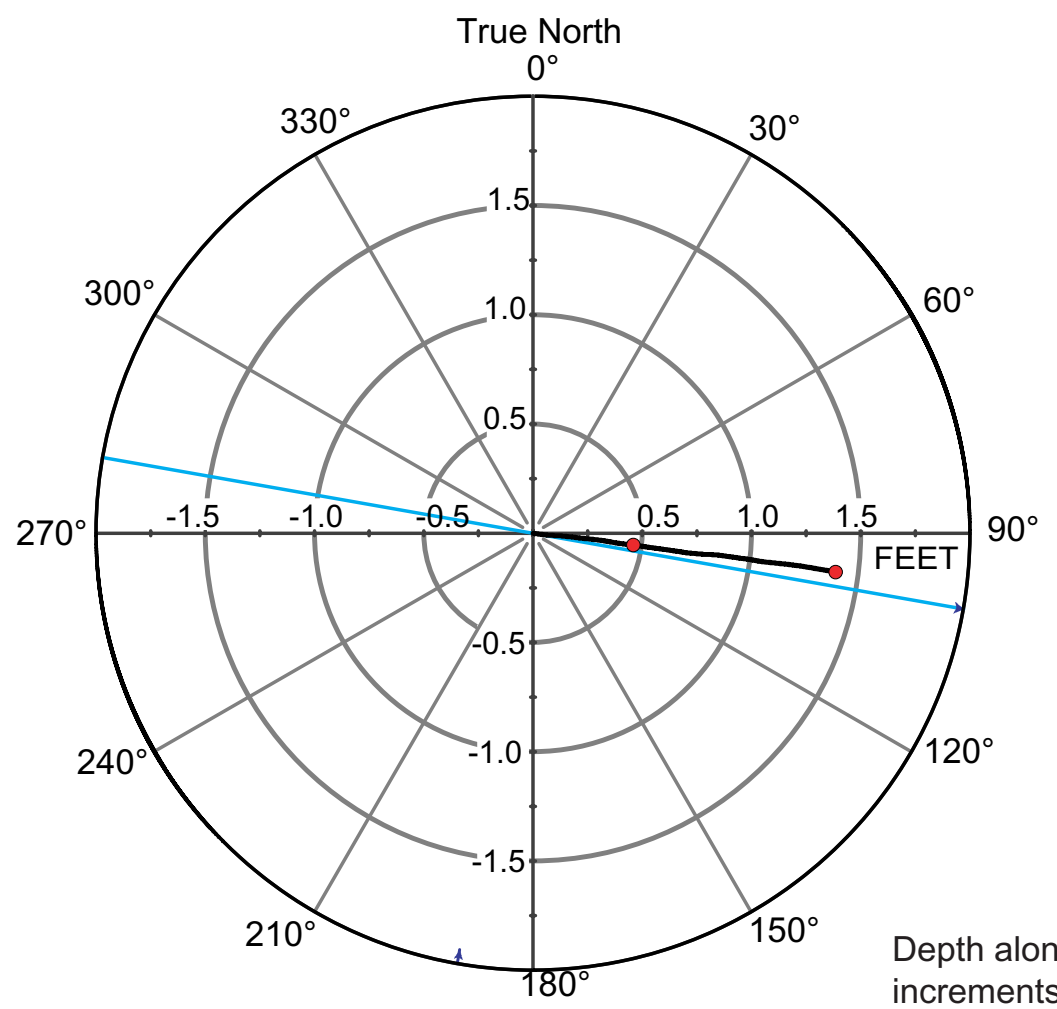

Depth along borehole in $10-\mathrm{ft}$ increments between circles

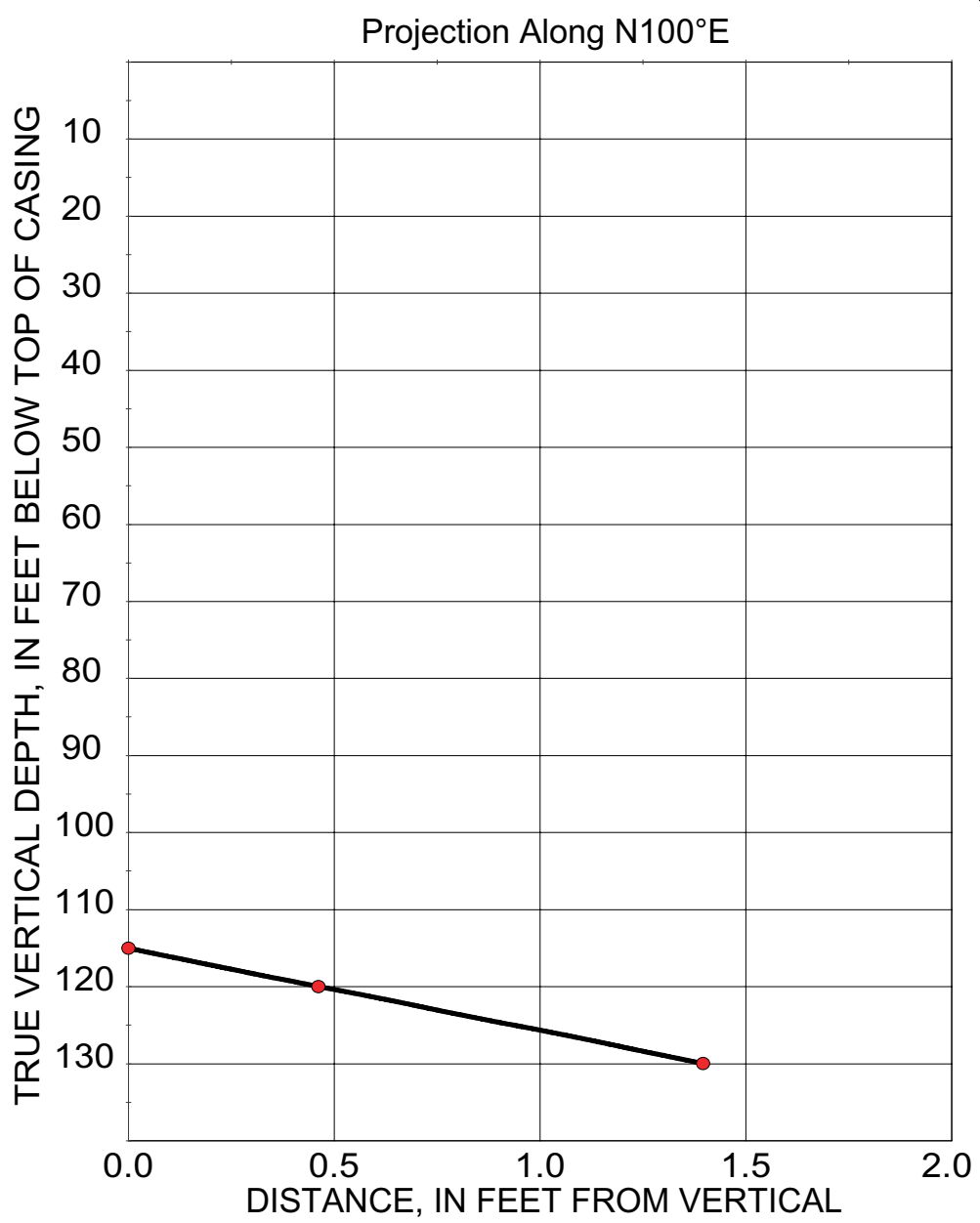

Figure 4E-1. Borehole deviation logs for borehole MW-11, near Machiasport, Maine. Blue line on radial plot (top) is line of projection for vertical plot (bottom).

[ft, foot; ATV, acoustic televiewer] 
Table 4E-1. Interpretation of acoustic televiewer logs for borehole MW-11, near Machiasport, Maine.

[Televiewer data are corrected for deviation and magnetic declination, so orientations are relative to true north; depths are below top of casing, which is 2.21 feet above land surface; dip azimuth is given in degrees east of true north; strike is reported in right-hand-rule (RHR)-azimuthal degrees east of true north and where the direction of dip is 90 degrees to the right of strike]

\begin{tabular}{crrrrcrl}
\hline $\begin{array}{c}\text { Depth, } \\
\text { in feet }\end{array}$ & $\begin{array}{c}\text { Depth, } \\
\text { in meters }\end{array}$ & $\begin{array}{c}\text { Dip } \\
\text { azimuth }\end{array}$ & $\begin{array}{c}\text { Strike, } \\
\text { in RHR }\end{array}$ & Dip & $\begin{array}{c}\text { Dip } \\
\text { direction }\end{array}$ & Dip descriptor & Comment \\
\hline 101.03 & 30.79 & 218 & 128 & 7 & SW & Nearly horizontal & Transmissive fracture \\
106.98 & 32.61 & 272 & 182 & 78 & W & Nearly vertical & Sealed fracture \\
117.90 & 35.93 & 240 & 150 & 66 & SW & Steep & Sealed fracture \\
125.32 & 38.20 & 251 & 161 & 69 & W & Steep & Sealed fracture \\
128.84 & 39.27 & 188 & 98 & 62 & S & Steep & Contact \\
128.87 & 39.28 & 191 & 101 & 64 & S & Steep & Minor fracture \\
131.84 & 40.18 & 313 & 223 & 85 & NW & Nearly vertical & Minor fracture \\
140.82 & 42.92 & 79 & 349 & 88 & $\mathrm{E}$ & Nearly vertical & Minor fracture \\
144.42 & 44.02 & 71 & 341 & 83 & $\mathrm{E}$ & Nearly vertical & Sealed fracture \\
152.16 & 46.38 & 197 & 107 & 75 & $\mathrm{~S}$ & Nearly vertical & Sealed fracture \\
153.78 & 46.87 & 105 & 15 & 61 & $\mathrm{E}$ & Steep & Contact \\
153.98 & 46.93 & 100 & 10 & 59 & $\mathrm{E}$ & Steep & Minor fracture \\
154.86 & 47.20 & 99 & 9 & 54 & $\mathrm{E}$ & Steep & Transmissive fracture \\
155.73 & 47.46 & 120 & 30 & 61 & SE & Steep & Transmissive fracture \\
158.67 & 48.36 & 81 & 351 & 67 & $\mathrm{E}$ & Steep & Minor fracture \\
160.51 & 48.92 & 60 & 330 & 81 & $\mathrm{NE}$ & Nearly vertical & Minor fracture \\
162.73 & 49.60 & 63 & 333 & 65 & $\mathrm{NE}$ & Steep & Sealed fracture \\
164.71 & 50.20 & 271 & 181 & 28 & $\mathrm{~W}$ & Shallow & Transmissive fracture \\
167.99 & 51.20 & 322 & 232 & 73 & $\mathrm{NW}$ & Nearly vertical & Minor fracture \\
168.77 & 51.44 & 36 & 306 & 78 & $\mathrm{NE}$ & Nearly vertical & Minor fracture \\
169.75 & 51.74 & 107 & 17 & 55 & $\mathrm{E}$ & Steep & Minor fracture \\
179.76 & 54.79 & 346 & 256 & 31 & $\mathrm{~N}$ & Moderate & Transmissive fracture \\
187.39 & 57.11 & 321 & 231 & 81 & $\mathrm{NW}$ & Nearly vertical & Minor fracture \\
190.88 & 58.18 & 287 & 197 & 55 & $\mathrm{~W}$ & Steep & Sealed fracture \\
193.78 & 59.06 & 260 & 170 & 73 & $\mathrm{~W}$ & Nearly vertical & Contact \\
193.84 & 59.08 & 246 & 156 & 69 & $\mathrm{SW}$ & Steep & Transmissive fracture \\
197.57 & 60.22 & 335 & 245 & 77 & $\mathrm{NW}$ & Nearly vertical & Minor fracture \\
\hline & & & & & & &
\end{tabular}




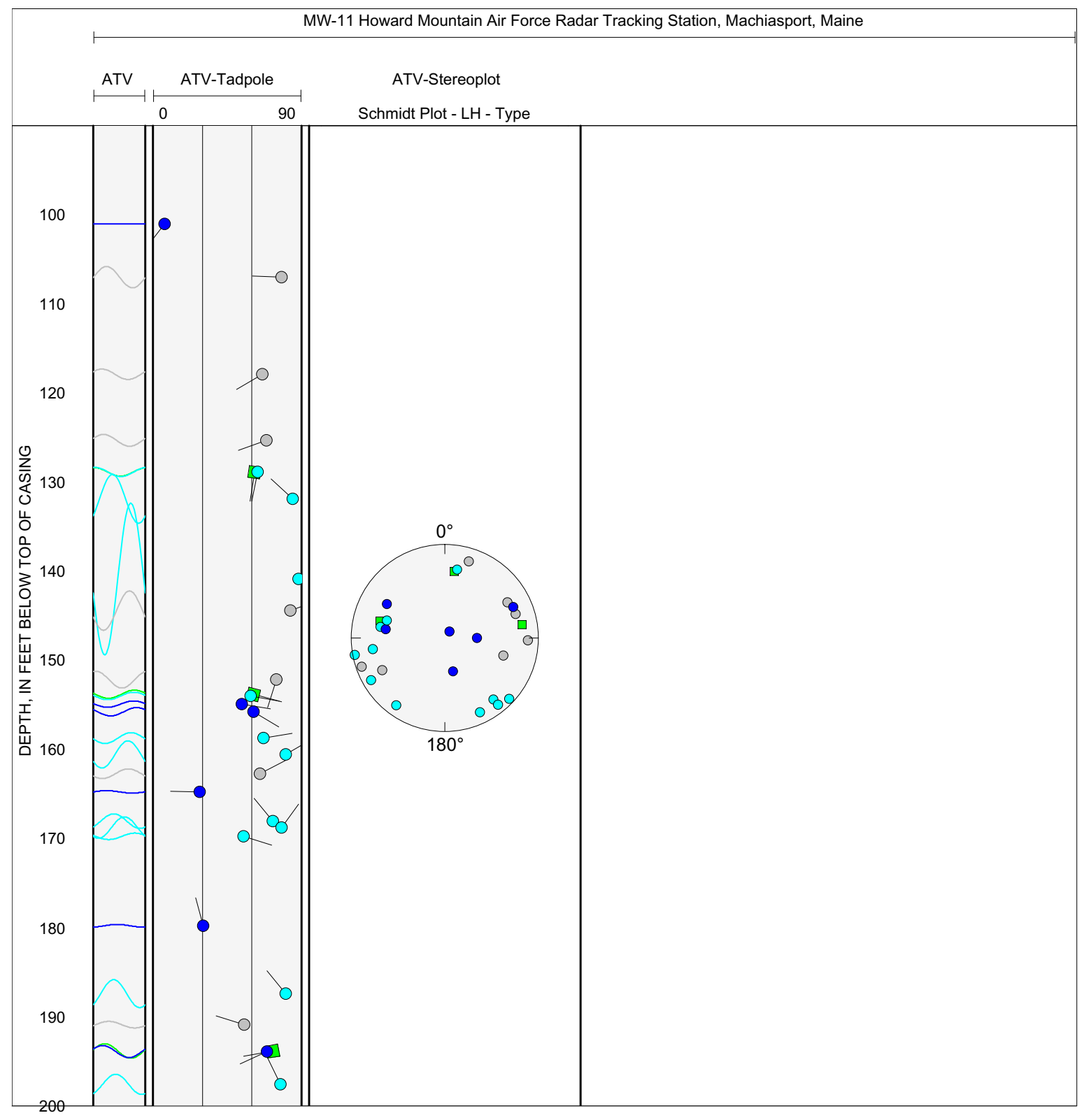

Figure 4E-2. Projection, tadpole, and stereoplots of interpretation of borehole image data for borehole MW-11, near Machiasport, Maine. 


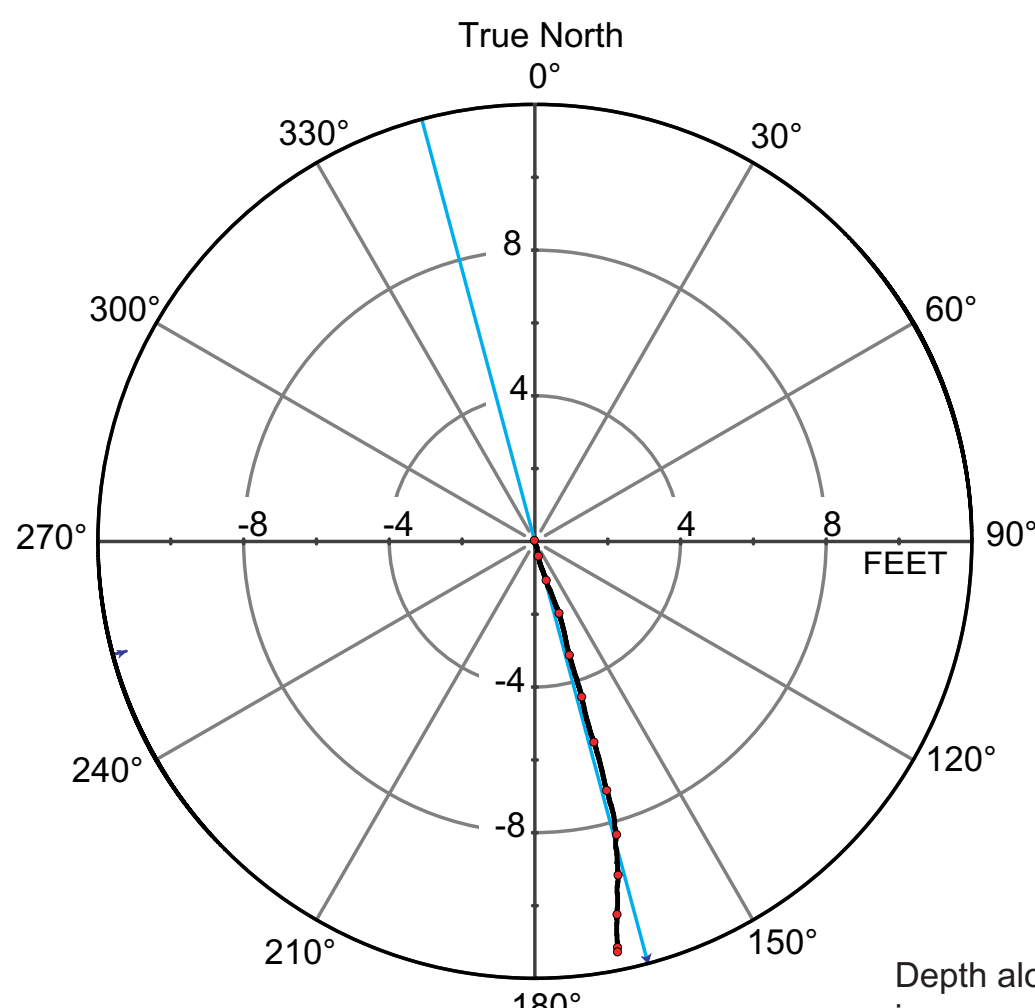

Depth along borehole in $20-\mathrm{ft}$ increments between circles

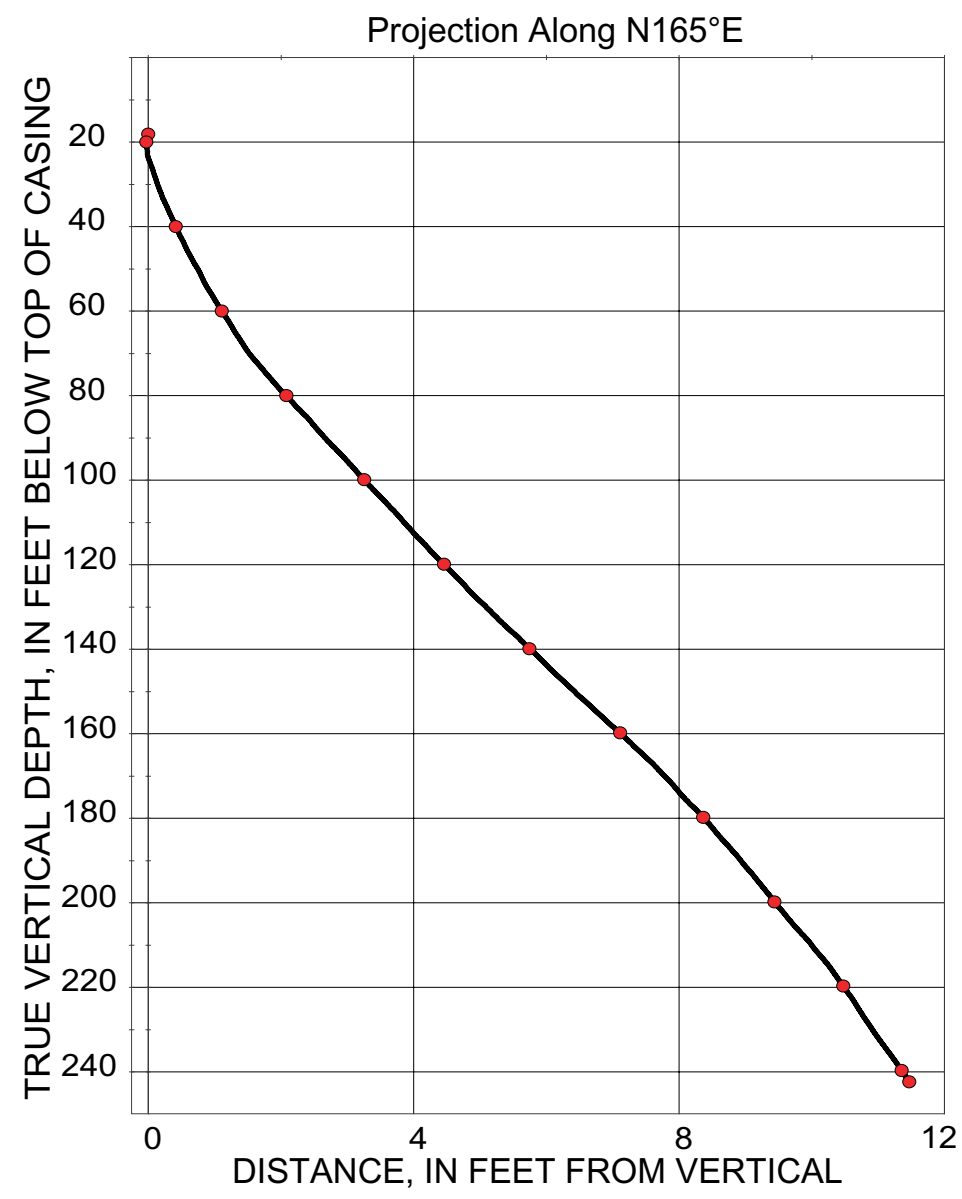

Figure 4F-1. Borehole deviation logs for borehole MW-12, near Machiasport, Maine. Blue line on radial plot (top) is line of projection for vertical plot (bottom).

[ft, foot; ATV, acoustic televiewer] 
Table 4F-1. Interpretation of acoustic televiewer logs for borehole MW-12, near Machiasport, Maine.

[Televiewer data are corrected for deviation and magnetic declination, so orientations are relative to true north; depths are below top of casing, which is 1.44 feet above land surface; dip azimuth is given in degrees east of true north; strike is reported in right-hand-rule (RHR)-azimuthal degrees east of true north and where the direction of dip is 90 degrees to the right of strike]

\begin{tabular}{|c|c|c|c|c|c|c|c|}
\hline $\begin{array}{l}\text { Depth, } \\
\text { in feet }\end{array}$ & $\begin{array}{l}\text { Depth, } \\
\text { in meters }\end{array}$ & $\begin{array}{c}\text { Dip } \\
\text { azimuth }\end{array}$ & $\begin{array}{c}\text { Strike, } \\
\text { in RHR }\end{array}$ & Dip & $\begin{array}{c}\text { Dip } \\
\text { direction }\end{array}$ & Dip descriptor & Comment \\
\hline 20.34 & 6.20 & 156 & 66 & 1 & SE & Nearly horizontal & Bottom of casing \\
\hline 21.44 & 6.53 & 160 & 70 & 1 & $\mathrm{~S}$ & Nearly horizontal & Minor fracture \\
\hline 23.89 & 7.28 & 111 & 21 & 40 & E & Moderate & Fracture \\
\hline 24.71 & 7.53 & 111 & 21 & 31 & $\mathrm{E}$ & Moderate & Fracture \\
\hline 26.00 & 7.92 & 241 & 151 & 77 & sw & Nearly vertical & Contact \\
\hline 28.64 & 8.73 & 168 & 78 & 81 & $\mathrm{~S}$ & Nearly vertical & Minor fracture \\
\hline 34.46 & 10.50 & 180 & 90 & 79 & S & Nearly vertical & Minor fracture \\
\hline 40.42 & 12.32 & 170 & 80 & 77 & S & Nearly vertical & Minor fracture \\
\hline 45.60 & 13.90 & 170 & 80 & 76 & $\mathrm{~S}$ & Nearly vertical & Transmissive fracture \\
\hline 48.39 & 14.75 & 190 & 100 & 78 & $\mathrm{~S}$ & Nearly vertical & Fracture \\
\hline 59.84 & 18.24 & 135 & 45 & 75 & SE & Nearly vertical & Minor fracture \\
\hline 61.21 & 18.66 & 138 & 48 & 74 & SE & Nearly vertical & Fracture \\
\hline 77.62 & 23.66 & 168 & 78 & 25 & $\mathrm{~S}$ & Shallow & Minor fracture \\
\hline 79.78 & 24.32 & 171 & 81 & 74 & S & Nearly vertical & Minor fracture \\
\hline 83.35 & 25.40 & 164 & 74 & 72 & S & Nearly vertical & Minor fracture \\
\hline 87.49 & 26.67 & 186 & 96 & 71 & $\mathrm{~S}$ & Nearly vertical & Minor fracture \\
\hline 97.53 & 29.73 & 182 & 92 & 77 & $\mathrm{~S}$ & Nearly vertical & Transmissive fracture \\
\hline 111.61 & 34.02 & 289 & 199 & 77 & W & Nearly vertical & Minor fracture \\
\hline 112.27 & 34.22 & 285 & 195 & 81 & W & Nearly vertical & Minor fracture \\
\hline 160.08 & 48.79 & 228 & 138 & 69 & sw & Steep & Minor fracture \\
\hline 164.47 & 50.13 & 85 & 355 & 81 & $\mathrm{E}$ & Nearly vertical & Minor fracture \\
\hline 171.43 & 52.25 & 284 & 194 & 81 & $\bar{W}$ & Nearly vertical & Contact \\
\hline 171.76 & 52.35 & 290 & 200 & 83 & W & Nearly vertical & Fracture \\
\hline 175.45 & 53.47 & 247 & 157 & 70 & SW & Nearly vertical & Minor fracture \\
\hline 183.73 & 56.00 & 64 & 334 & 37 & NE & Moderate & Minor fracture \\
\hline 207.02 & 63.10 & 258 & 168 & 73 & W & Nearly vertical & Minor fracture \\
\hline 209.34 & 63.80 & 239 & 149 & 57 & sw & Steep & Contact \\
\hline 219.55 & 66.92 & 256 & 166 & 72 & W & Nearly vertical & Fracture \\
\hline 219.56 & 66.92 & 264 & 174 & 73 & W & Nearly vertical & Possible fracture \\
\hline 220.44 & 67.19 & 242 & 152 & 68 & SW & Steep & Contact \\
\hline 235.30 & 71.72 & 340 & 250 & 79 & $\mathrm{~N}$ & Nearly vertical & Minor fracture \\
\hline
\end{tabular}




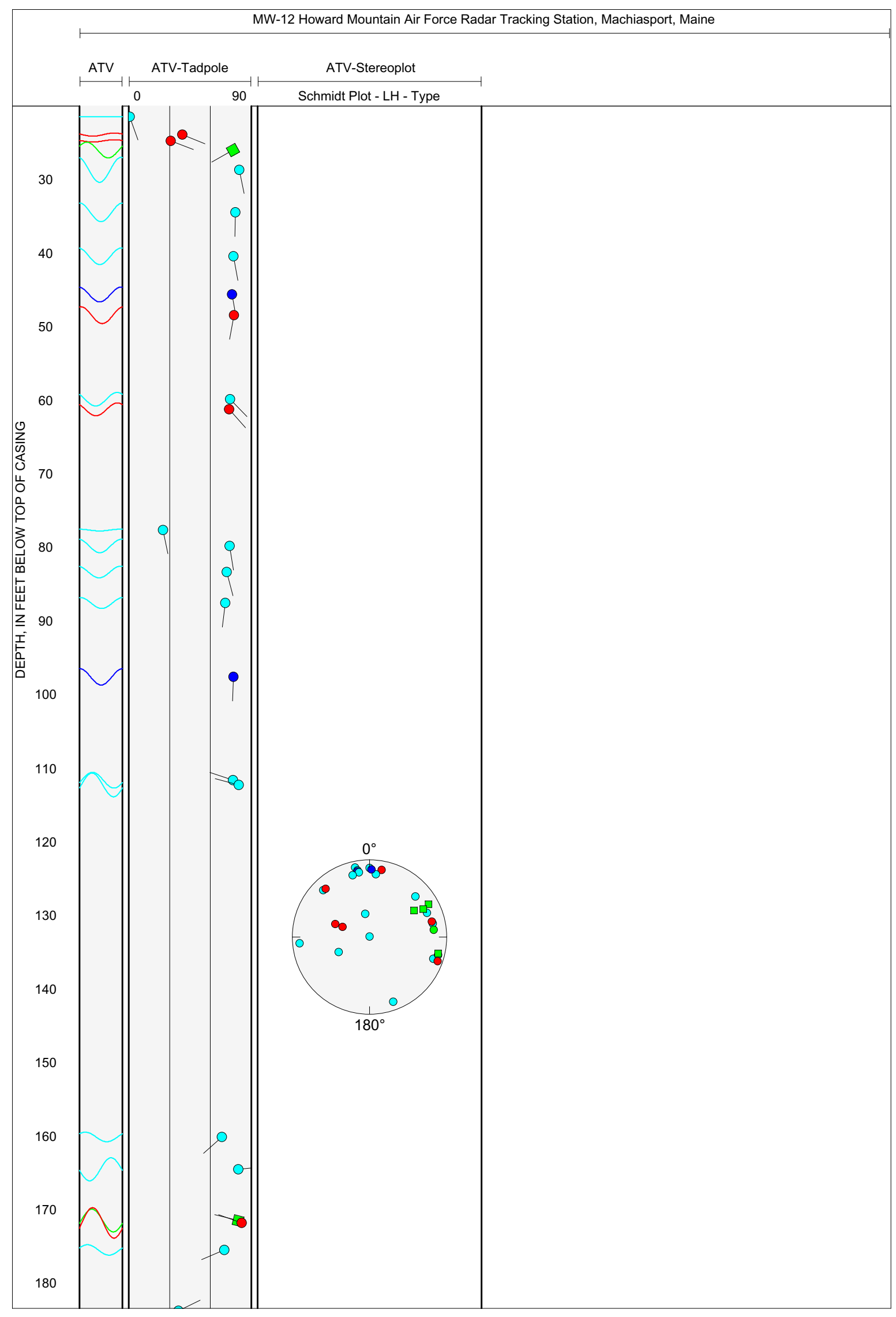

Figure 4F-2. Projection, tadpole, and stereoplots of interpretation of borehole image data for borehole MW-12, near Machiasport, Maine. 


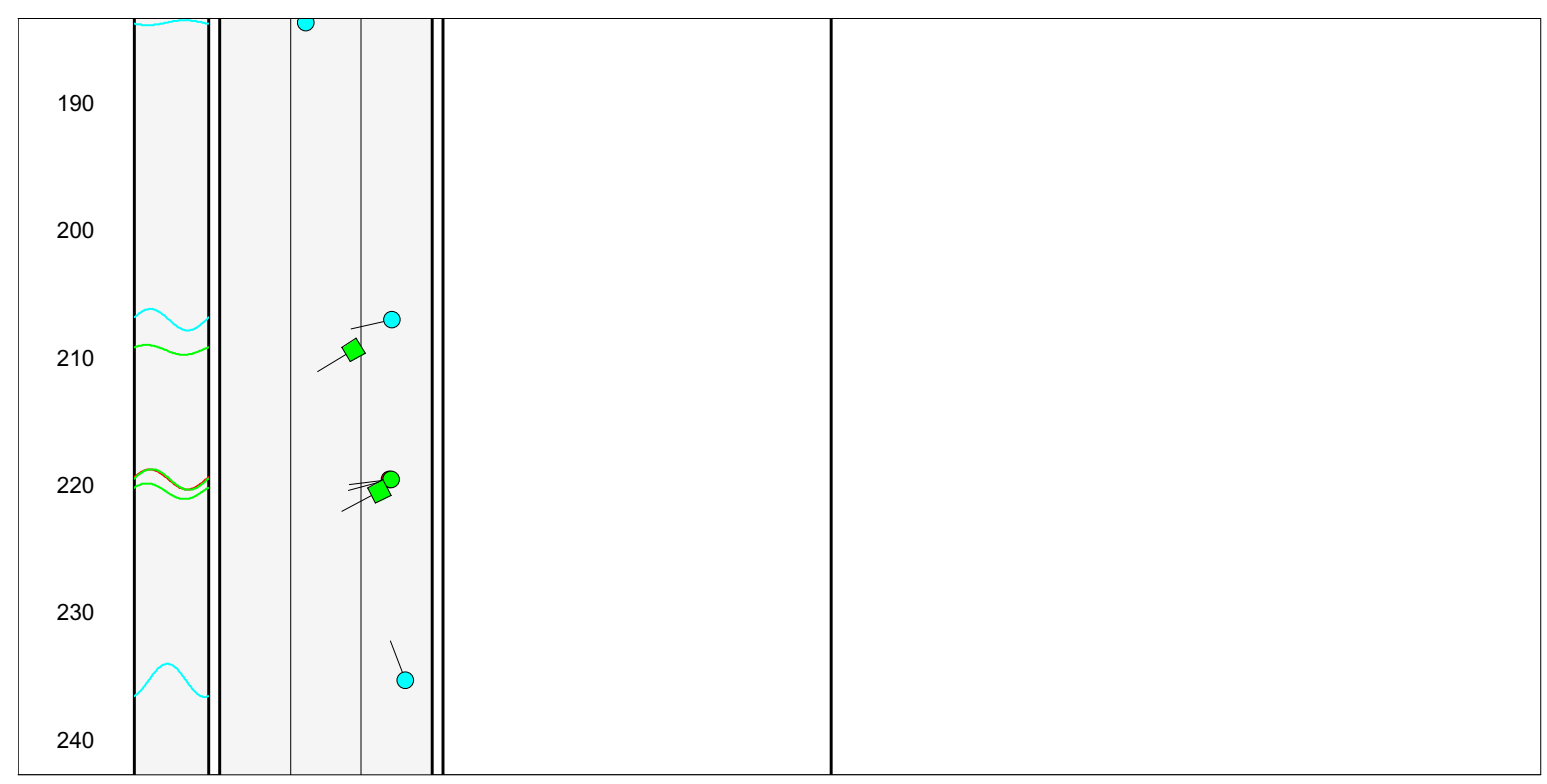

Figure 4F-2. Projection, tadpole, and stereoplots of interpretation of borehole image data for borehole MW-12, near Machiasport, Maine.-Continued 

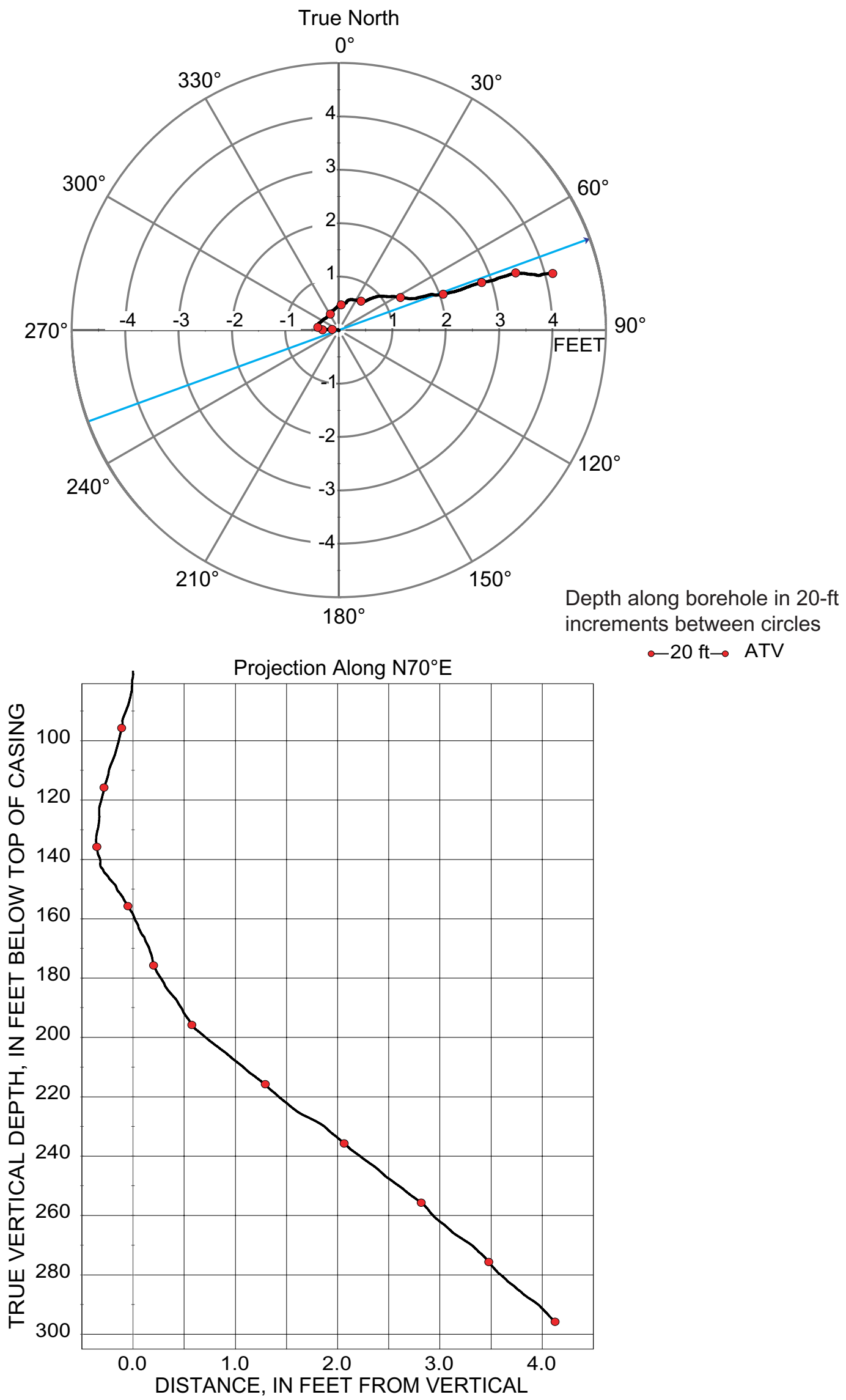

$-20 \mathrm{ft} \rightarrow$ ATV is line of projection for vertical plot (bottom).

[ft, foot; ATV, acoustic televiewer] 
Table 4G-1. Interpretation of acoustic televiewer logs for borehole WY-3, near Machiasport, Maine. [Televiewer data are corrected for deviation and magnetic declination, so orientations are relative to true north; depths are below top of casing, which is 0.91 feet above land surface; dip azimuth is given in degrees east of true north; strike is reported in right-hand-rule (RHR)-azimuthal degrees east of true north and where the direction of dip is 90 degrees to the right of strike]

\begin{tabular}{|c|c|c|c|c|c|c|c|}
\hline $\begin{array}{l}\text { Depth, } \\
\text { in feet }\end{array}$ & $\begin{array}{l}\text { Depth, } \\
\text { in meters }\end{array}$ & $\begin{array}{c}\text { Dip } \\
\text { azimuth }\end{array}$ & $\begin{array}{l}\text { Strike, } \\
\text { in RHR }\end{array}$ & Dip & $\begin{array}{c}\text { Dip } \\
\text { direction }\end{array}$ & Dip descriptor & Comment \\
\hline 83.78 & 8.65 & 352 & 262 & 7 & $\mathrm{~N}$ & Nearly horizontal & Bottom of casing \\
\hline 84.90 & 8.65 & 127 & 37 & 71 & SE & Nearly vertical & $\begin{array}{l}\text { Transmissive fracture, } \\
\text { inferred from fluid logs }\end{array}$ \\
\hline 88.07 & 8.65 & 237 & 147 & 68 & SW & Steep & Minor fracture \\
\hline 90.54 & 8.65 & 304 & 214 & 14 & NW & Shallow & $\begin{array}{l}\text { Transmissive fracture, } \\
\text { inferred from fluid logs }\end{array}$ \\
\hline 96.30 & 8.65 & 26 & 296 & 68 & NE & Steep & Minor fracture \\
\hline 97.82 & 8.65 & 34 & 304 & 58 & NE & Steep & Sealed feature \\
\hline 100.66 & 8.65 & 17 & 287 & 75 & $\mathrm{~N}$ & Nearly vertical & Minor fracture \\
\hline 106.41 & 8.65 & 52 & 322 & 69 & NE & Steep & Lithologic feature \\
\hline 109.84 & 8.65 & 359 & 269 & 72 & $\mathrm{~N}$ & Nearly vertical & Minor fracture \\
\hline 116.48 & 8.65 & 254 & 164 & 17 & W & Shallow & Minor fracture \\
\hline 120.63 & 8.65 & 220 & 130 & 65 & SW & Steep & Fracture \\
\hline 123.97 & 8.65 & 6 & 276 & 69 & $\mathrm{~N}$ & Steep & Minor fracture \\
\hline 125.27 & 8.65 & 50 & 320 & 43 & $\mathrm{NE}$ & Moderate & Lithologic feature \\
\hline 127.25 & 8.65 & 151 & 61 & 34 & SE & Moderate & Minor fracture \\
\hline 130.52 & 8.65 & 9 & 279 & 74 & $\mathrm{~N}$ & Nearly vertical & Partial fracture \\
\hline 131.31 & 8.65 & 74 & 344 & 30 & $E$ & Moderate & Partial fracture \\
\hline 131.55 & 8.65 & 253 & 163 & 70 & W & Nearly vertical & Minor fracture \\
\hline 132.15 & 8.65 & 16 & 286 & 75 & $\mathrm{~N}$ & Nearly vertical & Partial fracture \\
\hline 132.44 & 8.65 & 226 & 136 & 43 & SW & Moderate & Lithologic feature \\
\hline 132.84 & 8.65 & 225 & 135 & 34 & SW & Moderate & Minor fracture \\
\hline 138.68 & 8.65 & 220 & 130 & 83 & SW & Nearly vertical & Minor fracture \\
\hline 139.84 & 8.65 & 7 & 277 & 82 & $\mathrm{~N}$ & Nearly vertical & Minor fracture \\
\hline 143.23 & 8.65 & 68 & 338 & 55 & $E$ & Steep & sealed feature \\
\hline 144.48 & 8.65 & 52 & 322 & 38 & $\mathrm{NE}$ & Moderate & Lithologic feature \\
\hline 147.45 & 8.65 & 90 & 0 & 21 & $E$ & Shallow & Fracture \\
\hline 152.55 & 8.65 & 147 & 57 & 12 & SE & Shallow & Minor fracture \\
\hline 159.34 & 8.65 & 243 & 153 & 11 & SW & Shallow & Minor fracture \\
\hline 167.20 & 8.65 & 229 & 139 & 17 & SW & Shallow & Minor fracture \\
\hline 172.53 & 8.65 & 75 & 345 & 85 & $\mathrm{E}$ & Nearly vertical & Partial fracture \\
\hline 174.97 & 8.65 & 149 & 59 & 18 & SE & Shallow & Minor fracture \\
\hline 179.53 & 8.65 & 85 & 355 & 82 & $E$ & Nearly vertical & Minor fracture \\
\hline 180.39 & 8.65 & 171 & 81 & 7 & $\mathrm{~S}$ & Nearly horizontal & Minor fracture \\
\hline 181.72 & 8.65 & 291 & 201 & 18 & W & Shallow & Minor fracture \\
\hline 183.78 & 8.65 & 337 & 247 & 26 & NW & Shallow & Minor fracture \\
\hline 184.58 & 8.65 & 143 & 53 & 50 & SE & Steep & Lithologic feature \\
\hline 190.25 & 8.65 & 31 & 301 & 12 & $\mathrm{NE}$ & Shallow & Minor fracture \\
\hline 193.82 & 8.65 & 246 & 156 & 27 & SW & Shallow & Minor fracture \\
\hline 194.45 & 8.65 & 317 & 227 & 73 & NW & Nearly vertical & Minor fracture \\
\hline 196.28 & 8.65 & 41 & 311 & 31 & $\mathrm{NE}$ & Moderate & Minor fracture \\
\hline 199.65 & 8.65 & 54 & 324 & 24 & $N E$ & Shallow & Lithologic feature \\
\hline 206.13 & 8.65 & 220 & 130 & 85 & SW & Nearly vertical & Minor fracture \\
\hline 220.73 & 8.65 & 258 & 168 & 75 & W & Nearly vertical & Minor fracture \\
\hline 227.34 & 8.65 & 142 & 52 & 54 & SE & Steep & Minor fracture \\
\hline 232.63 & 8.65 & 143 & 53 & 68 & SE & Steep & Minor fracture \\
\hline 238.44 & 8.65 & 168 & 78 & 9 & $\mathrm{~S}$ & Nearly horizontal & Minor fracture \\
\hline 240.01 & 8.65 & 147 & 57 & 65 & SE & Steep & Minor fracture \\
\hline 240.40 & 8.65 & 19 & 289 & 48 & $\mathrm{~N}$ & Moderate & Lithologic feature \\
\hline 247.75 & 8.65 & 264 & 174 & 76 & W & Nearly vertical & $\begin{array}{l}\text { Transmissive fracture, } \\
\text { inferred from fluid logs }\end{array}$ \\
\hline 255.86 & 8.65 & 11 & 281 & 81 & $\mathrm{~N}$ & Nearly vertical & Minor fracture \\
\hline 255.94 & 8.65 & 79 & 349 & 54 & $E$ & Steep & Minor fracture \\
\hline 257.36 & 8.65 & 106 & 16 & 66 & $E$ & Steep & Minor fracture \\
\hline 263.83 & 8.65 & 22 & 292 & 83 & $\mathrm{~N}$ & Nearly vertical & $\begin{array}{l}\text { Transmissive fracture, } \\
\text { inferred from fluid logs }\end{array}$ \\
\hline
\end{tabular}


Table 4G-1. Interpretation of acoustic televiewer logs for borehole WY-3, near Machiasport, Maine.-Continued [Televiewer data are corrected for deviation and magnetic declination, so orientations are relative to true north; depths are below top of casing, which is 0.91 feet above land surface; dip azimuth is given in degrees east of true north; strike is reported in right-hand-rule (RHR)-azimuthal degrees east of true north and where the direction of dip is 90 degrees to the right of strike]

\begin{tabular}{cccccccc}
\hline $\begin{array}{c}\text { Depth, } \\
\text { in feet }\end{array}$ & $\begin{array}{c}\text { Depth, } \\
\text { in meters }\end{array}$ & $\begin{array}{c}\text { Dip } \\
\text { azimuth }\end{array}$ & $\begin{array}{c}\text { Strike, } \\
\text { in RHR }\end{array}$ & Dip & $\begin{array}{c}\text { Dip } \\
\text { direction }\end{array}$ & Dip descriptor & Comment \\
\hline 269.00 & 8.65 & 357 & 267 & 82 & $\mathrm{~N}$ & Nearly vertical & Minor fracture \\
275.81 & 8.65 & 152 & 62 & 43 & SE & Moderate & Minor fracture \\
277.00 & 8.65 & 142 & 52 & 62 & SE & Steep & Minor fracture \\
279.10 & 8.65 & 139 & 49 & 71 & SE & Nearly vertical & Minor fracture \\
280.94 & 8.65 & 177 & 87 & 69 & S & Steep & Minor fracture \\
283.31 & 8.65 & 141 & 51 & 71 & SE & Nearly vertical & Minor fracture \\
284.21 & 8.65 & 138 & 48 & 61 & SE & Steep & Minor fracture \\
285.12 & 8.65 & 133 & 43 & 64 & SE & Steep & Minor fracture \\
287.49 & 8.65 & 307 & 217 & 40 & NW & Moderate & Minor fracture \\
289.17 & 8.65 & 69 & 339 & 63 & $\mathrm{E}$ & Steep & Minor fracture \\
289.22 & 8.65 & 249 & 159 & 55 & W & Steep & Minor fracture \\
298.18 & 8.65 & 59 & 329 & 75 & NE & Nearly vertical & Minor fracture \\
\hline
\end{tabular}




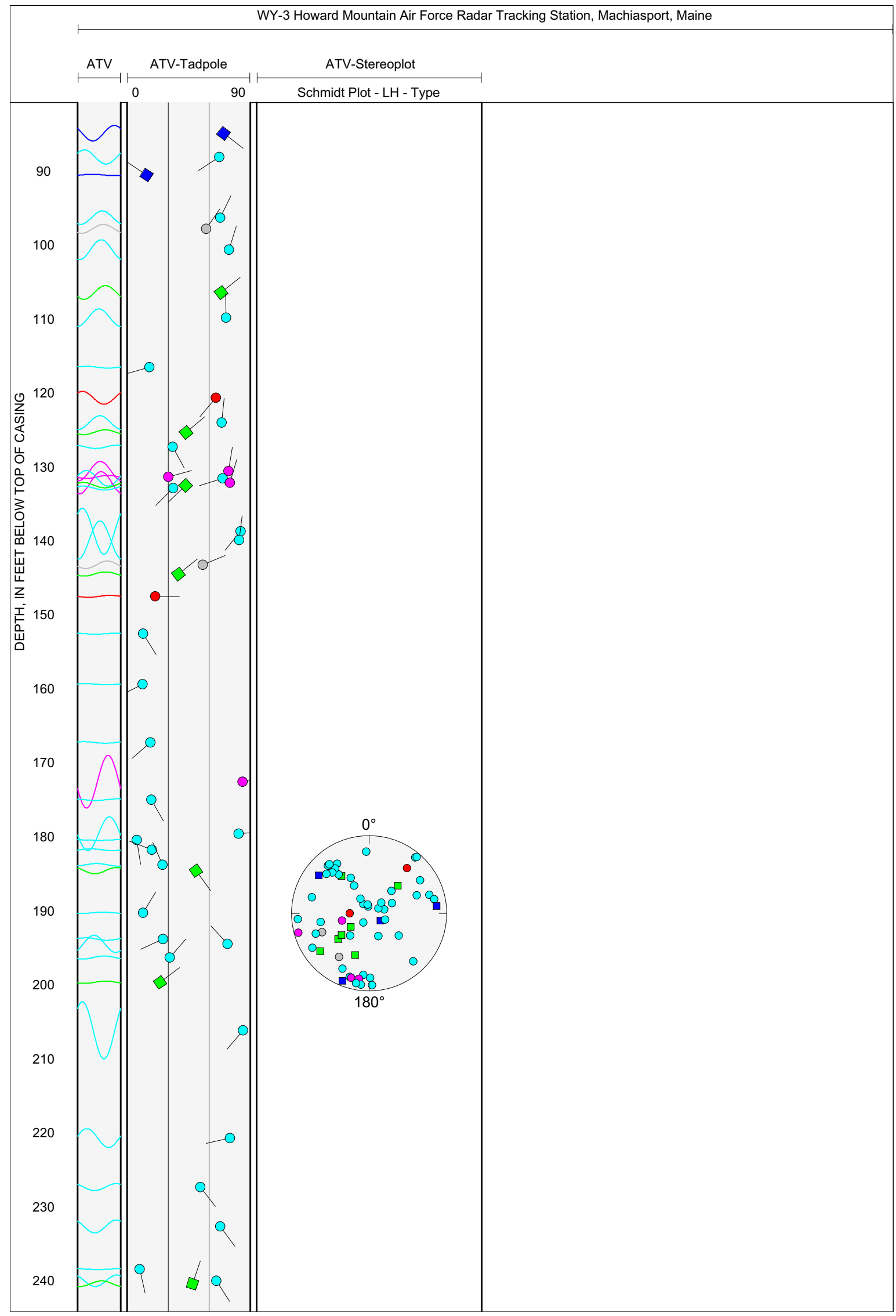

Figure 4G-2. Projection, tadpole, and stereoplots of interpretation of borehole image data for borehole WY-3, near Machiasport, Maine. 


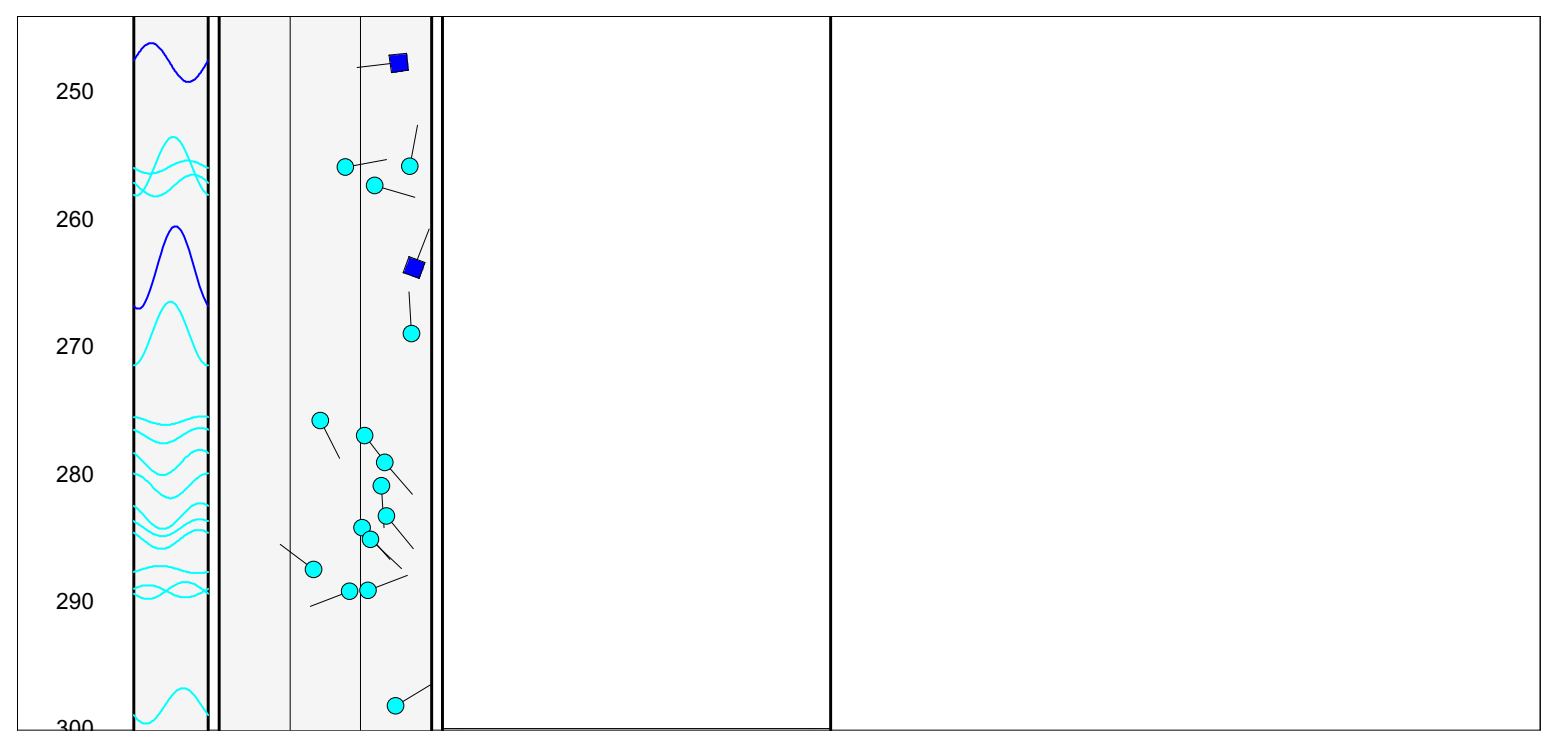

Figure 4G-2. Projection, tadpole, and stereoplots of interpretation of borehole image data for borehole WY-3, near Machiasport, Maine.-Continued 


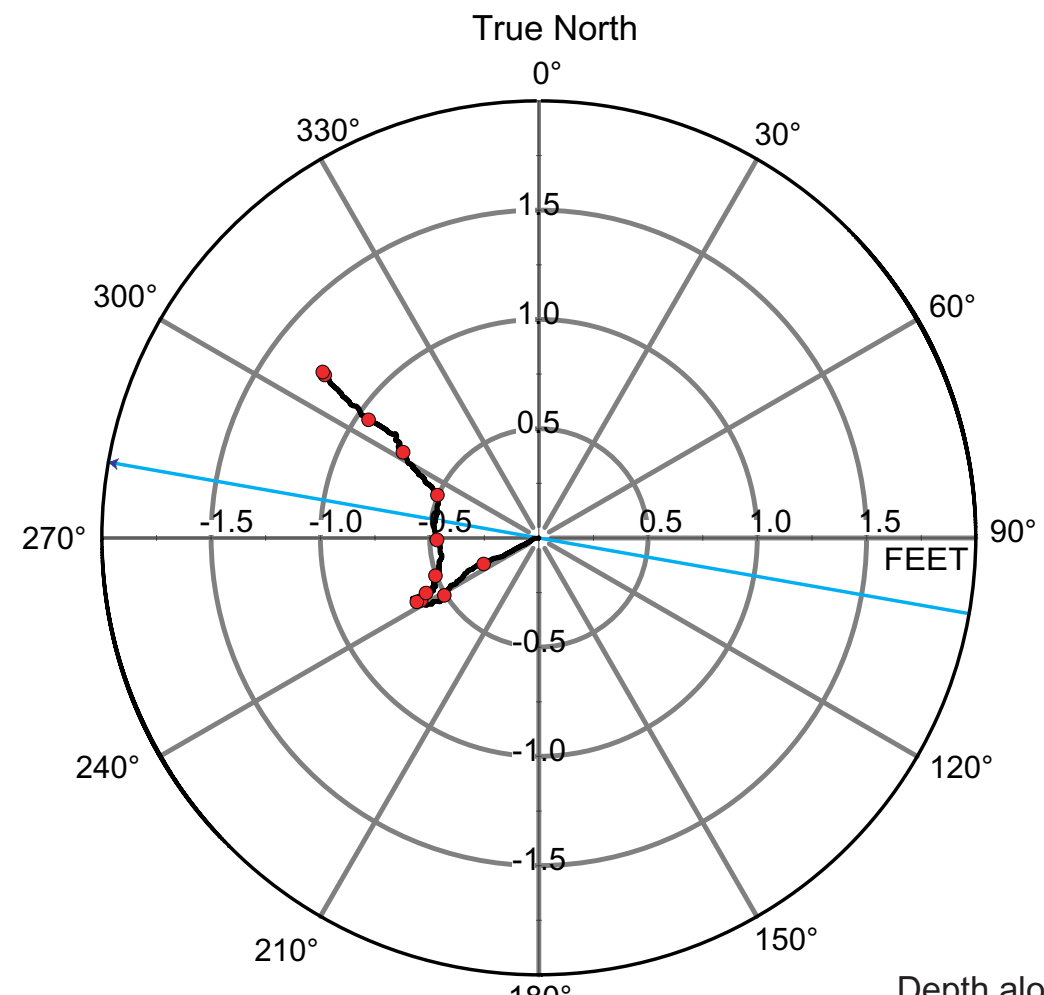

Depth along borehole in 20-ft increments between circles

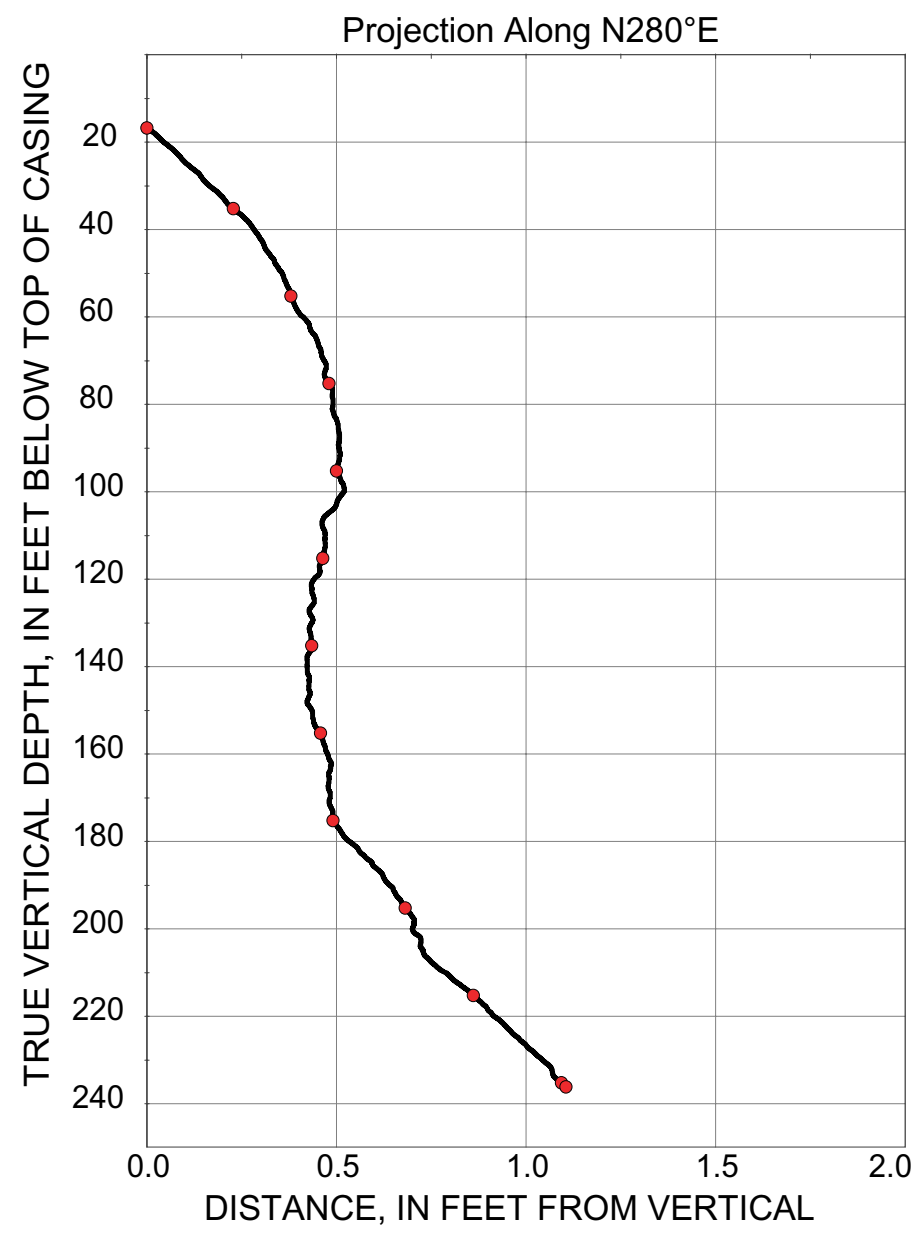

$\curvearrowleft 20 \mathrm{ft} \rightarrow$ ATV

Figure 4H-1. Borehole deviation logs for borehole DW-4, near Machiasport, Maine. Blue line on radial plot (top) is line of projection for vertical plot (bottom).

[ft, foot; ATV, acoustic televiewer] 
Table 4H-1. Interpretation of acoustic televiewer logs for borehole DW-4, near Machiasport, Maine.

[Televiewer data are corrected for deviation and magnetic declination, so orientations are relative to true north; depths are below top of casing, which is 1.06 feet above land surface; dip azimuth is given in degrees east of true north; strike is reported in right-hand-rule (RHR)-azimuthal degrees east of true north and where the direction of dip is 90 degrees to the right of strike]

\begin{tabular}{|c|c|c|c|c|c|c|c|}
\hline $\begin{array}{l}\text { Depth, } \\
\text { in feet }\end{array}$ & $\begin{array}{l}\text { Depth, } \\
\text { in meters }\end{array}$ & $\begin{array}{c}\text { Dip } \\
\text { azimuth }\end{array}$ & $\begin{array}{l}\text { Strike, } \\
\text { in RHR }\end{array}$ & Dip & $\begin{array}{c}\text { Dip } \\
\text { direction }\end{array}$ & Dip descriptor & Comment \\
\hline 25.05 & 7.63 & 333 & 243 & 78 & NW & Nearly vertical & Minor fracture \\
\hline 26.99 & 8.23 & 323 & 233 & 73 & NW & Nearly vertical & Minor fracture \\
\hline 28.88 & 8.80 & 313 & 223 & 78 & NW & Nearly vertical & Minor fracture \\
\hline 34.83 & 10.62 & 335 & 245 & 70 & NW & Nearly vertical & Minor fracture \\
\hline 38.77 & 11.82 & 316 & 226 & 73 & NW & Nearly vertical & Transmissive fracture \\
\hline 42.86 & 13.06 & 333 & 243 & 80 & NW & Nearly vertical & Minor fracture \\
\hline 45.49 & 13.86 & 323 & 233 & 75 & NW & Nearly vertical & Minor fracture \\
\hline 46.54 & 14.18 & 316 & 226 & 78 & NW & Nearly vertical & Minor fracture \\
\hline 48.50 & 14.78 & 321 & 231 & 77 & NW & Nearly vertical & Minor fracture \\
\hline 50.06 & 15.26 & 324 & 234 & 71 & NW & Nearly vertical & Minor fracture \\
\hline 51.67 & 15.75 & 251 & 161 & 14 & W & Shallow & Transmissive fracture \\
\hline 52.02 & 15.85 & 326 & 236 & 78 & NW & Nearly vertical & Minor fracture \\
\hline 52.83 & 16.10 & 327 & 237 & 77 & NW & Nearly vertical & Minor fracture \\
\hline 53.36 & 16.26 & 329 & 239 & 76 & NW & Nearly vertical & Minor fracture \\
\hline 54.13 & 16.50 & 329 & 239 & 73 & NW & Nearly vertical & Minor fracture \\
\hline 56.08 & 17.09 & 329 & 239 & 71 & NW & Nearly vertical & Minor fracture \\
\hline 64.75 & 19.73 & 302 & 212 & 65 & NW & Steep & Minor fracture \\
\hline 70.88 & 21.60 & 308 & 218 & 78 & NW & Nearly vertical & Minor fracture \\
\hline 81.40 & 24.81 & 346 & 256 & 74 & $\mathrm{~N}$ & Nearly vertical & Minor fracture \\
\hline 82.11 & 25.03 & 340 & 250 & 68 & $\mathrm{~N}$ & Steep & Minor fracture \\
\hline 82.76 & 25.22 & 340 & 250 & 70 & $\mathrm{~N}$ & Nearly vertical & Minor fracture \\
\hline 104.70 & 31.91 & 75 & 345 & 82 & $\mathrm{E}$ & Nearly vertical & Minor fracture \\
\hline 109.41 & 33.35 & 73 & 343 & 84 & $\mathrm{E}$ & Nearly vertical & Fracture \\
\hline 109.48 & 33.37 & 69 & 339 & 84 & $E$ & Nearly vertical & Contact \\
\hline 112.37 & 34.25 & 144 & 54 & 75 & SE & Nearly vertical & Minor fracture \\
\hline 115.03 & 35.06 & 159 & 69 & 69 & $\mathrm{~S}$ & Steep & Minor fracture \\
\hline 116.25 & 35.43 & 153 & 63 & 52 & SE & Steep & Minor fracture \\
\hline 117.42 & 35.79 & 46 & 316 & 75 & NE & Nearly vertical & Minor fracture \\
\hline 119.37 & 36.38 & 66 & 336 & 80 & NE & Nearly vertical & Minor fracture \\
\hline 119.49 & 36.42 & 218 & 128 & 75 & SW & Nearly vertical & Minor fracture \\
\hline 119.63 & 36.46 & 76 & 346 & 59 & $\mathrm{E}$ & Steep & Contact \\
\hline 125.68 & 38.31 & 255 & 165 & 85 & W & Nearly vertical & Minor fracture \\
\hline 132.14 & 40.27 & 259 & 169 & 82 & W & Nearly vertical & Minor fracture \\
\hline 144.31 & 43.98 & 252 & 162 & 77 & W & Nearly vertical & Minor fracture \\
\hline 148.02 & 45.11 & 245 & 155 & 76 & SW & Nearly vertical & Minor fracture \\
\hline 166.51 & 50.75 & 116 & 26 & 69 & SE & Steep & Minor fracture \\
\hline 167.30 & 50.99 & 111 & 21 & 73 & $\mathrm{E}$ & Nearly vertical & Minor fracture \\
\hline 167.81 & 51.15 & 118 & 28 & 73 & SE & Nearly vertical & Minor fracture \\
\hline 187.78 & 57.23 & 229 & 139 & 70 & SW & Steep & Transmissive fracture \\
\hline 193.36 & 58.93 & 265 & 175 & 45 & W & Moderate & Contact \\
\hline 194.81 & 59.38 & 119 & 29 & 21 & SE & Shallow & Minor fracture \\
\hline 194.94 & 59.41 & 330 & 240 & 80 & NW & Nearly vertical & Minor fracture \\
\hline 195.31 & 59.53 & 101 & 11 & 18 & $\mathrm{E}$ & Shallow & Minor fracture \\
\hline 195.72 & 59.65 & 97 & 7 & 49 & $\mathrm{E}$ & Moderate & Minor fracture \\
\hline 196.45 & 59.88 & 177 & 87 & 72 & $S$ & Nearly vertical & Minor fracture \\
\hline 197.41 & 60.17 & 229 & 139 & 59 & SW & Steep & Minor fracture \\
\hline 197.50 & 60.20 & 132 & 42 & 68 & SE & Steep & Minor fracture \\
\hline 198.57 & 60.52 & 256 & 166 & 72 & W & Nearly vertical & Minor fracture \\
\hline 201.76 & 61.49 & 201 & 111 & 57 & $\mathrm{~S}$ & Steep & Minor fracture \\
\hline 203.29 & 61.96 & 211 & 121 & 71 & SW & Nearly vertical & Fracture \\
\hline 203.40 & 61.99 & 119 & 29 & 50 & SE & Moderate & Minor fracture \\
\hline 204.32 & 62.27 & 247 & 157 & 64 & SW & Steep & Contact \\
\hline 209.15 & 63.75 & 283 & 193 & 11 & W & Shallow & Fracture \\
\hline 209.43 & 63.83 & 239 & 149 & 80 & SW & Nearly vertical & Minor fracture \\
\hline 214.42 & 65.35 & 281 & 191 & 81 & W & Nearly vertical & Minor fracture \\
\hline 224.21 & 68.34 & 239 & 149 & 72 & SW & Nearly vertical & Transmissive fracture \\
\hline 225.23 & 68.65 & 242 & 152 & 65 & SW & Steep & Minor fracture \\
\hline 227.11 & 69.22 & 244 & 154 & 69 & SW & Steep & Minor fracture \\
\hline
\end{tabular}




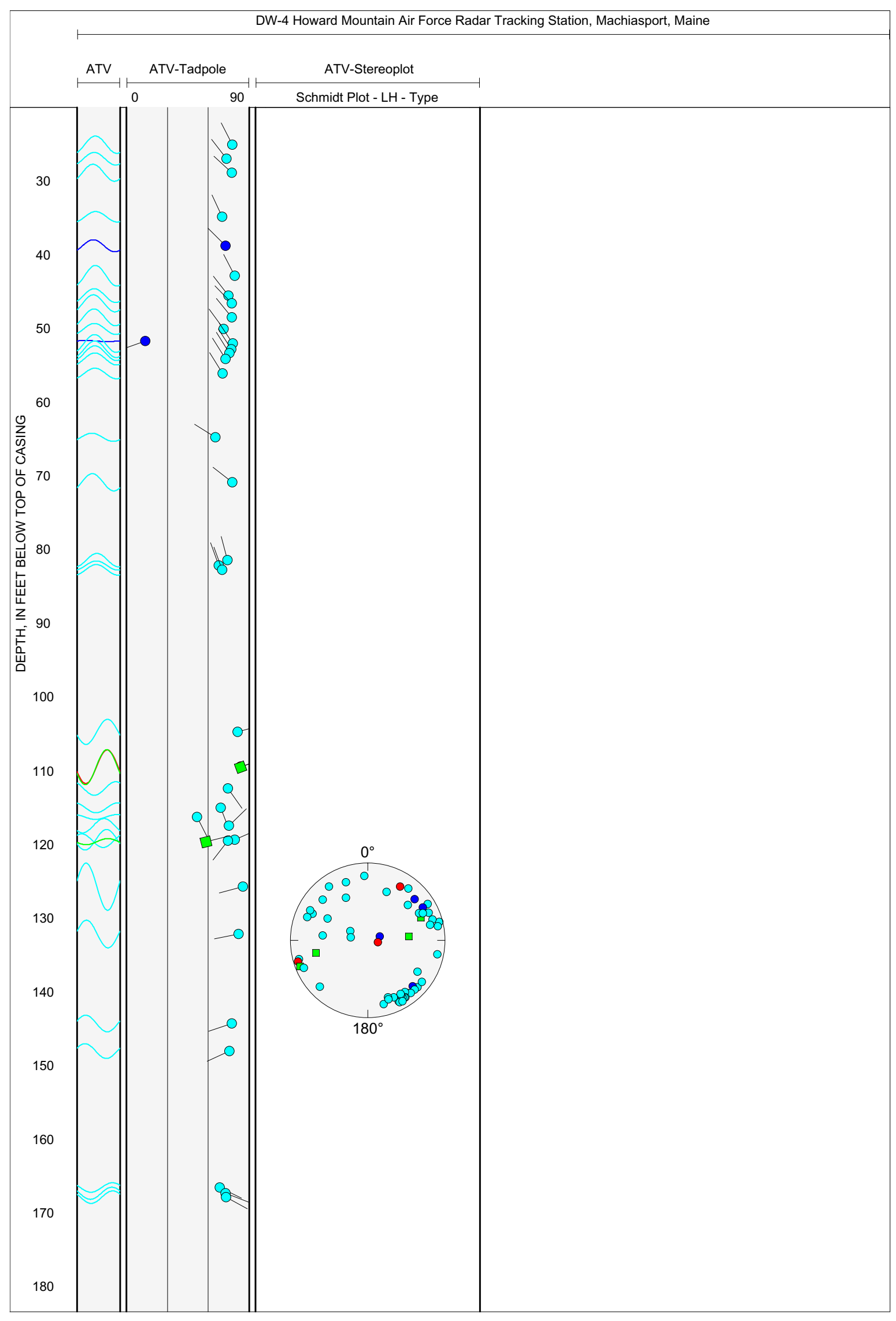

Figure 4H-2. Projection, tadpole, and stereoplots of interpretation of borehole image data for borehole DW-4, near Machiasport, Maine. 


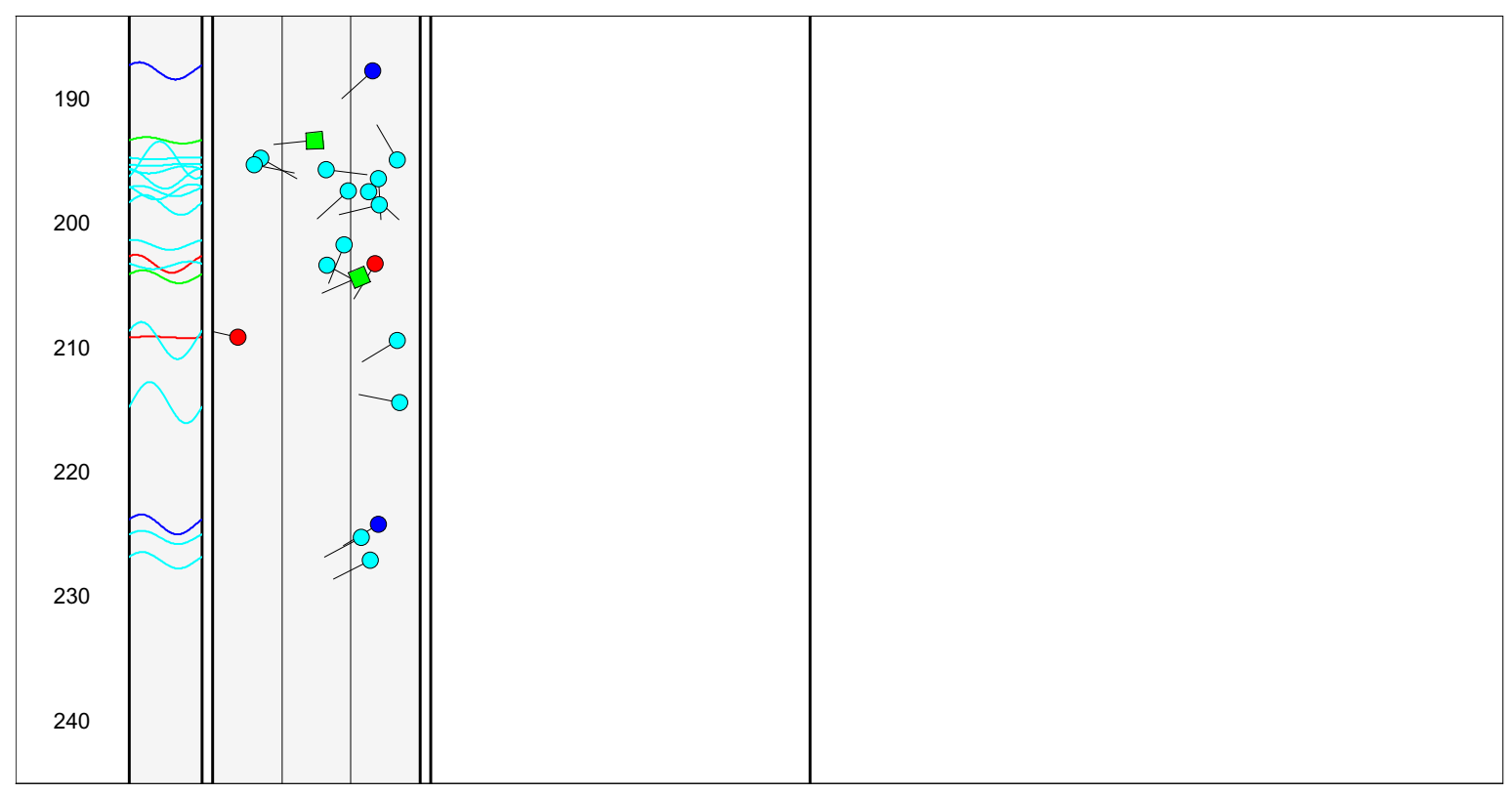

Figure 4H-2. Projection, tadpole, and stereoplots of interpretation of borehole image data for borehole DW-4, near Machiasport, Maine.-Continued 

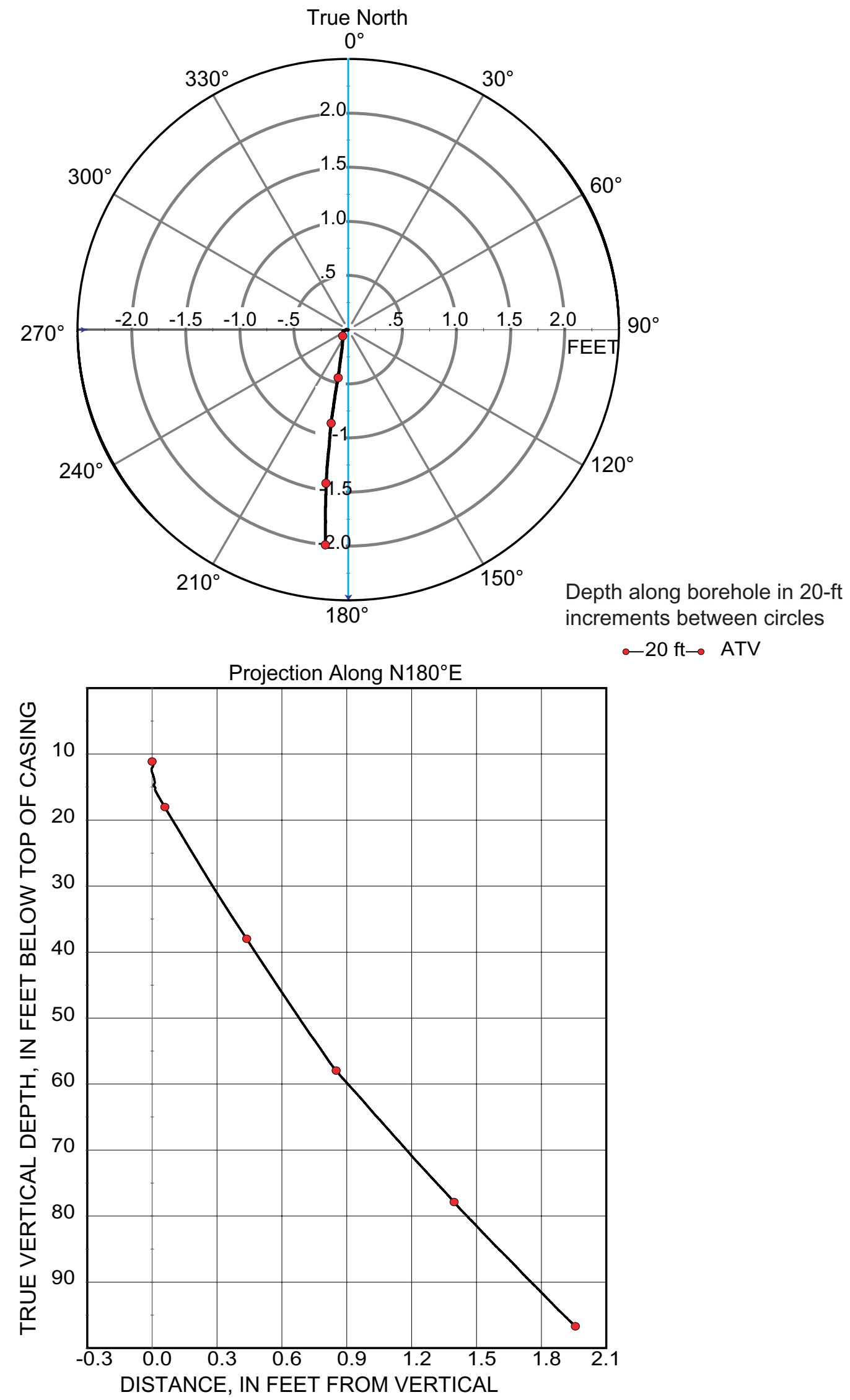

Figure 4I-1. Borehole deviation logs for borehole MW-4, near Machiasport, Maine. Blue line on radial plot (top) is line of projection for vertical plot (bottom).

[ft, foot; ATV, acoustic televiewer] 
Table 4I-1. Interpretation of acoustic televiewer logs for borehole MW-4, near Machiasport, Maine.

[Televiewer data are corrected for deviation and magnetic declination, so orientations are relative to true north; depths are below top of casing, which is 3.31 feet above land surface; dip azimuth is given in degrees east of true north; strike is reported in right-hand-rule (RHR)-azimuthal degrees east of true north and where the direction of dip is 90 degrees to the right of strike]

\begin{tabular}{|c|c|c|c|c|c|c|c|}
\hline $\begin{array}{l}\text { Depth, } \\
\text { in feet }\end{array}$ & $\begin{array}{l}\text { Depth, } \\
\text { in meters }\end{array}$ & $\begin{array}{c}\text { Dip } \\
\text { azimuth }\end{array}$ & $\begin{array}{l}\text { Strike, } \\
\text { in RHR }\end{array}$ & Dip & $\begin{array}{c}\text { Dip } \\
\text { direction }\end{array}$ & Dip descriptor & Comment \\
\hline 18.21 & 5.55 & 122 & 32 & 33 & SE & Moderate & Fracture \\
\hline 18.83 & 5.74 & 158 & 68 & 49 & $S$ & Moderate & Fracture \\
\hline 19.27 & 5.87 & 117 & 27 & 33 & SE & Moderate & Fracture \\
\hline 19.44 & 5.93 & 172 & 82 & 42 & $\mathrm{~S}$ & Moderate & Fracture \\
\hline 19.49 & 5.94 & 273 & 183 & 85 & W & Nearly vertical & Fracture \\
\hline 20.32 & 6.19 & 324 & 234 & 73 & NW & Nearly vertical & Fracture \\
\hline 21.47 & 6.54 & 352 & 262 & 53 & $\mathrm{~N}$ & Steep & Minor fracture \\
\hline 21.53 & 6.56 & 172 & 82 & 48 & $\mathrm{~S}$ & Moderate & Minor fracture \\
\hline 22.08 & 6.73 & 154 & 64 & 57 & SE & Steep & Minor fracture \\
\hline 22.86 & 6.97 & 155 & 65 & 44 & SE & Moderate & Fracture \\
\hline 23.18 & 7.06 & 7 & 277 & 38 & $\mathrm{~N}$ & Moderate & Fracture \\
\hline 23.41 & 7.14 & 166 & 76 & 42 & S & Moderate & Minor fracture \\
\hline 23.65 & 7.21 & 338 & 248 & 73 & $\mathrm{~N}$ & Nearly vertical & Minor fracture \\
\hline 23.73 & 7.23 & 188 & 98 & 33 & S & Moderate & Fracture \\
\hline 24.25 & 7.39 & 22 & 292 & 49 & $\mathrm{~N}$ & Moderate & Minor fracture \\
\hline 24.93 & 7.60 & 335 & 245 & 79 & NW & Nearly vertical & Transmissive fracture \\
\hline 25.21 & 7.68 & 301 & 211 & 71 & NW & Nearly vertical & Transmissive fracture \\
\hline 25.61 & 7.81 & 313 & 223 & 80 & NW & Nearly vertical & Minor fracture \\
\hline 26.49 & 8.07 & 145 & 55 & 35 & SE & Moderate & Minor fracture \\
\hline 26.57 & 8.10 & 325 & 235 & 76 & NW & Nearly vertical & Minor fracture \\
\hline 27.06 & 8.25 & 172 & 82 & 35 & $\mathrm{~S}$ & Moderate & Minor fracture \\
\hline 27.90 & 8.50 & 144 & 54 & 43 & SE & Moderate & Minor fracture \\
\hline 29.05 & 8.85 & 299 & 209 & 73 & NW & Nearly vertical & Fracture \\
\hline 29.70 & 9.05 & 295 & 205 & 81 & NW & Nearly vertical & Fracture \\
\hline 30.40 & 9.27 & 266 & 176 & 79 & W & Nearly vertical & Fracture \\
\hline 30.90 & 9.42 & 160 & 70 & 48 & S & Moderate & Fracture \\
\hline 31.82 & 9.70 & 278 & 188 & 78 & W & Nearly vertical & Minor fracture \\
\hline 32.57 & 9.93 & 342 & 252 & 74 & $\mathrm{~N}$ & Nearly vertical & Fracture \\
\hline 33.14 & 10.10 & 254 & 164 & 67 & W & Steep & Minor fracture \\
\hline 33.46 & 10.20 & 265 & 175 & 50 & W & Moderate & Fracture \\
\hline 33.88 & 10.33 & 297 & 207 & 51 & NW & Steep & Lithologic feature \\
\hline 35.57 & 10.84 & 314 & 224 & 77 & NW & Nearly vertical & Minor fracture \\
\hline 43.45 & 13.24 & 154 & 64 & 67 & SE & Steep & Fracture \\
\hline 43.67 & 13.31 & 280 & 190 & 75 & W & Nearly vertical & Minor fracture \\
\hline 45.60 & 13.90 & 177 & 87 & 42 & $\mathrm{~S}$ & Moderate & Fracture \\
\hline 46.66 & 14.22 & 168 & 78 & 56 & S & Steep & Fracture \\
\hline 53.57 & 16.33 & 162 & 72 & 88 & $\mathrm{~S}$ & Nearly vertical & Minor fracture \\
\hline 53.78 & 16.39 & 335 & 245 & 85 & NW & Nearly vertical & Minor fracture \\
\hline 54.43 & 16.59 & 150 & 60 & 71 & SE & Nearly vertical & Transmissive fracture \\
\hline 55.18 & 16.82 & 147 & 57 & 74 & SE & Nearly vertical & Transmissive fracture \\
\hline 61.20 & 18.65 & 249 & 159 & 42 & W & Moderate & Lithologic feature \\
\hline 70.21 & 21.40 & 214 & 124 & 68 & sw & Steep & Minor fracture \\
\hline 83.73 & 25.52 & 139 & 49 & 60 & SE & Steep & Transmissive fracture \\
\hline 83.97 & 25.59 & 150 & 60 & 60 & SE & Steep & Fracture \\
\hline 96.94 & 29.55 & 166 & 76 & 74 & $S$ & Nearly vertical & Sealed feature \\
\hline
\end{tabular}


Table 4I-2. Interpretation of optical televiewer logs for borehole MW-4, near Machiasport, Maine.

[Televiewer data are corrected for deviation and magnetic declination, so orientations are relative to true north; depths are below top of casing, which is 3.31 feet above land surface; dip azimuth is given in degrees east of true north; strike is reported in right-hand-rule (RHR)-azimuthal degrees east of true north and where the direction of dip is 90 degrees to the right of strike]

\begin{tabular}{|c|c|c|c|c|c|c|c|}
\hline $\begin{array}{l}\text { Depth, } \\
\text { in feet }\end{array}$ & $\begin{array}{l}\text { Depth, } \\
\text { in meters }\end{array}$ & $\begin{array}{c}\text { Dip } \\
\text { azimuth }\end{array}$ & $\begin{array}{c}\text { Strike, } \\
\text { in RHR }\end{array}$ & Dip & $\begin{array}{c}\text { Dip } \\
\text { direction }\end{array}$ & Dip descriptor & Comment \\
\hline 18.76 & 5.72 & 154 & 64 & 28 & SE & Shallow & Minor fracture \\
\hline 20.30 & 6.19 & 320 & 230 & 69 & NW & Steep & Minor fracture \\
\hline 21.41 & 6.53 & 353 & 263 & 34 & $\mathrm{~N}$ & Moderate & Minor fracture \\
\hline 23.09 & 7.04 & 353 & 263 & 30 & $\mathrm{~N}$ & Shallow & Fracture \\
\hline 23.67 & 7.21 & 126 & 36 & 25 & SE & Shallow & Minor fracture \\
\hline 24.86 & 7.58 & 290 & 200 & 71 & W & Nearly vertical & Minor fracture \\
\hline 25.22 & 7.69 & 273 & 183 & 55 & W & Steep & Transmissive fracture \\
\hline 26.45 & 8.06 & 95 & 5 & 23 & $E$ & Shallow & Minor fracture \\
\hline 26.53 & 8.09 & 287 & 197 & 69 & W & Steep & Sealed feature \\
\hline 27.03 & 8.24 & 128 & 38 & 22 & SE & Shallow & Minor fracture \\
\hline 27.89 & 8.50 & 99 & 9 & 30 & $E$ & Moderate & Minor fracture \\
\hline 29.66 & 9.04 & 274 & 184 & 76 & $\bar{W}$ & Nearly vertical & Minor fracture \\
\hline 29.92 & 9.12 & 11 & 281 & 43 & $\mathrm{~N}$ & Moderate & Fracture \\
\hline 32.48 & 9.90 & 297 & 207 & 65 & NW & Steep & Minor fracture \\
\hline 33.17 & 10.11 & 265 & 175 & 59 & W & Steep & Minor fracture \\
\hline 33.36 & 10.17 & 264 & 174 & 46 & W & Moderate & Fracture \\
\hline 34.50 & 10.52 & 256 & 166 & 29 & W & Shallow & Lithologic feature \\
\hline 35.18 & 10.72 & 247 & 157 & 51 & SW & Steep & Sealed feature \\
\hline 54.65 & 16.66 & 118 & 28 & 49 & SE & Moderate & Transmissive fracture \\
\hline 55.99 & 17.06 & 123 & 33 & 53 & SE & Steep & Fracture \\
\hline 70.06 & 21.35 & 290 & 200 & 52 & W & Steep & Minor fracture \\
\hline 70.27 & 21.42 & 291 & 201 & 64 & W & Steep & Minor fracture \\
\hline 76.65 & 23.36 & 262 & 172 & 65 & W & Steep & Sealed feature \\
\hline 83.85 & 25.56 & 128 & 38 & 49 & SE & Moderate & Fracture \\
\hline 85.16 & 25.96 & 116 & 26 & 60 & SE & Steep & Sealed feature \\
\hline 87.23 & 26.59 & 90 & 360 & 31 & $\mathrm{E}$ & Moderate & Sealed feature \\
\hline 92.20 & 28.10 & 302 & 212 & 63 & NW & Steep & Sealed feature \\
\hline 94.55 & 28.82 & 257 & 167 & 73 & W & Nearly vertical & Sealed feature \\
\hline 95.41 & 29.08 & 252 & 162 & 74 & W & Nearly vertical & Sealed feature \\
\hline 98.99 & 30.17 & 105 & 15 & 61 & $E$ & Steep & Minor fracture \\
\hline 100.76 & 30.71 & 119 & 29 & 52 & SE & Steep & Minor fracture \\
\hline
\end{tabular}




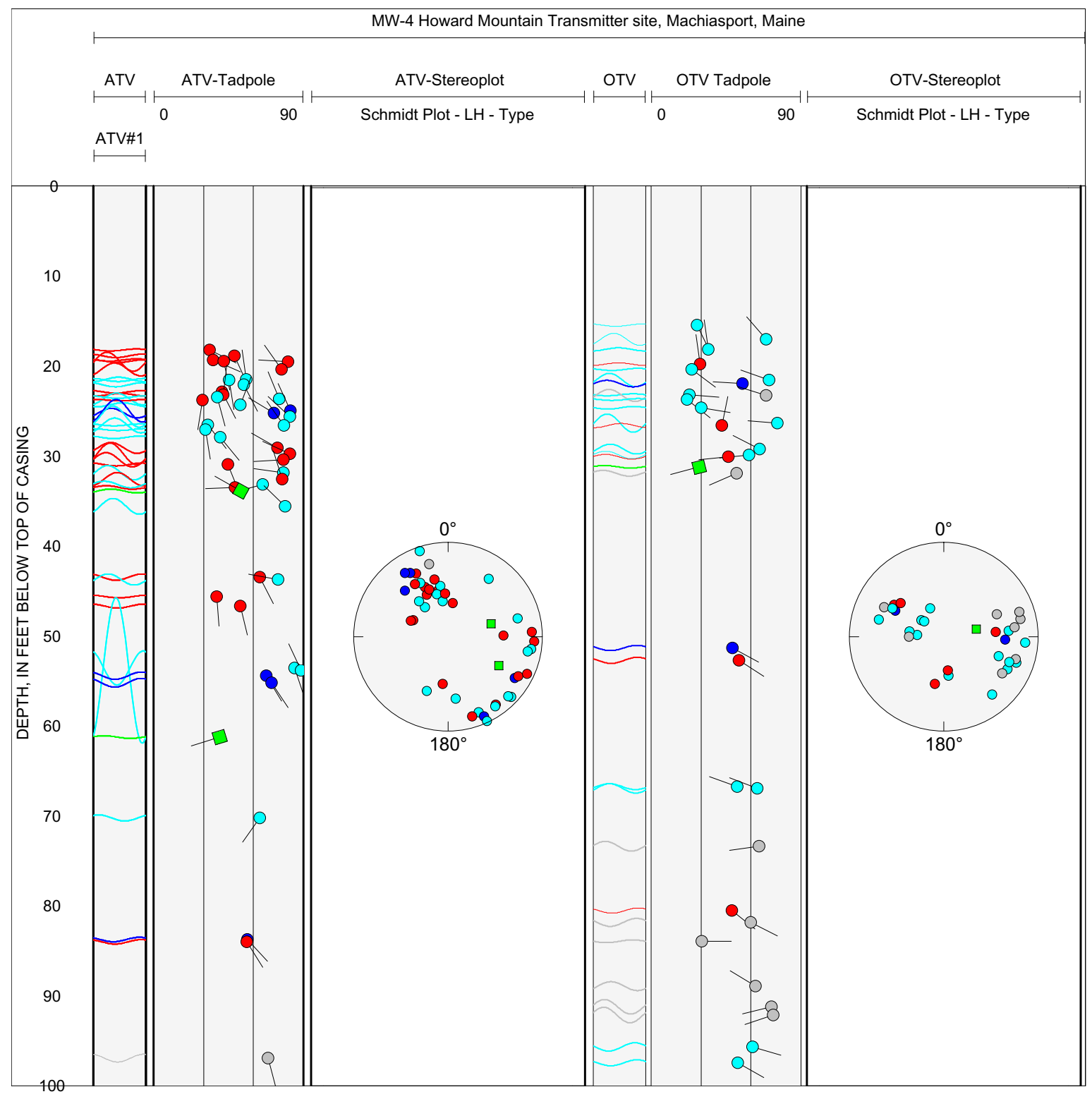

Figure 4I-2. Projection, tadpole, and stereoplots of interpretation of borehole image data for borehole MW-4, near Machiasport, Maine. 

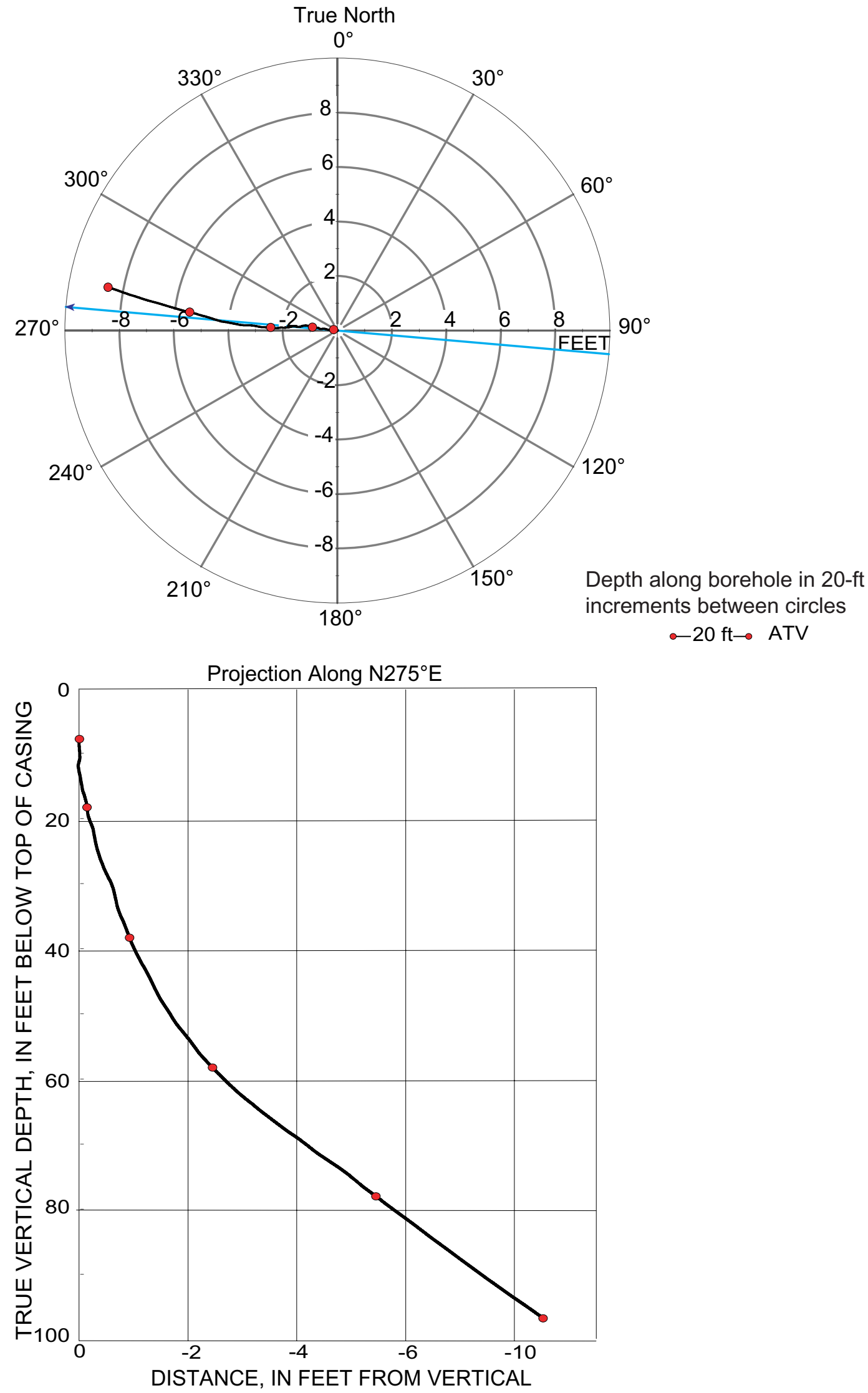

Figure 4J-1. Borehole deviation logs for borehole MW-5, near Machiasport, Maine. Blue line on radial plot (top) is line of projection for vertical plot (bottom).

[ft, foot; ATV, acoustic televiewer] 
Table 4J-1. Interpretation of acoustic televiewer logs for borehole MW-5, near Machiasport, Maine.

[tTeleviewer data are corrected for deviation and magnetic declination, so orientations are relative to true north; depths are below top of casing, which is 3.50 feet above land surface; dip azimuth is given in degrees east of true north; strike is reported in right-hand-rule (RHR)-azimuthal degrees east of true north and where the direction of dip is 90 degrees to the right of strike]

\begin{tabular}{|c|c|c|c|c|c|c|c|}
\hline $\begin{array}{l}\text { Depth, } \\
\text { in feet }\end{array}$ & $\begin{array}{l}\text { Depth, } \\
\text { in meters }\end{array}$ & $\begin{array}{c}\text { Dip } \\
\text { azimuth }\end{array}$ & $\begin{array}{l}\text { Strike, } \\
\text { in RHR }\end{array}$ & Dip & $\begin{array}{c}\text { Dip } \\
\text { direction }\end{array}$ & Dip descriptor & Comment \\
\hline 14.13 & 4.31 & 217 & 127 & 37 & SW & Moderate & Minor fracture \\
\hline 14.75 & 4.50 & 179 & 89 & 65 & $\mathrm{~S}$ & Steep & Minor fracture \\
\hline 16.31 & 4.97 & 148 & 58 & 65 & SE & Steep & Minor fracture \\
\hline 16.39 & 5.00 & 274 & 184 & 89 & W & Nearly vertical & Minor fracture \\
\hline 18.66 & 5.69 & 292 & 202 & 84 & W & Nearly vertical & Minor fracture \\
\hline 19.18 & 5.85 & 83 & 353 & 30 & $E$ & Moderate & Minor fracture \\
\hline 22.78 & 6.94 & 110 & 20 & 45 & $\bar{E}$ & Moderate & Minor fracture \\
\hline 22.90 & 6.98 & 265 & 175 & 21 & W & Shallow & Minor fracture \\
\hline 23.16 & 7.06 & 291 & 201 & 83 & W & Nearly vertical & Minor fracture \\
\hline 25.15 & 7.67 & 302 & 212 & 80 & NW & Nearly vertical & Minor fracture \\
\hline 27.26 & 8.31 & 320 & 230 & 84 & NW & Nearly vertical & Minor fracture \\
\hline 29.20 & 8.90 & 208 & 118 & 62 & SW & Steep & Transmissive fracture \\
\hline 29.22 & 8.91 & 183 & 93 & 8 & $\mathrm{~S}$ & Nearly horizontal & Transmissive fracture \\
\hline 30.26 & 9.22 & 229 & 139 & 53 & SW & Steep & Minor fracture \\
\hline 31.91 & 9.73 & 200 & 110 & 54 & $\mathrm{~S}$ & Steep & Minor fracture \\
\hline 33.16 & 10.11 & 198 & 108 & 62 & $\mathrm{~S}$ & Steep & Minor fracture \\
\hline 43.26 & 13.19 & 189 & 99 & 50 & $\mathrm{~S}$ & Moderate & Minor fracture \\
\hline 45.84 & 13.97 & 196 & 106 & 46 & S & Moderate & Minor fracture \\
\hline 46.65 & 14.22 & 183 & 93 & 50 & $\mathrm{~S}$ & Moderate & Minor fracture \\
\hline 49.49 & 15.08 & 260 & 170 & 23 & W & Shallow & Minor fracture \\
\hline 50.57 & 15.41 & 290 & 200 & 21 & W & Shallow & Minor fracture \\
\hline 57.84 & 17.63 & 311 & 221 & 83 & NW & Nearly vertical & Minor fracture \\
\hline 64.46 & 19.65 & 147 & 57 & 37 & SE & Moderate & Transmissive fracture \\
\hline 69.67 & 21.23 & 160 & 70 & 28 & $\mathrm{~S}$ & Shallow & Minor fracture \\
\hline 71.88 & 21.91 & 328 & 238 & 80 & NW & Nearly vertical & Minor fracture \\
\hline 77.61 & 23.65 & 305 & 215 & 84 & NW & Nearly vertical & Minor fracture \\
\hline 77.64 & 23.66 & 142 & 52 & 61 & SE & Steep & Minor fracture \\
\hline 82.29 & 25.08 & 212 & 122 & 6 & SW & Nearly horizontal & Transmissive fracture \\
\hline 82.90 & 25.27 & 191 & 101 & 15 & $\mathrm{~S}$ & Shallow & Minor fracture \\
\hline 83.87 & 25.56 & 318 & 228 & 85 & NW & Nearly vertical & Minor fracture \\
\hline 88.64 & 27.02 & 314 & 224 & 87 & NW & Nearly vertical & Minor fracture \\
\hline 100.64 & 30.67 & 325 & 235 & 63 & NW & Steep & Minor fracture \\
\hline 101.65 & 30.98 & 332 & 242 & 65 & NW & Steep & Minor fracture \\
\hline
\end{tabular}




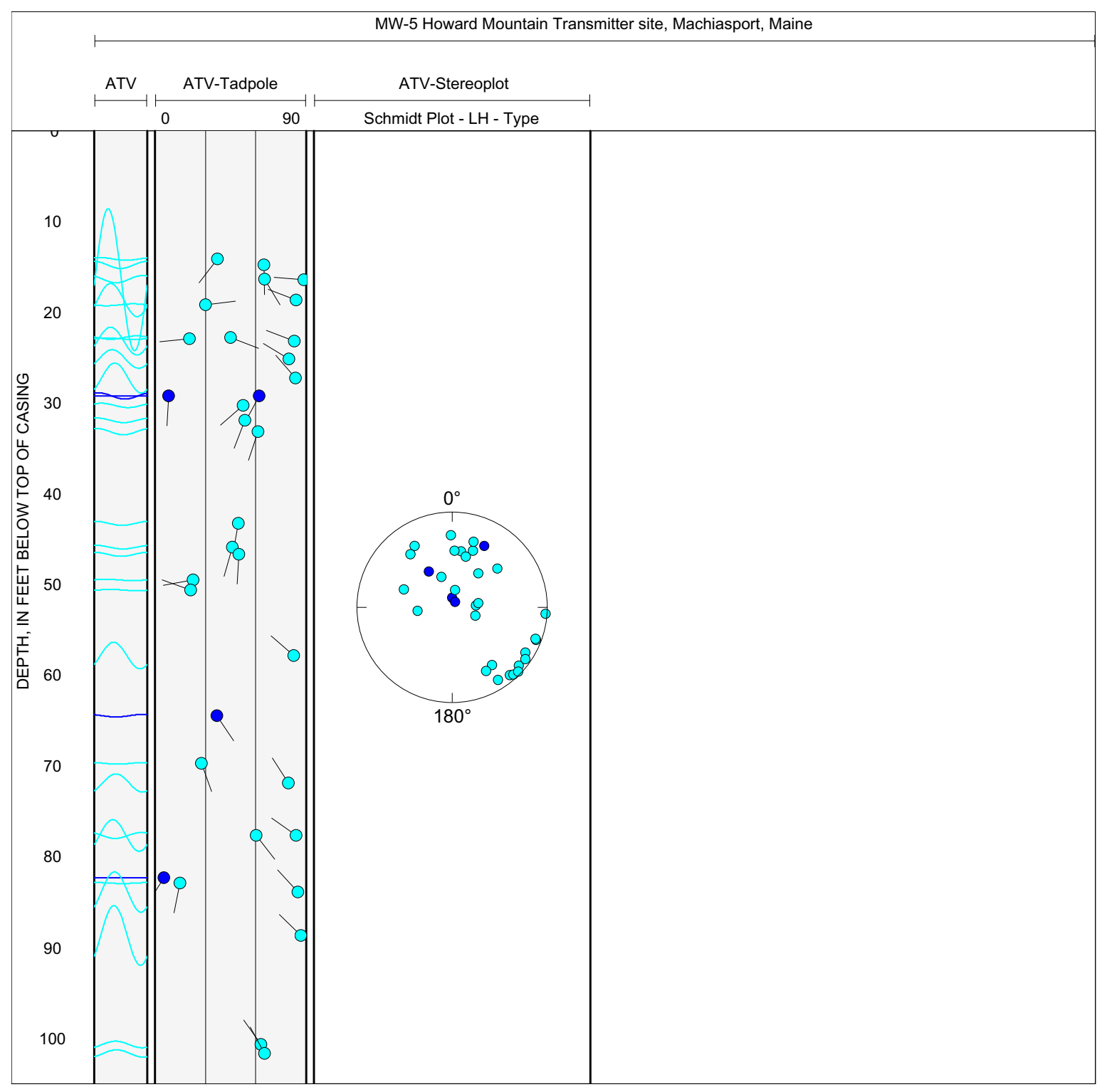

Figure 4J-2. Projection, tadpole, and stereoplots of interpretation of borehole image data for borehole MW-5, near Machiasport, Maine. 

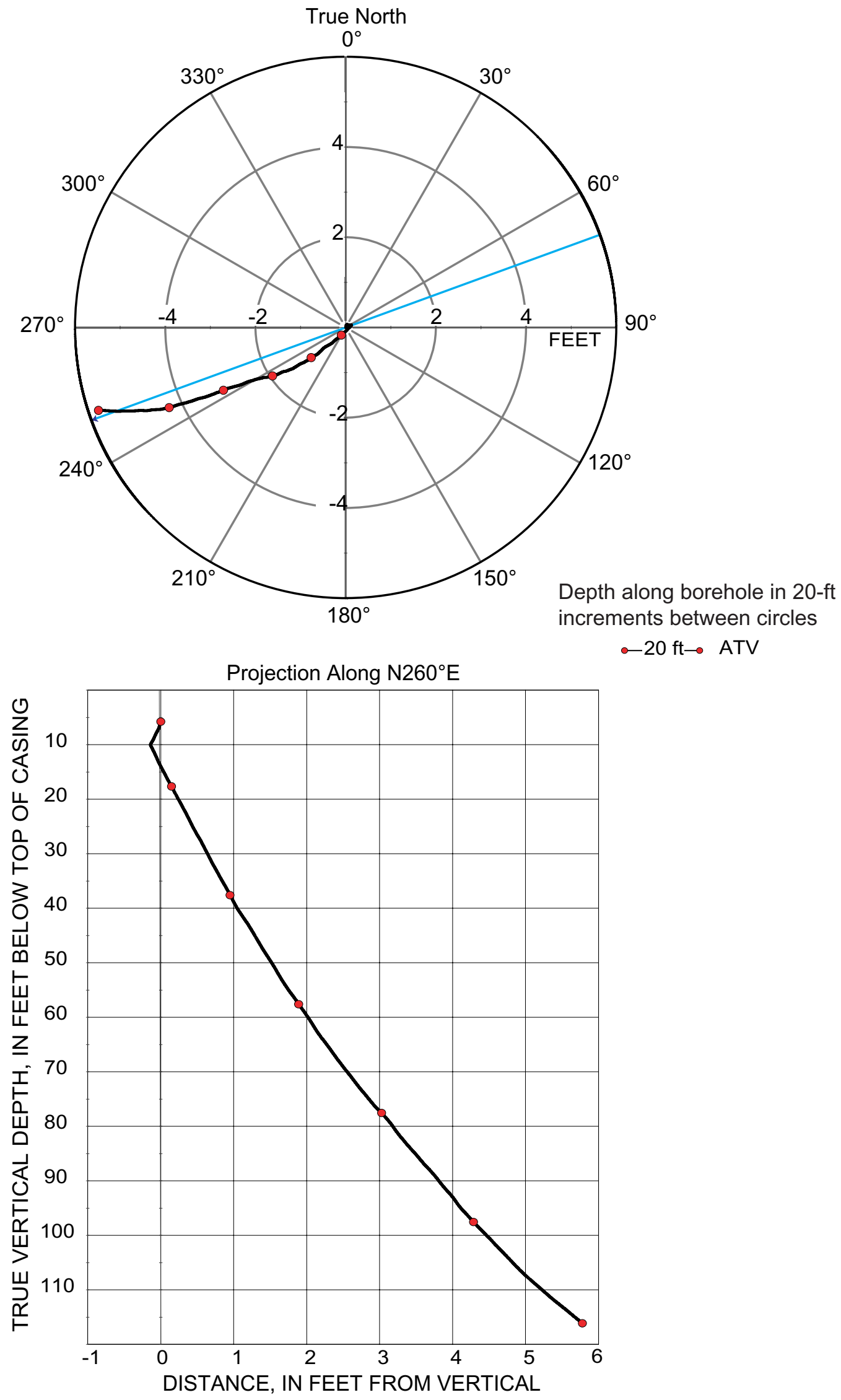

Figure 4K-1. Borehole deviation logs for borehole MW-6, near Machiasport, Maine. Blue line on radial plot (top) is line of projection for vertical plot (bottom).

[ft, foot; ATV, acoustic televiewer] 
Table 4K-1. Interpretation of acoustic televiewer logs for borehole MW-6, near Machiasport, Maine.

[Televiewer data are corrected for deviation and magnetic declination, so orientations are relative to true north; depths are below top of casing, which is 3.21 feet above land surface; dip azimuth is given in degrees east of true north; strike is reported in right-hand-rule (RHR)-azimuthal degrees east of true north and where the direction of dip is 90 degrees to the right of strike]

\begin{tabular}{rrrrrcrl}
\hline $\begin{array}{c}\text { Depth, } \\
\text { in feet }\end{array}$ & $\begin{array}{c}\text { Depth, } \\
\text { in meters }\end{array}$ & $\begin{array}{c}\text { Dip } \\
\text { azimuth }\end{array}$ & $\begin{array}{c}\text { Strike, } \\
\text { in RHR }\end{array}$ & Dip & $\begin{array}{c}\text { Dip } \\
\text { direction }\end{array}$ & Dip descriptor & Comment \\
\hline 13.44 & 4.10 & 96 & 6 & 19 & $\mathrm{E}$ & Shallow & Transmissive fracture \\
17.73 & 5.40 & 311 & 221 & 84 & $\mathrm{NW}$ & Nearly vertical & Minor fracture \\
20.45 & 6.23 & 110 & 20 & 36 & $\mathrm{E}$ & Moderate & Minor fracture \\
24.48 & 7.46 & 325 & 235 & 78 & $\mathrm{NW}$ & Nearly vertical & Minor fracture \\
36.50 & 11.12 & 328 & 238 & 79 & $\mathrm{NW}$ & Nearly vertical & Partial fracture \\
59.11 & 18.02 & 232 & 142 & 27 & $\mathrm{SW}$ & Shallow & Minor fracture \\
66.78 & 20.35 & 156 & 66 & 72 & $\mathrm{SE}$ & Nearly vertical & Transmissive fracture \\
67.27 & 20.50 & 351 & 261 & 80 & $\mathrm{~N}$ & Nearly vertical & Transmissive fracture \\
68.15 & 20.77 & 352 & 262 & 60 & $\mathrm{~N}$ & Steep & Transmissive fracture \\
69.70 & 21.24 & 358 & 268 & 80 & $\mathrm{~N}$ & Nearly vertical & Minor fracture \\
87.65 & 26.71 & 11 & 281 & 85 & $\mathrm{~N}$ & Nearly vertical & Minor fracture \\
90.55 & 27.60 & 16 & 286 & 83 & $\mathrm{~N}$ & Nearly vertical & Minor fracture \\
91.90 & 28.01 & 131 & 41 & 67 & $\mathrm{SE}$ & Steep & Fracture \\
93.73 & 28.57 & 31 & 301 & 84 & $\mathrm{NE}$ & Nearly vertical & Minor fracture \\
96.88 & 29.53 & 21 & 291 & 87 & $\mathrm{~N}$ & Nearly vertical & Minor fracture \\
99.88 & 30.44 & 319 & 229 & 78 & $\mathrm{NW}$ & Nearly vertical & Minor fracture \\
101.99 & 31.09 & 325 & 235 & 83 & $\mathrm{NW}$ & Nearly vertical & Minor fracture \\
103.39 & 31.51 & 310 & 220 & 81 & $\mathrm{NW}$ & Nearly vertical & Minor fracture \\
105.88 & 32.27 & 315 & 225 & 79 & $\mathrm{NW}$ & Nearly vertical & Minor fracture \\
108.16 & 32.97 & 311 & 221 & 69 & $\mathrm{NW}$ & Steep & Minor fracture \\
109.83 & 33.47 & 319 & 229 & 75 & $\mathrm{NW}$ & Nearly vertical & Minor fracture \\
112.12 & 34.17 & 325 & 235 & 79 & $\mathrm{NW}$ & Nearly vertical & Minor fracture \\
119.03 & 36.28 & 325 & 235 & 73 & $\mathrm{NW}$ & Nearly vertical & Minor fracture \\
119.29 & 36.36 & 20 & 290 & 82 & $\mathrm{~N}$ & Nearly vertical & Minor fracture \\
\hline
\end{tabular}




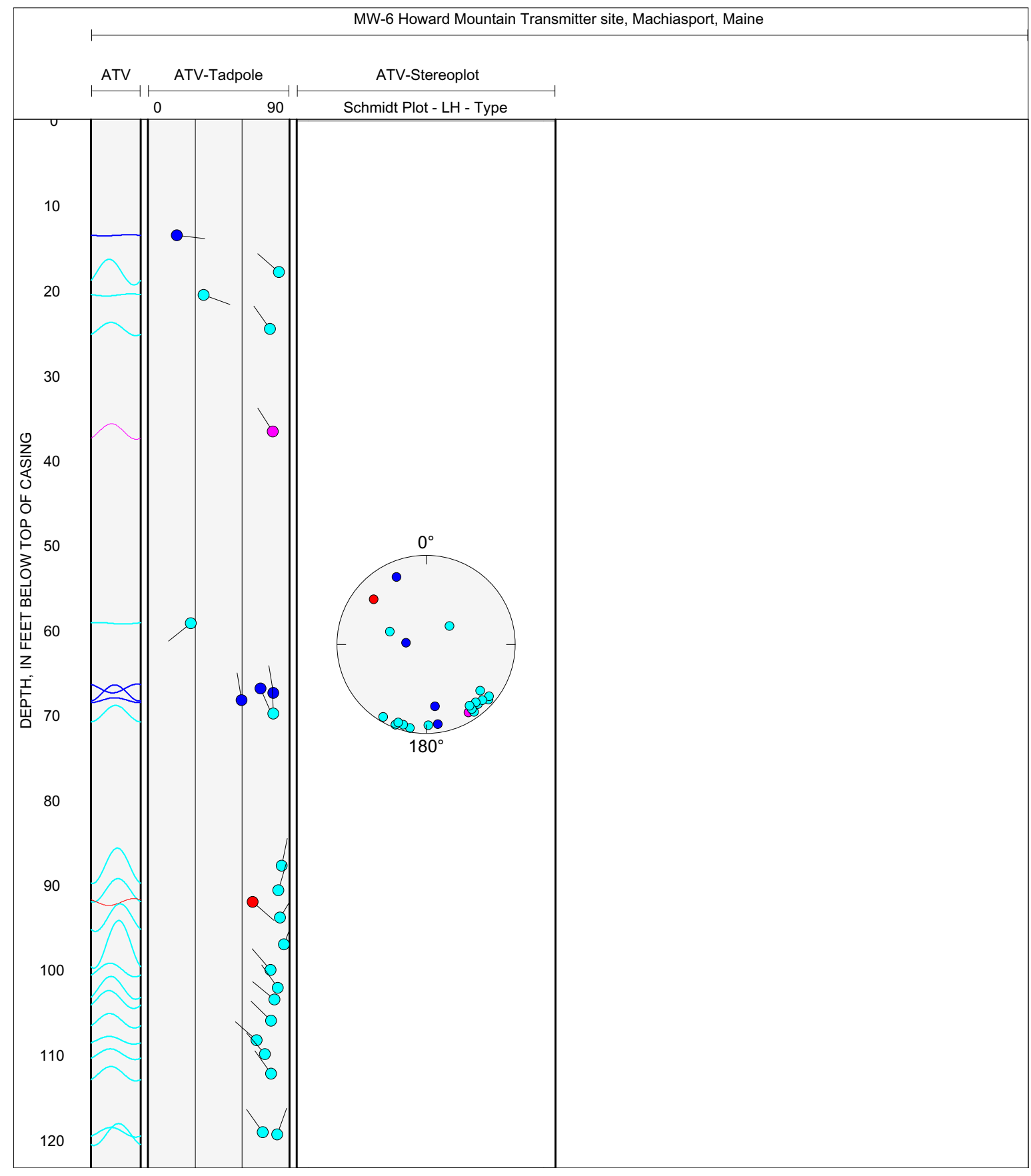

Figure 4K-2. Projection, tadpole, and stereoplots of interpretation of borehole image data for borehole MW-6, near Machiasport, Maine. 

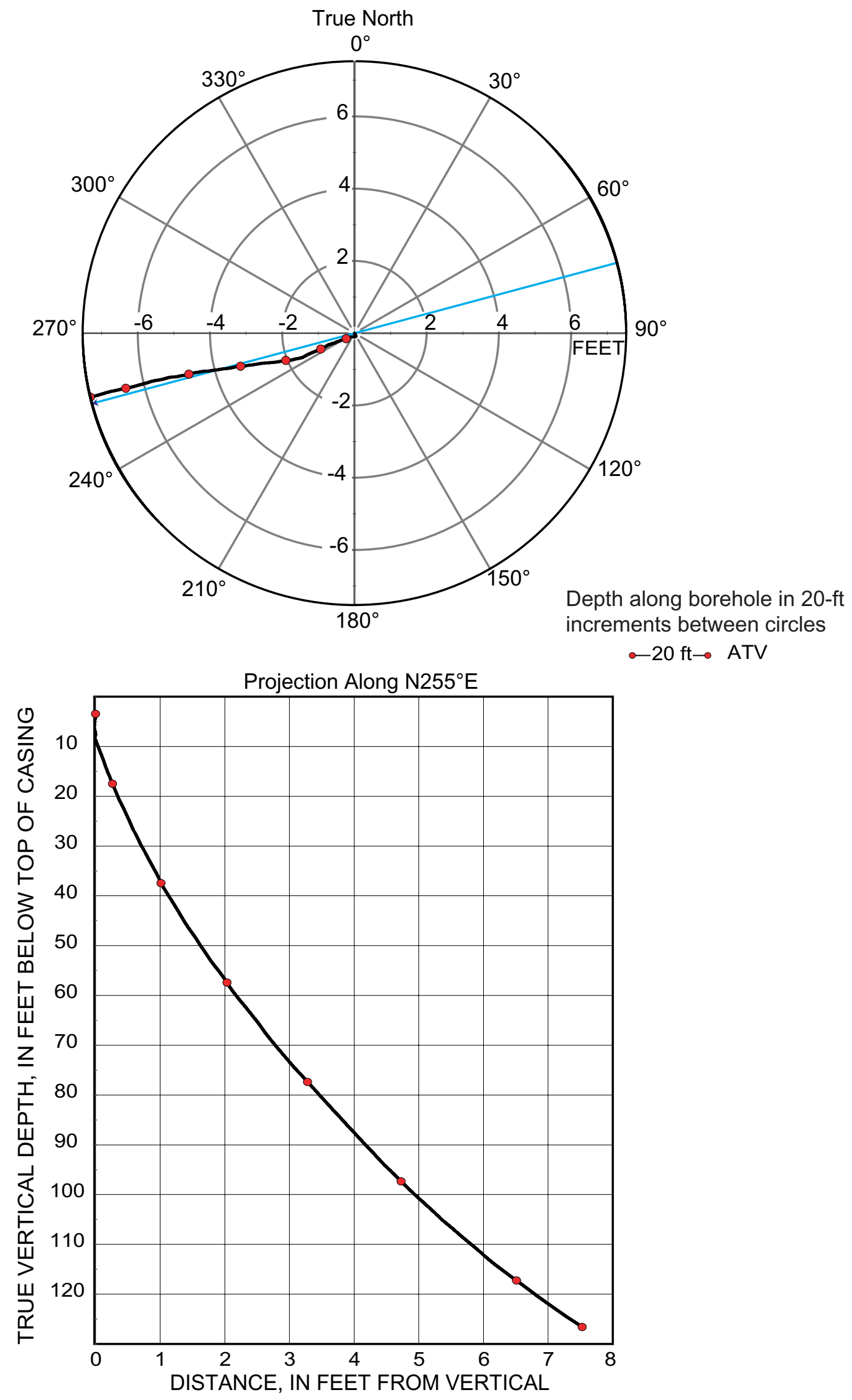

Figure 4L-1. Borehole deviation logs for borehole MW-7, near Machiasport, Maine. Blue line on radial plot (top) is line of projection for vertical plot (bottom).

[ft, foot; ATV, acoustic televiewer] 
Table 4L-1. Interpretation of acoustic televiewer logs for borehole MW-7, near Machiasport, Maine.

[Televiewer data are corrected for deviation and magnetic declination, so orientations are relative to true north; depths are below top of casing, which is 2.41 feet above land surface; dip azimuth is given in degrees east of true north; strike is reported in right-hand-rule (RHR)-azimuthal degrees east of true north and where the direction of dip is 90 degrees to the right of strike]

\begin{tabular}{|c|c|c|c|c|c|c|c|}
\hline $\begin{array}{l}\text { Depth, } \\
\text { in feet }\end{array}$ & $\begin{array}{l}\text { Depth, } \\
\text { in meters }\end{array}$ & $\begin{array}{c}\text { Dip } \\
\text { azimuth }\end{array}$ & $\begin{array}{l}\text { Strike, } \\
\text { in RHR }\end{array}$ & Dip & $\begin{array}{c}\text { Dip } \\
\text { direction }\end{array}$ & Dip descriptor & Comment \\
\hline 7.74 & 2.36 & 181 & 91 & 87 & $\mathrm{~S}$ & Nearly vertical & Minor fracture \\
\hline 9.25 & 2.82 & 276 & 186 & 2 & W & Nearly horizontal & Water level \\
\hline 9.36 & 2.85 & 292 & 202 & 2 & W & Nearly horizontal & Minor fracture \\
\hline 13.15 & 4.01 & 121 & 31 & 63 & SE & Steep & Minor fracture \\
\hline 15.18 & 4.63 & 115 & 25 & 13 & SE & Shallow & Transmissive fracture \\
\hline 15.24 & 4.64 & 116 & 26 & 79 & SE & Nearly vertical & Transmissive fracture \\
\hline 17.82 & 5.43 & 166 & 76 & 82 & $\mathrm{~S}$ & Nearly vertical & Minor fracture \\
\hline 18.34 & 5.59 & 155 & 65 & 81 & SE & Nearly vertical & Minor fracture \\
\hline 21.28 & 6.49 & 157 & 67 & 83 & SE & Nearly vertical & Minor fracture \\
\hline 22.83 & 6.96 & 154 & 64 & 80 & SE & Nearly vertical & Minor fracture \\
\hline 24.53 & 7.48 & 149 & 59 & 76 & SE & Nearly vertical & Minor fracture \\
\hline 27.07 & 8.25 & 125 & 35 & 59 & SE & Steep & Minor fracture \\
\hline 27.26 & 8.31 & 142 & 52 & 59 & SE & Steep & Minor fracture \\
\hline 29.76 & 9.07 & 138 & 48 & 74 & SE & Nearly vertical & Lithologic feature \\
\hline 34.26 & 10.44 & 144 & 54 & 66 & SE & Steep & Lithologic feature \\
\hline 39.23 & 11.96 & 1 & 271 & 81 & $\mathrm{~N}$ & Nearly vertical & Minor fracture \\
\hline 39.87 & 12.15 & 9 & 279 & 80 & $\mathrm{~N}$ & Nearly vertical & Fracture \\
\hline 41.63 & 12.69 & 360 & 270 & 85 & $\mathrm{~N}$ & Nearly vertical & Fracture \\
\hline 44.63 & 13.60 & 319 & 229 & 82 & NW & Nearly vertical & Minor fracture \\
\hline 50.35 & 15.35 & 73 & 343 & 25 & $\mathrm{E}$ & Shallow & Transmissive fracture \\
\hline 51.98 & 15.84 & 356 & 266 & 85 & $\mathrm{~N}$ & Nearly vertical & Transmissive fracture \\
\hline 55.82 & 17.01 & 3 & 273 & 83 & $\mathrm{~N}$ & Nearly vertical & Lithologic feature \\
\hline 57.50 & 17.53 & 4 & 274 & 84 & $\mathrm{~N}$ & Nearly vertical & Minor fracture \\
\hline 62.01 & 18.90 & 314 & 224 & 78 & NW & Nearly vertical & Minor fracture \\
\hline 74.09 & 22.58 & 171 & 81 & 83 & $\mathrm{~s}$ & Nearly vertical & Minor fracture \\
\hline 75.48 & 23.01 & 168 & 78 & 55 & $\mathrm{~S}$ & Steep & Minor fracture \\
\hline 79.00 & 24.08 & 295 & 205 & 71 & NW & Nearly vertical & Lithologic feature \\
\hline 83.52 & 25.46 & 115 & 25 & 76 & SE & Nearly vertical & Transmissive fracture \\
\hline 88.11 & 26.85 & 128 & 38 & 63 & SE & Steep & Transmissive fracture \\
\hline 90.71 & 27.65 & 124 & 34 & 68 & SE & Steep & Transmissive fracture \\
\hline 96.58 & 29.44 & 155 & 65 & 78 & SE & Nearly vertical & Minor fracture \\
\hline 105.91 & 32.28 & 337 & 247 & 75 & NW & Nearly vertical & Minor fracture \\
\hline 115.25 & 35.13 & 307 & 217 & 73 & NW & Nearly vertical & Fracture \\
\hline 121.12 & 36.92 & 314 & 224 & 75 & NW & Nearly vertical & Minor fracture \\
\hline
\end{tabular}




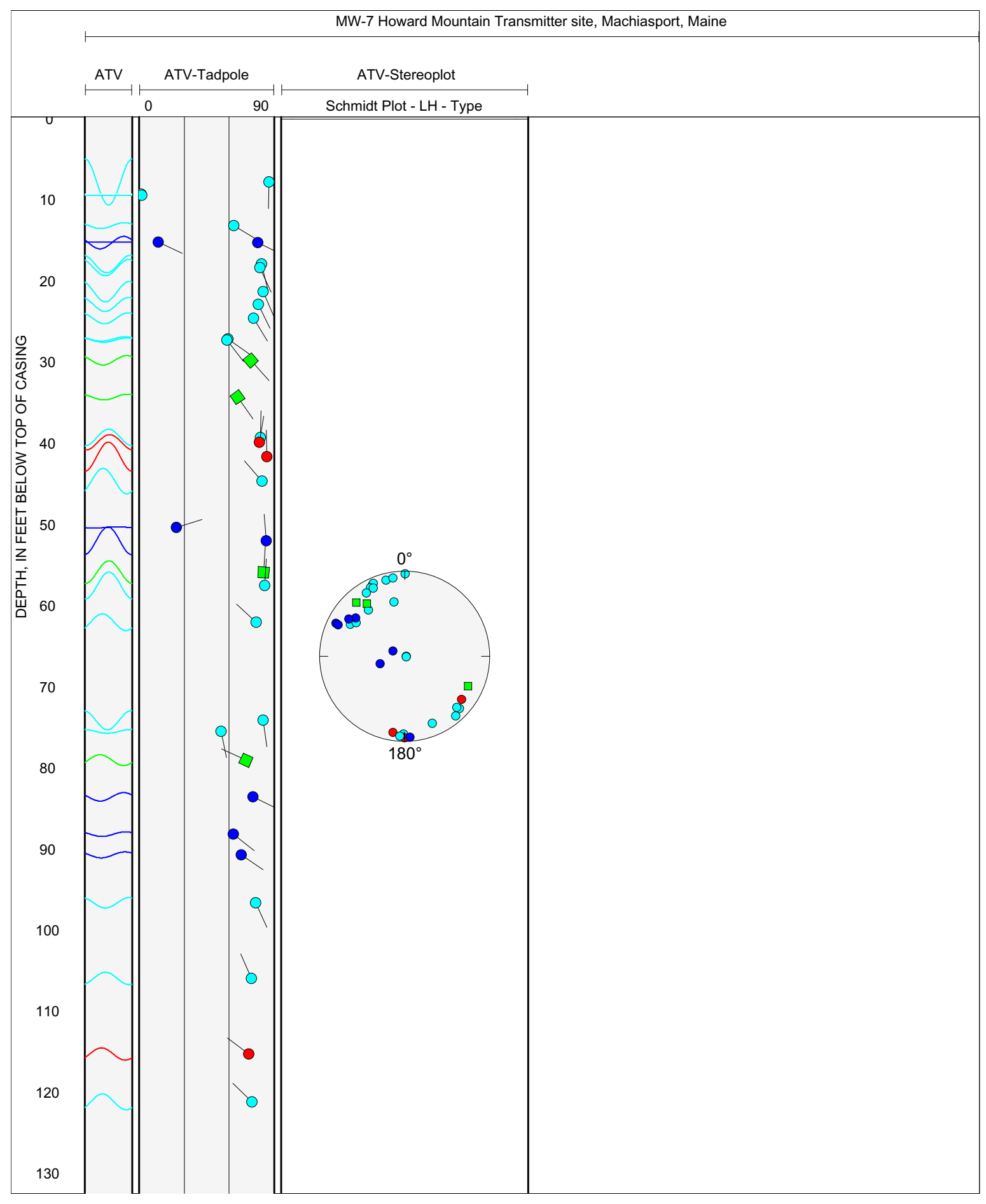

Figure 4L-2. Projection, tadpole, and stereoplots of interpretation of borehole image data for borehole MW-7, near Machiasport, Maine. 


\section{Appendix 5. Plots and interpretations of borehole geophysical logs collected by Hager- Richter Geoscience, Inc., for boreholes near Machiasport, Maine}




\section{Appendix 5.}

\section{Plots and interpretations of borehole geophysical logs collected by Hager-Richter Geoscience, Inc., for boreholes near Machiasport, Maine}

A. Borehole DW-29 (near the Ground-to-Air Transmitter/Receiver Site on Miller Mountain)

Figure 5A-1. Borehole deviation logs for borehole DW-29, near Machiasport, Maine.

Table 5A-1. Interpretation of acoustic televiewer logs for borehole DW-29, near Machiasport, Maine.

Table 5A-2. Interpretation of optical televiewer logs for borehole DW-29, near Machiasport, Maine.

Figure 5A-2. Projection, tadpole, and stereoplots of interpretation of borehole image data for borehole DW-29, near Machiasport, Maine.

Figure 5A-3. Interpretation and modeling of heat-pulse flowmeter logs for borehole DW-29, near Machiasport, Maine.

B. Borehole MW-15 (in the Air Force Radar Tracking Station area on Howard Mountain)

Figure 5B-1. Borehole deviation logs for borehole MW-15, near Machiasport, Maine.

Table 5B-1. Interpretation of acoustic televiewer logs for borehole MW-15, near Machiasport, Maine.

Table 5B-2. Interpretation of optical televiewer logs for borehole MW-15, near Machiasport, Maine.

Figure 5B-2. Projection, tadpole, and stereoplots of interpretation of borehole image data for borehole MW-15, near Machiasport, Maine.

Figure 5B-3. Interpretation and modeling of heat-pulse flowmeter logs for borehole MW-15, near Machiasport, Maine.

C. Borehole MW-16 (in the Air Force Radar Tracking Station area on Howard Mountain)

Figure 5C-1. Borehole deviation logs for borehole MW-16, near Machiasport, Maine.

Table 5C-1. Interpretation of acoustic televiewer logs for borehole MW-16, near Machiasport, Maine.

Table 5C-2. Interpretation of optical televiewer logs for borehole MW-16, near Machiasport, Maine.

Figure 5C-2. Projection, tadpole, and stereoplots of interpretation of borehole image data for borehole MW-16, near Machiasport, Maine.

Figure 5C-3. Interpretation and modeling of heat-pulse flowmeter logs for borehole MW-16, near Machiasport, Maine.

D. Borehole MW-17 (in the Air Force Radar Tracking Station area on Howard Mountain)

Figure 5D-1. Borehole deviation logs for borehole MW-17, near Machiasport, Maine.

Table 5D-1. Interpretation of acoustic televiewer logs for borehole MW-17, near Machiasport, Maine.

Table 5D-2. Interpretation of optical televiewer logs for borehole MW-17, near Machiasport, Maine.

Figure 5D-2. Projection, tadpole, and stereoplots of interpretation of borehole image data for borehole MW-17, near Machiasport, Maine.

Figure 5D-3. Interpretation and modeling of heat-pulse flowmeter logs for borehole MW-17, near Machiasport, Maine.

E. Borehole WY-3C (in the Air Force Radar Tracking Station area on Howard Mountain)

Figure 5E-1. Borehole deviation logs for borehole WY-3C, near Machiasport, Maine.

Table 5E-1. Interpretation of acoustic televiewer logs for borehole WY-3C, near Machiasport, Maine.

Figure 5E-2. Projection, tadpole, and stereoplots of interpretation of borehole image data for borehole WY-3C, near Machiasport, Maine.

Figure 5E-3. Interpretation and modeling of heat-pulse flowmeter logs for borehole WY-3C, near Machiasport, Maine. 
F. Borehole C-114 (in the Air Force Radar Tracking Station area on Howard Mountain)

Figure 5F-1. Borehole deviation logs for borehole C-114, near Machiasport, Maine.

Table 5F-1. Interpretation of acoustic televiewer logs for borehole C-114, near Machiasport, Maine.

Table 5F-2. Interpretation of optical televiewer logs for borehole C-114, near Machiasport, Maine.

Figure 5F-2. Projection, tadpole, and stereoplots of interpretation of borehole image data for borehole C-114, near Machiasport, Maine.

G. Borehole C-501 (in the Air Force Radar Tracking Station area on Howard Mountain)

Figure 5G-1. Borehole deviation logs for borehole C-501, near Machiasport, Maine.

Table 5G-1. Interpretation of acoustic televiewer logs for borehole C-501, near Machiasport, Maine.

Table 5G-2. Interpretation of optical televiewer logs for borehole C-501, near Machiasport, Maine.

Figure 5G-2. Projection, tadpole, and stereoplots of interpretation of borehole image data for borehole C-501, near Machiasport, Maine. 


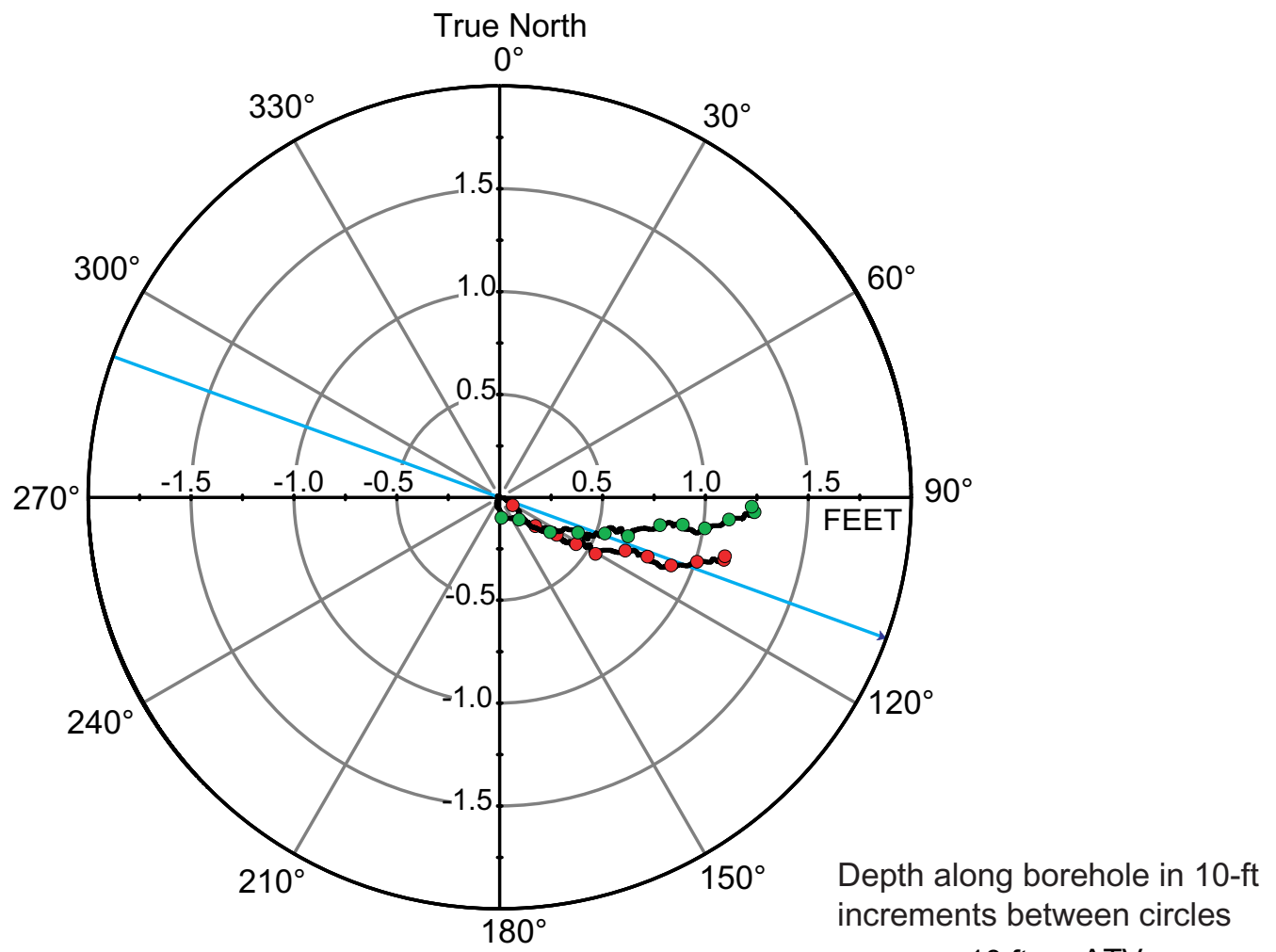

increments between circles

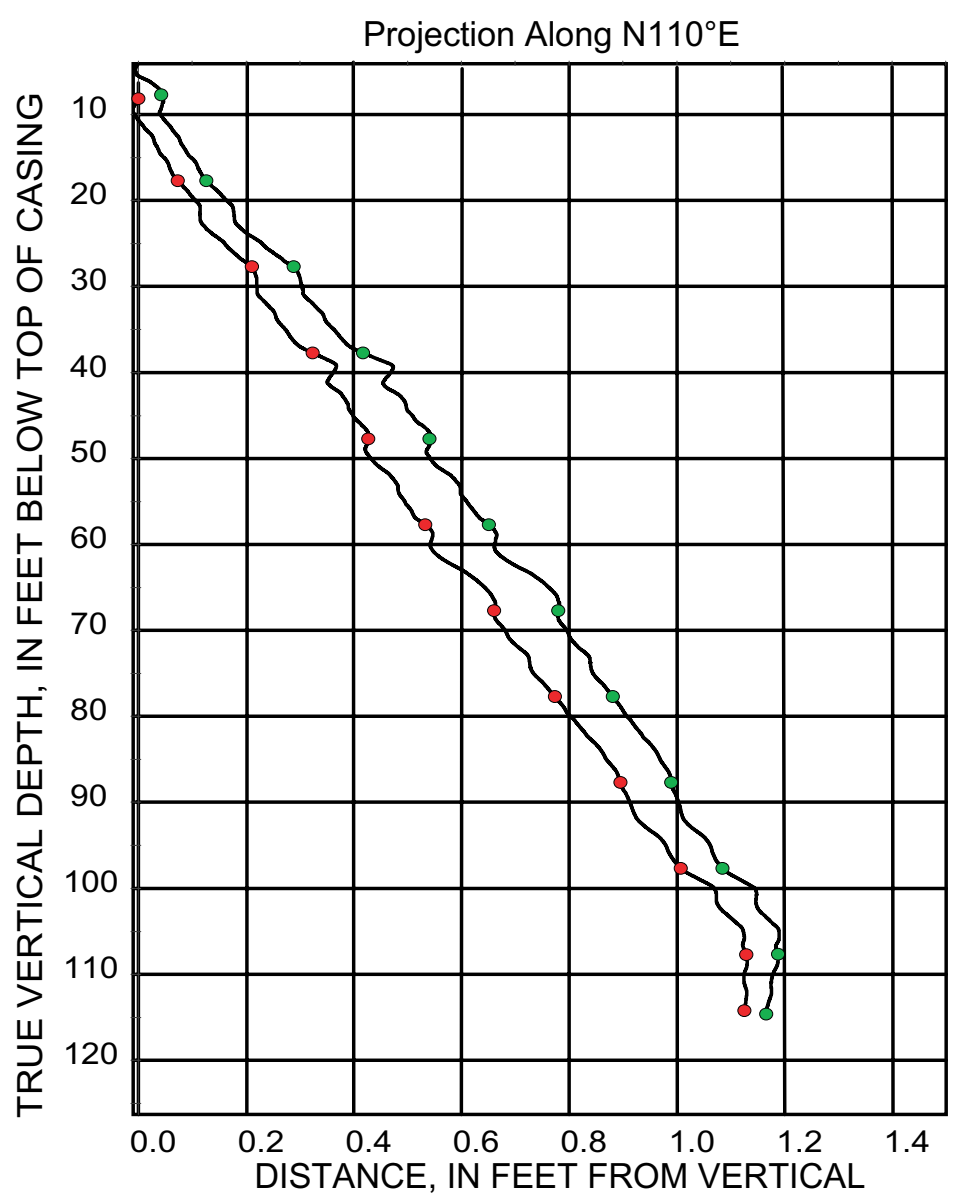

$\bullet 10 \mathrm{ft} \rightarrow$ ATV

$-10 \mathrm{ft} \rightarrow$ OTV

Figure 5A-1. Borehole deviation logs for borehole DW-29, near Machiasport, Maine. Blue line on radial plot (top) is line of projection for vertical plot (bottom).

[ft, foot; ATV, acoustic televiewer; OTV, optical televiewer] 
Table 5A-1. Interpretation of acoustic televiewer logs for borehole DW-29, near Machiasport, Maine.

[Televiewer data are corrected for deviation and magnetic declination, so orientations are relative to true north; depths are below top of casing, which is 2.54 feet above land surface; dip azimuth is given in degrees east of true north; strike is reported in right-hand-rule (RHR)-azimuthal degrees east of true north and where the direction of dip is 90 degrees to the right of strike]

\begin{tabular}{|c|c|c|c|c|c|c|c|}
\hline $\begin{array}{l}\text { Depth, } \\
\text { in feet }\end{array}$ & $\begin{array}{l}\text { Depth, } \\
\text { in meters }\end{array}$ & $\begin{array}{c}\text { Dip } \\
\text { azimuth }\end{array}$ & $\begin{array}{l}\text { Strike, } \\
\text { in RHR }\end{array}$ & Dip & $\begin{array}{c}\text { Dip } \\
\text { direction }\end{array}$ & Dip descriptor & Comment \\
\hline 13.37 & 4.07 & 222.79 & 133 & 57.66 & $\mathrm{SW}$ & Steep & Minor fracture \\
\hline 16.70 & 5.09 & 241.12 & 151 & 69.48 & SW & Steep & Minor fracture \\
\hline 17.14 & 5.22 & 41.83 & 312 & 57.61 & $\mathrm{NE}$ & Steep & Minor fracture \\
\hline 18.48 & 5.63 & 219.69 & 130 & 73.96 & SW & Nearly vertical & Minor fracture \\
\hline 21.39 & 6.52 & 312.84 & 223 & 72.02 & NW & Nearly vertical & Transmissive fracture \\
\hline 22.73 & 6.93 & 204.68 & 115 & 56.92 & SW & Steep & Transmissive fracture \\
\hline 22.96 & 7.00 & 202.87 & 113 & 36 & SW & Moderate & Lithologic feature \\
\hline 24.83 & 7.57 & 91.3 & 1 & 24.68 & $E$ & Shallow & Minor fracture \\
\hline 26.43 & 8.06 & 256.31 & 166 & 33.61 & W & Moderate & Minor fracture \\
\hline 29.21 & 8.90 & 326.78 & 237 & 81.3 & NW & Nearly vertical & Minor fracture \\
\hline 30.75 & 9.37 & 61.09 & 331 & 56.87 & $\mathrm{NE}$ & Steep & Minor fracture \\
\hline 31.55 & 9.62 & 318.38 & 228 & 74.52 & NW & Nearly vertical & Minor fracture \\
\hline 32.29 & 9.84 & 164.46 & 74 & 72.31 & $\mathrm{~S}$ & Nearly vertical & Minor fracture \\
\hline 33.20 & 10.12 & 258.51 & 169 & 72.35 & W & Nearly vertical & Minor fracture \\
\hline 36.37 & 11.09 & 237.96 & 148 & 84.08 & SW & Nearly vertical & Minor fracture \\
\hline 38.01 & 11.58 & 8.46 & 278 & 70.96 & $\mathrm{~N}$ & Nearly vertical & Minor fracture \\
\hline 38.03 & 11.59 & 90.12 & 0 & 81.47 & $E$ & Nearly vertical & Minor fracture \\
\hline 39.17 & 11.94 & 329.52 & 240 & 80.69 & NW & Nearly vertical & Minor fracture \\
\hline 40.41 & 12.32 & 329.94 & 240 & 82.85 & NW & Nearly vertical & Transmissive fracture \\
\hline 42.78 & 13.04 & 170.39 & 80 & 27.33 & $\mathrm{~S}$ & Shallow & Minor fracture \\
\hline 43.38 & 13.22 & 330.18 & 240 & 79.36 & NW & Nearly vertical & Minor fracture \\
\hline 43.88 & 13.37 & 190.47 & 100 & 71.69 & $S$ & Nearly vertical & Minor fracture \\
\hline 45.62 & 13.90 & 150.68 & 61 & 39.37 & SE & Moderate & Minor fracture \\
\hline 48.54 & 14.79 & 221.25 & 131 & 75.78 & SW & Nearly vertical & Minor fracture \\
\hline 49.28 & 15.02 & 194.79 & 105 & 65.51 & $\mathrm{~S}$ & Steep & Minor fracture \\
\hline 51.73 & 15.77 & 157.22 & 67 & 78.97 & SE & Nearly vertical & Fracture \\
\hline 55.39 & 16.88 & 261.16 & 171 & 81.08 & W & Nearly vertical & Minor fracture \\
\hline 56.18 & 17.12 & 160.57 & 71 & 31.95 & $\mathrm{~S}$ & Moderate & Minor fracture \\
\hline 57.76 & 17.60 & 172.65 & 83 & 45.58 & S & Moderate & Minor fracture \\
\hline 57.78 & 17.61 & 356.64 & 267 & 82.57 & $\mathrm{~N}$ & Nearly vertical & Minor fracture \\
\hline 59.72 & 18.20 & 326.3 & 236 & 73.13 & NW & Nearly vertical & Minor fracture \\
\hline 60.31 & 18.38 & 282.31 & 192 & 78.41 & W & Nearly vertical & Minor fracture \\
\hline 66.42 & 20.24 & 259.72 & 170 & 85.54 & W & Nearly vertical & Minor fracture \\
\hline 67.35 & 20.53 & 227.91 & 138 & 25.53 & SW & Shallow & Minor fracture \\
\hline 69.34 & 21.13 & 256.03 & 166 & 82.91 & W & Nearly vertical & Minor fracture \\
\hline 76.96 & 23.46 & 191.47 & 101 & 14.14 & $\mathrm{~S}$ & Shallow & Lithologic feature \\
\hline 77.67 & 23.67 & 217.74 & 128 & 27.93 & sw & Shallow & Lithologic feature \\
\hline 78.86 & 24.04 & 219.27 & 129 & 49.54 & SW & Moderate & Minor fracture \\
\hline 81.66 & 24.89 & 204.36 & 114 & 44.26 & SW & Moderate & Minor fracture \\
\hline 83.22 & 25.36 & 203.45 & 113 & 9.63 & SW & Nearly horizontal & Minor fracture \\
\hline 87.23 & 26.59 & 239.37 & 149 & 73.5 & SW & Nearly vertical & Lithologic feature \\
\hline 95.37 & 29.07 & 346.69 & 257 & 76.56 & $\mathrm{~N}$ & Nearly vertical & Transmissive fracture \\
\hline 98.50 & 30.02 & 7.98 & 278 & 12.7 & $N$ & Shallow & Minor fracture \\
\hline 99.78 & 30.41 & 308.13 & 218 & 67.47 & NW & Steep & Minor fracture \\
\hline 101.06 & 30.80 & 327.7 & 238 & 72.85 & NW & Nearly vertical & Minor fracture \\
\hline 106.27 & 32.39 & 252.93 & 163 & 79.62 & w & Nearly vertical & Transmissive fracture \\
\hline 106.62 & 32.50 & 86.07 & 356 & 21.45 & $\mathrm{E}$ & Shallow & Transmissive fracture \\
\hline 107.98 & 32.91 & 338.18 & 248 & 68.02 & $\mathrm{~N}$ & Steep & Minor fracture \\
\hline 108.64 & 33.11 & 353.85 & 264 & 70.67 & $\mathrm{~N}$ & Nearly vertical & Transmissive fracture \\
\hline 115.93 & 35.33 & 212.05 & 122 & 14.41 & sw & Shallow & Minor fracture \\
\hline
\end{tabular}


Table 5A-2. Interpretation of optical televiewer logs for borehole DW-29, near Machiasport, Maine.

[Televiewer data are corrected for deviation and magnetic declination, so orientations are relative to true north; depths are below top of casing, which is 2.54 feet above land surface; dip azimuth is given in degrees east of true north; strike is reported in right-hand-rule (RHR)-azimuthal degrees east of true north and where the direction of dip is 90 degrees to the right of strike]

\begin{tabular}{|c|c|c|c|c|c|c|c|}
\hline $\begin{array}{l}\text { Depth, } \\
\text { in feet }\end{array}$ & $\begin{array}{l}\text { Depth, } \\
\text { in meters }\end{array}$ & $\begin{array}{c}\text { Dip } \\
\text { azimuth }\end{array}$ & $\begin{array}{l}\text { Strike, } \\
\text { in RHR }\end{array}$ & Dip & $\begin{array}{c}\text { Dip } \\
\text { direction }\end{array}$ & Dip descriptor & Comment \\
\hline 7.87 & 2.40 & 293 & 203 & 3 & NW & Nearly horizontal & Bottom of casing \\
\hline 8.08 & 2.46 & 56 & 326 & 4 & NE & Nearly horizontal & Minor fracture \\
\hline 10.26 & 3.13 & 263 & 173 & 59 & W & Steep & Minor fracture \\
\hline 10.26 & 3.13 & 290 & 200 & 1 & W & Nearly horizontal & Water level \\
\hline 11.16 & 3.40 & 221 & 131 & 38 & SW & Moderate & Minor fracture \\
\hline 11.59 & 3.53 & 225 & 135 & 59 & SW & Steep & Minor fracture \\
\hline 12.76 & 3.89 & 232 & 142 & 69 & SW & Steep & Transmissive fracture \\
\hline 13.09 & 3.99 & 219 & 129 & 68 & SW & Steep & Minor fracture \\
\hline 13.27 & 4.04 & 30 & 300 & 14 & $\mathrm{NE}$ & Shallow & Lithologic feature \\
\hline 13.55 & 4.13 & 259 & 169 & 87 & W & Nearly vertical & Partial fracture \\
\hline 14.75 & 4.50 & 270 & 180 & 76 & w & Nearly vertical & Sealed feature \\
\hline 16.21 & 4.94 & 231 & 141 & 74 & SW & Nearly vertical & Minor fracture \\
\hline 16.55 & 5.04 & 226 & 136 & 76 & SW & Nearly vertical & Minor fracture \\
\hline 17.16 & 5.23 & 22 & 292 & 55 & $\mathrm{~N}$ & Steep & Minor fracture \\
\hline 18.33 & 5.59 & 208 & 118 & 71 & SW & Nearly vertical & Sealed feature \\
\hline 18.55 & 5.65 & 40 & 310 & 75 & $\mathrm{NE}$ & Nearly vertical & Partial fracture \\
\hline 18.93 & 5.77 & 329 & 239 & 27 & NW & Shallow & Minor fracture \\
\hline 19.22 & 5.86 & 226 & 136 & 72 & SW & Nearly vertical & Sealed feature \\
\hline 20.40 & 6.22 & 236 & 146 & 53 & SW & Steep & Minor fracture \\
\hline 22.00 & 6.71 & 318 & 228 & 78 & NW & Nearly vertical & Sealed feature \\
\hline 22.08 & 6.73 & 327 & 237 & 18 & NW & Shallow & Sealed feature \\
\hline 22.17 & 6.76 & 216 & 126 & 45 & SW & Moderate & Transmissive fracture \\
\hline 22.88 & 6.97 & 275 & 185 & 23 & w & Shallow & Lithologic feature \\
\hline 23.73 & 7.23 & 35 & 305 & 34 & NE & Moderate & Sealed feature \\
\hline 24.62 & 7.50 & 7 & 277 & 55 & $\mathrm{~N}$ & Steep & Minor fracture \\
\hline 25.71 & 7.84 & 35 & 305 & 61 & $\mathrm{NE}$ & Steep & Minor fracture \\
\hline 26.25 & 8.00 & 336 & 246 & 25 & NW & Shallow & Minor fracture \\
\hline 26.66 & 8.13 & 156 & 66 & 6 & $\mathrm{SE}$ & Nearly horizontal & Minor fracture \\
\hline 26.77 & 8.16 & 50 & 320 & 69 & $\mathrm{NE}$ & Steep & Sealed feature \\
\hline 27.10 & 8.26 & 100 & 10 & 20 & $\mathrm{E}$ & Shallow & Lithologic feature \\
\hline 27.50 & 8.38 & 80 & 350 & 79 & $\bar{E}$ & Nearly vertical & Partial fracture \\
\hline 28.98 & 8.83 & 12 & 282 & 30 & $\mathrm{~N}$ & Moderate & Lithologic feature \\
\hline 29.29 & 8.93 & 324 & 234 & 81 & NW & Nearly vertical & Minor fracture \\
\hline 29.38 & 8.95 & 69 & 339 & 16 & $E$ & Shallow & Lithologic feature \\
\hline 30.51 & 9.30 & 272 & 182 & 80 & W & Nearly vertical & Minor fracture \\
\hline 30.64 & 9.34 & 81 & 351 & 46 & $E$ & Moderate & Minor fracture \\
\hline 30.77 & 9.38 & 88 & 358 & 24 & $\bar{E}$ & Shallow & Minor fracture \\
\hline 32.01 & 9.76 & 144 & 54 & 53 & SE & Steep & Minor fracture \\
\hline 32.06 & 9.77 & 360 & 270 & 25 & $\mathrm{~N}$ & Shallow & Minor fracture \\
\hline 33.50 & 10.21 & 313 & 223 & 73 & NW & Nearly vertical & Minor fracture \\
\hline 34.57 & 10.54 & 122 & 32 & 10 & SE & Nearly horizontal & Minor fracture \\
\hline 35.46 & 10.81 & 77 & 347 & 15 & $\mathrm{E}$ & Shallow & Minor fracture \\
\hline 36.40 & 11.09 & 234 & 144 & 84 & sw & Nearly vertical & Minor fracture \\
\hline 37.52 & 11.44 & 334 & 244 & 75 & NW & Nearly vertical & Minor fracture \\
\hline 38.22 & 11.65 & 76 & 346 & 82 & $E$ & Nearly vertical & Minor fracture \\
\hline 39.52 & 12.05 & 326 & 236 & 81 & NW & Nearly vertical & Fracture \\
\hline 41.06 & 12.51 & 325 & 235 & 78 & NW & Nearly vertical & Transmissive fracture \\
\hline 42.64 & 13.00 & 171 & 81 & 31 & $\mathrm{~S}$ & Moderate & Partial fracture \\
\hline 42.74 & 13.03 & 358 & 268 & 73 & $\mathrm{~N}$ & Nearly vertical & Partial fracture \\
\hline 43.58 & 13.28 & 328 & 238 & 80 & NW & Nearly vertical & Minor fracture \\
\hline 43.84 & 13.36 & 189 & 99 & 71 & $\mathrm{~S}$ & Nearly vertical & Minor fracture \\
\hline 44.19 & 13.47 & 47 & 317 & 26 & $\mathrm{NE}$ & Shallow & Sealed feature \\
\hline 45.41 & 13.84 & 131 & 41 & 45 & SE & Moderate & Minor fracture \\
\hline 46.64 & 14.22 & 253 & 163 & 77 & W & Nearly vertical & Minor fracture \\
\hline 49.06 & 14.95 & 68 & 338 & 64 & $\mathrm{E}$ & Steep & Minor fracture \\
\hline 49.24 & 15.01 & 233 & 143 & 83 & sw & Nearly vertical & Minor fracture \\
\hline 49.28 & 15.02 & 264 & 174 & 77 & W & Nearly vertical & Partial fracture \\
\hline
\end{tabular}


Table 5A-2. Interpretation of optical televiewer logs for borehole DW-29, near Machiasport, Maine.-Continued [Televiewer data are corrected for deviation and magnetic declination, so orientations are relative to true north; depths are below top of casing, which is 2.54 feet above land surface; dip azimuth is given in degrees east of true north; strike is reported in right-hand-rule (RHR)-azimuthal degrees east of true north and where the direction of dip is 90 degrees to the right of strike]

\begin{tabular}{|c|c|c|c|c|c|c|c|}
\hline $\begin{array}{l}\text { Depth, } \\
\text { in feet }\end{array}$ & $\begin{array}{l}\text { Depth, } \\
\text { in meters }\end{array}$ & $\begin{array}{c}\text { Dip } \\
\text { azimuth }\end{array}$ & $\begin{array}{l}\text { Strike, } \\
\text { in RHR }\end{array}$ & Dip & $\begin{array}{c}\text { Dip } \\
\text { direction }\end{array}$ & Dip descriptor & Comment \\
\hline 50.18 & 15.29 & 67 & 337 & 78 & $\mathrm{NE}$ & Nearly vertical & Fracture \\
\hline 51.88 & 15.81 & 152 & 62 & 77 & SE & Nearly vertical & Fracture \\
\hline 53.45 & 16.29 & 150 & 60 & 71 & SE & Nearly vertical & Minor fracture \\
\hline 53.68 & 16.36 & 135 & 45 & 25 & SE & Shallow & Minor fracture \\
\hline 54.20 & 16.52 & 145 & 55 & 21 & SE & Shallow & Sealed feature \\
\hline 54.93 & 16.74 & 116 & 26 & 49 & SE & Moderate & Sealed feature \\
\hline 55.53 & 16.92 & 256 & 166 & 81 & W & Nearly vertical & Minor fracture \\
\hline 56.18 & 17.12 & 114 & 24 & 19 & SE & Shallow & Minor fracture \\
\hline 56.75 & 17.30 & 151 & 61 & 52 & SE & Steep & Minor fracture \\
\hline 57.04 & 17.38 & 148 & 58 & 46 & SE & Moderate & Lithologic feature \\
\hline 57.75 & 17.60 & 166 & 76 & 47 & $\mathrm{~S}$ & Moderate & Minor fracture \\
\hline 58.31 & 17.77 & 329 & 239 & 81 & NW & Nearly vertical & Minor fracture \\
\hline 59.41 & 18.11 & 226 & 136 & 69 & sw & Steep & Fracture \\
\hline 59.76 & 18.21 & 316 & 226 & 73 & NW & Nearly vertical & Fracture \\
\hline 60.91 & 18.56 & 176 & 86 & 15 & $S$ & Shallow & Minor fracture \\
\hline 61.15 & 18.64 & 352 & 262 & 77 & $\mathrm{~N}$ & Nearly vertical & Minor fracture \\
\hline 61.60 & 18.77 & 82 & 352 & 69 & E & Steep & Minor fracture \\
\hline 62.83 & 19.15 & 76 & 346 & 62 & $E$ & Steep & Sealed feature \\
\hline 62.84 & 19.15 & 211 & 121 & 30 & SW & Moderate & Lithologic feature \\
\hline 63.18 & 19.26 & 243 & 153 & 31 & SW & Moderate & Lithologic feature \\
\hline 64.71 & 19.72 & 169 & 79 & 24 & $\mathrm{~s}$ & Shallow & Lithologic feature \\
\hline 66.40 & 20.24 & 257 & 167 & 85 & W & Nearly vertical & Minor fracture \\
\hline 66.51 & 20.27 & 107 & 17 & 21 & $E$ & Shallow & Minor fracture \\
\hline 66.79 & 20.36 & 257 & 167 & 83 & W & Nearly vertical & Minor fracture \\
\hline 67.36 & 20.53 & 215 & 125 & 20 & SW & Shallow & Minor fracture \\
\hline 69.45 & 21.17 & 252 & 162 & 83 & w & Nearly vertical & Minor fracture \\
\hline 71.40 & 21.76 & 301 & 211 & 76 & NW & Nearly vertical & Lithologic feature \\
\hline 74.95 & 22.84 & 351 & 261 & 73 & $N$ & Nearly vertical & Sealed feature \\
\hline 77.01 & 23.47 & 237 & 147 & 25 & SW & Shallow & Lithologic feature \\
\hline 77.38 & 23.58 & 263 & 173 & 83 & W & Nearly vertical & Sealed feature \\
\hline 77.69 & 23.68 & 224 & 134 & 24 & sw & Shallow & Lithologic feature \\
\hline 78.75 & 24.00 & 256 & 166 & 85 & w & Nearly vertical & Sealed feature \\
\hline 78.86 & 24.04 & 215 & 125 & 50 & sw & Moderate & Sealed feature \\
\hline 81.38 & 24.80 & 234 & 144 & 21 & SW & Shallow & Lithologic feature \\
\hline 81.95 & 24.98 & 73 & 343 & 69 & $E$ & Steep & Minor fracture \\
\hline 82.04 & 25.00 & 251 & 161 & 64 & W & Steep & Minor fracture \\
\hline 83.21 & 25.36 & 197 & 107 & 9 & $\mathrm{~s}$ & Nearly horizontal & Sealed feature \\
\hline 84.23 & 25.67 & 153 & 63 & 55 & $\mathrm{SE}$ & Steep & Minor fracture \\
\hline 84.59 & 25.78 & 246 & 156 & 70 & SW & Nearly vertical & Sealed feature \\
\hline 85.14 & 25.95 & 206 & 116 & 8 & SW & Nearly horizontal & Minor fracture \\
\hline 87.28 & 26.60 & 227 & 137 & 71 & sw & Nearly vertical & Fracture \\
\hline 88.90 & 27.10 & 234 & 144 & 69 & SW & Steep & Partial fracture \\
\hline 91.49 & 27.88 & 315 & 225 & 73 & NW & Nearly vertical & Sealed feature \\
\hline 93.83 & 28.60 & 310 & 220 & 75 & NW & Nearly vertical & Minor fracture \\
\hline 95.10 & 28.99 & 334 & 244 & 74 & NW & Nearly vertical & Transmissive fracture \\
\hline 98.50 & 30.02 & 344 & 254 & 14 & $N$ & Shallow & Transmissive fracture \\
\hline 99.64 & 30.37 & 298 & 208 & 69 & NW & Steep & Lithologic feature \\
\hline 101.79 & 31.02 & 258 & 168 & 82 & W & Nearly vertical & Lithologic feature \\
\hline 105.17 & 32.05 & 319 & 229 & 64 & NW & Steep & Sealed feature \\
\hline 106.46 & 32.45 & 87 & 357 & 37 & $E$ & Moderate & Transmissive fracture \\
\hline 106.64 & 32.50 & 252 & 162 & 83 & W & Nearly vertical & Lithologic feature \\
\hline 108.18 & 32.97 & 310 & 220 & 73 & NW & Nearly vertical & Minor fracture \\
\hline 108.65 & 33.11 & 58 & 328 & 54 & $\mathrm{NE}$ & Steep & Transmissive fracture \\
\hline 109.08 & 33.25 & 315 & 225 & 68 & NW & Steep & Sealed feature \\
\hline 110.98 & 33.83 & 321 & 231 & 68 & NW & Steep & Sealed feature \\
\hline 115.90 & 35.32 & 242 & 152 & 11 & SW & Shallow & Minor fracture \\
\hline 115.93 & 35.33 & 96 & 6 & 75 & $E$ & Nearly vertical & Sealed feature \\
\hline 116.88 & 35.62 & 205 & 115 & 8 & SW & Nearly horizontal & Sealed feature \\
\hline
\end{tabular}




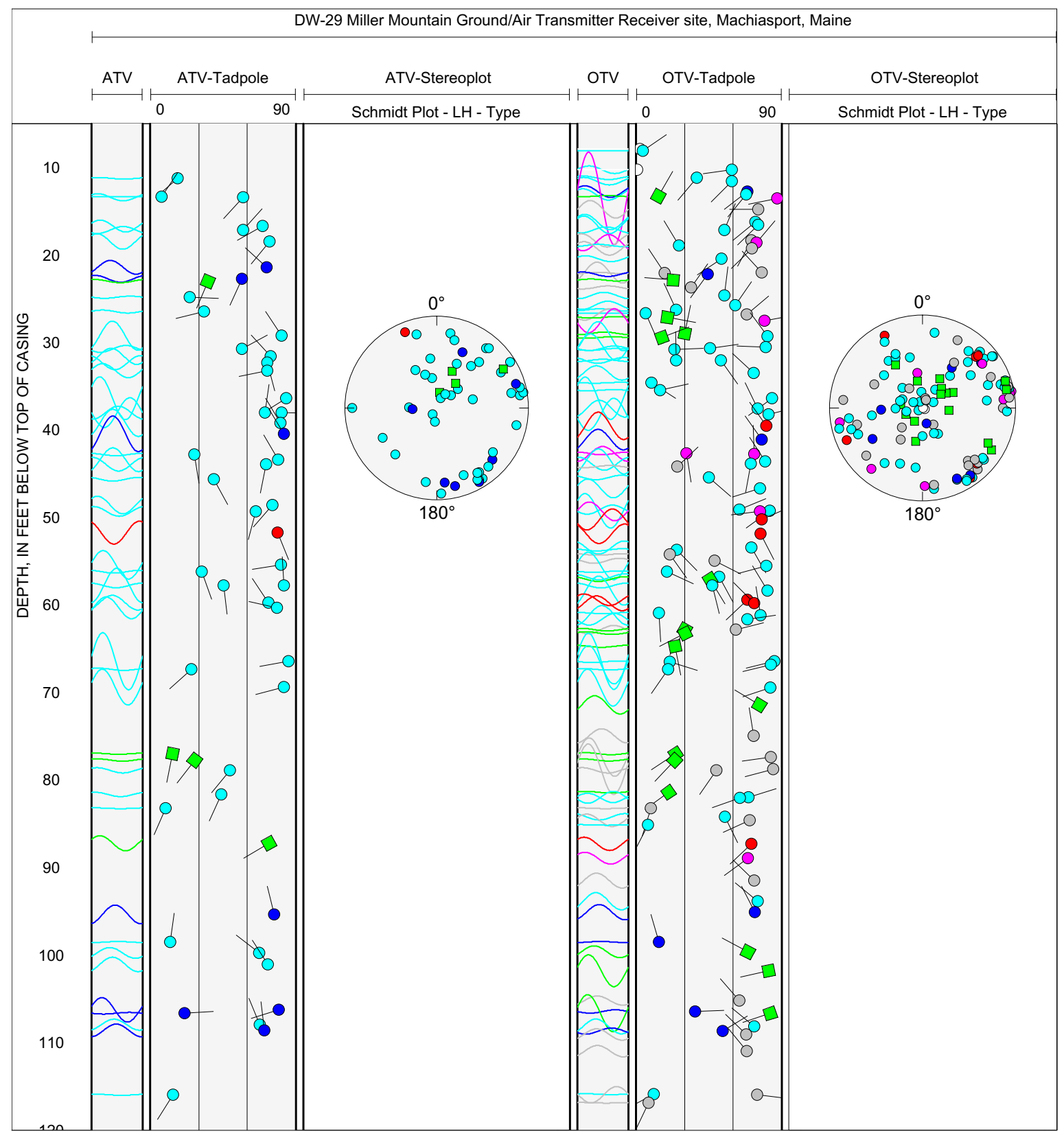

Figure 5A-2. Projection, tadpole, and stereoplots of interpretation of borehole image data for borehole DW-29, near Machiasport, Maine. 

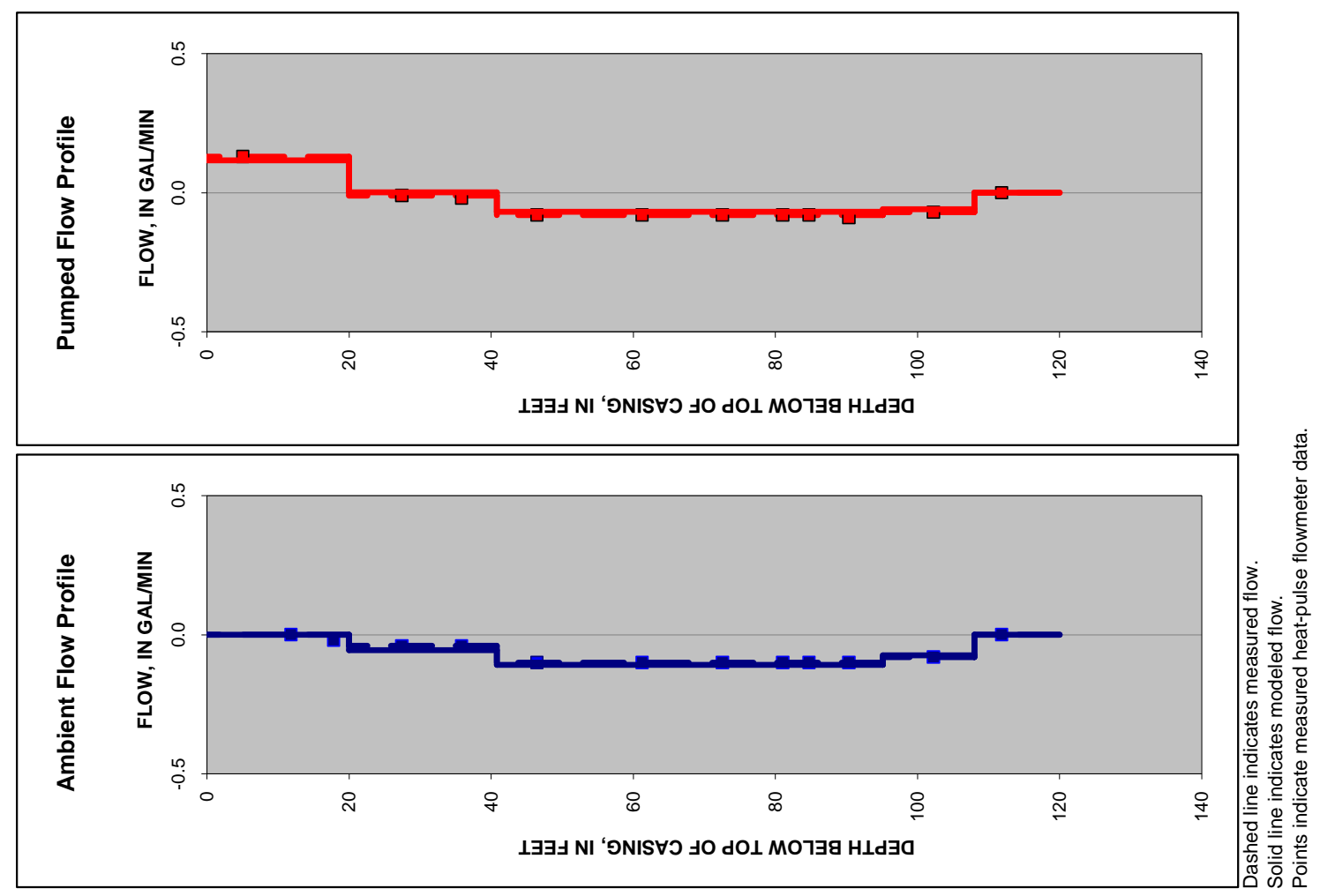

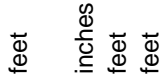




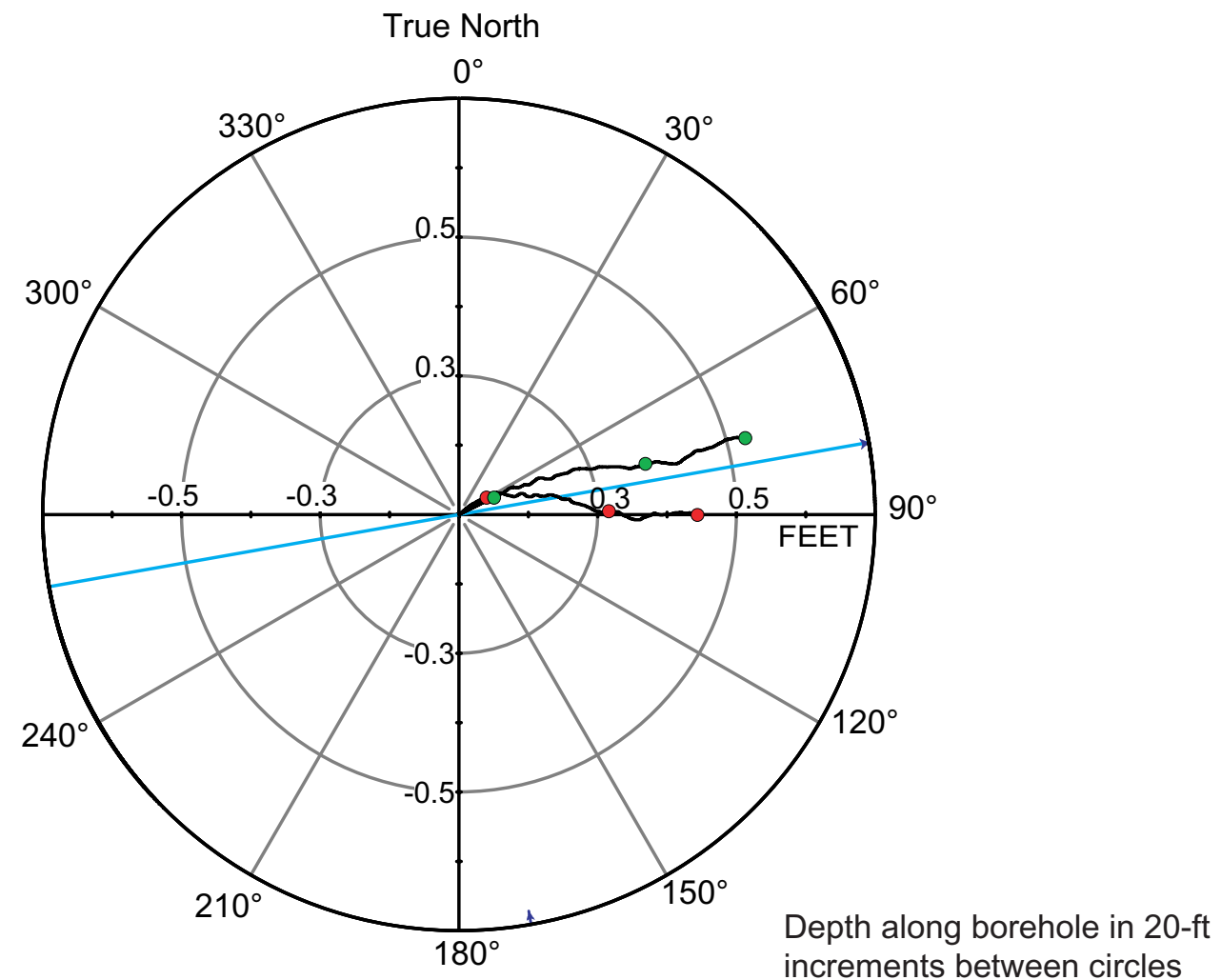

increments between circles

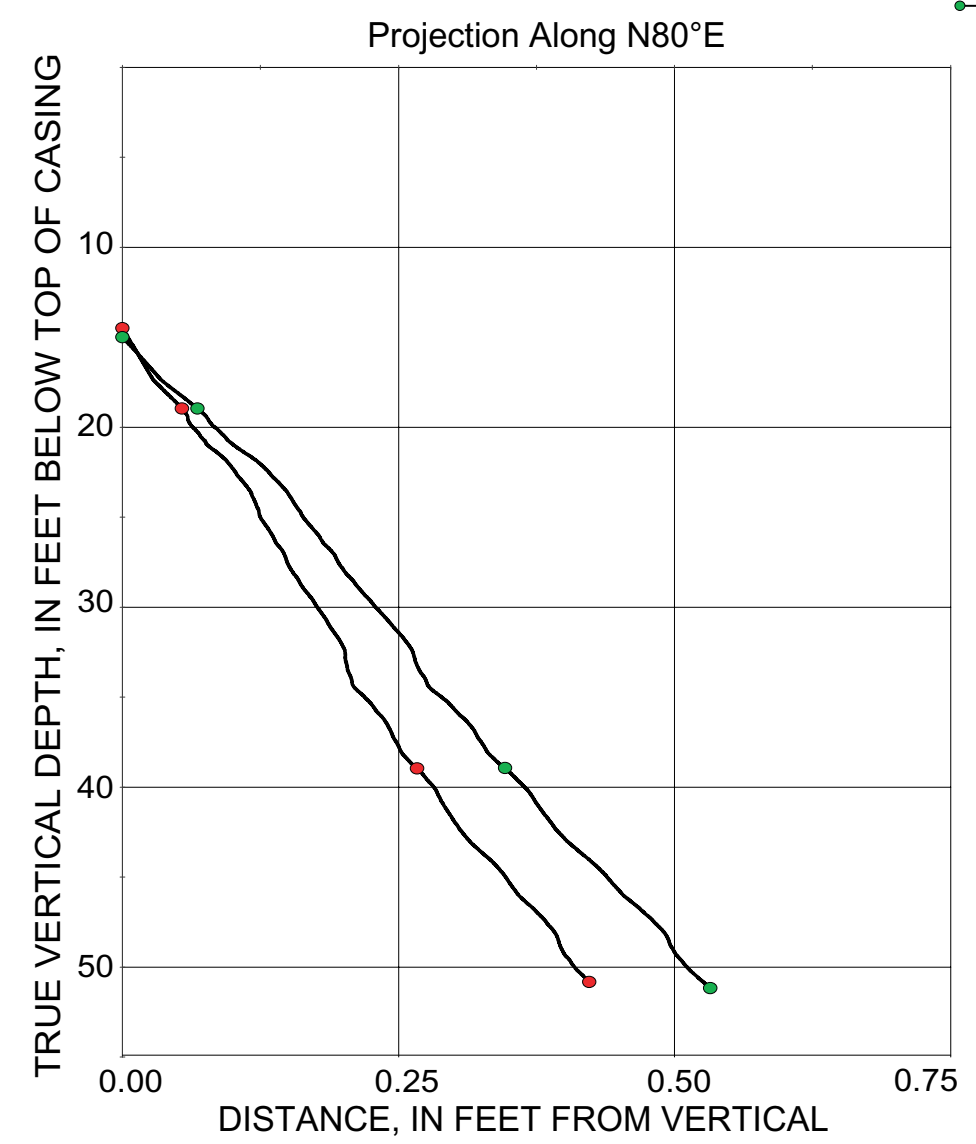

$-20 \mathrm{ft} \rightarrow$ ATV

$-20 \mathrm{ft} \rightarrow$ OTV

Figure 5B-1. Borehole deviation logs for borehole MW-15, near Machiasport, Maine. Blue line on radial plot (top) is line of projection for vertical plot (bottom).

[ft, foot; ATV, acoustic televiewer; OTV, optical televiewer] 
Table 5B-1. Interpretation of acoustic televiewer logs for borehole MW-15, near Machiasport, Maine. [Televiewer data are corrected for deviation and magnetic declination, so orientations are relative to true north; depths are below top of casing, which is 2.8 feet above land surface; dip azimuth is given in degrees east of true north; strike is reported in right-hand-rule (RHR)-azimuthal degrees east of true north and where the direction of dip is 90 degrees to the right of strike]

\begin{tabular}{crrrrccl}
\hline $\begin{array}{c}\text { Depth, } \\
\text { in feet }\end{array}$ & $\begin{array}{c}\text { Depth, } \\
\text { in meters }\end{array}$ & $\begin{array}{c}\text { Dip } \\
\text { azimuth }\end{array}$ & $\begin{array}{c}\text { Strike, } \\
\text { in RHR }\end{array}$ & Dip & $\begin{array}{c}\text { Dip } \\
\text { direction }\end{array}$ & Dip descriptor & Comment \\
\hline 17.75 & 5.41 & 235.7 & 146 & 0.6 & $\mathrm{~N}$ & Nearly horizontal & Bottom of casing \\
18.44 & 5.62 & 230.49 & 140 & 24.44 & $\mathrm{NE}$ & Shallow & Minor fracture \\
19.28 & 5.88 & 42.14 & 312 & 54.48 & $\mathrm{NE}$ & Steep & Transmissive fracture \\
20.23 & 6.17 & 63.59 & 334 & 32.75 & $\mathrm{NE}$ & Moderate & Transmissive fracture \\
23.25 & 7.09 & 25.06 & 295 & 46.18 & $\mathrm{NE}$ & Moderate & Minor fracture \\
26.85 & 8.18 & 40.42 & 310 & 88.09 & $\mathrm{E}$ & Nearly vertical & Minor fracture \\
28.46 & 8.67 & 46.65 & 317 & 82.83 & $\mathrm{E}$ & Nearly vertical & Minor fracture \\
29.03 & 8.85 & 39.5 & 310 & 80.09 & $\mathrm{E}$ & Nearly vertical & Minor fracture \\
32.79 & 9.99 & 208.76 & 119 & 44.52 & $\mathrm{NE}$ & Moderate & Minor fracture \\
33.39 & 10.18 & 215.94 & 126 & 42.49 & $\mathrm{NE}$ & Moderate & Minor fracture \\
34.63 & 10.55 & 109.53 & 20 & 23.41 & $\mathrm{NE}$ & Shallow & Minor fracture \\
50.69 & 15.45 & 149.92 & 60 & 57.78 & $\mathrm{NE}$ & Steep & Minor fracture \\
\hline
\end{tabular}

Table 5B-2. Interpretation of optical televiewer logs for borehole MW-15, near Machiasport, Maine. [Televiewer data are corrected for deviation and magnetic declination, so orientations are relative to true north; depths are below top of casing, which is 2.8 feet above land surface; dip azimuth is given in degrees east of true north; strike is reported in right-hand-rule (RHR)-azimuthal degrees east of true north and where the direction of dip is 90 degrees to the right of strike]

\begin{tabular}{rrrccccl}
\hline $\begin{array}{c}\text { Depth, } \\
\text { in feet }\end{array}$ & $\begin{array}{c}\text { Depth, } \\
\text { in meters }\end{array}$ & $\begin{array}{c}\text { Dip } \\
\text { azimuth }\end{array}$ & $\begin{array}{c}\text { Strike, } \\
\text { in RHR }\end{array}$ & Dip & $\begin{array}{c}\text { Dip } \\
\text { direction }\end{array}$ & Dip descriptor & Comment \\
\hline 17.68 & 5.39 & 245 & 155 & 1 & SW & Nearly horizontal & Bottom of casing \\
19.37 & 5.90 & 16 & 286 & 31 & N & Moderate & Transmissive fracture \\
20.11 & 6.13 & 70 & 340 & 24 & E & Shallow & Transmissive fracture \\
21.41 & 6.53 & 159 & 69 & 56 & S & Steep & Minor fracture \\
22.95 & 6.99 & 60 & 330 & 18 & NE & Shallow & Minor fracture \\
24.45 & 7.45 & 249 & 159 & 83 & W & Nearly vertical & Minor fracture \\
24.86 & 7.58 & 270 & 180 & 48 & W & Moderate & Minor fracture \\
26.34 & 8.03 & 160 & 70 & 51 & S & Steep & Minor fracture \\
26.86 & 8.19 & 151 & 61 & 57 & SE & Steep & Minor fracture \\
28.28 & 8.62 & 172 & 82 & 74 & S & Nearly vertical & Minor fracture \\
28.92 & 8.81 & 36 & 306 & 80 & NE & Nearly vertical & Partial fracture \\
32.86 & 10.02 & 234 & 144 & 39 & SW & Moderate & Lithologic feature \\
33.50 & 10.21 & 234 & 144 & 41 & SW & Moderate & Lithologic feature \\
34.15 & 10.41 & 182 & 92 & 60 & S & Steep & Minor fracture \\
38.30 & 11.67 & 160 & 70 & 51 & S & Steep & Minor fracture \\
40.52 & 12.35 & 137 & 47 & 34 & SE & Moderate & Minor fracture \\
40.67 & 12.40 & 142 & 52 & 39 & SE & Moderate & Minor fracture \\
41.25 & 12.57 & 115 & 25 & 50 & SE & Steep & Minor fracture \\
42.64 & 13.00 & 142 & 52 & 29 & SE & Shallow & Lithologic feature \\
44.85 & 13.67 & 142 & 52 & 66 & SE & Steep & Minor fracture \\
50.86 & 15.50 & 158 & 68 & 55 & S & Steep & Minor fracture \\
\hline
\end{tabular}




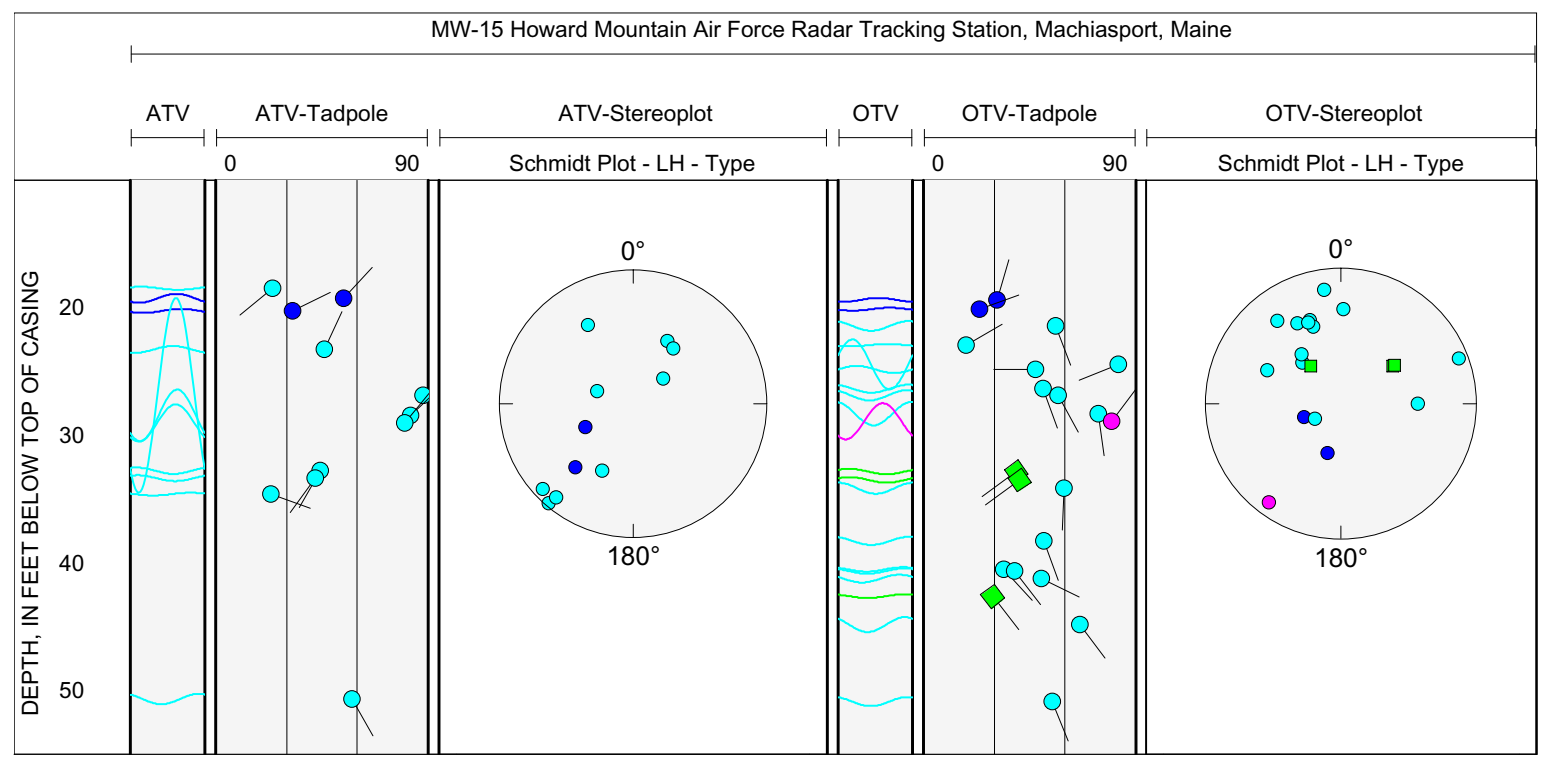

Figure 5B-2. Projection, tadpole, and stereoplots of interpretation of borehole image data for borehole MW-15, near Machiasport, Maine. 

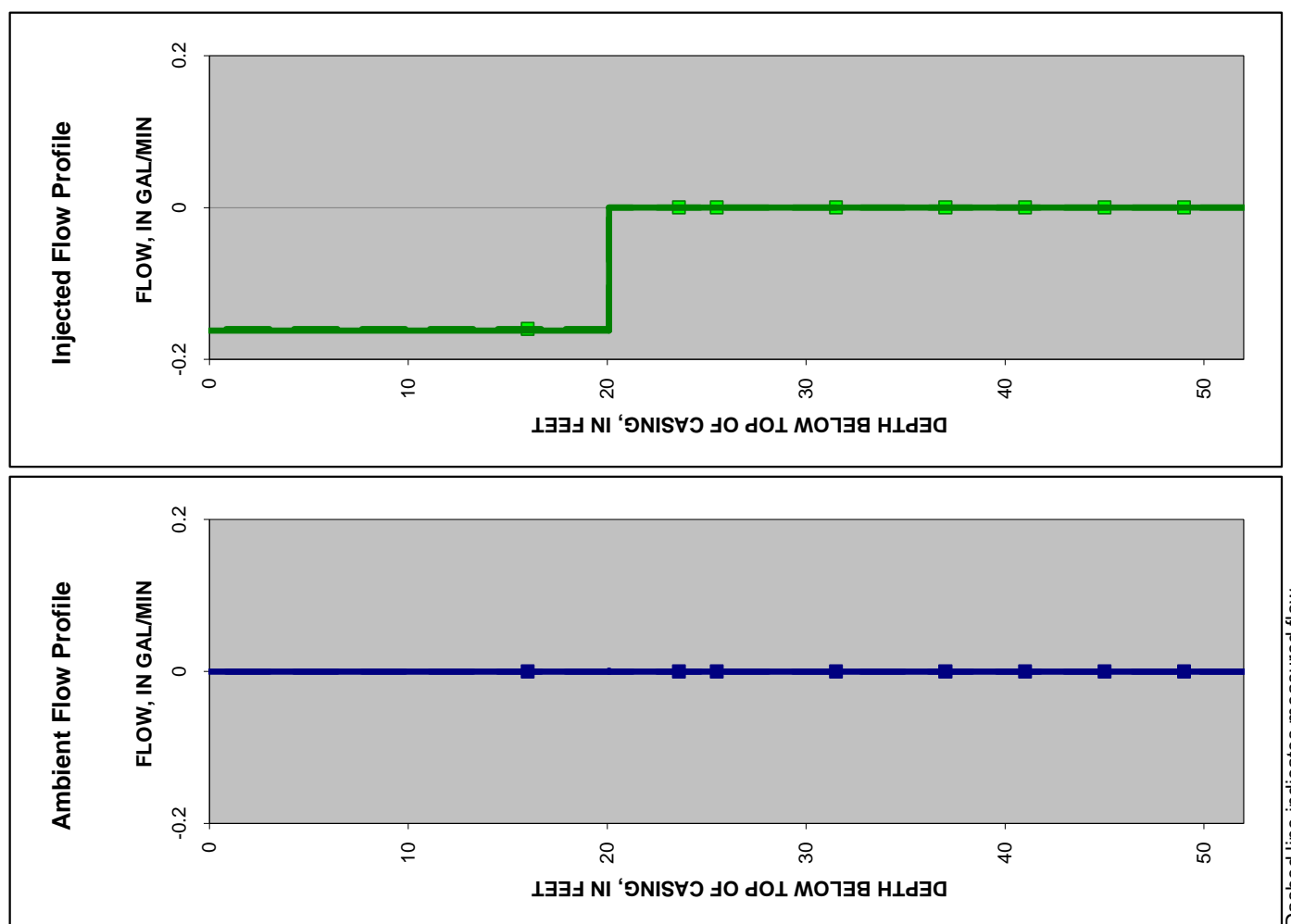

总
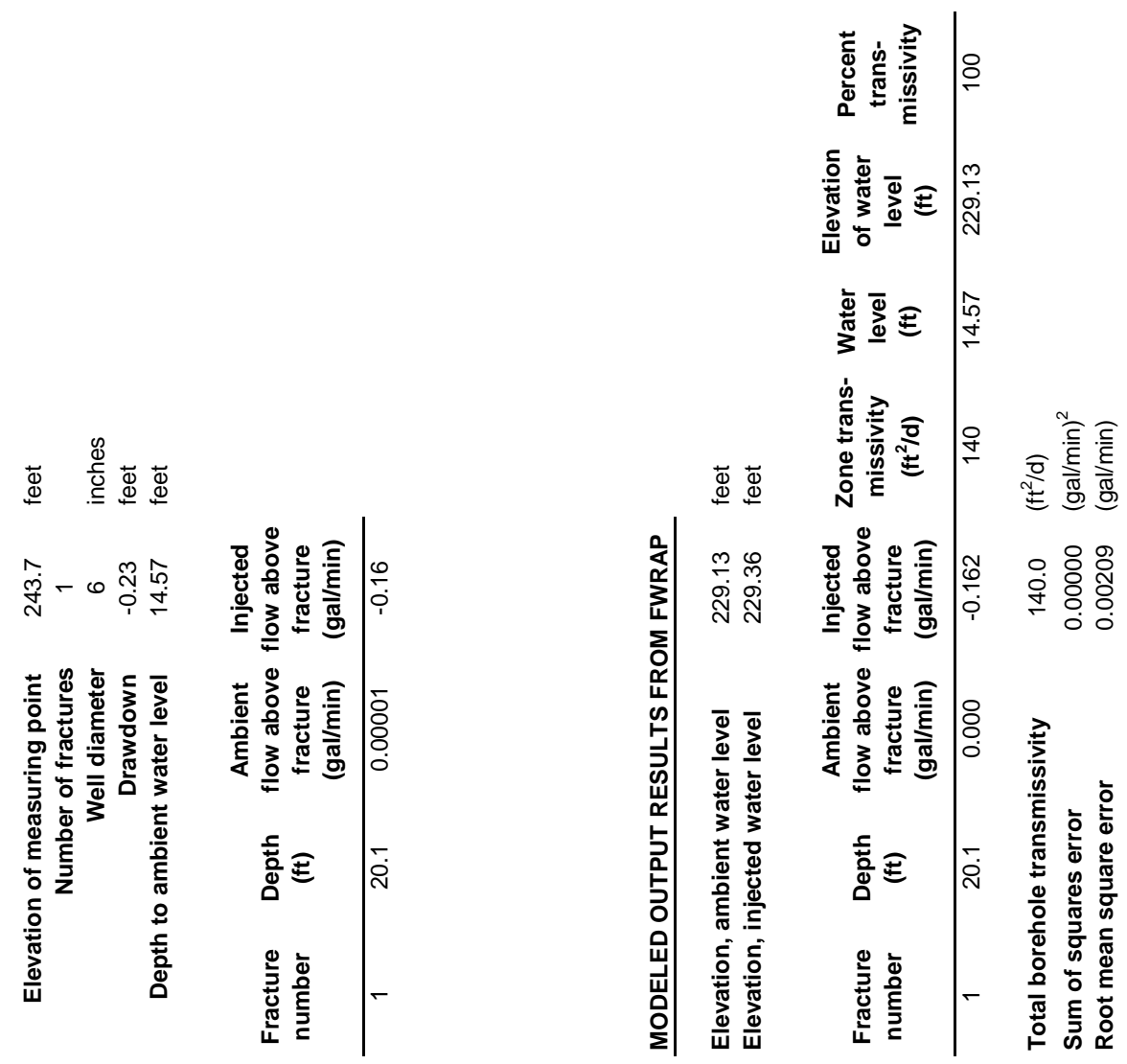

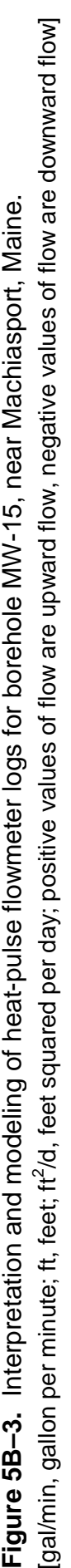



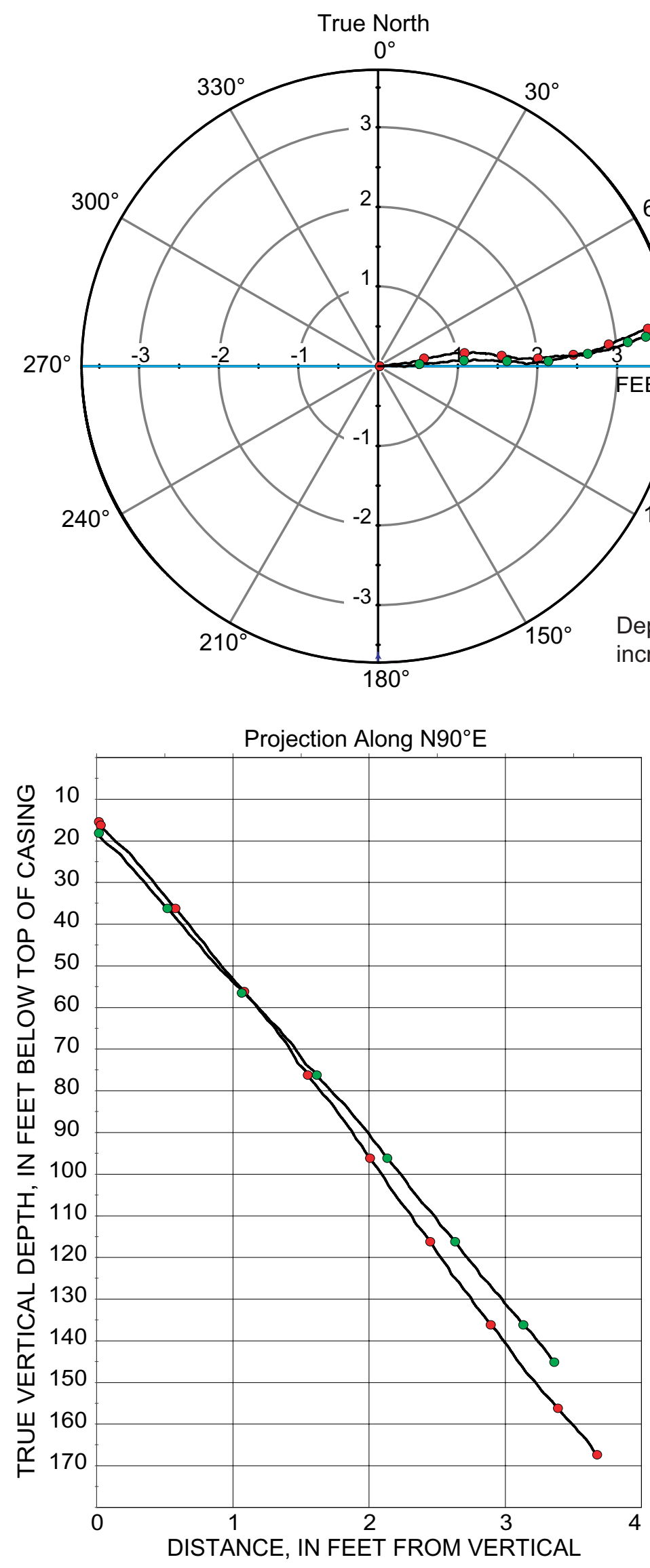

Depth along borehole in 20-ft increments between circles

$\bullet-20 \mathrm{ft} \rightarrow$ ATV 
Table 5C-1. Interpretation of acoustic televiewer logs for borehole MW-16, near Machiasport, Maine. [Televiewer data are corrected for deviation and magnetic declination, so orientations are relative to true north; depths are below top of casing, which is 2.5 feet above land surface; dip azimuth is given in degrees east of true north; strike is reported in right-hand-rule (RHR)-azimuthal degrees east of true north and where the direction of dip is 90 degrees to the right of strike]

\begin{tabular}{|c|c|c|c|c|c|c|c|}
\hline $\begin{array}{l}\text { Depth, } \\
\text { in feet }\end{array}$ & $\begin{array}{l}\text { Depth, } \\
\text { in meters }\end{array}$ & $\begin{array}{c}\text { Dip } \\
\text { azimuth }\end{array}$ & $\begin{array}{l}\text { Strike, } \\
\text { in RHR }\end{array}$ & Dip & $\begin{array}{c}\text { Dip } \\
\text { direction }\end{array}$ & Dip descriptor & Comment \\
\hline 22.82 & 6.96 & 264 & 174 & 2 & $\mathrm{~W}$ & Nearly horizontal & Water level \\
\hline 23.05 & 7.03 & 216 & 126 & 2 & SW & Nearly horizontal & Minor fracture \\
\hline 23.86 & 7.27 & 195 & 105 & 23 & $\mathrm{~s}$ & Shallow & Minor fracture \\
\hline 30.08 & 9.17 & 172 & 82 & 15 & $\mathrm{~S}$ & Shallow & Minor fracture \\
\hline 30.86 & 9.41 & 246 & 156 & 57 & SW & Steep & Minor fracture \\
\hline 32.76 & 9.98 & 357 & 267 & 31 & $\mathrm{~N}$ & Moderate & Minor fracture \\
\hline 34.25 & 10.44 & 18 & 288 & 54 & $\mathrm{~N}$ & Steep & Minor fracture \\
\hline 35.27 & 10.75 & 346 & 256 & 50 & $\mathrm{~N}$ & Moderate & Minor fracture \\
\hline 35.53 & 10.83 & 280 & 190 & 81 & W & Nearly vertical & Minor fracture \\
\hline 37.94 & 11.56 & 257 & 167 & 81 & W & Nearly vertical & Partial fracture \\
\hline 38.05 & 11.60 & 276 & 186 & 63 & W & Steep & Minor fracture \\
\hline 39.12 & 11.92 & 241 & 151 & 78 & SW & Nearly vertical & Partial fracture \\
\hline 39.83 & 12.14 & 2 & 272 & 55 & $\mathrm{~N}$ & Steep & Minor fracture \\
\hline 42.59 & 12.98 & 286 & 196 & 66 & W & Steep & Minor fracture \\
\hline 43.16 & 13.15 & 283 & 193 & 56 & W & Steep & Minor fracture \\
\hline 43.82 & 13.36 & 276 & 186 & 73 & W & Nearly vertical & Minor fracture \\
\hline 45.69 & 13.93 & 349 & 259 & 56 & $\mathrm{~N}$ & Steep & Minor fracture \\
\hline 47.67 & 14.53 & 328 & 238 & 81 & NW & Nearly vertical & Partial fracture \\
\hline 54.86 & 16.72 & 314 & 224 & 74 & NW & Nearly vertical & Partial fracture \\
\hline 61.67 & 18.80 & 143 & 53 & 78 & SE & Nearly vertical & Partial fracture \\
\hline 65.23 & 19.88 & 272 & 182 & 76 & W & Nearly vertical & Minor fracture \\
\hline 76.11 & 23.20 & 71 & 341 & 73 & $E$ & Nearly vertical & Minor fracture \\
\hline 83.51 & 25.45 & 338 & 248 & 75 & $\mathrm{~N}$ & Nearly vertical & Minor fracture \\
\hline 85.71 & 26.12 & 341 & 251 & 85 & $\mathrm{~N}$ & Nearly vertical & Partial fracture \\
\hline 85.95 & 26.20 & 355 & 265 & 82 & $\mathrm{~N}$ & Nearly vertical & Minor fracture \\
\hline 86.84 & 26.47 & 7 & 277 & 83 & $\mathrm{~N}$ & Nearly vertical & Minor fracture \\
\hline 92.54 & 28.20 & 340 & 250 & 74 & $\mathrm{~N}$ & Nearly vertical & Minor fracture \\
\hline 107.50 & 32.76 & 358 & 268 & 87 & $\mathrm{~N}$ & Nearly vertical & Minor fracture \\
\hline 114.46 & 34.89 & 0 & 270 & 84 & $\mathrm{~N}$ & Nearly vertical & Minor fracture \\
\hline 114.62 & 34.93 & 254 & 164 & 29 & W & Shallow & Minor fracture \\
\hline 117.69 & 35.87 & 360 & 270 & 76 & $\mathrm{~N}$ & Nearly vertical & Partial fracture \\
\hline 119.83 & 36.52 & 351 & 261 & 48 & $\mathrm{~N}$ & Moderate & Minor fracture \\
\hline 130.41 & 39.75 & 0 & 270 & 78 & $\mathrm{~N}$ & Nearly vertical & Minor fracture \\
\hline 131.80 & 40.17 & 0 & 270 & 77 & $\mathrm{~N}$ & Nearly vertical & Minor fracture \\
\hline 131.91 & 40.20 & 7 & 277 & 82 & $\mathrm{~N}$ & Nearly vertical & Partial fracture \\
\hline 132.37 & 40.34 & 8 & 278 & 65 & $\mathrm{~N}$ & Steep & Minor fracture \\
\hline 133.00 & 40.54 & 7 & 277 & 83 & $\mathrm{~N}$ & Nearly vertical & Partial fracture \\
\hline 134.33 & 40.94 & 355 & 265 & 84 & $\mathrm{~N}$ & Nearly vertical & Partial fracture \\
\hline 136.46 & 41.59 & 355 & 265 & 78 & $\mathrm{~N}$ & Nearly vertical & Minor fracture \\
\hline 142.50 & 43.43 & 358 & 268 & 78 & $\mathrm{~N}$ & Nearly vertical & Minor fracture \\
\hline 143.89 & 43.86 & 5 & 275 & 75 & $\mathrm{~N}$ & Nearly vertical & Partial fracture \\
\hline 146.77 & 44.73 & 351 & 261 & 73 & $\mathrm{~N}$ & Nearly vertical & Minor fracture \\
\hline 147.37 & 44.92 & 166 & 76 & 24 & $\mathrm{~S}$ & Shallow & Transmissive fracture \\
\hline 153.39 & 46.75 & 355 & 265 & 77 & $\mathrm{~N}$ & Nearly vertical & Minor fracture \\
\hline 155.18 & 47.30 & 1 & 271 & 74 & $\mathrm{~N}$ & Nearly vertical & Partial fracture \\
\hline 159.83 & 48.71 & 351 & 261 & 76 & $\mathrm{~N}$ & Nearly vertical & Minor fracture \\
\hline 160.85 & 49.02 & 7 & 277 & 71 & $\mathrm{~N}$ & Nearly vertical & Minor fracture \\
\hline 162.38 & 49.49 & 359 & 269 & 72 & $\mathrm{~N}$ & Nearly vertical & Minor fracture \\
\hline 167.89 & 51.17 & 347 & 257 & 69 & $\mathrm{~N}$ & Steep & Minor fracture \\
\hline
\end{tabular}


Table 5C-2. Interpretation of optical televiewer logs for borehole MW-16, near Machiasport, Maine.

[Televiewer data are corrected for deviation and magnetic declination, so orientations are relative to true north; depths are below top of casing, which is 2.5 feet above land surface; dip azimuth is given in degrees east of true north; strike is reported in right-hand-rule (RHR)-azimuthal degrees east of true north and where the direction of dip is 90 degrees to the right of strike]

\begin{tabular}{|c|c|c|c|c|c|c|c|}
\hline $\begin{array}{l}\text { Depth, } \\
\text { in feet }\end{array}$ & $\begin{array}{l}\text { Depth, } \\
\text { in meters }\end{array}$ & $\begin{array}{c}\text { Dip } \\
\text { azimuth }\end{array}$ & $\begin{array}{l}\text { Strike, } \\
\text { in RHR }\end{array}$ & Dip & $\begin{array}{c}\text { Dip } \\
\text { direction }\end{array}$ & Dip descriptor & Comment \\
\hline 22.77 & 6.94 & 268 & 178 & 2 & $\mathrm{~W}$ & Nearly horizontal & Water level \\
\hline 26.30 & 8.02 & 146 & 56 & 32 & SE & Moderate & Lithologic feature \\
\hline 30.03 & 9.15 & 168 & 78 & 15 & $\mathrm{~S}$ & Shallow & Minor fracture \\
\hline 30.61 & 9.33 & 155 & 65 & 61 & SE & Steep & Lithologic feature \\
\hline 32.14 & 9.80 & 152 & 62 & 53 & SE & Steep & Minor fracture \\
\hline 34.60 & 10.55 & 151 & 61 & 51 & SE & Steep & Minor fracture \\
\hline 37.89 & 11.55 & 261 & 171 & 81 & W & Nearly vertical & Minor fracture \\
\hline 38.80 & 11.83 & 151 & 61 & 56 & SE & Steep & Minor fracture \\
\hline 39.81 & 12.13 & 358 & 268 & 56 & $\mathrm{~N}$ & Steep & Minor fracture \\
\hline 42.31 & 12.90 & 171 & 81 & 63 & $\mathrm{~S}$ & Steep & Minor fracture \\
\hline 50.85 & 15.50 & 154 & 64 & 68 & SE & Steep & Minor fracture \\
\hline 52.11 & 15.88 & 264 & 174 & 68 & $\mathrm{~W}$ & Steep & Lithologic feature \\
\hline 55.78 & 17.00 & 137 & 47 & 68 & SE & Steep & Minor fracture \\
\hline 61.17 & 18.64 & 161 & 71 & 55 & $\mathrm{~S}$ & Steep & Minor fracture \\
\hline 62.01 & 18.90 & 177 & 87 & 60 & $\mathrm{~S}$ & Steep & Minor fracture \\
\hline 66.07 & 20.14 & 151 & 61 & 44 & SE & Moderate & Minor fracture \\
\hline 69.94 & 21.32 & 152 & 62 & 50 & SE & Steep & Minor fracture \\
\hline 72.50 & 22.10 & 193 & 103 & 23 & $\mathrm{~S}$ & Shallow & Minor fracture \\
\hline 72.93 & 22.23 & 173 & 83 & 17 & S & Shallow & Minor fracture \\
\hline 74.11 & 22.59 & 178 & 88 & 19 & $\mathrm{~S}$ & Shallow & Minor fracture \\
\hline 75.82 & 23.11 & 73 & 343 & 79 & $E$ & Nearly vertical & Minor fracture \\
\hline 76.31 & 23.26 & 65 & 335 & 68 & $\overline{N E}$ & Steep & Minor fracture \\
\hline 79.13 & 24.12 & 141 & 51 & 21 & SE & Shallow & Minor fracture \\
\hline 83.49 & 25.45 & 358 & 268 & 13 & $\mathrm{~N}$ & Shallow & Sealed feature \\
\hline 83.59 & 25.48 & 234 & 144 & 11 & sW & Shallow & Sealed feature \\
\hline 85.23 & 25.98 & 347 & 257 & 78 & $\mathrm{~N}$ & Nearly vertical & Minor fracture \\
\hline 89.48 & 27.27 & 164 & 74 & 55 & $\mathrm{~S}$ & Steep & Lithologic feature \\
\hline 89.87 & 27.39 & 168 & 78 & 18 & S & Shallow & Minor fracture \\
\hline 99.14 & 30.22 & 7 & 277 & 69 & $\mathrm{~N}$ & Steep & Minor fracture \\
\hline 101.12 & 30.82 & 188 & 98 & 47 & $\mathrm{~S}$ & Moderate & Minor fracture \\
\hline 103.58 & 31.57 & 244 & 154 & 35 & SW & Moderate & Minor fracture \\
\hline 104.16 & 31.75 & 293 & 203 & 48 & NW & Moderate & Minor fracture \\
\hline 105.53 & 32.16 & 360 & 270 & 36 & $\mathrm{~N}$ & Moderate & Minor fracture \\
\hline 108.13 & 32.96 & 161 & 71 & 72 & $\mathrm{~S}$ & Nearly vertical & Minor fracture \\
\hline 114.12 & 34.78 & 258 & 168 & 55 & W & Steep & Minor fracture \\
\hline 114.87 & 35.01 & 254 & 164 & 55 & W & Steep & Minor fracture \\
\hline 117.43 & 35.79 & 193 & 103 & 56 & $\mathrm{~S}$ & Steep & Minor fracture \\
\hline 119.84 & 36.53 & 342 & 252 & 49 & $\mathrm{~N}$ & Moderate & Sealed feature \\
\hline 121.78 & 37.12 & 208 & 118 & 45 & SW & Moderate & Minor fracture \\
\hline 122.52 & 37.34 & 192 & 102 & 61 & $\mathrm{~S}$ & Steep & Minor fracture \\
\hline 123.64 & 37.68 & 188 & 98 & 69 & S & Steep & Sealed feature \\
\hline 126.11 & 38.44 & 167 & 77 & 41 & $\mathrm{~S}$ & Moderate & Lithologic feature \\
\hline 130.71 & 39.84 & 181 & 91 & 64 & $\mathrm{~S}$ & Steep & Lithologic feature \\
\hline 132.33 & 40.33 & 182 & 92 & 60 & $\mathrm{~S}$ & Steep & Minor fracture \\
\hline 132.68 & 40.44 & 355 & 265 & 75 & $\mathrm{~N}$ & Nearly vertical & Minor fracture \\
\hline 134.39 & 40.96 & 175 & 85 & 52 & S & Steep & Minor fracture \\
\hline 136.32 & 41.55 & 355 & 265 & 77 & $\mathrm{~N}$ & Nearly vertical & Minor fracture \\
\hline 141.51 & 43.13 & 177 & 87 & 66 & $\mathrm{~S}$ & Steep & Lithologic feature \\
\hline 144.82 & 44.14 & 241 & 151 & 65 & SW & Steep & Lithologic feature \\
\hline 146.53 & 44.66 & 203 & 113 & 34 & SW & Moderate & Minor fracture \\
\hline 147.39 & 44.92 & 136 & 46 & 17 & SE & Shallow & Minor fracture \\
\hline
\end{tabular}




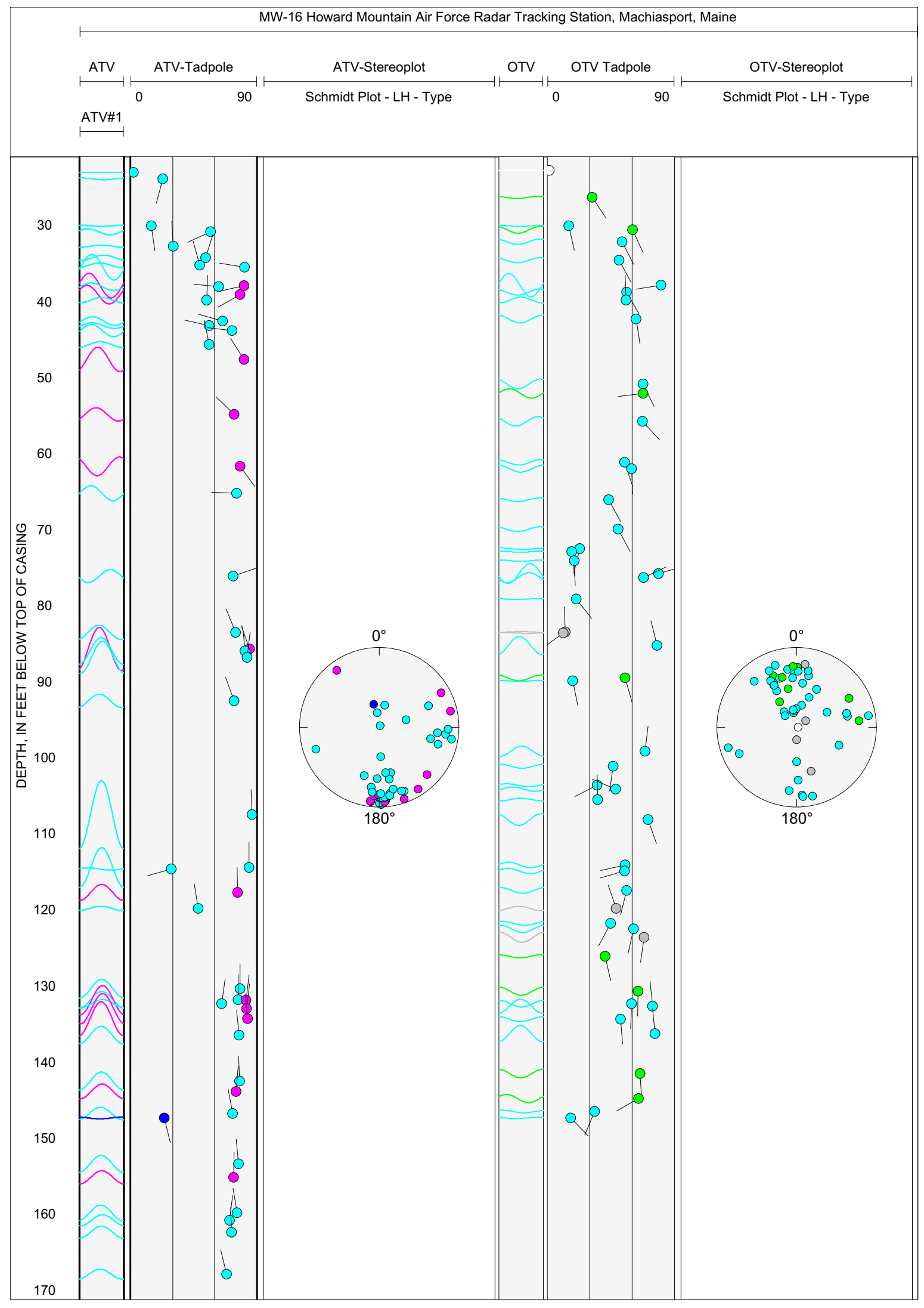

Figure 5C-2. Projection, tadpole, and stereoplots of interpretation of borehole image data for borehole MW-16, near Machiasport, Maine. 


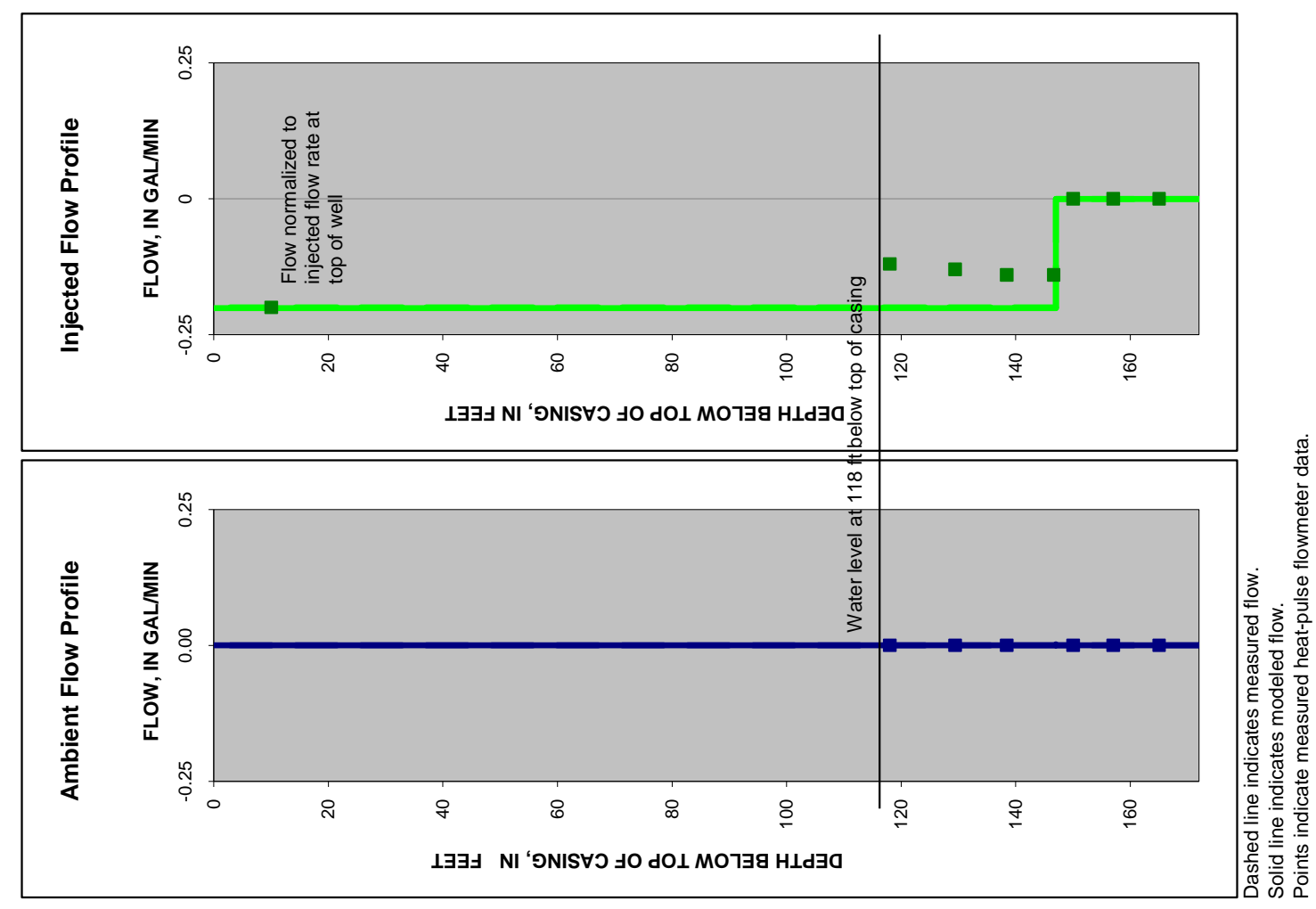

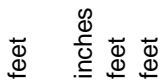

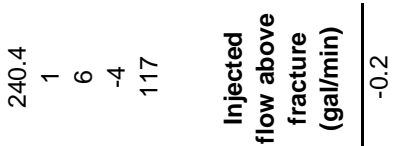

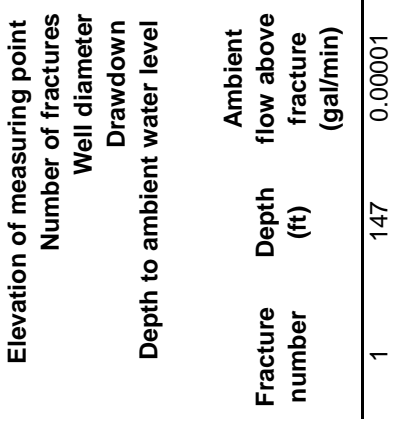

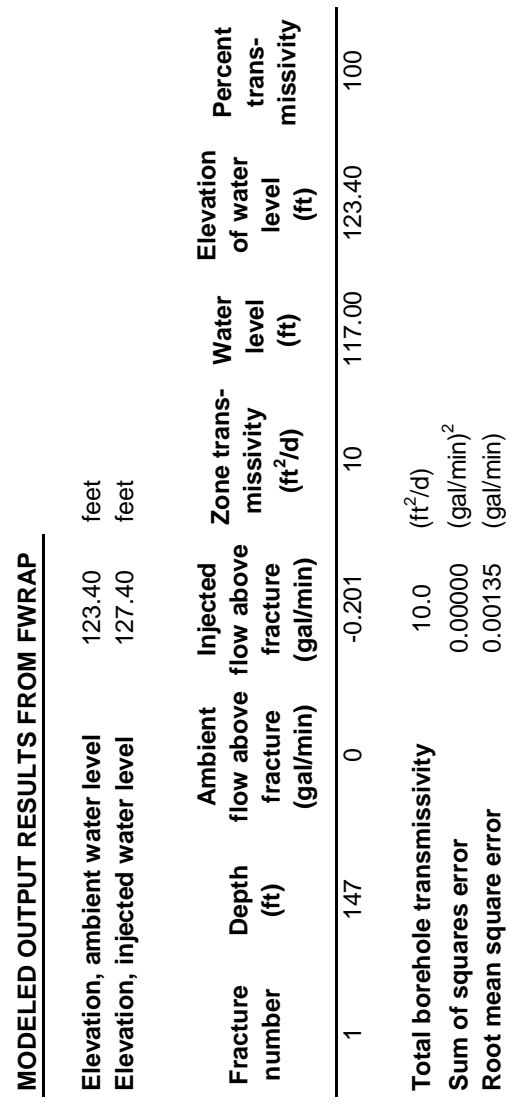

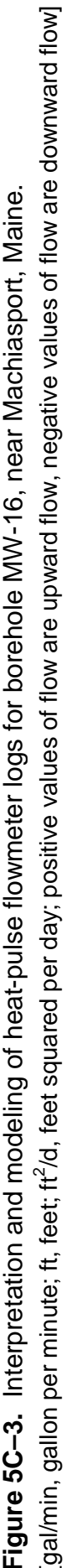



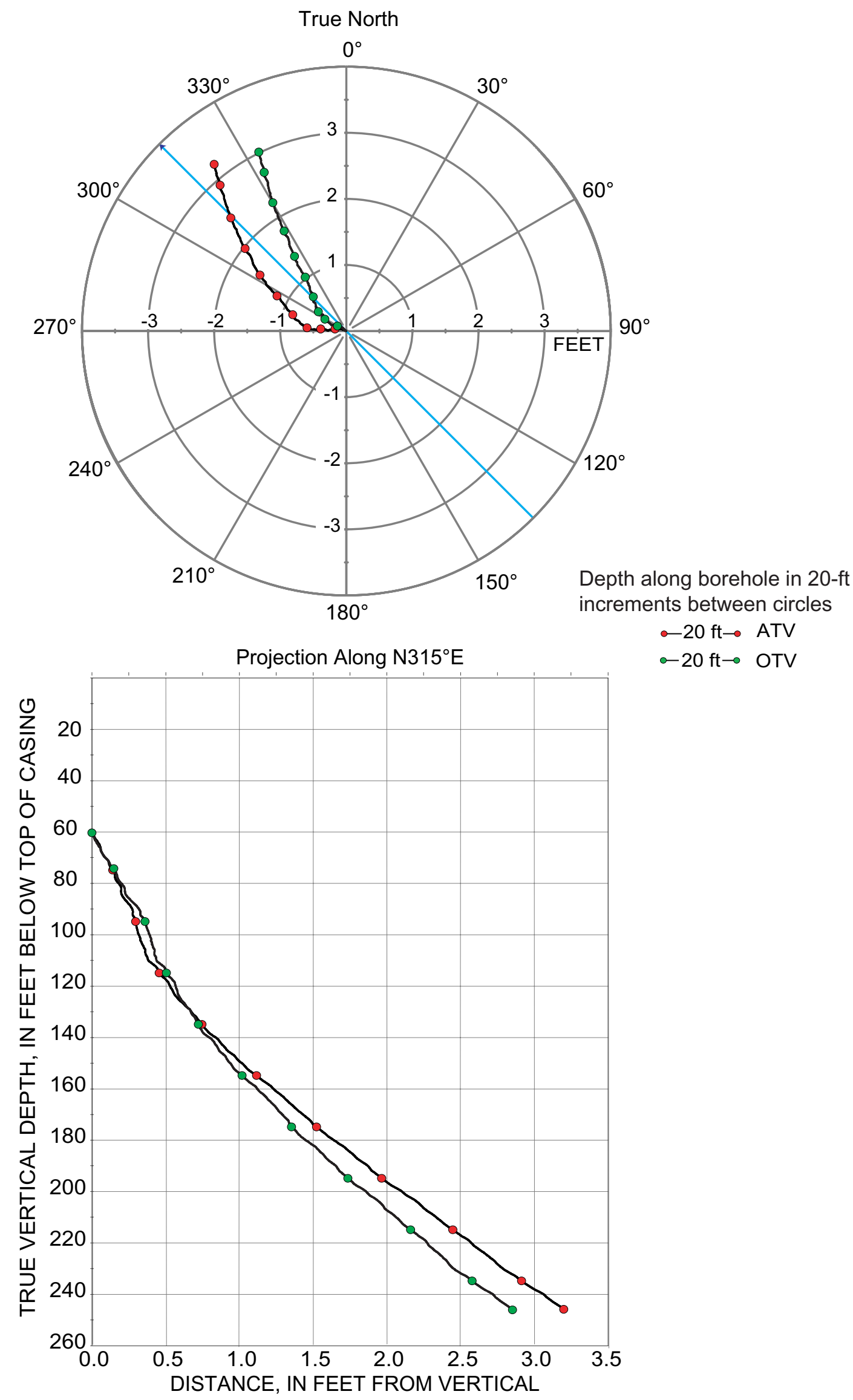

$-20 \mathrm{ft} \rightarrow$ ATV

$-20 \mathrm{ft} \rightarrow$ OTV

Figure 5D-1. Borehole deviation logs for borehole MW-17, near Machiasport, Maine. Blue line on radial plot (top) is line of projection for vertical plot (bottom).

[ft, foot; ATV, acoustic televiewer; OTV, optical televiewer] 
Table 5D-1. Interpretation of acoustic televiewer logs for borehole MW-17, near Machiasport, Maine.

[Televiewer data are corrected for deviation and magnetic declination, so orientations are relative to true north; depths are below top of casing, which is 2.3 feet above land surface; dip azimuth is given in degrees east of true north; strike is reported in right-hand-rule (RHR)-azimuthal degrees east of true north and where the direction of dip is 90 degrees to the right of strike]

\begin{tabular}{rrrccccl}
\hline $\begin{array}{c}\text { Depth, } \\
\text { in feet }\end{array}$ & $\begin{array}{c}\text { Depth, } \\
\text { in meters }\end{array}$ & $\begin{array}{c}\text { Dip } \\
\text { azimuth }\end{array}$ & $\begin{array}{c}\text { Strike, } \\
\text { in RHR }\end{array}$ & Dip & $\begin{array}{c}\text { Dip } \\
\text { direction }\end{array}$ & Dip descriptor & Comment \\
\hline 66.78 & 20.35 & 101 & 11 & 1 & E & Nearly horizontal & Bottom of casing \\
72.16 & 21.99 & 270 & 180 & 78 & W & Nearly vertical & Minor fracture \\
75.29 & 22.95 & 323 & 233 & 78 & NW & Nearly vertical & Minor fracture \\
77.62 & 23.66 & 279 & 189 & 63 & W & Steep & Minor fracture \\
89.19 & 27.18 & 317 & 227 & 82 & NW & Nearly vertical & Minor fracture \\
91.16 & 27.78 & 322 & 232 & 78 & NW & Nearly vertical & Minor fracture \\
93.99 & 28.65 & 319 & 229 & 72 & NW & Nearly vertical & Minor fracture \\
96.28 & 29.34 & 321 & 231 & 54 & NW & Steep & Minor fracture \\
100.17 & 30.53 & 164 & 74 & 67 & S & Steep & Transmissive fracture \\
105.24 & 32.08 & 349 & 259 & 77 & N & Nearly vertical & Lithologic feature \\
105.88 & 32.27 & 101 & 11 & 84 & E & Nearly vertical & Minor fracture \\
109.12 & 33.26 & 320 & 230 & 67 & NW & Steep & Lithologic feature \\
110.17 & 33.58 & 87 & 357 & 70 & E & Nearly vertical & Transmissive fracture \\
114.91 & 35.02 & 282 & 192 & 74 & W & Nearly vertical & Transmissive fracture \\
116.59 & 35.53 & 295 & 205 & 66 & NW & Steep & Minor fracture \\
143.17 & 43.64 & 92 & 2 & 72 & E & Nearly vertical & Minor fracture \\
144.59 & 44.07 & 108 & 18 & 81 & E & Nearly vertical & Minor fracture \\
177.04 & 53.96 & 230 & 140 & 80 & SW & Nearly vertical & Partial fracture \\
179.76 & 54.79 & 277 & 187 & 76 & W & Nearly vertical & Transmissive fracture \\
198.94 & 60.63 & 244 & 154 & 82 & SW & Nearly vertical & Minor fracture \\
209.17 & 63.75 & 52 & 322 & 71 & NE & Nearly vertical & Minor fracture \\
223.06 & 67.99 & 76 & 346 & 60 & E & Steep & Minor fracture \\
225.77 & 68.81 & 304 & 214 & 42 & NW & Moderate & Minor fracture \\
230.84 & 70.36 & 47 & 317 & 65 & NE & Steep & Minor fracture \\
237.81 & 72.48 & 67 & 337 & 83 & NE & Nearly vertical & Minor fracture \\
243.99 & 74.36 & 115 & 25 & 76 & SE & Nearly vertical & Minor fracture \\
\hline
\end{tabular}


Table 5D-2. Interpretation of optical televiewer logs for borehole MW-17, near Machiasport, Maine.

[Televiewer data are corrected for deviation and magnetic declination, so orientations are relative to true north; depths are below top of casing, which is 2.3 feet above land surface; dip azimuth is given in degrees east of true north; strike is reported in right-hand-rule (RHR)-azimuthal degrees east of true north and where the direction of dip is 90 degrees to the right of strike]

\begin{tabular}{|c|c|c|c|c|c|c|c|}
\hline $\begin{array}{l}\text { Depth, } \\
\text { in feet }\end{array}$ & $\begin{array}{l}\text { Depth, } \\
\text { in meters }\end{array}$ & $\begin{array}{c}\text { Dip } \\
\text { azimuth }\end{array}$ & $\begin{array}{l}\text { Strike, } \\
\text { in RHR }\end{array}$ & Dip & $\begin{array}{c}\text { Dip } \\
\text { direction }\end{array}$ & Dip descriptor & Comment \\
\hline 66.55 & 20.28 & 247 & 157 & 76 & SW & Nearly vertical & Fracture intersects boc \\
\hline 66.56 & 20.29 & 248 & 158 & 61 & W & Steep & Fracture intersects boc \\
\hline 66.81 & 20.36 & 133 & 43 & 1 & SE & Nearly horizontal & Bottom of casing \\
\hline 68.00 & 20.73 & 242 & 152 & 77 & SW & Nearly vertical & Minor fracture \\
\hline 68.30 & 20.82 & 49 & 319 & 74 & NE & Nearly vertical & Minor fracture \\
\hline 70.27 & 21.42 & 57 & 327 & 79 & NE & Nearly vertical & Transmissive fracture \\
\hline 71.65 & 21.84 & 134 & 44 & 39 & SE & Moderate & Transmissive fracture \\
\hline 73.04 & 22.26 & 306 & 216 & 80 & NW & Nearly vertical & Transmissive fracture \\
\hline 79.71 & 24.29 & 244 & 154 & 86 & SW & Nearly vertical & Partial fracture \\
\hline 80.65 & 24.58 & 262 & 172 & 70 & w & Nearly vertical & Lithologic feature \\
\hline 85.50 & 26.06 & 75 & 345 & 73 & $E$ & Nearly vertical & Sealed feature \\
\hline 85.54 & 26.07 & 153 & 63 & 69 & SE & Steep & Sealed feature \\
\hline 88.88 & 27.09 & 307 & 217 & 82 & $\mathrm{NW}$ & Nearly vertical & Minor fracture \\
\hline 89.17 & 27.18 & 305 & 215 & 82 & NW & Nearly vertical & Minor fracture \\
\hline 90.97 & 27.73 & 315 & 225 & 76 & NW & Nearly vertical & Minor fracture \\
\hline 92.15 & 28.09 & 159 & 69 & 66 & $\mathrm{~S}$ & Steep & Sealed feature \\
\hline 93.90 & 28.62 & 321 & 231 & 67 & NW & Steep & Minor fracture \\
\hline 95.71 & 29.17 & 325 & 235 & 65 & NW & Steep & Lithologic feature \\
\hline 96.11 & 29.29 & 312 & 222 & 57 & NW & Steep & Minor fracture \\
\hline 97.53 & 29.73 & 345 & 255 & 48 & $\mathrm{~N}$ & Moderate & Minor fracture \\
\hline 100.28 & 30.56 & 146 & 56 & 65 & SE & Steep & Transmissive fracture \\
\hline 105.52 & 32.16 & 140 & 50 & 77 & SE & Nearly vertical & Partial fracture \\
\hline 105.60 & 32.19 & 2 & 272 & 75 & $\mathrm{~N}$ & Nearly vertical & Lithologic feature \\
\hline 105.71 & 32.22 & 78 & 348 & 83 & $E$ & Nearly vertical & Minor fracture \\
\hline 109.91 & 33.50 & 82 & 352 & 64 & $E$ & Steep & Lithologic feature \\
\hline 110.36 & 33.64 & 82 & 352 & 66 & $\mathrm{E}$ & Steep & Transmissive fracture \\
\hline 114.94 & 35.03 & 276 & 186 & 80 & W & Nearly vertical & Transmissive fracture \\
\hline 116.40 & 35.48 & 279 & 189 & 69 & W & Steep & Lithologic feature \\
\hline 116.50 & 35.51 & 280 & 190 & 70 & W & Steep & Fracture \\
\hline 118.25 & 36.04 & 62 & 332 & 77 & NE & Nearly vertical & Sealed feature \\
\hline 120.72 & 36.79 & 59 & 329 & 65 & NE & Steep & Sealed feature \\
\hline 124.73 & 38.02 & 114 & 24 & 53 & SE & Steep & Sealed feature \\
\hline 128.68 & 39.22 & 147 & 57 & 31 & SE & Moderate & Minor fracture \\
\hline 132.32 & 40.33 & 178 & 88 & 50 & $\mathrm{~S}$ & Steep & Minor fracture \\
\hline 132.59 & 40.41 & 44 & 314 & 67 & $\mathrm{NE}$ & Steep & Sealed feature \\
\hline 135.19 & 41.20 & 48 & 318 & 72 & $\mathrm{NE}$ & Nearly vertical & Sealed feature \\
\hline 137.59 & 41.94 & 39 & 309 & 72 & NE & Nearly vertical & Sealed feature \\
\hline 142.78 & 43.52 & 64 & 334 & 84 & NE & Nearly vertical & Lithologic feature \\
\hline 146.54 & 44.66 & 222 & 132 & 73 & SW & Nearly vertical & Lithologic feature \\
\hline 147.27 & 44.89 & 174 & 84 & 55 & $\mathrm{~S}$ & Steep & Lithologic feature \\
\hline 149.68 & 45.62 & 50 & 320 & 72 & NE & Nearly vertical & Sealed feature \\
\hline 154.38 & 47.05 & 89 & 359 & 79 & $\mathrm{E}$ & Nearly vertical & Lithologic feature \\
\hline 155.86 & 47.50 & 87 & 357 & 75 & $\mathrm{E}$ & Nearly vertical & Sealed feature \\
\hline 163.33 & 49.78 & 81 & 351 & 66 & $\bar{E}$ & Steep & Minor fracture \\
\hline 163.40 & 49.80 & 82 & 352 & 67 & $E$ & Steep & Lithologic feature \\
\hline 165.77 & 50.52 & 280 & 190 & 52 & W & Steep & Lithologic feature \\
\hline 167.79 & 51.14 & 69 & 339 & 59 & $E$ & Steep & Transmissive fracture \\
\hline 169.35 & 51.62 & 63 & 333 & 74 & $\mathrm{NE}$ & Nearly vertical & Minor fracture \\
\hline 170.21 & 51.88 & 54 & 324 & 77 & NE & Nearly vertical & Minor fracture \\
\hline 179.66 & 54.76 & 255 & 165 & 75 & W & Nearly vertical & Transmissive fracture \\
\hline 180.62 & 55.05 & 93 & 3 & 28 & $\mathrm{E}$ & Shallow & Minor fracture \\
\hline 189.96 & 57.90 & 40 & 310 & 67 & $\mathrm{NE}$ & Steep & Minor fracture \\
\hline 193.96 & 59.12 & 69 & 339 & 74 & $\mathrm{E}$ & Nearly vertical & Sealed feature \\
\hline 195.22 & 59.50 & 63 & 333 & 56 & $\mathrm{NE}$ & Steep & Minor fracture \\
\hline 195.42 & 59.56 & 38 & 308 & 58 & $\mathrm{NE}$ & Steep & Minor fracture \\
\hline
\end{tabular}


Table 5D-2. Interpretation of optical televiewer logs for borehole MW-17, near Machiasport, Maine.-Continued [Televiewer data are corrected for deviation and magnetic declination, so orientations are relative to true north; depths are below top of casing, which is 2.3 feet above land surface; dip azimuth is given in degrees east of true north; strike is reported in right-hand-rule (RHR)-azimuthal degrees east of true north and where the direction of dip is 90 degrees to the right of strike]

\begin{tabular}{cccccccl}
\hline $\begin{array}{c}\text { Depth, } \\
\text { in feet }\end{array}$ & $\begin{array}{c}\text { Depth, } \\
\text { in meters }\end{array}$ & $\begin{array}{c}\text { Dip } \\
\text { azimuth }\end{array}$ & $\begin{array}{c}\text { Strike, } \\
\text { in RHR }\end{array}$ & Dip & $\begin{array}{c}\text { Dip } \\
\text { direction }\end{array}$ & Dip descriptor & Comment \\
\hline 196.58 & 59.91 & 57 & 327 & 69 & NE & Steep & Minor fracture \\
205.54 & 62.65 & 283 & 193 & 63 & W & Steep & Sealed feature \\
206.88 & 63.05 & 181 & 91 & 26 & S & Shallow & Sealed feature \\
208.98 & 63.69 & 58 & 328 & 70 & NE & Steep & Minor fracture \\
211.04 & 64.32 & 335 & 245 & 74 & NW & Nearly vertical & Sealed feature \\
222.99 & 67.96 & 59 & 329 & 61 & NE & Steep & Lithologic feature \\
225.73 & 68.80 & 317 & 227 & 55 & NW & Steep & Sealed feature \\
230.85 & 70.36 & 47 & 317 & 68 & NE & Steep & Lithologic feature \\
237.28 & 72.32 & 60 & 330 & 75 & NE & Nearly vertical & Lithologic feature \\
243.79 & 74.30 & 125 & 35 & 75 & SE & Nearly vertical & Sealed feature \\
246.83 & 75.23 & 221 & 131 & 30 & SW & Shallow & Sealed feature \\
\hline
\end{tabular}




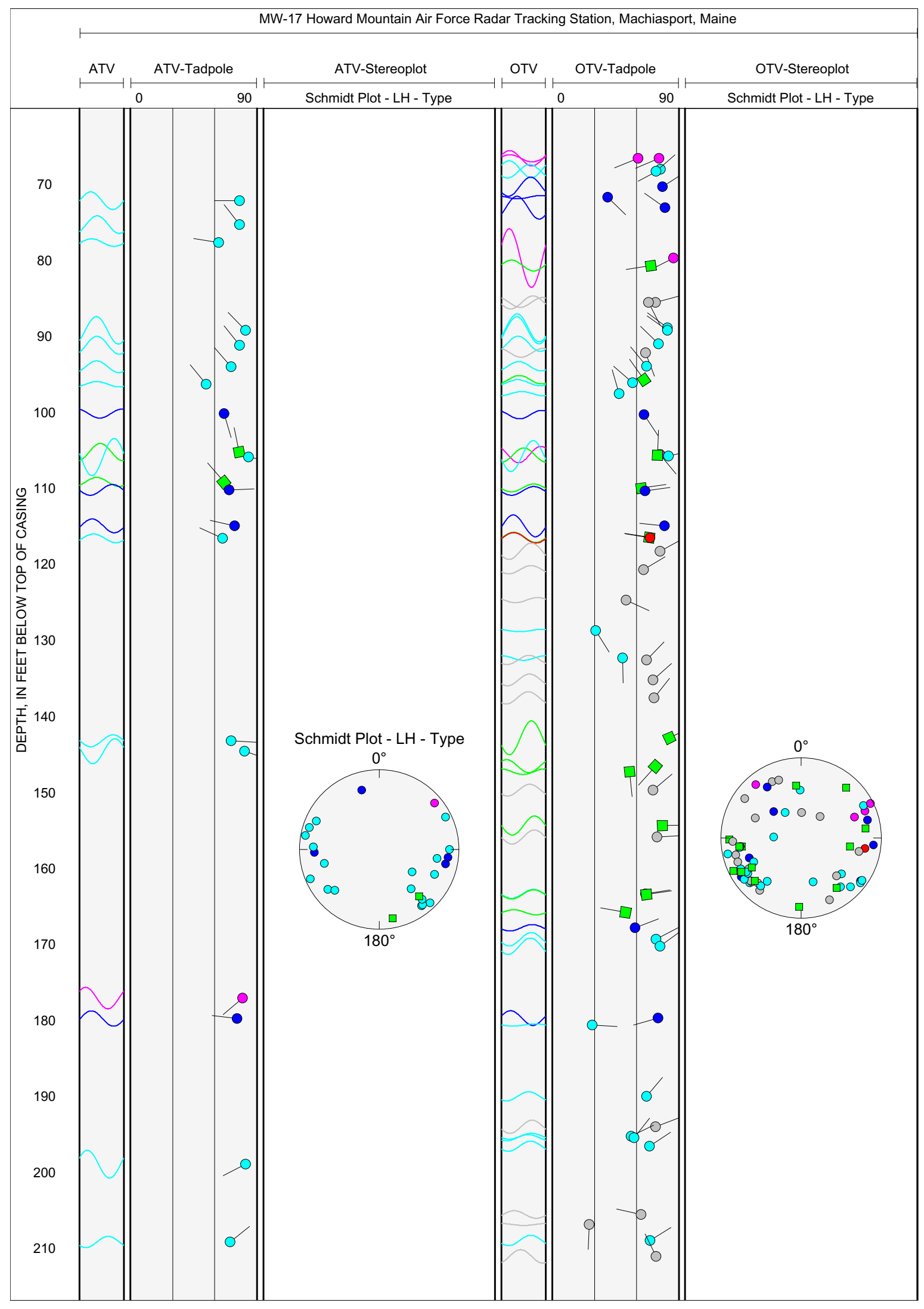

Figure 5D-2. Projection, tadpole, and stereoplots of interpretation of borehole image data for borehole MW-17, near Machiasport, Maine. 


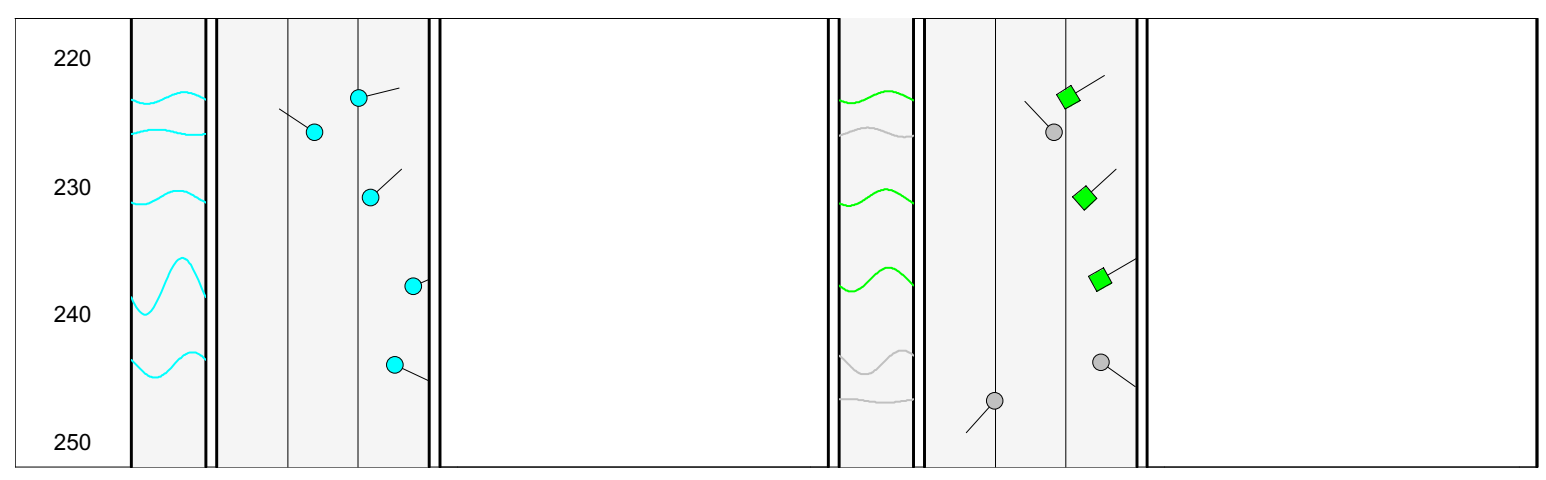

Figure 5D-2. Projection, tadpole, and stereoplots of interpretation of borehole image data for borehole MW-17, near Machiasport, Maine.-Continued 

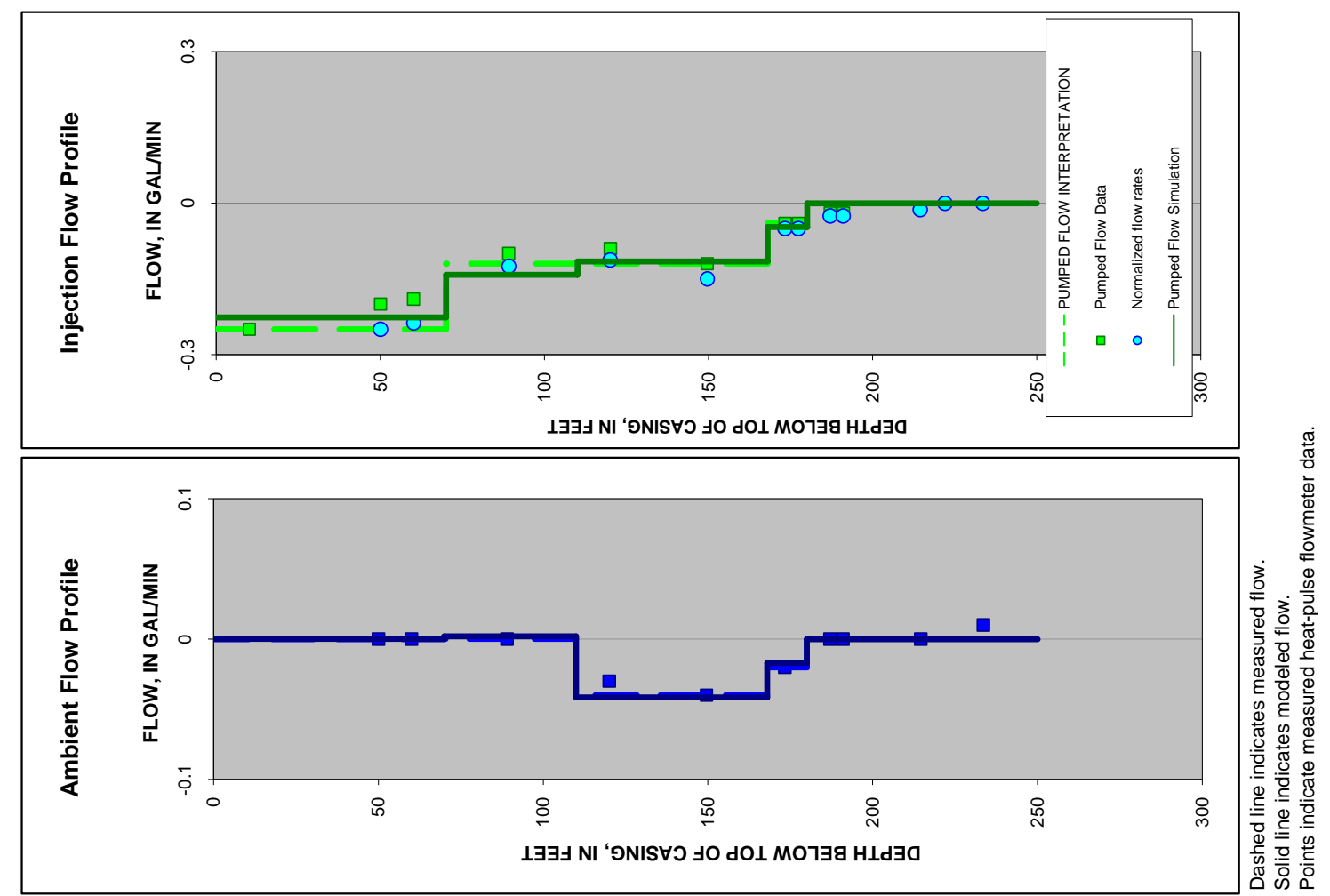



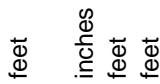

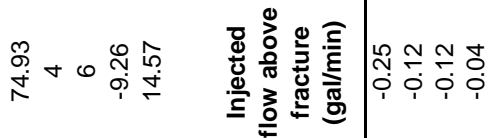

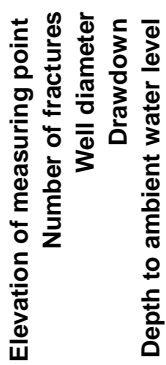

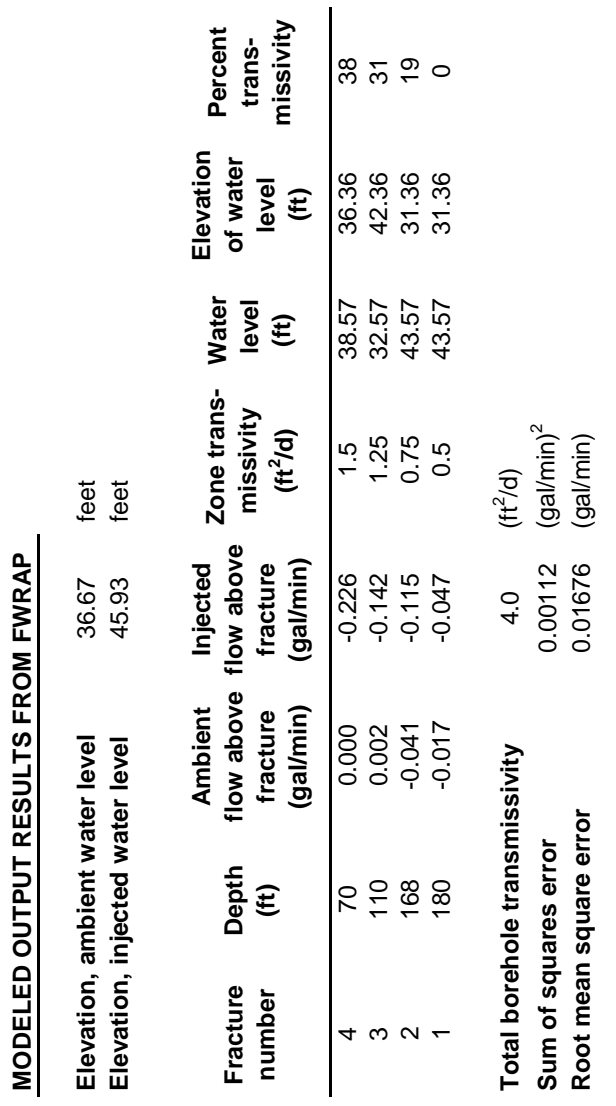

흔

응 을 

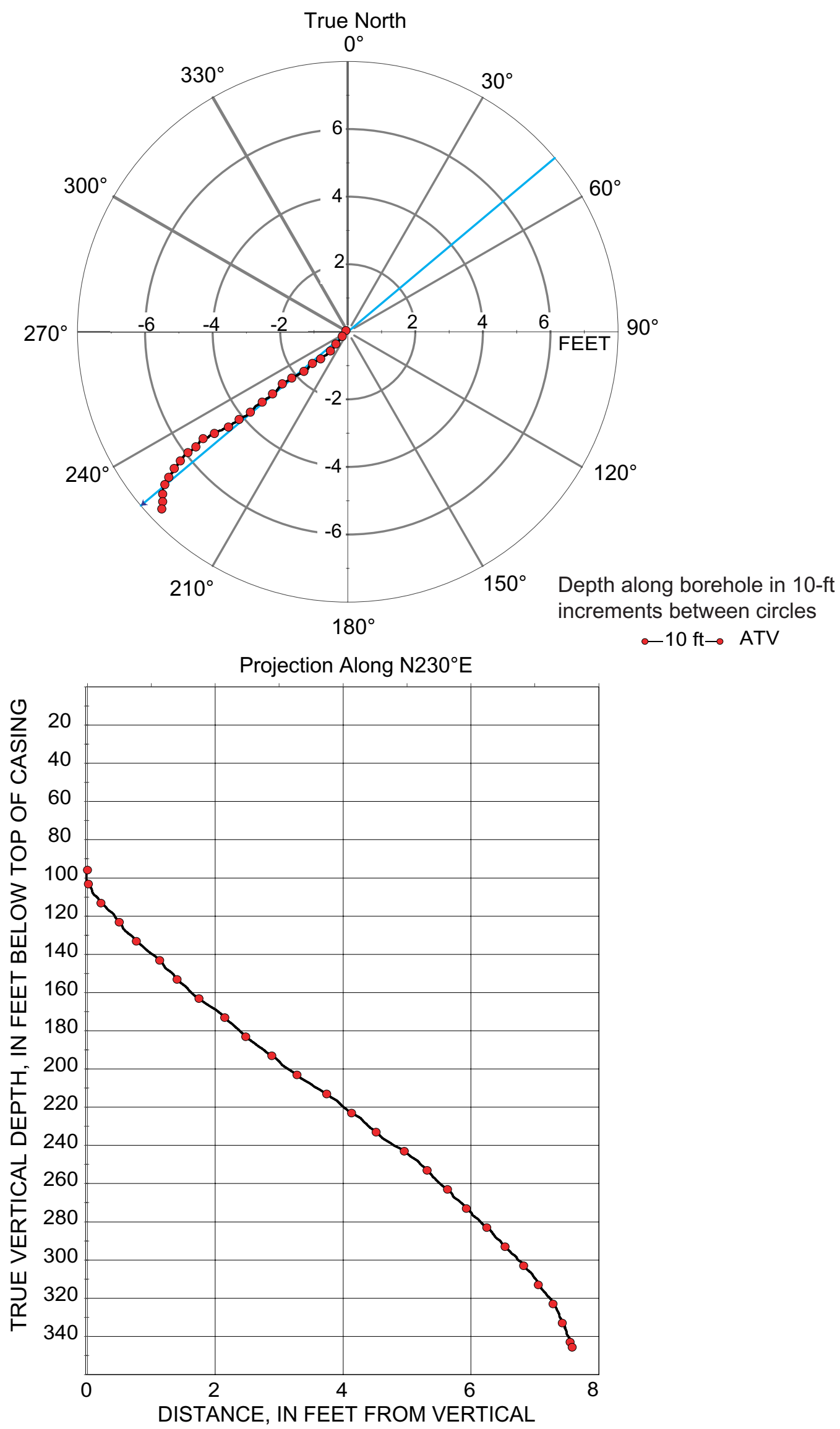

Figure 5E-1. Borehole deviation logs for borehole WY-3C, near Machiasport, Maine. Blue line on radial plot (top) is line of projection for vertical plot (bottom).

[ft, foot; ATV, acoustic televiewer] 
Table 5E-1. Interpretation of acoustic televiewer logs for borehole WY-3C, near Machiasport, Maine.

[Televiewer data are corrected for deviation and magnetic declination, so orientations are relative to true north; depths are below top of casing, which is 1.5 feet above land surface; dip azimuth is given in degrees east of true north; strike is reported in right-hand-rule (RHR)-azimuthal degrees east of true north and where the direction of dip is 90 degrees to the right of strike]

\begin{tabular}{|c|c|c|c|c|c|c|c|}
\hline $\begin{array}{l}\text { Depth, } \\
\text { in feet }\end{array}$ & $\begin{array}{l}\text { Depth, } \\
\text { in meters }\end{array}$ & $\begin{array}{c}\text { Dip } \\
\text { azimuth }\end{array}$ & $\begin{array}{l}\text { Strike, } \\
\text { in RHR }\end{array}$ & Dip & $\begin{array}{c}\text { Dip } \\
\text { direction }\end{array}$ & Dip descriptor & Comment \\
\hline 104.40 & 31.82 & 157 & 67 & 1 & SE & Nearly horizontal & Bottom of casing \\
\hline 105.67 & 32.21 & 137 & 47 & 30 & SE & Shallow & Transmissive fracture \\
\hline 107.26 & 32.69 & 351 & 261 & 38 & $\mathrm{~N}$ & Moderate & Minor fracture \\
\hline 108.11 & 32.95 & 333 & 243 & 20 & NW & Shallow & Transmissive fracture \\
\hline 109.87 & 33.49 & 273 & 183 & 46 & W & Moderate & Minor fracture \\
\hline 116.74 & 35.58 & 267 & 177 & 71 & W & Nearly vertical & Minor fracture \\
\hline 117.45 & 35.80 & 286 & 196 & 41 & W & Moderate & Minor fracture \\
\hline 123.31 & 37.58 & 41 & 311 & 71 & NE & Nearly vertical & Minor fracture \\
\hline 154.18 & 46.99 & 103 & 13 & 81 & $E$ & Nearly vertical & Minor fracture \\
\hline 154.68 & 47.14 & 164 & 74 & 16 & $\mathrm{~S}$ & Shallow & Minor fracture \\
\hline 164.44 & 50.12 & 212 & 122 & 60 & SW & Steep & Transmissive fracture \\
\hline 165.28 & 50.37 & 98 & 8 & 73 & $\mathrm{E}$ & Nearly vertical & Partial fracture \\
\hline 166.88 & 50.86 & 90 & 360 & 82 & $\mathrm{E}$ & Nearly vertical & Minor fracture \\
\hline 179.94 & 54.84 & 322 & 232 & 45 & NW & Moderate & Lithologic feature \\
\hline 183.86 & 56.04 & 337 & 247 & 71 & NW & Nearly vertical & Minor fracture \\
\hline 194.83 & 59.38 & 347 & 257 & 75 & $\mathrm{~N}$ & Nearly vertical & Minor fracture \\
\hline 207.36 & 63.20 & 280 & 190 & 42 & W & Moderate & Minor fracture \\
\hline 208.29 & 63.48 & 158 & 68 & 64 & $\mathrm{~S}$ & Steep & Minor fracture \\
\hline 219.70 & 66.96 & 240 & 150 & 49 & SW & Moderate & Minor fracture \\
\hline 231.13 & 70.44 & 275 & 185 & 40 & W & Moderate & Minor fracture \\
\hline 247.93 & 75.57 & 303 & 213 & 75 & NW & Nearly vertical & Minor fracture \\
\hline 261.80 & 79.79 & 121 & 31 & 67 & SE & Steep & Minor fracture \\
\hline 270.27 & 82.37 & 89 & 359 & 82 & $E$ & Nearly vertical & Minor fracture \\
\hline 274.09 & 83.54 & 138 & 48 & 57 & SE & Steep & Minor fracture \\
\hline 277.18 & 84.48 & 318 & 228 & 77 & NW & Nearly vertical & Minor fracture \\
\hline 280.49 & 85.49 & 300 & 210 & 79 & NW & Nearly vertical & Minor fracture \\
\hline 284.30 & 86.65 & 107 & 17 & 30 & $\mathrm{E}$ & Moderate & Sealed feature \\
\hline 286.90 & 87.44 & 307 & 217 & 57 & NW & Steep & Minor fracture \\
\hline 293.37 & 89.41 & 9 & 279 & 67 & $\mathrm{~N}$ & Steep & Minor fracture \\
\hline 297.64 & 90.72 & 28 & 298 & 47 & NE & Moderate & Minor fracture \\
\hline 299.67 & 91.33 & 33 & 303 & 53 & $\mathrm{NE}$ & Steep & Minor fracture \\
\hline 305.35 & 93.07 & 109 & 19 & 59 & $E$ & Steep & Partial fracture \\
\hline 307.79 & 93.81 & 321 & 231 & 80 & $\mathrm{NW}$ & Nearly vertical & Partial fracture \\
\hline 311.57 & 94.96 & 326 & 236 & 82 & NW & Nearly vertical & Minor fracture \\
\hline 316.94 & 96.60 & 328 & 238 & 83 & NW & Nearly vertical & Minor fracture \\
\hline 317.25 & 96.69 & 317 & 227 & 88 & NW & Nearly vertical & Partial fracture \\
\hline 321.13 & 97.88 & 354 & 264 & 71 & $\mathrm{~N}$ & Nearly vertical & Minor fracture \\
\hline 325.58 & 99.23 & 111 & 21 & 51 & $\mathrm{E}$ & Steep & Lithologic feature \\
\hline 327.47 & 99.81 & 113 & 23 & 64 & SE & Steep & Minor fracture \\
\hline 350.29 & 106.76 & 93 & 3 & 47 & $E$ & Moderate & Lithologic feature \\
\hline 352.79 & 107.53 & 30 & 300 & 72 & $\mathrm{NE}$ & Nearly vertical & Partial fracture \\
\hline
\end{tabular}




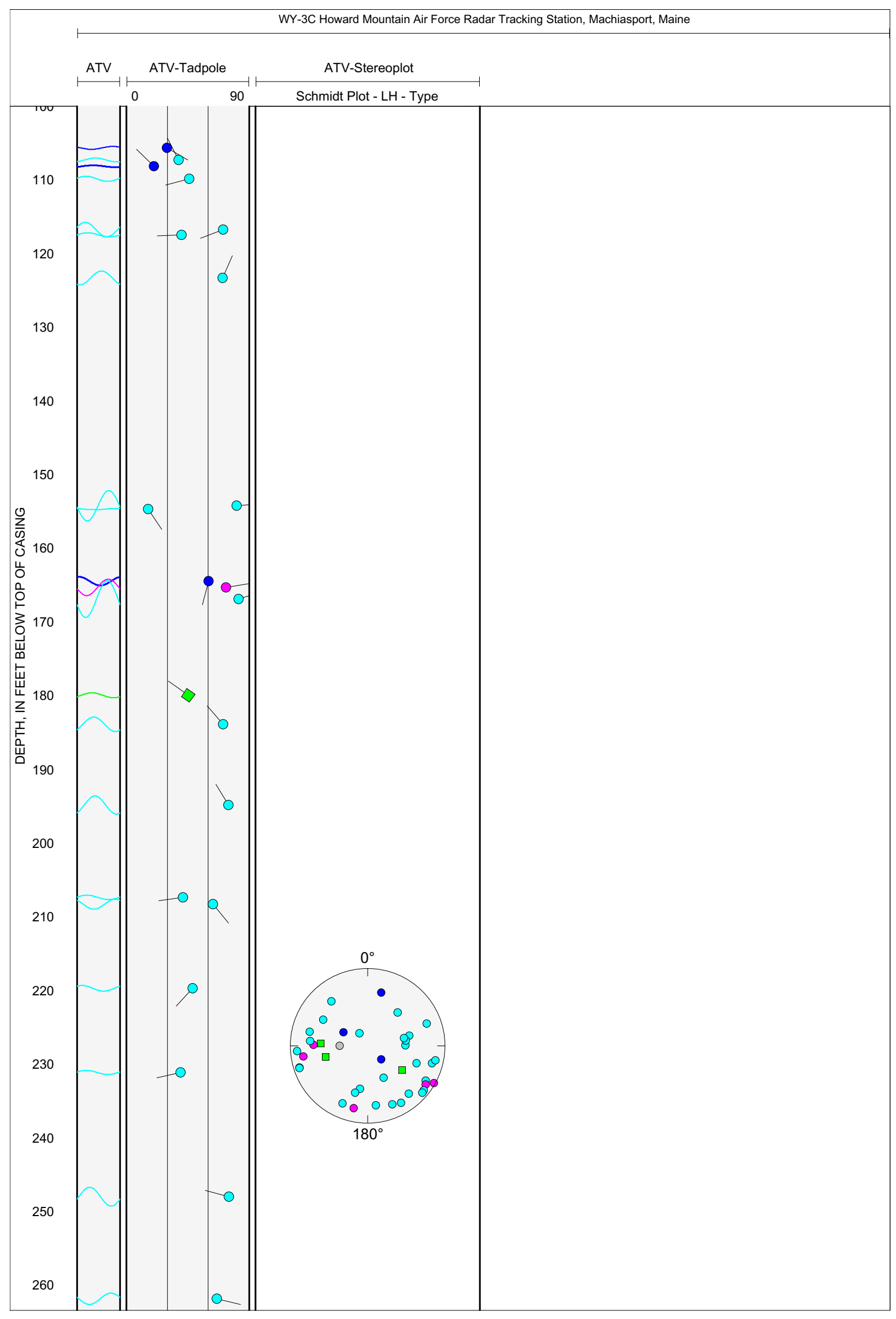

Figure 5E-2. Projection, tadpole, and stereoplots of interpretation of borehole image data for borehole WY-3C, near Machiasport, Maine. 


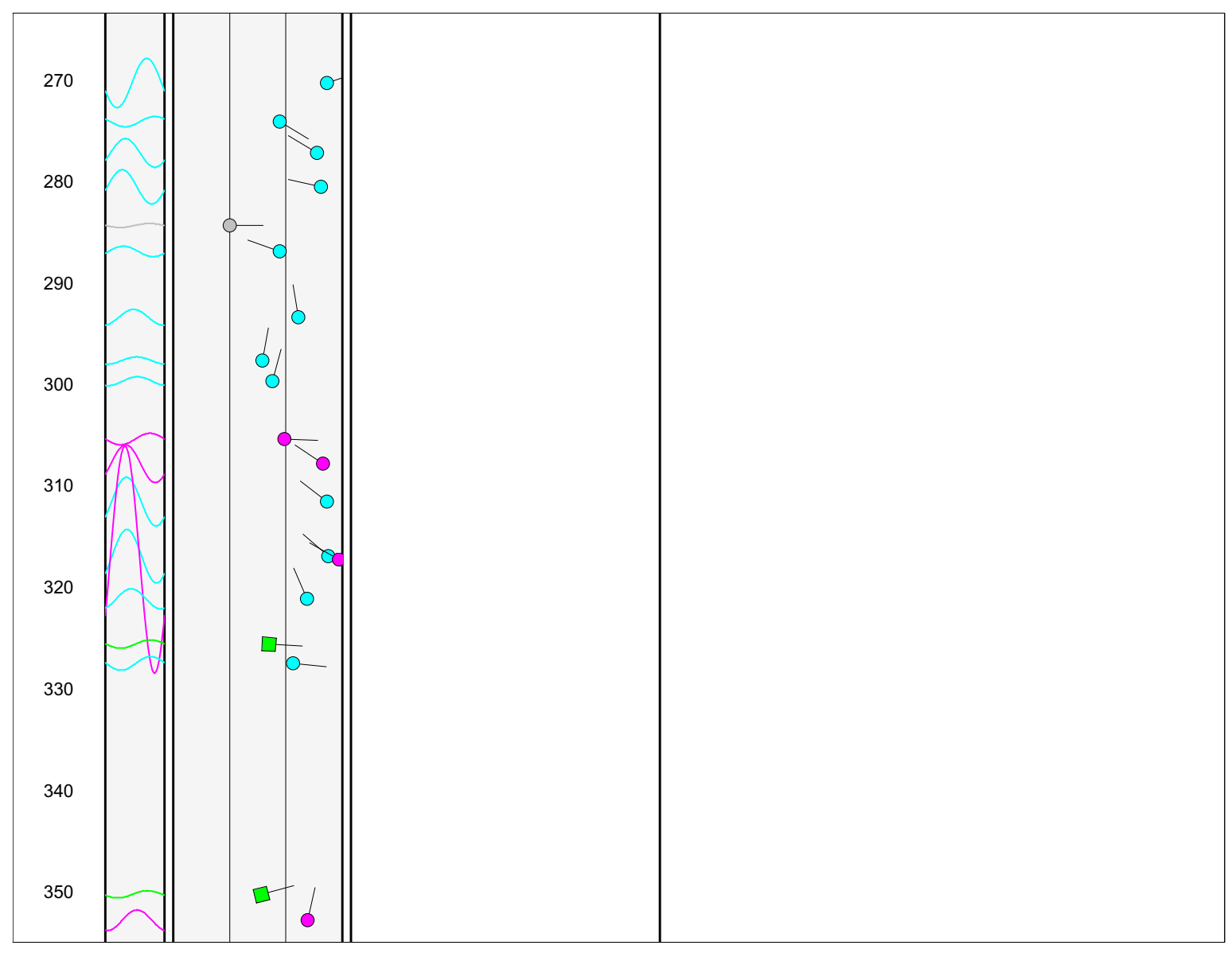

Figure 5E-2. Projection, tadpole, and stereoplots of interpretation of borehole image data for borehole WY-3C, near Machiasport, Maine.-Continued 


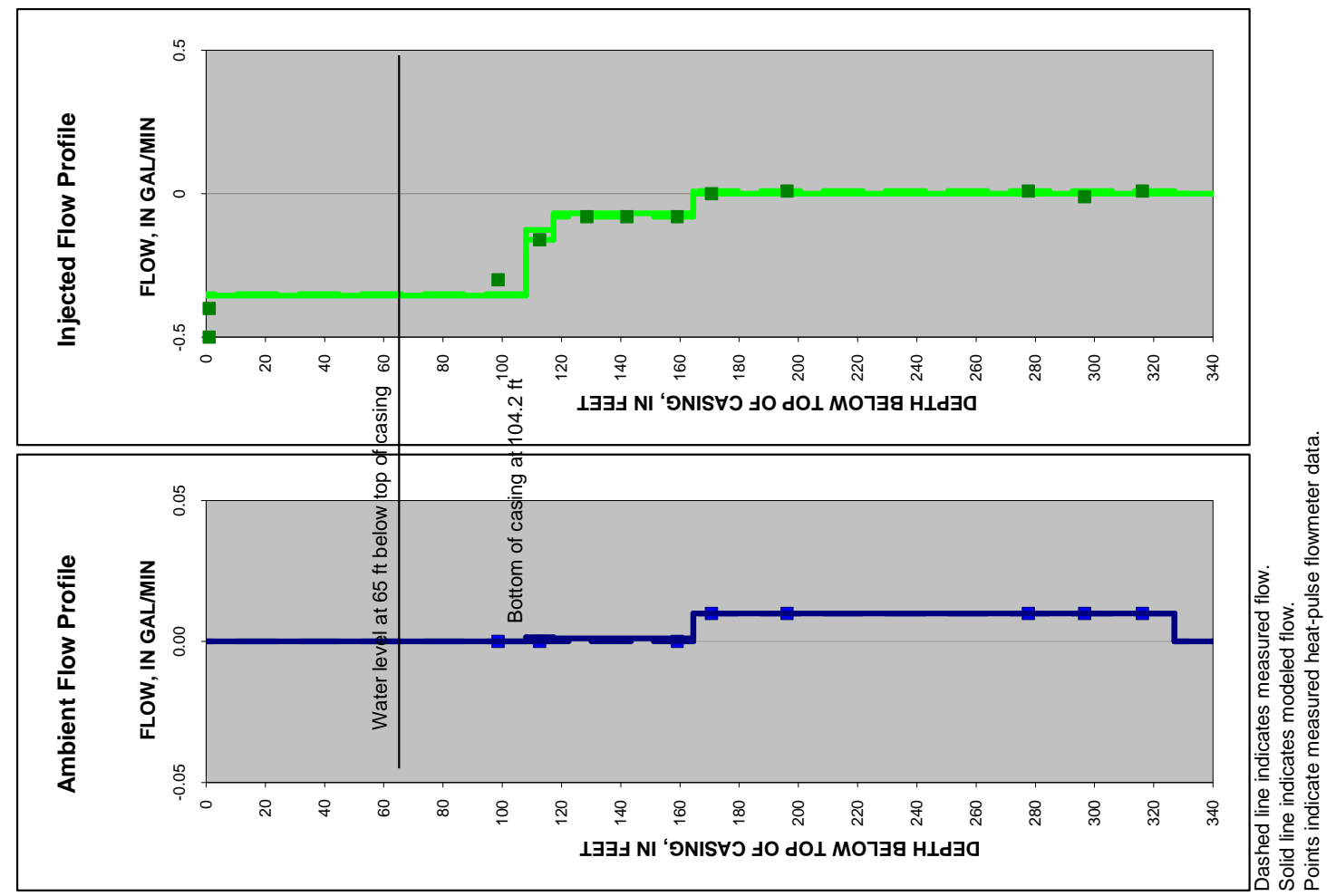

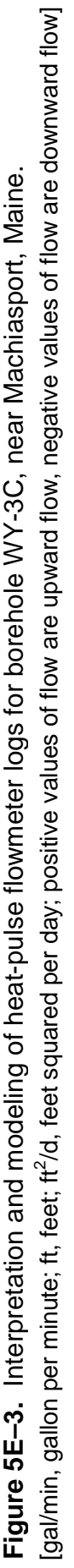



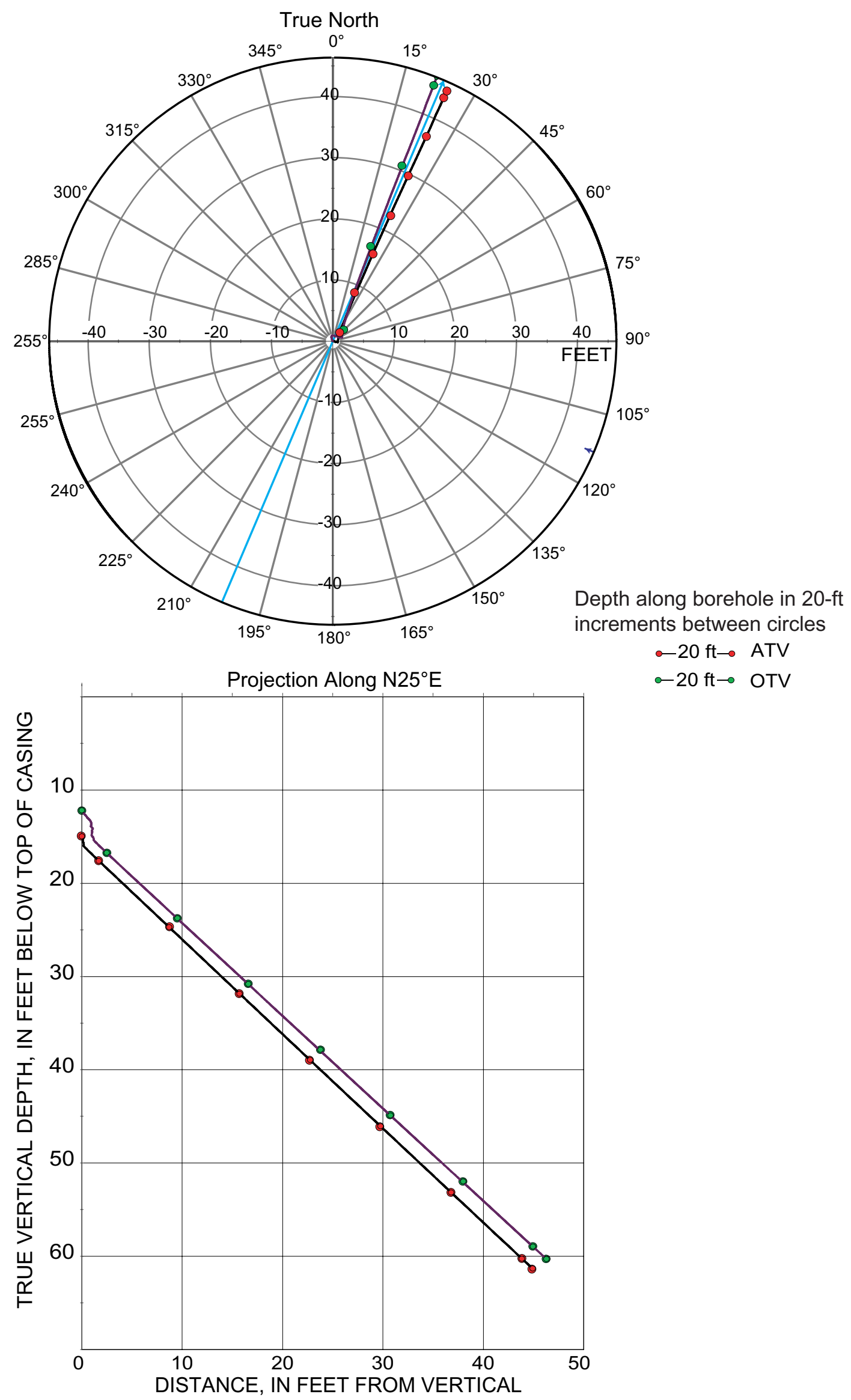

$-20 \mathrm{ft} \rightarrow$ ATV

$-20 \mathrm{ft} \rightarrow$ OTV

Figure 5F-1. Borehole deviation logs for borehole C-114, near Machiasport, Maine. Blue line on radial plot (top) is line of projection for vertical plot (bottom).

[ft, foot; ATV, acoustic televiewer; OTV, optical televiewer] 
Table 5F-1. Interpretation of acoustic televiewer logs for borehole C-114, near Machiasport, Maine.

[The borehole is inclined at $45^{\circ}$ from vertical in a direction of $\mathrm{N}^{\circ} 5^{\circ} \mathrm{E}$. Televiewer data are corrected for deviation and magnetic declination, so orientations are relative to true north; depths are below top of casing, which is 2.3 feet above land surface; TVD, true vertical depth; LS, land surface; dip azimuth is given in degrees east of true north; strike is reported in right-hand-rule (RHR)-azimuthal degrees east of true north and where the direction of dip is 90 degrees to the right of strike]

\begin{tabular}{|c|c|c|c|c|c|c|c|c|}
\hline $\begin{array}{l}\text { Depth, } \\
\text { in feet }\end{array}$ & $\begin{array}{l}\text { Depth, } \\
\text { in meters }\end{array}$ & $\begin{array}{l}\text { TVD, in feet } \\
\text { below LS }\end{array}$ & $\begin{array}{c}\text { Dip } \\
\text { azimuth }\end{array}$ & $\begin{array}{l}\text { Strike, } \\
\text { in RHR }\end{array}$ & Dip & $\begin{array}{c}\text { Dip } \\
\text { direction }\end{array}$ & Dip descriptor & Comment \\
\hline 15.43 & 4.70 & 9.44 & 64 & 334 & 65 & $\mathrm{NE}$ & Steep & Minor fracture \\
\hline 16.22 & 4.94 & 10.01 & 191 & 101 & 16 & $\mathrm{~S}$ & Shallow & Water level-should have 0 dip \\
\hline 16.35 & 4.98 & 10.11 & 162 & 72 & 89 & $\mathrm{~S}$ & Nearly vertical & Minor fracture \\
\hline 16.90 & 5.15 & 10.50 & 111 & 21 & 33 & $\mathrm{E}$ & Moderate & Minor fracture \\
\hline 17.55 & 5.35 & 10.97 & 67 & 337 & 5 & $\overline{N E}$ & Nearly horizontal & Minor fracture \\
\hline 17.63 & 5.37 & 11.03 & 36 & 306 & 70 & NE & Steep & Minor fracture \\
\hline 17.92 & 5.46 & 11.24 & 104 & 14 & 19 & $\mathrm{E}$ & Shallow & Minor fracture \\
\hline 17.94 & 5.47 & 11.25 & 277 & 187 & 76 & W & Nearly vertical & Minor fracture \\
\hline 18.44 & 5.62 & 11.61 & 39 & 309 & 79 & NE & Nearly vertical & Minor fracture \\
\hline 19.48 & 5.94 & 12.36 & 60 & 330 & 73 & NE & Nearly vertical & Minor fracture \\
\hline 19.57 & 5.96 & 12.42 & 239 & 149 & 57 & SW & Steep & Minor fracture \\
\hline 19.60 & 5.97 & 12.44 & 49 & 319 & 33 & NE & Moderate & Minor fracture \\
\hline 19.75 & 6.02 & 12.55 & 259 & 169 & 70 & W & Nearly vertical & Minor fracture \\
\hline 19.89 & 6.06 & 12.65 & 265 & 175 & 64 & W & Steep & Minor fracture \\
\hline 20.03 & 6.10 & 12.75 & 258 & 168 & 74 & W & Nearly vertical & Minor fracture \\
\hline 20.24 & 6.17 & 12.90 & 237 & 147 & 65 & sw & Steep & Fracture \\
\hline 20.36 & 6.21 & 12.99 & 234 & 144 & 64 & SW & Steep & Fracture \\
\hline 20.48 & 6.24 & 13.08 & 239 & 149 & 61 & sw & Steep & Minor fracture \\
\hline 20.82 & 6.35 & 13.32 & 240 & 150 & 65 & SW & Steep & Minor fracture \\
\hline 21.20 & 6.46 & 13.60 & 243 & 153 & 61 & SW & Steep & Minor fracture \\
\hline 21.50 & 6.55 & 13.81 & 251 & 161 & 62 & w & Steep & Minor fracture \\
\hline 21.64 & 6.60 & 13.91 & 251 & 161 & 71 & W & Nearly vertical & Minor fracture \\
\hline 21.66 & 6.60 & 13.93 & 8 & 278 & 78 & $\mathrm{~N}$ & Nearly vertical & Minor fracture \\
\hline 21.93 & 6.68 & 14.12 & 246 & 156 & 59 & SW & Steep & Minor fracture \\
\hline 22.15 & 6.75 & 14.28 & 184 & 94 & 89 & $\mathrm{~s}$ & Nearly vertical & Minor fracture \\
\hline 22.55 & 6.87 & 14.57 & 353 & 263 & 89 & $\mathrm{~N}$ & Nearly vertical & Minor fracture \\
\hline 22.57 & 6.88 & 14.58 & 250 & 160 & 69 & W & Steep & Minor fracture \\
\hline 22.91 & 6.98 & 14.83 & 4 & 274 & 83 & $\mathrm{~N}$ & Nearly vertical & Minor fracture \\
\hline 23.04 & 7.02 & 14.92 & 267 & 177 & 62 & W & Steep & Minor fracture \\
\hline 23.24 & 7.08 & 15.06 & 7 & 277 & 87 & $\mathrm{~N}$ & Nearly vertical & Minor fracture \\
\hline 23.67 & 7.21 & 15.37 & 1 & 271 & 89 & $\mathrm{~N}$ & Nearly vertical & Minor fracture \\
\hline 23.91 & 7.29 & 15.54 & 301 & 211 & 47 & NW & Moderate & Partial fracture \\
\hline 24.04 & 7.33 & 15.64 & 352 & 262 & 87 & $\mathrm{~N}$ & Nearly vertical & Minor fracture \\
\hline 24.08 & 7.34 & 15.67 & 185 & 95 & 90 & $\mathrm{~S}$ & Nearly vertical & Minor fracture \\
\hline 24.47 & 7.46 & 15.95 & 359 & 269 & 80 & $\mathrm{~N}$ & Nearly vertical & Minor fracture \\
\hline 24.71 & 7.53 & 16.12 & 260 & 170 & 75 & W & Nearly vertical & Minor fracture \\
\hline 24.76 & 7.55 & 16.16 & 352 & 262 & 77 & $\mathrm{~N}$ & Nearly vertical & Minor fracture \\
\hline 24.92 & 7.60 & 16.27 & 261 & 171 & 72 & W & Nearly vertical & Minor fracture \\
\hline 24.97 & 7.61 & 16.31 & 1 & 271 & 82 & $\mathrm{~N}$ & Nearly vertical & Partial fracture \\
\hline 25.24 & 7.69 & 16.50 & 186 & 96 & 90 & $\mathrm{~S}$ & Nearly vertical & Minor fracture \\
\hline 25.34 & 7.72 & 16.57 & 6 & 276 & 84 & $\mathrm{~N}$ & Nearly vertical & Minor fracture \\
\hline 25.45 & 7.76 & 16.65 & 356 & 266 & 84 & $\mathrm{~N}$ & Nearly vertical & Minor fracture \\
\hline 25.70 & 7.83 & 16.83 & 8 & 278 & 83 & $\mathrm{~N}$ & Nearly vertical & Minor fracture \\
\hline 25.98 & 7.92 & 17.03 & 1 & 271 & 84 & $\mathrm{~N}$ & Nearly vertical & Minor fracture \\
\hline 26.15 & 7.97 & 17.16 & 4 & 274 & 89 & $\mathrm{~N}$ & Nearly vertical & Minor fracture \\
\hline 26.41 & 8.05 & 17.34 & 351 & 261 & 85 & $\mathrm{~N}$ & Nearly vertical & Minor fracture \\
\hline 26.78 & 8.16 & 17.61 & 353 & 263 & 85 & $\mathrm{~N}$ & Nearly vertical & Minor fracture \\
\hline 27.38 & 8.35 & 18.04 & 227 & 137 & 76 & SW & Nearly vertical & Minor fracture \\
\hline 27.44 & 8.36 & 18.08 & 166 & 76 & 87 & $\mathrm{~S}$ & Nearly vertical & Minor fracture \\
\hline 27.49 & 8.38 & 18.12 & 116 & 26 & 21 & SE & Shallow & Minor fracture \\
\hline 27.57 & 8.40 & 18.18 & 134 & 44 & 34 & SE & Moderate & Minor fracture \\
\hline 28.10 & 8.56 & 18.56 & 316 & 226 & 87 & $\mathrm{NW}$ & Nearly vertical & Partial fracture \\
\hline 28.20 & 8.59 & 18.63 & 4 & 274 & 85 & $\mathrm{~N}$ & Nearly vertical & Minor fracture \\
\hline 28.50 & 8.69 & 18.85 & 185 & 95 & 89 & $\mathrm{~S}$ & Nearly vertical & Minor fracture \\
\hline 28.97 & 8.83 & 19.18 & 185 & 95 & 11 & $\mathrm{~S}$ & Shallow & Fracture \\
\hline 29.04 & 8.85 & 19.24 & 155 & 65 & 21 & SE & Shallow & Minor fracture \\
\hline 29.16 & 8.89 & 19.32 & 156 & 66 & 89 & SE & Nearly vertical & Partial fracture \\
\hline
\end{tabular}


Table 5F-1. Interpretation of acoustic televiewer logs for borehole C-114, near Machiasport, Maine.-Continued [The borehole is inclined at $45^{\circ}$ from vertical in a direction of $\mathrm{N}^{\circ} 5^{\circ} \mathrm{E}$. Televiewer data are corrected for deviation and magnetic declination, so orientations are relative to true north; depths are below top of casing, which is 2.3 feet above land surface; TVD, true vertical depth; LS, land surface; dip azimuth is given in degrees east of true north; strike is reported in right-hand-rule (RHR)-azimuthal degrees east of true north and where the direction of dip is 90 degrees to the right of strike]

\begin{tabular}{|c|c|c|c|c|c|c|c|c|}
\hline $\begin{array}{l}\text { Depth, } \\
\text { in feet }\end{array}$ & $\begin{array}{l}\text { Depth, } \\
\text { in meters }\end{array}$ & $\begin{array}{l}\text { TVD, in feet } \\
\text { below LS }\end{array}$ & $\begin{array}{c}\text { Dip } \\
\text { azimuth }\end{array}$ & $\begin{array}{l}\text { Strike, } \\
\text { in RHR }\end{array}$ & Dip & $\begin{array}{c}\text { Dip } \\
\text { direction }\end{array}$ & Dip descriptor & Comment \\
\hline 29.36 & 8.95 & 19.47 & 49 & 319 & 65 & NE & Steep & Partial fracture \\
\hline 29.56 & 9.01 & 19.61 & 227 & 137 & 74 & SW & Nearly vertical & Minor fracture \\
\hline 29.62 & 9.03 & 19.65 & 1 & 271 & 85 & $\mathrm{~N}$ & Nearly vertical & Minor fracture \\
\hline 29.86 & 9.10 & 19.83 & 183 & 93 & 90 & $\mathrm{~s}$ & Nearly vertical & Minor fracture \\
\hline 30.19 & 9.20 & 20.06 & 356 & 266 & 82 & $\mathrm{~N}$ & Nearly vertical & Minor fracture \\
\hline 30.40 & 9.27 & 20.21 & 4 & 274 & 84 & $\mathrm{~N}$ & Nearly vertical & Minor fracture \\
\hline 30.71 & 9.36 & 20.44 & 360 & 270 & 84 & $\mathrm{~N}$ & Nearly vertical & Minor fracture \\
\hline 30.88 & 9.41 & 20.56 & 231 & 141 & 66 & SW & Steep & Minor fracture \\
\hline 31.05 & 9.46 & 20.68 & 358 & 268 & 83 & $\mathrm{~N}$ & Nearly vertical & Minor fracture \\
\hline 31.50 & 9.60 & 21.00 & 1 & 271 & 83 & $\mathrm{~N}$ & Nearly vertical & Minor fracture \\
\hline 31.51 & 9.60 & 21.01 & 240 & 150 & 61 & SW & Steep & Minor fracture \\
\hline 31.87 & 9.71 & 21.27 & 8 & 278 & 85 & $\mathrm{~N}$ & Nearly vertical & Minor fracture \\
\hline 32.08 & 9.78 & 21.42 & 141 & 51 & 29 & SE & Shallow & Minor fracture \\
\hline 32.09 & 9.78 & 21.43 & 182 & 92 & 87 & $\mathrm{~S}$ & Nearly vertical & Minor fracture \\
\hline 32.55 & 9.92 & 21.76 & 179 & 89 & 87 & $\mathrm{~S}$ & Nearly vertical & Minor fracture \\
\hline 32.64 & 9.95 & 21.82 & 352 & 262 & 88 & $\mathrm{~N}$ & Nearly vertical & Minor fracture \\
\hline 32.81 & 10.00 & 21.95 & 301 & 211 & 65 & NW & Steep & Minor fracture \\
\hline 32.81 & 10.00 & 21.95 & 91 & 1 & 13 & $\mathrm{E}$ & Shallow & Minor fracture \\
\hline 33.09 & 10.09 & 22.15 & 359 & 269 & 84 & $\mathrm{~N}$ & Nearly vertical & Minor fracture \\
\hline 33.17 & 10.11 & 22.21 & 350 & 260 & 86 & $\mathrm{~N}$ & Nearly vertical & Minor fracture \\
\hline 33.36 & 10.17 & 22.34 & 183 & 93 & 90 & $\mathrm{~s}$ & Nearly vertical & Minor fracture \\
\hline 33.58 & 10.23 & 22.50 & 172 & 82 & 88 & $\mathrm{~S}$ & Nearly vertical & Minor fracture \\
\hline 34.23 & 10.43 & 22.97 & 262 & 172 & 34 & W & Moderate & Fracture \\
\hline 34.33 & 10.46 & 23.04 & 358 & 268 & 86 & $\mathrm{~N}$ & Nearly vertical & Minor fracture \\
\hline 34.42 & 10.49 & 23.11 & 353 & 263 & 87 & $\mathrm{~N}$ & Nearly vertical & Fracture \\
\hline 34.86 & 10.62 & 23.42 & 355 & 265 & 87 & $\mathrm{~N}$ & Nearly vertical & Minor fracture \\
\hline 35.13 & 10.71 & 23.62 & 2 & 272 & 83 & $\mathrm{~N}$ & Nearly vertical & Minor fracture \\
\hline 35.25 & 10.74 & 23.70 & 225 & 135 & 67 & SW & Steep & Minor fracture \\
\hline 35.36 & 10.78 & 23.78 & 358 & 268 & 86 & $\mathrm{~N}$ & Nearly vertical & Minor fracture \\
\hline 36.90 & 11.25 & 24.89 & 140 & 50 & 18 & SE & Shallow & Minor fracture \\
\hline 37.10 & 11.31 & 25.03 & 1 & 271 & 86 & $\mathrm{~N}$ & Nearly vertical & Minor fracture \\
\hline 37.28 & 11.36 & 25.16 & 355 & 265 & 87 & $\mathrm{~N}$ & Nearly vertical & Minor fracture \\
\hline 37.75 & 11.51 & 25.50 & 359 & 269 & 83 & $\mathrm{~N}$ & Nearly vertical & Minor fracture \\
\hline 37.84 & 11.53 & 25.57 & 352 & 262 & 88 & $\mathrm{~N}$ & Nearly vertical & Minor fracture \\
\hline 38.00 & 11.58 & 25.68 & 107 & 17 & 27 & $\mathrm{E}$ & Shallow & Partial fracture \\
\hline 38.05 & 11.60 & 25.72 & 172 & 82 & 89 & $\mathrm{~S}$ & Nearly vertical & Minor fracture \\
\hline 38.19 & 11.64 & 25.82 & 248 & 158 & 49 & W & Moderate & Minor fracture \\
\hline 38.24 & 11.65 & 25.85 & 1 & 271 & 86 & $\mathrm{~N}$ & Nearly vertical & Minor fracture \\
\hline 38.36 & 11.69 & 25.94 & 0 & 270 & 86 & $\mathrm{~N}$ & Nearly vertical & Minor fracture \\
\hline 38.52 & 11.74 & 26.05 & 171 & 81 & 90 & $\mathrm{~s}$ & Nearly vertical & Minor fracture \\
\hline 38.84 & 11.84 & 26.28 & 5 & 275 & 88 & $\mathrm{~N}$ & Nearly vertical & Minor fracture \\
\hline 39.04 & 11.90 & 26.43 & 2 & 272 & 87 & $\mathrm{~N}$ & Nearly vertical & Minor fracture \\
\hline 39.21 & 11.95 & 26.55 & 277 & 187 & 60 & W & Steep & Minor fracture \\
\hline 39.23 & 11.96 & 26.57 & 356 & 266 & 88 & $\mathrm{~N}$ & Nearly vertical & Minor fracture \\
\hline 40.03 & 12.20 & 27.14 & 242 & 152 & 76 & SW & Nearly vertical & Minor fracture \\
\hline 40.31 & 12.29 & 27.34 & 239 & 149 & 69 & SW & Steep & Minor fracture \\
\hline 40.43 & 12.32 & 27.43 & 185 & 95 & 89 & $\mathrm{~S}$ & Nearly vertical & Minor fracture \\
\hline 40.75 & 12.42 & 27.66 & 358 & 268 & 89 & $\mathrm{~N}$ & Nearly vertical & Minor fracture \\
\hline 40.85 & 12.45 & 27.73 & 243 & 153 & 48 & SW & Moderate & Minor fracture \\
\hline 41.53 & 12.66 & 28.22 & 355 & 265 & 86 & $\mathrm{~N}$ & Nearly vertical & Fracture \\
\hline 41.84 & 12.75 & 28.44 & 1 & 271 & 85 & $\mathrm{~N}$ & Nearly vertical & Minor fracture \\
\hline 42.28 & 12.89 & 28.76 & 178 & 88 & 83 & $\mathrm{~S}$ & Nearly vertical & Minor fracture \\
\hline 42.35 & 12.91 & 28.81 & 80 & 350 & 89 & $E$ & Nearly vertical & Minor fracture \\
\hline 42.49 & 12.95 & 28.91 & 12 & 282 & 87 & $\mathrm{~N}$ & Nearly vertical & Minor fracture \\
\hline 42.50 & 12.95 & 28.92 & 325 & 235 & 88 & NW & Nearly vertical & Partial fracture \\
\hline 42.75 & 13.03 & 29.10 & 5 & 275 & 87 & $\mathrm{~N}$ & Nearly vertical & Minor fracture \\
\hline 43.02 & 13.11 & 29.29 & 190 & 100 & 88 & $\mathrm{~S}$ & Nearly vertical & Minor fracture \\
\hline
\end{tabular}


Table 5F-1. Interpretation of acoustic televiewer logs for borehole C-114, near Machiasport, Maine.-Continued [The borehole is inclined at $45^{\circ}$ from vertical in a direction of $\mathrm{N}^{\circ} 5^{\circ} \mathrm{E}$. Televiewer data are corrected for deviation and magnetic declination, so orientations are relative to true north; depths are below top of casing, which is 2.3 feet above land surface; TVD, true vertical depth; LS, land surface; dip azimuth is given in degrees east of true north; strike is reported in right-hand-rule (RHR)-azimuthal degrees east of true north and where the direction of dip is 90 degrees to the right of strike]

\begin{tabular}{|c|c|c|c|c|c|c|c|c|}
\hline $\begin{array}{l}\text { Depth, } \\
\text { in feet }\end{array}$ & $\begin{array}{l}\text { Depth, } \\
\text { in meters }\end{array}$ & $\begin{array}{l}\text { TVD, in feet } \\
\text { below LS }\end{array}$ & $\begin{array}{c}\text { Dip } \\
\text { azimuth }\end{array}$ & $\begin{array}{l}\text { Strike, } \\
\text { in RHR }\end{array}$ & Dip & $\begin{array}{c}\text { Dip } \\
\text { direction }\end{array}$ & Dip descriptor & Comment \\
\hline 43.11 & 13.14 & 29.36 & 112 & 22 & 18 & $\mathrm{E}$ & Shallow & Partial fracture \\
\hline 43.11 & 13.14 & 29.36 & 7 & 277 & 90 & $\mathrm{~N}$ & Nearly vertical & Minor fracture \\
\hline 43.33 & 13.21 & 29.51 & 187 & 97 & 84 & $\mathrm{~S}$ & Nearly vertical & Minor fracture \\
\hline 43.54 & 13.27 & 29.67 & 44 & 314 & 72 & NE & Nearly vertical & Minor fracture \\
\hline 43.58 & 13.28 & 29.69 & 105 & 15 & 16 & $E$ & Shallow & Minor fracture \\
\hline 43.61 & 13.29 & 29.72 & 194 & 104 & 81 & $\mathrm{~S}$ & Nearly vertical & Minor fracture \\
\hline 43.70 & 13.32 & 29.78 & 112 & 22 & 22 & $E$ & Shallow & Minor fracture \\
\hline 43.91 & 13.38 & 29.93 & 121 & 31 & 21 & SE & Shallow & Partial fracture \\
\hline 44.17 & 13.46 & 30.12 & 197 & 107 & 78 & $\mathrm{~S}$ & Nearly vertical & Fracture \\
\hline 44.24 & 13.48 & 30.17 & 244 & 154 & 54 & SW & Steep & Minor fracture \\
\hline 44.27 & 13.49 & 30.19 & 161 & 71 & 14 & $\mathrm{~S}$ & Shallow & Fracture \\
\hline 44.47 & 13.55 & 30.33 & 141 & 51 & 11 & SE & Shallow & Minor fracture \\
\hline 44.62 & 13.60 & 30.44 & 203 & 113 & 75 & SW & Nearly vertical & Minor fracture \\
\hline 45.16 & 13.76 & 30.83 & 178 & 88 & 88 & $\mathrm{~S}$ & Nearly vertical & Minor fracture \\
\hline 45.31 & 13.81 & 30.94 & 182 & 92 & 87 & $\mathrm{~S}$ & Nearly vertical & Minor fracture \\
\hline 45.39 & 13.83 & 31.00 & 340 & 250 & 18 & $\mathrm{~N}$ & Shallow & Partial fracture \\
\hline 45.67 & 13.92 & 31.20 & 176 & 86 & 87 & $\mathrm{~S}$ & Nearly vertical & Minor fracture \\
\hline 46.14 & 14.06 & 31.54 & 114 & 24 & 16 & SE & Shallow & Partial fracture \\
\hline 46.50 & 14.17 & 31.79 & 66 & 336 & 86 & NE & Nearly vertical & Fracture \\
\hline 46.53 & 14.18 & 31.82 & 351 & 261 & 72 & $\mathrm{~N}$ & Nearly vertical & Minor fracture \\
\hline 46.83 & 14.27 & 32.03 & 27 & 297 & 36 & NE & Moderate & Partial fracture \\
\hline 46.88 & 14.29 & 32.07 & 263 & 173 & 82 & W & Nearly vertical & Minor fracture \\
\hline 48.00 & 14.63 & 32.87 & 185 & 95 & 90 & $\mathrm{~S}$ & Nearly vertical & Minor fracture \\
\hline 48.28 & 14.72 & 33.08 & 294 & 204 & 35 & NW & Moderate & Partial fracture \\
\hline 48.34 & 14.73 & 33.12 & 14 & 284 & 73 & $\mathrm{~N}$ & Nearly vertical & Minor fracture \\
\hline 48.39 & 14.75 & 33.15 & 251 & 161 & 86 & W & Nearly vertical & Fracture \\
\hline 48.44 & 14.76 & 33.19 & 358 & 268 & 90 & $\mathrm{~N}$ & Nearly vertical & Minor fracture \\
\hline 48.51 & 14.79 & 33.24 & 240 & 150 & 77 & SW & Nearly vertical & Fracture \\
\hline 48.53 & 14.79 & 33.26 & 103 & 13 & 16 & $\mathrm{E}$ & Shallow & Minor fracture \\
\hline 48.95 & 14.92 & 33.56 & 121 & 31 & 22 & SE & Shallow & Minor fracture \\
\hline 49.03 & 14.94 & 33.61 & 5 & 275 & 86 & $\mathrm{~N}$ & Nearly vertical & Minor fracture \\
\hline 49.16 & 14.98 & 33.71 & 102 & 12 & 20 & $E$ & Shallow & Fracture \\
\hline 49.25 & 15.01 & 33.77 & 185 & 95 & 79 & $\mathrm{~S}$ & Nearly vertical & Minor fracture \\
\hline 49.31 & 15.03 & 33.82 & 1 & 271 & 86 & $\mathrm{~N}$ & Nearly vertical & Minor fracture \\
\hline 49.56 & 15.11 & 34.00 & 165 & 75 & 48 & $\mathrm{~S}$ & Moderate & Partial fracture \\
\hline 49.57 & 15.11 & 34.00 & 14 & 284 & 79 & $\mathrm{~N}$ & Nearly vertical & Minor fracture \\
\hline 49.65 & 15.13 & 34.06 & 93 & 3 & 15 & $\mathrm{E}$ & Shallow & Minor fracture \\
\hline 50.25 & 15.32 & 34.49 & 66 & 336 & 88 & NE & Nearly vertical & Minor fracture \\
\hline 50.37 & 15.35 & 34.58 & 185 & 95 & 89 & $\mathrm{~S}$ & Nearly vertical & Minor fracture \\
\hline 50.91 & 15.52 & 34.97 & 231 & 141 & 89 & SW & Nearly vertical & Minor fracture \\
\hline 51.45 & 15.68 & 35.36 & 187 & 97 & 87 & $\mathrm{~S}$ & Nearly vertical & Minor fracture \\
\hline 51.71 & 15.76 & 35.54 & 279 & 189 & 65 & W & Steep & Minor fracture \\
\hline 51.74 & 15.77 & 35.56 & 192 & 102 & 88 & $\mathrm{~S}$ & Nearly vertical & Minor fracture \\
\hline 51.85 & 15.80 & 35.64 & 120 & 30 & 15 & SE & Shallow & Partial fracture \\
\hline 51.92 & 15.82 & 35.69 & 216 & 126 & 83 & SW & Nearly vertical & Minor fracture \\
\hline 51.97 & 15.84 & 35.73 & 123 & 33 & 13 & SE & Shallow & Minor fracture \\
\hline 52.09 & 15.88 & 35.82 & 204 & 114 & 72 & SW & Nearly vertical & Minor fracture \\
\hline 52.55 & 16.02 & 36.15 & 216 & 126 & 83 & SW & Nearly vertical & Minor fracture \\
\hline 52.66 & 16.05 & 36.23 & 41 & 311 & 87 & $\mathrm{NE}$ & Nearly vertical & Minor fracture \\
\hline 52.70 & 16.06 & 36.25 & 17 & 287 & 90 & $\mathrm{~N}$ & Nearly vertical & Minor fracture \\
\hline 52.89 & 16.12 & 36.39 & 39 & 309 & 84 & NE & Nearly vertical & Minor fracture \\
\hline 53.19 & 16.21 & 36.61 & 233 & 143 & 76 & SW & Nearly vertical & Minor fracture \\
\hline 53.37 & 16.27 & 36.74 & 224 & 134 & 72 & SW & Nearly vertical & Minor fracture \\
\hline 53.76 & 16.39 & 37.02 & 255 & 165 & 71 & W & Nearly vertical & Minor fracture \\
\hline 54.34 & 16.56 & 37.43 & 7 & 277 & 89 & $\mathrm{~N}$ & Nearly vertical & Minor fracture \\
\hline 54.45 & 16.60 & 37.51 & 182 & 92 & 90 & $\mathrm{~S}$ & Nearly vertical & Minor fracture \\
\hline 54.52 & 16.62 & 37.56 & 279 & 189 & 66 & W & Steep & Fracture \\
\hline
\end{tabular}


Table 5F-1. Interpretation of acoustic televiewer logs for borehole C-114, near Machiasport, Maine.-Continued [The borehole is inclined at $45^{\circ}$ from vertical in a direction of $\mathrm{N}^{\circ} 5^{\circ} \mathrm{E}$. Televiewer data are corrected for deviation and magnetic declination, so orientations are relative to true north; depths are below top of casing, which is 2.3 feet above land surface; TVD, true vertical depth; LS, land surface; dip azimuth is given in degrees east of true north; strike is reported in right-hand-rule (RHR)-azimuthal degrees east of true north and where the direction of dip is 90 degrees to the right of strike]

\begin{tabular}{|c|c|c|c|c|c|c|c|c|}
\hline $\begin{array}{l}\text { Depth, } \\
\text { in feet }\end{array}$ & $\begin{array}{l}\text { Depth, } \\
\text { in meters }\end{array}$ & $\begin{array}{l}\text { TVD, in feet } \\
\text { below LS }\end{array}$ & $\begin{array}{c}\text { Dip } \\
\text { azimuth }\end{array}$ & $\begin{array}{l}\text { Strike, } \\
\text { in RHR }\end{array}$ & Dip & $\begin{array}{c}\text { Dip } \\
\text { direction }\end{array}$ & Dip descriptor & Comment \\
\hline 55.25 & 16.84 & 38.09 & 13 & 283 & 89 & $\mathrm{~N}$ & Nearly vertical & Minor fracture \\
\hline 55.30 & 16.85 & 38.13 & 178 & 88 & 90 & $\mathrm{~S}$ & Nearly vertical & Minor fracture \\
\hline 55.62 & 16.95 & 38.36 & 232 & 142 & 76 & SW & Nearly vertical & Minor fracture \\
\hline 56.18 & 17.12 & 38.76 & 75 & 345 & 85 & $E$ & Nearly vertical & Minor fracture \\
\hline 56.27 & 17.15 & 38.82 & 1 & 271 & 85 & $\bar{N}$ & Nearly vertical & Minor fracture \\
\hline 56.54 & 17.23 & 39.02 & 232 & 142 & 67 & SW & Steep & Minor fracture \\
\hline 56.66 & 17.27 & 39.10 & 232 & 142 & 80 & SW & Nearly vertical & Partial fracture \\
\hline 56.75 & 17.30 & 39.17 & 152 & 62 & 15 & SE & Shallow & Minor fracture \\
\hline 56.89 & 17.34 & 39.27 & 238 & 148 & 83 & SW & Nearly vertical & Minor fracture \\
\hline 57.32 & 17.47 & 39.58 & 164 & 74 & 74 & $\mathrm{~s}$ & Nearly vertical & Lithologic feature \\
\hline 57.94 & 17.66 & 40.02 & 238 & 148 & 72 & SW & Nearly vertical & Minor fracture \\
\hline 58.11 & 17.71 & 40.15 & 248 & 158 & 86 & W & Nearly vertical & Minor fracture \\
\hline 58.83 & 17.93 & 40.66 & 183 & 93 & 90 & $\mathrm{~S}$ & Nearly vertical & Minor fracture \\
\hline 58.93 & 17.96 & 40.74 & 183 & 93 & 89 & $\mathrm{~S}$ & Nearly vertical & Minor fracture \\
\hline 59.22 & 18.05 & 40.94 & 242 & 152 & 66 & sw & Steep & Minor fracture \\
\hline 59.28 & 18.07 & 40.99 & 262 & 172 & 74 & W & Nearly vertical & Partial fracture \\
\hline 59.66 & 18.18 & 41.26 & 3 & 273 & 87 & $\mathrm{~N}$ & Nearly vertical & Minor fracture \\
\hline 60.39 & 18.41 & 41.79 & 246 & 156 & 63 & sw & Steep & Minor fracture \\
\hline 60.67 & 18.49 & 41.99 & 247 & 157 & 64 & SW & Steep & Minor fracture \\
\hline 60.82 & 18.54 & 42.10 & 229 & 139 & 49 & SW & Moderate & Minor fracture \\
\hline 61.14 & 18.63 & 42.33 & 5 & 275 & 81 & $N$ & Nearly vertical & Minor fracture \\
\hline 61.42 & 18.72 & 42.53 & 3 & 273 & 86 & $\mathrm{~N}$ & Nearly vertical & Minor fracture \\
\hline 61.60 & 18.77 & 42.66 & 255 & 165 & 74 & W & Nearly vertical & Minor fracture \\
\hline 61.68 & 18.80 & 42.71 & 360 & 270 & 84 & $\mathrm{~N}$ & Nearly vertical & Minor fracture \\
\hline 61.83 & 18.84 & 42.82 & 3 & 273 & 89 & $\mathrm{~N}$ & Nearly vertical & Minor fracture \\
\hline 62.05 & 18.91 & 42.98 & 1 & 271 & 89 & $\mathrm{~N}$ & Nearly vertical & Minor fracture \\
\hline 62.40 & 19.02 & 43.23 & 264 & 174 & 67 & W & Steep & Minor fracture \\
\hline 62.54 & 19.06 & 43.33 & 258 & 168 & 61 & W & Steep & Minor fracture \\
\hline 62.59 & 19.08 & 43.37 & 9 & 279 & 88 & $\mathrm{~N}$ & Nearly vertical & Minor fracture \\
\hline 62.80 & 19.14 & 43.52 & 357 & 267 & 86 & $\mathrm{~N}$ & Nearly vertical & Minor fracture \\
\hline 63.01 & 19.20 & 43.67 & 6 & 276 & 86 & $\mathrm{~N}$ & Nearly vertical & Minor fracture \\
\hline 63.06 & 19.22 & 43.71 & 192 & 102 & 86 & $\mathrm{~S}$ & Nearly vertical & Minor fracture \\
\hline 63.35 & 19.31 & 43.92 & 7 & 277 & 86 & $\mathrm{~N}$ & Nearly vertical & Minor fracture \\
\hline 63.64 & 19.40 & 44.12 & 1 & 271 & 89 & $\mathrm{~N}$ & Nearly vertical & Minor fracture \\
\hline 63.72 & 19.42 & 44.18 & 8 & 278 & 90 & $\mathrm{~N}$ & Nearly vertical & Minor fracture \\
\hline 63.85 & 19.46 & 44.28 & 263 & 173 & 59 & W & Steep & Minor fracture \\
\hline 64.00 & 19.51 & 44.38 & 6 & 276 & 85 & $\mathrm{~N}$ & Nearly vertical & Minor fracture \\
\hline 64.18 & 19.56 & 44.51 & 7 & 277 & 88 & $\mathrm{~N}$ & Nearly vertical & Minor fracture \\
\hline 64.33 & 19.61 & 44.62 & 7 & 277 & 86 & $\mathrm{~N}$ & Nearly vertical & Minor fracture \\
\hline 64.80 & 19.75 & 44.96 & 7 & 277 & 85 & $\mathrm{~N}$ & Nearly vertical & Minor fracture \\
\hline 65.30 & 19.90 & 45.32 & 120 & 30 & 19 & SE & Shallow & Partial fracture \\
\hline 65.57 & 19.98 & 45.51 & 340 & 250 & 6 & $\mathrm{~N}$ & Nearly horizontal & Minor fracture \\
\hline 65.62 & 20.00 & 45.55 & 183 & 93 & 88 & $\mathrm{~S}$ & Nearly vertical & Minor fracture \\
\hline 65.92 & 20.09 & 45.76 & 359 & 269 & 85 & $\mathrm{~N}$ & Nearly vertical & Minor fracture \\
\hline 66.35 & 20.22 & 46.07 & 1 & 271 & 85 & $N$ & Nearly vertical & Minor fracture \\
\hline 66.51 & 20.27 & 46.19 & 247 & 157 & 63 & SW & Steep & Minor fracture \\
\hline 66.70 & 20.33 & 46.33 & 279 & 189 & 25 & w & Shallow & Minor fracture \\
\hline 66.99 & 20.42 & 46.53 & 102 & 12 & 15 & $\mathrm{E}$ & Shallow & Minor fracture \\
\hline 67.11 & 20.45 & 46.62 & 1 & 271 & 79 & $\mathrm{~N}$ & Nearly vertical & Minor fracture \\
\hline 67.12 & 20.46 & 46.63 & 253 & 163 & 64 & W & Steep & Minor fracture \\
\hline 67.27 & 20.50 & 46.74 & 349 & 259 & 82 & $\mathrm{~N}$ & Nearly vertical & Minor fracture \\
\hline 67.36 & 20.53 & 46.80 & 89 & 359 & 14 & $E$ & Shallow & Partial fracture \\
\hline 67.58 & 20.60 & 46.96 & 261 & 171 & 88 & W & Nearly vertical & Minor fracture \\
\hline 68.11 & 20.76 & 47.34 & 244 & 154 & 68 & sW & Steep & Minor fracture \\
\hline 68.11 & 20.76 & 47.34 & 275 & 185 & 62 & W & Steep & Partial fracture \\
\hline 68.12 & 20.76 & 47.35 & 355 & 265 & 81 & $\mathrm{~N}$ & Nearly vertical & Minor fracture \\
\hline 68.19 & 20.78 & 47.40 & 147 & 57 & 16 & SE & Shallow & Minor fracture \\
\hline
\end{tabular}


Table 5F-1. Interpretation of acoustic televiewer logs for borehole C-114, near Machiasport, Maine.-Continued [The borehole is inclined at $45^{\circ}$ from vertical in a direction of $\mathrm{N}^{\circ} 5^{\circ} \mathrm{E}$. Televiewer data are corrected for deviation and magnetic declination, so orientations are relative to true north; depths are below top of casing, which is 2.3 feet above land surface; TVD, true vertical depth; LS, land surface; dip azimuth is given in degrees east of true north; strike is reported in right-hand-rule (RHR)-azimuthal degrees east of true north and where the direction of dip is 90 degrees to the right of strike]

\begin{tabular}{|c|c|c|c|c|c|c|c|c|}
\hline $\begin{array}{l}\text { Depth, } \\
\text { in feet }\end{array}$ & $\begin{array}{c}\text { Depth, } \\
\text { in meters }\end{array}$ & $\begin{array}{l}\text { TVD, in feet } \\
\text { below LS }\end{array}$ & $\begin{array}{c}\text { Dip } \\
\text { azimuth }\end{array}$ & $\begin{array}{c}\text { Strike, } \\
\text { in RHR }\end{array}$ & Dip & $\begin{array}{c}\text { Dip } \\
\text { direction }\end{array}$ & Dip descriptor & Comment \\
\hline 68.74 & 20.95 & 47.79 & 358 & 268 & 80 & $\mathrm{~N}$ & Nearly vertical & Minor fracture \\
\hline 68.95 & 21.01 & 47.94 & 256 & 166 & 64 & W & Steep & Minor fracture \\
\hline 68.95 & 21.01 & 47.94 & 102 & 12 & 21 & $\mathrm{E}$ & Shallow & Minor fracture \\
\hline 69.00 & 21.03 & 47.98 & 356 & 266 & 79 & $\mathrm{~N}$ & Nearly vertical & Minor fracture \\
\hline 69.09 & 21.06 & 48.04 & 274 & 184 & 59 & W & Steep & Minor fracture \\
\hline 69.11 & 21.06 & 48.06 & 35 & 305 & 63 & NE & Steep & Partial fracture \\
\hline 69.79 & 21.27 & 48.55 & 265 & 175 & 74 & W & Nearly vertical & Minor fracture \\
\hline 69.89 & 21.30 & 48.62 & 335 & 245 & 82 & NW & Nearly vertical & Minor fracture \\
\hline 69.97 & 21.33 & 48.68 & 85 & 355 & 19 & $\mathrm{E}$ & Shallow & Minor fracture \\
\hline 70.02 & 21.34 & 48.71 & 275 & 185 & 72 & W & Nearly vertical & Minor fracture \\
\hline 70.17 & 21.39 & 48.82 & 280 & 190 & 88 & W & Nearly vertical & Partial fracture \\
\hline 70.59 & 21.51 & 49.12 & 233 & 143 & 52 & SW & Steep & Fracture \\
\hline 70.63 & 21.53 & 49.15 & 0 & 270 & 85 & $\mathrm{~N}$ & Nearly vertical & Minor fracture \\
\hline 71.08 & 21.66 & 49.48 & 86 & 356 & 20 & $\mathrm{E}$ & Shallow & Minor fracture \\
\hline 71.79 & 21.88 & 49.99 & 144 & 54 & 25 & SE & Shallow & Fracture \\
\hline 72.28 & 22.03 & 50.34 & 200 & 110 & 62 & $\mathrm{~S}$ & Steep & Minor fracture \\
\hline 72.49 & 22.09 & 50.49 & 359 & 269 & 82 & $\mathrm{~N}$ & Nearly vertical & Minor fracture \\
\hline 72.54 & 22.11 & 50.53 & 153 & 63 & 72 & SE & Nearly vertical & Minor fracture \\
\hline 73.34 & 22.35 & 51.10 & 168 & 78 & 82 & $\mathrm{~S}$ & Nearly vertical & Minor fracture \\
\hline 74.00 & 22.55 & 51.58 & 138 & 48 & 87 & SE & Nearly vertical & Minor fracture \\
\hline 74.62 & 22.74 & 52.02 & 145 & 55 & 86 & SE & Nearly vertical & Minor fracture \\
\hline 74.98 & 22.85 & 52.28 & 208 & 118 & 43 & SW & Moderate & Minor fracture \\
\hline 75.17 & 22.91 & 52.42 & 165 & 75 & 89 & $\mathrm{~S}$ & Nearly vertical & Minor fracture \\
\hline 75.29 & 22.95 & 52.50 & 207 & 117 & 40 & SW & Moderate & Minor fracture \\
\hline 75.38 & 22.97 & 52.57 & 3 & 273 & 84 & $\mathrm{~N}$ & Nearly vertical & Minor fracture \\
\hline 76.53 & 23.33 & 53.40 & 358 & 268 & 85 & $\mathrm{~N}$ & Nearly vertical & Minor fracture \\
\hline 76.89 & 23.43 & 53.66 & 179 & 89 & 21 & $\mathrm{~S}$ & Shallow & Minor fracture \\
\hline 78.55 & 23.94 & 54.85 & 210 & 120 & 43 & SW & Moderate & Minor fracture \\
\hline 78.74 & 24.00 & 54.99 & 203 & 113 & 46 & SW & Moderate & Minor fracture \\
\hline 78.95 & 24.06 & 55.14 & 276 & 186 & 87 & W & Nearly vertical & Minor fracture \\
\hline 79.27 & 24.16 & 55.37 & 61 & 331 & 76 & NE & Nearly vertical & Minor fracture \\
\hline 80.66 & 24.58 & 56.37 & 91 & 1 & 87 & $\mathrm{E}$ & Nearly vertical & Minor fracture \\
\hline
\end{tabular}


Table 5F-2. Interpretation of optical televiewer logs for borehole C-114, near Machiasport, Maine.

[The borehole is inclined at $45^{\circ}$ from vertical in a direction of $\mathrm{N}^{\circ} 5^{\circ} \mathrm{E}$. Televiewer data are corrected for deviation and magnetic declination, so orientations are relative to true north; depths are below top of casing, which is 2.3 feet above land surface; TVD, true vertical depth; LS, land surface; dip azimuth is given in degrees east of true north; strike is reported in right-hand-rule (RHR)-azimuthal degrees east of true north and where the direction of dip is 90 degrees to the right of strike]

\begin{tabular}{|c|c|c|c|c|c|c|c|c|}
\hline $\begin{array}{l}\text { Depth, } \\
\text { in feet }\end{array}$ & $\begin{array}{l}\text { Depth, } \\
\text { in meters }\end{array}$ & $\begin{array}{l}\text { TVD, in feet } \\
\text { below LS }\end{array}$ & $\begin{array}{c}\text { Dip } \\
\text { azimuth }\end{array}$ & $\begin{array}{l}\text { Strike, } \\
\text { in RHR }\end{array}$ & Dip & $\begin{array}{c}\text { Dip } \\
\text { direction }\end{array}$ & Dip descriptor & Comment \\
\hline 13.46 & 4.10 & 8.01 & 343 & 253 & 0 & $\mathrm{~N}$ & Horizontal & Minor fracture \\
\hline 14.12 & 4.30 & 8.53 & 335 & 245 & 90 & NW & Vertical & Lithologic feature \\
\hline 15.69 & 4.78 & 9.76 & 149 & 59 & 82 & SE & Nearly vertical & Minor fracture \\
\hline 16.00 & 4.88 & 10.01 & 207 & 117 & 20 & SW & Shallow & water level \\
\hline 16.43 & 5.01 & 10.35 & 105 & 15 & 58 & $\mathrm{E}$ & Steep & Minor fracture \\
\hline 16.90 & 5.15 & 10.72 & 105 & 15 & 24 & $\mathrm{E}$ & Shallow & Minor fracture \\
\hline 19.61 & 5.98 & 12.85 & 226 & 136 & 55 & sw & Steep & Minor fracture \\
\hline 19.78 & 6.03 & 12.99 & 245 & 155 & 61 & SW & Steep & Minor fracture \\
\hline 20.46 & 6.24 & 13.52 & 236 & 146 & 47 & SW & Moderate & Minor fracture \\
\hline 20.62 & 6.28 & 13.65 & 136 & 46 & 78 & SE & Nearly vertical & Minor fracture \\
\hline 21.26 & 6.48 & 14.15 & 157 & 67 & 61 & SE & Steep & Lithologic feature \\
\hline 21.67 & 6.60 & 14.48 & 241 & 151 & 74 & SW & Nearly vertical & Minor fracture \\
\hline 27.58 & 8.41 & 19.13 & 135 & 45 & 39 & SE & Moderate & Fracture \\
\hline 29.00 & 8.84 & 20.25 & 178 & 88 & 12 & $\mathrm{~S}$ & Shallow & Fracture \\
\hline 30.87 & 9.41 & 21.73 & 214 & 124 & 81 & sw & Nearly vertical & Minor fracture \\
\hline 34.24 & 10.44 & 24.38 & 256 & 166 & 35 & W & Moderate & Fracture \\
\hline 35.26 & 10.75 & 25.18 & 231 & 141 & 61 & SW & Steep & Minor fracture \\
\hline 37.12 & 11.31 & 26.65 & 355 & 265 & 87 & $\mathrm{~N}$ & Nearly vertical & Minor fracture \\
\hline 37.46 & 11.42 & 26.92 & 158 & 68 & 79 & $\mathrm{~S}$ & Nearly vertical & Minor fracture \\
\hline 37.82 & 11.53 & 27.20 & 155 & 65 & 75 & SE & Nearly vertical & Minor fracture \\
\hline 38.06 & 11.60 & 27.39 & 349 & 259 & 88 & $\mathrm{~N}$ & Nearly vertical & Minor fracture \\
\hline 44.16 & 13.46 & 32.20 & 197 & 107 & 38 & $\mathrm{~S}$ & Moderate & Minor fracture \\
\hline 44.29 & 13.50 & 32.30 & 132 & 42 & 16 & SE & Shallow & Minor fracture \\
\hline 45.31 & 13.81 & 33.10 & 181 & 91 & 86 & $S$ & Nearly vertical & Minor fracture \\
\hline 46.52 & 14.18 & 34.06 & 59 & 329 & 82 & NE & Nearly vertical & Minor fracture \\
\hline 46.76 & 14.25 & 34.25 & 27 & 297 & 36 & $\mathrm{NE}$ & Moderate & Minor fracture \\
\hline 48.30 & 14.72 & 35.46 & 290 & 200 & 36 & W & Moderate & Minor fracture \\
\hline 48.88 & 14.90 & 35.92 & 85 & 355 & 22 & $E$ & Shallow & Minor fracture \\
\hline 49.15 & 14.98 & 36.13 & 112 & 22 & 16 & $\mathrm{E}$ & Shallow & Minor fracture \\
\hline 55.24 & 16.84 & 40.93 & 174 & 84 & 85 & $\bar{S}$ & Nearly vertical & Minor fracture \\
\hline 61.07 & 18.61 & 45.52 & 57 & 327 & 24 & $\mathrm{NE}$ & Shallow & Lithologic feature \\
\hline 70.19 & 21.39 & 52.71 & 142 & 52 & 35 & SE & Moderate & Lithologic feature \\
\hline 70.92 & 21.62 & 53.29 & 243 & 153 & 24 & SW & Shallow & Lithologic feature \\
\hline 71.76 & 21.87 & 53.95 & 123 & 33 & 22 & SE & Shallow & Minor fracture \\
\hline 72.10 & 21.98 & 54.22 & 163 & 73 & 74 & $\mathrm{~S}$ & Nearly vertical & Minor fracture \\
\hline 79.96 & 24.37 & 60.41 & 190 & 100 & 51 & $\mathrm{~S}$ & Steep & Lithologic feature \\
\hline 80.36 & 24.49 & 60.72 & 209 & 119 & 74 & SW & Nearly vertical & Lithologic feature \\
\hline
\end{tabular}




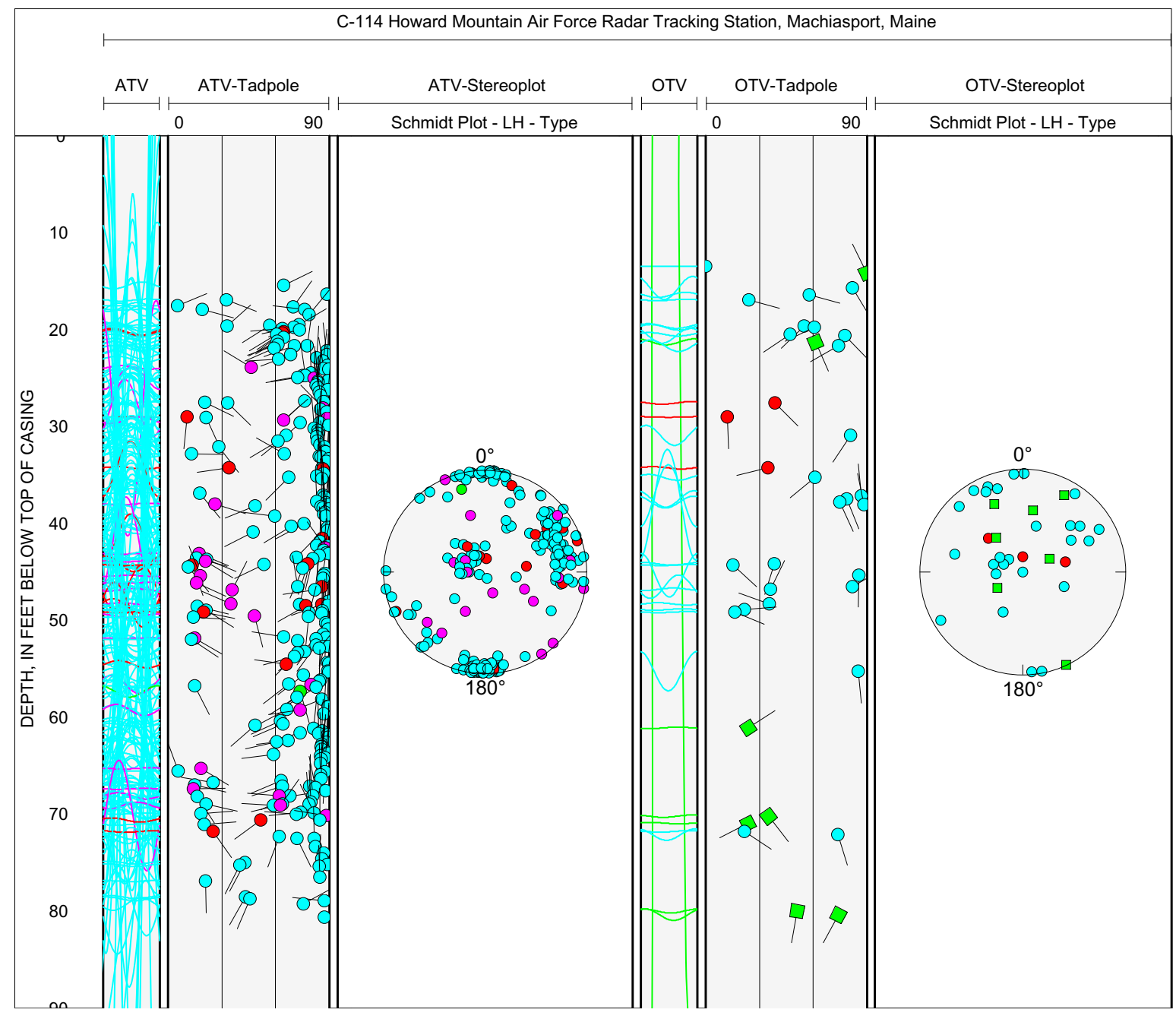

Figure 5F-2. Projection, tadpole, and stereoplots of interpretation of borehole image data for borehole C-114, near Machiasport, Maine. 

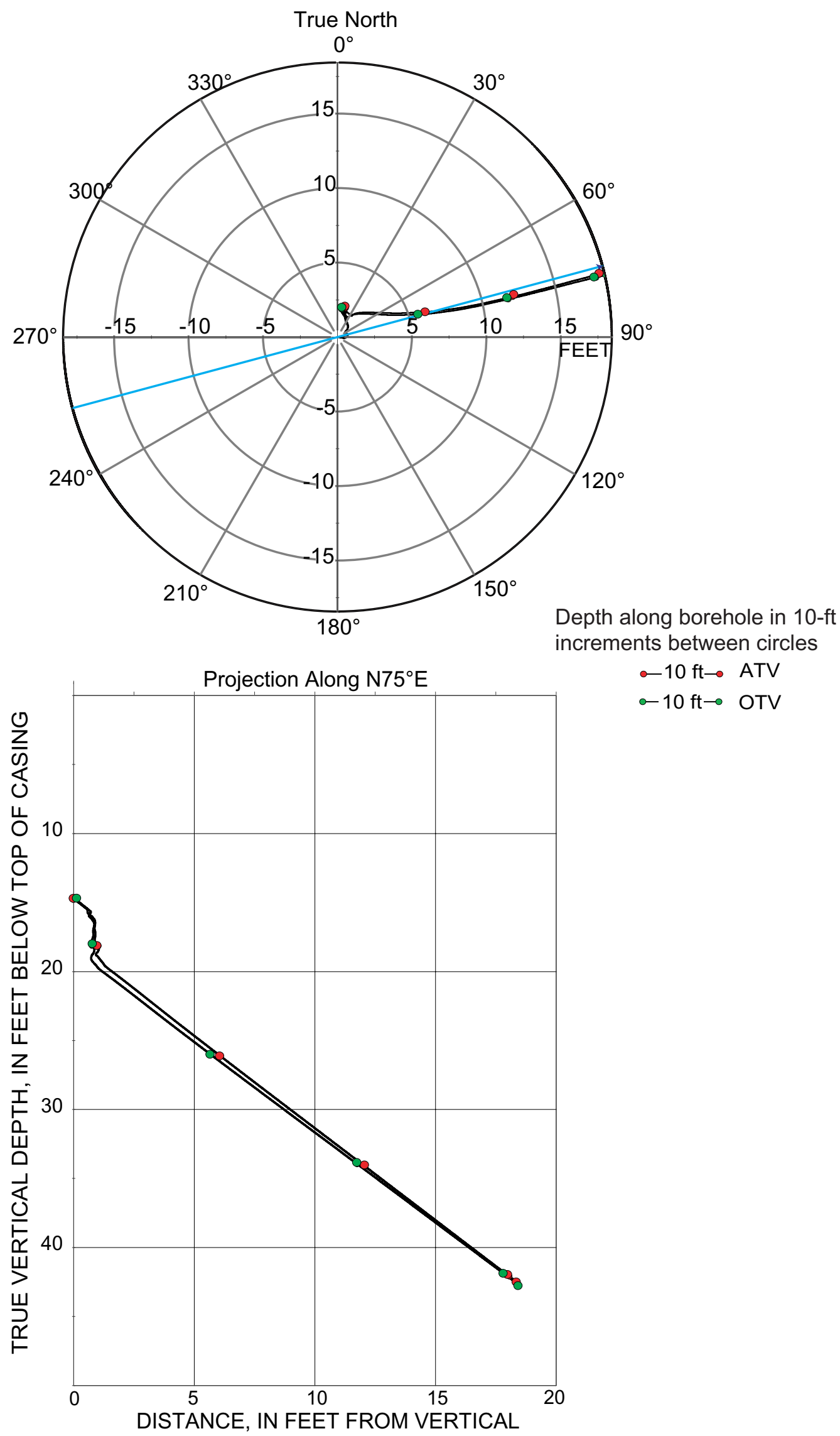

$-10 \mathrm{ft} \rightarrow$ ATV

$-10 \mathrm{ft} \rightarrow$ OTV

Figure 5G-1. Borehole deviation logs for borehole C-501, near Machiasport, Maine. Blue line on radial plot (top) is line of projection for vertical plot (bottom).

[ft, foot; ATV, acoustic televiewer; OTV, optical televiewer] 
Table 5G-1. Interpretation of acoustic televiewer logs for borehole C-501, near Machiasport, Maine.

[The borehole is inclined at $38^{\circ}$ from vertical in a direction of $N 77^{\circ} \mathrm{E}$. Televiewer data are corrected for deviation and magnetic declination, so orientations are relative to true north; depths are below top of casing, which is 3.3 feet above land surface; TVD, true vertical depth; LS, land surface; dip azimuth is given in degrees east of true north; strike is reported in right-hand-rule (RHR)-azimuthal degrees east of true north and where the direction of dip is 90 degrees to the right of strike]

\begin{tabular}{|c|c|c|c|c|c|c|c|c|}
\hline $\begin{array}{l}\text { Depth, } \\
\text { in feet }\end{array}$ & $\begin{array}{l}\text { Depth, } \\
\text { in meters }\end{array}$ & $\begin{array}{l}\text { TVD, in feet } \\
\text { below LS }\end{array}$ & $\begin{array}{c}\text { Dip } \\
\text { azimuth }\end{array}$ & $\begin{array}{l}\text { Strike, } \\
\text { in RHR }\end{array}$ & Dip & $\begin{array}{c}\text { Dip } \\
\text { direction }\end{array}$ & Dip descriptor & Comment \\
\hline 17.02 & 5.19 & 10.81 & 253 & 163 & 38 & $\mathrm{~W}$ & Moderate & Bottom of casing? \\
\hline 17.16 & 5.23 & 10.92 & 172 & 82 & 13 & $\mathrm{~S}$ & Shallow & Minor fracture \\
\hline 17.39 & 5.30 & 11.10 & 184 & 94 & 23 & $\mathrm{~S}$ & Shallow & Fracture \\
\hline 17.69 & 5.39 & 11.34 & 207 & 117 & 8 & SW & Nearly horizontal & Minor fracture \\
\hline 18.55 & 5.65 & 12.02 & 178 & 88 & 44 & $\mathrm{~S}$ & Moderate & Minor fracture \\
\hline 18.86 & 5.75 & 12.26 & 126 & 36 & 81 & SE & Nearly vertical & Minor fracture \\
\hline 20.85 & 6.35 & 13.83 & 332 & 242 & 86 & NW & Nearly vertical & Minor fracture \\
\hline 21.30 & 6.49 & 14.18 & 331 & 241 & 82 & NW & Nearly vertical & Partial fracture \\
\hline 21.70 & 6.61 & 14.50 & 31 & 301 & 88 & NE & Nearly vertical & Minor fracture \\
\hline 22.19 & 6.76 & 14.89 & 192 & 102 & 18 & $\mathrm{~S}$ & Shallow & Minor fracture \\
\hline 23.41 & 7.14 & 15.85 & 337 & 247 & 6 & NW & Nearly horizontal & Minor fracture \\
\hline 23.99 & 7.31 & 16.30 & 332 & 242 & 80 & NW & Nearly vertical & Minor fracture \\
\hline 24.26 & 7.39 & 16.52 & 295 & 205 & 27 & NW & Shallow & Minor fracture \\
\hline 24.89 & 7.59 & 17.01 & 326 & 236 & 90 & NW & Nearly vertical & Minor fracture \\
\hline 25.15 & 7.67 & 17.22 & 147 & 57 & 87 & SE & Nearly vertical & Minor fracture \\
\hline 25.76 & 7.85 & 17.70 & 149 & 59 & 90 & SE & Nearly vertical & Minor fracture \\
\hline 26.63 & 8.12 & 18.38 & 67 & 337 & 10 & NE & Shallow & Minor fracture \\
\hline 26.77 & 8.16 & 18.49 & 154 & 64 & 90 & SE & Nearly vertical & Minor fracture \\
\hline 26.78 & 8.16 & 18.50 & 76 & 346 & 78 & $E$ & Nearly vertical & Minor fracture \\
\hline 26.94 & 8.21 & 18.63 & 197 & 107 & 33 & $\mathrm{~S}$ & Moderate & Minor fracture \\
\hline 27.08 & 8.25 & 18.74 & 149 & 59 & 88 & SE & Nearly vertical & Partial fracture \\
\hline 27.35 & 8.34 & 18.95 & 218 & 128 & 21 & SW & Shallow & Partial fracture \\
\hline 28.73 & 8.76 & 20.04 & 146 & 56 & 82 & $\mathrm{SE}$ & Nearly vertical & Minor fracture \\
\hline 30.48 & 9.29 & 21.42 & 142 & 52 & 79 & SE & Nearly vertical & Minor fracture \\
\hline 32.46 & 9.89 & 22.98 & 151 & 61 & 86 & SE & Nearly vertical & Minor fracture \\
\hline 32.84 & 10.01 & 23.28 & 146 & 56 & 89 & SE & Nearly vertical & Minor fracture \\
\hline 33.70 & 10.27 & 23.96 & 312 & 222 & 86 & NW & Nearly vertical & Minor fracture \\
\hline 34.23 & 10.43 & 24.37 & 137 & 47 & 83 & SE & Nearly vertical & Fracture \\
\hline 35.66 & 10.87 & 25.50 & 315 & 225 & 89 & NW & Nearly vertical & Minor fracture \\
\hline 36.05 & 10.99 & 25.81 & 42 & 312 & 11 & $\mathrm{NE}$ & Shallow & Minor fracture \\
\hline 36.67 & 11.18 & 26.30 & 236 & 146 & 6 & SW & Nearly horizontal & Minor fracture \\
\hline 38.43 & 11.71 & 27.68 & 133 & 43 & 84 & SE & Nearly vertical & Minor fracture \\
\hline 39.08 & 11.91 & 28.20 & 327 & 237 & 85 & NW & Nearly vertical & Minor fracture \\
\hline 39.29 & 11.98 & 28.36 & 123 & 33 & 85 & $\mathrm{SE}$ & Nearly vertical & Minor fracture \\
\hline 39.49 & 12.04 & 28.52 & 213 & 123 & 31 & SW & Moderate & Minor fracture \\
\hline 43.13 & 13.15 & 31.39 & 124 & 34 & 82 & SE & Nearly vertical & Minor fracture \\
\hline 44.08 & 13.43 & 32.14 & 133 & 43 & 86 & SE & Nearly vertical & Minor fracture \\
\hline 44.46 & 13.55 & 32.43 & 313 & 223 & 86 & NW & Nearly vertical & Fracture \\
\hline 44.52 & 13.57 & 32.48 & 255 & 165 & 37 & W & Moderate & Minor fracture \\
\hline 45.42 & 13.84 & 33.19 & 114 & 24 & 26 & SE & Shallow & Fracture \\
\hline 45.48 & 13.86 & 33.24 & 132 & 42 & 31 & SE & Moderate & Minor fracture \\
\hline 46.37 & 14.13 & 33.94 & 186 & 96 & 26 & $\mathrm{~S}$ & Shallow & Minor fracture \\
\hline 46.43 & 14.15 & 33.99 & 124 & 34 & 16 & SE & Shallow & Minor fracture \\
\hline 46.89 & 14.29 & 34.35 & 129 & 39 & 87 & SE & Nearly vertical & Minor fracture \\
\hline 47.01 & 14.33 & 34.44 & 142 & 52 & 68 & SE & Steep & Partial fracture \\
\hline 48.42 & 14.76 & 35.56 & 309 & 219 & 80 & NW & Nearly vertical & Minor fracture \\
\hline 48.81 & 14.88 & 35.86 & 160 & 70 & 70 & $\mathrm{~S}$ & Nearly vertical & Minor fracture \\
\hline 49.48 & 15.08 & 36.39 & 313 & 223 & 76 & NW & Nearly vertical & Minor fracture \\
\hline 49.67 & 15.14 & 36.54 & 316 & 226 & 88 & NW & Nearly vertical & Minor fracture \\
\hline 49.91 & 15.21 & 36.73 & 312 & 222 & 87 & NW & Nearly vertical & Minor fracture \\
\hline 50.36 & 15.35 & 37.08 & 313 & 223 & 87 & NW & Nearly vertical & Partial fracture \\
\hline 50.62 & 15.43 & 37.29 & 319 & 229 & 61 & NW & Steep & Partial fracture \\
\hline
\end{tabular}


Table 5G-2. Interpretation of optical televiewer logs for borehole C-501, near Machiasport, Maine.

[The borehole is inclined at $38^{\circ}$ from vertical in a direction of $\mathrm{N} 77^{\circ} \mathrm{E}$. Televiewer data are corrected for deviation and magnetic declination, so orientations are relative to true north; depths are below top of casing, which is 3.3 feet above land surface; TVD, true vertical depth; LS, land surface; dip azimuth is given in degrees east of true north; strike is reported in right-hand-rule (RHR)-azimuthal degrees east of true north and where the direction of dip is 90 degrees to the right of strike]

\begin{tabular}{|c|c|c|c|c|c|c|c|c|}
\hline $\begin{array}{l}\text { Depth, } \\
\text { in feet }\end{array}$ & $\begin{array}{c}\text { Depth, } \\
\text { in meters }\end{array}$ & $\begin{array}{l}\text { TVD, in feet } \\
\text { below LS }\end{array}$ & $\begin{array}{c}\text { Dip } \\
\text { azimuth }\end{array}$ & $\begin{array}{l}\text { Strike, } \\
\text { in RHR }\end{array}$ & Dip & $\begin{array}{l}\text { Dip } \\
\text { direction }\end{array}$ & Dip descriptor & Comment \\
\hline 17.02 & 5.19 & 10.81 & 254 & 164 & 38 & $\mathrm{~W}$ & Moderate & Bottom of casing? \\
\hline 17.21 & 5.25 & 10.96 & 16 & 286 & 10 & $\mathrm{~N}$ & Shallow & Fracture \\
\hline 17.45 & 5.32 & 11.15 & 175 & 85 & 6 & $\mathrm{~S}$ & Nearly horizontal & Lithologic feature \\
\hline 17.69 & 5.39 & 11.34 & 227 & 137 & 10 & SW & Nearly horizontal & Lithologic feature \\
\hline 18.60 & 5.67 & 12.06 & 213 & 123 & 19 & SW & Shallow & Minor fracture \\
\hline 18.96 & 5.78 & 12.34 & 252 & 162 & 87 & W & Nearly vertical & Lithologic feature \\
\hline 20.83 & 6.35 & 13.81 & 146 & 56 & 87 & SE & Nearly vertical & Minor fracture \\
\hline 22.18 & 6.76 & 14.88 & 236 & 146 & 8 & SW & Nearly horizontal & Minor fracture \\
\hline 22.27 & 6.79 & 14.95 & 254 & 164 & 80 & W & Nearly vertical & Sealed feature \\
\hline 22.94 & 6.99 & 15.48 & 102 & 12 & 89 & $E$ & Nearly vertical & Lithologic feature \\
\hline 23.41 & 7.14 & 15.85 & 332 & 242 & 6 & NW & Nearly horizontal & Minor fracture \\
\hline 24.28 & 7.40 & 16.53 & 294 & 204 & 42 & NW & Moderate & Minor fracture \\
\hline 24.60 & 7.50 & 16.78 & 343 & 253 & 88 & $\mathrm{~N}$ & Nearly vertical & Sealed feature \\
\hline 25.77 & 7.85 & 17.71 & 340 & 250 & 83 & $\mathrm{~N}$ & Nearly vertical & Minor fracture \\
\hline 26.62 & 8.11 & 18.38 & 45 & 315 & 12 & NE & Shallow & Minor fracture \\
\hline 26.88 & 8.19 & 18.58 & 332 & 242 & 90 & NW & Nearly vertical & Lithologic feature \\
\hline 26.88 & 8.19 & 18.58 & 324 & 234 & 11 & NW & Shallow & Minor fracture \\
\hline 27.35 & 8.34 & 18.95 & 222 & 132 & 16 & SW & Shallow & Minor fracture \\
\hline 28.77 & 8.77 & 20.07 & 132 & 42 & 74 & SE & Nearly vertical & Minor fracture \\
\hline 30.40 & 9.27 & 21.36 & 342 & 252 & 86 & $\mathrm{~N}$ & Nearly vertical & Minor fracture \\
\hline 31.85 & 9.71 & 22.50 & 335 & 245 & 80 & NW & Nearly vertical & Lithologic feature \\
\hline 33.36 & 10.17 & 23.69 & 224 & 134 & 80 & SW & Nearly vertical & Minor fracture \\
\hline 33.83 & 10.31 & 24.06 & 309 & 219 & 88 & NW & Nearly vertical & Minor fracture \\
\hline 34.11 & 10.40 & 24.28 & 295 & 205 & 17 & NW & Shallow & Minor fracture \\
\hline 34.21 & 10.43 & 24.36 & 121 & 31 & 86 & SE & Nearly vertical & Minor fracture \\
\hline 35.08 & 10.69 & 25.04 & 126 & 36 & 85 & SE & Nearly vertical & Lithologic feature \\
\hline 35.82 & 10.92 & 25.63 & 116 & 26 & 75 & SE & Nearly vertical & Minor fracture \\
\hline 36.07 & 10.99 & 25.82 & 13 & 283 & 16 & $\mathrm{~N}$ & Shallow & Sealed feature \\
\hline 36.58 & 11.15 & 26.22 & 140 & 50 & 87 & SE & Nearly vertical & Lithologic feature \\
\hline 36.67 & 11.18 & 26.30 & 289 & 199 & 11 & W & Shallow & Minor fracture \\
\hline 39.06 & 11.90 & 28.18 & 142 & 52 & 89 & SE & Nearly vertical & Minor fracture \\
\hline 39.52 & 12.05 & 28.54 & 224 & 134 & 26 & sW & Shallow & Minor fracture \\
\hline 41.92 & 12.78 & 30.43 & 300 & 210 & 78 & NW & Nearly vertical & Lithologic feature \\
\hline 43.33 & 13.21 & 31.54 & 314 & 224 & 87 & NW & Nearly vertical & Sealed feature \\
\hline 43.83 & 13.36 & 31.94 & 125 & 35 & 89 & SE & Nearly vertical & Lithologic feature \\
\hline 44.23 & 13.48 & 32.25 & 121 & 31 & 89 & SE & Nearly vertical & Minor fracture \\
\hline 44.45 & 13.55 & 32.43 & 125 & 35 & 89 & SE & Nearly vertical & Minor fracture \\
\hline 45.42 & 13.84 & 33.19 & 115 & 25 & 26 & SE & Shallow & Fracture \\
\hline 45.47 & 13.86 & 33.23 & 121 & 31 & 87 & SE & Nearly vertical & Lithologic feature \\
\hline 46.39 & 14.14 & 33.96 & 153 & 63 & 16 & SE & Shallow & Fracture \\
\hline 46.90 & 14.29 & 34.36 & 127 & 37 & 85 & SE & Nearly vertical & Minor fracture \\
\hline 49.76 & 15.17 & 36.61 & 119 & 29 & 79 & SE & Nearly vertical & Minor fracture \\
\hline 50.38 & 15.36 & 37.10 & 127 & 37 & 86 & SE & Nearly vertical & Partial fracture \\
\hline 50.60 & 15.42 & 37.27 & 311 & 221 & 79 & NW & Nearly vertical & Partial fracture \\
\hline
\end{tabular}




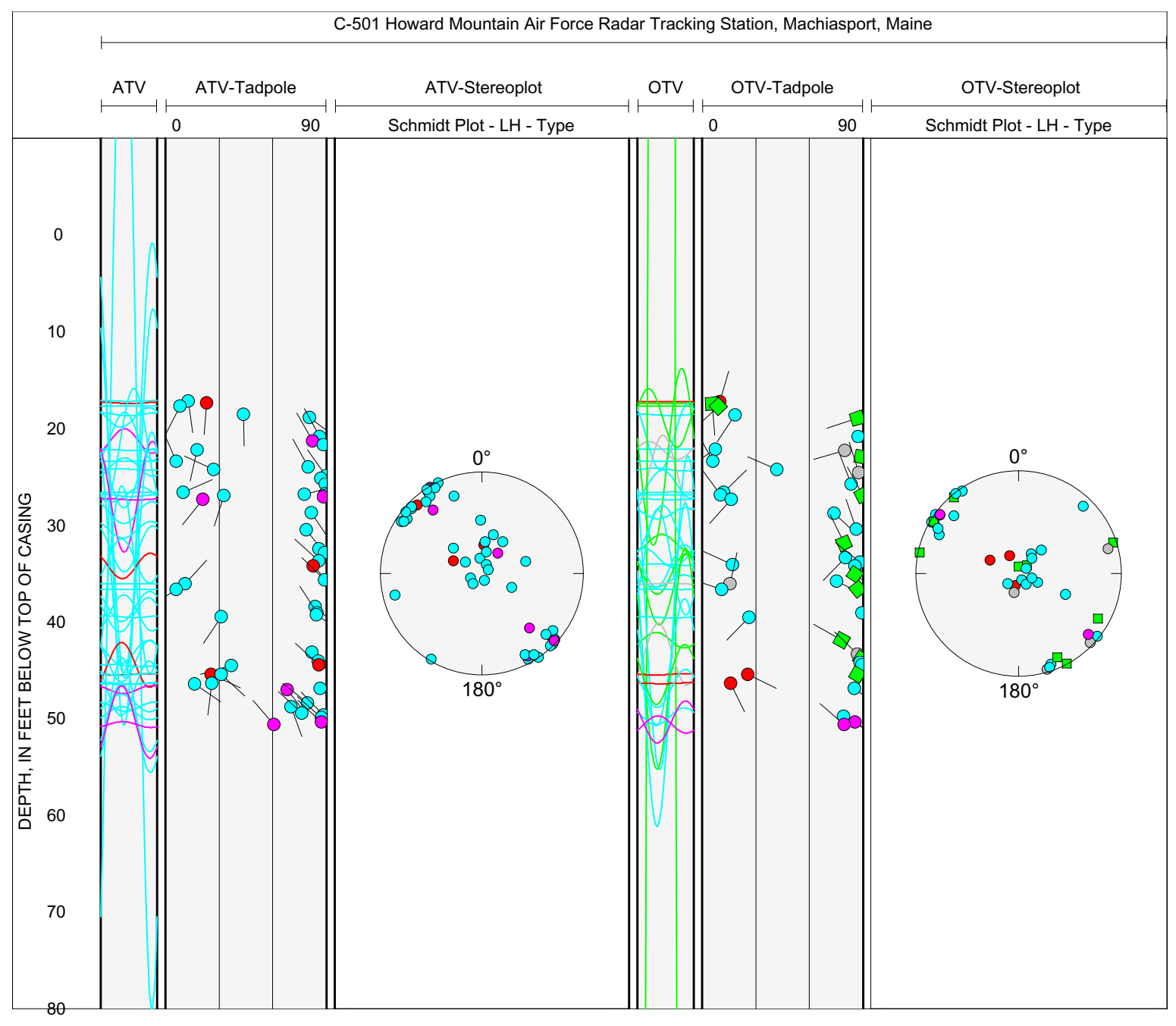

Figure 5G-2. Projection, tadpole, and stereoplots of interpretation of borehole image data for borehole C-501, near Machiasport, Maine. 


\section{Appendix 6. Summary of structure interpreted from geophysical logs for boreholes near Machiasport, Maine}




\section{Appendix 6.}

\section{Summary of structure interpreted from geophysical logs for boreholes near Machiasport, Maine}

A. Summary of structure interpreted from geophysical logs of boreholes on or near Miller Mountain, near Machiasport, Maine - WY-GATR, MW-13, MW-14, DW-29, DW-22, DW-23, DW-24, DW-25, DW-31, DW-32, DW-33, DW-34, DW-39, and DW-40

Figure 6A-1. In depth below land surface-projection and tadpole plots for all features; fracture density plots at 10 -foot intervals; stereoplots for all features in the boreholes; rose diagram of dip directions for all features in the boreholes.

Figure 6A-2. In depth below land surface-projection and tadpole plots for all features; fracture density plots; stereoplots for all features the entire boreholes; rose diagrams for the entire boreholes, all at 100 -foot intervals.

Figure 6A-3. In elevation above NAVD 88-projection and tadpole plots for all features at 100-foot intervals; fracture density plots (all fractures and transmissive fractures) at 10-foot intervals; rose diagrams of dip direction at 100-foot intervals.

Figure 6A-4. Fracture density plots at 10-foot intervals for borehole WY-GATR, the deepest borehole in the group.

B. Summary of structure interpreted from geophysical logs of boreholes near the Air Force Radar Tracking Station on Howard Mountain, near Machiasport, Maine - DW-2, DW-4, WY-3, WY-3B, WY-3C, WY-4, WY-15, MW-8, MW-9, MW-10, MW-11, MW12, MW-15, MW-16, MW-17, C-114, and C-501

Figure 6B-1. In depth below land surface-projection and tadpole plots for all features; fracture density plots at 10-foot intervals; stereoplots for all features in the boreholes; rose diagram of dip directions for all features in the boreholes.

Figure 6B-2. In depth below land surface-projection and tadpole plots for all features; fracture density plots; stereoplots for all features the entire boreholes; rose diagrams for the entire boreholes, all at 100 -foot intervals.

Figure 6B-3. In elevation above NAVD 88-projection and tadpole plots for all features at 100-foot intervals; fracture density plots (all fractures and transmissive fractures) at 10-foot intervals; rose diagrams of dip direction at 100-foot intervals.

Figure 6B-4. Fracture density plots at 10-foot intervals for boreholes WY-3, WY-3B, and WY-15, the deepest boreholes in the group.

C. Summary of structure interpreted from geophysical logs of boreholes near the Transmitter Site on Howard Mountain, near Machiasport, Maine - DW-6, DW-10, MW-4, MW-5, MW-6, and MW-7

Figure 6C-1. In depth below land surface-projection and tadpole plots for all features; fracture density plots at 10 -foot intervals; stereoplots for all features in the boreholes; rose diagram of dip directions for all features in the boreholes.

Figure 6C-2. In depth below land surface-projection and tadpole plots for all features; fracture density plots; stereoplots for all features the entire boreholes; rose diagrams for the entire boreholes, all at 100 -foot intervals.

Figure 6C-3. In elevation above mean sea level-projection and tadpole plots for all features at 100-foot intervals; fracture density plots (all fractures and transmissive fractures) at 10-foot intervals; rose diagrams of dip direction at 100foot intervals.

Figure 6C-4. Fracture density plots at 10-foot intervals for borehole DW-10, the only borehole near the Transmitter Site on Howard Mountain that exceeds a depth of 120 feet. 


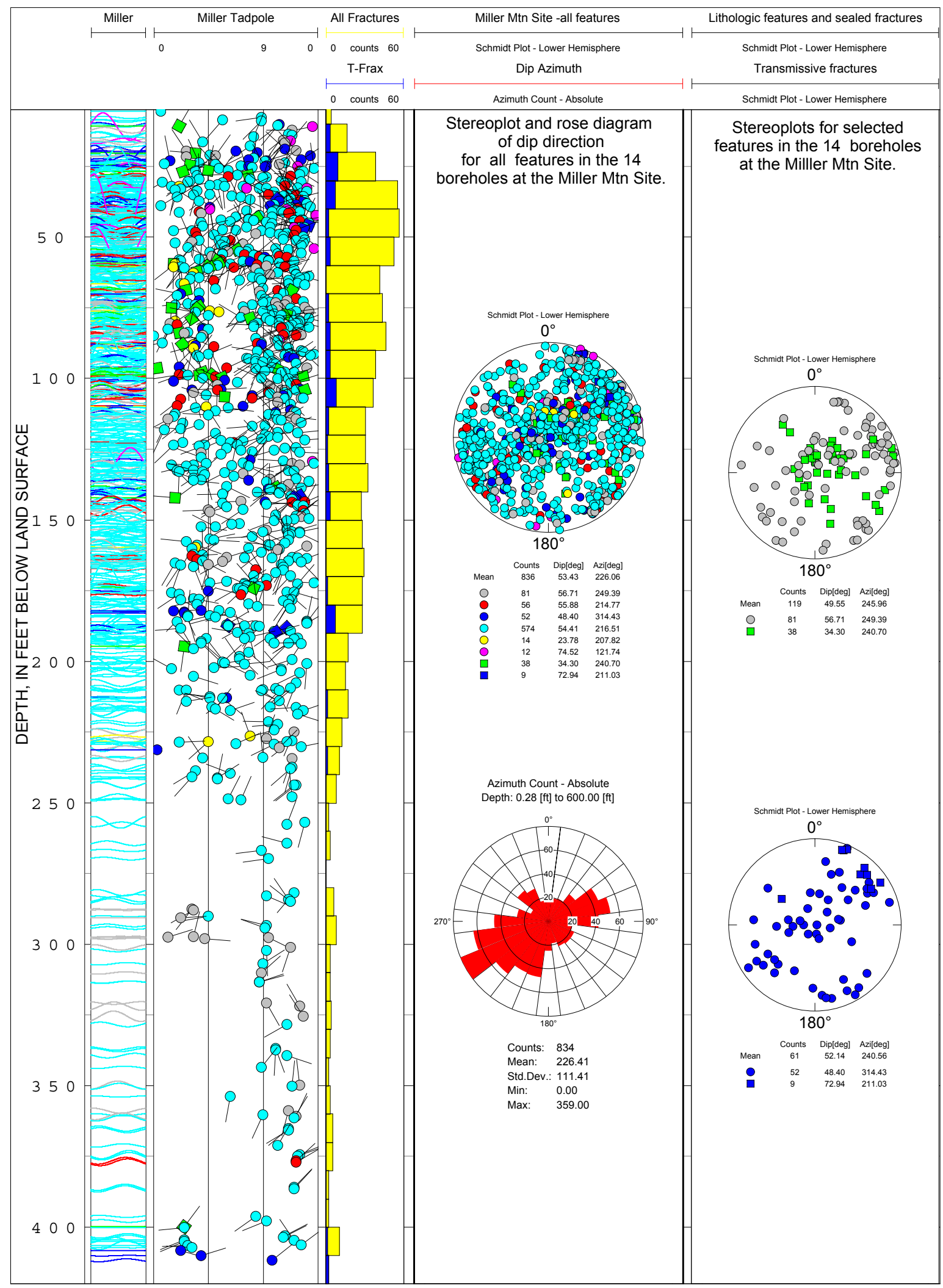

Figure 6A-1. Summary of structure interpreted from geophysical logs of boreholes on or near Miller Mountain, near Machiasport, Maine. In depth below land surface-projection and tadpole plots for all features; fracture density plots at 10-foot intervals; stereoplots for all features in the boreholes; rose diagram of dip directions for all features in the boreholes.

[Mtn, Mountain; T-Frax, transmissive fracture; deg, degrees; ft, feet; Std. Dev., standard deviation; Min, minimum; Max, maximum] 


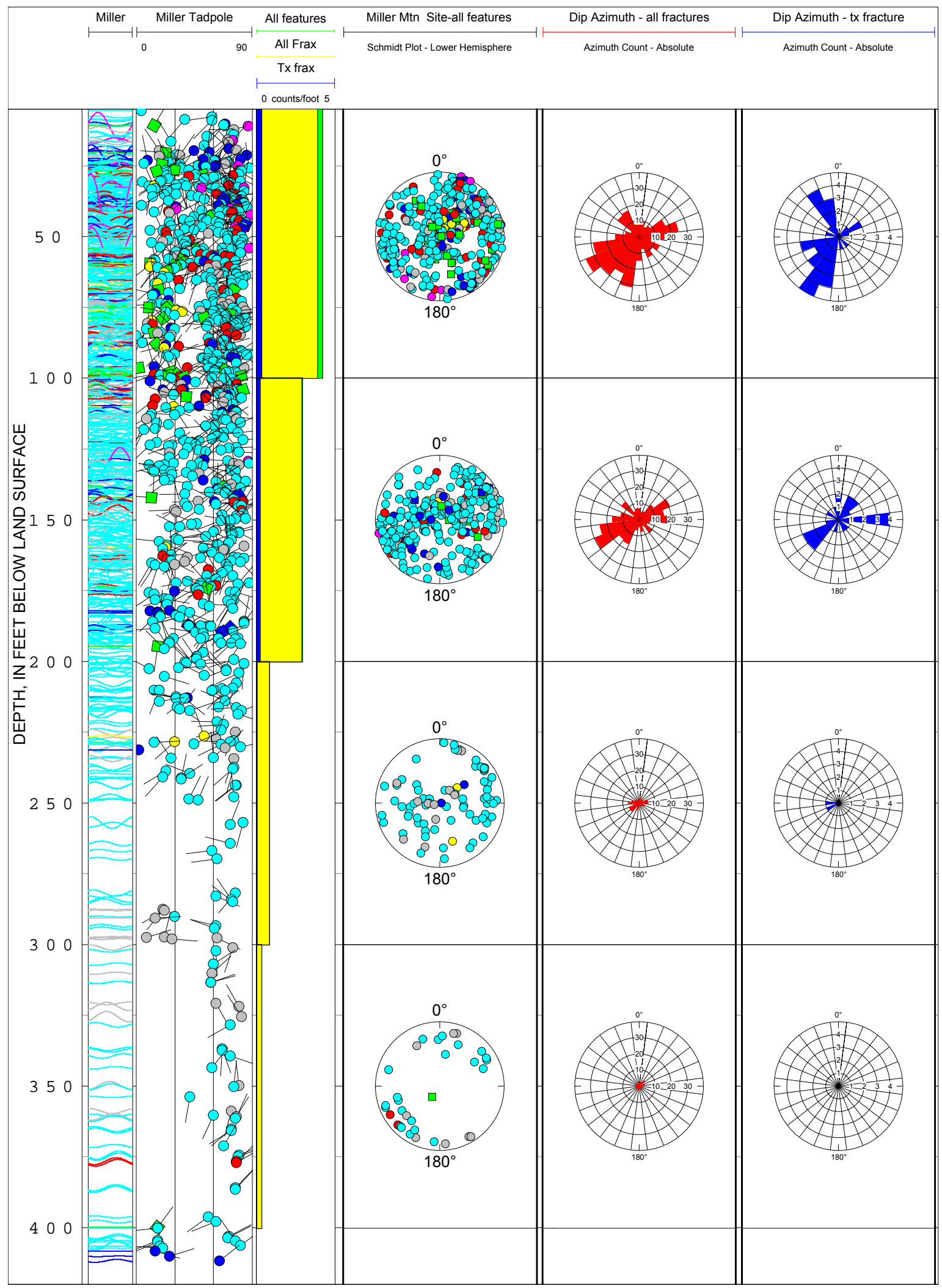

Figure 6A-2. Summary of structure interpreted from geophysical logs of boreholes on or near Miller Mountain, near Machiasport, Maine. In depth below land surface-projection and tadpole plots for all features; fracture density plots; stereoplots for all features in the entire boreholes; rose diagrams for the entire boreholes, all at 100-foot intervals.

[Tx, transmissive; Frax, fracture] 


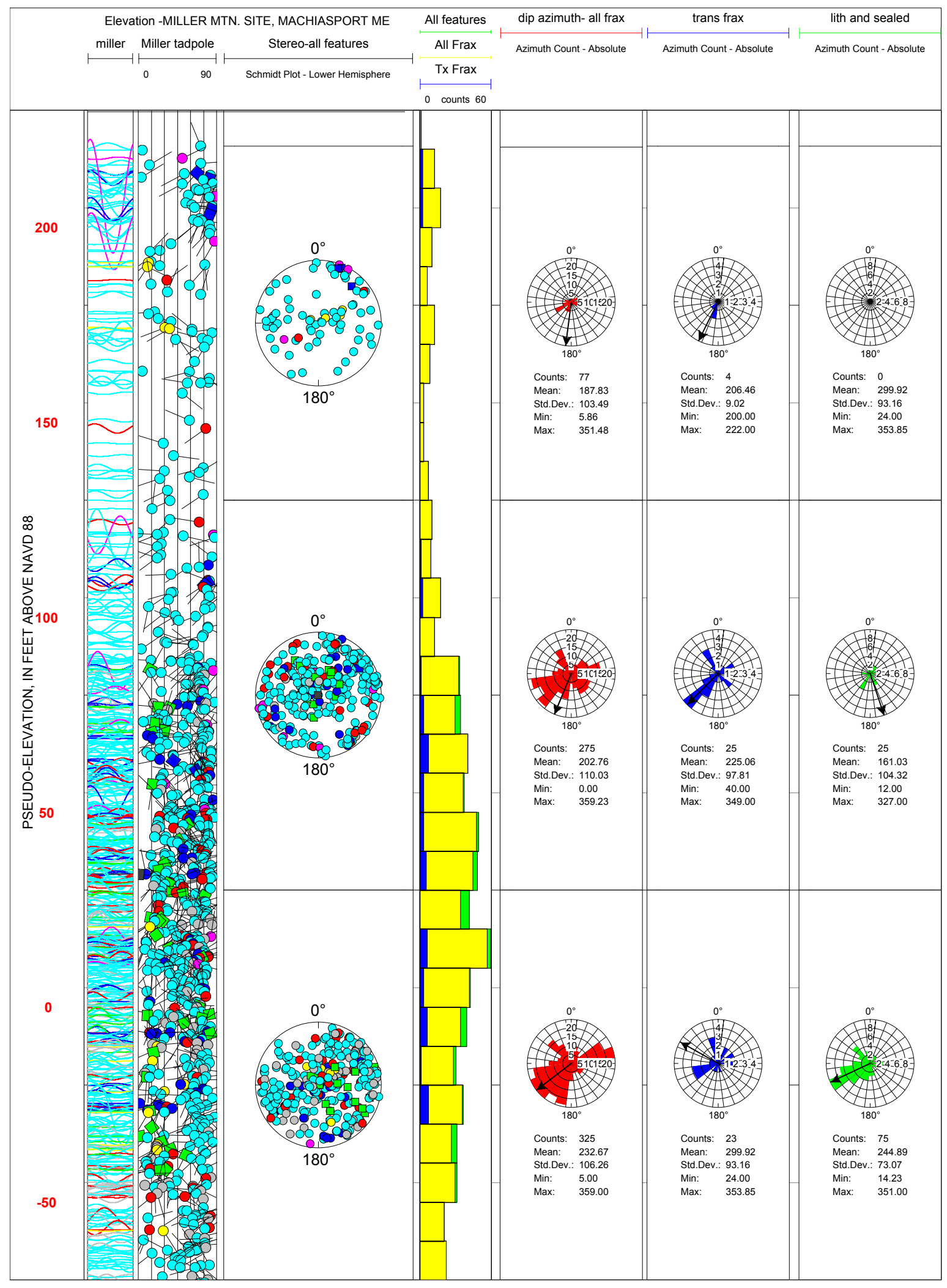

Figure 6A-3. Summary of structure interpreted from geophysical logs of boreholes on or near Miller Mountain, near Machiasport, Maine. In elevation above NAVD 88-projection and tadpole plots for all features at 100-foot intervals; fracture density plots (all fractures and transmissive fractures) at 10-foot intervals; rose diagrams of dip direction at 100 -foot intervals.

[Frax, fracture; Tx, transmissive; Std. Dev., standard deviation; Min, minimum; Max, maximum] 


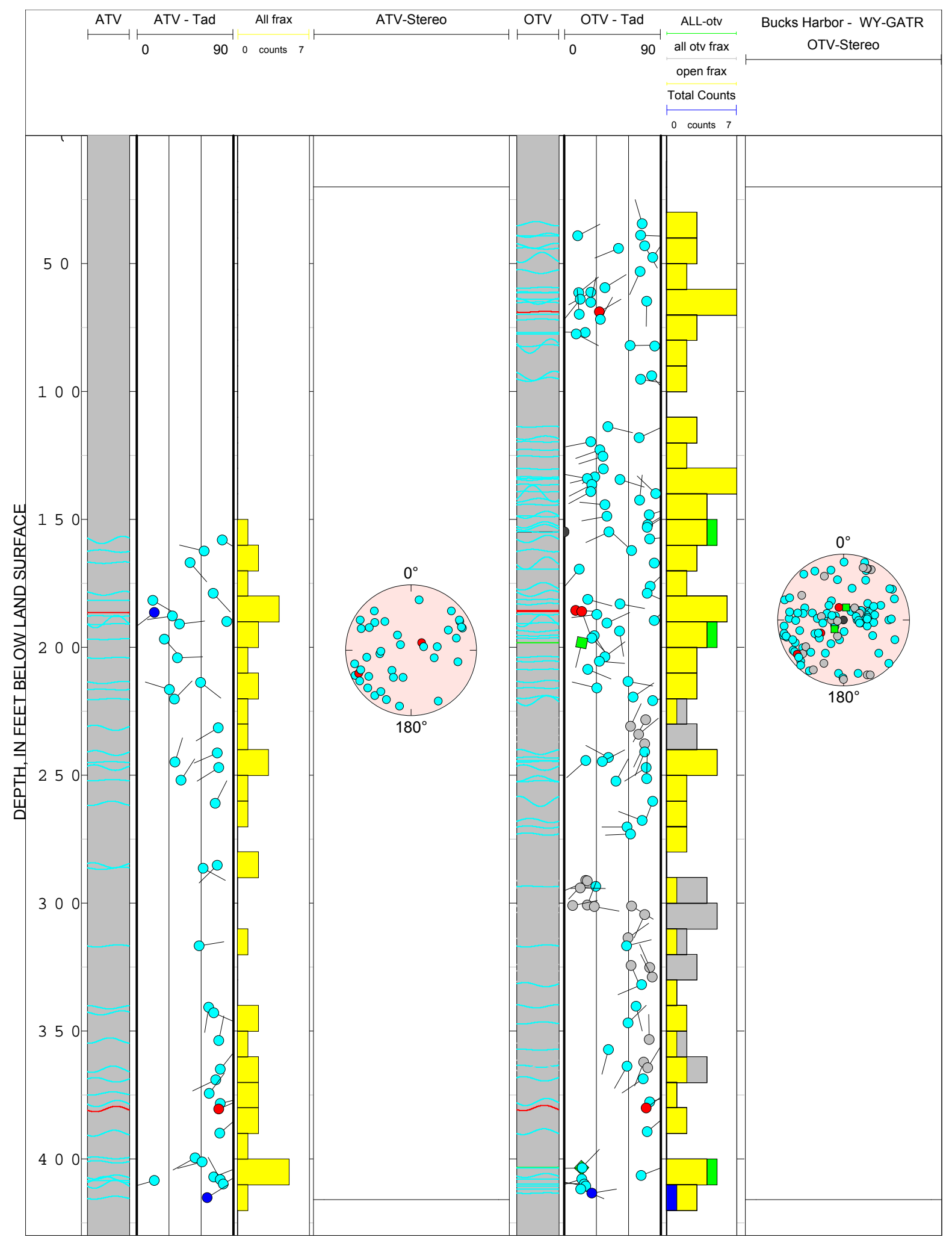

Figure 6A-4. Summary of structure interpreted from geophysical logs of boreholes on or near Miller Mountain, near Machiasport, Maine. Fracture density plots at 10-foot intervals for borehole WY-GATR, the deepest borehole in the group.

[frax, fracture] 


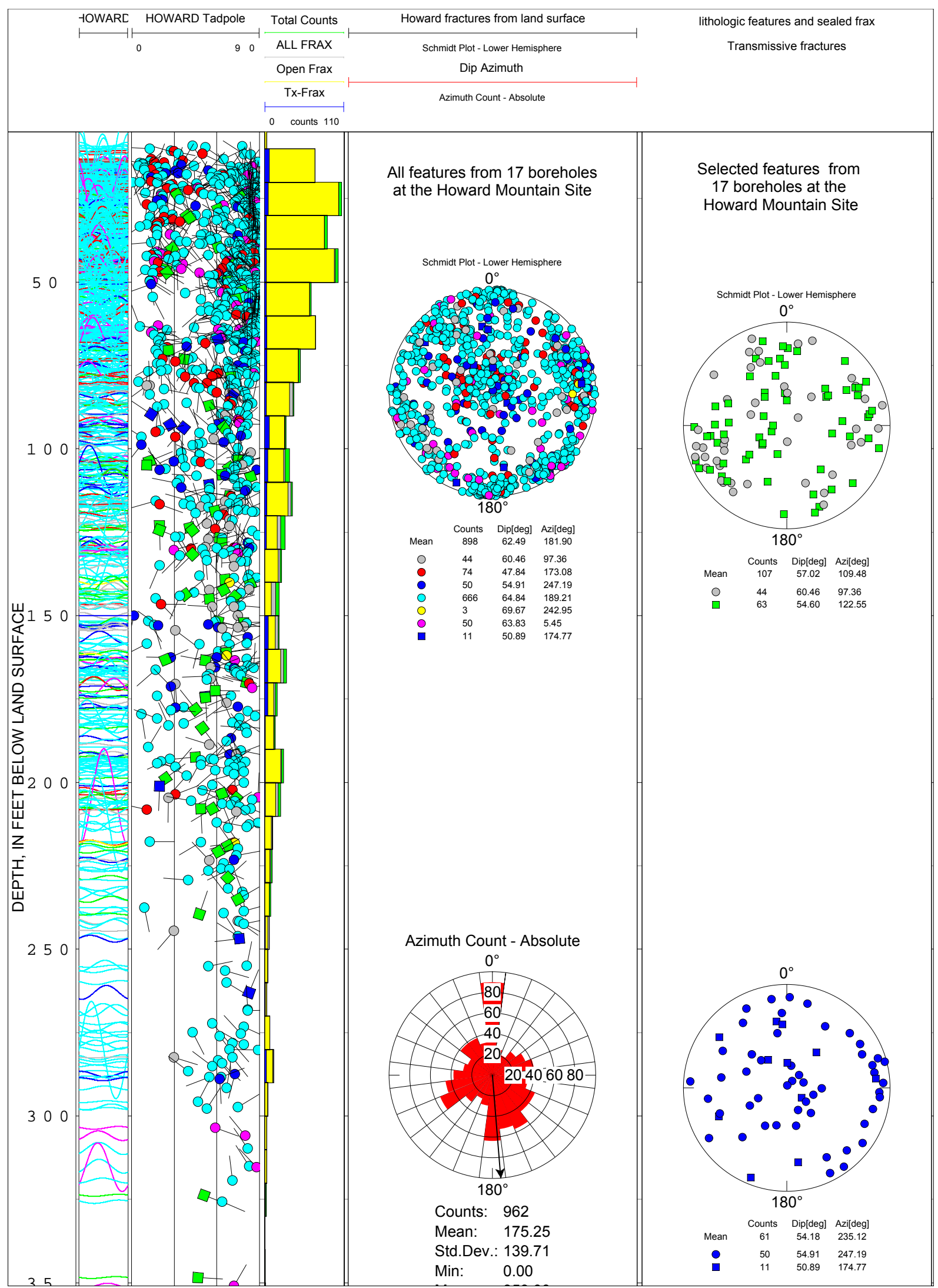

Figure 6B-1. Summary of structure interpreted from geophysical logs of boreholes near the Air Force Radar Tracking Station on Howard Mountain, near Machiasport, Maine. In depth below land surface-projection and tadpole plots for all features; fracture density plots at 10-foot intervals; stereoplots for all features in the boreholes; rose diagram of dip directions for all features in the boreholes.

[Frax, fracture; Tx, transmissive; deg, degrees; Std. Dev., standard deviation] 


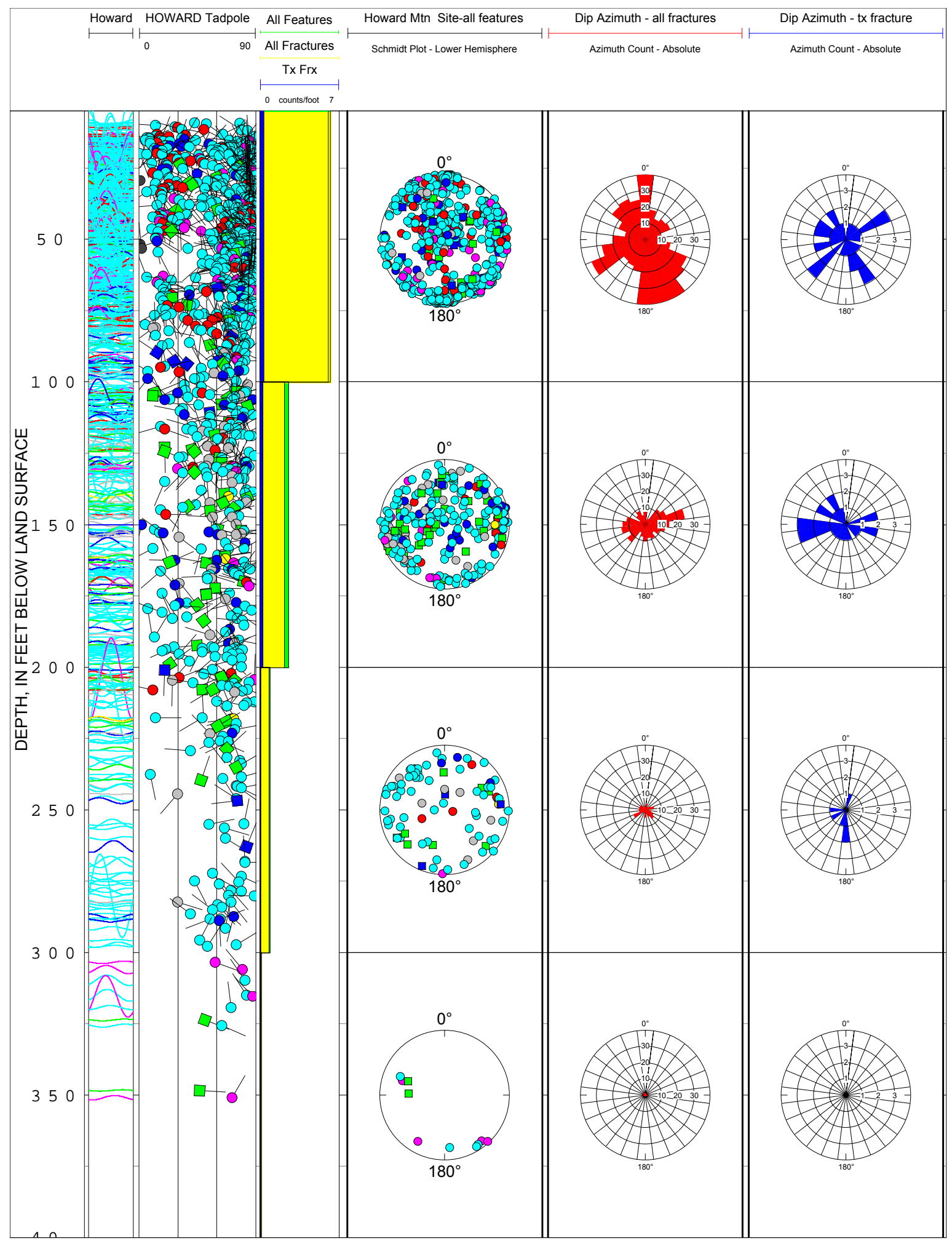

Figure 6B-2. Summary of structure interpreted from geophysical logs of boreholes near the Air Force Radar Tracking Station on Howard Mountain, near Machiasport, Maine. In depth below land surface-projection and tadpole plots for all features; fracture density plots; stereoplots for all features the entire boreholes; rose diagrams for the entire boreholes, all at 100 -foot intervals.

[Tx, transmissive; Frax, fracture] 


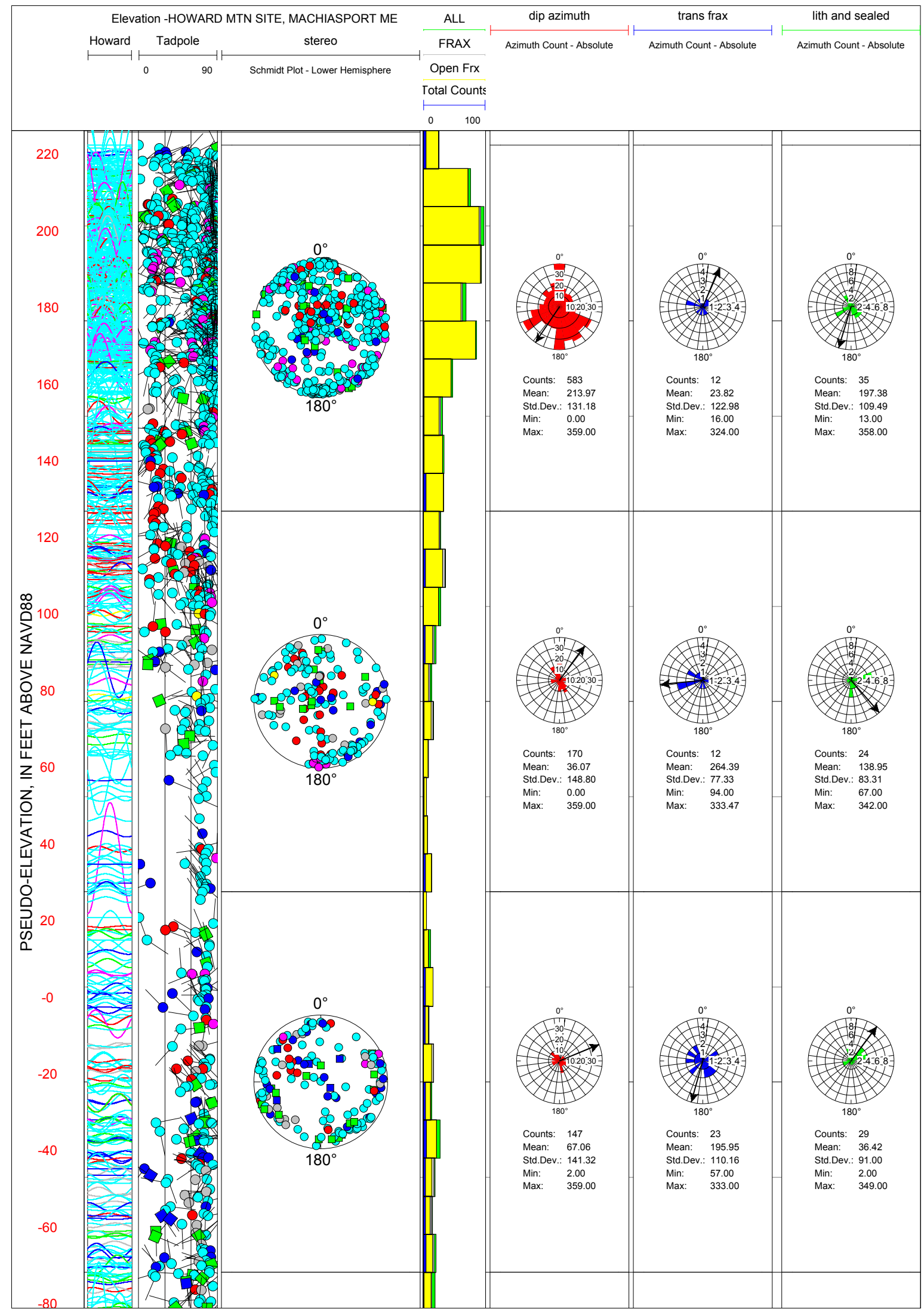

Figure 6B-3. Summary of structure interpreted from geophysical logs of boreholes near the Air Force Radar Tracking Station on Howard Mountain, near Machiasport, Maine. In elevation above NAVD 88-projection and tadpole plots for all features at 100-foot intervals; fracture density plots (all fractures and transmissive fractures) at 10-foot intervals; rose diagrams of dip direction at 100-foot intervals.

[Frax, fracture; Std. Dev., standard deviation; Min, minimum; Max, maximum] 


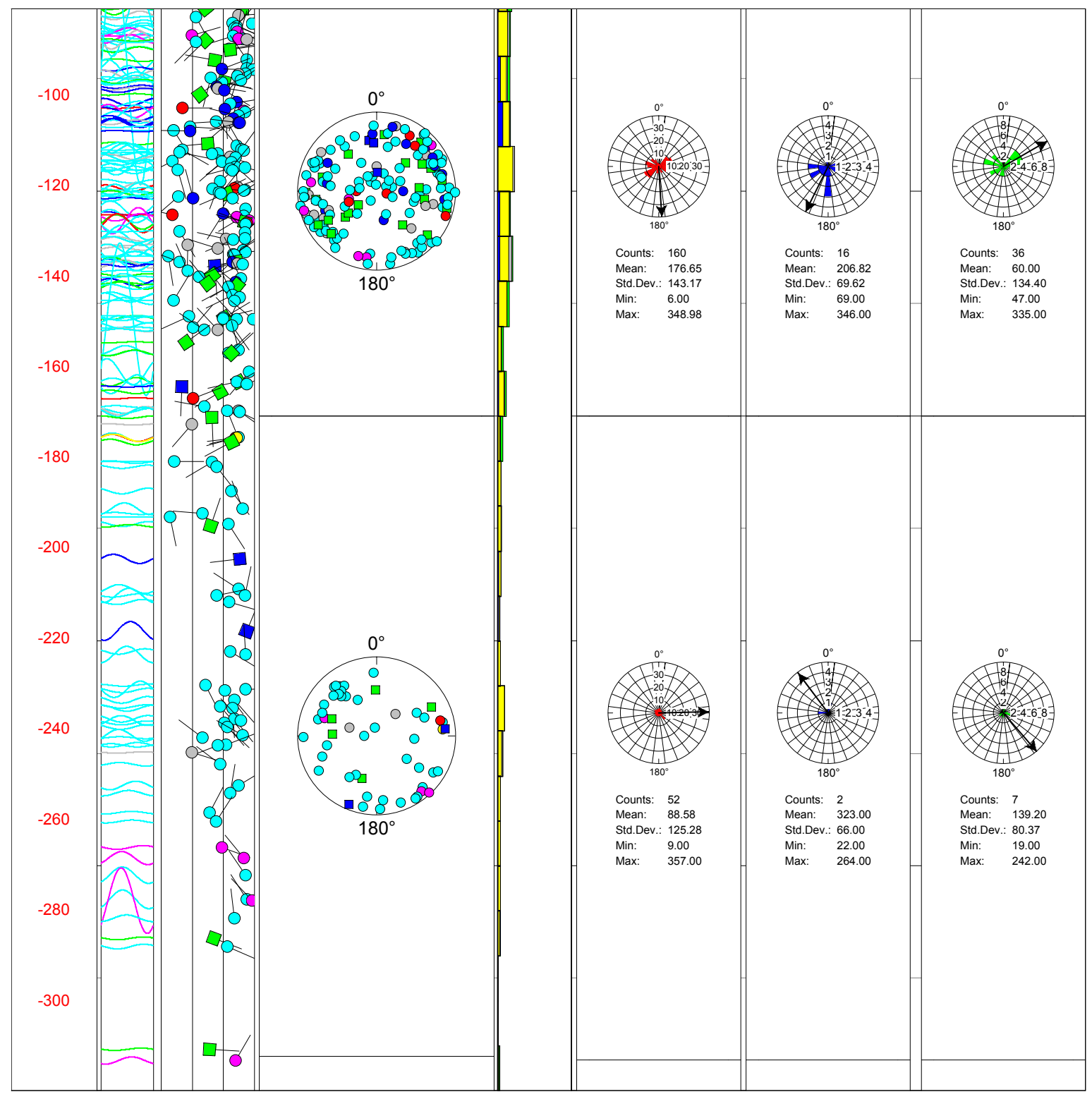

Figure 6B-3. Summary of structure interpreted from geophysical logs of boreholes near the Air Force Radar Tracking Station on Howard Mountain, near Machiasport, Maine. In elevation above NAVD 88-projection and tadpole plots for all features at 100-foot intervals; fracture density plots (all fractures and transmissive fractures) at 10-foot intervals; rose diagrams of dip direction at 100-foot intervals.-Continued [Frax, fracture; Std. Dev., standard deviation; Min, minimum; Max, maximum] 


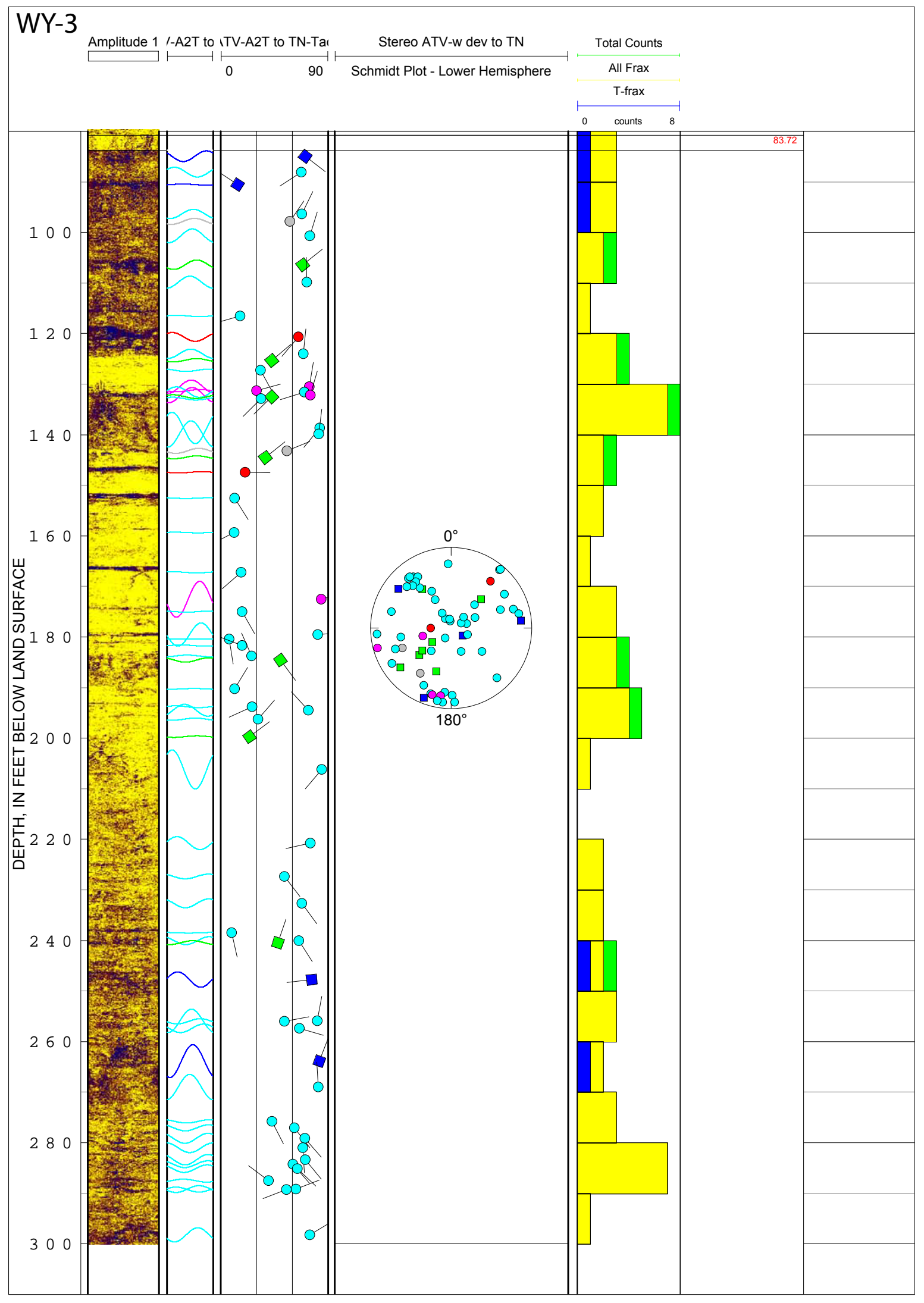

Figure 6B-4. Summary of structure interpreted from geophysical logs of boreholes near the Air Force Radar Tracking Station on Howard Mountain, near Machiasport, Maine. Fracture density plots at 10-foot intervals for boreholes WY-3, WY-3B, and WY-15, the deepest boreholes in the group.

[T-frax, transmissive fracture; Tx, transmissive; TN, true north; dev, deviation] 


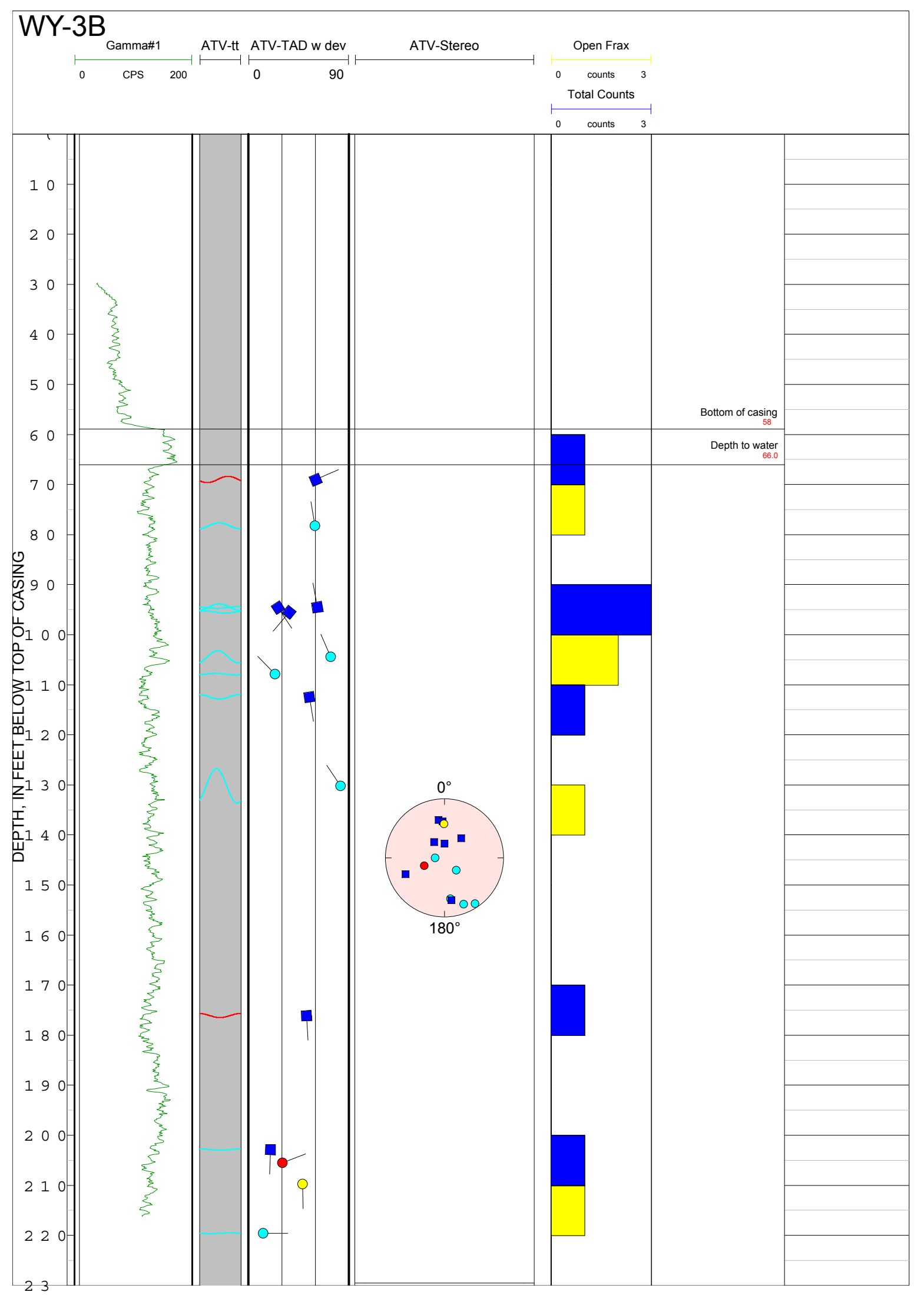

Figure 6B-4. Summary of structure interpreted from geophysical logs of boreholes near the Air Force Radar Tracking Station on Howard Mountain, near Machiasport, Maine. Fracture density plots at 10-foot intervals for boreholes WY-3, WY-3B, and WY-15, the deepest boreholes in the group.-Continued [T-frax, transmissive fracture; Tx, transmissive; TN, true north; dev, deviation] 


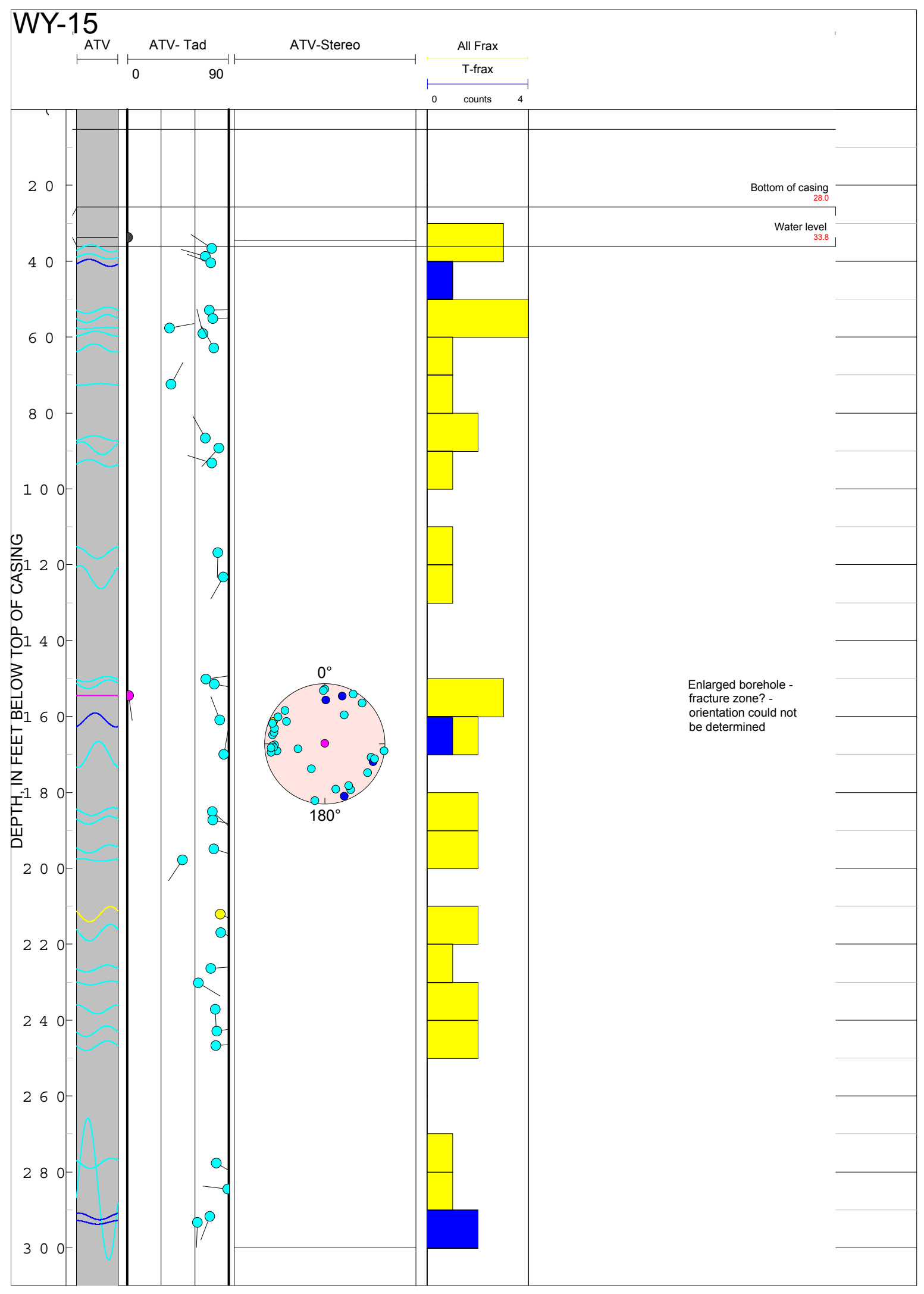

Figure 6B-4. Summary of structure interpreted from geophysical logs of boreholes near the Air Force Radar Tracking Station on Howard Mountain, near Machiasport, Maine. Fracture density plots at 10-foot intervals for boreholes WY-3, WY-3B, and WY-15, the deepest boreholes in the group.-Continued [T-frax, transmissive fracture; Tx, transmissive; TN, true north; dev, deviation] 


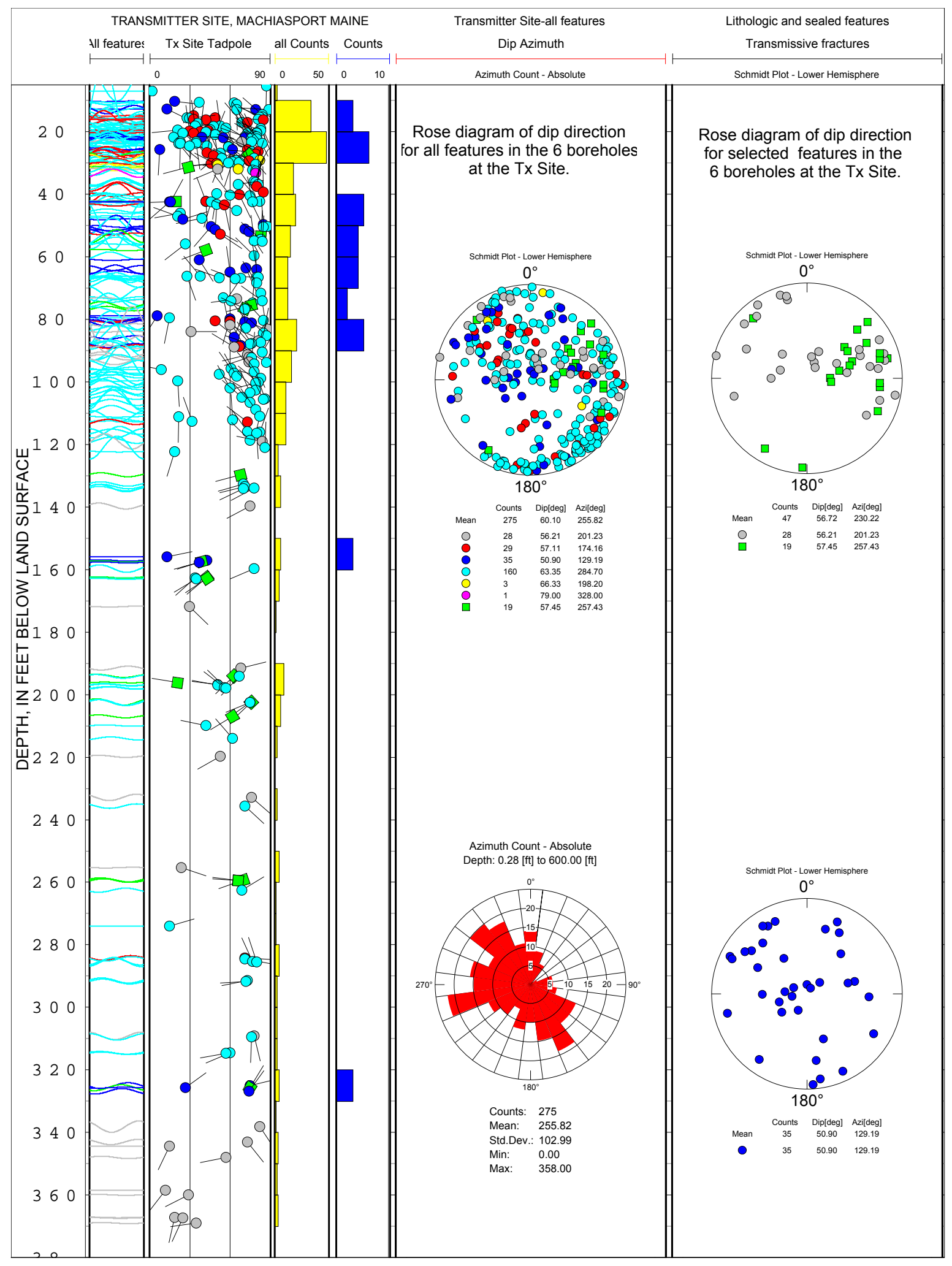

Figure 6C-1. Summary of structure interpreted from geophysical logs of boreholes near the Transmitter Site on Howard Mountain, near Machiasport, Maine. In depth below land surface-projection and tadpole plots for all features; fracture density plots at 10-foot intervals; stereoplots for all features in the boreholes; rose diagram of dip directions for all features in the boreholes.

[Tx, transmissive; deg, degree; Std. Dev., standard deviation; Min, minimum; Max, maximum] 


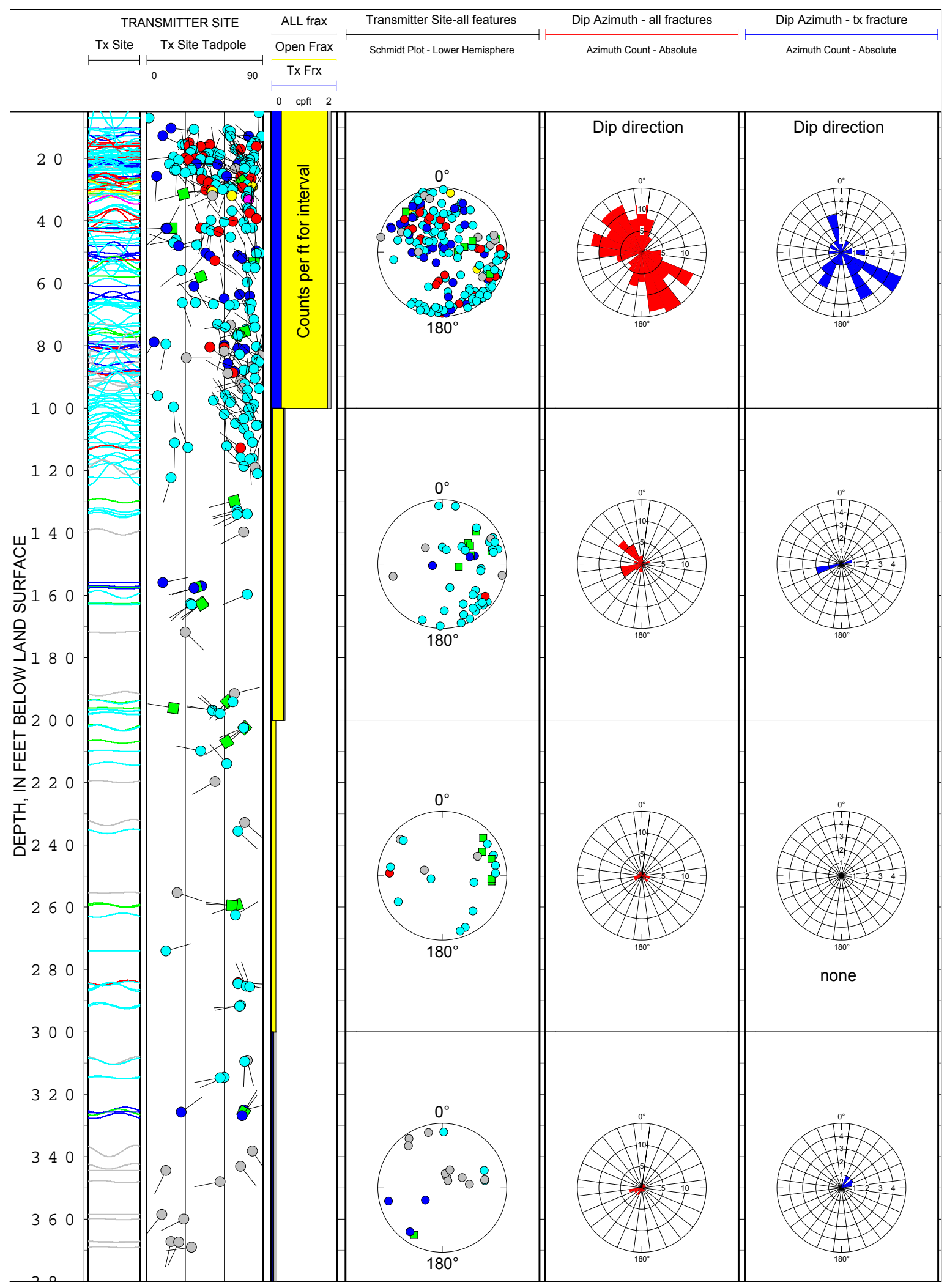

Figure 6C-2. Summary of structure interpreted from geophysical logs of boreholes near the Transmitter Site on Howard Mountain, near Machiasport, Maine. In depth below land surface-projection and tadpole plots for all features; fracture density plots; stereoplots for all features the entire boreholes; rose diagrams for the entire boreholes, all at 100 -foot intervals.

[Tx, transmissive; Frax, fracture] 


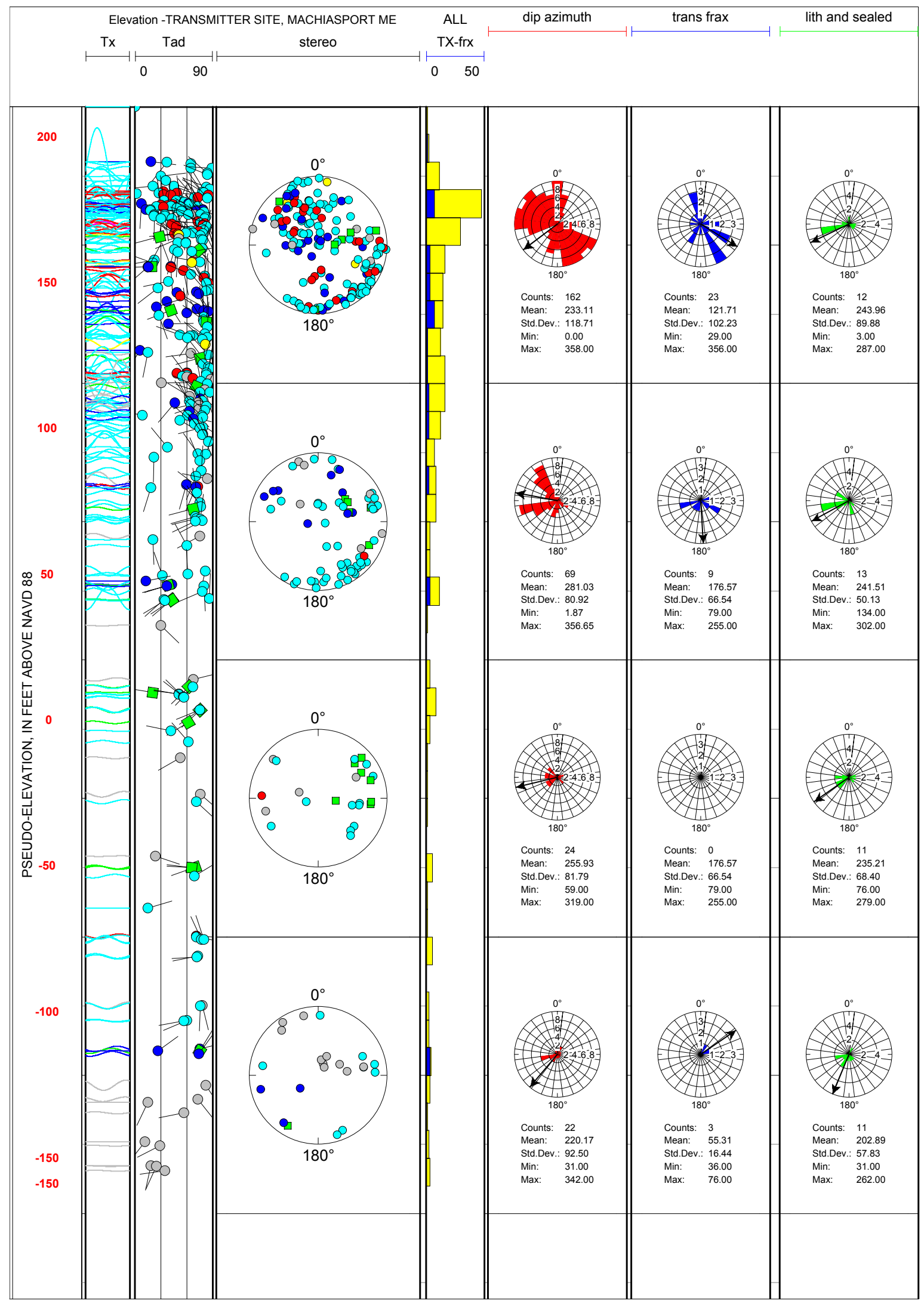

Figure 6C-3. Summary of structure interpreted from geophysical logs of boreholes near the Transmitter Site on Howard Mountain, near Machiasport, Maine. In elevation above mean sea level-projection and tadpole plots for all features at 100-foot intervals; fracture density plots (all fractures and transmissive fractures) at 10-foot intervals; rose diagrams of dip direction at 100 -foot intervals.

[Tx, transmissive; Tad, tadpole; trans frax, transmissive fracture; lith, lithologic feature; Std. Dev., standard deviation; Min, minimum; Max, maximum] 


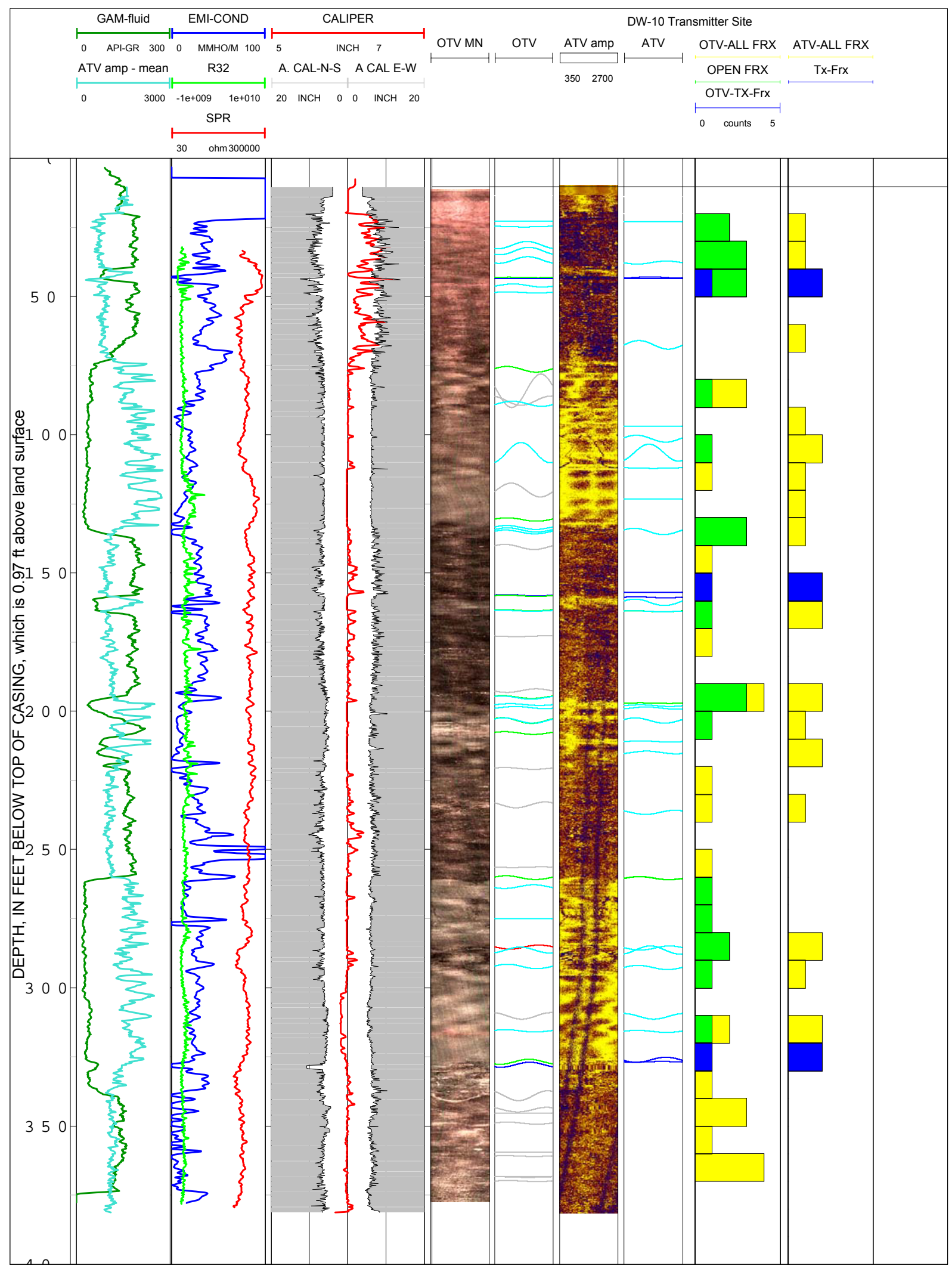

Figure 6C-4. Summary of structure interpreted from geophysical logs of boreholes near the Transmitter Site on Howard Mountain, near Machiasport, Maine. Fracture density plots at 10-foot intervals for borehole DW-10, the only borehole near the Transmitter Site on Howard Mountain that exceeds a depth of 120 feet.

[Tx, transmissive; Frax, fracture] 
Prepared by the Pembroke and West Trenton Publishing Service Centers.

For more information concerning this report, contact:

\section{Chief}

U.S. Geological Survey

Office of Groundwater, Branch of Geophysics

11 Sherman Place, Unit 5015

Storrs, CT 06269

GS-W_OGW_BG_Chief@usgs.gov

or visit our Web site at: http://water.usgs.gov/ogw/bgas 


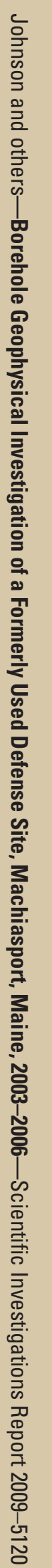

